Zakład Przedsiębiorczości i Gospodarki Przestrzennej Instytut Geografii

Akademia Pedagogiczna im. Komisji Edukacji Narodowej w Krakowie

\title{
Rola przedsiębiorczości \\ w aktywizacji gospodarczej
}

praca zbiorowa pod redakcją

Zbigniewa Zioło i Tomasza Rachwala

Warszawa - Kraków 2007

Przedsiębiorczość - Edukacja nr 3 
Rola przedsiębiorczości w aktywizacji gospodarczej 
Zakład Przedsiębiorczości i Gospodarki Przestrzennej Instytut Geografii Akademia Pedagogiczna im. Komisji Edukacji Narodowej w Krakowie

Przedsiębiorczość - Edukacja Nr 3 


\section{Rola przedsiębiorczości w aktywizacji gospodarczej}

pod redakcją

Zbigniewa Zioło i Tomasza Rachwała 
Recenzenci: prof. dr hab. Antoni Fajferek

Redakcja naukowa: prof. zw. dr hab. Zbigniew Zioło, dr Tomasz Rachwał

Projekt okładki: Tomasz Rachwał, Dorota Domagała

Projekt graficzny i opracowanie graficzne: Jarosław Naus, Iwona Gałuszka

Realizacja projektu graficznego: Dorota Domagała

Opracowanie redakcyjne i redakcja językowa: Zofia Psota

Wspólpraca redakcyjna: Tomasz Rachwał

ISBN 978-83-7409-529-7

(C) Copyright by Wydawnictwo Nowa Era w Warszawie \& Zakład Przedsiębiorczości i Gospodarki Przestrzennej IG AP w Krakowie

Warszawa - Kraków 2007

Rada Redakcyjna: Monika Borowiec, Paweł Czapliński, Sławomir Dorocki, Roman Fedan, Wioletta Kamińska, Wioletta Kilar (sekretarz), Zbigniew Makieła, Paweł Pocheć, Tomasz Rachwał (zastępca przewodniczącego), Anna Tobolska, Zbigniew Zioło (przewodniczący)

Skład i lamanie: Nowa Era Sp. z o.o.

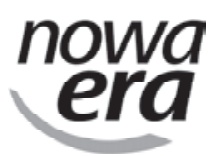

Nowa Era Sp. z o.o.

Aleje Jerozolimskie 146 D, 02-305 Warszawa

tel. 0225702580 , faks 0225702581

www.nowaera.pl, e-mail: nowaera@nowaera.pl

Druk i oprawa: ABEDIK S.A., Poznań 


\section{Wprowadzenie}

Współczesne procesy rozwoju społeczno-gospodarczego i kulturowego, w różnej skali układów przestrzennych (od skali lokalnej poprzez regionalną, krajową, do skali światowej), wykazują coraz silniejsze powiązania z procesami rozwoju globalnego. Procesy te zjednej strony pobudzają mechanizmy konkurencyjności podmiotów gospodarczych i instytucji, a z drugiej - powodują podnoszenie atrakcyjności układów przestrzennych dla generowania endogenicznych i przyciągania egzogenicznych czynników rozwoju. Podejmowane w tym zakresie decyzje opierają się na zasadzie optymalizacji, która pozwala najefektywniej realizować założone cele rozwojowe firm, przy określonych środkach kapitałowych, w danych uwarunkowaniach. Celowe działania zmierzają do stopniowego zwiększania efektywności ekonomicznej działalności produkcyjnej i usługowej oraz podnoszenia konkurencyjności firm, a także rozwijania wewnętrznych czynników wzrostu określonej skali układów przestrzennych oraz podnoszenia ich stopnia atrakcyjności dla napływu zewnętrznych czynników rozwojowych.

Przyjmujemy założenie, że tymi procesami przemian, odnoszącymi się zarówno do zarządzania określonymi podmiotami gospodarczymi, jak i do rozwoju różnej skali układów przestrzennych, steruje człowiek. W zależności od stopnia przygotowania zawodowego może on umiejętnie wykorzystywać współczesne procesy przemian i powodować przyspieszanie rozwoju przedsiębiorstw i układów przestrzennych lub skazać je na recesję czy upadek. Dlatego do odpowiedniego zarządzania tymi złożonymi procesami jest potrzebna odpowiednio przygotowana przedsiębiorcza osoba, która rozumie i zdobyła umiejętności posługiwania się z jednej strony mechanizmami kreowania i sterowania procesami rozwoju przedsiębiorstw, a z drugiej - mechanizmami intensyfikowania aktywizacji gospodarczej określonego obszaru.

W nawiązaniu do przedstawionych założeń Zakład Przedsiębiorczości i Gospodarki Przestrzennej Instytutu Geografii Akademii Pedagogicznej im. Komisji Edukacji Narodowej w Krakowie, przy udziale Fundacji Edukacja dla Społeczeństwa, przygotował kolejny, trzeci tom prac z serii „Przedsiębiorczość - Edukacja”, poświęcony roli przedsiębiorczości w aktywizacji gospodarczej. Zawarte w nim prace autorów pochodzących z krajowych ośrodków naukowych podejmują analizę tego złożonego problemu z różnych punktów widzenia. Chcemy w ten sposób kontynuować szerszą dyskusję, która w przyszłości powinna doprowadzić do całościowego ujęcia tej szczególnie ważnej kwestii, nie tylko od strony ujęć modelowych, ale także od strony praktyki gospodarczej oraz dydaktyki przedsiębiorczości, by w konsekwencji przyspieszyć proces kształtowania przedsiębiorczych postaw całego społeczeństwa.

W nurcie tej bardzo złożonej problematyki badawczej znajdują się prace prezentowane w niniejszym tomie, których autorami są przedstawiciele wielu krajowych ośrodków akademickich (Katowic, Koszalina, Krakowa, Lublina, Łodzi, Poznania, Rzeszowa, Słupska, Szczecina, Torunia, Warszawy, Wrocławia) oraz nauczyciele przedsiębiorczości szkół ponadgimnazjalnych i doradcy metodyczni z województw: dolnośląskiego, kujawsko-pomorskiego, łódzkiego, małopolskiego, mazowieckiego, podlaskiego, śląskiego i zachodniopomorskiego.

Chcemy w ten sposób z jednej strony doskonalić proces przenikania treści wypracowanych w kręgach akademickich, które powinny być wykorzystywane w procesie dydaktycznym z zakresu przedsiębiorczości w szkole ponadgimnazjalnej, a z drugiej strony - lepiej poznać aktualne potrzeby merytoryczne i dydaktyczne nauczycieli tego nowego przedmiotu. 
Zdajemy sobie sprawę, że zarówno proces kształcenia nauczycieli przedsiębiorczości, jak i metody przekazywania treści w procesie edukacyjnym wymagają ciągłego doskonalenia. W warunkach nasilających się procesów globalizacji i integracji europejskiej, które przyspieszają rozwój światowych i europejskich powiązań ekonomicznych, technologicznych i organizacyjnych, niezwykle ważnym zagadnieniem jest rozwijanie postaw przedsiębiorczych młodzieży, które pozwoląjej znaleźć dla siebie miejsce w coraz szybciej zmieniającym się świecie.

Prezentowane prace koncentrują się na kilku ważnych problemach dotyczących:

- roli przedsiębiorczości w aktywizacji gospodarczej układów regionalnych i lokalnych,

- rozwijania przedsiębiorczości dla aktywizacji obszarów wiejskich,

- wizerunku przedsiębiorcy i kształtowania postaw przedsiębiorczych,

- funkcji kapitału społecznego w rozwijaniu przedsiębiorczości,

- doskonalenia treści, form i metod w dydaktyce przedsiębiorczości.

Oddając do rąk czytelnika trzeci tom serii „Przedsiębiorczość - Edukacja”, chcemy podziękować wszystkim osobom i instytucjom wspierających nasze prace za pomoc finansową, która umożliwiła publikację niniejszego tomu. Zainteresowanych prezentowaną problematyką zachęcamy do współpracy z Zakładem Przedsiębiorczości i Gospodarki Przestrzennej Instytutu Geografii Akademii Pedagogicznej w Krakowie. Zwracamy się z prośbą o uwagi, które pomogą nam podnosić poziom prac i rozszerzać podjętą problematykę badawczą i edukacyjną.

Zbigniew Zioło, Tomasz Rachwał 


\section{Introduction}

Modern processes in social, economic, and cultural growth - in various spatial systems (from local scale to regional, national and global) - are more and more related to the processes of global growth. The processes stimulate mechanisms of competition between business entities and institutions and on the other hand they make spatial systems more attractive for generating endogenic and for luring exogenous elements of the development. Relevant decisions are based on the optimization that allows companies to the most efficient achieving the goals of growing in given environment and with given capital. Works focus on the gradual increasing in economic efficiency in production and services as well as on improvement in competitiveness of a company; and on develop the intrinsic factors of growth in given scale of spatial systems and on making them more attractive for luring external factors of growth.

We start with the premise that a human being controls the processes of changes - both in business entities and in various spatial systems. According to his professional competency he is able to skillfully use the modern processes of changes and to cause the acceleration in growth of a company or spatial systems - also he can doom it to recession or collapse. For that reason a properly prepared entrepreneurial person is needed to manage these complicated processes; a person who understands and is able to skillfully deal with the mechanisms of creation and control the processes of companies growth as well as deal with the mechanisms of amplification the economic activation in given area.

Referring to these presumptions Department of Entrepreneurships and Spatial Economy in Institute of Geography in KEN Pedagogical Academy in Kraków together with Education for Society Foundation have prepared the third volume from series "Entrepreneurship - Education"; it is dedicated to the role of an entrepreneurships in the activation of economy. Essays by the authors from various science centers analyze this complex problem from various points of views. In this way we are going to continue the broader debate that in future should lead to the comprehensive grasp this especially important matter - not only in the model frame but also in the economic practice and in the teaching entrepreneurship. Consequently it is able to accelerate the process of creating entrepreneurial attitudes in whole society.

These complex study problems are the subject of presented here works by representatives from numerous academic centers (Katowice, Koszalin, Kraków, Lublin, Łódź, Poznań, Rzeszów, Słupsk, Szczecin, Torun, Warszawa, and Wrocław) and the entrepreneurship teachers from secondary schools as well as the methodical consultants from followed provinces: Dolnośląskie, Kujawsko-Pomorskie, Łódzkie, Małopolskie, Mazowieckie, Podlaskie, Śląskie, and Zachodniopomorskie.

On the one hand our intention is to develop a process of passing the ideas from academic circles to the didactical processes of teaching entrepreneurship in secondary schools, an on the other hand to better understand needs of the teachers of this new subject.

We realize that both the education of the entrepreneurship teachers and the methodology of passing the content needs permanent improvement. In the environment of accelerated globalization and European integration that amplify development of economic, technologic, and organizational relations in the world and Europe, evolving the entrepreneurial attitudes among young people who will find their positions in the increasingly changing world is extraordinary important question. 
Presented works focus on some important problems:

- role of entrepreneurship in economic activation of local and regional systems

- entrepreneurship development for activation the rural areas

- image of entrepreneur and creation entrepreneurial attitudes

- function of social resources in entrepreneurship development

- development the ideas, forms and methodology of teaching entrepreneurship

Giving the third volume from series "Entrepreneurship - Education" to readers, we want to thank all the people and institutions for support to our work and Nowa Era Publishing House from Warsaw for the financial help that made possible to publish this book. We invite all persons interested in these problems to cooperation with Department of Entrepreneurships and Spatial Economy in Institute of Geography in KEN Pedagogical Academy in Kraków. All comments that help us improve the quality of our works and extend taken study and educational questions are welcomed.

Zbigniew Zioło, Tomasz Rachwał 
Przedsiębiorczość w aktywizacji

\section{gospodarczej układów regionalnych \\ i lokalnych}




\section{Zbigniew Zioło}

Zakład Przedsiębiorczości i Gospodarki Przestrzennej

Instytut Geografii

Akademia Pedagogiczna w Krakowie

\section{Rola przedsiębiorczości w aktywizacji gospodarczej - zarys modelu}

Znana jest teza, że przedsiębiorczość to podstawowy warunek rozwoju gospodarczego społecznego i kulturowego układów przestrzennych o różnej skali. Związana jest ona z działalnością różnego typu przedsiębiorstw, od mikroprzedsiębiorstw, które reprezentują indywidualne podmioty gospodarcze, przez grupy małych i średnich przedsiębiorstw (MSP) i przedsiębiorstw o funkcjach krajowych, do korporacji ponadnarodowych. Kształtowanie się tej kategorii firm w określonym stopniu oddziałuje z kolei na gospodarkę układów lokalnych, regionalnych, krajowych, po skalę światową.

Współcześnie kształtujące się procesy rozwoju społeczno-gospodarczego i kulturowego w skali światowej wywołują konkurencyjne zachowania podmiotów gospodarczych i instytucji oraz wpływają na podnoszenie atrakcyjności układów przestrzennych w zakresie generowania endogenicznych i przyciagania egzogenicznych czynników rozwoju.

W tych procesach podstawową rolę odgrywają reprezentanci odpowiednio przygotowanego społeczeństwa, którzy podejmują decyzje, kierując się ekonomicznymi przesłankami rozwoju podmiotów produkcyjnych, usługowych czy produkcyjno-usługowych oraz dążeniem do aktywizacji gospodarczej różnej skali układów przestrzennych.

W procesach rozwojowych przedsiębiorczości i związanej z nią aktywizacji gospodarczej układów przestrzennych ważną rolę odgrywają także systemy zarządzania, które prowadzą do zmian uwarunkowań wewnętrznych i zewnętrznych oraz umożliwiają zdobywanie odpowiednich źródeł zasilania kapitałowego, a także generują nowe, korzystne relacje rynkowe. Stwarzają one odpowiednią podstawę do rozszerzania i zwiększania rozmiarów produkcji i wzrostu efektywności ekonomicznej firm oraz rozwoju społecznego i kulturowego związanych z nimi układów przestrzennych.

Przyjmujemy zatem, że w procesie rozwoju przedsiębiorczości (przedsiębiorstw) należy realizować nie tylko cele ekonomiczne przedsiębiorstw. Trzeba także mieć na uwadze cele społeczne i kulturowe związanych z nimi układów lokalnych i regionalnych. Wyższy poziom kulturowy decyduje w znacznym stopniu o jakości społeczeństwa, które z kolei potrafi efektywniej realizować cele ekonomiczne i społeczne.

W latach transformacji gospodarczej rozwój przedsiębiorczości uważany jest za szczególnie ważny czynnik wzrostu gospodarczego. Znajduje to odzwierciedlenie jako ważny cel w konstruowanych strategiach rozwoju regionalnego na lata 2007-20201. W literaturze przedmiotu tematyka

\footnotetext{
${ }^{1}$ Podkreśla to fakt, że w ramach prac nad Narodowym Programem Rozwoju na lata 2007-2013 rozwijanie postaw przedsiębiorczości oraz nauka przedsiębiorczości i kształtowanie postaw przedsiębiorczych w systemie edukacji są jednym z priorytetów wzrostu konkurencyjności gospodarki [w:] Aspekty konkurencyjności gospodarki. Materiał przygotowany na konferencję w ramach prac nad NPR na lata 2007 -2013, Lublin 20.09.2004 r., Ministerstwo Gospodarki i Pracy, Warszawa, wrzesień 2004.
} 
wpływu przedsiębiorczości na aktywizację gospodarcząjest rozpatrywana z wielu punktów widzenia i winna zmierzać do ujęć syntetycznych (Zioło, Rachwał 2005, 2006, Jaremczuk 2004, 2006).

Z przedstawionych przesłanek wynika przedmiot niniejszych rozważań, w których podjęto próbę całościowego ujęcia relacji przedsiębiorczości i aktywizacji gospodarczej układów przestrzennych. Zdajemy sobie sprawę z potrzeby takiego ujęcia, które pozwoli na usystematyzowanie i precyzyjniejsze poznanie relacji tych złożonych procesów gospodarczych dokonujących się pod wpływem reguł mikro-, mezo- i makroekonomicznych. Wydaje się również, że niezbędne są dalsze prace badawcze nad tą złożoną problematyką badawczą, które powinny stanowić ważną przesłankę zarówno do podejmowania działań o charakterze aplikacyjnym, związanych z zarządzaniem, prognozowaniem, oceną kierunków przemian i sterowaniem złożonymi procesami rozwoju firm, jak i rozwoju różnej skali układów przestrzennych, a także działalności edukacyjnej. Racjonalne wykorzystanie procesu rozwoju przedsiębiorczości w zakresie aktywizacji gospodarczej danego układu przestrzennego wymaga podejmowania wielu prac empirycznych oraz ujęć syntetycznych i modelowych, pozwalających na określenie znaczenia podstawowych elementów związanych z tymi procesami, a także relacji zachodzących między nimi.

Podejmując próbę budowy modelu określającego relacje między przedsiębiorczością (przedsiębiorstwami) a aktywizacją gospodarczą danego obszaru, wychodzimy z założenia, że występują między nimi ścisłe związki, które wyrażają różnorodne sprzężenia łańcuchowe i zwrotne. Proces rozwoju przedsiębiorczości przejawiający się powstawaniem i kształtowaniem się nowych podmiotów gospodarczych nawiązuje do reguł rozwoju mikroekonomicznego i w różnym stopniu oddziałuje na inne przedsiębiorstwa, instytucje oraz społeczność danej jednostki przestrzennej. W różnych układach przestrzennych następuje więc nakładanie się reguł mikroekonomicznego rozwoju poszczególnych jednostek produkcyjnych i usługowych, które wraz z instytucjami tworzą nowe reguły rozwoju mezoekonomicznego. Równocześnie zarówno reguły mikroekonomicznego, jak i mezoekonomicznego rozwoju nawiązują do ogólniejszych reguł rozwoju makroekonomicznego (Zioło 1996).

Można więc przyjąć, że pod wpływem procesów mikro-, mezo-i makroekonomicznych dokonuje się z jednej strony wzrost różnej wielkości przedsiębiorstw, a z drugiej - następuje aktywizacja gospodarcza różnej skali układów przestrzennych. Należy zaznaczyć, że poszczególne układy przestrzenne stwarzają odmienne uwarunkowania dla pobudzania i kształtowania się na ich obszarze procesów rozwoju społeczno-gospodarczego, czego wyrazem są bardzo poważne zróżnicowania przestrzenne w tym zakresie ${ }^{2}$. Wynika to z różnego stopnia ich konkurencyjności w zakresie generowania wewnętrznych i przyciagania zewnętrznych czynników rozwoju (Kudełko 2005).

Na rozwój przedsiębiorczości szczególny wpływ wywierają procesy rozwoju cywilizacyjnego, które generują procesy globalizacji. Współczesne procesy rozwoju cywilizacyjnego zmierzają do kształtowania społeczeństwa informacyjnego, którego podstawową bazą ekonomicznego i społecznego rozwoju w coraz poważniejszym stopniu stają się zasoby intelektualne umożliwiające kształtowanie się gospodarki opartej na wiedzy (Kukliński 1994).

Rozwój przedsiębiorczości i aktywizacji gospodarczej układów regionalnych czy lokalnych dokonuje się w danym otoczeniu, w którym kształtują się procesy rozwoju społeczno-gospodarczego. Poprzez różnorodne powiązania te układy mogą generować określone czynniki rozwoju i wpływać na zmianę ich pozycji konkurencyjnej poprzez zmianę wewnętrznych uwarunkowań.

\footnotetext{
${ }^{2}$ Wyrazem tego mogą być procesy restrukturyzacji układów subregionalnych południowo-wschodniej Polski w wyniku zmian systemu gospodarowania. Dystans czasowy zainicjowania zmian w zakresie struktury rynku pracy między dawnymi województwami krakowskim i rzeszowskim wynosił około 10 lat (Zioło 1999).
} 
Ryc. 1. Model relacji przedsiębiorczości - aktywizacja gospodarcza

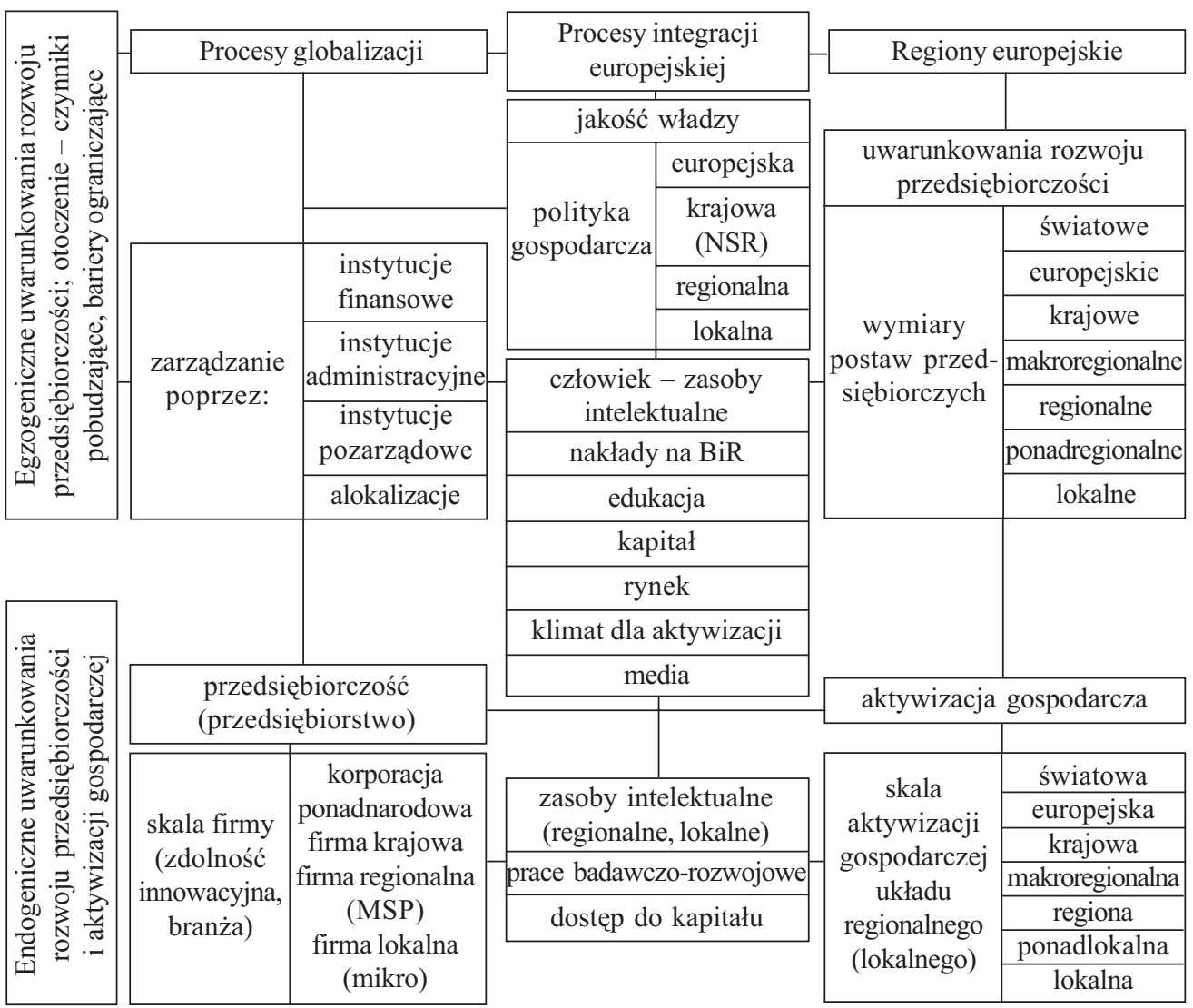

W zaproponowanym modelu relacji ,,przedsiębiorczość - aktywizacja gospodarcza” wyróżniono szereg elementów, między którymi określono funkcjonalne powiązania (ryc. 1).

Przyjmujemy, że przedsiębiorstwo i związany z nim układ przestrzenny nie są elementami odosobnionymi, ale poprzez różnego rodzaju sprzężenia wpływają na nie egzogeniczne uwarunkowania wynikające $\mathrm{z}$ tendencji procesów globalizacji, procesów integracji europejskiej oraz przemian regionów europejskich. Z różnych kategorii otoczenia mogą bowiem wypływać zarówno czynniki pobudzające wzrost społeczno-gospodarczy danego regionu, jak i bariery ograniczające jego rozwój.

W niniejszych rozważaniach przyjmujemy, że procesy globalizacji należy traktować jako wynik obiektywnych procesów ekonomicznych, społecznych i kulturowych, które na skutek koncentracji kapitału w coraz większych korporacjach światowych i poprzez różnego rodzaju powiązania kapitałowe, organizacyjne, produkcyjne i rynkowe coraz silniej integrują przestrzeń światową. Uwidaczniają się one zarówno w procesach polaryzacyjnych, które różnicują przestrzeń gospodarczą, społeczną i kulturowa, jak i w procesach unifikacyjnych, prowadzących do wyrównywania dysproporcji rozwojowych krajów i regionów (Kukliński 1995)³ .

\footnotetext{
${ }^{3}$ Wyrazem tego jest bardzo silne zróżnicowanie przestrzeni światowej w zakresie produktu krajowego brutto poszczególnych krajów, stopnia skupienia siedzib zarządów wiodących korporacji światowych, stopnia analfabetyzmu, poziomu edukacji czy poziomu zarażonych wirusem HIV i in. (Czerny 2005).
} 
Procesy globalizacji i kształtowanie się dwóch światowych biegunów wzrostu gospodarczego (Stanów Zjednoczonych i Japonii) wpłynęły na procesy integracji europejskiej. Gospodarki krajów europejskich w stosunku do gospodarek wspomnianych światowych biegunów są zbyt słabe, aby skutecznie mogły z nimi konkurować, podjęto zatem decyzję o budowie trzeciego światowego bieguna wzrostu, jakim jest UE. Należy się liczyć z tym, że dalszy proces kształtowania UE będzie zmierzał do stworzenia struktury w rodzaju Stanów Zjednoczonych Europy. Wskazują na to kolejne działania integracyjne, przejawiające się przyjęciem wspólnej waluty, wspólnego parlamentu, a w przyszłości wspólnej konstytucji (Kukliński 1995).

W strukturach europejskich za przestrzenny rozwój społeczno-gospodarczy w coraz większym stopniu odpowiedzialne będą regiony. Wynika to ze stałego doskonalenia polityki regionalnej UE oraz przeznaczania znacznych środków na rozwój regionów i wyrównywanie dysproporcji przestrzennych między nimi (Pietrzyk 2000).

Z wymienionych kategorii otoczenia wypływają zarówno określone impulsy rozwojowe, jak i pewne zagrożenia dla rozwoju społeczno-gospodarczego i kulturowego. Znając reguły funkcjonowania podmiotów gospodarki w różnych kategoriach otoczeniach, w wyniku przyjęcia odpowiedniej polityki gospodarczej, społecznej czy regionalnej, można je wykorzystać do przyspieszenia procesów wzrostu określonej skali układów (krajowych, regionalnych, lokalnych). Dlatego ważnym zagadnieniem jest jakość władzy wspomnianych układów przestrzennych, która rozumie współczesne tendencje rozwoju gospodarczego i potrafi stworzyć korzystne uwarunkowania napływu zewnętrznych czynników rozwoju oraz generowania czynników wewnętrznych.

W zależności od jakości władzy następuje także koordynacja instytucji, występuje określona efektywność zarządzania w instytucjach finansowych, administracyjnych, pozarządowych i podejmowane są działania na rzecz rozwoju istniejących i przyciagania nowych lokalizacji działalności gospodarczej ${ }^{4}$.

Efektem jakości władzy i stosowanych poprzez różnego rodzaju instytucje form zarządzania są: człowiek i jego zasoby intelektualne, nakłady na prace badawczo-rozwojowe ${ }^{5}(B+R)$, edukacja (poziom i nowoczesność na różnym poziomie kształcenia), kapitał (wewnętrzne zasoby kapitałowe oraz możliwości przyciagania kapitału z różnej skali otoczenia), rynek (chłonność i nisze), klimat proprzedsiębiorczy aktywizujący społeczeństwo do rozwoju postaw przedsiębiorczych i korzystnych uwarunkowań dla aktywizacji gospodarczej, dla inwestycji (stwarzany przez społeczeństwo i władzę samorządową) oraz media (poziom merytoryczny, obiektywność w przekazywaniu informacji, prezentowanie właściwych wzorców zachowań dla rozwoju przedsiębiorczości, pobudzania aktywizacji gospodarczej, podnoszenia poziomu edukacyjnego społeczeństwa i in.).

Wymienione grupy przesłanek (procesy globalizacji, integracja europejska, zróżnicowanie regionalne Europy, jakość władzy, zarządzanie instytucjonalne tworzą określone uwarunkowania dla aktywizacji gospodarczej, społecznej i kulturowej oraz kształtują różnorodne wymiary postaw

\footnotetext{
${ }^{4}$ Wyrazem tego jest ocena konkurencyjności krajów w 2005 r. w zakresie rozwoju gospodarczego na podstawie 11 tys. ankiet wysłanych do szefów firm światowych. Wśród 56 krajów na pierwszych miejscach znalazły się: Szwajcaria, Finlandia, Szwecja, Dania, Stany Zjednoczone, Singapur, Japonia, Niemcy, Holandia, Wielka Brytania, na 43 miejscu Indie, na 47 miejscu Grecja, a za nią Polska i Bahrajn. Wysoka pozycja wynikała głównie ze stabilności instytucji oraz inwestowania w rozwój nowoczesnych technologii. Słabość Polski jest skutkiem szczególnej ochrony rynku pracy oraz niepewności wynikającej ze słabości instytucji, korupcji i słabej ochrony własności intelektualnej.

${ }^{5} \mathrm{~W} 2003$ r. nakłady na działalność badawczo-rozwojową w 33 najlepiej rozwiniętych krajach wynosiły 780,4 mld USD, z czego na Stany Zjednoczone przypadało 36,5\%, na Japonię 14,6\%, na Chiny 10,8\%, na Niemcy 7,3\% (Polska 0,3\%). W stosunku do PKB nakłady na działalność badawczo-rozwojową wyniosły w Szwecji 4,3\%, w Finlandii - 3,3\%, w Japonii - 3,2\%, w Niemczech 2,6, a w Polsce 0,5\% (tab. 2).
} 
przedsiębiorczości odnoszące się do różnych skal przestrzennych (światowej, europejskiej, krajowej, makroregionalnej, regionalnej, ponadlokalnej czy lokalnej).

Na zarysowane uwarunkowania rozwoju przedsiębiorczości wpływają formy zarządzania stosowane przez: instytucje finansowe (dostępność do kredytów), administracyjne (wyznaczanie i stwarzanie korzystnych warunków realizacji strategicznych celów rozwoju), pozarządowe (jakość elit opiniotwórczych) czy podejmowane decyzje o prorozwojowej alokacji kapitału. Te uwarunkowania i formy zarządzania stwarzają określone możliwości rozwoju przedsiębiorczości (przedsiębiorstw). Umożliwiają one kształtowanie się różnego rodzaju firm o funkcjach: ponadnarodowych (korporacje ponadnarodowe), krajowych, regionalnych (MSP) czy lokalnych (mikrofirmy).

Rozwój firm o coraz poważniejszych funkcjach w przestrzeni gospodarczej jest możliwy tylko w warunkach: bogatych zasobów intelektualnych (dobrze i nowocześnie wykształconego społeczeństwa regionalnego i lokalnego oraz rozwiniętych postawach przedsiębiorczości), odpowiednich nakładów na prace badawczo-rozwojowe, sprzyjającego klimatu dla rozwoju, dostępu do tanich źródeł kapitału oraz sprawności instytucji publicznych.

Kształtowanie się firm wpływa na skalę aktywizacji gospodarczej, która może mieć wymiar od układu lokalnego po układ światowy. Firmy o funkcjach ponadnarodowych (np. Microsoft, General Electric, korporacje paliwowe, bankowe) poprzez różnorodne powiązania sieciowe mogą wpływać na aktywizację gospodarczą przestrzeni światowej lub jej znaczną część. Firmy o funkcjach europejskich (np. Royal Dutch Shell) wpływają na aktywizację gospodarczą przestrzeni Europy. Podobnie firmy o funkcjach krajowych, w wyniku powiązań przestrzenno-produkcyjnych, mogą oddziaływać na gospodarkę krajową (poprzez powstawanie nowych firm lub stwarzanie nowych powiązań kooperacyjnych).

W warunkach krajowych i regionalnych wpływ przedsiębiorczości na aktywizację gospodarczą zaznacza się także w odległych regionach dzięki dogodnym powiązaniom infrastruktury sieciowej (np. budowa i funkcjonowanie autostrady A-4 zintensyfikuje możliwość powiązań społeczno-gospodarczych województw Polski południowej, od dolnośląskiego poprzez opolskie, śląskie, małopolskie po podkarpackie, i podniesie ich konkurencyjność w stosunku do Czech i Słowacji), powiązaniom produkcyjnym, kooperacyjnym, usługowym itd.

Rozwój przedsiębiorczości w skali ponadlokalnej i lokalnej oraz jej wpływ na aktywizację gospodarczą przejawiają się głównie wzrostem liczby podmiotów gospodarczych (głównie małych i mikrofirm osób fizycznych), które zwiększają rynek pracy, powodują wzrost dochodów ludności z pracy i dochodów samorządowych układów lokalnych i przyczyniają się do ograniczenia bezrobocia. W zależności od poziomu konkurencyjności, na ich terenie mogą także powstawać oddziały korporacji ponadnarodowych, mogą włączać się w ich struktury istniejące przedsiębiorstwa, może następować lokalizacja nowoczesnych firm krajowych, które będązdobywać coraz szersze krajowe i światowe rynki zbytu.

Podmioty gospodarcze (także podmioty osób fizycznych) w strukturze gospodarczej moga spełniać różne funkcje. W zależności od powiązań produkcyjno-rynkowych można wśród nich wyróżnić jednostki pracujące na potrzeby otoczenia: światowego, europejskiego, krajowego, ponadregionalnego, regionalnego, ponadlokalnego i lokalnego. Odbiorcami ich produkcji moga więc być inne przedsiębiorstwa produkcyjne (dostawy kooperacyjne), usługowe, gospodarstwa domowe, mogą one także produkować na potrzeby konsumpcyjne ludności. Poszczególne typy podmiotów gospodarczych charakteryzują się różnym stopniem wrażliwości na zmieniające się uwarunkowania rozwoju. Największe szanse na rozwój i systematycznie unowocześnianie produkcji oraz podnoszenie kwalifikacji pracowniczych mają podmioty gospodarcze pracujące w ramach umów kooperacyjnych na potrzeby dużych firm ponadnarodowych (np. samochodowych). Firmy tej kategorii, o dużym potencjale ekonomicznym, mają bowiem największe szanse 
przetrwania na rynku i wymuszają na współpracujących z nimi podmiotach gospodarczych ciągłą dbałość o doskonalenie i unowocześnianie produkcji nowych lub ciagle udoskonalanych produktów. Najmniejsze możliwości rozwoju mają podmioty gospodarcze pracujące na potrzeby lokalne, głównie osób fizycznych (mikrofirmy). Podlegają one silnemu wpływowi zmieniających się zasobów finansowych ludności oraz związanych z nimi uwarunkowań rynku lokalnego. Podmioty te najczęściej już nasyciły swoją ofertą rynek lokalny (np. sklepy, zakłady fryzjerskie, punkty usługowe), a ich dalszy rozwój zależy od możliwości zwiększenia rozmiarów rynku lokalnego, którego pojemność wyznaczają rozmiary zasobów finansowych ludności. Ograniczanie zasobów finansowych ludności tworzy dla podmiotów gospodarczych barierę popytową która ogranicza ich działalność produkcyjną czy usługową (lub powoduje jej zanik), natomiast zwiększanie zasobów finansowych ludności powoduje zwiększanie popytu i wzrost działalności gospodarczej.

Należy zaznaczyć, że współcześnie układ lokalny wykazuje bardzo silnie powiązania z nadrzędnymi układami europejskimi i światowymi. Na przykład napływ taniej odzieży czy obuwia z Azji Południowo-Wschodniej poważnie ogranicza zdolności produkcyjne wielu małych firm produkcyjno-usługowych o funkcjach lokalnych, regionalnych czy krajowych (np. produkcja skarpet, wyrobów dzianych, odzieży). Ogranicza także możliwości rozwoju lokalnych podmiotów związanych z usługami, np. krawieckimi czy szewskimi.

Omawiana problematyka wymaga dalszych pogłębionych studiów empirycznych układów lokalnych. Należy zweryfikować powszechnie przyjmowaną tezę, że aktywizacja gospodarcza układów lokalnych może się dokonywać w wyniku rozwoju małych firm. Wydaje się, że rozwój gospodarczy zapewniają duże firmy, oferujące swoje produkty na dobrze zorganizowanym rynku. Pośrednio funkcje te mogą spełniać także mały firmy powiązane relacjami produkcyjno-usługowymi z dużymi firmami. Dbałość o powstawanie i rozwój małych firm przyspiesza proces kształtowania się tzw. warstwy średniej, która jest konsumentem produktów oferowanych przez duże firmy i tworzy rynek o określonym rozmiarze, dla działalności małych firm produkcyjno-usługowych, których poziom rozwoju ograniczany jest przez bariery popytu.

Należy zaznaczyć, że procesy globalizacji i integracji wzmacniają przestrzenne powiązania ekonomiczne oraz odznaczają się zróżnicowanym zasięgiem i nasileniem oddziaływania, od skali światowej, poprzez krajowa, do lokalnej. Obejmują one:

- lokalizację nowych i rozbudowę istniejących firm,

- rozwój produkcji nowych lub tradycyjnych wyrobów, kierowanych na rynki różnej kategorii otoczenia,

- nasilenie powiązań w zakresie: przepływu wiedzy i rozwiązań technologicznych, zbytu gotowych produktów, zaopatrzenia w części zamienne, powiązań kooperacyjnych, dostawy surowców i półfabrykatów, prac remontowo-budowlanych.

Wpływ przedsiębiorczości na aktywizację gospodarczą układu lokalnego, ponadlokalnego i regionalnego przejawia się poprzez:

- zwiększenie rozmiarów i zmianę jakości rynku pracy,

- ograniczenie bezrobocia,

- zwiększenie zasobów finansowych ludności,

- ograniczenie bariery popytowej ludności na rynku,

- zwiększenie strumieni finansowych płynących do instytucji samorządowych w postaci dochodów z podatków,

- doinwestowanie w zakresie sieciowej infrastruktury techniczno-ekonomicznej danego układu osadniczego (drogi, bocznice kolejowe, sieć energetyczna, gazowa, wodna), 
- zmiany w użytkowaniu terenu,

- aktywizację pozostałych sektorów działalności gospodarczej, w tym rozwój usług,

- zmiany kierunków migracji odpowiedniej jakości zasobów pracy.

Reasumując, można przyjąć, że wpływ rozwoju przedsiębiorczości na aktywizację gospodarcząjest problemem złożonym. Rozwiązywanie go wymaga dalszych pogłębionych badań, dotyczących m.in. doskonalenia metod negocjacji w zakresie łagodzenia konfliktów, które wynikają z odmiennego podejścia firm (producentów) do zagadnień produkcyjnych czy usługowych (dla których podstawowe znacznie mają efekty ekonomiczne) i podejścia samorządowych układów lokalnych czy regionalnych, które mają na uwadze ich rozwój społeczno-gospodarczy i kulturowy. Szczególnie ważne w tym zakresie są metody zarządzania prowadzące do wzrostu potencjału i podnoszenia jakości lokalnych i regionalnych czynników rozwoju dla nasilania różnego rodzaju powiązań przestrzenno-produkcyjnych, podnoszenia konkurencyjności danej jednostki, które z kolei na zasadzie sprzężeń wpływają na ich rozwój społeczno-gospodarczy i kulturowy.

\section{Literatura}

1. Czerny M., 2005, Globalizacja i rozwój, Wydawnictwo Naukowe PWN, Warszawa

2. Gospodarka oparta na wiedzy - wyzwanie dla Polski XXI wieku, 2001, A. Kukliński (red.), KBN, Warszawa

3. Jaremczuk K. (red.), 2004, Uwarunkowania przedsiębiorczości, Państwowa Wyższa Szkoła Zawodowa im. prof. S. Tarnowskiego, Tarnobrzeg

4. Jaremczuk K. (red.), 2006, Uwarunkowania przedsiębiorczości - aspekty ekonomiczne i antropologiczno-społeczne, Państwowa Wyższa Szkoła Zawodowa im. prof. S. Tarnowskiego, Tarnobrzeg

5. Kudełko J., 2005, Rozwój regionalny a konkurencyjność regionów [w:] Uwarunkowania rozwoju regionu i konkurencyjność regionów, Instytut Gospodarki WSIiZ, Rzeszów

6. Pietrzyk I., 2000, Polityka regionalna Unii Europejskiej i regiony w państwach członkowskich, Wydawnictwo Naukowe PWN, Warszawa

7. Problematyka przestrzeni europejskiej, 1997, A. Kukliński (red.), Euroreg, Warszawa

8. Przedsiębiorczość a wspótczesne wyzwania cywilizacyjne, seria: Przedsiębiorczość - Edukacja nr 1, 2005, Z. Zioło, T. Rachwał (red.), Zakład Przedsiębiorczości i Gospodarki Przestrzennej Instytutu Geografii Akademii Pedagogicznej im. Komisji Edukacji Narodowej w Krakowie, Wydawnictwo MiWa, Kraków

9. Rola przedsiębiorczości w podnoszeniu konkurencyjności społeczeństwa i gospodarki, seria: Przedsiębiorczość - Edukacja nr 2, 2006, Z. Zioło, T. Rachwał, (red.), Wydawnictwo Nowa Era, Zakład Przedsiębiorczości i Gospodarki Przestrzennej Instytutu Geografii Akademii Pedagogicznej im. Komisji Edukacji Narodowej w Krakowie, Warszawa-Kraków

10. Science, technology, economy, 1994, A. Kukliński (red.), KBN, Warszawa

11. Zioło Z., 1996, Miejsce mezoekonomii w ekonomii [w:] Rola mezoekonomii w rynkowym systemie zarzqdzania gospodarkq. Księga Jubileuszowa dla uczczenia 50-lecia pracy naukowo-dydaktycznej Profesora Józefa Gajdy, Akademia Ekonomiczna, Kraków

12. Zioło Z., 1999, Transformacja struktur subregionalnych Polski Poludniowo-Wschodniej w okresie zmian systemu gospodarowania, Prace Komisji Nauk Ekonomicznych PAN Oddz. w Krakowie, nr 24, Wyd. Oddziału PAN, Kraków 


\section{Role of Entrepreneurships in an Activation of Economy - an Outline of a Model}

The goal of the article is to present a role of entrepreneurships in a model of the activation of economy. Impact of entrepreneurships on economic activation of the local, beyond-local and regional systems appears in a qualitative and quantitative alteration of the labor market, the reduction of unemployment, the growth of people's resources, the reduction of demand barrier, the increasing finances streaming from taxes to local governments, the investments in technological-economic infrastructures of settlement systems. Impact of entrepreneurships on economic activation is very complicated problem and it require more research and deeper studies. 


\section{Zbigniew Makiela}

Krakowska Szkoła Wyższa im. A. Frycza Modrzewskiego

\section{Przedsiębiorczość w Polsce w układzie regionalnym}

\section{Definicje przedsiębiorczości}

„Przedsiębiorczość" jest pojęciem często używanym w języku potocznym, kojarzonym z określeniami: „zmysł gospodarczy”, ,duch przedsiębiorczości” (Stańda, Wierzbowska 2004), ,zachowania przedsiębiorcze”. Pojęcie to jest przeważnie rozumiane jako specyficzny rodzaj aktywności człowieka, którego celem jest dążenie do osiagania jak najlepszych wyników własnej pracy, nauki i studiów, dążenie do wytyczonego celu, kreatywność w działaniu.

Najczęściej cytowany w literaturze ekonomicznej J. Schumpeter (1960) uważa, że przedsiębiorczość wynika z funkcji realizowanych przez przedsiębiorcę, a funkcją przedsiębiorcy jest „kombinowanie” czynników produkcji. Analizując przyczyny rozwoju gospodarczego, wprowadził on pojęcia „,nowych kombinacji” dla rozwoju gospodarczego: wprowadzanie na rynek nowego towaru, z jakim konsumenci nie są jeszcze obeznani, wprowadzenie nowej metody produkcji, otwarcie nowego rynku, rynku, na którym wprowadza się nową produkcję, lub budowa takiego rynku, zdobycie nowego źródła surowców lub półfabrykatów, wprowadzenie nowej organizacji przemysłu poprzez stworzenie lub złamanie monopolu. Realizacja tych założeń opierała się na kombinacji, które nazwano ,przedsięwzięciami”, a osoby, które realizują te kombinacje, nazwano „przedsiębiorcami” (Podstawy nauki... 2003).

Przedsiębiorczość jest cechą lub sposobem zachowania się przedsiębiorcy, które to zachowanie lub cechę sprowadza do gotowości i zdolności podejmowania i rozwiązywania w sposób twórczy i nowatorski nowych problemów, umiejętność wykorzystania pojawiających się szans i okazji oraz elastycznego przystosowania się do zmieniających się warunków funkcjonowania gospodarki (Stańda, Wierzbowska 2004). Przedsiębiorczość jest pojęciem często używanym potocznie, kojarzącym się z takimi określeniami, jak: „,zmysł gospodarczy”, „dobra organizacja”, „gotowość do działania”, „permanentna aktywność”, zdolność do działania”. Tak sformułowane określenia opisują rodzaj aktywności, gotowości do działania, dążenie do osiagnięcia założonego celu, twórczego i efektywnego działania. Przez przedsiębiorczość często rozumie się umiejętność dostrzegania i wykorzystywania nowych możliwości produkcyjnych, usługowych, organizacyjnych, dających szansę na relatywnie duże korzyści w warunkach braku pewności odnośnie do sukcesu całego przedsięwzięcia (Barańska, Gierczyńska, Szostek 2002).

Przedsiębiorczość to także zespół określonych cech osobowości człowieka, które pozwalaja mu aktywnie uczestniczyć w życiu społeczno-gospodarczym (w tym rodzinnym) oraz czerpać z niego wiele radości i satysfakcji. Człowiek przedsiębiorczy potrafi kreować potrzeby dla siebie i innych, a także zaspokajać je niezależnie od warunków otoczenia. Dzięki zauważaniu i wykorzystywaniu możliwości osiagnięcia wybranych przez siebie celów, jest filarem, na którym opiera się gospodarka rynkowa.

Co to znaczy być człowiekiem przedsiębiorczym? Czy wystarczy mieć cechy powszechnie uznane za świadczące o przedsiębiorczości? 
Tab. 1. Czynniki wpływające na rozwój przedsiębiorczości

\begin{tabular}{|l|l|}
\hline Czynniki powodujące rozwój przedsiębiorczości & Czynniki hamujące rozwój przedsiębiorczości \\
\hline - łatwość tworzenia nowych przedsiębiorstw & • wysoka stopa kredytowa \\
- tania i wysoko wykształcona siła robocza & • brak stabilnej polityki rządu wobec \\
- łatwy dostęp do wiedzy & przedsiębiorstw \\
- dostępność komunikacyjna & - wysokie koszty pracy \\
- przejrzysty system podatkowy & - niestabilność przepisów dotyczących \\
- możliwość otrzymania nisko oprocentowanego & zatrudnienia \\
- kredytu & - korupcja \\
- dostęp do nowoczesnych technologii & - niestabilna polityka fiskalna \\
- przye nośniki energii & - niski poziom rozwoju infrastruktury \\
- stabilna sytuacja polityczna & techniczno-ekonomicznej \\
& - długi okres zwrotu inwestycji \\
& - brak planów przestrzennego zagospodarowania \\
\hline
\end{tabular}

Tab. 2. Ważne cechy, postawy i umiejętności człowieka przedsiębiorczego

\begin{tabular}{|c|c|}
\hline \multicolumn{1}{|c|}{ Cechy } & Postawy i umiejętności \\
\hline - posiadanie marzeń, wytyczanie sobie ambitnych & - umiejętność znoszenia porażek i znajdowania \\
celów, snucie planów na przyszłość, wizja & w nich inspiracji do działania \\
swojego życia, odwaga w działaniu i myśleniu & - umiejętność cieszenia się z sukcesu \\
- ciekawość świata, pragnienie poznawania & - umiejętność bycia liderem, wpływania \\
nowych rzeczy & na innych i zachęcania ich do współpracy \\
- energia, zapał, wytrzymałość, zdolność do & - pomysłowość, zaradność, wykazywanie \\
szybkiej regeneracji sił psychofizycznych & inicjatywy \\
- wytrwałość i upór w działaniu przez dłuższy & - poszukiwanie wiedzy i docieranie do jej źródeł \\
czas & - praktyczne stosowanie wiedzy \\
- wiara we własne siły, docenianie własnych umie- & - podnoszenie kwalifikacji, samodoskonalenie \\
jętności, pewność siebie & - panowanie nad własnymi emocjami \\
- zaradność & - dobre komunikowanie się z innymi ludźmi \\
- zdolność do podejmowania ryzyka i umiejętność & - uczciwość w stosunku do siebie i innych \\
oceny związanych z nim zagrożeń & - odpowiedzialność za siebie i innych \\
- optymizm wynikający z posiadanej wiedzy & - solidarność międzyludzka \\
i znajomości uwarunkowań społeczno-prawnych & - dbałość o rodzinę \\
otoczenia lokalnego, krajowego i międzynaro- & - dbałość o ochronę środowiska przyrodniczego \\
dowego, pozwalający na znajdowanie szans & \\
nawet w niesprzyjających warunkach & \\
- empatia & \\
- zdolności organizatorskie &
\end{tabular}

\section{Poziom przedsiębiorczości w Polsce}

Rozwój przedsiębiorczości jest procesem, który przebiega etapami i charakteryzuje się zmiennym natężeniem. Potrzebne są więc takie metody i instrumenty pomiaru, za których pomocą można precyzyjnie śledzić jej obraz na poszczególnych etapach. Opierając się na badaniach prowadzonych przez Global Entrepreneurship Monitor, można zidentyfikować dwie grupy osób zaangażowanych w nowe przedsięwzięcia gospodarcze. Pierwsza grupa to początkujący przedsiębiorcy, aktywni w rozwijaniu swoich firm, funkcjonujących 3-4 lat. Druga grupa to osoby starające się rozpocząć działalność gospodarczą i podejmujące w tym celu samodzielnie lub z partnerami jakieś konkretne działania (np. poszukiwanie lokalizacji firmy, opracowanie strategii działania, poszukiwanie kapitału, poszukiwanie partnerów biznesowych). 
Podstawową miarą poziomu przedsiębiorczość jest tzw. stopa przedsiębiorczości (stopa zaangażowania w nowe przedsięwzięcia gospodarcze). W 2004 r. stopa przedsiębiorczości w Polsce wynosiła 8,83\%. Oznacza to, że wśród tysiąca Polaków w wieku 18-64 lat przeciętnie prawie 90 jest zaangażowanych w rozpoczynanie bądź rozwijanie działalności gospodarczej. Wartość tego wskaźnika była wyższa niż w poprzednich latach $(2001,2002)$ o 1,6 punktu procentowego. Wartość stopy przedsiębiorczości w Polsce jest wysoka, wyższa od stopy podobnego wskaźnika w Irlandii, Norwegii, Izraelu, Wielkiej Brytanii, Francji i Grecji. Wyższą wartość mają: Kanada, Stany Zjednoczone, Argentyna, Australia i Brazylia. Porównując wartość analizowanego wskaźnika wśród krajów UE, stwierdzamy, że Polskę wyprzedza jedynie Irlandia, przy czym nie ma statystycznie istotnej różnicy pomiędzy wartością wskaźnika w Polsce i Irlandii. Spośród krajów po transformacji ustrojowej, oprócz Polski tylko Węgry miały wysoką wartość tego wskaźnika, a w Chorwacji, Słowenii i Rosji były one najniższe w Europie.

\section{Przesłanki podejmowania działalności gospodarczej}

W analizie przedsiębiorczości szczególnie istotne są powody podejmowania działalności gospodarczej. Motywy podejmowania decyzji są bardzo ważne, wywołują bowiem odmienne implikacje. Często są one bardzo skrajne, np. motywem podejmowania działalności może być z jednej strony chęć wykorzystania szans, jakie się pojawiają w otoczeniu lub - z drugiej strony - zakładanie własnej firmy z konieczności, czyli braku alternatywy zarobkowej.

W pierwszym typie zachowań leży założenie, że podejmując decyzję o działalności gospodarczej wybrano świadomie lepszą alternatywę, wywołaną impulsem wewnętrznym. Kluczowe znaczenie ma świadomość pojawiającej się szansy w otoczeniu na udane przedsięwzięcie, która została dostrzeżona przez potencjalnego przedsiębiorcę.

Drugi typ zachowań, wynikający z odmiennych motywów, to podjęcie decyzji o rozpoczęciu działalności gospodarczej na skutek długotrwałego bezrobocia lub zagrożenia utratą pracy. Tworzenie przedsiębiorstw jest więc reakcją na socjalne utrudnienia lub małe szanse na rynku pracy. W 2004 r. wśród badanych krajów ponad 75\% przedsięwzięć było podejmowanych z chęci wykorzystania pojawiającej się szansy, a niewiele ponad 20\% - z konieczności. Dla Polski wskaźniki te wynosiły odpowiednio 65\% (przedsięwzięcia z wyboru) i 35\% (z konieczności). Oznacza to, że co trzecia osoba zaangażowana w Polsce w działalność gospodarczą uważa, że jest do tego przymuszona okolicznościami: brakiem pracy lub groźbąjej utraty. Stosunek przedsięwzięć z chęci wykorzystania szansy oraz z konieczności, wynoszący 1,43, jest w Polsce najniższy spośród wszystkich badanych państw. Najlepsza pod tym względem sytuacja występuje w krajach skandynawskich, gdzie przedsięwzięcia wynikające z chęci wykorzystania szansy przeważają kilkunastokrotnie. ${ }^{1}$

Dlaczego decyzje o zakładaniu firm wynikające z chęci wykorzystania szans są tak istotne? Przedsiębiorczość z konieczności nie przynosi aż tak dobrych efektów, jak ta podejmowana z chęci wykorzystania szansy. Cechuje się niższym wskaźnikiem przetrwania oraz niższym potencjałem wzrostu. Silne oddziaływanie czynników wymuszających zachowania przedsiębiorcze jest w dużej mierze przyczyną niskiej jakości przedsięwzięć gospodarczych w Polsce.

${ }^{1}$ Global Entrepreneurship Monitor. 


\section{Regionalne zróżnicowanie aktywności gospodarczej}

Tab. 3. Współczynniki aktywności ekonomicznej ludności w Polsce według województw w 2004 r.

\begin{tabular}{|c|c|c|c|c|c|c|}
\hline \multirow[b]{2}{*}{ Województwo } & \multirow[b]{2}{*}{$\begin{array}{c}\text { Poziom } \\
\text { rozwoju } \\
\text { w 2002 r. } \\
(\mathrm{UE}=100)\end{array}$} & \multirow{2}{*}{$\begin{array}{l}\text { Ludność } \\
\text { w wieku } \\
\text { produk- } \\
\text { cyjnym } \\
\text { (w tys.) }\end{array}$} & \multirow[b]{2}{*}{$\begin{array}{c}\text { Stopa } \\
\text { bezrobocia } \\
\text { w } 2004 \text { r. }\end{array}$} & \multirow{2}{*}{$\begin{array}{c}\text { Wskaźnik } \\
\text { zatrudnienia } \\
\text { - liczba osób } \\
\text { zatrudnio- } \\
\text { nych na } 100 \\
\text { w wieku } \\
\text { 18-64 lat }\end{array}$} & \multicolumn{2}{|c|}{$\begin{array}{l}\text { Stopa zaangażowania* } \\
\text { w nowe przedsięwzięcia }\end{array}$} \\
\hline & & & & & $\begin{array}{l}\text { z koniecz- } \\
\text { ności }\end{array}$ & $\begin{array}{c}\text { z chęci } \\
\text { wykorzy- } \\
\text { stania } \\
\text { szansy }\end{array}$ \\
\hline Lubelskie & 32,0 & 1336,1 & 16,1 & 46,5 & 2,6 & 2,8 \\
\hline Podkarpackie & 32,6 & 1280,4 & 15,1 & 44,4 & 0,9 & 4,7 \\
\hline Warmińsko-mazurskie & 34,1 & 901,1 & 23,7 & 39,1 & 4,0 & 8,1 \\
\hline Podlaskie & 35,1 & 731,1 & 14,7 & 48,0 & 3,0 & 3,3 \\
\hline Świętokrzyskie & 35,7 & 795,3 & 20,4 & 42,4 & 4,5 & 6,1 \\
\hline Opolskie & 37,4 & 672,3 & 19,4 & 41,3 & 3,6 & 1,8 \\
\hline Małopolskie & 39,5 & 2018,4 & 16,8 & 47,2 & 3,0 & 10,2 \\
\hline Lubuskie & 39,9 & 1009,2 & 24,9 & 41,2 & 5,6 & 9,3 \\
\hline Łódzkie & 41,3 & 2592,6 & 18,8 & 43,9 & 3,7 & 5,1 \\
\hline Kujawsko-pomorskie & 41,6 & 1312,5 & 22,0 & 45,4 & 2,8 & 5,5 \\
\hline Zachodniopomorskie & 45,1 & 1098,2 & 23,8 & 41,5 & 0,7 & 5,6 \\
\hline Pomorskie & 45,5 & 1395,5 & 19,8 & 42,3 & 2,6 & 4,3 \\
\hline Wielkopolskie & 47,1 & 2144,2 & 17,2 & 47,5 & 1,1 & 8,5 \\
\hline Dolnośląskie & 47,4 & 1877,2 & 26,7 & 39,3 & 5,8 & 7,1 \\
\hline Śląskie & 50,6 & 3054,3 & 18,5 & 41,7 & 3,9 & 3,9 \\
\hline Mazowieckie & 69,5 & 3233,2 & 16,0 & 46,2 & 3,4 & 4,5 \\
\hline
\end{tabular}

* Stopa zaangażowania - liczba osób podejmujących działalność gospodarczą na 100 w wieku 18-64 lat

Biorąc pod uwagę etap zaangażowania w przedsięwzięcie gospodarcze, stwierdzono, że najwięcej osób starających się rozpocząć biznes jest w województwach najlepiej rozwiniętych. Najwięcej początkujących przedsiębiorców jest wśród mieszkańców województw na średnim poziomie rozwoju. Świadczy to o tym, że w latach 2001-2004 tam najczęściej podejmowano udane inicjatywy gospodarcze. Najwyraźniej starania mieszkańców tych województw częściej niż gdzie indziej skutkują faktycznym rozpoczęciem działalności, a jednocześnie większe są tam szanse utrzymania się na rynku. Najmniejsze zaangażowanie w nowe przedsięwzięcia gospodarcze wykazują mieszkańcy województw o niższym poziomie rozwoju, z wyjątkiem województw warmińsko-mazurskiego i świętokrzyskiego, charakteryzujących się wysokim bezrobociem. Zróżnicowanie regionalne przedsiębiorczości w Polsce pod względem poziomu rozwoju bądź dochodów ludności nie odpowiada relacjom występującym w porównaniach międzynarodowych. W krajach uboższych stwierdzany jest bowiem wyraźnie wyższy udział ludności zaangażowanej w inicjatywy gospodarcze w ogóle ludności niż w krajach zamożniejszych. Prawidłowość taka nie występuje w Polsce w układzie województw, ponieważ województwa: lubelskie, podkarpackie, 
podlaskie i opolskie, cechujące się niższym poziomem rozwoju, charakteryzują się jednocześnie niższymi wskaźnikami bezrobocia i wyższymi współczynnikami zatrudnienia. W szczególności województwa tzw. ściany wschodniej mają - paradoksalnie - zbliżone albo nawet lepsze wskaźniki dotyczące zatrudnienia i bezrobocia niż województwa na wyższym poziomie rozwoju. Województwa te cechuje, z jednej strony, niska industrializacja i w konsekwencji również mniejsze problemy strukturalne wynikające $\mathrm{z}$ restrukturyzacji przemysłu, a z drugiej strony - duże rozdrobnienie gospodarstw rolnych, a co za tym idzie, ukryte bezrobocie na wsi. Wskaźniki aktywności gospodarczej oszacowane dla tych województw są jednak zdecydowanie niekorzystne. Poziom zaangażowania w nowe przedsięwzięcia jest niski, a na dodatek w bardzo dużym stopniu wynika to z konieczności. Pod względem motywacji wyraźnie na korzyść wyróżnia się województwo wielkopolskie, a także małopolskie, które charakteryzują się wysokimi współczynnikami przedsiębiorczości z chęci wykorzystania szansy, kilkakrotnie wyższymi od współczynników obrazujących aktywność wymuszoną brakiem alternatywy. Jedynie w województwie opolskim stwierdzono przewagę czynników wymuszających nad przyciągającymi. Korelacja między poziomem bezrobocia a stopą zaangażowania w nowe przedsięwzięcia gospodarcze z konieczności jest wyraźna.

\section{Literatura}

1. Barańska B., Gierczyńska J., Szostek D., 2002, Przedsiębiorczość, Videograf Edukacja, Katowice

2. Podstawy nauki o przedsiębiorstwie, 2003, J. Lichtarski (red.), Wydawnictwo AE we Wrocławiu

3. Schumpeter J., 1960, Teorie rozwoju gospodarczego, PWN, Warszawa

4. Stańda B., Wierzbowska B., 2004, Badź przedsiębiorczy, Wydawnictwo Szkolne PWN, Warszawa

\section{Entrepreneurship in Poland in Regional Configuration}

Entrepreneurship is a process which proceeds in stages and is characterized by variable intensity. That is why we need methods and measurement instruments that help us to follow its image with precision and in particular stages. According the studies conducted by Global Entrepreneurship Monitor, two groups of people who are involved in a new economic enterprise, can be identified. The first group consists beginning entrepreneurs, active in developing of their companies run for 3-4 years. People from the second group are trying to start their business and independently or together with their partners undertake some definite activities (such as looking for location of the company, working out the strategy of their activity, looking for funds and business partners).

Basal measurement or so called coefficient of entrepreneurship (the engagement rate in a new economic enterprise) reckons sum of two indexes for two groups. In 2004 the entrepreneurship coefficient in Poland amounted 8,3\%. It means that among thousand Poles at the age of 18-64, almost 90 are involved in starting or developing their business. The value of this coefficient has increased to 1,6\% in comparison with the previous 2000/2001 years. The value of this entrepreneurship coefficient in Poland is high and is higher than similar one in Ireland, Norway, Israel, Great Britain, France, and Greece. Only such countries as Canada, Argentina, Australia and 
Brazil have higher value of the coefficient. Comparing the value of analyzed coefficient among the countries of European Union, only Ireland gets ahead Poland and at the same time there wasn't statistically essential difference between coefficient of value in Poland and Ireland. Among countries in political system transformation, except Poland, only Hungary had a high coefficient of value, however Croatia, Slovenia and Russia accepted the lowest value among European countries. 
Krzysztof Wiedermann

Zakład Geografii Ekonomicznej

Instytut Geografii

Akademia Pedagogiczna w Krakowie

\section{Regionalne efekty mnożnikowe rozwoju przemysłu motoryzacyjnego w aktywizacji gospodarczej województwa śląskiego}

Transformacja systemu społeczno-gospodarczego w Polsce po 1989 r. przełożyła się na zmiany w funkcjonowaniu gospodarki, w tym także na przestrzenną organizację produkcji. Powszechny jest pogląd, że okres ten w polskiej gospodarce charakteryzował się wzrostem zróżnicowań przestrzennych w skali międzyregionalnej. Struktura ukształtowana w warunkach gospodarki centralnie sterowanej nie uległa szybkim i radykalnym zmianom, a w polityce gospodarczej nie było miejsca dla polityki regionalnej (Kukliński 1991, Bagdziński, Maik 1994). Procesy gospodarcze zainicjowane po 1989 r. nasiliły zjawisko powstawania przestrzennych form koncentracji przedsiębiorstw działających w tej samej branży.

W sytuacji, gdy rozwój regionalny i lokalny po 1990 r. regulowany jest głównie przez mechanizmy rynkowe, ważna wydaje się odpowiedź na pytanie: Gdzie w przestrzeni regionu lokalizują się nowe i uważane za względnie innowacyjne przedsiębiorstwa produkcyjne branży motoryzacyjnej? Jest to szczególnie ważne na obszarze woj. śląskiego, które przechodzi głębokie przemiany związane z restrukturyzacją gospodarczą. Poznanie przyczyn lokalizacji i określenie zasięgu oddziaływania regionalnego przemysłu motoryzacyjnego pozwoli wskazać miejsca kumulowania się nowych korzyści rozwojowych, co jest ważne z perspektywy rozwoju tego obszaru. Przemysł motoryzacyjny ma tu szczególne znaczenie, gdyż jest uznawany za branżę, która obecnie przynosi najwięcej korzyści gospodarce lokalnej i regionalnej ze względu na najwyższe wskaźniki efektów mnożnikowych. Wynika to przede wszystkim z najbardziej rozbudowanej sieci powiązań, ukształtowanej dzięki znacznej wielkości produkcji i złożoności wyrobu, jaki stanowi samochód.

Obszar woj. śląskiego, ze względu na liczbę nowych zakładów dostarczających podzespoły samochodowe, zlokalizowanie w Gliwicach fabryki samochodów General Motors (GM) oraz rozwój dawnej FSM w Tychach i Bielsku-Białej po przejęciu jej przez Fiata, zaczęto nazywać zagłębiem motoryzacyjnym. Oprócz wymienionych fabryk samochodów działa tu wiele wytwórni części i podzespołów, w większości renomowanych marek światowych, wśród których najważniejszymi są: amerykański Delphi i TRW, japoński Isuzu, włoskie zależne od Fiata - Magneti Marelli i Teksid oraz Manuli Rubber, a także niemieckie koncerny Mahle i HP-Pelzer. Według danych Polskiej Agencji Inwestycji Zagranicznych firmy motoryzacyjne zainwestowały w tym regionie blisko 4 mld USD. Znaczna część inwestorów wybrała tereny należące do Katowickiej Specjalnej Strefy Ekonomicznej, a szczególnym zainteresowaniem cieszyły się obszary podstref tyskiej i gliwickiej. 


\section{Rozwój przemysłu motoryzacyjnego w województwie śląskim}

Rozwój przemysłu motoryzacyjnego na obszarze woj. śląskiego rozpoczął się stosunkowo późno. Pierwsze zakłady zaczęły się specjalizować w tej produkcji dopiero $\mathrm{w}$ drugiej połowie XX w. Przełomową inwestycją w tym zakresie było uruchomienie w Bielsku-Białej produkcji jednostek napędowych dla wytwarzanych w Fabryce Samochodów Osobowych na Żeraniu samochodów Syrena. Dalszy rozwój FSO spowodowany zakupem licencji na produkcję modelu Fiat 125 spowodował przeniesienie produkowanej tam Syreny do Bielska-Białej. Od tego momentu w woj. śląskim były wytwarzane samochody osobowe.

Dalszy rozwój przemysłu motoryzacyjnego na tym obszarze postępował bardzo szybko. Było to także związane z przejęciem władzy w Polsce po 1970 r. przez układ związany z wywodzącym się z tego terenu I Sekretarzem KC PZPR Edwardem Gierkiem. Należy pamiętać, że w okresie PRL najważniejszym czynnikiem lokalizacji nowych inwestycji i rozwoju przemysłu były decyzje polityczne. Już w 1971 r. podpisano umowę na zakup nowej licencji na samochód Fiat 126, który miał być montowany w Tychach, a bielskie zakłady WSM miały być dostawca jednostek napędowych. Decyzja o powstaniu tej fabryki (FSM) wiązała się z szeregiem korzyści dla gospodarki regionalnej. Nastąpił transfer nowoczesnych technologii do zakładów, które weszły w skład FSM, a także do ich kooperantów.

Rozbudowa tych zakładów miała bardzo duże znaczenie dla dalszego rozwoju przemysłu samochodowego. Wiele zmodernizowanych fabryk, także ta powstała od podstaw w Tychach, stanowi obecnie podstawę funkcjonowania największego producenta samochodów w kraju - Fiata Auto Poland (FAP).

Po przemianach gospodarczych przełomu lat 80. i 90. XX w. w Polsce, model centralnego zarządzania i związana z nim dominacja polityki w ekonomii ustąpiły mechanizmom rynkowym, co wpłynęło na funkcjonowanie przedsiębiorstw.

Łączny napływ nowych inwestycji do przemysłu motoryzacyjnego woj. śląskiego wyniósł w latach 1990-2005 prawie 5,7 mld USD (ryc. 1). Większość z tych inwestycji stanowiły nakłady w istniejące zakłady, a ich udział w łącznej wartości zainwestowanego w latach 1990-2004 kapitału wyniósł prawie $60 \%$ (ryc. 2). Wynikało to z dotychczasowego rozwoju tego przemysłu na terenie woj. śląskiego oraz szybkich przekształceń organizacyjnych i własnościowych, którym poddano tę branżę. Dzięki temu rozwinęła działalność zdecydowana większość istniejących tu wcześniej dużych przedsiębiorstw.

Na początku okresu transformacji łączna wielkość zatrudnienia w przedsiębiorstwach przemysłu motoryzacyjnego przekroczyła 24,3 tys. W końcu 2005 r. zatrudnienie osiagnęło prawie 43,2 tys. Podobnie jak w przypadku napływu inwestycji, wielkość zatrudnienia zaczęła rosnąć w drugiej połowie lat 90 . XX w. (ryc. 1). Spadek zatrudnienia w pierwszym okresie był związany ze zwiększeniem wydajności pracy w zakładach istniejących tu przed 1990 r., które weszły w okres transformacji z przerostem zatrudnienia. Dotyczyło to przede wszystkim firm, które wyrosły na bazie dawnych zakładów FSM. Zatrudnienie w tych zakładach było redukowane również w końcu lat 90. XX w. i na początku pierwszej dekady XXI w., ale napływ inwestorów, którzy generowali nowe miejsca pracy, znacznie przewyższał te redukcje. Sama tylko fabryka Fiat Auto Poland z zakładami w Bielsku-Białej i Tychach zmniejszyła zatrudnienie w okresie 1998 -2004 z poziomu przekraczającego 9,7 tys. do niespełna 3,7 tys. pracowników.

W świetle przedstawionej analizy rozwoju przemysłu motoryzacyjnego w latach transformacji gospodarki narodowej można wyróżnić dwa główne okresy przemian. Pierwszy - początek lat 90. XX w. - związany był głównie z restrukturyzacją i modernizacją przedsiębiorstw istniejących tu przed 1989 r. W drugiej połowie tej dekady nastapił gwałtowny wzrost inwestycji w nowe zakłady. Było to związane z powstaniem Katowickiej SSE i inwestycją General Motors na tym terenie. 
Ryc. 1. Skumulowana wartość inwestycji i wielkość zatrudnienia w przemyśle motoryzacyjnym woj. śląskiego w latach 1992-2005

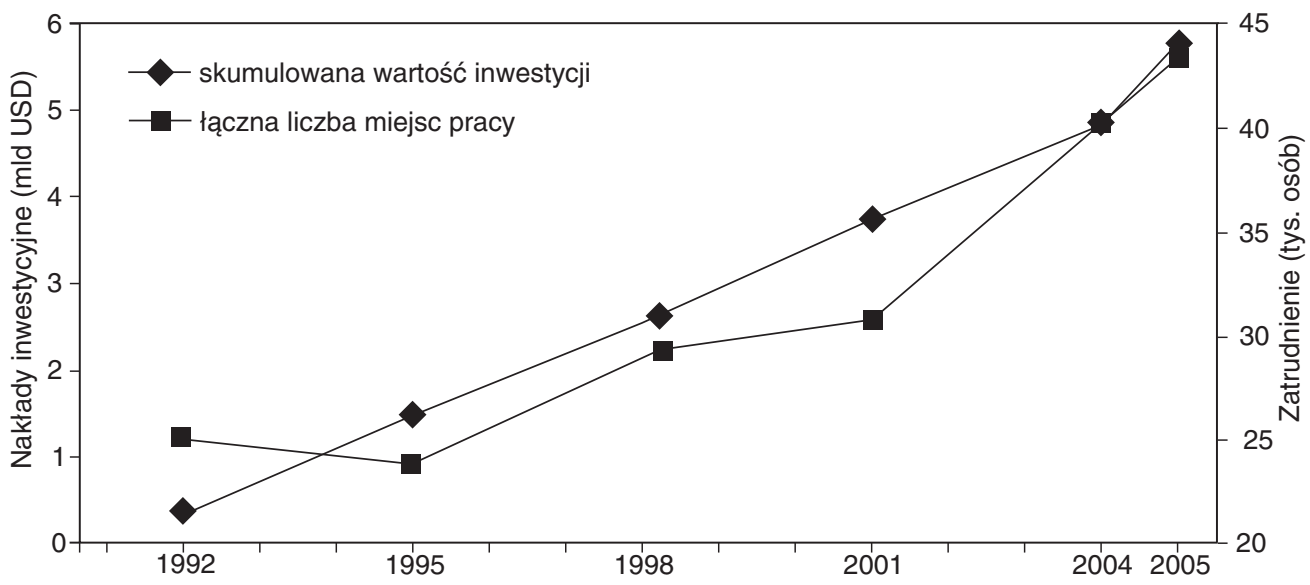

Źródło: opracowanie autora na podstawie wywiadów w przedsiębiorstwach

Ryc. 2. Struktura skumulowanych nakładów inwestycyjnych w przemyśle motoryzacyjnym woj. śląskiego w latach 1992-2004

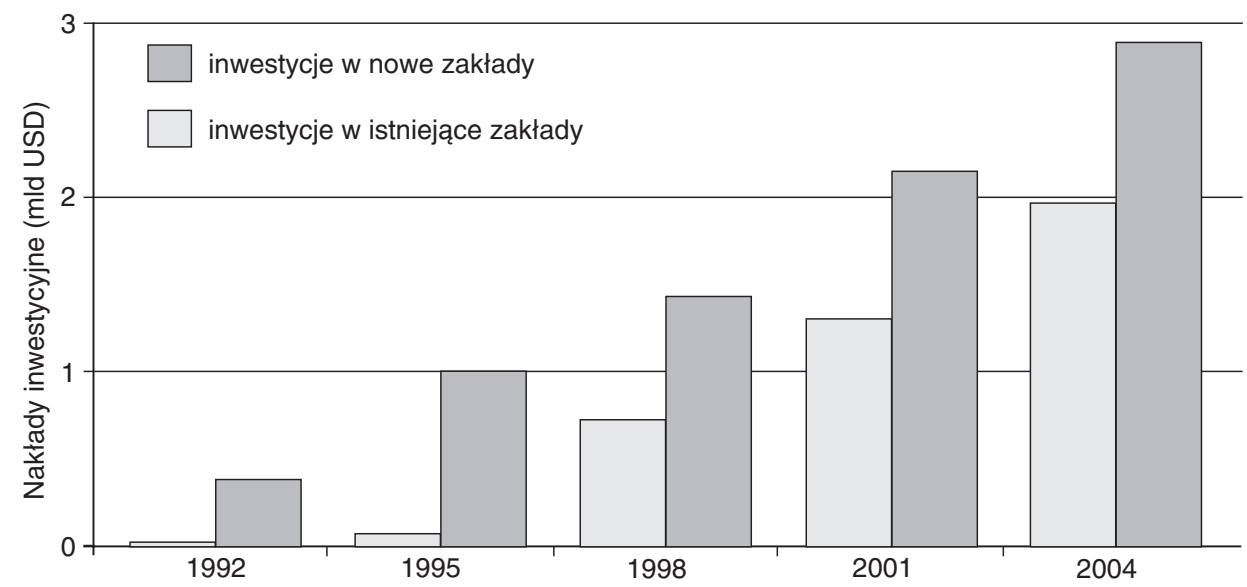

W niedługim okresie, przede wszystkim w Tychach, Gliwicach i Bielsku-Białej, powstało wiele nowych podmiotów, które zaczęły kooperować z zakładami FAP i GM.

Struktura przedsiębiorstw jest zróżnicowana pod względem wielkości podmiotów (ryc. 3), kraju pochodzenia kapitału (ryc. 4) i rodzaju prowadzonej działalności (ryc. 5). Pod względem zainwestowanego kapitału i zatrudnienia przeważają podmioty duże i bardzo duże. Jest to spowodowane specyfiką branży, w której przedsiębiorstwa znajdujące się w motoryzacyjnych łańcuchach dostaw cechuje bardzo duży wolumen produkcji. W strukturze własnościowej przeważają przedsiębiorstwa zagraniczne, w tym głównie firmy włoskie i amerykańskie. Jest to związane z pochodzeniem kapitału producentów samochodów, którzy na kooperantów wybierają często rodzime przedsiębiorstwa. 
Ryc. 3. Struktura wielkości przedsiębiorstw przemysłu motoryzacyjnego woj. śląskiego w 2004 r.

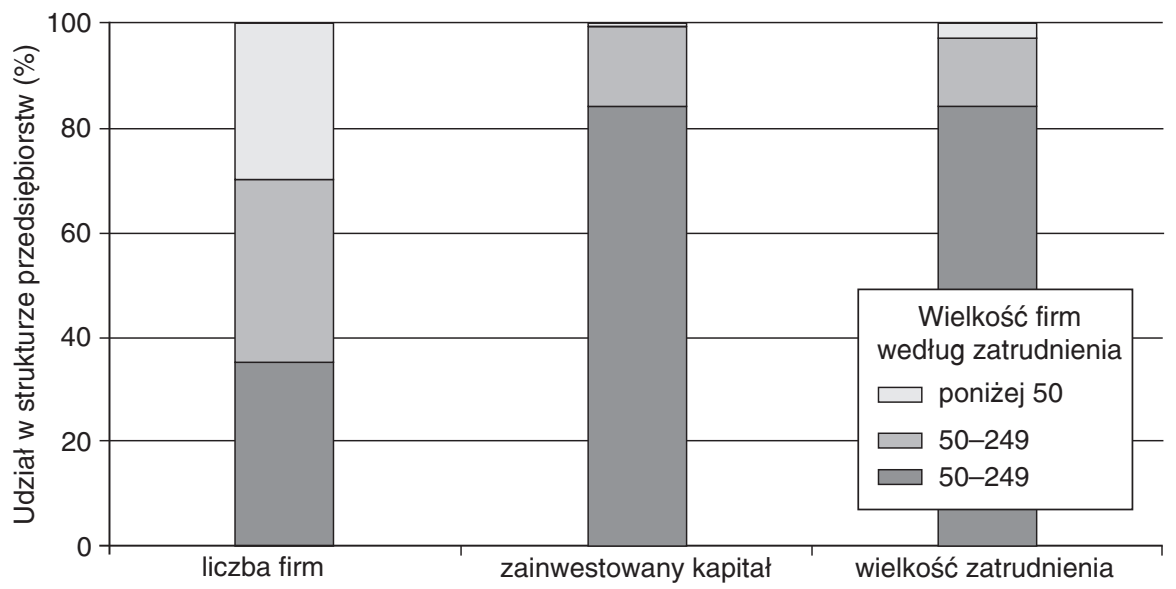

Źródło: opracowanie autora na podstawie wywiadów w przedsiębiorstwach

Ryc. 4. Wielkość i rozmieszczenie przedsiębiorstw motoryzacyjnych według pochodzenia kapitału

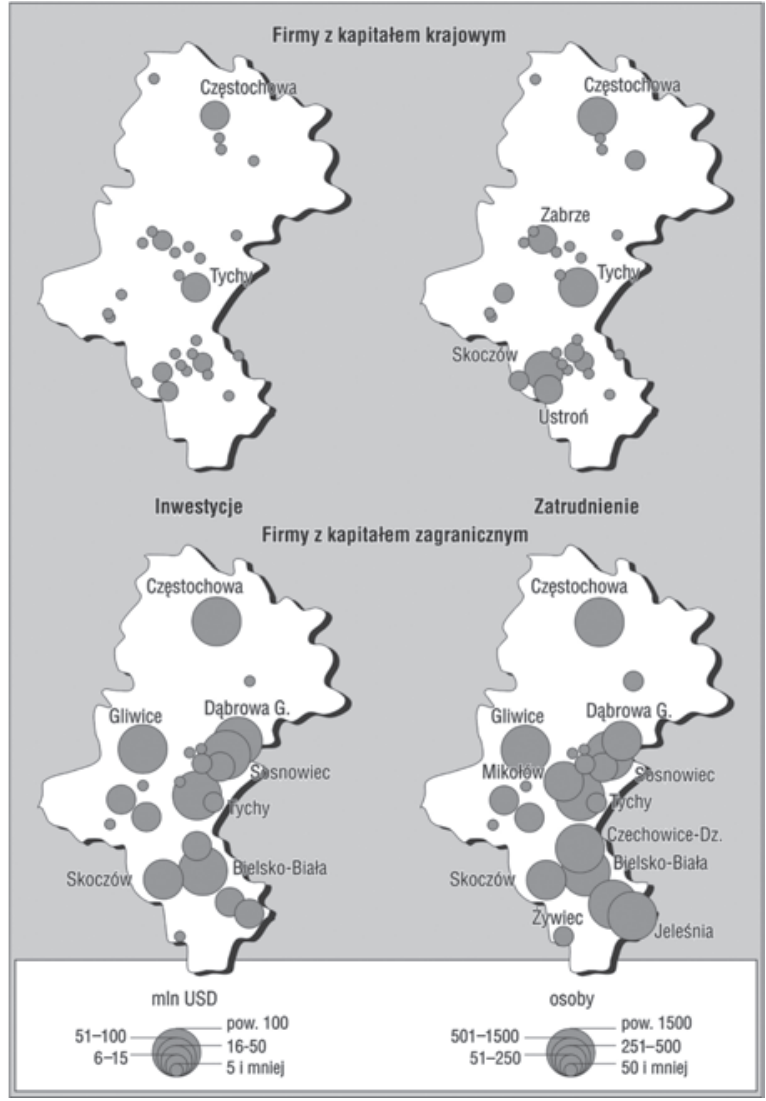

W rozmieszczeniu podmiotów z branży na terenie województwa widać wyraźną przestrzenną koncentrację. Zarówno pod względem zainwestowanego kapitału, jak i poziomu zatrudnienia najważniejszą rolę odgrywają trzy ośrodki miejskie - Tychy, Gliwice i Bielsko-Biała (ryc. 4). Wynika to z prowadzonej na ich terenie produkcji samochodów i jednostek napędowych. Tego typu inwestycje należą do najbardziej kapitałochłonnych, a zarazem generują największy popyt zaopatrzeniowy, który często jest realizowany w gospodarce lokalnej.

Źródło: opracowanie autora na podstawie wywiadów w przedsiębiorstwach 
Ryc. 5. Struktura branżowa przemysłu motoryzacyjnego w woj. śląskim

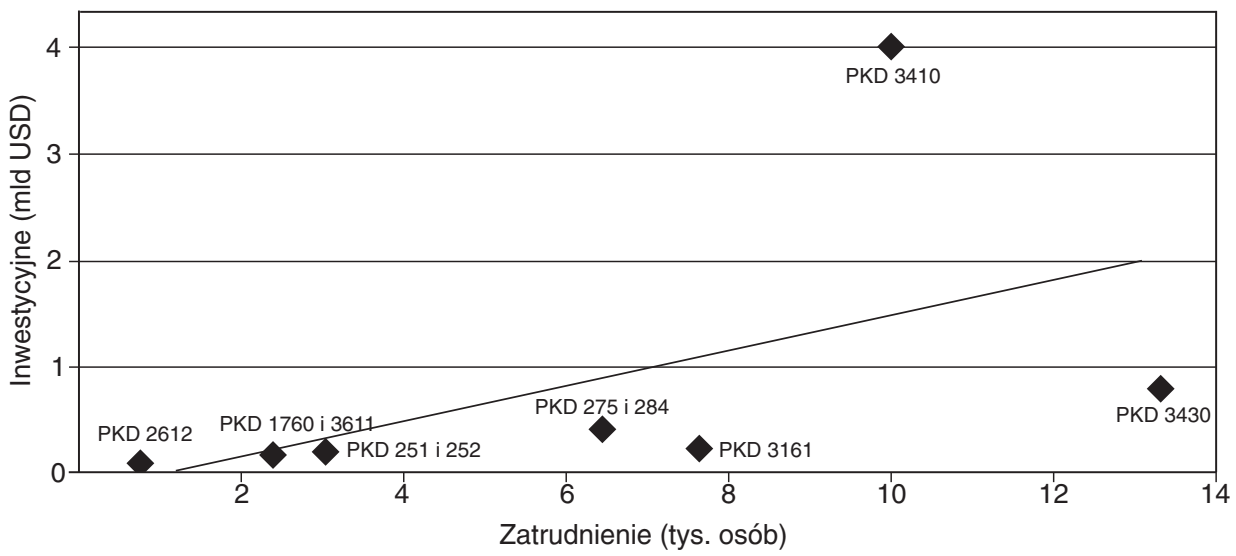

Źródło: opracowanie autora na podstawie wywiadów w przedsiębiorstwach

Oprócz produkcji samochodów i silników do samochodów ważną rolę pełni produkcja części samochodowych oraz metalowych wyrobów i elektrycznych komponentów motoryzacyjnych. W przypadkach tych rodzajów działalności (oprócz Tychów, Gliwic i Bielska-Białej) te zakłady pełnią rolę ważnych producentów w Częstochowie, Sosnowcu, Jeleśni, Czechowicach-Dziedzicach, Żywcu i Skoczowie.

Ryc. 6. Nakłady inwestycyjne i wielkość zatrudnienia w przedsiębiorstwach motoryzacyjnych woj. śląskiego według ośrodków

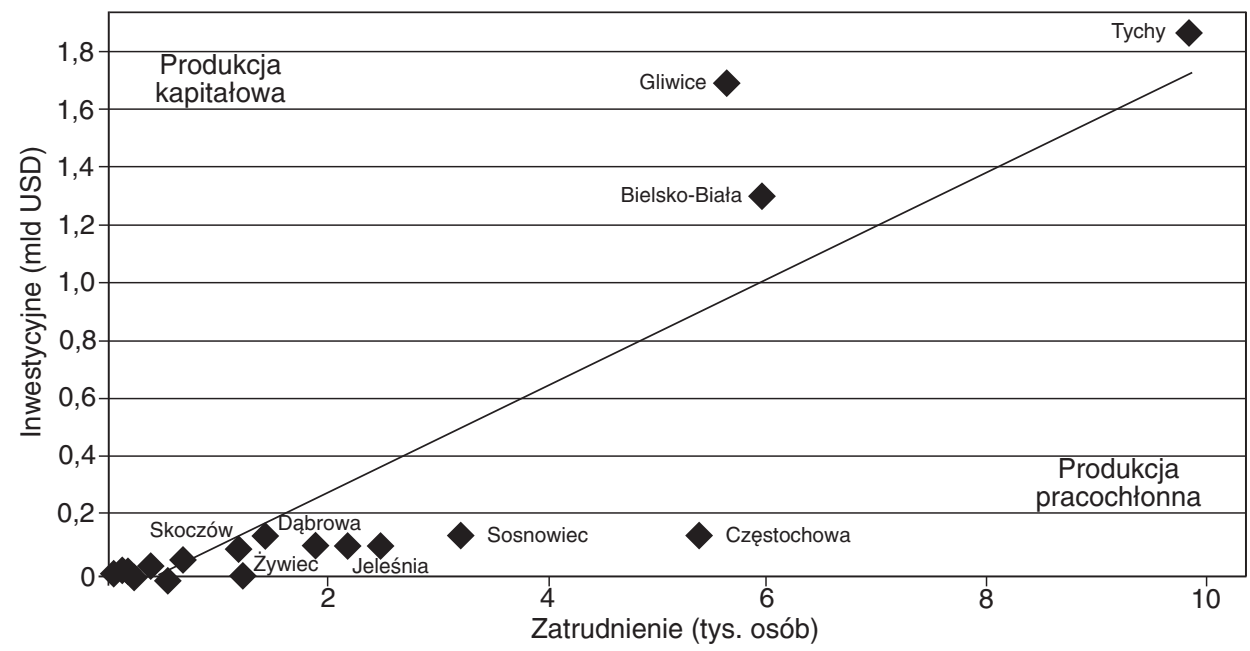

Źródło: opracowanie autora na podstawie wywiadów w przedsiębiorstwach

Metoda wyznaczania wpływu przedsiębiorstw na otoczenie - teoria efektów mnożnikowych

Od ponad dwudziestu lat wśród geografów przemysłu widoczny jest wzrost zainteresowań badawczych relacjami pomiędzy kształtowaniem się sieci firm w regionie a wpływem na jego rozwój (Hayter i Watts 1983, Scott i Storper 1987, Scott 1988, Dicken, Forsgreen i Malmberg 1994, Dicken i Malmberg 2001). Badania te skupiają się na procesach kształtowania relacji wewnątrz sieci firm, szczególnie w kontekście tworzenia przez nie dzielnic i aglomeracji przemysłowych. 
Spośród szerokich opracowań dotyczących czynników lokalizacji należy wymienić opracowanie H.D. Watts (1987). W ostatnim czasie powstało także kilka opracowań dotyczących powiązań przedsiębiorstw w skali regionalnej i lokalnej (m.in. Stryjakiewicz 2004, Domański, Gwosdz 2005), określanych terminem embeddedness, thumaczonym na język polski jako „zakorzenienie”.

Przedmiotem badań była wielokrotnie siła powiązań nowych dużych inwestorów zagranicznych, a z takimi mamy najczęściej do czynienia w branży przedsiębiorstw motoryzacyjnych, z ich otoczeniem w krajach Europy Środkowej i Wschodniej. W wyniku badań można stwierdzić, że zakorzenienie (embeddedness) lokalne tego typu inwestorów jest generalnie niewielkie. Została nawet w tym kontekście użyta metafora „katedr na pustyni” (Grabher 1994), mająca wyrażać słabe osadzenie nowych inwestycji przemysłowych w otoczeniu lokalnym i regionalnym wschodnich Niemiec, a tym samym ich niewielki wpływ na szerszy rozwój gospodarczy. Charakter izolowanej enklawy, pozbawionej istotnych powiązań z otoczeniem lokalnym, regionalnym, a nawet krajowym, przypisywany jest również niektórym inwestycjom w Polsce (np. Hardy 1998). Szersze badania nad funkcjonowaniem inwestorów zagranicznych w Polsce pokazująjednak znacznie bardziej złożony obraz ich relacji z otoczeniem, w tym powiązań usługowych i oddziaływania za pośrednictwem kadry i jej dochodów (Domański 2001, 2004; Domański, Gwosdz 2005; SobalaGwosdz 2000; Stryjakiewicz 2004).

Produkcja samochodów to dziedzina przemysłu, która w dużym stopniu oddziałuje na swoje otoczenie zewnętrzne. Wynika to ze znaczenia jej wyrobów końcowych, samochodów, dla funkcjonowania współczesnej gospodarki i społeczeństwa. Wartość jednostkowa samochodów oraz wolumen ich produkcji powoduje, że przemysł ten ma znaczący wpływ na gospodarkę poprzez generowane efekty mnożnikowe. Składają się na nie zarówno zapotrzebowanie na duże ilości komponentów do produkcji, jak i zapotrzebowanie na usługi. Przedsiębiorstwa tej branży należą też do ważnych pracodawców, mają więc znaczny wpływ na efekty mnożnikowe generowane poprzez dochody pracowników.

W celu przeanalizowania tego wpływu wyznaczono wskaźniki efektów mnożnikowych, które są generowane przez przedsiębiorstwa przemysłu motoryzacyjnego zlokalizowane w woj. śląskim.

Powstanie lub rozwój działalności gospodarczej na pewnym obszarze może prowadzić do wzrostu dochodów i zatrudnienia wielu innych przedsiębiorstw, a także zwiększenia wpływów podatkowych władz lokalnych. Wzrost ten jest określany mianem efektów mnożnikowych, a ich wielkość pozwala ocenić wpływ działalności przedsiębiorstwa na funkcjonowanie firm w jego otoczeniu.

Najczęściej rozpatruje się dwa podstawowe rodzaje efektów mnożnikowych: efekty zaopatrzeniowe i efekty dochodowe. Efekty zaopatrzeniowe wynikają z dodatkowego popytu tworzonego przez nowo powstałe lub rozwijające się przedsiębiorstwa, umożliwiającego wzrost firm będących dla nich dostawcami dóbr i usług (ryc. 7). Efekty dochodowe są skutkiem zwiększenia się siły nabywczej ludności poprzez wynagrodzenia pracowników; tym samym przyczyniają się one do rozwoju firm zaspokajających potrzeby konsumpcyjne (ryc. 8). W ten sposób rozwój jednych firm za pośrednictwem dodatkowego zapotrzebowania na produkty i usługi ,pomnaża się" w postaci rozwoju innych podmiotów gospodarczych. Podmioty te z kolei same stwarzają większy popyt, wywołując kolejne cykle efektów mnożnikowych.

Ponieważ firmy i ich pracownicy płacą podatki, rozwój firm zwiększa także dochody budżetu państwa oraz gmin i powiatów. Dotyczy to zarówno podatków od dochodów osób fizycznych i prawnych (PIT, CIT), jak i podatków od nieruchomości i środków transportu, które wpływają wyłącznie do budżetów gmin. Odprowadzane podatki mogą stać się z kolei źródłem inwestycji finansowanych z budżetu centralnego i prowadzonych na różnych szczeblach administracji samorządowej. 
Ryc. 7. Algorytm obliczania zaopatrzeniowych efektów mnożnikowych

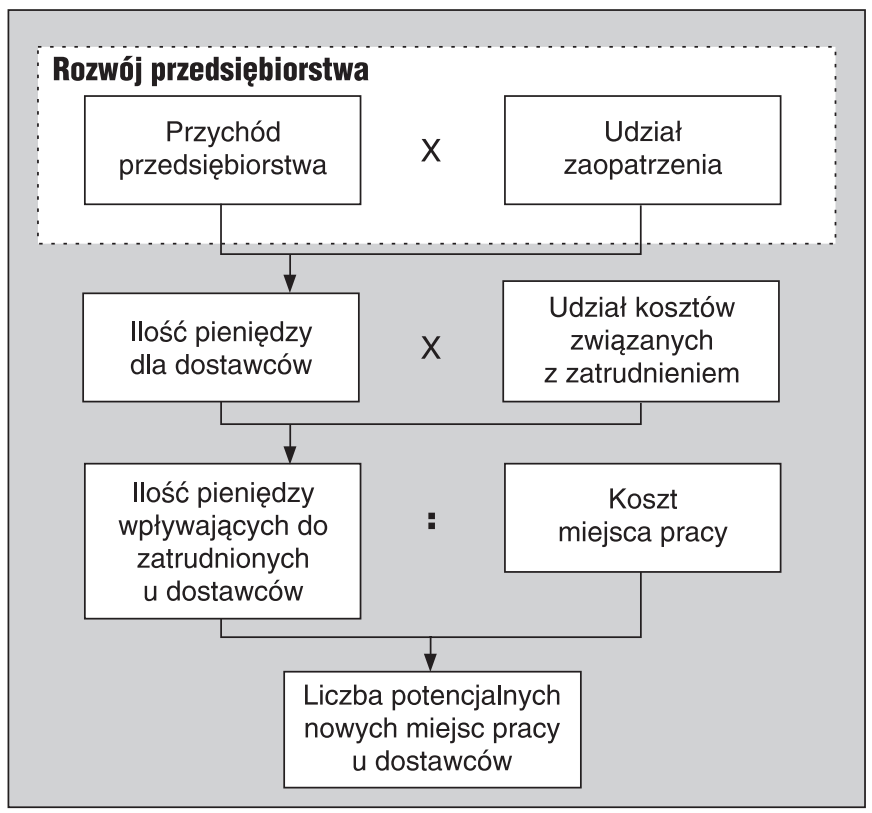

Źródło: opracowanie autora

Wielkość efektów mnożnikowych jest wyznaczana zawsze dla określonego przedziału czasu. Jeżeli pomiędzy dwoma przekrojami czasowymi wyznaczającymi daną jednostkę nastąpił rozwój określonych przedsiębiorstw, tak że wygenerowały one dodatkowy popyt konsumpcyjny bądź zaopatrzeniowy, efekty mnożnikowe są korzystne dla danej gospodarki, gdyż dzięki nim powstają na danym obszarze nowe miejsca pracy. Do obliczenia ilości miejsc pracy powstałych dzięki funkcjonowaniu przedsiębiorstw motoryzacyjnych poprzez proces efektów mnożnikowych konieczne jest wyznaczenie okresu, dla którego te efekty się oblicza. W badaniach przyjęto, że okres ten to czas od powstania przemysłu motoryzacyjnego na terenie obecnego woj. śląskiego do końca 2005 r. Założenie to pozwala przyjać, że liczba miejsc pracy wytworzona dzięki istniejącemu tu przemysłowi motoryzacyjnemu w końcu 2005 r. stanowi całość efektów mnożnikowych będących wynikiem rozwoju tego przemysłu.

Do zaopatrzeniowych efektów mnożnikowych należy dostawa surowców i materiałów produkcyjnych (zaopatrzeniowe produkcyjne efekty mnożnikowe) oraz świadczenie usług na rzecz przedsiębiorstwa (zaopatrzeniowe usługowe efekty mnożnikowe). W celu przeprowadzenia analizy przedsiębiorstw motoryzacyjnych znajdujących się na różnych szczeblach łańcucha dostaw, w produkcyjnych efektach zaopatrzeniowych uwzględniono dostawców półproduktów (np. stopy metali, granulaty tworzyw sztucznych), także pochodzących z przedsiębiorstw nieklasyfikowanych jako firmy motoryzacyjne, np. hut i zakładów chemicznych.

Pierwszą grupę dostawców stanowią producenci półwyrobów i komponentów wykorzystywanych do produkcji komponentów motoryzacyjnych i samochodów. Zalicza się do niej głównie firmy produkujące wyroby hutnicze, przemysłu metalowego i chemicznego. Wśród wyrobów wyodrębnia się następujące grupy materiałów:

- stopy metali przeznaczane dla odlewni i kuźniczych zakładów motoryzacyjnych,

- blachę służącą do wyrobu wytłoczek,

- rury i kształtowniki służące do wytwarzania konstrukcji i urządzeń, 
- wyroby przemysłu metalowego mające zastosowanie uniwersalne, np. elementy złączne (śruby, nakrętki, podkładki) czy sprężyny,

- granulaty tworzyw sztucznych dla zakładów wytwarzających wyroby z tych tworzyw,

- mieszanki gumy dla zakładów wytwarzających elementy gumowe,

- inne wyroby przemysłu chemicznego, np. farby, lakiery i kleje,

- tkaniny oraz skóry do produkcji elementów tapicerowanych (np. fotele) i niektórych urządzeń (np. pasy bezpieczeństwa),

- wyroby przemysłu elektrycznego i elektronicznego np. półprzewodniki, przełączniki, żarówki.

Ryc. 8. Algorytm obliczania dochodowych efektów mnożnikowych

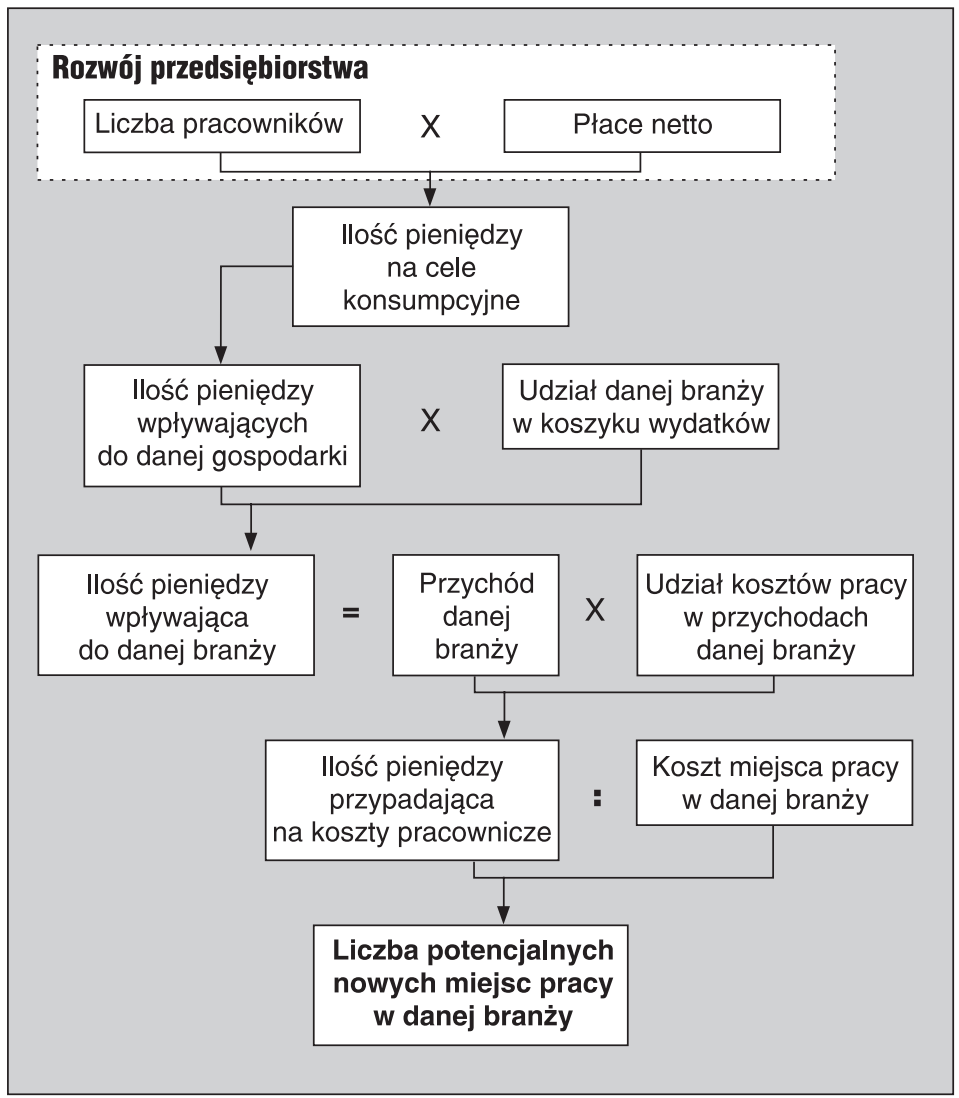

Źródło: opracowanie autora

Większość spośród tych materiałów i komponentów przeznaczanych bezpośrednio do produkcji jest nabywana przez przedsiębiorstwa spoza granic nie tylko woj. śląskiego, ale i Polski. U podłoża tego zjawiska leżą dwie przyczyny. Po pierwsze, najważniejsze surowce produkcyjne są kupowane przez koncerny na poziomie centralnym. Oznacza to, że działające tu międzynarodowe korporacje starają się je nabywać poprzez swoje główne siedziby dla wszystkich oddziałów produkcyjnych działających w danej części świata (np. w Europie). Z ich punktu widzenia przynosi to dwie ważne korzyści - korzyści skali, gdyż łatwiej wynegocjować korzystne kontrakty na zakup surowców bądź półwyrobów dla kilku czy kilkunastu firm jednocześnie, a także powtarzalnąjakość i rodzaj wyrobu (np. odcień lakieru czy faktura tapicerki od dwóch dostawców najczęściej się różni). Drugą przyczyną dużego importu materiałów produkcyjnych jest niewielka liczba 
zlokalizowanych w Polsce przedsiębiorstw, które mogłyby podjąć się produkcji na taką skalę, aby wytwarzane przez nie wyroby stanowiły wsad produkcyjny nie tylko dla krajowych firm motoryzacyjnych, ale także dla wszystkich oddziałów danego koncernu zlokalizowanych w Europie.

W zakresie zaopatrzeniowych efektów mnożnikowych wyznaczono grupę usług, z których potencjalnie mogą korzystać przedsiębiorstwa. Należą do nich następujące rodzaje usług świadczonych na rzecz firm motoryzacyjnych:

- usługi transportowe,

- sprzątanie i utrzymanie ruchu,

- wykonywanie narzędzi i serwisowanie urządzeń,

- ochrona,

- usługi w zakresie projektowania i prace badawcze,

- usługi prawne,

- usługi finansowe,

- usługi informatyczne,

- usługi w zakresie szkolenia pracowników.

W przeciwieństwie do dostaw materiałów i surowców produkcyjnych, popyt na usługi jest realizowany na znacznie węższym obszarze. Powoduje to większe domknięcie lokalne i regionalne usługowych efektów mnożnikowych. Jednak w przypadku usług istnieje również pewne zróżnicowanie zasięgu świadczeń w zależności od rodzaju działalności. W skali lokalnej najczęściej zaspokajany jest popyt na usługi podstawowe, do których można zaliczyć ochronę i sprzątanie. Jest to spowodowane kilkoma czynnikami. Po pierwsze, pracownicy tego typu firm nie muszą wykazywać się specjalistycznym wykształceniem i umiejętnościami, łatwo ich zatem pozyskać nawet na obszarach peryferyjnych. Drugim uwarunkowaniem są niskie płace, na jakie mogą liczyć pracownicy tych sektorów. Często wahają się one wokół najniższego dopuszczalnego prawem wynagrodzenia, przez co koszty związane z dojazdami na większe odległości stanowią barierę opłacalności podjęcia takiej pracy. W przypadku usług specjalistycznych, takich jak usługi księgowe, prawne czy projektowo-badawcze, widać wyraźną koncentrację tych podmiotów na obszarach większych ośrodków miejskich. Rodzajem działalności gospodarczej, który najbardziej zyskuje na rozwoju w wyniku kooperacji z przemysłem motoryzacyjnym, jest transport. Wynika to z dużego wolumenu dostaw, wielkości komponentów oraz dużych dystansów, na których często odbywa się przemieszczanie towarów. Generalnie, widoczne są dwa główne rodzaje powiązań transportowych pomiędzy samymi firmami motoryzacyjnymi, a także pomiędzy ich kooperantami. Część firm, które są zlokalizowane w tzw. parkach dostawców albo działają w pobliżu swoich odbiorców - głównie producentów samochodów - prowadzi regularną, kilkakrotną w ciągu jednego dnia wysyłkę wytwarzanych komponentów. Przed załadunkiem są one pakowane w odpowiedniej sekwencji, tak aby ich rozładunek odbywał się bezpośrednio na linię produkcyjną. Tego typu wysyłki wystarczają najczęściej na kilka godzin cyklu produkcyjnego, więc po upływie tego czasu konieczny jest następny transport. Przy wysyłce towaru na większe odległości odbywa się to często poprzez magazyny zlokalizowane w pobliżu odbiorcy. Funkcją takiego magazynu, oprócz gromadzenia zapasu, jest przygotowywanie towarów w odpowiednich grupach sekwencyjnych przed ich dalszą wysyłką na linie produkcyjne. Towary transportowane są z magazynu do odbiorcy w sposób opisany wyżej. Transport może być świadczony na zlecenie zarówno dostawcy, jak i odbiorcy; jest to zależne od zapisów w kontraktach. Z analizy świadczonych usług transportowych w tej branży przemysłu wynika, że są one częścią szerszego procesu, jakim jest logistyka. Firmy świadczące te usługi, oprócz przewozu dóbr, często obsługują także magazyny, w których prowadzą konfekcjonowanie wyrobów. 
Przemysł motoryzacyjny w woj. śląskim stanowi także istotny czynnik rozwoju gospodarki lokalnej poprzez dochodowe efekty mnożnikowe pracowników, zarówno ze względu na wielkość łącznego zatrudnienia, jak i wysokość płac. Duzi pracodawcy przemysłowi, szczególnie inwestorzy zagraniczni, oferują z reguły wyższe płace niż małe i średnie firmy, a większość zatrudnionych w tej branży pracuje właśnie w zakładach tego typu podmiotów. Wielkość oferowanych płac jest jednak silnie związana z branża, co wynika przede wszystkim z wymogów dotyczących kwalifikacji siły roboczej. W przypadku przemysłu motoryzacyjnego najwyższe płace są w fabrykach samochodów i silników (PKD 34.10), zakładach produkujących części i komponenty dla motoryzacji (PKD 34.30) oraz w firmach zajmujących się produkcją elementów metalowych na potrzeby motoryzacji (PKD 27.5 i 28.4). Najniższe płace są w dziedzinach najbardziej pracochłonnych, do których należą przede wszystkim produkcja wiązek elektrycznych (PKD 31.61) i produkcja wyrobów z tkanin, np. wyrobów tapicerskich (PKD 17.60). Należy podkreślić, że miejsca pracy generowane poprzez efekty dochodowe charakteryzują się największym domknięciem lokalnym.

Liczba miejsc pracy powstałych poprzez poszczególne rodzaje efektów mnożnikowych generowanych przez śląskie przedsiębiorstwa motoryzacyjne, obliczona według procedur przedstawionych na powyższych algorytmach (ryc. 7 i 8), wynosi przynajmniej 13 tys. Na tę wartość składa się 1009 miejsc pracy wynikających bezpośrednio i pośrednio z zaopatrzenia produkcyjnego firm motoryzacyjnych, 6443 miejsca pracy powstałe dzięki zaspokajaniu w regionie zapotrzebowania na usługi oraz 5613 miejsc pracy utworzonych dzięki popytowi konsumpcyjnemu pracowników firm motoryzacyjnych.

\section{Podsumowanie}

Dla dalszego rozwoju tego przemysłu bardzo ważną kwestią jest rozwój zakładów zajmujących się montażem samochodów. To właśnie dzięki nim kształtuje się sieć powiązań kooperacyjnych wynikających z największego zapotrzebowania tych przedsiębiorstw na dostawy. Dzięki tym firmom następuje także największy transfer wiedzy i technologii do innych dziedzin przemysłu.

Zarówno Fiat Auto Poland, jak i General Motors Poland są najlepszymi oddziałami w ramach swoich koncernów pod względem wydajności pracy, jakości wyrobów i wyników finansowych. Te cechy powoduja, że nowe projekty samochodów często trafiają do dalszej produkcji właśnie w polskich zakładach. W przypadku gliwickiego GM jest to pozyskany niedawno nowy model Zafiry, a FAP po sukcesie produkcyjnym nowego modelu Pandy zamierza uruchomić produkcję nowego modelu Fiata 500 i wspólnie z Fordem uruchamia w Tychach produkcję nowego modelu forda Ka. W najbliższym okresie można się więc spodziewać wzrostu wielkości produkcji w obu zakładach, co przełoży się na wzrost zapotrzebowania na dostawy i przyczyni do dalszego rozwijania zakładów kooperantów.

Sytuacja większości dostawców jest podobna do sytuacji producentów samochodów. Dobre wyniki odbiorców i duże zapotrzebowanie na wyroby przekładają się na wzrost zamówień. Sprzyja to osiaganiu lepszych wyników, a jest to najważniejszy czynnik przy podejmowaniu decyzji przez centrale koncernów o przyznawaniu nowych projektów. W ten sposób kooperanci GM i Fiata coraz częściej pozyskują także nowe zamówienia od podmiotów zlokalizowanych nie tylko poza granicami województwa, ale także kraju.

\section{Literatura}

1. Bagdziński S., Maik W., 1994, Determinants of regional and spatial policy in the period of system transformation [w:] R. Domański, E. Judge (red.), Changes in the regional economy in the period of system transformation, Wydawnictwo Naukowe PWN, Warszawa 
2. Dicken P., Forsgreen M., Malmberg A., 1994, Local embeddedness and transnational corporations [In:] A. Amin, N. Thrift (eds), Globalisation, institutions and regional development in Europe, Oxford University Press, Oxford

3. Dicken P., Malmberg A., 2001, Firms in territories: a relational perspective, Economic Geography, Clark University, Worcester

4. Domański B., 2001, Kapitat zagraniczny w przemyśle Polski, Instytut Geografii i Gospodarki Przestrzennej, Uniwersytet Jagielloński, Kraków

5. Domański B., 2004, Local and regional embededdness of foreign industrial investors in Poland, „Prace Geograficzne", Instytut Geografii i Gospodarki Przestrzennej, Uniwersytet Jagielloński, Kraków

6. Domański B., Gwosdz K., Huculak M., Wiedermann K., 2005, Oddziaływanie SSE Euro-Park Mielec na otoczenie lokalne. Powiqzania firm i efekty mnożnikowe [w:] Dziesięć lat doświadczeń pierwszej polskiej specjalnej strefy ekonomicznej, Mielec 1995-2005, Instytut Geografii i Gospodarki Przestrzennej Uniwersytet Jagielloński i Agencja Rozwoju Przemysłu, Oddział Mielec, Kraków

7. Dziesięć lat doświadczeń pierwszej polskiej specjalnej strefy ekonomicznej. Mielec 1995-2005, 2005, B. Domański., K. Gwosdz (red.), Instytut Geografii i Gospodarki Przestrzennej, Uniwersytet Jagielloński i Agencja Rozwoju Przemysłu, Oddział Mielec, Kraków

8. Grabher G., 1994, The disembedded regional economy: the transformation of East German industrial complexes into western enclaves [In:] A. Amin, N. Thrift (eds) Globalization, institutions and regional development in Europe, Oxford University Press, Oxford

9. Hardy J., 1998, Cathedrals in the desert? Transnationals, corporate strategy and locality in Wroctaw, Regional Studies, 32, Routledge, London

10. Hayter R., Watts H.D., 1983, The geography of enterprise: a reappraisal, Progress in Human Geography, 7, Arnold, London

11. Kukliński A., 1991, Restrukturyzacja regionów jako problem wspótpracy europejskiej [w:] A. Kukliński, B. Jałowiecki (red.), Restrukturyzacja regionów jako problem wspótpracy europejskiej, t. 1, Studia Regionalne i Lokalne, 1 (34), Uniwersytet Warszawski, Warszawa

12. Scott A.J., 1988, New industrial space: flexible production and regional economic development in the USA and Western Europe, Pion, London

13. Scott A.J., Storper M., 1987, High technology industry and regional development: a theoretical critique and reconstruction, International Social Science Journal, 112, UNESCO, Paris

14. Sobala-Gwosdz A., 2000, The influence of large manufacturing firmson the local development of Jarostaw in the 1990s [w:] T. Marszał (red.), Local eceonomy and urban development of Poland, Wydawnictwo Uniwersytetu Łódzkiego, Łódź

15. Watts H.D., 1987, Industrial geography, John Wiley, New York

16. Wplyw inwestorów zagranicznych na rozwój regionalny i lokalny, 2004, T. Stryjakiewicz. (red.), Bogucki Wydawnictwo Naukowe, Poznań

\section{Regional Factor Effects of the Growth in Auto Industry as the Economic Activators in Silesian Province}

The goal of this article is to present the change in the economic structure of Silesian Province based on the growth in auto industry that, because of its wide partners relations and because it has a lot of plants, it introduces very big factor effects in local and regional environment. Results of the research confirm the important role of auto industry in economic development of Silesian Province. 


\section{Krzysztof Wach}

Katedra Przedsiębiorczości i Innowacji

Uniwersytet Ekonomiczny w Krakowie

\section{Potencjał małych i średnich przedsiębiorstw regionu południowego}

Przedsiębiorczość w Polsce jest zróżnicowana regionalnie. Ogromna większość małych i średnich przedsiębiorstw działa w pięciu województwach (mazowieckim, śląskim, wielkopolskim, dolnośląskim, małopolskim). W ujęciu regionów statystycznych stworzonych na potrzeby europejskiej nomenklatury statystycznej, region południowej Polski jest jednym z liderów pod względem wskaźnika przedsiębiorczości. Dotychczas brak jest zarówno analiz przekrojowych w tej mierze, jak i porównawczych w ujęciu regionalnym (czyli według klasyfikacji NUTS-1, a nie w ujęciu województw zgodnie z klasyfikacją NUTS-2). Spowodowane jest to sztucznym podziałem Polski na sześć dużych regionów statystycznych. Interesujące jednak wydaje się sporządzenie takiej analizy, celem artykułu jest zatem diagnoza sytuacji społeczno-ekonomicznej regionu południowego (region II według klasyfikacji NUTS-1) z uwzględnieniem stanu i tendencji rozwoju małych i średnich przedsiębiorstw w ujęciu dynamicznym.

\section{Struktura społeczno-ekonomiczna regionu południowego ${ }^{1}$}

Region południowy został wyróżniony dla potrzeb nomenklatury statystycznej 1.05.2004 r. (z dniem wejścia Polski do Unii Europejskiej) na mocy rozporządzenia Rady Ministrów RP (Rozporzq̨dzenie..., 2004). Obejmuje on dwa województwa: małopolskie i śląskie; siedem podregionów (trzy w woj. małopolskim: krakowsko-tarnowski, miasto Kraków, nowosądecki oraz cztery w woj. śląskim: częstochowski, centralny śląski, rybnicko-jastrzębski i bielsko-bialski); 36 powiatów (19 w woj. małopolskim i 17 w woj. śląskim) oraz 349 gmin (182 w woj. małopolskim i 167 w woj. śląskim).

W regionie powstały ośrodki szczególnej koncentracji przedsiębiorczości prywatnej (małych i średnich przedsiębiorstw prywatnych), przy jednoczesnym zacofaniu ośrodków peryferyjnych (Dębski 2002a, 2002b). Na podstawie wyników badań J. Dębskiego, w regionie południowym można wyróżnić lokalne i regionalne ośrodki wzrostu przedsiębiorczości prywatnej (Dębski 2002a). W tym regionie autor wyróżnia 5 regionalnych ognisk wzrostu przedsiębiorczości prywatnej ( 2 w woj. małopolskim: Kraków, Tarnów oraz 3 w woj. śląskim: Częstochowa, Bielsko-Biała oraz konurbacja górnośląska: Katowice, Gliwice, Sosnowiec, Zabrze, Bytom, Tychy, Rybnik, Dąbrowa Górnicza, Chorzów) oraz 5 lokalnych biegunów wzrostu przedsiębiorczości prywatnej (1 w woj. małopolskim: Spytkowice oraz 4 w woj. śląskim: Jejkowice, Starcza, Ślemień, Krupski Młyn). W 2003 r. Centrum Badań Regionalnych w Warszawie sporząadziło ranking potencjału rozwojowego miast polskich, którym objęto 839 miast, zgodnie z kryteriami OECD w zakresie gęstości

\footnotetext{
${ }^{1}$ Profil społeczno-ekonomiczny regionu południowego sporządzono głównie na podstawie danych statystycznych GUS (zarówno publikowanych, jak i udostępnionych na zamówienie). Wykorzystano także publikacje Centrum Badań Regionalnych w Warszawie, Instytutu Badań nad Gospodarką Rynkową w Gdańsku, Urzędu Marszałkowskiego Województwa Małopolskiego oraz Urzędu Marszałkowskiego Województwa Śląskiego. Przytaczane dane, jeśli nie wskazano inaczej, odnoszą się do 2004 r.
} 
zaludnienia (Wielki Ranking... 2003). W regionie południowym znajduje się aż 29 miast o największym w Polsce potencjale rozwojowym, z których 9 zaklasyfikowano jako ,ekstraklasa” (6 w woj. małopolskim, pozostałe 3 w woj. śląskim), 20 miast jako ,pierwsza klasa” (13 w woj. małopolskim, 8 w woj. śląskim $)^{2}$. Dominującą pozycję w woj. małopolskim odgrywa Kraków, który jest nie tylko regionalnym, ale i krajowym ogniskiem wzrostu, które oddziałuje na sąsiednie województwa, zwłaszcza w zakresie szkolnictwa wyższego oraz działalności naukowo-badawczej i kulturalnej (Dębski 2002a). W woj. śląskim decydujące znaczenie odgrywa konurbacja górnośląska (z Katowicami na czele), a także Częstochowa oraz Bielsko-Biała. O ile regionalne ogniska wzrostu są jednoznacznie określone, o tyle lokalne bieguny wzrostu nie są zbyt silnie wyodrębnione. Rozwój gmin peryferyjnych pozostaje w tyle (niekiedy daleko) za ośrodkami o znaczeniu regionalnym (konurbacja górnośląska w woj. śląskim oraz Kraków w woj. małopolskim).

W ujęciu sześciu regionów najwyższą ocenę atrakcyjności inwestycyjnej w Polsce w $2005 \mathrm{r}$. uzyskał region południowy (region centralny znalazł się na 2 pozycji) w świetle badań nad przestrzennym zróżnicowaniem atrakcyjności inwestycyjnej Polski prowadzonych od $1994 \mathrm{r}$. przez Instytut Badań nad Gospodarką Rynkową w Gdańsku (Atrakcyjność... 2005). Do najwyższej klasy atrakcyjności inwestycyjnej w przekroju województw zaszeregowane zostały (oprócz woj. mazowieckiego - klasa A, ranga 2) zarówno woj. śląskie (klasa A, ranga 1), jak i małopolskie (klasa A, ranga 3). Najwyższe oceny uzyskały takie cechy cząstkowe (por. tab. 1), jak zasoby i koszty pracy, dostępność transportowa, poziom rozwoju infrastruktury gospodarczej, poziom rozwoju infrastruktury społecznej (woj. śląskie uzyskało dodatkowo najwyższą ocenę w kryterium chłonności wojewódzkiego rynku zbytu). Bardzo interesujące są również klasyfikacje przestrzenne regionu. Trzy podregiony regionu południowego charakteryzują się najwyższą w Polsce

Tab. 1. Ocena atrakcyjności inwestycyjnej regionu południowego w 2005 r.

\begin{tabular}{|l|c|c|c|}
\hline \multicolumn{1}{|c|}{ Kryterium cząstkowe $^{1}$} & $\begin{array}{c}\text { Region } \\
\text { południowy }\end{array}$ & Woj. małopolskie & Woj. śląskie $^{\text {(n) }}$ \\
\hline Dostępność transportowa & A & A & A \\
\hline Zasoby i koszty pracy & A & A & A \\
\hline Chłonność rynku zbytu & A & B & A \\
\hline Infrastruktura gospodarcza & A & A & A \\
\hline Infrastruktura społeczna & A & A & A \\
\hline Poziom bezpieczeństwa powszechnego & D & D & E \\
\hline Aktywność wobec inwestorów & B & B & C \\
\hline Ogólna atrakcyjność inwestycyjna $^{3}$ & A & A & A \\
\hline
\end{tabular}

${ }^{1}$ Do ewaluacji zastosowano pięć klas (A-E, spośród których A jest najlepsza) oraz szesnaście rang.

${ }^{2}$ Oceny dla regionu stanowią średnią rang i klas dla woj. małopolskiego i woj. śląskiego.

${ }^{3}$ Ocena ogólna jest wypadkową wartości wskaźników cząstkowych.

Źródło: opracowanie autora na podstawie: Atrakcyjność inwestycyjna województw i podregionów Polski 2005, 2005, T. Kalinowski (red.), Instytut Badań nad Gospodarką Rynkową, Gdańsk

\footnotetext{
${ }^{2}$ Syntetyczny wskaźnik potencjału rozwojowego miast został skonstruowany przez Centrum Badań Regionalnych w Warszawie na podstawie czterech czynników cząstkowych: aktywność gospodarcza, aktywność obywatelska, infrastruktura miejska, przyciagganie nowych mieszkańców.
} 
atrakcyjnością inwestycyjną dla działalności przemysłowej. Są to centralny śląski (pozycja 1), rybnicko-jastrzębski (pozycja 2), krakowsko-tarnowski łącznie z miastem Kraków (pozycja 3). Podregion bielsko-bialski znalazł się na piątym miejscu. W pierwszej piątce rankingu atrakcyjności inwestycyjnej dla działalności usługowej znalazły się aż trzy podregiony wchodzące w skład regionu południowego: centralny śląski (pozycja 2), krakowsko-tarnowski łącznie z miastem Kraków (pozycja 4) oraz bielsko-bialski (pozycja 5), a podregion częstochowski znalazł się na ósmym miejscu. Również trzy podregiony zostały uznane za jedne z najbardziej atrakcyjnych inwestycyjnie dla działalności zaawansowanej technologicznie: centralny śląski (pozycja 3), krakowsko-tarnowski łącznie z miastem Kraków (pozycja 4) oraz bielsko-bialski (pozycja 6).

Zgodnie z planami rozwoju województw małopolskiego i śląskiego, w regionie południowym można wyodrębnić kilka obszarów strategicznego rozwoju. Na podstawie szczegółowej diagnozy w woj. małopolskim wyróżniono trzy obszary rozwojowe: obszar rozwoju rolnictwa (północny); obszar intensywnego rozwoju gospodarczego (środkowy, wokół istniejącej i planowanej autostrady A4); obszar rozwoju turystyki (południowy). Analogicznie w woj. śląskim wyodrębniono cztery obszary polityki rozwoju województwa: obszar rozwoju rolnictwa (północny, wokół aglomeracji częstochowskiej); obszar rozwoju turystyki (południowy, wokół aglomeracji bielskiej) oraz dwa obszary intensywnego rozwoju gospodarczego (środkowy oraz zachodni), przy czym obszar środkowy (wokół aglomeracji górnośląskiej) cechuje się zróżnicowaniem funkcji rozwoju cywilizacyjnego i gospodarczego, zrestrukturyzowaną gospodarką z dużą liczbą przedsiębiorstw zaawansowanych technologii oraz koncentracją sfery usług, a obszar zachodni (wokół aglomeracji rybnickiej) ma zróżnicowaną strukturę gospodarczą z ograniczonym wydobyciem węgla kamiennego, dobrze rozwiniętą sieć małych i średnich przedsiębiorstw o profilu usługowym i wytwórczym (Strategie rozwoju... 2005). Można zaobserwować podobieństwa w przestrzennym rozmieszczeniu obszarów rozwojowych obydwu województw, na co wskazuje logiczne ich rozmieszczenie w całym regionie południowym (ryc. 1).

Ryc. 1. Obszary rozwojowe regionu południowego

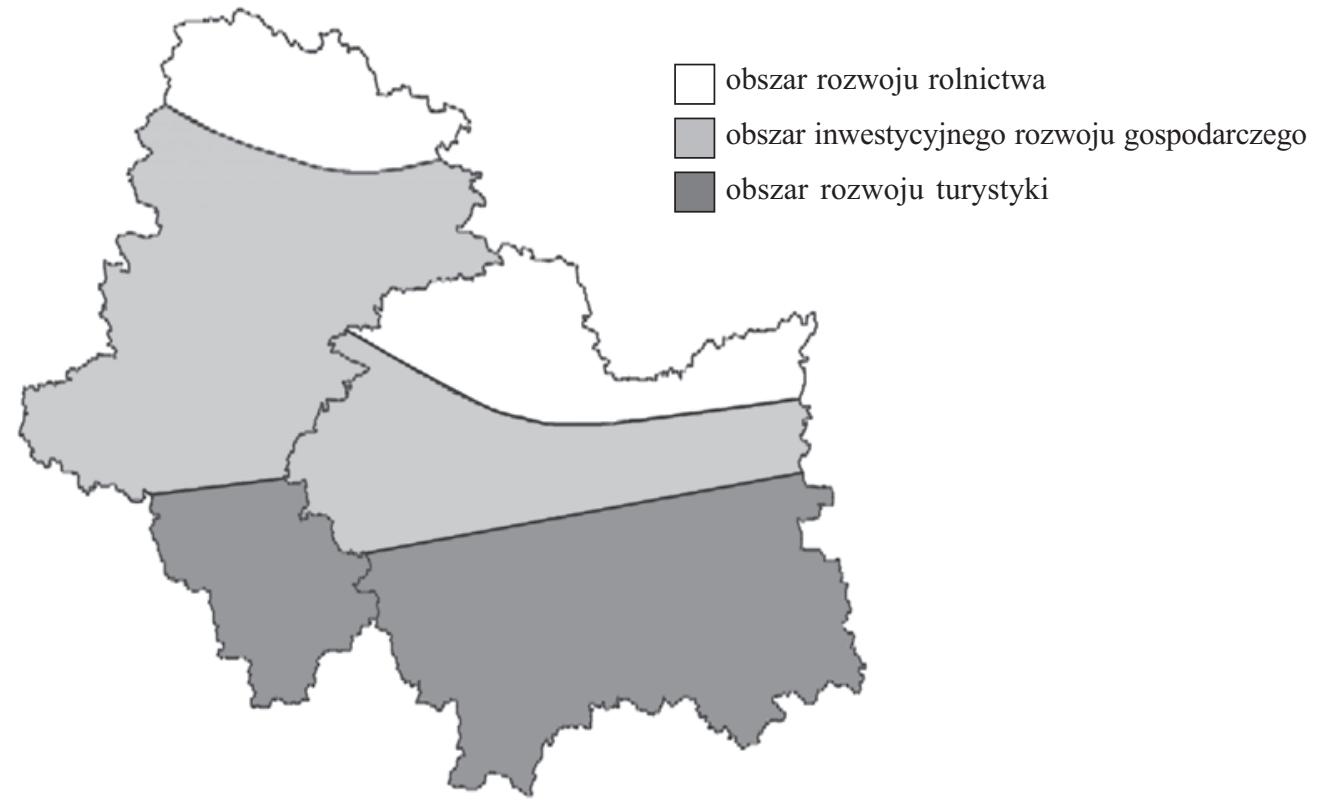

Źródło: opracowanie autora 
Potencjał rozwojowy jest bardzo zróżnicowany zarówno w regionie, jak w województwach. Najwyższy potencjał występuje w Krakowie, Katowicach, Dąbrowie Górniczej, Rudzie Śląskiej, Tarnowie, Nowym Sączu, a także powiatach bielskim i tatrzańskim (Surażka 1999). Woj. małopolskie jest zdominowane przez potencjał Krakowa, poza którym (oprócz Tarnowa i Podhala) potencjał rozwojowy jest bardzo niski. Głównym źródłem potencjału rozwojowego województwa jest (nie do końca wykorzystane) potężne zaplecze naukowo-badawcze ${ }^{3}$. Drugą determinantą rozwoju jest atrakcyjność turystyczna regionu, jednak słabe wyposażenie w odpowiednią infrastrukturę turystyczną uniemożliwia pełne wykorzystanie tego czynnika. Cechą charakterystyczną woj. śląskiego w stosunku do innych województw jest duża chłonność rynku, wyznaczona głównie gęstością zaludnienia i dochodami ludności.

Region południowy jest drugim (po regionie centralnym) najsilniejszym gospodarczo regionem Polski, przy czym w układzie województw woj. śląskie zajmuje pozycję 2, a małopolskie - 5 . W regionie w 2003 r. wytworzono 21,1\% PKB Polski (w tym woj. śląskie 13,7\%, a woj. małopolskie $7,4 \%$ ). Region południowy wytworzył w 2003 r. łącznie 21,1\% wartości dodanej brutto Polski, co niewątpliwie stanowi o sile gospodarczej regionu. Warto jednak zaznaczyć, że znaczący udział ma woj. śląskie, wytwarza ono bowiem niemal dwa razy więcej wartości dodanej brutto w skali kraju niż woj. małopolskie.

Rozmieszczenie ośrodków wspierania innowacji przedsiębiorstw jest bardzo zróżnicowane w regionie. W woj. małopolskim ośrodki koncentrują się w obrębie miasta Kraków ${ }^{4}$, a w woj. śląskim można zaobserwować silną tendencję do ich skupienia w konurbacji górnośląskiej (Katowice, Sosnowiec, Tychy, Gliwice, Będzin $)^{5}$. Pomiędzy lokalizacją instytucji proinnowacyjnych a koncentracją przemysłów zaawansowanych technologii w poszczególnych powiatach występuje silna korelacja wynosząca 0,72 (Ośrodki innowacji... 2005). Jeden ośrodek proinnowacyjny zlokalizowany w regionie południowym pociagga za sobą koncentrację 3,9 branż wysoko i średnio zaawansowanych technologicznie, co jest najwyższym wskaźnikiem w skali kraju. W rozkładzie przestrzennym współczynnik ten dla woj. małopolskiego wynosi 2, a dla śląskiego 4,8 (ryc. 2$)^{6}$.

W celu podniesienia konkurencyjności polskich małych i średnich przedsiębiorstw poprzez dostarczenie im wysokiej jakości kompleksowych usług, w 1996 r. powołano sieć ośrodków w ramach Krajowego Systemu Usług (KSU) dla małych i średnich przedsiębiorstw. Ośrodki są nadzorowane i certyfikowane przez Polską Agencję Rozwoju Przedsiębiorczości, a specjalizują się w świadczeniu usług doradczych, informacyjnych, szkoleniowych, finansowych i proinnowacyjnych. Pod względem liczby ośrodków KSU region południowy znajduje się na drugiej pozycji w kraju (39 ośrodków, lepsze miejsce zajmuje region wschodni-41 ośrodków), przy czym w ujęciu województw śląskie jest ogólnopolskim liderem (28 ośrodków), a małopolskie (11 ośrodków) sytuuje się poniżej średniej dla Polski i zajmuje miejsce 8.

\footnotetext{
${ }^{3}$ Krakowskie uczelnie i powstałe na ich bazie szkoły wyższe w innych miastach regionu mogą zasilić znacznie bardziej rozbudowany sektor badawczo-rozwojowy niż obecnie istniejący, przyczyniając się rozwoju branż opartych na nowoczesnych technologiach.

${ }^{4} \mathrm{~W}$ Tarnowie zlokalizowany jest Tarnowski Klaster Przemysłowy „Plastikowa Dolina”, jednak wchodzi on w skład Krakowskiego Parku Technologicznego i nie jest typowym ośrodkiem proinnowacyjnym.

${ }^{5}$ Pozostałe ośrodki zlokalizowane są w Częstochowie i Bielsku-Białej.

${ }^{6}$ Obliczenia autora na podstawie wyników badań przeprowadzonych w 2005 r. przez Instytut Badań nad Gospodarką Rynkową w Gdańsku na zlecenie Polskiej Agencji Rozwoju Przedsiębiorczości.
} 
Ryc. 2. Lokalizacja ośrodków innowacji i przedsiębiorczości w regionie południowym w 2004 r.

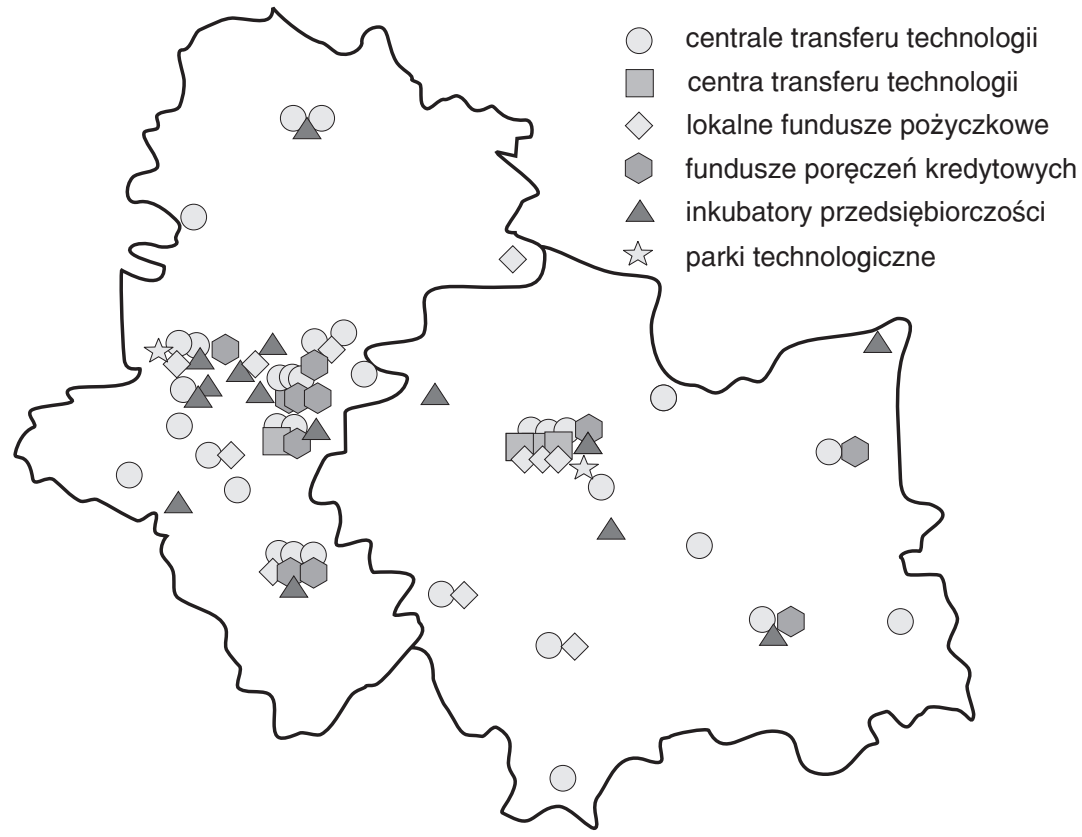

Źródło: Ośrodki innowacji i przedsiębiorczości w Polsce. Raport 2004, 2005, K.B. Matusiak (red.), Instytut Ekonomii Uniwersytetu Łódzkiego, Stowarzyszenie Organizatorów Ośrodków Innowacji i Przedsiębiorczości w Polsce, Poznań-Warszawa

Na podstawie zaprezentowanej analizy sytuacji społeczno-ekonomicznej regionu można sporządzić typogram gospodarczy regionu ${ }^{7}$. Do sporządzenia typogramu potencjału gospodarczego regionu południowego wykorzystano następujące wskaźniki:

- współczynnik urbanizacji, czyli procentowy udział mieszkańców miast w ogólnej liczbie ludności;

- współczynnik aktywności zawodowej, czyli relacja między liczbą ludności w wieku produkcyjnym a zasobami siły roboczej ${ }^{8}$;

- współczynnik przedsiębiorczości osób fizycznych mierzony liczbą przedsiębiorstw osób fizycznych na 1000 mieszkańców;

\footnotetext{
${ }^{7} \mathrm{~W}$ pracy zaprezentowano jedynie syntetyczny profil społeczno-ekonomiczny regionu. Szczegółowe informacje zawarte są w opracowaniach w przekroju województw, m.in.: Opis sytuacji społeczno-ekonomicznej województwa ślaskiego, 2005a oraz Województwo matopolskie 2004, 2005. Obszerne i wnikliwe profile społeczno-ekonomiczne poszczególnych województw i regionów zostały omówione w pracach: Aktualizacja raportu o stanie zagospodarowania przestrzennego kraju, 2003 oraz Regionalne zróżnicowanie rozwoju gospodarczego [w:] Polska 2005. Raport o stanie gospodarki, 2005b).
}

${ }^{8}$ Współczynnik obliczany jest według wzoru: gdzie: $W_{A Z}=\frac{S}{L} * 100 \%$, przy czym $S=Z+B$

W - współczynnik aktywności zawodowej

S - zasoby siły roboczej

Z - liczba zatrudnionych

B - liczba bezrobotnych

L - liczba ludności w wieku produkcyjnym 
- współczynnik wykształcenia wyższego, czyli procentowy udział ludności z wykształceniem wyższym w liczbie ludności ogółem;

- atrakcyjność inwestycyjna ${ }^{9}$;

- stopa bezrobocia;

- PKB na mieszkańca.

Ryc. 3. Typogram regionu południowego na tle Polski

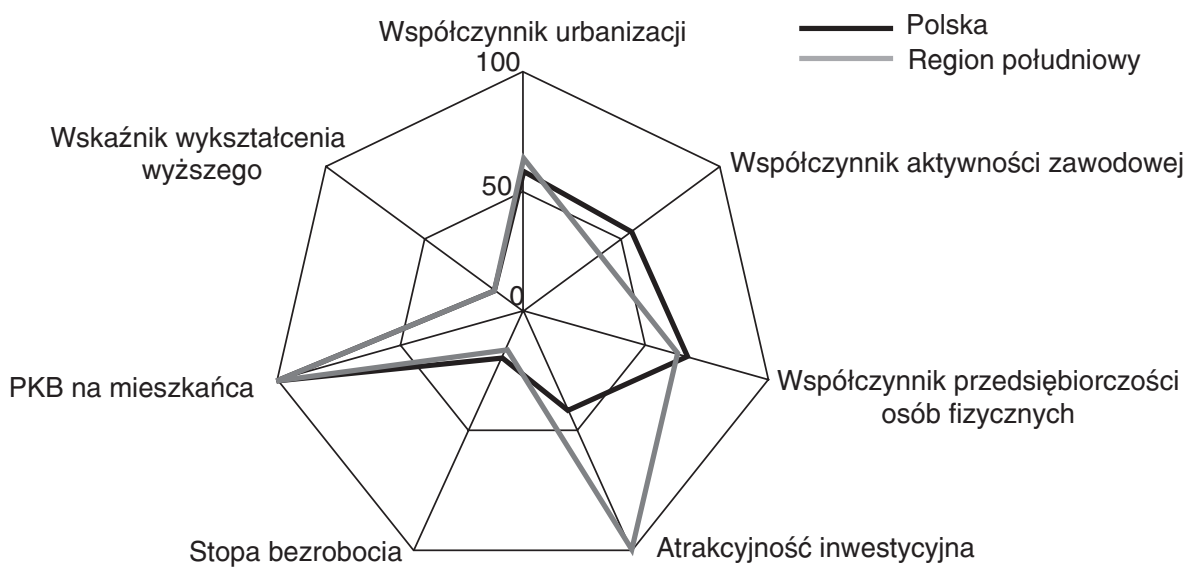

Źródło: opracowanie autora na podstawie danych GUS z 2004 r.

$\mathrm{Z}$ analizy wynika, że region południowy charakteryzuje się wyższymi wskaźnikami potencjału gospodarczego niż uśrednione wskaźniki w skali kraju (ryc. 3), w ujęciu województw woj. śląskie ma wyższy potencjał niż woj. małopolskie (ryc. 4). Warto zwrócić uwagę, że wcześniej przytoczone rankingi atrakcyjności inwestycyjnej potwierdzają trafność takiego doboru wskaźników (wnioski z obydwu analiz są zbliżone). Woj. malopolskie ma ogromny niewykorzystany potencjał naukowo-badawczy oraz turystyczny, co pozwala na optymistyczne prognozy rozwoju województwa, a nawet regionu, który pozostaje pod wpływem Krakowa - aglomeracji o zasięgu ponadregionalnym.

Ryc. 4. Typogram porównawczy województw regionu południowego

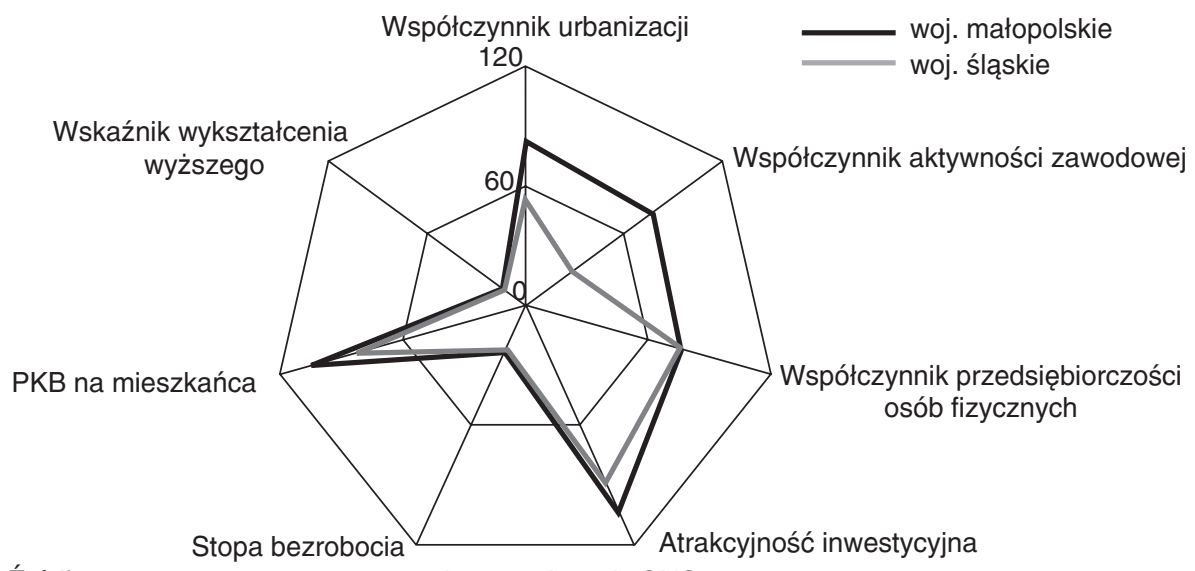

Źródło: opracowanie autora na podstawie danych GUS z 2004 r.

\footnotetext{
${ }^{9}$ Wykorzystano miarę zaproponowaną przez Instytut Badań nad Gospodarką Rynkową w Gdańsku (patrz wyżej).
} 


\section{Małe i średnie przedsiębiorstwa w województwach małopolskim i śląskim}

Początek lat 90. XX w. przyniósł w Polsce rozwój przedsiębiorczości prywatnej, również w układzie regionalnym. Powszechny i równy dostęp obywateli do wielu gałęzi gospodarki stworzył ogromne szanse rozwoju prywatnej przedsiębiorczości. Zniesienie wielu barier prawnych, charakterystycznych dla gospodarki etatystycznej, ograniczających rozwój przedsiębiorczości, pozwoliło obywatelom na tworzenie własnych firm. Nowe warunki funkcjonowania gospodarki okazały się ogromną szansą dla rozwoju przedsiębiorczości, zwłaszcza dla małych i średnich firm prywatnych. Dodatkowym czynnikiem mającym istotny wpływ na rozwój przedsiębiorczości było duże zapotrzebowanie rynku na wszelkiego rodzaju dobra i usługi. Szczególnie szanse te wykorzystały przedsiębiorstwa z sektora MSP, co zaowocowało imponującym przyrostem ich liczby. Społeczeństwo żyjące we wciąż zmieniających się warunkach wykształca przedsiębiorczy klimat, ćwiczy kreatywność i skłonność do podejmowania inicjatyw. Dane statystyczne jednoznacznie wskazują, że podmioty sektora prywatnego w Polsce na przełomie XX i XXI w. charakteryzowały się ogromną dynamiką wzrostu, co przyspieszyło procesy transformacyjne w polskiej gospodarce - przejście od gospodarki socjalistycznej do gospodarki wolnorynkowej. Obecnie przedsiębiorstwa sektora prywatnego stanowią 96,5\% wszystkich przedsiębiorstw w Polsce.

Porównawcze badania międzynarodowe sytuują Polskę wśród państw o średnim poziomie przedsiębiorczości (Przedsiębiorczość w Polsce 2003). Miarą przedsiębiorczości jest w tej mierze procentowy udział osób prowadzących własną działalność gospodarczą lub zarządzających firmą w ogólnej liczbie osób w wieku produkcyjnym, przy uwzględnieniu podmiotów stosunkowo młodych, czyli działających nie dłużej niż 3,5 roku. Niestety, tym, co odróżnia przedsiębiorców w Polsce od przedsiębiorców z innych krajów uczestniczących w badaniu, jest wyjątkowo wysoki odsetek odpowiedzi wiążących rozpoczęcie działalności gospodarczej tylko z koniecznością stworzenia sobie warunków do zarobkowania.

Sektor MSP jest jednym z czynników wzrostu gospodarczego każdego kraju, również Polski. Pozycja tego sektora w Polsce jest co roku wyższa. Jakkolwiek dynamiczny wzrost MSP jest charakterystyczny dla okresu transformacji ekonomicznej w Polsce, pozostaje jednak nadal istotnym czynnikiem wzrostu gospodarczego (tab. 2). W końcu 2005 r. Krajowy Rejestr Urzędowy Podmiotów Gospodarki Narodowej REGON liczył ponad 3,6 mln małych i średnich przedsiębiorstw, co stanowiło 99,9\% wszystkich zarejestrowanych przedsiębiorstw. Największą grupą przedsiębiorstw są firmy najmniejsze, zatrudniające do 9 osób. Stanowią one $95 \%$ ogółu polskich przedsiębiorstw. Udział firm małych (10 - 49 pracowników) wynosi 4\%, a średnich (50-249 pracowników) - 0,8\%, podczas gdy firmy duże (powyżej 250 pracowników) stanowią około $0,1 \%$ ogółu przedsiębiorstw (raport Polska 2005). Warto zaznaczyć, że taka struktura przedsiębiorstw nie jest typowa tylko dla Polski. Występuje w niemal wszystkich krajach Unii Europejskiej. W 2004 r. odnotowano spadek o 1,2\% liczby zakładów osób fizycznych, przy czym od kilku lat systematycznie wzrasta liczba spółek handlowych.

Tab. 2. Liczba zarejestrowanych przedsiębiorstw w Polsce w latach 2001-2005 (według rejestru REGON)

\begin{tabular}{|l|c|c|c|c|c|c|c|}
\hline \multirow{2}{*}{ Rok } & \multirow{2}{*}{ Ogółem } & \multicolumn{7}{|c|}{ Przedsiębiorstwa według wielkości zatrudnienia } \\
\cline { 3 - 8 } & & $\mathbf{0 - 9}$ & $\mathbf{1 0 - 4 9}$ & $\mathbf{0 - 4 9}$ & $\mathbf{5 0 - 2 4 9}$ & $\mathbf{0 - 2 4 9}$ & $\mathbf{2 5 0 +}$ \\
\hline 2001 & 3374956 & 3206452 & 131106 & 3337557 & 30809 & 3368366 & 6589 \\
\hline 2002 & 3468218 & 3302411 & 131480 & 3433891 & 28884 & 3462775 & 5443 \\
\hline 2003 & 3581593 & 3410233 & 137974 & 3548207 & 28329 & 3576536 & 5057 \\
\hline 2004 & 3576830 & 3402150 & 141499 & 3543649 & 28309 & 3571958 & 4872 \\
\hline 2005 & 3615621 & 3436841 & 145745 & 3582586 & 28343 & 3610929 & 4692 \\
\hline
\end{tabular}

Źródło: opracowanie autora na podstawie danych GUS 
Przedsiębiorczość w Polsce jest zróżnicowana regionalnie. Ogromna większość małych i średnich przedsiębiorstw działa w pięciu województwach (mazowieckim, śląskim, wielkopolskim, dolnośląskim, małopolskim). W tych województwach zarejestrowanych jest około 55\% wszystkich zarejestrowanych w Polsce małych i średnich przedsiębiorstw. Liczba przedsiębiorstw aktywnych w tych województwach wynosi około 54\% wszystkich aktywnych przedsiębiorstw w Polsce. Dla porównania: na obszarze pięciu województw o najmniejszej liczbie przedsiębiorstw (opolskiego, podlaskiego, lubuskiego, świętokrzyskiego, warmińsko-mazurskiego) zarejestrowanych jest około 14\% wszystkich małych i średnich przedsiębiorstw zarejestrowanych w Polsce.

W regionie południowym zarejestrowanych jest ponad 715 tys. małych i średnich przedsiębiorstw, co stanowi 19,8\% ogółu przedsiębiorstw tej wielkości zarejestrowanych w Polsce. Oznacza to, że region południowy znajduje się w czołówce regionów w Polsce. W ujęciu przestrzennym w woj. śląskim zarejestrowanych jest 11,8\%, a w woj. małopolskim 8\% ogółu przedsiębiorstw z sektora MSP zarejestrowanych w systemie REGON. Spośród przedsiębiorstw sektora MSP zlokalizowanych w regionie południowym, aż 94,65\% to mikroprzedsiębiorstwa, przy czym wskaźnik ten w woj. małopolskim wynosi 94,8\%, a w woj. śląskim 94,5\%. W woj. śląskim zarejestrowanych jest znacznie więcej dużych przedsiębiorstw (12,6\% w skali kraju) niż w woj. małopolskim (7,5\%). Bezwzględna liczba zarejestrowanych małych i średnich przedsiębiorstw jest wyższa w woj. śląskim niż w woj. małopolskim, przy czym rozkład przedsiębiorstw według wielkości zatrudnienia jest zbliżony (por. tab. 3 i 4). Jak wynika z prowadzonych przez Główny Urząd Statystyczny w 2004 r. badań strukturalnych ${ }^{1}$ aktywnych przedsiębiorstw, podmioty zatrudniające do 49 pracowników stanowiły 75\% wszystkich przedsiębiorstw aktywnych w woj. śląskim; jednocześnie był to najwyższy wskaźnik w kraju.

Tab. 3. Liczba zarejestrowanych przedsiębiorstw w woj. małopolskim w latach 2001-2005 (według rejestru REGON)

\begin{tabular}{|l|c|c|c|c|c|c|c|}
\hline \multirow{2}{*}{ Rok } & \multirow{2}{*}{ Ogółem } & \multicolumn{7}{|c|}{ Przedsiębiorstwa według wielkości zatrudnienia } \\
\cline { 3 - 8 } & & $\mathbf{0 - 9}$ & $\mathbf{1 0 - 4 9}$ & $\mathbf{0 - 4 9}$ & $\mathbf{5 0 - 2 4 9}$ & $\mathbf{0 - 2 4 9}$ & $\mathbf{2 5 0 +}$ \\
\hline 2001 & 270695 & 257596 & 10292 & 267932 & 2371 & 270303 & 392 \\
\hline 2002 & 278350 & 264649 & 10995 & 275644 & 2287 & 277931 & 419 \\
\hline 2003 & 285887 & 271479 & 11769 & 283248 & 2244 & 285492 & 395 \\
\hline 2004 & 288773 & 273892 & 12226 & 286118 & 2282 & 288400 & 373 \\
\hline 2005 & 289712 & 274329 & 12750 & 287079 & 2280 & 289359 & 353 \\
\hline
\end{tabular}

Tab. 4. Liczba zarejestrowanych przedsiębiorstw w woj. śląskim w latach 2001-2005 (według rejestru REGON)

\begin{tabular}{|l|l|c|c|c|c|c|c|}
\hline \multirow{2}{*}{ Rok } & \multirow{2}{*}{ Ogółem } & \multicolumn{7}{|c|}{ Przedsiębiorstwa według wielkości zatrudnienia } \\
\cline { 3 - 8 } & & $\mathbf{0 - 9}$ & $\mathbf{1 0 - 4 9}$ & $\mathbf{0 - 4 9}$ & $\mathbf{5 0 - 2 4 9}$ & $\mathbf{0 - 2 4 9}$ & $\mathbf{2 5 0 +}$ \\
\hline 2001 & 403004 & 381438 & 17130 & 398568 & 3665 & 402233 & 771 \\
\hline 2002 & 417945 & 395413 & 18201 & 413614 & 3597 & 417211 & 734 \\
\hline 2003 & 424031 & 401028 & 18779 & 419807 & 3541 & 423348 & 683 \\
\hline 2004 & 429173 & 405726 & 19293 & 425019 & 3526 & 428545 & 628 \\
\hline 2005 & 426266 & 402339 & 19825 & 422164 & 3510 & 425674 & 592 \\
\hline
\end{tabular}

Źródło: opracowanie autora na podstawie danych GUS

${ }^{10}$ Badania strukturalne prowadzone są na podstawie rozporządzenia Rady Ministrów RP w sprawie programu badań statystyki publicznej na dany rok. 
Nie stwierdzono rozbieżności w wartości przychodów ze sprzedaży pomiędzy przedsiębiorstwami zlokalizowanymi w województwach śląskim i małopolskim. Przedsiębiorstwa o przychodach poniżej 2 mln zł stanowiły w 2004 r. w woj. śląskim 33,9\%, a w woj. małopolskim 32,7\% wszystkich przedsiębiorstw. Dla przedsiębiorstw o wartości przychodów powyżej 25 mln zł wskaźniki te wyniosły $12,4 \%$ dla woj. śląskiego i $12,3 \%$ dla woj. małopolskiego.

W 2004 r. w przekroju terytorialnym najwięcej mikroprzedsiębiorstw prowadziło działalność na terenie województw mazowieckiego i śląskiego. Liczba mikroprzedsiębiorstw aktywnych w woj. śląskim wyniosła 209,3 tys. i stanowiła 12,7\% wszystkich najmniejszych przedsiębiorstw w Polsce. W woj. małopolskim zlokalizowanych było 142 tys. takich przedsiębiorstw, co stanowiło blisko 8,6\% mikroprzedsiębiorstw w Polsce. Łącznie w regionie funkcjonowała jedna piąta wszystkich aktywnych mikroprzedsiębiorstw w Polsce. Wysoki współczynnik aktywności mikroprzedsiębiorstw (relacja mikroprzedsiębiorstw aktywnych do zarejestrowanych), który w 2004 r. wynosił $52,1 \%$ (średnia dla kraju 48,5\%), jest ogromną zaletą regionu. W regionie południowym zaobserwowano zbliżone zagęszczenie badanych przedsiębiorstw mierzone wskaźnikiem drobnej przedsiębiorczości (wyrażonym liczbą mikroprzedsiębiorstw na 1000 mieszkańców), który wynosił 44,1\% (w woj. śląskim 44,5, w woj. małopolskim 43,6\%) wobec średniej dla Polski 43,3\%. Przeciętne zatrudnienie $\mathrm{w}$ jednym mikroprzedsiębiorstwie $\mathrm{w}$ regionie wynosiło 0,93 osoby na jeden zakład, a przy uwzględnieniu właścicieli mikrofirm 2,13. Przeciętne dochody mikroprzedsiębiorstwa z regionu południowego były w 2004 r. nieco wyższe niż w kraju i wynosiły 34,7 tys. zł, jest to jednak zasługa przedsiębiorstw zlokalizowanych na Śląsku, których rentowność jest wyższa (tab. 5).

\section{Podsumowanie}

Województwa wchodzące w skład regionu południowego od kilku lat stanowią trzon sektora MSP w Polsce pod względem liczby aktywnych przedsiębiorstw. Miejscem prowadzenia działalności gospodarczej przez dwie trzecie małych i średnich przedsiębiorstw regionu są gminy miejskie, przy czym relatywnie niewielka liczba przedsiębiorstw prowadzi działalność w gminach wiejskich. Małe i średnie przedsiębiorstwa zapewniają zatrudnienie ponad 1,2 mln mieszkańców, co stanowi dla woj. śląskiego $13,9 \%$, a dla małopolskiego 8,3\% wszystkich miejsc pracy oferowanych w regionie. W ocenie sytuacji należy uwzględnić samozatrudnionych prowadzących własne przedsiębiorstwa jednoosobowe. Region południowy odgrywa znaczącą rolę w obrotach handlowych małych i średnich przedsiębiorstw w kraju. Udział regionu w eksporcie małych i średnich przedsiębiorstw wynosi około $15 \%$, a w imporcie ponad 13\%, przy czym wskaźniki te dla woj. mazowieckiego nawet kilkakrotnie przewyższały prezentowane wskaźniki dla omawianego regionu, a woj. wielkopolskie zanotowało zbliżone wskaźniki do wskaźników województw małopolskiego i śląskiego łącznie. 
Tab. 5. Mikroprzedsiębiorstwa w regionie południowym w $2004 \mathrm{r}$.

\begin{tabular}{|c|c|c|c|c|}
\hline Kryterium & Polska & $\begin{array}{c}\text { Region } \\
\text { poludniowy }\end{array}$ & $\begin{array}{c}\text { Woj. } \\
\text { małopolskie }\end{array}$ & Woj. śląskie \\
\hline $\begin{array}{l}\text { Liczba mikroprzedsiębiorstw } \\
\text { zarejestrowanych w rejestrze REGON }\end{array}$ & 3402150 & $-\frac{674380}{19,8 \%}--$ & $\begin{array}{l}273352 \\
--\frac{-}{8,0 \%}--\end{array}$ & $\begin{array}{c}401028 \\
--\overline{11,8 \%}-\overline{0}\end{array}$ \\
\hline Liczba mikroprzedsiębiorstw aktywnych & 1651200 & $-\frac{351335}{21,3 \%}--$ & $\begin{array}{c}142033 \\
--\overline{8}, \overline{6} \% \\
--\end{array}$ & $\begin{array}{c}209302 \\
--\overline{12,7} \overline{7} \overline{0}\end{array}$ \\
\hline $\begin{array}{l}\text { Współczynnik aktywności mikro- } \\
\text { przedsiębiorstw (w \%) }\end{array}$ & 48,5 & 52,1 & 52,0 & 52,2 \\
\hline Współczynnik drobnej przedsiębiorczości & 43,3 & 44,1 & 43,6 & 44,5 \\
\hline $\begin{array}{l}\text { Liczba pracujących } \\
\text { w mikroprzedsiębiorstwach }\end{array}$ & 3389234 & $\begin{array}{r}749585 \\
-\overline{22,1 \%}-\overline{-} \\
\end{array}$ & $\begin{array}{c}287855 \\
-\overline{8}, \overline{5} \%- \\
\end{array}$ & $\begin{array}{r}461730 \\
--\overline{12} \overline{8} \% \overline{0} \\
\end{array}$ \\
\hline $\begin{array}{l}\text { Liczba pracujących w mikroprzedsiębior- } \\
\text { stwach na } 1000 \text { mieszkańców }\end{array}$ & 88,8 & 93,3 & 88,3 & 98,2 \\
\hline $\begin{array}{l}\text { Liczba zatrudnionych w mikro- } \\
\text { przedsiębiorstwach }\end{array}$ & 1427541 & $\begin{array}{l}325421 \\
-\overline{2} 2, \overline{8} \% \\
\end{array}$ & $\begin{array}{c}121163 \\
--\overline{8}, \overline{5} \%\end{array}$ & $\begin{array}{r}204258 \\
--\overline{14}, \overline{3} \% \\
\end{array}$ \\
\hline $\begin{array}{l}\text { Przeciętne zatrudnienie w jednym } \\
\text { mikroprzedsiębiorstwie }\end{array}$ & 0,86 & 0,93 & 0,85 & 0,98 \\
\hline $\begin{array}{l}\text { Przeciętna liczba pracujących w jednym } \\
\text { mikroprzedsiębiorstwie }\end{array}$ & 2,05 & 2,13 & 2,03 & 2,21 \\
\hline $\begin{array}{l}\text { Przeciętne wynagrodzenie miesięczne } \\
\text { brutto w drobnej przedsiębiorczości }\end{array}$ & 1391 & 1304 & 1292 & 1316 \\
\hline $\begin{array}{l}\text { Przychody na jedno mikro- } \\
\text { przedsiębiorstwo (w tys. zł) }\end{array}$ & 323,4 & 347,6 & 365,4 & 329,7 \\
\hline $\begin{array}{l}\text { Koszty na jedno mikro- } \\
\text { przedsiębiorstwo (w tys. zł) }\end{array}$ & 289,7 & 312,9 & 331,8 & 293,9 \\
\hline $\begin{array}{l}\text { Udział kosztów w przychodach } \\
\text { mikroprzedsiębiorstw (w \%) }\end{array}$ & 89,6 & 90,0 & 90,8 & 89,1 \\
\hline $\begin{array}{l}\text { Przeciętne dochody jednego mikro- } \\
\text { przedsiębiorstwa (w tys. zł) }\end{array}$ & 33,7 & 34,7 & 33,6 & 35,8 \\
\hline
\end{tabular}

Źródło: opracowanie autora na podstawie danych GUS 


\section{Literatura}

1. Aktualizacja raportu o stanie zagospodarowania przestrzennego kraju 2003, 2005, Instytut Geografii i Przestrzennego Zagospodarowania, PAN, Warszawa

2. Atrakcyjność inwestycyjna województw i podregionów Polski 2005, 2005, T. Kalinowski (red.), Instytut Badań nad Gospodarką Rynkową, Gdańsk

3. Dębski J., 2002a, Lokalne bieguny wzrostu w Polsce na przełomie XX i XXI wieku, t. 2, Wyższa Szkoła Finansów i Zarządzania w Białymstoku, Białystok

4. Dębski J., 2002b, Przedsiębiorczość prywatna w Polsce na przełomie XX i XXI wieku, t. 1, Wyższa Szkoła Finansów i Zarządzania w Białymstoku, Białystok

5. Opis sytuacji społeczno-ekonomicznej województwa ślaskiego, 2005, Urząd Marszałkowski Województwa Śląskiego, Katowice

6. Ośrodki innowacji w Polsce, 2005, Agencja Rozwoju Przedsiębiorczości, Stowarzyszenie Organizatorów Ośrodków Innowacji i Przedsiębiorczości w Polsce, Poznań-Warszawa

7. Przedsiębiorczość w Polsce 2003, 2003, Ministerstwo Gospodarki i Pracy, Warszawa

8. Przedsiębiorczość w Polsce 2005, 2005, Ministerstwo Gospodarki i Pracy, Warszawa

9. Regionalne zróżnicowanie rozwoju gospodarczego [w:] Polska 2005. Raport o stanie gospodarki, 2005, Ministerstwo Gospodarki i Pracy, Warszawa

10. Rozporzqdzenie Rady Ministrów z dnia 27 kwietnia 2004 r. zmieniajace rozporzqdzenie w sprawie wprowadzenia nomenklatury jednostek terytorialnych dla celów statystycznych NTS (Dz.U. z 2004 r., Nr 98, poz. 998)

11. Strategia rozwoju województwa ślaskiego na lata 2000-2020, 2005, Urząd Marszałkowski Województwa Śląskiego, Katowice

12. Surażska W., 1999, Potencjat rozwojowy województw 1999, Centrum Badań Regionalnych w Warszawie, Warszawa

13. Wielki Ranking Miast 2003, 2003, Centrum Badań Regionalnych w Warszawie, Warszawa

14. Województwo małopolskie 2004, 2005, Urząd Marszałkowski Województwa Małopolskiego, Kraków

\section{Potential of Small and Medium-sized Enterprises in Southern Poland}

The paper presents the synthetic diagnosis of the social and economical situation of the studied region, especially referring to the state and development tendencies of small and medium-sized enterprises in dynamic perspective, that is in years 2001-2005. The author presents conditions for small and medium-sized enterprises' functioning and development, which are laid in regional business environment, on the other hand he focuses on developmental tendencies of SMEs sector in the studied region. 
Diana Dryglas

Uniwersytet Jagielloński

Krzysztof Wach

Uniwersytet Ekonomiczny w Krakowie

\section{Klimat dla rozwoju przedsiębiorczości turystycznej w Małopolsce w świetle badań empirycznych}

Ostatnie lata to okres wzmożonej aktywności gospodarczej, która owocuje powstawaniem nowych podmiotów gospodarczych, zwłaszcza małych i średnich przedsiębiorstw (MSP). Kierowanie firmą wymaga fachowych umiejętności menedżerskich i gruntownej wiedzy o czynnikach wpływających na funkcjonowanie i rozwój MSP. Na konkurencyjność przedsiębiorstw wpływają zarówno czynniki wewnętrzne, na których opierają się przedsiębiorcy, budując przewagę konkurencyjna, jak i czynniki zewnętrzne, tkwiące w otoczeniu przedsiębiorstwa, które można rozpatrywać w skali makro, mikro oraz mezo, czyli na poziomie regionu. Każda organizacja gospodarcza musi właściwie postrzegać poszczególne elementy swojego otoczenia, aby mogła wśród nich prawidłowo funkcjonować. W praktyce zarządzania ważne jest szczegółowe określenie istotnych dla przedsiębiorstwa czynników i aspektów otoczenia, aby organizacja mogła efektywnie działać. To otoczenie przedsiębiorstwa postrzegane jest subiektywnie przez menedżerów, co wynika głównie ze zróżnicowanych doświadczeń oraz intuicji poszczególnych menedżerów, ich wiedzy oraz kompetencji. Determinuje to zachowania konkurencyjne na rynku, zwłaszcza lokalnym.

Do czynników zewnętrznych wpływających na zachowania konkurencyjne MSP na rynku należy przede wszystkim zaliczyć warunki otoczenia konkurencyjnego i regionalnego. Intensywność zmian mezootoczenia w ostatnich latach wpływa na wzrost znaczenia strategicznego uwarunkowań regionalnego otoczenia biznesu. Każde przedsiębiorstwo dąży do osiagnięcia przewagi konkurencyjnej na rynku lokalnym, krajowym czy wreszcie na międzynarodowym. Realizacja tego celu pociaga za sobą konieczność rozwoju przedsiębiorstwa w wielu płaszczyznach oraz uwzględnianie wielu czynników otoczenia mających wpływ na funkcjonowanie oraz rozwój podmiotu gospodarczego (Wach 2004).

Celem tego artykułu jest ewaluacja regionalnego klimatu dla rozwoju przedsiębiorczości turystycznej w Małopolsce, który z kolei determinuje aktywność gospodarczą tego regionu. Artykuł przedstawia wyniki badań przeprowadzonych w gminach woj. małopolskiego oraz na losowej próbie małych i średnich przedsiębiorstw turystycznych zlokalizowanych w tym województwie ${ }^{1}$.

\section{Założenia metodyczne}

W celu identyfikacji klimatu dla rozwoju przedsiębiorczości turystycznej w woj. małopolskim przeprowadzono dogłębną analizę literatury przedmiotu, w której wiele uwagi poświęcono

\footnotetext{
${ }^{1}$ Artykuł powstał na podstawie badań przeprowadzonych przez autorów tego artykułu w ramach projektu badawczego finansowanego przez Ministerstwo Nauki i Informatyzacji (nr projektu 2 H02D 03325 pt. „Małe i średnie przedsiębiorstwa na polskim rynku turystycznym”, Uniwersytet Jagielloński, Kraków 2004-2006, pod kier. prof. dr hab. Małgorzaty Bednarczyk).
} 
zagadnieniom związanym z otoczeniem przedsiębiorstwa. Na jej podstawie sporządzono wstępną listę uwarunkowań funkcjonowania małych i średnich przedsiębiorstw turystycznych, którą poddano weryfikacji z zastosowaniem metody eksperckiej. Te prace posłużyły do skonstruowania dwóch ankiet skierowanych do:

- małych i średnich przedsiębiorstw turystycznych zlokalizowanych w woj. małopolskim, określonych zgodnie z klasyfikacją PKD,

- gmin woj. małopolskiego.

Ankiety skierowane do przedsiębiorców zostały wysłane do 340 przedsiębiorstw turystycznych, co stanowiło $1 \%$ populacji. Otrzymano 74 kompletne ankiety, co pozwoliło na przeprowadzenie badań na próbie stanowiącej 0,2\% ogółu. Współczynnik zwrotu wyniósł 22\%. Ankietę skierowaną do władz terytorialnych wysłano do wszystkich gmin woj. małopolskiego. Otrzymano 82 kompletnie wypełnione ankiety; wskaźnik zwrotu wyniósł 49,1\%. Badaniami objęto 45\% gmin woj. małopolskiego (82 gminy spośród 182 wszystkich gmin województwa). Gminy miejskie stanowiły $11 \%$, wiejskie $70 \%$, a miejsko-wiejskie $19 \%$ próby badawczej. Ta struktura jest zbliżona do rzeczywistego rozkładu gmin województwa w ujęciu rodzajowym. Łącznie przebadano 60\% wszystkich gmin miejskich, 45\% gmin wiejskich i 40\% gmin miejsko-wiejskich, więc uzyskane wyniki można uznać za reprezentatywne dla całej zbiorowości.

\section{Wyniki badań empirycznych}

Działania poszczególnych gmin woj. małopolskiego na rzecz przedsiębiorstw turystycznych są mało zróżnicowane ze względu na charakter gmin (por. ryc. 1). W celu wskazania różnic w ocenie działań poszczególnych grup gmin w ujęciu rodzajowym, obliczono średnią arytmetyczną ocen. Uśredniona wartość liczbowa mogła przybierać postać ze zbioru liczbowego od 1 do 5 (gdzie 1 -zdecydowanie niekorzystnie, 2 - niekorzystnie, 3 - trudno powiedzieć [przeciętnie], 4 -korzystnie, 5 -zdecydowanie korzystnie). Średnia ocena dla gmin miejskich wyniosła 4,0, wiejskich - 4,02, a miejsko-wiejskich -3,87. Na tej podstawie można wnosić, że najwyższą samoocenę deklarowały gminy wiejskie, przy zastrzeżeniu niewielkich odchyleń (dysproporcji) między średnimi dla badanych grup gmin. Najwyższy odsetek ocen pozytywnych (88,89\% łącznych odpowiedzi ,,korzystnie” oraz ,zdecydowanie korzystnie”) odnotowano wśród gmin miejskich oraz gmin wiejskich $(85,96 \%)$, natomiast najmniejszy odsetek odpowiedzi pozytywnych wystapił wśród gmin miejsko-wiejskich $(68,75 \%)$. Gminy miejsko-wiejskie przeważały jednak w ocenach zdecydowanie korzystnych, podczas gdy odsetek tych odpowiedzi dla gmin miejskich był najniższy.

Ocena działań gmin na rzecz przedsiębiorstw turystycznych z uwzględnieniem siedzib oceniających firm jest zróżnicowana (por. ryc. 2). Firmy zlokalizowane w gminie miejskiej Kraków (64,9\% badanej zbiorowości, 48 przedsiębiorstw) nieco częściej oceniały negatywnie działania gminy $(53,33 \%)$ niż przedsiębiorstwa zlokalizowane w pozostałej części województwa $(51,72 \%)$. Podobnie oceny pozytywne wystapiły rzadziej w wypadku firm krakowskich $(15,55 \%)$ niż pozostałych (24,14\%). Uśredniona ocena w przedziale $0-5$ dokonana przez przedsiębiorstwa turystyczne zlokalizowane w gminie Kraków wyniosła 2,4, a uśredniona ocena przedsiębiorstw zlokalizowanych w innych gminach województwa-2,6.

Wskaźnik ogólnej oceny czynników otoczenia regionalnego zbudowano, opierając się na 4 wskaźnikach cząstkowych: wsparciu finansowym w regionie, kadrze pracowniczej w regionie, inicjatywach samorządowych, infrastrukturze regionalnej (por. ryc. 3) ${ }^{2}$. Generalnie rzecz ujmując,

\footnotetext{
${ }^{2}$ Autorzy skupili się na wymienionych 4 kluczowych czynnikach regionalnych z punktu widzenia kierowania i rozwoju przedsiębiorstwa turystycznego.
} 
Ryc. 1. Samoocena działań gmin woj. małopolskiego na rzecz przedsiębiorczości turystycznej

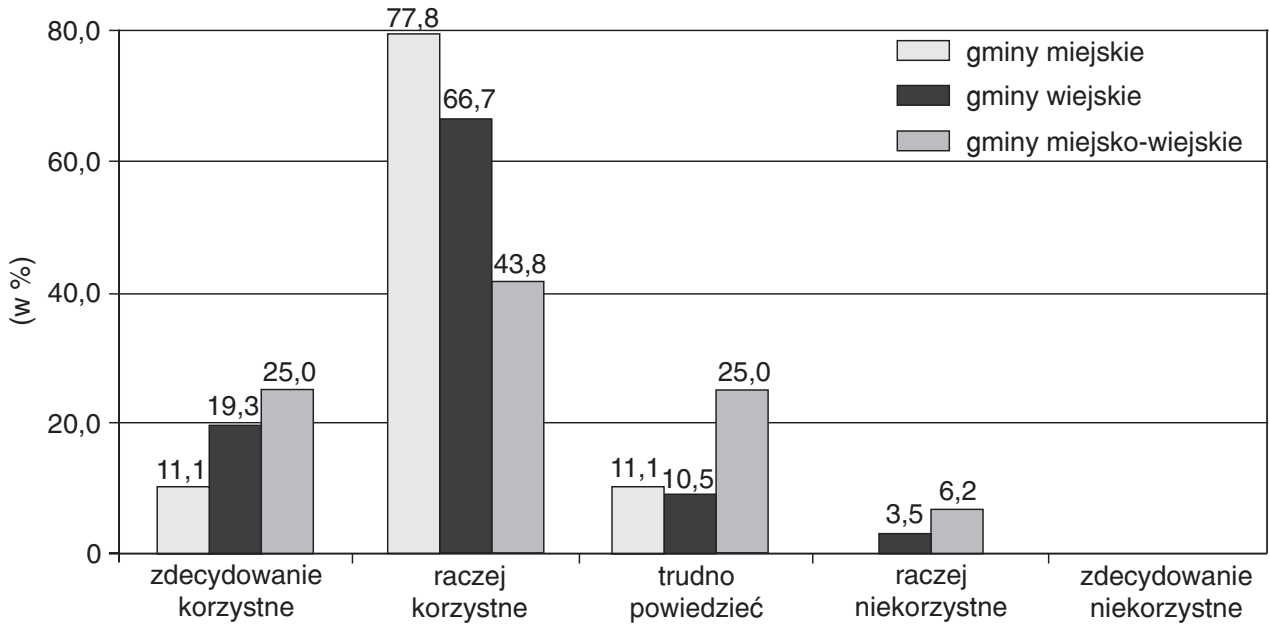

Źródło: opracowanie autorów na podstawie badań empirycznych

Ryc. 2. Klimat dla rozwoju przedsiębiorczości turystycznej w opinii przedsiębiorców z woj. małopolskiego

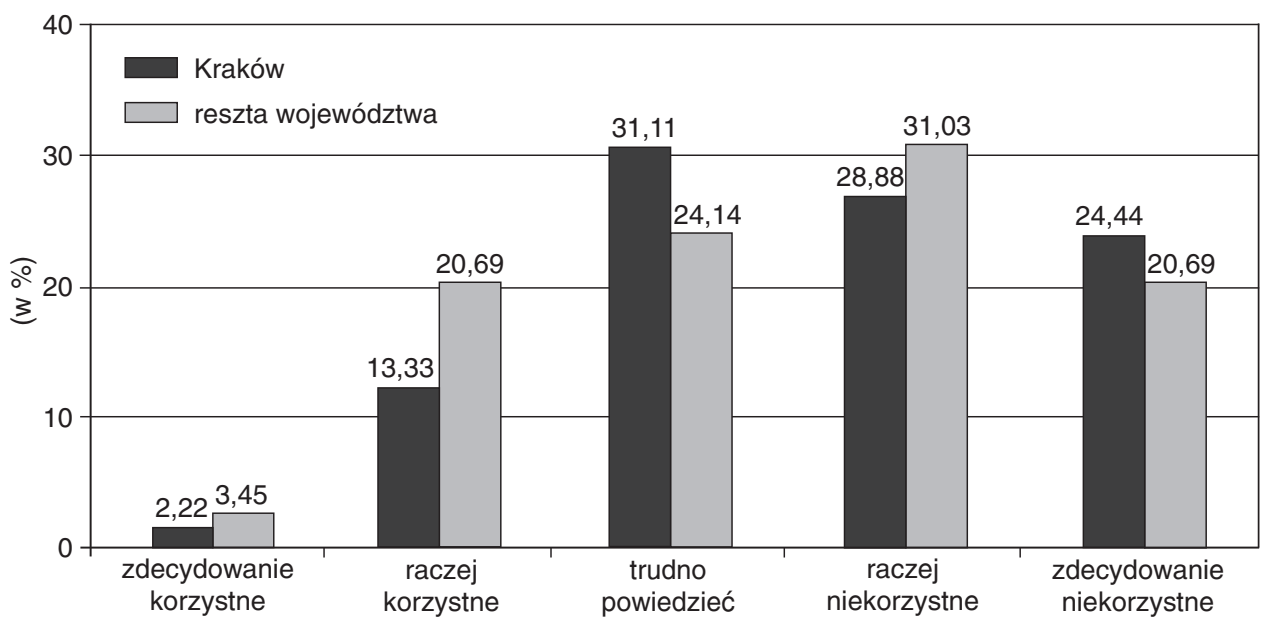

Źródło: opracowanie autorów na podstawie badań empirycznych

zarówno badane przedsiębiorstwa (57,75\%), jak i przedstawiciele władz gminnych (42,39\%) ocenili pozytywnie czynniki otoczenia regionalnego, a wartość wyrażająca ocenę negatywną tego wskaźnika była zdecydowanie wyższa w przypadku przedsiębiorstw $(44,14 \%)$ niż decydentów lokalnych $(23,88 \%)$. Należy podkreślić, że istnieją równomiernie rozkładające się rozbieżności w ocenie przedsiębiorców, podczas gdy ocena dokonana przez władze gminne przyjmuje rozkład normalny. To pozwala wnioskować, że nie ma jednoznacznej opinii wśród przedsiębiorców o wpływie czynników otoczenia regionalnego na rozwój ich przedsiębiorstw. Na przykład: czynniki związane z infrastrukturą stanowią zdecydowaną barierę dla przedsiębiorstw transportowych, ale mają niewielki wpływ na rozwój przedsiębiorstw gastronomicznych. Te same czynniki otoczenia regionalnego mogą być w zależności od rodzaju prowadzonej działalności gospodarczej zarówno stymulatorami, jak i barierami rozwoju. 
Przedsiębiorcom zadano również pytanie „Jak oceniają Państwo swoją miejscowość jako miejsce do prowadzenia biznesu?" (por. ryc. 4). Przedsiębiorcy w znaczącej większości (74,36\%) pozytywnie ocenili swoją miejscowość jako miejsce prowadzenia działalności gospodarczej. Ta wartość jest zdecydowanie wyższa niż wynik ogólnej oceny czynników otoczenia regionalnego (57,75\%) czy poszczególnych wskaźników cząstkowych.

Można zatem sądzić, że przedsiębiorcy - pomimo świadomości występowania barier w rozwoju przedsiębiorstw turystycznych - nauczyli się koegzystencji z otoczeniem oraz wykorzystywania stymulatorów tkwiących w otoczeniu regionalnym.

Ryc. 3. Wskaźnik ogólnej oceny czynników otoczenia regionalnego w Małopolsce

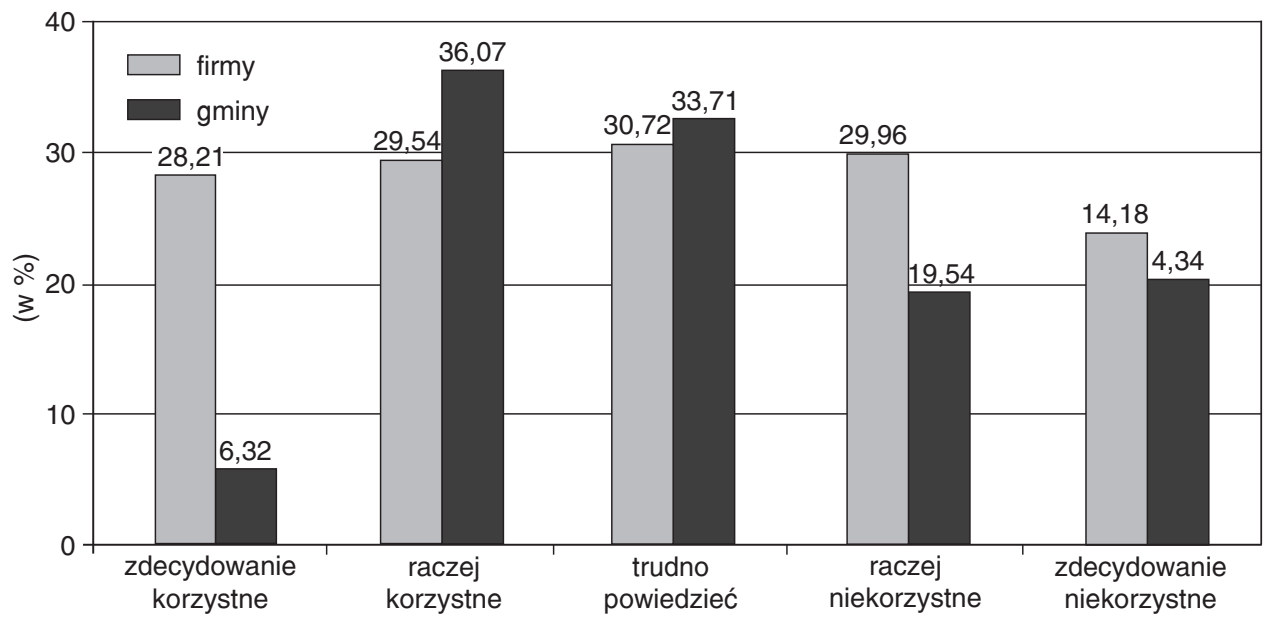

Źródło: opracowanie autorów na podstawie badań empirycznych

\section{Konkluzje}

Woj. małopolskie jest jednym z najbardziej atrakcyjnych przyrodniczo rejonów Polski. Przyczyniło się to do rozwoju turystyki w tym rejonie. Walory turystyczne kwalifikują Małopolskę jako całoroczny region turystyczny. W 2004 r. do Małopolski przyjechało ponad 9 mln turystów, a wpływy z ich obsługi wyniosły szacunkowo około 3,3 mld zł. Region przoduje w wielu wskaźnikach charakteryzujących gospodarkę turystyczną. Pod względem wskaźnika korzystania z noclegów przez turystów zagranicznych region zajmuje jedno z pierwszych miejsc w kraju.

Dynamiczny rozwój przedsiębiorczości w turystyce w Małopolsce następuje dzięki m.in. walorom kulturalnym, przyrodniczym i historycznym głównie Krakowa, Zakopanego, Oświęcimia, Wieliczki, Wadowic, ale także setek innych miejscowości. Liczba turystów odwiedzających Kraków liczona jest w milionach i szybko rośnie od czasu wstąpienia Polski do Unii Europejskiej. Władze regionalne prowadzą intensywną kampanię reklamującą walory turystyczne i liczą na dalszy napływ turystów.

Dobre warunki rozwoju przedsiębiorczości turystycznej występują w regionie tatrzańskim, głównie ze względu na jego specjalizację turystyczną. W badaniach przeprowadzonych przez M. Bednarczyk i zespół w latach 2003 i 2004 zwrócono uwagę na istotne różnice między wskaźnikiem przedsiębiorczości dla poszczególnych powiatów woj. małopolskiego w ramach danej sekcji PKD: „Dominacja hotelarstwa i transportu w powiecie tatrzańskim wynika z roli, jaką on pełni na turystycznej mapie Polski” (Bednarczyk i in. 2004).Wskaźnik drobnej przedsiębiorczości w regionie tatrzańskim jest od kilku lat jednym z najwyższych w województwie. Podobne wnioski zostały potwierdzone przez M. Bednarczyk i zespół w 2002 r. w badaniach nad produktami turystycznymi Piwnicznej i Szczawnicy oraz rozwojem przedsiębiorczości prywatnej (Bednarczyk 
Ryc. 4. Miejscowość zamieszkania przedsiębiorcy jako miejsce prowadzenia biznesu w woj. małopolskim

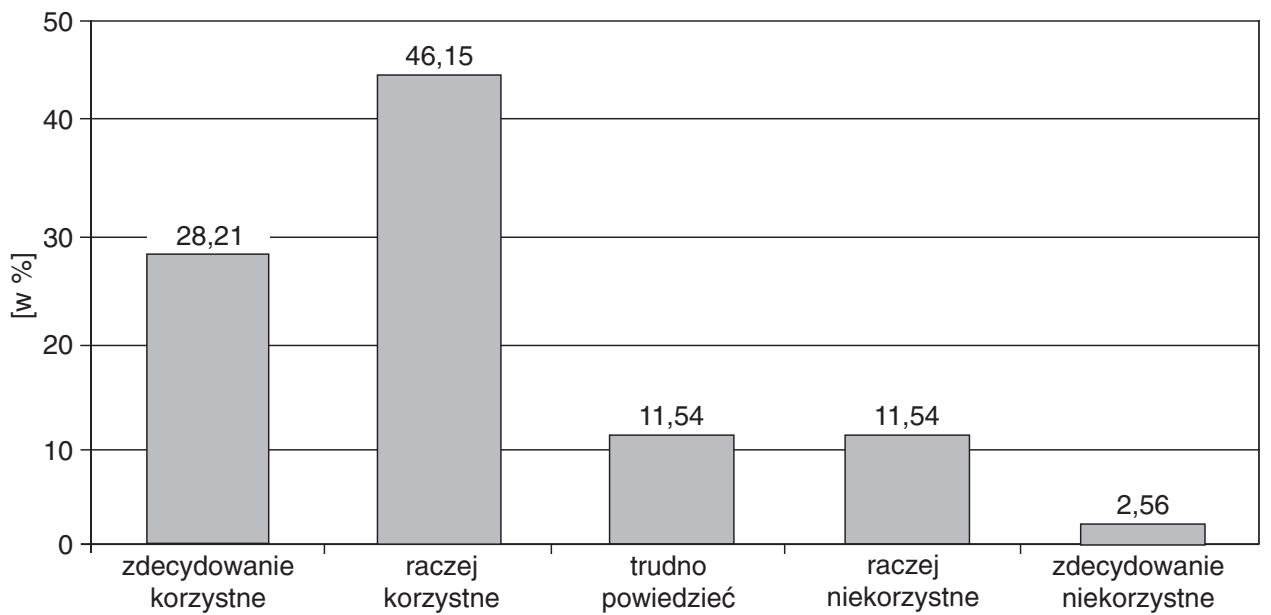

Źródło: opracowanie autorów na podstawie badań empirycznych

i in. 2002). Można wnioskować, że władze lokalne nie zaspokajają potrzeb przedsiębiorców i realizują opracowaną przez siebie strategię rozwoju przedsiębiorczości turystycznej bez uprzedniej analizy potrzeb MSP. Wyniki badań potwierdzają występowanie tzw. luki niedopasowania, czyli niedopasowanie między potrzebami małych i średnich przedsiębiorstw a polityką władz lokalnych wspierającą przedsiębiorczość turystyczną na poziomie regionalnym. „Przed obszarami górskich powiatów nowosądeckiego, nowotarskiego i tatrzańskiego - jako części województwa małopolskiego - stają nowe wyzwania wynikające z potrzeby dostosowania się do współczesnych trendów światowej gospodarki, uwzględnienia w procesach transformacji postulatów Unii Europejskiej i sprostania konkurencji na rynkach” (Bednarczyk i in. 2002).

Badania zmierzające do wyjaśnienia wpływu czynników otoczenia regionalnego na rozwój przedsiębiorstw turystycznych są pionierskie zarówno w krajowej, jak i międzynarodowej literaturze przedmiotu. Na podstawie ich wyników można stwierdzić, że te czynniki odgrywają kluczową rolę w rozwoju regionalnej przedsiębiorczości turystycznej. Przedstawione wyniki wyznaczają kierunki dalszych badań, w szczególności w zakresie regionalnych determinant rozwoju przedsiębiorstw turystycznych oraz obszarów budowy ich przewagi konkurencyjnej. Jest bowiem potrzeba skonstruowania modelu thumaczącego wzrost przedsiębiorczości turystycznej, który - oprócz czynników związanych z osobą założyciela oraz specyfiką firmy turystycznej - uwzględniłby również czynniki związane z otoczeniem regionalnym jako determinanty przeżycia i sukcesu nowych firm. W wyniku analizy zebranych materiałów sformułowano następujące wnioski:

- wśród badanych przedsiębiorców zaobserwowano wysoką inercję, która przejawia się niską interakcją przedsiębiorstw turystycznych z pozostałymi podmiotami otoczenia regionalnego. Niespełna $20 \%$ badanych przedsiębiorców korzysta z ośrodków wsparcia małych i średnich przedsiębiorstw turystycznych;

- zastanawia niski poziom wiedzy przedsiębiorców o otoczeniu biznesu, zarówno w aspekcie przedmiotowym, jak i podmiotowym. Był to jeden z głównych powodów nieskorzystania z pomocy ośrodków wsparcia małych i średnich przedsiębiorstw turystycznych $(50,34 \%)$ i niezrzeszania się w ramach samorządu gospodarczego $(24,77 \%)$;

- zaobserwowano wyraźne niedopasowanie inicjatyw samorządowych do potrzeb przedsiębiorstw turystycznych, potwierdzone opiniami o polityce gminy wśród przedsiębiorców z jednej strony i samooceną działań gmin - z drugiej. Decydenci lokalni byli bardziej skłonni do 
pozytywnej samooceny, jednak weryfikacja ich działań dokonana przez przedsiębiorców nie była już taka przychylna;

- wobec dynamiki zmian w otoczeniu (również regionalnym) oraz aktualnych potrzeb przedsiębiorców lokalni decydenci będą zmuszeni do stałego monitoringu oraz aktualizacji swoich działań na rzecz wspierania przedsiębiorstw turystycznych.

\section{Literatura}

1. Badania ruchu turystycznego w Małopolsce, 2004, Małopolska Organizacja Turystyczna, Kraków

2. Bednarczyk M. i in., 2002, Ekologiczna kolejka górska elementem zrównoważonego rozwoju regionu turystycznego w Polsce, w ramach projektu „Europejska Inicjatywa EUREKA E! RAIL MOUNT”, Uniwersytet Jagielloński, Kraków (maszynopis powielony)

3. Bednarczyk M. i in., 2004, Małe i średnie przedsiębiorstwa w Polsce a integracja europejska, Wydawnictwo Akademii Ekonomicznej w Krakowie, Kraków

4. Diagnoza, analiza i ocena kondycji sektora MŚP w Krakowie na podstawie badań ankietowych, 2004, Urząd Miasta Krakowa, Kraków (maszynopis powielony)

5. Małopolska w liczbach, 2004, Urząd Marszałkowski Województwa Małopolskiego, Kraków

6. Rapacz A. i in., 2001, Przedsiębiorstwo turystyczne w gospodarce rynkowej, Wydawnictwo Akademii Ekonomicznej we Wrocławiu, Wrocław

7. Wach K., Istota otoczenia regionalnego $w$ funkcjonowaniu matych i średnich przedsiębiorstw [w:] „Prace Naukowe Akademii Ekonomicznej im. O. Langego we Wrocławiu”1023/2004 pt. Gospodarka lokalna i regionalna w teorii i praktyce, R. Brol (red.), Wydawnictwo Akademii Ekonomicznej we Wrocławiu, Wrocław

8. Wach K., 2005, Model badania wpływu otoczenia regionalnego na rozwój małych i średnich przedsiębiorstw [w:] Uwarunkowania rozwoju i konkurencyjności regionów, Z. Zioło (red.), Wyższa Szkoła Informatyki i Zarządzania w Rzeszowie, Kraków-Rzeszów

9. Wach K., Rola państwa i samorzadu terytorialnego w rozwoju małych i średnich przedsiębiorstw [w:] „Zeszyty Naukowe Uniwersytetu Gdańskiego, Prace i Materiały Wydziału Zarządzania”, 2/2004, Uniwersytet Gdański, Sopot

\section{Climate for Tourist Entrepreneurship in Małopolska on the Basis of Empirical Research}

The paper elaborates on the influence of regional factors (mezoenvironment) on tourist enterprises' development in the region. These factors create so called favorable regional climate for tourist entrepreneurship development. Analyzing impact of mezzoenvironment factors on tourist enterprises development, the authors limit themselves only to small and medium-sized tourist enterprises considering their dominant character in tourist sector, as well as the key significance for development of entrepreneurship and region or country competitiveness. The article presents results of empirical research conducted on a random sample of small and medium-sized tourist enterprises in Małopolska Province. 
Mirosław Wójtowicz

Zakład Geografii Regionalnej

Instytut Geografii

Akademia Pedagogiczna w Krakowie

\section{Rozwój przewozów pasażerskich w Międzynarodowym Porcie Lotniczym im. Jana Pawła II w Krakowie na tle innych portów regionalnych w Polsce}

Procesy metropolizacji w największych polskich miastach charakteryzują się m.in. rozbudową sieci bezpośrednich połączeń transportowych i komunikacyjnych z innymi metropoliami w Europie i na świecie. Stan rozwoju infrastruktury sieciowej, głównie transportowej i telekomunikacyjnej, może celnie określać poziom metropolizacji danego ośrodka. Połączenia lotnicze, a precyzyjniej, ich częstotliwość oraz wielkość przewozów, mogą służyć jako jeden ze wskaźników międzynarodowego czy globalnego charakteru miasta-metropolii, a także określać główne kierunki powiązań międzynarodowych i ich znaczenie, mierzone wielkością przewozów lotniczych, (Cattan 1995, Jałowiecki 1999, Witlox i in. 2004, Derudder i in. 2005).

Aspiracje Krakowa do pełnienia roli ważnej metropolii o znaczeniu nie tylko krajowym, ale także europejskim muszą nieodłącznie prowadzić do rozwoju portu lotniczego oraz zwiększania ilości i zróżnicowania geograficznego połączeń lotniczych. W latach 1996-2006 dokonał się w tym zakresie spektakularny postęp, nieodnotowany w przypadku żadnego innego regionalnego portu lotniczego.

\section{Rozwój infrastruktury krakowskiego lotniska na tle innych portów regionalnych}

W latach 1995-2006 regionalne porty lotnicze przeszły gruntowną modernizację i rozbudowę zarówno terminali pasażerskich, jak i obsługujących przewozy cargo. Pozwoliło to sprostać wymogom bezpieczeństwa i zapewnić odpowiedni komfort obsługi rosnącej liczbie pasażerów. W przypadku krakowskiego lotniska szczególnie ważne prace modernizacyjne wykonano w 1995 r., kiedy to wyremontowano i przedłużono o $150 \mathrm{~m}$ drogę startową oraz oddano w całości do użytku nowy terminal pasażerski. Kolejna, ważna z punktu widzenia rosnącego ruchu pasażerskiego, rozbudowa terminalu rozpoczęła się w grudniu 1999 r., a zakończyła w styczniu 2001 r. Dzięki niej przepustowość terminalu wzrosła z 450 tys. do 1,3 mln pasażerów rocznie.

Nastąpiły także istotne przekształcenia prawno-własnościowe organu zarządzającego lotniskiem. W lipcu 1996 r. powołano spółkę z ograniczoną odpowiedzialnością: „Międzynarodowy Port Lotniczy Kraków-Balice”, która rozpoczęła działalność 1 lipca 1997 r., przejmując wcześniejszych pracowników Przedsiębiorstwa Państwowego „Porty Lotnicze”. W styczniu 1998 r. zmieniono jej nazwę na Międzynarodowy Port Lotniczy im. Jana Pawła II Kraków-Balice Spółka z o.o. Najważniejszym udziałowcem spółki jest P.P. „Porty Lotnicze”, posiadające 78,83\% udziałów. Na kolejnych miejscach znajdują się: województwo małopolskie - 20,05\%, gmina miejska Kraków - 1,08\% oraz gmina Zabierzów - 0,04\% udziałów ${ }^{1}$.

\footnotetext{
${ }^{1} \mathrm{~W}$ opracowaniu wykorzystano informacje, komunikaty i dane statystyczne dostępne w latach 2004 -2006 na stronie internetowej Międzynarodowego Portu Lotniczego im. Jana Pawła II Kraków-Balice Sp. z o.o.; http://www.lotnisko-balice.pl/.
} 
Krakowskie lotnisko, podobnie jak inne regionalne porty lotnicze, położone jest stosunkowo blisko centrum aglomeracji i należy do większych, biorąc pod uwagę potencjalną roczną przepustowość. Lotnisko to ma najlepsze warunki do rozwoju przewozów, gdyż w jego strefie oddziaływania o promieniu $100 \mathrm{~km}$ (odpowiadającej w przybliżeniu czasowi dojazdu około $90 \mathrm{~min}$ ) zamieszkuje około 7,9 mln osób. Należy jednak pamiętać, że obszar ciążenia krakowskiego lotniska pokrywa się częściowo ze strefą oddziaływania katowickiego portu lotniczego w Pyrzowicach, który jest oddalony zaledwie o $90 \mathrm{~km}$ od lotniska w Balicach (tab.1).

Tab.1. Parametry wybranych regionalnych portów lotniczych (grudzień 2004 r.)

\begin{tabular}{|l|c|c|c|c|}
\hline Porty lotnicze & $\begin{array}{c}\text { Odległość } \\
\text { od centrum } \\
\text { aglomeracji } \\
\mathbf{( w ~ k m )}\end{array}$ & $\begin{array}{c}\text { Powierzchnia } \\
\text { terminalu } \\
\text { pasażerskiego } \\
\left.\mathbf{( w ~ m}^{\mathbf{2}}\right)\end{array}$ & $\begin{array}{c}\text { Przepustowość } \\
\text { roczna } \\
\text { (w mln osób) }\end{array}$ & $\begin{array}{c}\text { Liczba ludności } \\
\text { w strefie oddziały- } \\
\text { wania w promie- } \\
\text { niu 100 km od } \\
\text { lotniska (w mln) }\end{array}$ \\
\hline Gdańsk & $10 / 11 / 23^{*}$ & 7260 & 1,0 & 2,5 \\
\hline Katowice & 34 & 7600 & 1,6 & 7,5 \\
\hline Kraków & 18 & 5000 & 1,3 & 7,9 \\
\hline Poznań & 7,5 & 14000 & $1,2-1,5$ & 4,2 \\
\hline Wrocław & 10 & 6500 & 0,6 & 3,4 \\
\hline
\end{tabular}

*Odległości podano w kolejności od centrum Gdańska, Sopotu i Gdyni

Źródło: opracowanie autora na podstawie: Czecharowski 2002a, b; 2003a, b, c, oraz informacji uzyskanych z poszczególnych portów lotniczych

W porównaniu z pozostałymi portami lotniczymi, wspomniane dwa porty dysponują największym potencjałem demograficznym w obszarze swojego ciążenia, co pozwala przypuszczać, że w miarę rozwoju gospodarczego i podnoszenia poziomu życia społeczeństwa na ich obszarze ciążenia będzie notowany najszybszy wzrost zapotrzebowania na przewozy lotnicze. Dodatkowym czynnikiem powodującym wzrost przewozów na krakowskim lotnisku jest dynamiczny rozwój międzynarodowego ruchu turystycznego. Jest on wynikiem intensywnej akcji promocyjnej w innych europejskich metropoliach, prezentującej unikatowe walory turystyczne miasta oraz jego najbliższego sąsiedztwa.

\section{Wzrost wielkości ruchu pasażerskiego w latach 1996-2005}

Polska jest jednym z najszybciej rozwijających się rynków pod względem wielkości przewozów lotniczych. W latach 1996-2005 ogólna wielkość ruchu pasażerskiego na polskich lotniskach wzrosła aż trzykrotnie (z 3,8 mln do 11,5 mln osób). W pięciu analizowanych regionalnych portach lotniczych przyrost liczby obsługiwanych pasażerów był jeszcze szybszy - blisko sześciokrotny, z 742,6 tys. do 4430 tys. osób. W przypadku krakowskich Balic wielkość przewozów wzrosła ponadośmiokrotnie, z 196,5 tys. do blisko 1,6 mln pasażerów (ryc.1).

Znacznie szybsze tempo wzrostu wielkości przewozów lotniczych w regionalnych portach lotniczych sprawia, że maleje monopolistyczna rola warszawskiego lotniska. W 1996 r. lotnisko Okęcie obsłużyło aż 80,6\% całego ruchy pasażerskiego, a w roku 2005 jedynie $61,5 \%$. W tym samym okresie udział krakowskich Balic wzrósł z 5,1\% do 13,8\% ogólnej liczby pasażerów odprawionych w kraju. 
Ryc. 1. Zmiany wielkości ruchu pasażerskiego w głównych regionalnych portach lotniczych w latach 1996-2005

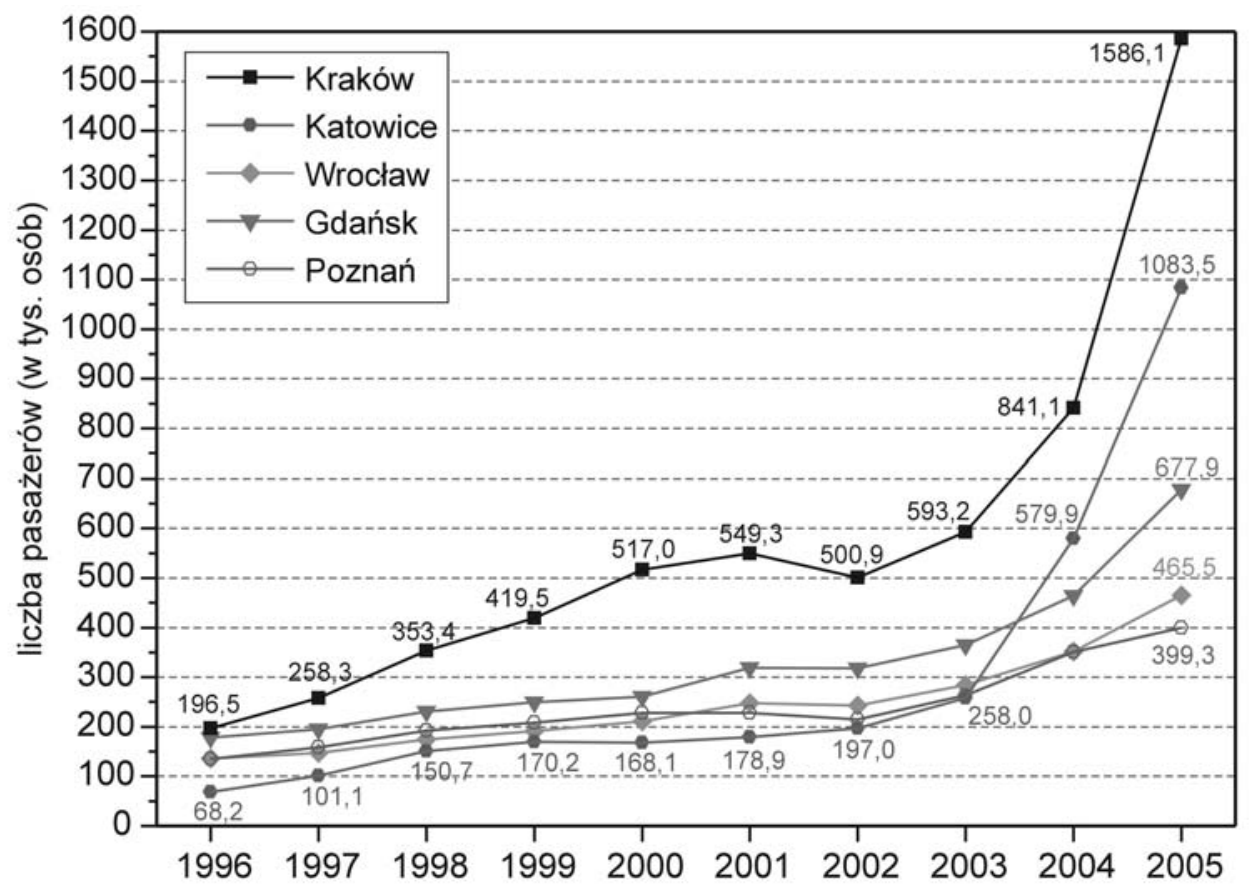

Źródło: opracowanie autora na podstawie danych Urzędu Lotnictwa Cywilnego

Ryc. 2. Dynamika wzrostu przewozów pasażerskich w wybranych regionalnych portach lotniczych w latach 1996-2005 $(1996=100)$

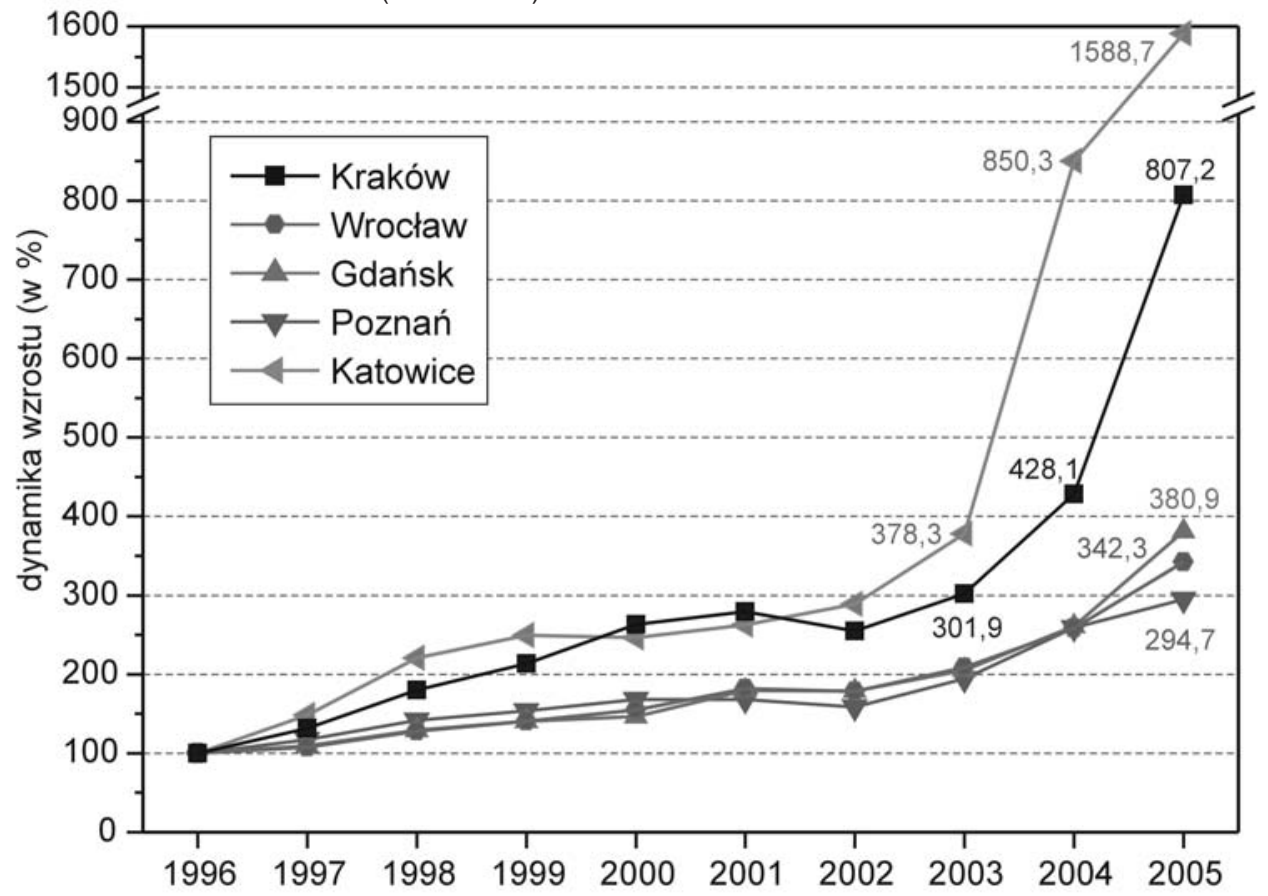

Źródło: opracowanie autora na podstawie danych Urzędu Lotnictwa Cywilnego 
W latach 1996-2005 krakowskie lotnisko oraz katowickie Pyrzowice należały do najszybciej rozwijających się lotnisk w kraju. Najwyższą dynamikę wzrostu wielkości przewozów odnotowano w przypadku Pyrzowic - wielkość przewozów w latach 1996-2005 wzrosła blisko 16-krotnie, podczas gdy krakowskie lotnisko zwiększyło przewozy 8-krotnie. W badanym okresie osiagnęły one jednak największą dynamikę wzrostu wśród analizowanych pięciu regionalnych portów lotniczych (ryc. 2).

Szczególnie dynamiczny wzrost wielkości przewozów odnotowano w tych dwóch portach lotniczych w latach 2004 i 2005. W Pyrzowicach wielkość ruchu pasażerskiego w 2004 r. była o 124,8\% większa niż w roku poprzednim, a w 2005 r. wzrosła o kolejne 86,8\%. W Balicach tempo wzrostu ruchu pasażerskiego w 2004 r. wzrosło o 41,8\% w porównaniu z rokiem poprzednim, a w 2005 r. aż o 88,6\%. Tempo wzrostu przewozów na tych dwóch lotniskach było zdecydowanie wyższe niż w pozostałych analizowanych portach lotniczych i znacznie przekraczało średnie tempo wzrostu wielkości ruchu pasażerskiego na polskich lotniskach, który w 2004 r. wzrósł o $24,2 \%$, a w 2005 - o $30,2 \%$.

Dynamiczny wzrost wielkości ruchu pasażerskiego w latach 2004 i 2005 na polskich lotniskach wynikał nie tylko z ogólnych tendencji związanych ze wzrostem mobilności społeczeństwa, większego międzynarodowego ruchu turystycznego i zwiększenia liczby kontaktów handlowo-biznesowych z innymi krajami. Spowodowało go przede wszystkim wkroczenie na polski rynek tanich przewoźników lotniczych. Na krakowskim lotnisku pierwsze tanie linie lotnicze (Low-Cost Carriers - LCC) pojawiły się w połowie 2004 r.: Volareweb.com - 18 czerwca, Germanwings - 24 czerwca, SkyEurop - 30 września, easyJet - 13 października. Przewiozły one w tym samym roku zaledwie około 190 tys. osób, a w 2005 r. wielkość przewozów wzrosła ponadsiedmiokrotnie, do około 770 tys., co spowodowało, że ich udział w ogólnej obsłudze ruchu pasażerskiego w Balicach wzrósł z 13,4\% do 48,5\%. W tym samym okresie tradycyjni przewoźnicy przewieźli jedynie o 14,1\% więcej pasażerów, co sprawiło, że ich udział w ogólnej obsłudze ruchu obniżył się z 74,1\% do 43,5\% (ryc. 3).

Jeszcze większy udział tanich linii lotniczych w obsłudze ruchu pasażerskiego odnotowano w Pyrzowicach, w których w 2005 r. aż 62,5\% ogólnej wielkości przewozów obsługiwały tanie linie, a udział tradycyjnych przewoźników obniżył się do 14,1\% (ryc. 3).

Omawiane porty lotnicze jako jedne z pierwszych otworzyły się dla tanich przewoźników, zachęcając ich do rozwijania połączeń, wspomagając w akcjach reklamowych i stwarzając inne udogodnienia. Wynikiem takiej polityki jest szczególnie aktywna obecność tych przewoźników na wspomnianych lotniskach, która wydatnie wpływa na urozmaicenie sieci dostępnych połączeń bezpośrednich. Należy podkreślić, że te porty nie mają szans stać się regionalnymi hub-ami żadnego tradycyjnego przewoźnika i traktowane są wyłącznie jako porty dowozowe do głównych hub-ów najważniejszych tradycyjnych przewoźników. Z tego względu LOT rozwija głównie połączenia z Warszawą, Lufthansa - z Frankfurtem nad Menem i Monachium, a Austrian Airlines $-z$ Wiedniem. Z punktu widzenia tanich linii są one jednak bardzo atrakcyjne ze względu na potencjalne duże zainteresowanie transportem lotniczym, szczególnie w przypadku Krakowa i Katowic, które mają największy potencjał demograficzny w swoich strefach oddziaływania, a ponadto są albo bardzo atrakcyjne dla turystów (Kraków), albo mają silne kontakty gospodarcze i społeczne z Niemcami (Katowice).

\section{Geograficzna struktura ruchu pasażerskiego w krakowskim porcie lotniczym}

Krakowskie lotnisko ma najlepiej rozwiniętą siatkę połączeń pasażerskich spośród wszystkich regionalnych portów lotniczych w Polsce. Pod względem liczby miast, z którymi ma bezpośrednie połączenia, ustępuje jedynie warszawskiemu Okęciu. W 2004 r. z krakowskiego lotniska 
Ryc. 3. Struktura ruchu pasażerskiego w wybranych portach lotniczych według typu przewoźnika w latach 2004 i 2005

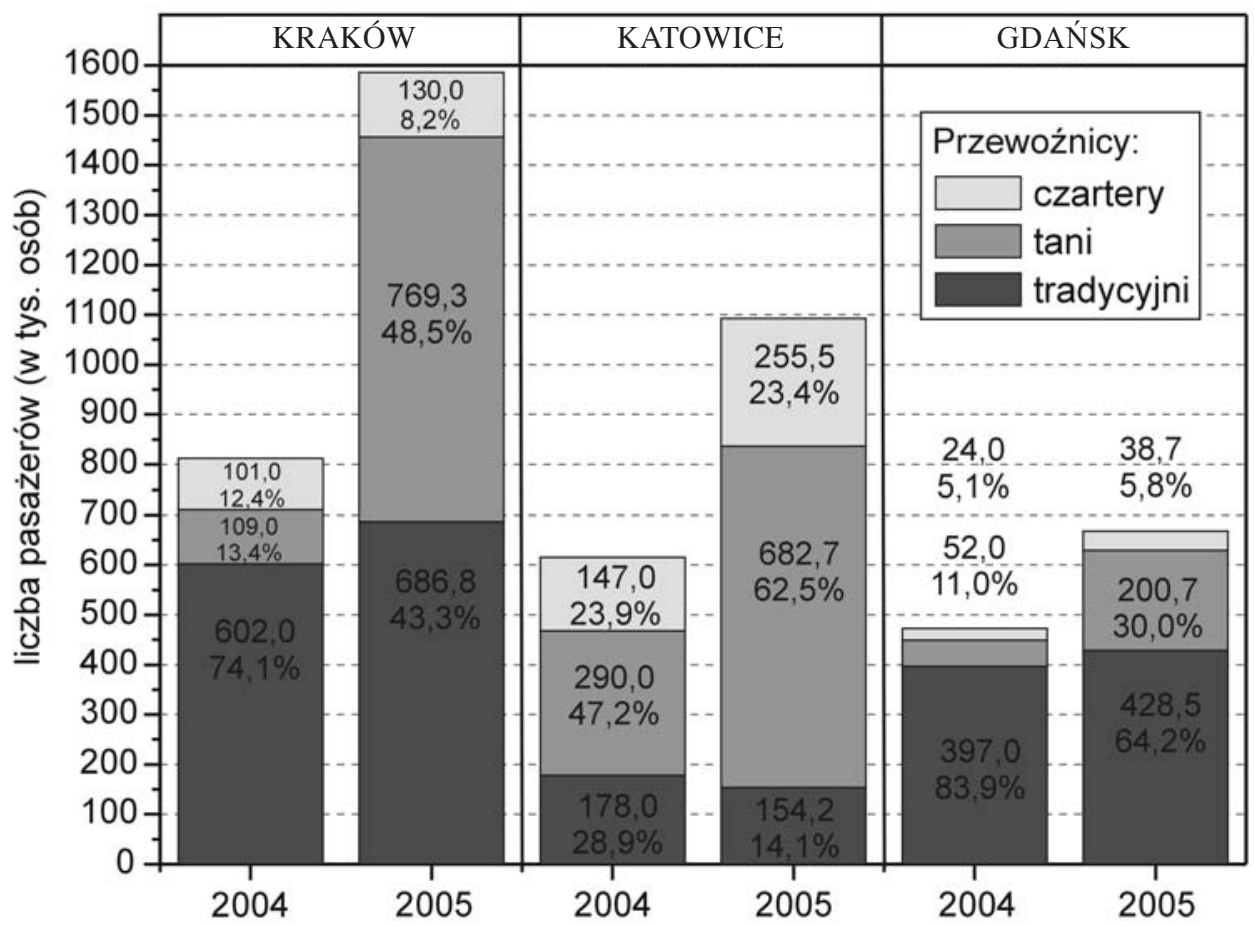

Źródło: opracowanie autora na podstawie danych uzyskanych z portów lotniczych

można było bezpośrednio dolecieć do 19 miast za granicą oraz do Warszawy. W 2005 r. siatka połączeń stała się jeszcze bogatsza, gdyż umożliwiała podróż do 25 miast za granicą oraz do Warszawy (por. ryc. 4 i 5).

W geograficznej strukturze przewozów krakowskiego lotniska w latach 2004 i 2005 dokonała się zmiana głównego kierunku przepływów pasażerskich. W 2004 r. największe znaczenie miało połączenie z Warszawą, z którego skorzystało ponad 186,8 tys. osób, co stanowiło 26,3\% ogólnej wielkości przewozów w ruchu regularnym. W 2005 r., pomimo wzrostu przewozów na tej trasie o 3,7\% (do 193,7 tys. osób), jej znaczenie spadło, ustępując połączeniom z aglomeracją Londynu, obsługiwanym przez kilku przewoźników. Spadło również znaczenie połączenia Kraków - Warszawa, gdyż w 2005 r. skorzystało z niego już tylko 13,3\% ogółu pasażerów obsłużonych w regularnym ruchu lotniczym. W tym samym czasie połączenie z Londynem przesunęło się z drugiego na pierwsze miejsce, a wielkość przewozów wzrosła z 132,9 tys. do 336,3 tys. pasażerów, co stanowiło wzrost z $18,7 \%$ do $23,1 \%$ ogółu pasażerów obsłużonych w regularnym ruchu lotniczym (ryc. 4 i 5).

Specyfiką krakowskiego portu lotniczego jest utrzymywanie połączeń transatlantyckich z miastami, które są głównymi skupiskami Polonii w Stanach Zjednoczonych. Jest to obecnie jedyne lotnisko regionalne obsługujące tego typu połączenia. Jest to związane z liczną emigracją mieszkańców Małopolski i Podkarpacia do Stanów Zjednoczonych oraz ciagłym utrzymywaniem kontaktów z rodzinnymi stronami. W 2004 r. z linii Kraków - Chicago skorzystało około 52,5 tys. podróżnych, co stawiało ją na drugim miejscu wśród połączeń międzynarodowych pod względem wielkości przewozów (10,0\%). W 2005 r. przewieziono na tej trasie około 58,2 tys. osób, co 
Ryc. 4. Kraków. Wielkość przewozów pasażerskich w ruchu regularnym na kierunkach obsługiwanych w 2004 r. (w tys. osób)

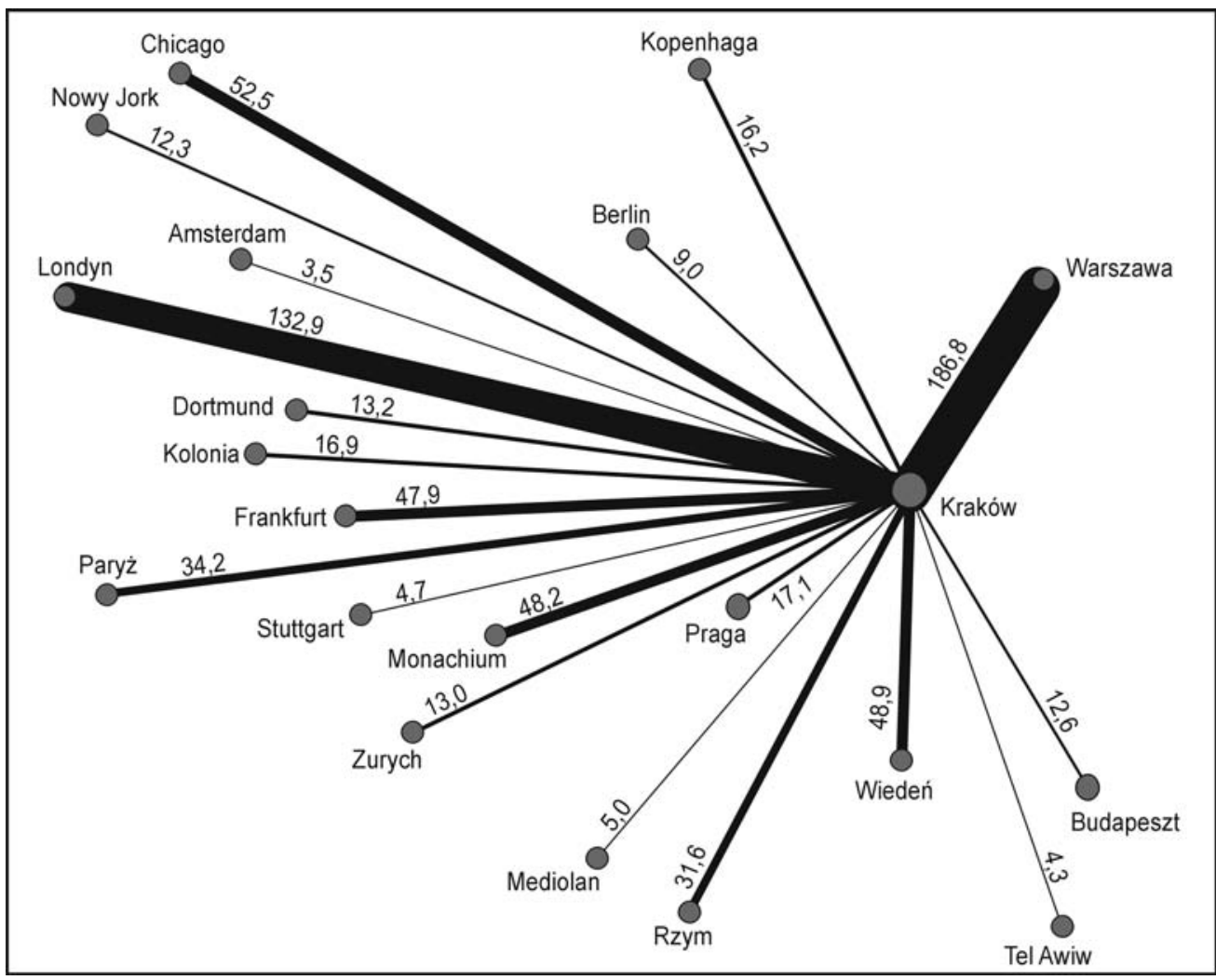

Źródło: opracowanie autora na podstawie informacji uzyskanych z Międzynarodowego Portu Lotniczego Kraków-Balice: http//www.lotnisko-balice.pl/stat_ruch_pasazerski.asp.

stanowiło już jedynie 4,6\% wielkości przewozów międzynarodowych. Znacznie mniejsze przewozy odnotowano na trasie Kraków - Nowy Jork. Wzrosły one w analizowanym okresie z 12,3 tys. do 16,0 tys. pasażerów. Nieznaczny wzrost wielkości przewozów odnotowany na obydwu trasach transatlantyckich świadczy o niesłabnącym zainteresowaniu tymi połączeniami, warto jednak zaznaczyć, że wraz z dynamicznym rozwojem połączeń europejskich w latach 2004 i 2005 ich znaczenie w ogólnej wielkości przewozów międzynarodowych bardzo zmalało.

Istotną rolę wśród połączeń międzynarodowych odgrywały w 2004 r. także trasy dowozowe do głównych hub-ów partnerów LOT-u z aliansu Star: Frankfurtu, Monachium i Wiednia. Na tych trzech kierunkach wielkości przewozów wahały się od 47,9 tys. do 48,9 tys. pasażerów (ryc. 4). W 2005 r. najważniejszą rolę odgrywało połączenie z Monachium, obsługiwane przez LOT i Lufthansę. Wielkość przewozów na tej trasie wzrosła z 48,2 tys. do 110,7 tys. pasażerów, podczas gdy w przypadku połączenia z Frankfurtem nad Menem odnotowano wyraźny spadek wielkości przewozów, a w przypadku połączenia z Wiedniem - jedynie nieznaczny wzrost. Fakt ten należy wiązać ze strategią niemieckiego przewoźnika, który kieruje ruch dowozowy z krakowskiego lotniska do swojego $h u b-u$ w Monachium, zwiększając na tej trasie liczbę połączeń do 21 tygodniowo, a ograniczając liczbę połączeń z Frankfurtem nad Menem, do którego kieruje się głównie ruch dowozowy z katowickiego lotniska (40 połączeń tygodniowo). 
Ryc. 5. Kraków. Wielkość przewozów pasażerskich w ruchu regularnym na kierunkach obsługiwanych w 2005 r. (w tys. osób)

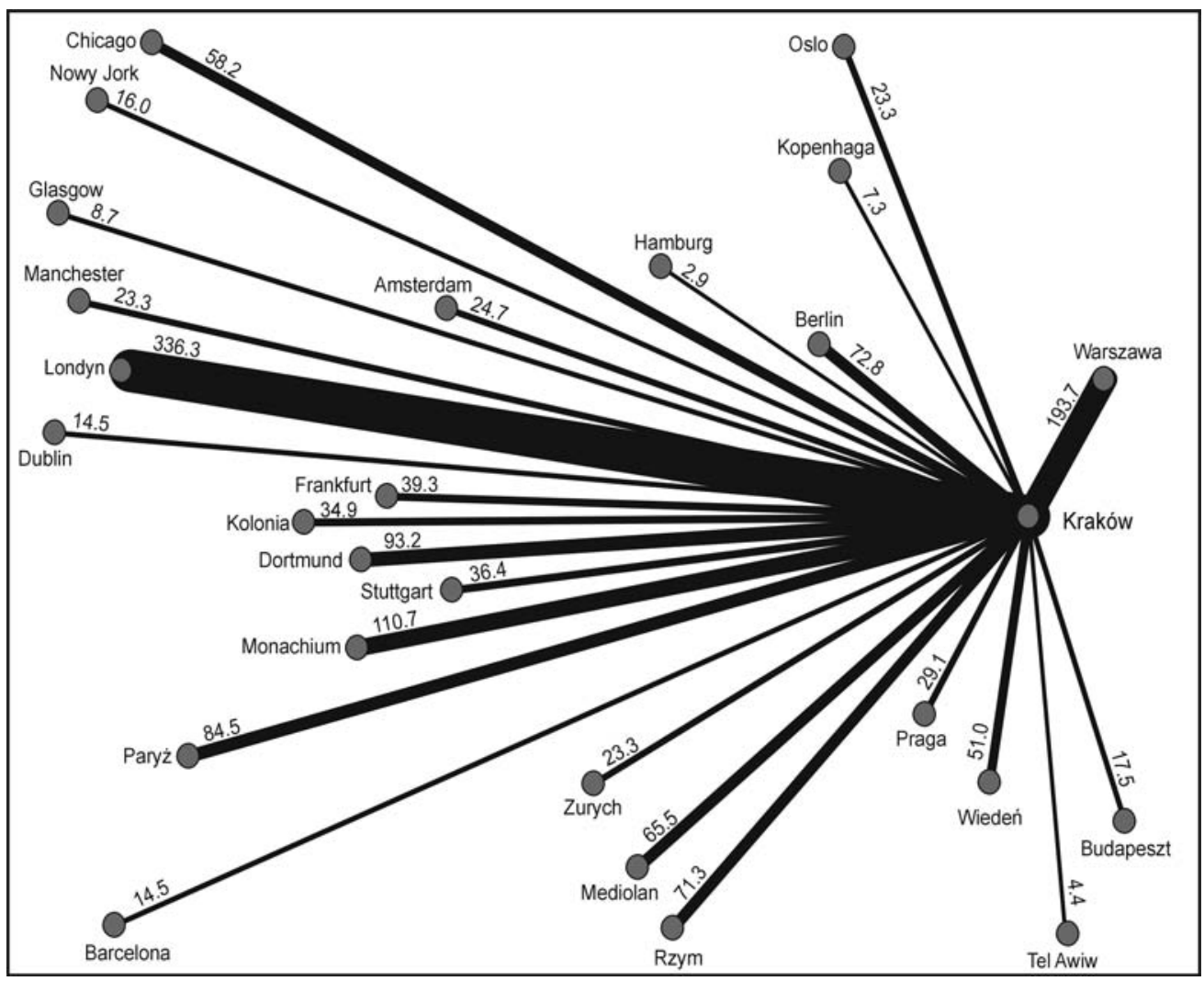

Źródło: opracowanie autora na podstawie informacji uzyskanych z Międzynarodowego Portu Lotniczego Kraków-Balice: http//www.lotnisko-balice.pl/stat_ruch_pasazerski.asp.

Warto również odnotować stosunkowo dynamiczny wzrost ruchu pasażerskiego na trasach między Krakowem a Dortmundem (z 13,2 tys. do 93,2 tys. osób), Paryżem (z 34,2 tys. do 84,5 tys. osób), Berlinem (z 9 tys. do 72,8 tys. osób), Rzymem (z 31,6 tys. do 71,3 tys. osób). Ustawia to te miasta na trzecim (po Londynie i Monachium) szczeblu w hierarchii powiązań lotniczych Krakowa z metropoliami europejskimi (ryc. 4 i 5 ).

Czwarty szczebel w hierarchii powiązań lotniczych Krakowa stanowiły te, na których w 2004 r. wielkość ruchu pasażerskiego wahała się od około 10 tys. do 20 tys. osób, a w 2005 r. - między 20 tys. a 65,5 tys. osób. W tej grupie miast znalazły się w 2004 r.: Budapeszt, Dortmund, Kolonia, Kopenhaga, Praga i Zurych, a w 2005 r.: Amsterdam, Frankfurt nad Menem, Kolonia, Manchester, Mediolan, Oslo, Praga, Stuttgart, Wiedeń i Zurych (ryc. 4 i 5).

Ostatnią w hierarchii - piątą grupę - stanowią miasta, w przypadku których wielkość przewozów pasażerskich nie przekroczyła w 2004 r. 10 tys. osób, a w 2005 r. była niższa od 20 tys. osób. W 2004 r. znalazło się w tej grupie pięć miast, a w 2005 r. ich liczba wzrosła do siedmiu (por. ryc. 4 i 5).W analizowanym okresie dokonały się znaczne zmiany w hierarchii głównych międzynarodowych połączeń lotniczych Krakowa. Najważniejsze pod względem wielkości przewozów 
pozostaje połączenie z portami lotniczymi aglomeracji Londynu, ale na drugie miejsce awansowało połączenie z Monachium, a straciły tę pozycję połączenia z Frankfurtem nad Menem i Wiedniem. Trzeci szczebel w hierarchii tworzyły początkowo połączenia z Paryżem i Rzymem, ale w 2005 r. doszły także połączenia z Dortmundem i Berlinem. Na kolejnych szczeblach hierarchii szczególnie godny podkreślenia jest spadek znaczenia połączenia z Kopenhagą, co wiąże się ze stopniowym wycofywaniem się z krakowskiego lotniska skandynawskich linii SAS, oraz stosunkowo wolny wzrost przewozów na linii Kraków - Budapeszt. Należy jednak podkreślić, że w przypadku połączeń sklasyfikowanych w 2004 r. na czwartym i piątym szczeblu hierarchii dokonują się obecnie najszybsze zmiany i przesunięcia wynikające z rozwoju przewozów na tych trasach, które często rozpoczynano dopiero w drugiej połowie 2004 r. wraz z pojawieniem się tanich przewoźników (Wójtowicz 2005).

\section{Wnioski}

Krakowski port lotniczy należy do najszybciej rozwijających się lotnisk w kraju. Wskazuje na to nie tylko ponadośmiokrotny wzrost liczby odprawionych pasażerów w latach 1996-2005, ale także stały rozwój sieci połączeń, która w 1996 r. ograniczała się tylko do połączenia z Warszawą, a w 2005r. powiększyła się o połączenia z 25 miastami za granicą. Na koniec 2005 r. Balice miały połączenia z 23 miastami, w tym z 22 za granica, obsługiwane przez 10 tradycyjnych oraz 6 tanich przewoźników.

Warto zauważyć, że krakowskie lotnisko, obsłużywszy w 2005 r. blisko 1,6 mln pasażerów, przekroczyło planowaną na 1,3 mln osób rocznie przepustowość terminala pasażerskiego i stanęło wobec konieczności jak najszybszej jego rozbudowy. Dalszy dynamiczny wzrost przewozów potwierdzają także dane Urzędu Lotnictwa Cywilnego z pierwszego półrocza 2006 r., w którym przewieziono 979,3 tys. osób, czyli o 46,4\% więcej niż w tym samym okresie 2005 r. W sezonie letnim 2006 r. krakowskie lotnisko oferowało szczególnie bogatą sieć połączeń do 40 miast za granicą oraz 2 w kraju, obsługiwanych przez 11 tradycyjnych i 9 tanich przewoźników. Przyczyniło się to do jeszcze szybszego wzrostu wielkości przewozów. Już 3 listopada 2006 r. świętowano obsłużenie dwumilionowego pasażera.

Lotnisko Balice ma bardzo zróżnicowaną strukturę przewoźników, w której, w przeciwieństwie do innych portów regionalnych, nie ma całkowitej dominacji tanich linii, a są także obecni tradycyjni przewoźnicy, gwarantujący większą stabilność połączeń.

Krakowski port ma najlepiej rozbudowaną i zróżnicowaną sieć połączeń spośród wszystkich portów regionalnych, dzięki czemu odgrywa ważną rolę w aktywizacji gospodarczej i pobudzaniu przedsiębiorczości zarówno na terenie miasta, jak i regionu. Przykładem jest gwałtowny wzrost liczby turystów zagranicznych w Krakowie, z 605 tys. w 2003 r. do 1250 tys. osób w 2005 r. W 2003 r. jedynie 19\% turystów zagranicznych dotarło do Krakowa samolotem, podczas gdy w 2005 r. już 48\% z nich wybrało ten środek transportu (Krakowski Rynek Nieruchomości, 2006). Nadchodzące lata będą miały decydujące znaczenie dla rozwoju i przyszłości krakowskiego lotniska. Jedynie szybka rozbudowa terminala pasażerskiego pozwoli mu utrzymać obecną pozycję, biorąc pod uwagę szybką rozbudowę lotniska w Pyrzowicach, które już w 2007 r. osiągnęło przepustowość ponad $3 \mathrm{mln}$ pasażerów rocznie. Wobec rosnącego zatłoczenia na Balicach, część przewoźników może przenieść się do Pyrzowic, co może doprowadzić do zahamowania rozwoju krakowskiego lotniska i przełożyć się pośrednio na spadek wielkości ruchu turystycznego, rynek nieruchomości oraz inne sektory gospodarki. 


\section{Literatura}

1. Biuletyn Informacyjny Lotnictwa Cywilnego. Działalność lotnisk w Polsce w latach 1999-2003, 2004, Urząd Lotnictwa Cywilnego, Warszawa

2. Biuletyn Informacyjny Lotnictwa Cywilnego. Działalność lotnisk w Polsce w latach 2000-2004, 2005, Urząd Lotnictwa Cywilnego, Warszawa

3. Cattan N., 1995, Attractivity and Internationalization of Major European Cities: The Example of Air Traffic. „Urban Studies”, vol. 32, no. 2

4. Czecharowski S., 2002a, Polskie regionalne porty lotnicze po kilku latach (1), „Przegląd Komunikacyjny" 7-8/2002

5. Czecharowski S., 2002b, Polskie regionalne porty lotnicze po kilku latach (4), „Przegląd Komunikacyjny" $12 / 2002$

6. Czecharowski S., 2003a, Polskie regionalne porty lotnicze po kilku latach (5), „Przegląd Komunikacyjny" $1 / 2003$

7. Czecharowski S., 2003b, Polskie regionalne porty lotnicze po kilku latach (7), „Przegląd Komunikacyjny" $3 / 2003$

8. Czecharowski S., 2003c, Polskie regionalne porty lotnicze po kilku latach (8), „Przegląd Komunikacyjny" $4 / 2003$

9. Derudder B., Devriendt L., Witlox F., 2005, Flying Where You Don't Want to Go: An Empirical Analysis of Hubs in the Global Airline Network, GaWC Research Bulletin, no. 187, http://www.lboro.ac.uk/gawc/rb/rb187.html.

10. Jałowiecki B., 1999, Metropolie, Wyższa Szkoła Finansów i Zarządzania w Białymstoku, Białystok

11. Krakowski Rynek Nieruchomości. Raport 2006, 2006, Urząd Miasta Krakowa, Wydział Strategii i Rozwoju Miasta, Kraków

12. Witlox F., Vereecken L., Derudder B., 2004, Mapping the Global Network Economy on the Basis of Air Passenger Transport Flows. GaWC Research Bulletin, no. 157, http://www.lboro.ac.uk/gawc/rb/rb157.html.

13. Wójtowicz M., 2005, Rozwój międzynarodowych powiqzań lotniczych głównych polskich metropolii [w:] Infrastruktura techniczno-ekonomiczna w obszarach metropolitalnych, Z. Makieła, T. Marszał (red.), Biuletyn KPZK PAN, z. 222

\section{Development of Passenger Transport at the John Paul II International Airport in Kraków in Comparison with Other Regional Airports in Poland}

The aim of this paper is to examine the changes of the passenger air traffic at the John Paul II International Airport in Kraków in comparison with other regional airports in Poland in the years 1996-2005. The analysis also covers the development of aviation network from the Kraków Airport and the changes in size of passenger flows on individual routes. Special attention was put on low-cost carriers and their impact on growth of passenger flows and the diversification of the offered connections. 


\section{Magdalena Kochmańska}

Instytut Politologii

Akademia Pedagogiczna w Krakowie

\section{Działalność gminy w zakresie rozwoju przedsiębiorczości lokalnej}

\section{Rozwój przedsiębiorczości lokalnej}

Przedsiębiorczość w ujęciu ekonomicznym jest traktowana jako czwarty czynnik produkcji, przejawiający się działaniami w obszarze racjonalizacji i twórczym stosowaniu nowatorskich rozwiązań przynoszących lepsze efekty wykorzystania pozostałych czynników rozwoju gospodarczego. Odgrywa istotną rolę w efektywnej alokacji istniejących i tworzeniu nowych oraz doskonalszych zasobów. Polega na poszukiwaniu innowacji oraz wykrywaniu nowych związków w istniejącym systemie społeczno-gospodarczym. ${ }^{1}$ Jest to zdolność jednostki do dostrzegania luk na rynku, wybiegania w przyszłość, poszukiwania zmiany i reagowania na nią oraz wykorzystywania jej do społecznej lub gospodarczej innowacji. ${ }^{2}$ Literatura przedmiotu podkreśla znaczenie innowacji społecznej i akcentuje jej znaczną trudność przeprowadzenia w porównaniu do innowacji technicznej. ${ }^{3}$

Z badań wynika, że we wdrażaniu wszelkich zmian główną rolę odgrywa lokalna grupa zawodowa, dzięki przynależności jej członków do stowarzyszeń, zrzeszeń politycznych, zespołów doradczych, agencji rozwoju regionalnego, rad nadzorczych. E. Skawińska pisze: „Sama obecność liderów w środowisku nie wystarcza do zapewnienia dynamizmu lokalnego, który może ulec osłabieniu, jeśli nie znajdą współrozmówców. Dominująca grupa społeczna uruchamia strategię rozwoju, np. gminy, która najlepiej chroni interesy gospodarcze tej i pozostałych grup społecznych". ${ }^{4}$ Można więc stwierdzić, że warunkiem przedsiębiorczości poszczególnych organizacji jest środowisko lokalne. ${ }^{5}$

Doświadczenia krajów gospodarczo rozwiniętych wskazują, że w środowisku lokalnym istotna jest rola animatorów. Cele animacji muszą odzwierciedlać cele lokalne oraz istniejące zasady, a ich realizacja powinna być oparta na współpracy animatora ze społecznością lokalną. Ta współpraca jest niezbędna dla zidentyfikowania zasobów, określenia celów i ich rozwiązania, wynegocjowania zaangażowania i poparcia lokalnych przywódców oraz agencji z zewnątrz, w tym poparcia kapitałowego. ${ }^{6}$ Rozwój przedsiębiorczości powinien być rozpatrywany w szerszym kontekście różnych elementów składających się na ogólny efekt rozwoju lokalnego. Te elementy lokalne to środowisko, kultura, gospodarka i władza.

${ }^{1}$ E. Skawińska, 2002, Konkurencyjność przedsiębiorstw. Nowe podejście, Wydawnictwo Naukowe PWN, Warszawa-Poznań.

${ }^{2}$ P.F Drucker, 1992, Innowacje i przedsiębiorczość. Praktyka i zasady, PWE, Warszawa.

${ }^{3}$ Ibidem.

${ }^{4}$ E. Skawińska, 2002, op. cit.

${ }^{5}$ B. Bojewska, 2002, Przedsiębiorczość w zarzqdzaniu i rozwoju matych i średnich przedsiębiorstw [w:] Zarzadzanie matym i średnim przedsiębiorstwem, uwarunkowania europejskie, M. Strużycki (red.), Difin, Warszawa.

${ }^{6}$ J. Bryden, 1989, The Standing Commission on the Scottish Economy. A Policy for Rural Scotland, Report of the Rural Issues Group. 
Liczne badania wskazują regiony, których rozwój nastąpił w wyniku połączenia różnych czynników lokalnych. Do istotnych czynników należą nie tylko elementy tradycyjnie uznawane za gospodarcze, lecz również te, którym dotychczas takiego znaczenia nie przypisywano. Do tej grupy należą m.in.: tradycja uprawiania danej dziedziny wytwórczości, tradycja samodzielnej działalności ekonomicznej, znajomość podstawowych zasad rynku, tradycje kooperacji, istnienie instytucji tworzących infrastrukturę przedsiębiorczości (parki technologiczne, małe banki, izby przemysłowe), zaufanie pozwalające na natychmiastowe zawieranie umów, zaciaganie kredytów i inne zobowiązania. Istotna jest również rola władz lokalnych rozumiejących i wspólnie wspierających przedsiębiorczość. Pobudzanie przedsiębiorczości i inicjatyw w skali lokalnej ułatwia tworzenie systemu harmonijnego, w którym każdy członek społeczności ma możliwość odegrania swojej roli, wzrasta zatem poczucie uczestnictwa.

Istota roli gminy w rozwoju przedsiębiorczości wynika z ustawowych cech samorządu terytorialnego. Oto one:

- Zadania gminy są określone ustawowo. Znaczna część finansów, jakimi gmina dysponuje, przeznaczona jest na realizację wytyczonych zadań. Do tych zadań należą: edukacja, opieka zdrowotna i społeczna, budowa i utrzymanie ulic i dróg lokalnych, gospodarka komunalna i mieszkaniowa, gospodarka przestrzenna i wydawanie pozwoleń budowlanych, zapewnienie funkcjonowania targowisk i niektóre funkcje administracyjne. Jeśli gmina wykracza poza te zadania, to mogą wystąpić trudności finansowe w ich realizacji.

- Najważniejszym zadaniem gminy jest stwarzanie warunków zaspokajania potrzeb jej mieszkańców.

- Pierwszeństwo w podejmowaniu inicjatyw oraz określaniu hierarchii potrzeb i sposobów ich zaspokojenia mają mieszkańcy gminy. Władza gminy pełni funkcje koordynacyjne, regulacyjne $\mathrm{i}$ informacyjne, ale nie narzuca mieszkańcom swojego punktu widzenia.

- Podstawowym zadaniem władzy lokalnej jest zaspokajanie potrzeb mieszkańców, co oznacza, że różne mogą być: hierarchia celów, sposób wykorzystania zasobów, stawiane czy akceptowane ograniczenia. Władza lokalna jest zwykle zainteresowana rozwojem gospodarczym o tyle, o ile realizowane są w ten sposób inne cele lub zadania, za które jest ona odpowiedzialna.

$\mathrm{W}$ artykule przedstawiono podstawowe płaszczyzny działania gminy w zakresie rozwoju przedsiębiorczości. Należą do nich: polityka gminy, instrumenty finansowe, inwestycje, gospodarowanie mieniem, działalność gminy, rynek pracy, promocja gminy, strategia rozwoju gminy i tworzenie klimatu inwestycyjnego, wpierającego przedsiębiorczość.

\section{Polityka gminy}

Zasadnicze znaczenie dla rozwoju przedsiębiorczości ma odpowiednio prowadzona polityka gminy. Z punktu widzenia tej polityki przedsiębiorczość należy rozumieć jako postawę sprzyjającą rozwojowi gospodarczemu gminy, inicjatywom lokalnym i samodzielnemu rozwiązywaniu problemów. Rozwój gospodarczy na szczeblu lokalnym oznacza przyrost środków i możliwości, które pozwalają lokalnej władzy i mieszkańcom lepiej zaspokajać większą liczbę potrzeb na wyższym poziomie. Ten rozwój nie powinien powodować wzrostu zanieczyszczeń środowiska przyrodniczego ani zmiany sposobu życia, który dotychczas był ceniony przez mieszkańców.

Oto warunki, których spełnienie jest konieczne, aby nastąpił rozwój:

- wolny dostęp do rynku i konkurencja,

- dominacja sektora prywatnego,

- otwartość na zmiany otoczenia,

- prorozwojowy, elastyczny rynek pracy,

- niskie obciążenia zysku i płac,

- stabilność polityczna i makroekonomiczna. 
Cele strategii rozwoju mogą dotyczyć rozmaitych zagadnień, a dokonywane wybory - odzwierciedlać rozmaite kierunki działań, np. silne programy promocji inwestycji, rozwoju przedsiębiorczości oraz prywatyzacji przedsiębiorstw i usług komunalnych, rozbudowę infrastruktury i udostępnianie terenów. Działania te mogą także polegać na dążeniu do zaspokojenia potrzeb mieszkaniowych czy poprawy sytuacji na rynku pracy. Mogą wreszcie być skoncentrowane na problemie uzdrowienia finansów lokalnych lub innych kwestiach.

\section{Instrumenty finansowe oddziaływania gminy na przedsiębiorczość}

Najważniejszym instrumentem finansowym gminy jest budżet składający się z różnego rodzaju źródeł dochodów oraz wydatków, z których każdy może być narzędziem oddziałującym na lokalne zadania gospodarcze. Narzędzia te należy wykorzystywać kompleksowo. Formułując zasady fiskalnej polityki gminy, należy przede wszystkim rozstrzygnąć podstawowe zagadnienia: czy lepiej obniżać, czy podwyższać podatki i opłaty? jeśli obniżać, to czy wszystkie? czy gmina ma w tym zakresie jakieś możliwości? jakie skutki dla budżetu gminy oraz lokalnego rozwoju gospodarczego i rozwoju przedsiębiorczości będą miały te operacje? Literatura przedmiotu podkreśla, że możliwe skutki obniżenia podatków lub opłat są korzystne dla rozwoju gospodarki i przedsiębiorczości gminy. ${ }^{7}$ Najkorzystniejszym skutkiem obniżenia podatków dla rozwoju gospodarczego i rozwoju przedsiębiorczości lokalnej jest wzrost inwestycji. Niezależnie od tego, czy chodzi o inwestorów z terenu gminy, czy też o inwestorów spoza gminy, o dobrych warunkach do inwestowania mówimy tylko wtedy, gdy inwestorzy mogą przewidzieć efekty swoich działań i efekty inwestycji na wiele lat. Każdy inwestor chce mieć pewność, że inwestycja przyniesie mu określone zyski w określonym czasie. Z tego punktu widzenia ważne są dwie kwestie, na które władze gminy mają wyraźny wpływ: stabilność oraz przewidywalność warunków inwestowania (w tym kosztów) i funkcjonowania firmy po ukończeniu inwestycji.

Istotny dla polityki finansowej gminy z punktu widzenia rozwoju przedsiębiorczości jest sposób kształtowania i prowadzenia tej polityki oraz podejmowania decyzji wpływających na otoczenie. Ważne, aby podejmować decyzje finansowe, opierając się na przemyślanej polityce (strategii) i racjonalnych metodach podejmowania decyzji. Przedsiębiorca nie może tracić zaufania do lokalnych władz w wyniku zagrożenia jego interesów. Aby decyzje finansowe gminy mogły pozytywnie oddziaływać na rozwój przedsiębiorczości, należy zwrócić uwagę na:

- skoordynowanie decyzji,

- stworzenie kompleksowego, wieloletniego planu, najlepiej strategii rozwoju,

- jawność poczynań i podejmowanych decyzji,

- wyraźne zdefiniowanie kompetencji organów gminy (tych, które nie są wymienione w ustawie o samorządzie terytorialnym lub w innych aktach prawnych), jeżeli może zaistnieć wątpliwość, który organ gminy jest odpowiedzialny za podejmowanie określonych decyzji,

- precyzyjne określenie kompetencji i odpowiedzialności poszczególnych komórek organizacyjnych i osób,

- oddzielenie funkcji kontrolnych od decyzyjnych i wykorzystanie kontrolnych uprawnień rad gminy,

- konsekwentne realizowanie przyjętych programów gospodarczych, zasad czy strategii, co musi mieć odzwierciedlenie w corocznie podejmowanych uchwałach budżetowych. ${ }^{8}$

\footnotetext{
${ }^{7}$ E. Bończak-Kucharczyk, K. Herbst, K. Chmura, 1998, Jak władze lokalne mogq wspierać przedsiębiorczość, Fundacja Inicjatyw Społeczno-Ekonomicznych, Polska Fundacja Promocji Małych i Średnich Przedsiębiorstw, Warszawa.

${ }^{8}$ Ibidem.
} 


\section{Inwestycje jako obszar rozwoju przedsiębiorczości}

Trwały wzrost gospodarczy oraz rozwój przedsiębiorczości nie są możliwe bez inwestycji. Władze samorządowe powinny być zainteresowane nie tylko inwestycjami finansowanymi bezpośrednio przez gminę, lecz także dokonywanymi przez inne podmioty na terenie gminy. Istnieje ścisły związek inwestycji gminnych z innymi inwestycjami prowadzonymi już nie przez gminę. O ważności inwestycji na terenie gminy decydują następujące elementy:

- Prawidłowo zaplanowane inwestycje infrastrukturalne powodują kolejne inwestycje.

- Inwestycje są najbardziej skuteczną metodą zwalczania bezrobocia, gdyż tworzą lokalny rynek pracy.

- Brak pewnego rodzaju inwestycji przekreśla rozwój niektórych dziedzin działalności gospodarczej. Na przykład brak inwestycji w dziedzinie telekomunikacji, zaopatrzenia w wodę, energię itp. stanowi barierę dla lokalnego rozwoju gospodarczego.

- Brak inwestycji w niektórych dziedzinach (np. mieszkaniowych) powoduje, że nie zostają zaspokojone podstawowe potrzeby mieszkańców, co wywołuje niezadowolenie społeczne.

Szczególnie istotne dla rozwoju innowacyjności i przedsiębiorczości są inwestycje w tzw. parki technologiczne. Parki technologiczne to jednostki gospodarcze, których zasadniczym celem jest wytwarzanie zaawansowanej technologii oraz świadczenie usług w zakresie wdrażania innowacji na rzecz przedsiębiorstw funkcjonujących na określonym, zintegrowanym obszarze. Obejmują wspólne przedstawicielstwa na zewnątrz parku, użytkowanie wspólnych urządzeń serwisowych lub realizację wspólnych inwestycji w zakresie infrastruktury technicznej albo socjalnej. Park technologiczny można rozpatrywać jako zainicjowany oraz subwencjonowany ze środków publicznych zorganizowany kompleks przemysłowy, w ramach którego jest realizowana polityka w zakresie:

- wspomagania młodych innowacyjnych przedsiębiorstw, nastawionych na rozwój produktów i metod wytwarzania w technologicznie zaawansowanych branżach,

- optymalizacji warunków transferu technologii i komercjalizacji rezultatów badań z instytucji naukowych do praktyki gospodarczej. ${ }^{9}$

Jeśli mówimy o inwestycjach jako o czynniku stymulowania rozwoju i przedsiębiorczości, to należy zwracać uwagę nie tylko na inwestycje w sferze gospodarki, ale także inwestycje w ludzi (wykształcenie, umiejętności, postawy), w środowisko przyrodnicze, środowisko społeczne i struktury organizacyjne. W wyborze inwestycji komunalnych władze gminy - oprócz kryterium efektywności - powinny stosować inne kryteria, np. zadania, zakres świadczonych usług, poprawę standardu życia mieszkańców. Należy podkreślić znaczenie roli samorządu terytorialnego w inwestycjach prowadzonych z udziałem mieszkańców (inwestycje czynowe). Te inwestycje zwykle dotyczą uzbrojenia osiedli, budowy dróg, wodociagów itp. Władze gminy powinny tworzyć warunki do inwestowania. Są to głównie: przekonanie inwestorów w gminie o stabilności warunków działania, określenie warunków zabudowy i zagospodarowania niektórych terenów, ustalenie stałych i czytelnych zasad w zakresie zbywania, nabywania oraz zamiany nieruchomości i lokali przez gminę.

\section{Gospodarowanie mieniem w gminie jako obszar rozwoju przedsiębiorczości}

Mienie komunalne służy do wykonywania zadań własnych gminy (zadań publicznych). Istnieje prosty związek pomiędzy ustawowymi celami działania gminy, czyli pełnieniem zadań publicznych, a koniecznością posiadania mienia. Zarządzanie mieniem w gminie wymaga od władz

${ }^{9}$ J. Bogdanienko, 1998, Zarzqdzanie innowacjami, Warszawa; M. Strużycki, 2006, Przedsiębiorczość w teorii i praktyce, Oficyna Wydawnicza Szkoły Głównej Handlowej, Warszawa. 
samorządowych znacznej przedsiębiorczości. Gminy zwykle dysponują dużo większym mieniem niż tylko to, które służy do pełnienia zadań publicznych. To mienie powinno być zarządzane i wykorzystywane jak najlepiej. W tym celu władze gminy powinny: zinwentaryzować obiekty gminy; przygotować i zatwierdzić program konserwacji nieruchomości komunalnych i uzyskać na nie odpowiednie środki; przeprowadzić prace konserwatorskie i remontowe zgodnie z opracowanymi planami, dokonać kontroli przeprowadzonych prac i sposobu wykorzystywania środków; ocenić efektywność realizowanych programów. ${ }^{10}$

Ważne zadanie stojące przed gminą to opracowanie efektywnej strategii zarządzania mieniem i zbywania poszczególnych jego składników. Składniki mienia można podzielić na:

- te, które służą wykonywaniu zadań publicznych,

- te, które nie są do tego potrzebne (ani nie będą w przyszłości),

- te, które przynoszą gminie dochód i będą go przynosić w przyszłości,

- te, które dochodu nie przynoszą ani nie będą go przynosiły.

Zasady zbywania, nabywania, zamiany i obciążania mienia gminy należy traktować jako instrument tworzenia warunków rozwoju przedsiębiorczości. Znacznej aktywności przedsiębiorczej władz samorządowych wymagają takie operacje, jak:

- oddawanie gruntu w użytkowanie wieczyste,

- oddawanie nieruchomości w trwały zarząd,

- użyczanie,

- wnoszenie mienia do spółek prawa handlowego. ${ }^{11}$

Aby dobrze zarządzać nieruchomościami, należy przede wszystkim mieć o nich dostateczną wiedzę. W tym zakresie powinna być pomocna gminna baza danych o nieruchomościach, którą w zasadzie każda gmina powinna założyć i stale aktualizować, co wymaga odpowiedniego jej umiejscowienia w gminnych strukturach organizacyjnych oraz uwzględniania w zakresach obowiązków pracowników poszczególnych komórek organizacyjnych gminy.

Prawidłowa ocena efektów ekonomicznych związanych z posiadaniem i użytkowaniem danej nieruchomości jest podstawą racjonalnego ekonomicznie gospodarowania nieruchomościami komunalnymi. Ocena finansowych skutków sprzedaży powinna też stanowić podstawę do podjęcia decyzji o zbyciu określonych składników mienia gminy.

W niektórych gminach ważne dla rozwoju przedsiębiorczości mogą być zasady korzystania z gminnych obiektów i urządzeń użyteczności publicznej. Głównie chodzi o trzy ich rodzaje:

- obiekty i urządzenia infrastruktury technicznej,

- obiekty i urządzenia infrastruktury społecznej (szkoły, żłobki, przedszkola, obiekty sportowe, teatry itp.)

- urzędy i inne obiekty administracyjne, w których załatwiane są sprawy mieszkańców.

Stymulowanie rozwoju przedsiębiorczości przez gminę wymaga konstruowania planów zagospodarowania przestrzennego oraz planowania i prowadzenia inwestycji infrastrukturalnych w taki sposób, aby przewidywały one potencjalne potrzeby inwestorów, wyprzedzały je i pozwalały na korzystanie z infrastruktury maksymalnej liczbie podmiotów gospodarczych i osób na jak najlepszych warunkach.

${ }^{10}$ E. Bończak-Kucharczyk, K. Herbst, K. Chmura, op. cit.

${ }^{11}$ K. Wąsowicz, T. Ostrowski, 2003, Przedsiębiorczość komunalna, Izba Gospodarcza Komunikacji Miejskiej, Kraków. 


\section{Działalność gospodarcza gminy jako płaszczyzna rozwoju przedsiębiorczości}

Możliwości prowadzenia działalności gospodarczej przez gminę są ograniczone prawem. Gmina jako właściciel, zleceniodawca i odbiorca w procesach gospodarowania jest złożonym uczestnikiem gry rynkowej. Działalność gospodarcza gminy jest uwarunkowana innymi czynnikami niż działalność gospodarcza przedsiębiorców niepublicznych. W projektowanych zamierzeniach gmina nie zawsze może kierować się korzyściami ekonomicznymi. Strona finansowa, opłacalność ekonomiczna podejmowanych działań nie zawsze jest priorytetem. Stopień zaangażowania gminy w życie gospodarcze lokalnej wspólnoty został ogólnie określony w ustawie o samorządzie gminnym oraz w ustawie o gospodarce. W celu wykonania spoczywających na niej zadań, gmina może prowadzić działalność gospodarczą wykraczającą poza zadania o charakterze użyteczności publicznej. Podstawowym zakresem zainteresowania gminy są zadania własne. Jednak samorząd ma zadanie działania w kierunku rozwoju lokalnego, dlatego też polityka gospodarcza gminy musi stanowić odpowiedź na problemy rozwoju danej przestrzeni społeczno-gospodarczej. ${ }^{12}$

W zależności od charakteru i rozmiaru prowadzonej działalności gospodarczej gmina może wybrać różne jej formy organizacyjno-prawne. Mogą to być: jednostki budżetowe, gospodarstwa pomocnicze, zakłady budżetowe, spółki prawa handlowego - akcyjne z ograniczoną odpowiedzialnością, fundacje, spółdzielnie osób prawnych. W literaturze podkreśla się, że najwłaściwszymi formami prowadzenia działalności gospodarczej przez gminę są spółki prawa handlowego. ${ }^{13}$

Działania gminy w zakresie rozwoju przedsiębiorczości powinny obejmować:

- aktywizację lokalnych zasobów kapitału i pracy oraz efektywne wykorzystanie zasobów naturalnych, walorów lokalizacji przestrzennej,

- kreowanie nowych zasobów lokalnych poprzez stwarzanie korzystnych warunków do rozwoju,

- zarządzanie infrastrukturą w celu ułatwienia nawiązywania stosunków gospodarczych,

- zarządzanie zasobami pracy, które są szczególnym czynnikiem rozwoju lokalnego,

- kreowanie powiązań integracyjnych pomiędzy uczestnikami procesów gospodarczych, wzmacnianie przejawów życia gospodarczego w wymiarze lokalnym. ${ }^{14}$

\section{Rynek pracy i jego związek z przedsiębiorczością}

W procesie tworzenia i rozwoju innowacji i przedsiębiorczości w środowisku lokalnym podstawowym problemem jest zapewnienie zgodności społecznego zapotrzebowania na innowacje z treścią zaprowadzanej zmiany. Wprowadzając innowacje technologiczne, organizacyjne, ekonomiczne itp. dokonujemy zmian w dotychczas funkcjonujących strukturach. Dla ludzi, których ta zmiana dotyczy, oznacza to naruszenie dotychczasowego stanu, a ściślej - ich dotychczasowej pozycji. Czynnik ludzki ma podstawowe znaczenie w rozwoju innowacyjności i przedsiębiorczości. Zapoznanie społeczności lokalnej z wartością społecznych i ekonomicznych korzyści uzyskanych w wyniku wdrażania innowacji pozwala szybciej zlikwidować opór przeciw innowacji. Niedocenianie stosunku pracowników do zmian może spowodować wiele trudności i komplikacji, ujawniających się czasem w sposób ostry i konfliktowy. Mogą one niekiedy doprowadzić do niepowodzenia przedsięwzięcia w całości lub też znacznego zmniejszenia jego efektów.

Według ustawy samorządowej gmina jest zobowiązana zająć się sprawami publicznymi o znaczeniu lokalnym, w tym w zakresie zmniejszenia bezrobocia. Bezrobocie marnuje ludzkie zdolności i doświadczenia; bezrobotni tracą zdolność do angażowania się w różne sprawy, mobilizowania do działań, wykorzystania swych pomysłów i umiejętności, czyli tracą przedsiębiorczość.

\footnotetext{
${ }^{12}$ Ibidem.

${ }^{13}$ E. Bończak-Kucharczyk, K. Herbst, K. Chmura, op. cit.

${ }^{14} \mathrm{~K}$. Wąsowicz, T. Ostrowski, op.cit.
} 
Gmina ma odpowiednią pozycję, aby zorganizować współpracę z rejonowym urzędem pracy i może wykorzystać wszystkie dostępne środki, aby łagodzić bezrobocie i wpływać na rozwój gospodarczy. Ponadto może stymulować rynek pracy za pomocą działań zmierzających do rozwiązania konkretnych problemów tego rynku i wyzwalać swoistą mobilizację do działań związanych z pobudzaniem lokalnej aktywności i przedsiębiorczości.

Korzystną formą aktywizacji rozwoju gospodarczego i przedsiębiorczości lokalnej jest wspieranie takich inwestycji, które dają zatrudnienie i pobudzają rozwój innych dziedzin gospodarki gminy oraz tworzenie wszelkiego rodzaju kluby pracy.

Zasadnicze znaczenie dla rozwoju przedsiębiorstw i przedsiębiorczości ma odpowiedni system edukacji i dokształcania. Chodzi o system edukacji dobrze dopasowany do wymagań miejscowego rynku pracy. Przedsiębiorczość jako postawa życiowa człowieka będzie się rozwijała, jeżeli zostanie zaszczepiona już w trakcie edukacji. Coraz większe znaczenie mają więc systemy dokształcania.

\section{Promocja gminy jako sposób wspierania rozwoju lokalnego}

Promocja, nazywana także komunikacją marketingową, to zespół środków i działań, za których pomocą gmina przekazuje na rynek informacje charakteryzujące gminę, kształtuje potrzeby nabywców, ukierunkowuje popyt. Pod pojęciem promocji gminy rozumiemy działania zmierzające do zachęcenia określonych osób prawnych i fizycznych taką działalnością gospodarczą tak ukierunkowaną, aby dawała efekty pożądane przez władze gminy. Gminy miejskie częściej niż wiejskie zainteresowane są promocją. Mają więcej atrakcji mogących służyć za ,przynętę” i zwabić pożądanych gości. Dotyczy to przede wszystkim inwestorów i przedsiębiorców. Władze gminy starają się oferować potencjalnemu nabywcy cały serwis usług, na który składa się m.in. zaplecze administracyjne. Wpływ władz lokalnych będących liderem wspierania przedsiębiorczości na kształtowanie gminnego ośrodka działalności gospodarczej jest znaczny. Z punktu widzenia celów można wskazać pięć zasadniczych strategii promocji gminy:

- informujące o produkcie gminy,

- aktywizujące zainteresowanie produktem,

- wskazujące na elementy przewagi konkurencyjnej,

- podtrzymujące lojalność i relacje (budujące więź),

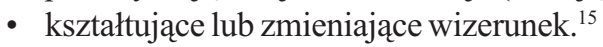

Strategia taka obejmuje następujące działania:

1. Stworzenie realnie funkcjonującego pozytywnego wizerunku gminy.

2. Przekazanie do otoczenia zewnętrznego i wewnętrznego gminy informacji o możliwościach (w bazach danych, na targach i konferencjach, wśród odwiedzających itd.).

3. Inwestowanie w poprawę swojej pozycji konkurencyjnej.

4. Stosowanie zachęt (niskie ceny terenów i budynków, ulgi i wakacje w podatkach, strefy ekonomiczne, pomoc w przeprowadzeniu części prac adaptacyjnych itp.).

5. Mobilizowanie dynamiki gospodarczej.

Marketingowy styl zarządzania gminą polega na świadomym i umiejętnym realizowaniu celów gminy przez jej organy i administracje. Podejście marketingowe w wewnętrznym zarządzaniu gminą nie jest jeszcze w Polsce powszechne. Należy zauważyć, że stosowanie marketingu wewnętrznego jest bardzo ważne w dwóch dziedzinach: w stosunku do działań doskonalących funkcjonowanie

${ }^{15}$ W. Wrzoska, 2004, Strategie marketingowe, PWE, Warszawa. 
urzędów oraz w relacjach gminy ze środowiskami opiniotwórczymi na jej terenie. Zdecydowanie lepiej przedstawia się sytuacja marketingu zewnętrznego. Przy ogólnym niedostatku środków inwestycyjnych konkurowanie o środki pochodzące z zewnątrz zostało gminom niemal narzucone.

Rolą podstawową władz lokalnych jest stworzenie sieci powiązań pomiędzy nimi a podmiotami gospodarczymi, organizacjami i instytucjami działającymi na terenie gminy. Tak sieć powiązań umożliwia wykorzystanie oraz koordynację wiedzy i umiejętności wszystkich uczestników wspólnej misji lokalnej. Przejęcie przez samorządy lokalne roli przedsiębiorczego organizatora i koordynatora działań w sieci podmiotów lokalnych wpływa korzystnie na zmianę stosunków pomiędzy władzą a społecznością lokalna, podmiotami gospodarczymi i innymi aktorami sceny lokalnej.

\section{Strategie rozwoju gminy jako podstawa wzrostu przedsiębiorczości}

Zarządzanie strategiczne jest skutecznym środkiem rozwoju gospodarki i przedsiębiorczości lokalnej w Polsce. Ewolucja od administrowania do zarządzania publicznego rozpoczęła się od wykorzystania zarządzania strategicznego w procesie dostosowywania się regionów i gmin do nowych warunków określonych przez procesy transformacji systemowej, a następnie przez zapoczątkowanie procesu integracji z Unią Europejską. Lokalna gospodarka powinna być analizowana, rozumiana i wspierana w sposób uwzględniający specyficzne miejscowe warunki, a lokalna strategia rozwoju powinna mobilizować efektywne wykorzystanie miejscowych zasobów oraz opisywać niezbędne kroki prowadzące do realizacji głównych celów i przewidywać możliwe działania alternatywne.

W literaturze przedmiotu podkreśla się, że „spośród organizacji publicznych zarządzanie strategiczne najszybciej rozwinęło się w samorządzie terytorialnym oraz w systemie edukacji zarówno w szkolnictwie wyższym, jak i w oświacie". ${ }^{16}$ Zarządzanie strategiczne gminą jest procesem cyklicznym, obejmującym analizę i planowanie strategiczne oraz kontrolę skuteczności podejmowanych działań. Jest ono szczególnie przydatne w sterowaniu gminą w warunkach niestabilnego otoczenia, niepewności i ryzyka w działaniu oraz przy wykorzystywaniu własnych zasobów jednostki samorządu terytorialnego. ${ }^{17}$

Proces budowania strategii opiera się na otwartym dialogu pomiędzy przedstawicielami różnych grup i wykorzystuje w pełni specyficzną analizę aktualnej sytuacji społeczno-gospodarczej gminy oraz perspektywiczną wizję jej przyszłego rozwoju. Zbudowanie szerokiego lokalnego partnerstwa z władzami gminy, odpowiedzialnymi politycznie za całość przedsięwzięcia, i lokalnymi liderami wyłonionymi spośród szczególnie aktywnych przedsiębiorców, firm i różnych organizacji - tworzy zupełnie nowe możliwości wspólnych działań przedsiębiorczych. W ramach strategii rozwoju gmina określa programy, których wykonanie zapewnia realizację wybranej strategii rozwoju. Przykładowy wykaz programów przedstawiono niżej:

- programy inwestycyjne i związane z tym kształtowanie budżetu lokalnego,

- programy wsparcia przedsiębiorstw,

- pomoc dla małych firm,

- programy marketingu, wsparcia eksportu, promocji lokalnych produktów,

- tworzenie inkubatorów biznesu,

- przygotowanie lokalizacji,

- programy edukacyjne,

- programy rozwoju,

- programy rynku pracy.

${ }^{16}$ B. Kożuch, 2004, Zarzqdzanie publiczne. W teorii i praktyce polskich organizacji, Placet, Warszawa.

${ }^{17}$ D. Bartkowska-Nowak, J. Nowak, J. Webby, 1998, Zarzqdzanie w gminie, PWE, Warszawa. 


\section{Klimat sprzyjający rozwojowi przedsiębiorczości w gminie}

Na tworzenie klimatu sprzyjającego rozwojowi przedsiębiorczości w gminie wpływa całokształt działań i decyzji gminy. Inaczej można powiedzieć, że gmina „wysyła” dużą ilość informacji w swoim codziennym działaniu, które wyraźnie kreują (lub nie) pozytywny klimat.

Podstawowym elementem stwarzającym klimat jest stosunek władz (i społeczności) gminy do przedsiębiorców. Jest on szczególnie istotny, ponieważ w latach gospodarki centralnie sterowanej przedsiębiorcy byli grupą napiętnowaną i tępioną przez władze. Duże znaczenie dla klimatu sprzyjającego rozwojowi przedsiębiorczości ma sposób bieżącego zarządzania gminą na zasadzie partnerstwa z innymi podmiotami gospodarki, a nawet sposób rozumienia samej definicji gminy i rozwoju gospodarczego. Władza gminy powinna praktycznie wykazać, że chce pomagać indywidualnym członkom wspólnoty w realizowaniu ich dążenia do dobrobytu. Dobrym sprawdzianem postaw władz gminy wobec przedsiębiorczości jest sposób traktowania przez nie działalności gospodarczej, w tym sfery usług komunalnych. Na przykład: całość usług komunalnych niekoniecznie powinna być świadczona przez własne przedsiębiorstwa gminy. Władze gminy mogą pokazać społeczności, że starają się wprowadzić zasady rynkowe w sferze usług komunalnych. Jest to sygnał dla mieszkańców gminy, że warto być przedsiębiorczym. Bardzo istotny jest klimat wokół zamówień publicznych. Postępowanie przy zlecaniu zamówień publicznych powinno być jak najbardziej klarowne. Sposób, w jaki gmina realizuje te zamówienia, ma istotny wpływ na decyzje o podjęciu (lub nie) działalności gospodarczej. Jest to szczególnie istotne w mniejszych środowiskach, gdzie gmina jest jednym z najpoważniejszych inwestorów i zamawiających. Innym przykładem budowania przedsiębiorczości wręcz bezpośrednio jest sprawa zakupu niektórych usług. Jest wiele usług, które gmina może zakupić w formie zlecenia usługi. Wymusza się przez to postawy przedsiębiorcze (bo zwykle są to te same osoby, które gmina zatrudniłaby do wykonania danej usługi), powoduje powstawanie małych firm, zmusza do pracy na własny rachunek, uczy dbałości o jakość usług itd. Gmina jest zamawiającym usługi i łatwiej może uzyskać lepszą ich jakość i z tej jakości rozliczać. Sytuacja jest jednoznaczna. Zlecenia otrzymuje ten, kto zaoferuje najlepsze i najtańsze usługi. Innymi czynnikami wpływającymi na rozwój przedsiębiorczości gminy są: klimat wokół strategii rozwoju gminy, obsługa inwestorów, polityka społeczna, polityka finansowa, ceny usług, wspieranie innowacji i estetyka.

Reasumując: klimat sprzyjający przedsiębiorczości zależy od niemal każdej codziennej decyzji władz samorządowych oraz działań innych instytucji. Czynników wpływających na klimat jest wiele, a przedsiębiorczość nie jest czymś oderwanym od społeczności lokalnej.

\section{Specyficzne formy wspomagania rozwoju przedsiębiorczości}

Rozwój przedsiębiorczości lokalnej jest procesem, który z upływam czasu przyjmuje coraz to nowe formy. Wynika to stąd, że po upływie pewnego okresu zbliżamy się do kolejnych barier, co prowadzi do konieczności stosowania nowych form przedsiębiorczości.

W praktyce działania gmin można spotkać różne specyficzne formy wspomagania rozwoju przedsiębiorczości. Specyficznym czynnikiem jest podejmowanie współpracy i koordynacji działań instytucji i organizacji ważnych dla rozwoju przedsiębiorczości także z instytucjami szczebla wojewódzkiego oraz ogólnokrajowego. Współpraca także może obejmować różne dziedziny, m.in. wymianę informacji, rozwiązywanie problemów ważnych społecznie (np. problemu ograniczania bezrobocia).

Należy podkreślić istotną rolę polityki edukacyjnej i systemu kształcenia zawodowego w tworzeniu warunków sprzyjających rozwojowi gospodarczemu. Ważnym czynnikiem wpływającym na rozwój przedsiębiorczości lokalnej są: efektywne wykorzystanie dostępnych zasobów finansowych, współpraca władz gminy z działającymi na jej terenie placówkami badawczymi 
i naukowymi, współpraca z niekomercyjnymi organizacjami wspierającymi przedsiębiorczość, wykorzystywanie pomocy doradczej, rozwój parków technologicznych, organizowanie konkursów na najlepszą firmę (lub produkt).

Reasumując: prowadzenie nowej działalności w rozpatrywanych płaszczyznach pozwala na rozwój przedsiębiorczości lokalnej. Warunkiem pomyślności w tym działaniu jest umiejętność przedstawicieli samorządu gminnego - myślenia strategicznego w zakresie wykorzystania silnych stron gminy i wykorzystania przez nią szans, jakie dają zmiany w otoczeniu lokalnym. Będzie to możliwe w przypadku zrozumienia (przez władzę i całą społeczność gminy), że rozwój przedsiębiorczości jest niezbędnym warunkiem rozwoju gminy, przynoszącym poprawę bytu lokalnej społeczności.

\section{Work of Commune in the Sphere of Local Entrepreneurship Development}

The study presents range of commune's work for local entrepreneurship that include commune politics, financial instruments, managing property, job market, promotion commune, strategy of commune growth, and creating investment environment that support entrepreneurship. Commune government representative's efficient strategic thinking about useing commune's advantages and grasping opportunities of environmental changes is a condition of the success of work for the entrepreneurship development. 


\author{
Wojciech Jarczewski \\ Instytut Geografii i Gospodarki Przestrzennej \\ Uniwersytet Jagielloński
}

\title{
Duch przedsiębiorczości w proinwestycyjnych działaniach władz lokalnych
}

Pozyskiwanie nowych inwestorów dla gmin nie należy do bezpośrednich obowiązków władz lokalnych i jest jednym z przejawów wskazywanej często (m.in. Osborne, Gaebler 1995; Swianiewicz i in. 2004) zmiany filozofii kierowania gmina - od administrowania (local government) do rządzenia (local governance). Czaso- i kosztochłonne kompleksowe działania proinwestycyjne mogą być wdrażane tylko w tych gminach, w których żywy jest duch przedsiębiorczości wśród władz lokalnych. G. Gorzelak (1998) wskazał, że jakość przywództwa na szczeblu lokalnym jest najważniejszym endogenicznym czynnikiem sukcesu lokalnego, w tym pozyskiwania nowych inwestorów.

W celu zbadania znaczenia i zróżnicowania postaw władz lokalnych w działaniach proinwestycyjnych, w samorządach lokalnych przeprowadzono analizę porównawczą dla czternastu wybranych w Polsce gmin (tab. 1). W badanej grupie znalazły się dwie metropolie: Kraków i Wrocław, oraz 12 małych i średnich miast i gmin wiejskich. W 9 badanych gminach po $1990 \mathrm{r}$. lokowali się nowi, średni i duzi inwestorzy. Te gminy, nazwane w pracy gminami proinwestycyjnymi, podzielono na dwie grupy. Do pierwszej - doświadczonych gmin proinwestycyjnych - zaliczono te, w których inwestorzy lokowali się już w latach 90. XX w. Do drugiej-nowych gmin proinwestycyjnych - włączono gminy, do których inwestorzy zaczęli napływać głównie po 2000 r. Przebadano także 3 gminy, które nie pozyskały istotnych nowych inwestorów po $1990 \mathrm{r}$. W pracy nazwano je gminami nieinwestycyjnymi.

Analizowano działania proinwestycyjne podejmowane od 1990 r. oraz ich efekty - napływ nowych inwestorów. Do badania włączono gminy charakteryzujące się potencjalnie wysoką atrakcyjnością inwestycyjną słabo zależną od działań władz lokalnych: dobrą dostępnością komunikacyjna, znacznymi zasobami nieruchomości nadającymi się potencjalnie dla inwestorów, dobrą dostępnością wykwalifikowanej siły roboczej. Wykluczono gminy, w których nawet bardzo intensywne zabiegi władz lokalnych nie dałyby zbyt wielu szans pozyskania nowych firm.

W badaniach starano się odpowiedzieć na pytanie, które elementy postawy władz lokalnych - wskaźniki dobrego przywództwa, jak to definiują R. Hambelton i S. Bulloc (1996) - mają podstawowe znaczenie w procesie pozyskiwania inwestorów do gmin.

Do wskaźników tych zalicza się (Hambelton, Bulloc 1996, za: Swianiewicz i in. 2004):

- Określenie jasnej wizji dla terenu swojego działania - ustalenie, w jakim kierunku idziemy, i sformułowanie długoterminowych strategii i kierunków polityki; słuchanie w tym zakresie mieszkańców i przewodzenie inicjatywom.

- Promowanie specyficznych cech/właściwości swojego miejsca - budowanie dumy obywatelskiej, promowanie korzyści społeczności lokalnej i przyciaganie inwestorów.

- Zdobywanie nowych zasobów - poszerzenie zakresu kompetencji i źródeł finansowania z budżetu centralnego, maksymalizacja dochodów z różnych źródeł. 
- Rozwój partnerstwa - istnienie szerokich sieci współpracy z miastem, zarówno wewnętrznych, jak i zewnętrznych, współpracujących dla zaspokojenia potrzeb mieszkańców.

- Utrzymanie spójności i poparcia - zarządzanie podzielonymi interesami i utrzymywanie poparcia wyborców w celu zachowania autorytetu.

Tab. 1. Typy proinwestycyjnego nastawienia władz lokalnych badanych gmin

\begin{tabular}{|l|l|c|l|}
\hline \multicolumn{2}{|c|}{ Typ gminy } & $\begin{array}{c}\text { Liczba } \\
\text { przeprowadzonych } \\
\text { wywiadów }\end{array}$ & \multicolumn{1}{c|}{ Nazwa gminy } \\
\hline \multirow{2}{*}{ Metropolie } & 3 & Wrocław \\
\cline { 2 - 4 } & 4 & Kraków \\
\hline $\begin{array}{l}\text { Gminy } \\
\text { proinwestycyjne }\end{array}$ & $\begin{array}{l}\text { doświadczone gminy } \\
\text { proinwestycyjne }\end{array}$ & 11 & $\begin{array}{l}\text { Niepołomice, Dobczyce, } \\
\text { Kobierzyce, Mielec }\end{array}$ \\
\cline { 2 - 4 } & $\begin{array}{l}\text { nowe gminy } \\
\text { proinwestycyjne }\end{array}$ & 10 & $\begin{array}{l}\text { Skawina, Tarnów, Mýlenice, } \\
\text { Święta Katarzyna, } \\
\text { Kąty Wrocławskie }\end{array}$ \\
\hline \multicolumn{2}{|l|}{ Gminy nieinwestycyjne } & 6 & Kęty, Źórawina, Olkusz \\
\hline
\end{tabular}

Źródło: opracowanie autora

Celem tego opracowania jest próba odpowiedzi na pytanie o znaczenie i zróżnicowanie postaw władz lokalnych wobec działań proinwestycyjnych w gminach. Opisując zróżnicowanie stabilności władzy w różnych samorządach, autor postara się także odpowiedzieć na pytanie, czy (a jeśli tak - to jak często) zmiana władzy w gminie może być korzystna z punktu widzenia skuteczności działań proinwestycyjnych. Analizując przywództwo w gminach, badano wyniki działań wójtów, burmistrzów i prezydentów, wybranych przez rady gmin po pierwszych wyborach samorządowych 27.05.1990 r.

\section{Wizja proinwestycyjna}

Zgodnie z teorią planowania strategicznego gmin, rozwijaną często w ostatnich latach przez specjalistów w dziedzinie marketingu terytorialnego, ogólne cele (wizja) powinny być określane po zebraniu i przeanalizowaniu możliwie wielu informacji związanych z sytuacją i możliwościami rozwoju gminy (Kotler i in. 1999, Wells, Wint 2000, T. Domański 2002, Rainisto 2003). Działania proinwestycyjne w każdej z badanych gmin zaczynały się od wykreowania wizji. Cele ogólne - pozyskiwanie inwestycji - są wypracowywane już przed powstaniem odpowiednich dokumentów programowych. Najczęściej animatorzy nowych wizji proinwestycyjnych wywodzą się nielicznego grona osób zarządzających gminą. To władze lokalne są najczęściej głównymi promotorami działań proinwestycyjnych i niejako naturalnie obejmują przewodnictwo w koalicjach, tworzących się na rzecz pozyskania do gminy nowych firm.

Zidentyfikowano dwie przyczyny nieprowadzenia działań na skalę umożliwiającą pozyskanie nowych zewnętrznych przedsiębiorców. W niektórych gminach brak takich działań wynika z nieudolności i niekompetencji władz, które nie umieją zaplanować i realizować działań proinwestycyjnych. Z taką sytuacją można było się zetknąć w podwrocławskiej Żórawinie i w Olkuszu, a do początku 2003 r. także w Myślenicach. Żórawina wydaje się być przykładem szczególnie dobitnie wskazującym na zależność między jakością władz lokalnych a pozyskiwaniem nowych inwestorów. Jedynym elementem istotnie różniącym tę gminę od sąsiadujących z nią Kobierzyc i Świętej Katarzyny oraz nieodległych Kątów Wrocławskich, gmin mogących się pochwalić ogromnymi 
sukcesami w pozyskiwaniu nowych inwestorów, była po 1990 r. postawa władz lokalnych. W Żórawinie nie pojawił się odważny reformator z odpowiednią wizją który chciałby zmienić charakter gminy z rolniczego na przemysłowo-usługowo-rolniczy.

W innych gminach władze lokalne nie widzą potrzeby lub możliwości pozyskiwania inwestorów zewnętrznych, co niewątpliwie miało miejsce w Kętach. Władze lokalne, zainteresowane realizacją ważnych i dobrze postrzeganych przez lokalną społeczność zadań, związanych z rozwojem infrastruktury technicznej i społecznej, nie sformułowały jasnej strategii pozyskiwania inwestorów i nie wypracowały metod jej realizacji. W warunkach zaostrzającej się konkurencji o nowych inwestorów, brak przygotowanej i promowanej oferty praktycznie uniemożliwia pozyskanie nowych inwestorów. Kęty to miasto, w którym dobrze postrzegana przez lokalną społeczność władza nie wykreowała wizji pozyskiwania inwestorów, a co za tym idzie - nie wdrożyła praktycznie żadnych działań proinwestycyjnych mimo teoretycznie dość dogodnych warunków.

Najprawdopodobniej brak odpowiednich działań jest często wynikiem współwystępowania, w różnych proporcjach, obu przyczyn: nieudolności i braku zwerbalizowanej potrzeby, które sprowadzają się do braku wizji proinwestycyjnej. Jak wynika z badań klimatu inwestycyjnego w Małopolsce (Domański, Jarczewski 2006), znaczna większość władz lokalnych nie ma wizji pozyskiwania inwestorów, a więc nie wdraża działań proinwestycyjnych. Należy jednak pamiętać, że nie każda gmina ma wystarczające możliwości i nie każda potrzebuje nowych zewnętrznych inwestorów. Gminy proinwestycyjne charakteryzuje natomiast - w każdym ze zbadanych przypadków - obecność przywódcy potrafiącego sformułować wizję, która z czasem staje się programem dla podległych urzędników.

W dwóch badanych gminach - Dobczycach i Skawinie - udało się prześledzić skutki odejścia przywódców mających wizję proinwestycyjną i zastąpienia ich przez osoby nieumiejące patrzeć w taki sposób. W 1998 r. na 4 lata swoją gminę zostawił burmistrz Marcin Pawlak, a w Skawinie funkcję burmistrza przestał pełnić Jacek Krupa. Mimo że odchodzący szefowie gmin zostawiali różnego rodzaju opracowane dokumenty programowe, ich następcy przez kolejne 4 lata nie potrafili kontynuować dzieła. Takie sytuacje wskazują, że siła proinwestycyjna gmin tkwi nie w programach, lecz w lokalnych przywódcach.

W kilku badanych gminach można było zaobserwować wykreowanie polityki proinwestycyjnej w wyniku przejęcia władzy przez nowy zespół ludzi. W Kątach Wrocławskich, Świętej Katarzynie i Tarnowie do 1998 r. pozyskiwanie inwestorów nie było ważnym zadaniem. W tych 3 gminach na trzecią kadencję samorządową wybrano osoby, które jako cel wyznaczyły sobie pozyskanie nowych firm. W Tarnowie przez kilka lat mieszkańcy i politycy bezradnie przyglądali się, jak bardzo duże inwestycje lokowane są w nieodległym Mielcu, który jest gorzej położony pod względem komunikacyjnym. Wybrany w 1998 r. prezydent Józef Rojek, przy wsparciu swojego zastępcy i dzięki doświadczeniom uzyskanym podczas wyjazdów do Wielkiej Brytanii, wskazał urzędnikom cel - pozyskiwanie inwestorów, który stopniowo zaczął być realizowany. Jego zamierzenia realizował wybrany w 2002 r. prezydent Mieczysław Bień, który sprawował już funkcję prezydenta w latach 90. Postawa tego prezydenta w latach sprawowania władzy wskazuje, że do zmiany polityki proinwestycyjnej nie zawsze jest konieczna zmiana władz lokalnych. Przywódcy, którzy w pierwszych latach rządzenia skupiali się na rozwiązywaniu podstawowych problemów społeczności lokalnej, z czasem mogą ewoluować w kierunku szerzej pojmowanego przywództwa, nastawionego na animowanie lokalnego rozwoju.

Kąty Wrocławskie i Święta Katarzyna, z powodu doskonałego położenia, po przygotowaniu atrakcyjnych ofert bardzo szybko zaczęły pozyskiwać inwestorów. Mając wizję proinwestycyjną i doskonałe położenie, te gminy przez wiele następnych lat będą miejscem lokalizacji nowych 
przedsiębiorstw. O tym, jak ważne jest podjęcie próby wykorzystania swoich atutów, świadczyć może przykład Myślenic, gdzie niestabilny samorząd przez 13 lat nie potrafił otworzyć gminy na inwestorów. Młody i ambitny burmistrz Maciej Ostrowski, który objął władzę w 2003 r., w ciagu kliku miesięcy przekonał urzędników do swojej wizji i po 2 latach pozyskał pierwszego poważnego inwestora. Gminy, które obecnie oceniane są jako liderzy w pozyskiwaniu inwestorów na skalę Polski czy poszczególnych regionów, prowadzą skuteczną politykę proinwestycyjną od pierwszej połowy lat 90 . XX w.

Spośród badanych gmin wiejskich i małych miast - niemal od samego początku transformacji ustrojowej - cel w postaci pozyskania nowych inwestycji niewątpliwie miały władze Niepołomic, Kobierzyc i Dobczyc. W każdej z tych gmin bardzo wąskie grono lokalnych przywódców już na początku lat 90. dostrzegło szansę gminy tam, gdzie inni jej nie widzieli. Przykładem gminy, w której sukces w postaci wielu nowych inwestycji był wynikiem działań prowadzonych od połowy lat 90 ., jest także Mielec, choć w tym przypadku znaczenie władz lokalnych było stosunkowo niewielkie.

\section{Metropolie}

W dużych miastach (metropoliach), takich jak Kraków i Wrocław, znacznie trudniej wiązać działania władz lokalnych z decyzjami lokalizacyjnymi inwestorów. Na scenie miejskiej istotne znacznie ma duża liczba silnych podmiotów, które są w stanie realizować różnego rodzaju cele bez wsparcia, a nawet mimo sprzeciwu władz i lokalnych społeczności. Niektórzy inwestorzy są zdeterminowani na lokalizację w dużym mieście i pozytywne lub negatywne działania nie mają większego wpływu na tę decyzję. W. Dziemianowicz i B. Jałowiecki (2004) uważają, że „wielki potencjał, skupiony w metropoliach, staje się głównym czynnikiem lokalizacji”. Taką postawę przyjmują często firmy usługowe, a także niektóre firmy zajmujące się wyspecjalizowaną produkcją, w szczególności korporacje międzynarodowe. Kierują się przede wszystkim ku największym ośrodkom miejskim, gdzie mogą stosunkowo łatwo znaleźć odpowiednią siłę roboczą, usługi dla biznesu, dogodne połączenia komunikacyjne, potencjał badawczy i odpowiednie warunki życia.

W przebadanej grupie 10 średnich firm, zajmujących się szeroko pojętymi usługami informatycznymi, które w Krakowie ulokowały się po 1990 r., działania władz lokalnych ani razu nie zostały wymienione wśród czynników istotnych przy podejmowaniu decyzji lokalizacyjnych. Działania władz lokalnych miały natomiast pewne znaczenie dla dużych międzynarodowych koncernów działających w sektorze usług, jak Motorola w Krakowie czy HP we Wrocławiu, szczególnie na etapie budowy lub przebudowy nieruchomości. Bardzo trudno jednak wyrokować o wpływie podejmowanych działań na decyzje lokalizacyjne. W ocenie przedstawicieli Motoroli - władze Krakowa nie ułatwiały procesu inwestycyjnego, a inwestycja powstała pomimo wielu problemów wynikających z braku profesjonalnej obsługi. Motorola chciała zainwestować w Krakowie i zrobiła to. Brak wsparcia ze strony władz Krakowa opóźnił rozpoczęcie działania firmy. Przedstawicielka innej dużej firmy, zajmującej się księgowością Airline Accounting Center Lufthansa - Hedwig E. Hardtke, wypowiadając się na temat procesu lokalizacyjnego, oceniła, że „nikt z władz miasta nie był zainteresowany planami naszego centrum BPO na 150 pracowników. Nie uzyskaliśmy pomocy nawet w znalezieniu powierzchni biurowej" (Polska-centrum ustug... 2003). Bardzo pozytywnie jest natomiast oceniane przez HP zaangażowanie władz Wrocławia w pomoc związaną z utworzeniem centrum usługowego. Dzięki wsparciu udało się tej firmie w ciagu kilku miesięcy rozpocząć działalność.

W badanych metropoliach różne style sprawowania władzy wywołują różnego rodzaju komentarze wśród inwestorów, którzy zdecydowali się na lokalizację w danym mieście, i tych, którzy wybrali inne miejsca. Wyniki, w postaci napływu nowych inwestycji zewnętrznych, nie wydają się 
jednak być bezpośrednio związane z działaniami władz lokalnych. Mimo nienajlepszej opinii, w Krakowie ciagle lokują się nowi inwestorzy. Można postawić tezę, wymagającą dalszych badań, że szczególnie profesjonalne prowadzenie działań proinwestycyjnych może w metropoliach wzmocnić napływ inwestorów w dłuższym okresie, a szczególnie złe - spowolnić ten proces.

\section{Stabilność władzy}

Oprócz wizji proinwestycyjnej i umiejętności (zdolności) jej realizacji - ważnym elementem wpływającym na skuteczność działań proinwestycyjnych jest stabilność władzy. Częstość zmian na stanowisku szefa gminy jest oceniana jako jeden z najważniejszych czynników wpływających na stabilność polityki lokalnej. Niewątpliwie zbyt częste zmiany uniemożliwiają prowadzenie skutecznej polityki, w tym proinwestycyjnej (Swianiewicz, Klimska 2003a, 2003b). Pojawia się jednak pytanie, kiedy zmiany są zbyt częste i czy zmiany na stanowisku prezydentów, wójtów i burmistrzów są, jako takie, czymś zawsze niekorzystnym dla lokalnych społeczności.

\section{Liczba kadencji a dzialania proinwestycyjne}

Szefowie gmin, w których przeprowadzano badania, podkreślają, że jedna kadencja to stanowczo zbyt mało, żeby wymyślić, zaplanować i zrealizować działania sprzyjające pozyskaniu inwestorów. Opinie takie wyrażają zarówno osoby zarządzające gminami więcej niż jedną kadencję (Niepołomice, Kobierzyce, Dobczyce, Święta Katarzyna, Tarnów), jak i ci, którzy swój urząd sprawują od początku obecnej kadencji - od 2002 r. (Wrocław, Kraków), a nawet krócej (Myślenice, Żórawina). Jak wskazuje przykład Skawiny, burmistrz mający jasną wizję i starający się ją energicznie realizować w trakcie jednej kadencji może nie zdążyć nawet przygotować oferty, nie mówiąc już o jej promocji i pozyskaniu inwestora. W trakcie jednej kadencji w najlepszym przypadku udaje się pozyskać jednego lub dwóch inwestorów (Myślenice, Święta Katarzyna).

Zdaniem szefów badanych gmin, osoba obejmująca urząd prezydenta, burmistrza czy wójta przez pierwszy rok poznaje swoje obowiązki i uczy się zasad zarządzania gminą. Jeżeli nie ma wcześniejszych doświadczeń na tym stanowisku, to dopiero w drugim roku urzędowania jest w stanie rozpocząć systematyczne programowanie i wdrażanie działań prorozwojowych, w tym proinwestycyjnych. Nieco krócej trwa ten proces w przypadku osób pełniących wcześniej funkcje zastępców szefa gminy lub członków zarządu. Czwarty rok każdej kadencji jest okresem wyborczym, co w znacznym stopniu ogranicza możliwość podejmowania decyzji trudnych i niepopularnych, a często koniecznych, szczególnie w procesie przygotowywania ofert inwestycyjnych.

Pozyskiwanie inwestorów to proces rozpisany na wiele lat. Przygotowanie działki zaczyna się od sporządzenia planu zagospodarowania, następnie należy ustalić stan własności, czasami wykupić nieruchomość i przynajmniej częściowo ją uzbroić, doprowadzić drogę dojazdową itd. Po przygotowaniu oferty rozpoczyna się jej promocja, a następnie negocjacje z potencjalnymi inwestorami, a w przypadku decyzji lokalizacyjnej - wsparcie podczas procesu inwestycyjnego. Za minimalny okres umożliwiający podjęcie działań i ocenę efektów uważa się w badanych gminach 8 lat, czyli 2 kadencje. Władze Tarnowa rozpoczęły działania proinwestycyjne w 1998 r.; 2 lata trwały prace koncepcyjne i uchwalanie odpowiedniego planu zagospodarowania terenu. Na początki 2006 r. w tym mieście rozpoczął się ósmy rok aktywnego pozyskiwania inwestorów i ciaggle był to, zdaniem jednego z urzędników - ,początek drogi”. Dynamiczny rozwój strefy inwestycyjnej i napływ nowych inwestorów w Świętej Katarzynie rozpoczął się w połowie drugiej kadencji wójta. Także w Kątach Wrocławskich dopiero druga kadencja burmistrza pozwoliła na realizację wizji sformułowanej podczas pierwszych 4 lat rządzenia. 
Należy się jednak zastanowić, czy każda kolejna kadencja - trzecia, czwarta - pozwala na coraz lepsze wdrażanie działań proinwestycyjnych. Na przykładzie przebadanych gmin można powiedzieć, że w niektórych przypadkach kolejne kadencje przynoszą coraz większe sukcesy. Taką gminą są Niepołomice. Burmistrz - mający jasną wizję i umiejący ją systematycznie wdrażać - największy sukces, jakim było pozyskanie fabryki ciężarówek MAN Trucks, odniósł w trakcie swojej czwartej kadencji.

Długie utrzymywanie władzy w gminie przez te same osoby nie musi być zawsze korzystne dla lokalnych społeczności. Osoby, sprawujące władzę i dążące do realizacji różnych celów, zmuszone są do wchodzenia w koalicje z różnego rodzaju graczami sceny lokalnej i ponadlokalnej. Umiejętność współpracy z różnymi partnerami i zawiązywania koalicji jest szczególną i zazwyczaj pozytywnie ocenianą cechą skutecznych władz lokalnych (por. Sagan 2000). Długie trwanie w lokalnych układach, a także sukcesy odnoszone na arenie gminnej i brak możliwości legalnego zwiększenia dochodów z powodu ograniczeń ustawowych mogą w niektórych przypadkach skłaniać przedstawicieli władz lokalnych do zachowań niezgodnych z prawem. Burmistrz Dobczyc i pierwszy wójt Kobierzyc to przykłady osób, które pomogły swoim gminom w osiagnięciu niezwykłych sukcesów w pozyskiwaniu inwestorów i które w trakcie trzeciej kadencji zostały oskarżone o korupcję. Oskarżeń o niegospodarność nie uniknął także burmistrz Niepołomic.

Innym problemem niektórych osób długo sprawujących urząd (ponad dwie kadencje) jest brak możliwości dalszego rozwoju. Szefowie gmin obejmują stanowisko często jako ludzie stosunkowo młodzi: trzydziesto-, czterdziestoletni. Po dwóch, trzech kadencjach dostrzegają że w gminie osiagnęli już wszystko i nie ma przed nimi dalszych możliwości awansu. Zarządzanie gminą realizowane jest według wypracowanych przez lata schematów i z czasem zaczyna im brakować świeżości. W niektórych przypadkach szefowie gmin rezygnują ze starania się o kolejną kadencję i próbują znaleźć swoje miejsce np. w innych organach samorządu terytorialnego, w sejmie, senacie. Prezydentami odnoszącymi sukcesy w zarządzaniu gminą, także w działaniach proinwestycyjnych, i dobrowolnie rezygnującymi z niemal pewnej kolejnej kadencji, byli Bogdan Zdrojewski we Wrocławiu w 2002 r. i Marcin Pawlak w Dobczycach w 1998 r. Swoich sił w parlamencie próbował także Stanisław Kracik z Niepołomic, ale stając przed wyborem: sejm czy gmina - wybrał gminę. Ta decyzja jest obrazem poważniejszego dylematu, przed którym stają szefowie gmin szukający innego miejsca w życiu. Burmistrz jednej z badanych gmin stwierdził, że „porównywalną samodzielność i możliwość realizacji swoich wizji, większy prestiż i wyższe zarobki dają dobrym i lubianym szefom gmin tylko bardzo nieliczne stanowiska w administracji samorządowej i rządowej, takie jak marszałek województwa, wojewoda, starosta, minister w rządzie, marszałek w sejmie i senacie". Z podobnymi opiniami podczas prowadzonych badań spotykano się częściej. Okazuje się, że samo bycie posłem czy senatorem, a nawet wiceministrem, wicemarszałkiem lub wicestarostą jest postrzegane jako rodzaj degradacji przez wielu dobrych szefów gmin, choć oczywiście nie przez wszystkich. Długoletni burmistrz Skawiny Jacek Krupa został starostą powiatu krakowskiego, a od 2005 r. jest posłem i nie podejmuje prób powrotu do Skawiny. Nie jest jednak przypadkiem, że Stanisław Kracik wybrał niewielką gminę miejsko-wiejska, a nie fotel posła, ani że Marcin Pawlak zrezygnował z sejmiku wojewódzkiego na rzecz malutkich Dobczyc.

\section{Przejęcie władzy w gminie}

Na podstawie przeanalizowanych przypadków można stwierdzić, że wymyślenie, zaplanowanie i rozpoczęcie realizacji działań proinwestycyjnych oraz pozyskanie pierwszych inwestorów wymaga zasadniczo dwóch kadencji (8 lat). Jeżeli szef gminy chciał pozyskiwać inwestorów od pierwszych lat swojego urzędowania i było to poparte obiektywnymi możliwościami zewnętrz- 
nymi, to trzecia kadencja działań proinwestycyjnych powinna przynosić liczne sukcesy w postaci napływu wielu nowych firm. Najczęściej w którymś momencie nawet bardzo dobrze prowadzonych działań proinwestycyjnych przychodzi jednak potrzeba zmiany władz lokalnych z szefem gminy na czele. Przyczyny zmiany na tym stanowisku mogą mieć dwojaką naturę:

- zewnętrzna, wynikającą z utraty poparcia lokalnej społeczności lub/i wejścia w konflikt z prawem;

- wewnętrzną, wynikającą z chęci zmiany miejsca pracy przez lokalnego przywódcę.

Wpływ zmian na stanowisku szefa gminy na działania proinwestycyjne może być pozytywny lub negatywny, ale każdorazowo jest trudny do przewidzenia. W gminach, w których nie prowadzi się działań proinwestycyjnych, każda zmiana to nowa szansa. W Myślenicach dopiero szósty burmistrz otworzył miasto dla inwestorów. W Kątach Wrocławskich i Świętej Katarzynie osoby, które przejęły władzę w 1998 r., potrafiły stworzyć warunki do lokowania nowych przedsiębiorstw. W Skawinie burmistrz rządzący od 2002 r. próbuje znowu włączyć swoją gminę na listę atrakcyjnych inwestycyjnie miejsc w Małopolsce. Wiele, a być może nawet większość gmin wciąż czeka na przywódcę potrafiącego stworzyć alternatywę dla dotychczasowego kierunku rozwoju. Mimo wielokrotnych zmian na stanowisku szefa gminy, nie rozpoczęto prowadzenia intensywnych działań proinwestycyjnych w Olkuszu.

Zmiana szefa gminy, który skutecznie prowadził działania proinwestycyjne, może spowolnić, a nawet zatrzymać na pewien czas napływ nowych przedsiębiorców. Rezygnacja burmistrza Dobczyc w 1998 r. praktycznie o całą kadencję spowolniła rozwój strefy inwestycyjnej. Burmistrz Skawiny Stanisław Pac nie wykorzystał sukcesu, jakim było pozyskanie fabryki Valeo przez poprzednika, i nie kontynuował działań proinwestycyjnych podczas swojej kadencji w latach 1998-2002.

W niektórych gminach zmiana władzy nie tylko nie zatrzymuje procesu proinwestycyjnego, ale wręcz go przyspiesza, i to zarówno w przypadku przejęcia władzy przez oponenta politycznego, jak i przez kandydata popieranego przez osobę ustępującą ze stanowiska. Przykładu przejęcia władzy przez oponenta politycznego dostarczają Kobierzyce. Wójt Ryszard Chomicz, po dekadzie niezwykle skutecznych działań, został odwołany w atmosferze skandalu. Na czele jego oponentów, którzy doprowadzili do dymisji, stał Ryszard Pacholik. Po przejęciu urzędu potrafił twórczo rozwinąć koncepcje swojego poprzednika, a pozyskanie koncernu LG przywróciło Kobierzycom sławę jednej z najlepszych proinwestycyjnie gmin w Polsce. Poparcie ustępującego prezydenta miały obie osoby rządzące Wrocławiem od 2002 r. Skutecznie zarządzający miastem, w tym działaniami proinwestycyjnymi, bardzo popularny prezydent Bogdan Zdrojewski postanowił zrezygnować z ubiegania się o kolejną kadencję w 2002 r. Poparł swego następcę Rafała Dutkiewicza, który wygrał wybory bezpośrednie i kontynuuje, a czasem modyfikuje rozpoczęte wcześniej działania, dostosowując je do zmieniającego się otoczenia.

\section{Wnioski}

Cechą charakterystyczną tych spośród badanych gmin, które odniosły sukces w pozyskiwaniu inwestorów, był silny lider lub - rzadziej - zespół dysponujący wizją rozwoju oraz umiejętnością wdrażania jej w życie za pomocą różnego rodzaju narzędzi. Niektóre samorządy przez wiele lat pozyskiwały niewielu nowych inwestorów lub w ogóle nie próbowały ich pozyskać, a po zmianie władz zaczęły odnosić sukcesy. Można także zaobserwować zależność odwrotną. Gminy, w których - mimo teoretycznie dobrych warunków zewnętrznych - nie lokują się inwestorzy, mają władze nieumiejące ich pozyskać lub niezainteresowane ich pozyskiwaniem.

W ramach badań starano się odpowiedzieć na pytanie, które elementy postawy władz lokalnych - wskaźniki dobrego przywództwa, jak to definiują R. Hambelton i S. Bulloc (1996) - mają 
kluczowe znaczenie w procesie pozyskiwania inwestorów do gmin. W każdej spośród badanych małych i średnich gmin, które skutecznie pozyskują nowe firmy, istnieje wizja działań proinwestycyjnych. Chęć pozyskania inwestorów oraz generalny pomysł, jak można to w warunkach lokalnych zorganizować, okazuje się fundamentem i napędem dalszych działań. Brakującą wiedzę (know-how) można uzupełnić, zbierając informacje od gmin bardziej doświadczonych i zatrudniając odpowiednich specjalistów, co doradzają konsultanci PAIiIZ. Różnego rodzaju szkolenia urządzają przedstawiciele PAIiIZ, urzędów marszałkowskich i regionalnych agencji rozwoju. Środki konieczne do przygotowania atrakcyjnej oferty, promocji i obsługi inwestorów można w miarę możliwości corocznie przydzielać z budżetu lub też pozyskiwać z funduszy pomocowych. Jak wykazują doświadczenia badanych gmin, jedynym elementem, który musi zostać wypracowany w gminie i którego nie da się w żaden sposób zastąpić ani ,importować” z zewnątrz, jest wizja i chęć jej wdrażania przez władze lokalne, a szczególnie przez szefa gminy. W wielu gminach, szczególnie małych i średnich, można zauważyć ścisłą zależność między pojawieniem się wizji proinwestycyjnej i rozpoczęciem jej realizacji a decyzjami lokalizacyjnymi nowych inwestorów. W gminach, które teoretycznie mają doskonałe warunki do pozyskiwania nowych firm, a w których nie prowadzi się działań proinwestycyjnych, nowi przedsiębiorcy lokują się rzadko (Domański, Jarczewski 2006).

W metropoliach, takich jak Kraków czy Wrocław, decyzje lokalizacyjne nowych inwestorów zewnętrznych wydają się słabiej związane z aktywnością władz gminnych. Duże miasta, jak pisze B. Jałowiecki (1999), są w pewien sposób dobrem rzadkim i przyciagają inwestorów bez względu na działania i postawę władz lokalnych. Badając relacje pomiędzy nowymi inwestorami, którzy lokowali się w Krakowie i Wrocławiu, a miejscowymi władzami lokalnymi, sformułowano następujące wnioski.

- Niektórzy lokalizujący się w dużych miastach inwestorzy nie potrzebują zbyt wielu kontaktów z władzami lokalnymi (np. firmy zajmujące się usługami, wynajmujące powierzchnię biurowa).

- Firmy lokalizują się w metropoliach głównie ze względu na pewne szczególnie atrakcyjne dla nich cechy (np. wykształconą siłę roboczą, rynek zbytu) i zdecydowane są na rozpoczęcie działalności w danym mieście nawet jeżeli będzie to trwało dłużej i kosztowało więcej niż gdzie indziej. W dłuższej perspektywie prawdopodobnie proinwestycyjna postawa władz lokalnych będzie miała istotne znaczenie, zwłaszcza jeżeli utrwalą się zróżnicowane postawy względem inwestorów.

W. Dziemianowicz i B. Jałowiecki (2004) zwracają uwagę na znaczenie ciągłości władzy w procesie pozyskiwania nowych inwestorów. Przeprowadzone przez autora badania wskazały, że utrzymanie poparcia wyborców, pozwalającego na pełnienie funkcji przez więcej niż jedną kadencję, jest warunkiem prowadzenia skutecznych działań proinwestycyjnych. W gminach, w których wielokrotnie zmieniali się szefowie, działania proinwestycyjne są zazwyczaj słabo zaawansowane lub nie ma ich wcale. Każda kolejna zmiana jest jednak także szansą na rozpoczęcie takich działań. Minimalnym okresem umożliwiającym sformułowanie wizji, przygotowanie atrakcyjnej oferty i jej promocję, a następnie doprowadzenie do zlokalizowania w gminie nowych inwestorów, są dwie kadencje - 8 lat. Kolejne kadencje, dzięki wypracowaniu odpowiednich procedur, pozwalają na skupienie wysiłków na działaniach mogących przynosić najlepsze rezultaty. W niektórych przypadkach zbyt długie pełnienie funkcji przez te same osoby jest jednak przyczyną utraty świeżości i energii działań proinwestycyjnych, a może nawet powodować uwikłanie się szefa gminy w działania niezgodne z prawem. W niektórych przypadkach zmiana na stanowisku szefa gminy powoduje znaczne spowolnienie, a nawet zaprzestanie prowadzenia działań proinwestycyjnych. Zdarzają się także gminy, w których zmiana na stanowisku wójta, 
burmistrza czy prezydenta nie tylko nie utrudnia napływu nowych inwestorów, ale wręcz go przyspiesza. Może się tak dziać zarówno w przypadku wyznaczenia następcy przez ustępującego szefa gminy, jak i przejęcia władzy przez jego oponentów politycznych. Ciągłość władzy nie jest równoznaczna z ciągłością działań proinwestycyjnych.

\section{Literatura}

1. Domański T., 2002, Skuteczna promocja miasta i regionu podstawowym zadaniem marketingu terytorialnego [w:] T. Markowski (red.), Marketing terytorialny, Studia Komitetu Przestrzennego Zagospodarowania Kraju PAN, T. CXII,. Warszawa

2. Dziemianowicz W., Jałowiecki B., 2004, Polityka miejska a inwestycje zagraniczne w polskich metropoliach, Scholar, Warszawa

3. Hambelton R., Bulloc S., 1996, Revitalizing local democracy - the leadership options, Association of District Councils/Local Government Management Bard, London

4. Jałowiecki B., 1999, Metropolie, Wyższa Szkoła Finansów i Zarządzania w Białymstoku, Białystok

5. Klimat inwestycyjny w województwie małopolskim, 2006, B. Domański, W. Jarczewski (red), Urząd Marszałkowski Województwa Małopolskiego, Kraków

6. Kotler P., Asplund C., Rein I., Haider D., 1999, Marketing places Europe, Pearson Education Ltd., London

7. Osborne D., Gaebler T., 1995, Rzadzić inaczej. Jak duch przedsiębiorczości przenika i przekształca administracje publiczna, Media Rodzina of Poznań, Poznań

8. Polska - centrum ustug dla Europy. Nowe szanse inwestycji zagranicznych w Polsce, 2003, McKinsley\&Company/Polska Rada Biznesu, Warszawa

9. Rainisto S., 2003, Success factors of place marketing: a study of place marketing practices in northern Europe and the United States, University of Technology, Helsinki

10. Sagan I., 2000, Miasto scena konfliktów i wspólpracy: rozwój miasta w świetle koncepcji reżimu miejskiego, Wydawnictwo Uniwersytetu Gdańskiego, Gdańsk

11. Swianiewicz P., Klimska U., 2003a, Czy wielkie miasta sq sterowalne? Wplyw sytuacji politycznej na warunki zarządzania największymi miastami Polski, „Samorząd Terytorialny” 3/2003

12. Swianiewicz P., Klimska U., 2003b, Kto rzqdzi gminq i jak? Lokalni liderzy polityczni w teorii i praktyce samorzqdów w Polsce, ,Studia Regionalne i Lokalne” 4 (14), 15-41/2003

13. Swianiewicz P., Łukomska J., 2004, Władze samorzqdowe wobec lokalnego rozwoju gospodarczego. Które polityki sq skuteczne? „Samorząd Terytorialny” 6, 14-32/2004

14. Wells L., Wint A., 2000, Marketing a country: promotion as a tool for attracting foreign investment, FIAS, Washington 


\section{The Spirit of Entrepreneurship in Pro-investment Activities of Municipalities}

The acquisition of new investors in a municipality is not a direct obligation of local governments but rather one of the indications of the change in the philosophy of municipal management - from administration (local government) to management (local governance). Time and cost consuming comprehensive pro-investment activities can be implemented only in those municipalities where among the local authorities the spirit of entrepreneurship is alive. G. Gorzelak (1998) indicated that on the local level the leadership quality is the most endogenic factor of local success, including luring new investors.

To examine the significance and diversity of local authorities' attitudes in their pro-investment activities in the local governments, in fourteen selected municipalities in Poland a comparative analysis was conducted. Pro-investment activities, implemented since 1990, and their effects, in the form of arrival of new investors, were studied. Our research covered the municipalities distinguished by potentially high investment attractiveness which is hardly dependent on the local authorities' activities: good transportation availability, considerable real-estate resources that are suitable for potential investors and good availability of qualified labor force. Consequently, we excluded the municipalities in which even very intense works of their local authorities failed to develop new opportunities to attract many new businesses. 


\author{
Slawomir Dorocki \\ Zakład Przedsiębiorczości i Gospodarki Przestrzennej \\ Instytut Geografii \\ Akademia Pedagogiczna w Krakowie
}

\title{
Stacja Narciarska „Wierchomla” - lokalny ośrodek aktywizacji gospodarczej
}

Celem pracy jest przedstawienie Stacji Narciarskiej ,Wierchomla” jako przedsiębiorstwa mającego duży wpływ na rozwój gospodarczy regionu. Wybór tego podmiotu wynika z jego znaczenia nie tylko dla rozwoju lokalnego, ale również rozwoju całej doliny Popradu. Ponadto jest on ważnym przykładem procesów restrukturyzacji oraz aktywizacji rejonów górskich Beskidów, mogących stać się wzorem dla innych jednostek terytorialnych, które w wyniku dotychczasowych uwarunkowań pozostawały poza zasięgiem rozwoju związanego ze sferą usług rekreacyjno-wypoczynkowych.

W celu wykazania wpływu działalności Stacji Narciarskiej „Wierchomla” na lokalną aktywizację gospodarczą, w badaniach oparto się na danych odnoszących się do wielkości zatrudnienia w stacji według miejsca zamieszkania pracowników oraz liczby umów i położenia jednostek gospodarczych współpracujących ze Stacją. Zakres czasowy obejmuje dane od momentu uruchomienia pierwszego wyciagu w styczniu 1998 r. do września 2006 r.

Wierchomla jest to sołectwo należące do gminy Piwniczna-Zdrój, leżącej w południowej części powiatu nowosądeckiego. Wieś położona jest na południowy-wschód od miasta Piwniczna. Rozciąga się wzdłuż potoku Wierchomlanka od granicy słowackiej na Popradzie po pasmo Jaworzyny Krynickiej na północy. Zachodnia granica oddzielająca Wierchomlę od wsi Łomnica przebiega wododziałem pomiędzy potokami Łomniczanka i Potasznia. Na wschodzie granica wsi pokrywa się z granicą gminy biegnącą wzdłuż grzbietu Pustej Wielkiej. Urozmaiconą powierzchnię wsi w ponad 60\% stanowią lasy należące do Popradzkiego Parku Krajobrazowego.

Wieś dzieli się na Wierchomlę Wielką w południowej części doliny i na Wierchomlę Małą w jej górnym odcinku. Zajmuje powierzchnię ok. $40 \mathrm{~km}^{2}$. Sołectwo liczy 700 mieszkańców i 100 gospodarstw. W przeszłości mieszkańcy wsi, oprócz rolnictwa, pracowali w ośrodkach wczasowych i pobliskich uzdrowiskach: Piwniczna-Zdrój, Łomnica-Zdrój, Żegiestów-Zdrój, Muszyna i Krynica. Ponadto zatrudnienie zapewniały: kamieniołom w Wierchomli Wielkiej, Nadleśnictwo Piwniczna obejmujące gminy Piwniczna, Rytro, Muszyna i Krynica oraz Zakłady Naprawcze Taboru Kolejowego w Nowym Sączu. W okresie transformacji gospodarczej po 1989 r. w całej gminie Piwniczna wzrosło bezrobocie, na skutek głównie upadku wielu ośrodków wypoczynkowych i rekreacyjnych powiązanych z wielkimi zakładami przemysłowymi.

Nowa sytuacja ekonomiczna oraz zmiany w preferencjach dotychczasowych i potencjalnych klientów przedsiębiorstw zlokalizowanych w Piwnicznej wymusiły reorientację rozwoju lokalnego w stronę poszerzenia oferowanych dotychczas usług. Główną rozwijaną sferą stały się usługi rekreacyjno-sportowe. Pod pojęciem usług rekreacyjno-sportowych rozumie się te usługi, które są tworzone poza obrębem zakładów noclegowych i żywieniowych, a mają charakter otwarty dla 
Ryc. 1. Bezrobocie w wybranych gminach powiatu nowosądeckiego w $2000 \mathrm{r}$.

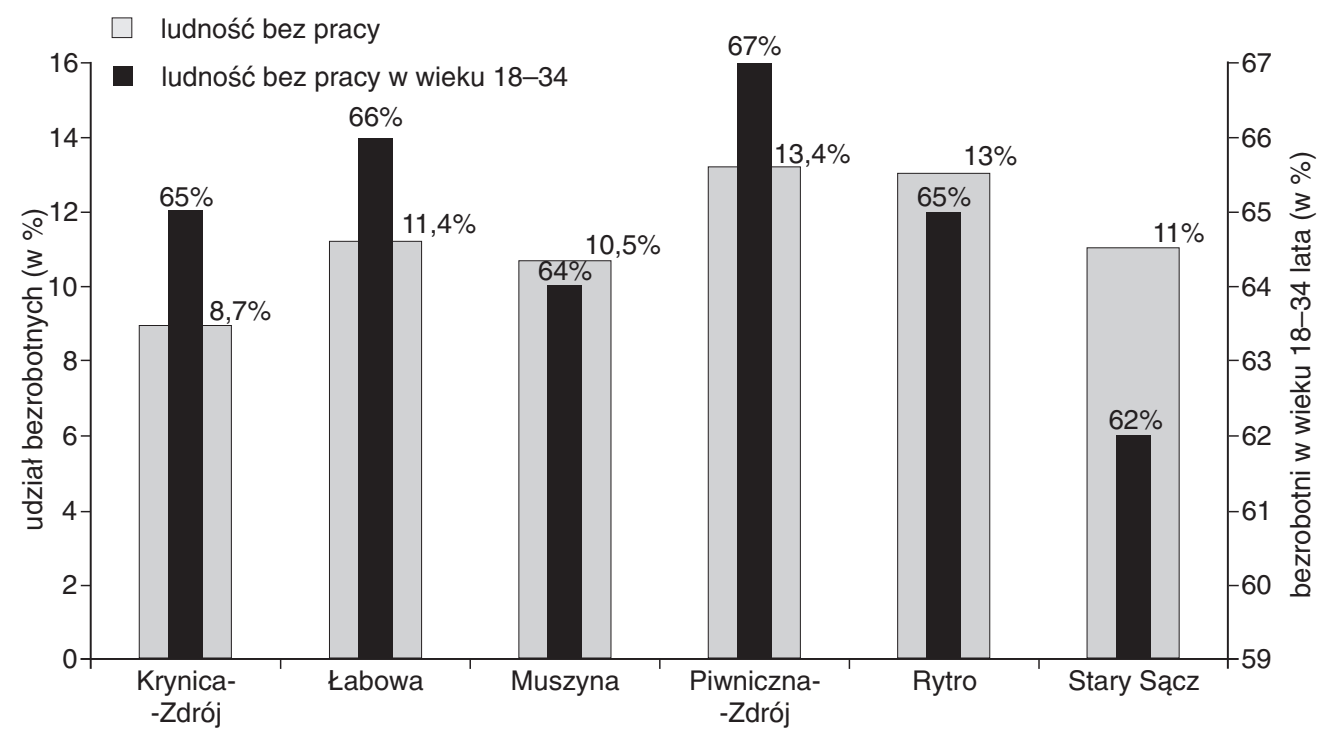

Źródło: dane Powiatowego Urzędu Pracy w Nowym Sączu, 31.12.2000 r.

każdego i wymagają osobnych inwestycji związanych z budową określonych obiektów i utrzymaniem ich w stanie funkcjonalności. Jedną z podstawowych zasad marketingu określanego jako rekreacyjno-sportowy jest rozpoznawanie istniejących i wyzwalanie nowych potrzeb konsumentów, by móc je przekształcić w popyt. Zadaniem jest skomponowanie takiej oferty, która w sposób harmonijny łączyłaby sprawdzone na rynku pakiety usługowe z elementami innowacji. Dlatego też produkt sportowy możemy zdefiniować jako pewnego rodzaju ofertę adresowaną do zorientowanych na sport konsumentów, zaspokajającą ich potrzeby zdrowia, aktywności ruchowej, rozrywki, przebywania w grupie, poprawy sylwetki, fascynacji i emocji oraz estetyki (Klisiński 1994).

Ze względu na ukształtowanie terenu, posiadane doświadczenie oraz renomę regionu skoncentrowano się na rozwoju infrastruktury dla sportów zimowych i turystyki. W wizji władz lokalnych sprawujących władzę w połowie lat 90. XX w. obszar gminy Piwniczna miał stać się centrum sportów zimowych.

Jednym z głównych czynników powodzenia inwestycji, oprócz elementu lokalizacji, jakim dla dobrych ośrodków narciarskich są stoki o różnym nachyleniu oraz odpowiednio duże opady i rodzaj śniegu nadającego się do uprawiania narciarstwa, są dostępny kapitał oraz identyfikacja jednostek współrealizujących określone cele.

W Wierchomli głównym inwestorem został Krzysztof Brzeski związany z branżami wydawniczą i nieruchomości. W latach 1995 i 1996 - zainteresowany stworzeniem w Polsce kompleksu narciarskiego - nawiązał kontakt z ówczesnym burmistrzem Piwnicznej Mariuszem Frydrychem. O lokalizacji stacji w Wierchomli, a nie w Suchej Dolinie, jak początkowo planowano, zadecydowały w głównej mierze przepisy prawne i złożone stosunki własnościowe w Kosarzyskach. Jednym z najtrudniejszych zadań przy uruchomieniu ośrodka narciarskiego w Polsce jest kupno ziemi (w przypadku stacji w Wierchomli 80 ha należących do 15 właścicieli). W Polsce, inaczej niż np. w Austrii czy Szwajcarii, gdzie obowiązuje tzw. prawo alpejskie, nazywane też prawem śniegu, narciarze nie mogąjeździć po pokrytych śniegiem stokach, jeśli nie należą one do właściciela wyciagu lub nie zostały przez niego wydzierżawione (Lubaś-Harny 1999). 
Ostatecznie budowę pierwszego wyciagu rozpoczęto jesienią 1997 r., a już 17.01.1998 r. odbyło się oficjalne otwarcie ośrodka narciarskiego „Wierchomla Mała”. Zaczęły działać 4 wyciagi talerzykowe o przepustowości 3000 osób na godzinę oraz trasy narciarskie o łącznej długości 2300 m. Obok wyciagów powstały parking i budynki serwisowe. W latach 1998 i 1999 trwała rozbudowa ośrodka: powstał system sztucznego zaśnieżania, przygotowano bazę noclegową i gastronomiczną. Uruchomiono także „białą linię” na trasie Nowy Sącz - Piwniczna - Wierchomla.

Po kolejnym sezonie 1999/2000 rozpoczęto budowę wyciąu krzesełkowego. Była to, obok Hali Gąsienicowej w Tatrach, największa inwestycja narciarska w Małopolsce. Kosztem $5 \mathrm{mln}$ zł powstała kolejka mogąca w ciągu godziny przewieźć 2 tys. osób. Ta inwestycja zapewniła stacji ciagłość świadczenia usług również w sezonie letnim, ponieważ służy również turystom pieszym i rowerowym. W następnym roku powstał kolejny obiekt hotelowy z 32 miejscami noclegowymi.

W 2002 r. zakupiono kolejne armatki śnieżne i zbudowano drugą tamę. W 2003 r. wybudowano kolejne dwa domki noclegowe, a w pobliżu górnej stacji kolejki powstał namiot gastronomiczny o powierzchni $400 \mathrm{~m}^{2}$. Na wiosnę 2005 r. rozpoczęto budowę hotelu na 200 miejsc noclegowych $\mathrm{z}$ rozbudowaną częścią spa. Budynek został oddany do użytku 15.01.2006 r.

Ryc. 2. Zmiana liczby zatrudnionych w Stacji Narciarskiej „Wierchomla” w latach 1997-2006 na podstawie umowy o pracę

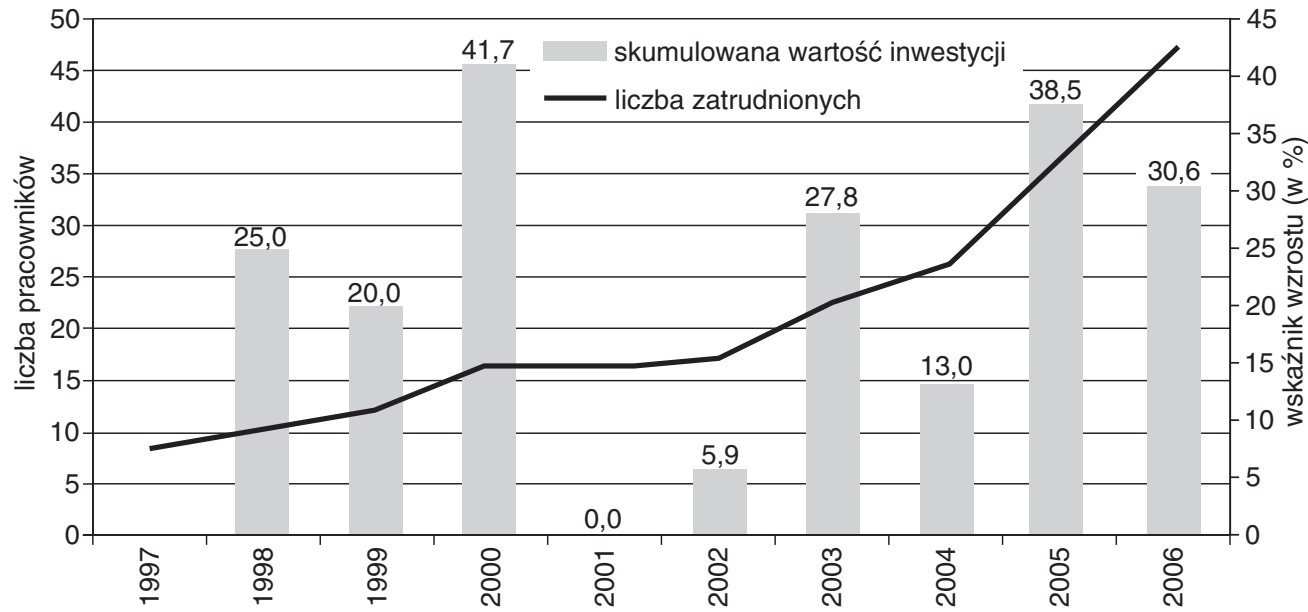

Źródło: opracowanie autora na podstawie danych Stacji Narciarskiej „Wierchomla”

Głównym celem Stacji Narciarskiej „Wierchomla” jako ośrodka narciarskiego jest stworzenie i obsługa tras narciarskich oraz urządzeń transportujących narciarzy, tzw. wyciągów. Liczba wyciagów, ich przepustowość i niezawodność działania ma zasadniczy wpływ na komfort korzystania z obiektu. Współczesny klient uprawiający sporty zimowe oczekuje kompletnej obsługi, w której skład wchodzi m.in. zróżnicowana baza gastronomiczna i noclegowa. To właśnie ta dodatkowa infrastruktura i świadczone usługi mają zasadniczy wpływ na aktywizację gospodarczą rejonu.

Działalność stacji wpływa bezpośrednio na rozwój lokalny głównie poprzez tworzenie nowych miejsc pracy i współpracę z miejscowymi przedsiębiorcami. Stacja narciarska zatrudnia obecnie 47 osób personelu stałego, a w sezonie zimowym dodatkowo średnio około 70 osób. Liczba zatrudnionych w miarę rozwoju stacji ciagle wzrasta w średnim rocznym tempie $22,5 \%$. 
Wśród zatrudnionych w stacji zarówno na stałe, jaki na czas określony najwięcej jest mieszkańców Wierchomli (ponad 50\%). Następną grupą są pracownicy dojeżdżający z Piwnicznej i sąsiedniej wsi Łomnica. W latach 1997-2006 średni udział pracowników z Wierchomli Wielkiej i Małej stanowił więcej niż połowę ogółu pracowników stacji (odpowiednio 33\% dla Wierchomli Wielkiej i 30\% dla Wierchomli Małej). Drugą pozycję zajmują mieszkańcy Piwnicznej, stanowiący średnio $24 \%$ pracowników. W okresie badawczym można zauważyć dwie tendencje: jedną z nich jest ciągły wzrost udziału liczby pracowników spoza Wierchomli (przede wszystkim z Piwnicznej), a drugą - wzrost udziału pracowników wykwalifikowanych (główny mechanik, główny elektryk, księgowa itp.) pochodzących z Wierchomli, co może świadczyć o restrukturyzacji zawodowej ludności wsi.

Ryc. 3. Struktura zatrudnienia w Stacji Narciarskiej „Wierchomla” w sezonie 2005/2006 według miejsca zamieszkania

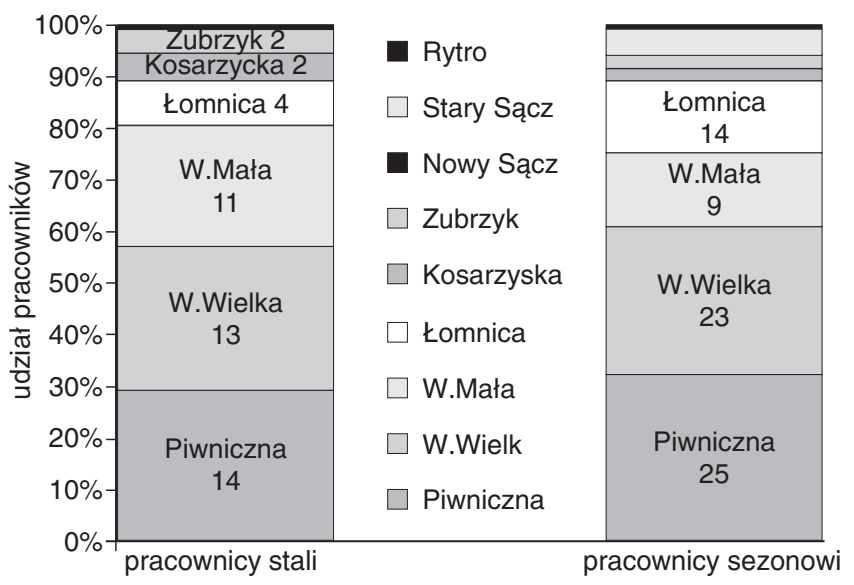

Źródło: opracowanie autora na podstawie danych Stacji Narciarskiej „Wierchomla”

Obecnie stacja zatrudnia w sezonie około 10\% ludności wsi Wierchomla. Ponadto stacja zawarła umowy z kilkudziesięcioma gospodarstwami agroturystycznymi z Wierchomli na świadczenie usług noclegowych dla klientów stacji narciarskiej. Również dzięki stacji w sezonie działa połączenie komunikacyjne między Piwniczną a Wierchomlą obsługiwane przez mieszkańców wsi.

Następną formą oddziaływania stacji na lokalną aktywizację gospodarczą jest współpraca z lokalnymi przedsiębiorstwami. Stacja Narciarska „Wierchomla” kooperuje stale z 57 firmami z Polski i 3 z zagranicy. Według lokalizacji najwięcej firm współpracujących ze stacjąjest zlokalizowanych w Nowym Sączu (38). Są to w większości firmy z branży spożywczej, dostarczające zaopatrzenie do obiektów stacji. Następną grupę stanowią firmy usługowe związane z funkcjonowaniem stacji. Spośród sąsiednich miejscowości wyróżnia się Piwniczna. Są tam zarejestrowane 4 firmy działające głównie w branży budowlanej. Ponadto stacja współpracuje z 5 warszawskimi firmami, które są przedstawicielstwami w Polsce dużych międzynarodowych przedsiębiorstw z branży usług specjalistycznych (np. systemy klimatyzacyjne). Zagranicznych kooperantów reprezentują 2 firmy słowackie zapewniające serwis techniczny wyciąów i 1 firma budowlana z Ukrainy. Pozostałe firmy są zarejestrowane w innych miejscowościach w Polsce. 
Ryc. 4. Zmiana liczby zatrudnionych na podstawie umowy o pracę w Stacji Narciarskiej „Wierchomla” w latach 1997-2006 według miejsca zamieszkania

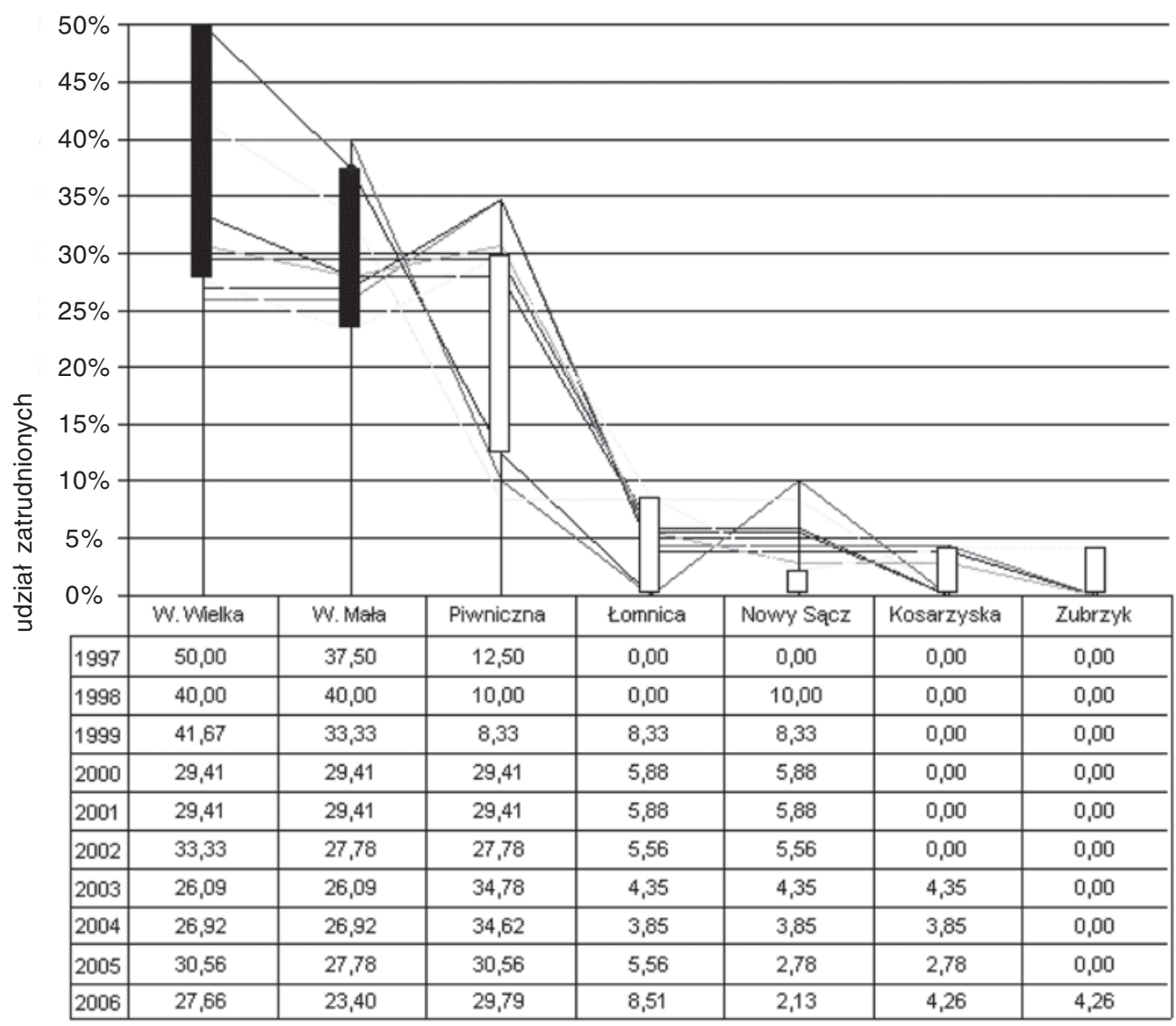

Źródło: opracowanie autora na podstawie danych Stacji Narciarskiej „Wierchomla”

Ryc. 5. Struktura firm stale współpracujących ze Stacja Narciarską „Wierchomla” ze względu na lokalizację

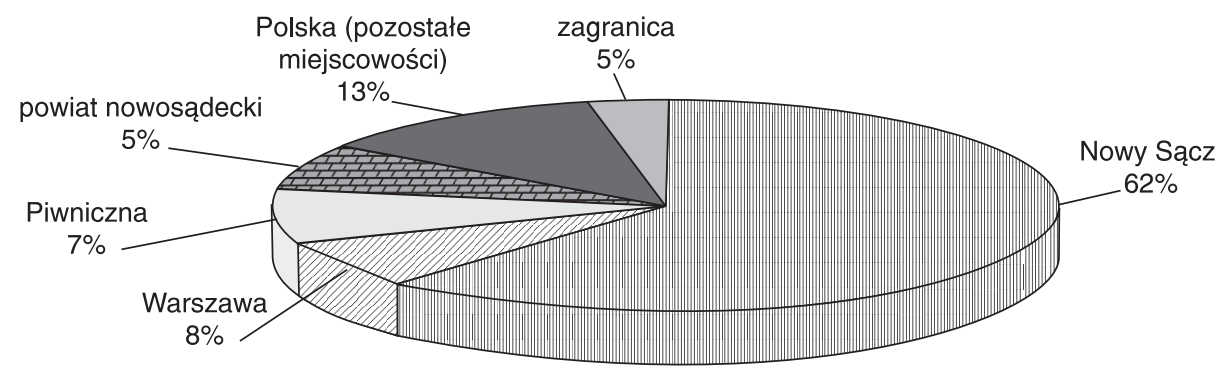

Źródło: opracowanie autora na podstawie danych Stacji Narciarskiej „Wierchomla” 


\section{Podsumowanie}

Stacja Narciarska „Wierchomla” wciąż się rozwija. W 2004 r. firma znalazła się w fazie dojrzałości, co zmusiło do podjęcia działań z zakresu modyfikacji produktu i udostępniania konsumentom coraz nowszych jego odmian. Liczba sprzedanych miejsc noclegowych i jej ciagły wzrost świadczą o tym, że ośrodek nadal przyciaga klientów. Działania podejmowane przez Stację mają na celu uchronienie jej od znalezienia się w fazie spadku. Przewiduje się, że stacja będzie z roku na rok przygotowywać dodatkowe atrakcje oraz modyfikować swój produkt, aby przedłużyć fazę dojrzałości i co pewien czas zaskakiwać nowymi propozycjami. Przykładem może być otwarty w $2000 \mathrm{r}$. ośrodek spa, park do paintballu, Nordic Walking i trasy downhillowe.

Te działania skutkują wzrostem zatrudnienia w regionie, a dzięki przyciagnięciu klientów będą wpływać na lokalne ożywienie gospodarcze. Szansę na wykorzystanie tej inwestycji w rozwoju regionu zauważyli lokalni samorządowcy. Stworzyli oni program Sportowe Stacje Doliny Popradu - rozwój turystyki aktywnej - sportów naturalnych, zawarty w strategii rozwoju zintegrowanego produktu turystycznego Perły Doliny Popradu. Program opracowało 6 gmin: Krynica-Zdrój, Łabowa, Muszyna, Piwniczna-Zdrój, Rytro i Stary Sącz. Celem programu jest połączenie siecią infrastruktury turystycznej 7 sąsiednich dolin, od Wierchomli po Łabową, w celu stworzenia największego w Europie Środkowej regionu narciarskiego (Siedem Dolin). Powodzenie tego planu może zwiastować planowane otwarcie wyciągu łączącego Szczawnik z Wierchomlą oraz przystąpienie do inwestycji Ryszarda Florka, prezesa firmy Fakro (drugiego na świecie producenta okien dachowych). Inwestycje mają zostać przyspieszone dzięki zmianie ustawy o wylesieniach. Gotowy jest już projekt poprawki, który zakłada zmniejszenie obciążeń finansowych dla inwestorów; mieliby oni płacić tylko za wylesienie pasa zieleni, na którym powstają wyciagi, natomiast nartostrady mogliby odlesiać bezpłatnie, pod warunkiem posiania na nich trawy. Ponadto po przystąpieniu Polski do UE otworzyły się nowe możliwości finansowania, np. powstały w $2006 \mathrm{r}$. hotel został w 30\% sfinansowany z funduszy unijnych.

Ryc. 6. Zmiany liczby osób zakwaterowanych w Stacji Narciarskiej „Wierchomla” oraz wskaźnik Charvata ${ }^{1}$ w latach 1999-2005

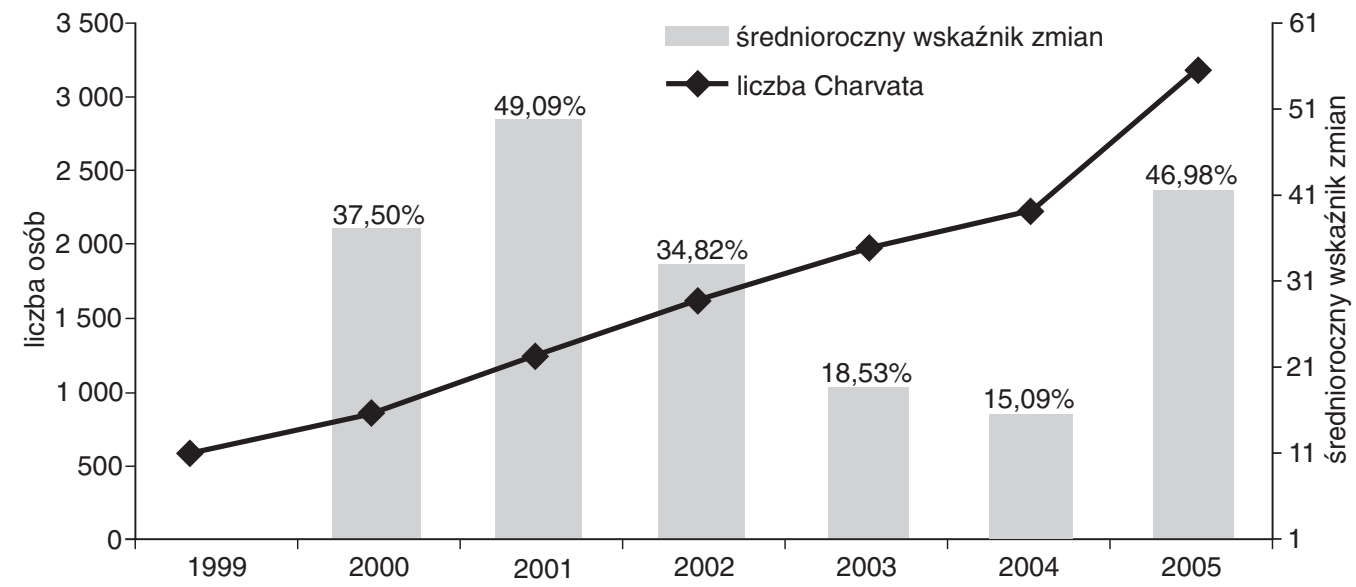

Źródło: opracowanie autora na podstawie danych Stacji Narciarskiej „Wierchomla”

${ }^{1}$ Wskaźnik Charvata - wskaźnik nasycenia bazą turystyczną, wyrażony liczbą miejsc noclegowych przypadających na $1 \mathrm{~km}^{2}$ powierzchni całkowitej 
Stację Narciarską, ,Wierchomla” zalicza się do najszybciej rozwijających się ośrodków sportowo-rekreacyjnych Polski. Ośrodek - zbudowany w ciagu kilku lat w okolicy pozbawionej infrastruktury technicznej-przynosi obecnie około $10 \mathrm{mln}$ zł przychodu, zapewnia pracę i pośrednio warunkuje rozwój całego regionu. Przykładem pośredniego oddziaływania ośrodków sportowych na region może być Krynica, w której według „Business Week” sami narciarze pozostawiają rocznie około $50 \mathrm{mln}$ zł na stacjach benzynowych i w sklepach. Rozwój stacji przekłada się na sytuację gospodarczą. Stopa bezrobocia w gminie wynosi 19\% (w powiecie nowosądeckim około 30,7\%). Liczba zarejestrowanych podmiotów gospodarczych na 1000 mieszkańców w 2003 r. w gminie Piwniczna-Zdrój (67,7 przedsiębiorstw) była znacznie wyższa od średniej dla powiatu (50 przedsiębiorstw). Można więc przyjąć, że Stacja Narciarska „Wierchomla” stała się kołem zamachowym i kierunkowskazem lokalnej aktywizacji gospodarczej.

\section{Literatura}

1. Klisiński J. 1994, Marketing w sporcie, Resortowe Centrum Metodyczno-Szkoleniowe Kultury Fizycznej i Sportu, Warszawa

2. Lubaś-Harny M., Prezes odstania twarz, „Gazeta Krakowska”, 23-24.01.1999 r.

3. Żytkowicz J., 2005, Polityka produktu sportowego na przykładzie Stacji Narciarskiej ,, Wierchomla”, Nowy Sącz (praca dyplomowa)

\section{Ski Station "Wierchomla" as a Local Center of Economic Activation}

The article examines the influence of the Ski Station "Wierchomla" on the local development by creating new vacancies and cooperation with local enterprises. The time frame covers the years between 1998 and 2006. The article is based on the local data of the station.

Thanks to the landscape the development of "Wierchomla", belonged to Piwniczna-Zdrój commune, is based on winter sports and tourism.

The Ski Station, built in 1998, employs 47 persons all year round and approximately 70 persons in the winter season. The number of employees is gradually growing up at about $22.5 \%$ a year. Taking into consideration the dwelling-place of the employees the majority comes from Wierchomla ( $10 \%$ of the village population) and from Piwniczna and Łomnica. A constant growth of the number of employees coming from outside Wierchomla as well as the growing number of qualified employees from the village may be observed in the examined period.

The Ski Station "Wierchomla" cooperates with 57 companies from Poland. 37 of them are situated in Nowy Sącz. Mostly the companies dealing with grocery trade and services. In Piwniczna there are 4 companies functioning in construction industry.

The Ski Station "Wierchomla" is considered to be one of the best developed ski and tourist resort in Poland created in the area devoid of technical infrastructure. It is supposed that "Wierchomla" has become an important factor of local economic development. 


\author{
Katarzyna Dajczak \\ Anna Rychly-Lipińska
}

Politechnika Koszalińska

\title{
Programy rozwoju przedsiębiorczości miasta Koszalin
}

Przedsiębiorczość jest szczególnym rodzajem aktywności ludzi działających indywidualnie lub wewnątrz organizacji, polegającej na wykorzystaniu pojawiających się w otoczeniu okazji, przez realizację przedsięwzięć, które przynoszą efekty ekonomiczne i/lub pozaekonomiczne ich podmiotom oraz otoczeniu (Kraśnicka 2002). Propagowanie zachowań przedsiębiorczych w różnych grupach społecznych oraz wspieranie wszelkich typów i form przedsiębiorczości, szczególnie tworzenie i funkcjonowanie małych i średnich przedsiębiorstw (MSP), przypisano w polityce rządu samorządom terytorialnym i gospodarczym. To właśnie samorząd jest podstawową instytucją wspierającą lokalny rozwój gospodarczy, poprzez promowanie przedsiębiorczości, działalność informacyjną i oświatową, organizowanie szkoleń czy współdziałanie z samorządem gospodarczym w tym zakresie, na podstawie własnych programów, dzięki własnej inicjatywie i możliwościom finansowym, zgodnie z obowiązującym prawem.

Celem niniejszego artykułu jest przedstawienie założeń Programu Wspierania Przedsiębiorczości Miasta Koszalin, z uwzględnieniem Strategii Rozwoju Miasta i Planu Rozwoju Lokalnego Miasta Koszalin na najbliższe lata.

\section{Strategia Rozwoju Koszalina (Uchwała Rady Miejskiej, 2001 r.)}

Strategia Rozwoju Koszalina jest najważniejszym dokumentem miasta, który przedstawia główne kierunki rozwoju Koszalina w najbliższych latach. Jest narzędziem koordynowania wszelkich działań ważnych dla rozwoju miasta oraz kierowania tymi procesami jego rozwoju, na które ma wpływ władza lokalna. Obecnie obowiązująca strategia została uchwalona przez Radę Miejską w marcu 2001 r. Określa ona obraz miasta do 2015 r. Przyjęta wizja mówi, że Koszalin - poprzez przedsiębiorczość, gospodarność i odpowiedzialność swoich mieszkańców - stanie się głównym ośrodkiem stałego i zrównoważonego rozwoju w środkowej części Pomorza, a jego misją jest przeobrażanie miasta w regionalne centrum społeczno-gospodarcze spełniające kluczową rolę w środkowej części Pomorza, ośrodek równoważenia rozwoju rangi krajowej.

Twórcy Strategii Rozwoju Koszalina założyli, że kolejne władze samorządowe będą dążyć do osiagnięcia wyznaczonych w dokumencie celów strategicznych, czyli:

- dynamicznego rozwoju gospodarczego;

- utworzenia miasta akademickiego i ośrodka innowacyjno-wdrożeniowego;

- stworzenia centrum kulturalno-sportowo-rekreacyjnego;

- utrzymania silnych związków z morzem oraz stworzenia ponadregionalnego ośrodka obsługi ruchu turystycznego;

- tworzenia warunków do uzyskania statusu „miasta inteligentnego” - przyjaznego w sferach: społecznej, przestrzennej i funkcjonalnej;

- poprawy jakości życia mieszkańców, by była porównywalna ze standardami unijnymi. 
Lista celów to propozycja rozwiązania istotnych problemów miasta, czyli łagodzenia skutków bezrobocia, wykorzystania akademickiego charakteru Koszalina i jego potencjału naukowego oraz silnych związków z morzem, podniesienia atrakcyjności turystycznej oraz poprawy układu komunikacyjnego i jakości życia mieszkańców. Wskazuje ona najważniejsze kierunki rozwoju miasta; pozwala planować rozwój Koszalina w sposób zrównoważony i zgodny z oczekiwaniami mieszkańców.

Strategia określiła cele strategiczne przewidziane do wykonania w perspektywie wieloletniej. Taktyka działań oraz sposoby wdrażania i realizacji poszczególnych przedsięwzięć zostały określone przez specjalne programy operacyjne. Przygotowano ich kilkanaście; oto najważniejsze:

- program dynamicznego rozwoju gospodarczego;

- program utworzenia miasta akademickiego i ośrodka innowacyjno-wdrożeniowego;

- program stworzenia centrum kulturalno-sportowo-rekreacyjnego;

- program utrzymania silnych związków z morzem oraz stworzenia ponadregionalnego ośrodka obsługi ruchu turystycznego;

- program tworzenia warunków do uzyskania statusu „miasta inteligentnego” - przyjaznego w sferach: społecznej, przestrzennej i funkcjonalnej;

- program poprawy jakości życia mieszkańców porównywalnej do standardów unijnych.

\section{Lokalny program wspierania przedsiębiorczości (Uchwała Rady Miejskiej, 2002 r.)}

Władze miasta w ramach obowiązujących przepisów prawnych oraz ze względu na strukturę gospodarki Koszalina zdominowaną przez małe i średnie przedsiębiorstwa (i ich znaczenie dla rozwoju lokalnej gospodarki) podjęły działania wspierające ten sektor, w tym m.in. realizację Programu wspierania przedsiębiorczości na lata 2002-2005, który został przyjęty przez Radę Miejską 22.02.2002 r. Jest to swoisty katalog wspólnych działań samorządu miasta, organizacji samorządu gospodarczego, środowiska naukowego oraz instytucji z otoczenia biznesu -w zakresie wspierania przedsiębiorczości. Cele zawarte w programie to:

- rozwój przedsiębiorczości;

- wzrost innowacyjności i rozwój technologiczny;

- aktywizacja lokalnego rynku pracy;

- marketing i promocja miasta.

Działania przyjęte w programie w ramach poszczególnych celów to:

dla celu 1 - rozwój przedsiębiorczości:

- instytucjonalne wspieranie przedsiębiorczości,

- finansowe instrumenty wspierania przedsiębiorców,

- rozbudowa systemu funduszy kapitałowych, poręczeniowych i pożyczkowych,

- zwiększenie dostępności do informacji, doradztwa i szkoleń,

- promowanie przedsiębiorczości,

- ułatwienie dostępu małych i średnich przedsiębiorstw do poradnictwa z zakresu regulacji prawnych obowiązujących w Unii Europejskiej,

- wspieranie organizacji pozarządowych,

- Centrum Mikrousługowe,

- Centrum Kongresowe;

dla celu 2 - wzrost innowacyjności i rozwoju technologicznego:

- Park Naukowo-Technologiczny,

- promowanie innowacyjności;

dla celu 3 - aktywizacja lokalnego rynku pracy:

- aktywne formy zwalczania bezrobocia, 
- przygotowanie młodzieży do wejścia na rynek pracy,

- doskonalenie organizacji szkoleń,

- stwarzanie warunków do pozostawania w mieście ludzi młodych;

dla celu 4 - marketing i promocja miasta w celu przyciagania zewnętrznego kapitału inwestycyjnego:

- prowadzenie aktywnej polityki inwestycyjne,

- obsługa informacyjna inwestorów,

- promocja,

- pomoc lokalnym przedsiębiorcom w nawiązywaniu kontaktów krajowych i zagranicznych,

- turystyka jako czynnik przyciągania inwestorów.

Przyjęto, że rozwój przedsiębiorczości jest podstawą ożywienia gospodarczego oraz łagodzenia skutków bezrobocia. Dla osiagnięcia tego celu konieczne jest stwarzanie korzystnych warunków - przez stosowanie różnorodnych działań wobec MSP. Są to zarówno instrumenty finansowe, jak i działania informacyjne, doradcze, szkoleniowe czy promocyjne. Podstawowe działania w tej dziedzinie dotyczą wprowadzania instrumentów finansowych: tworzenia i zasilania funduszy zwiększających dostęp do kapitału, możliwości uzyskiwania tanich kredytów oraz uelastycznienia lokalnego systemu podatkowego. Ponadto założono upowszechnianie wiedzy w zakresie wspierania przedsiębiorczości oraz podjęcie szerszych działań promujących lokalny biznes i nowych propozycji rozwiązań na rzecz przedsiębiorczości.

W związku z tymi działaniami przyjęto zastosowanie następujących instrumentów wspierania przedsiębiorczości:

- inwestycje infrastrukturalne - dobrze ukierunkowane wydatki inwestycyjne skutkują wzrostem atrakcyjności inwestycyjnej gminy oraz poprawą lokalnych warunków gospodarowania i jakości życia mieszkańców. Istotne jest odpowiednie planowanie inwestycji. Miasto Koszalin stworzyło Wieloletni Plan Inwestycyjny na lata 2003-2006, który jest instrumentem planowania długookresowego, skoordynowanego z potrzebami, priorytetami i możliwościami finansowymi. Zawiera zadania zgłoszone przez Miasto Koszalin do Narodowego Planu Rozwoju (NPR) na lata 2004-2006. W WPI zawarto 126 wniosków inwestycyjnych, których realizacja ma bezpośredni bądź pośredni wpływ na funkcjonowanie sfery gospodarczej w mieście. Są to zadania dotyczące gospodarki, transportu, łączności, gospodarki komunalnej i ochrony środowiska;

- wspieranie i funkcjonowanie instytucji z otoczenia biznesu - działalność tych instytucji jest ważna ze względu na bezpośrednie kontakty z przedsiębiorcami, prowadzenie doradztwa i szkoleń czy udzielanie kredytów. Instytucje te dostarczają informacji gospodarczych niezbędnych do efektywnego funkcjonowania przedsiębiorców i mają istotny wpływ na pobudzanie innowacji i transferu technologii. Duże osiagnięcia w tym zakresie mająjuż funkcjonujące w Koszalinie instytucje tego typu: Fundacja Centrum Innowacji i Przedsiębiorczości, Koszalińska Izba Przemysłowo-Handlowa, Zrzeszenie Kupców i Przedsiębiorców, Koszalińska Agencja Rozwoju Regionalnego i Fundusz Mikro;

- ulgi i zwolnienia podatkowe - polityka miasta dotycząca wspierania przedsiębiorczości zaczyna się już na etapie określania stawek podatkowych, które mogą być niższe od stawek maksymalnych określonych przez Ministra Finansów. W tym celu Rada Miejska z dniem 1.01.2003 r. wprowadziła obniżone stawki podatku od nieruchomości przeznaczonych na działalność gospodarczą. 21.02.2003 r. Rada Miejska przyjęła program pomocy dla przedsiębiorców w sprawie zwolnień z podatku od nieruchomości dla przedsiębiorców na terenie miasta Koszalin. W wyniku ich zastosowania będą wspierane nowe inwestycje związane z uruchomieniem lub poszerzeniem działalności gospodarczej i tworzeniem nowych miejsc pracy. Zwolnienia przewidziane uchwałą przysługują na określony czas w zależności od poniesionych 
nakładów inwestycyjnych i liczby utworzonych nowych miejsc pracy. Ze zwolnień objętych tą uchwałą wykluczono obiekty przeznaczone na handel, usługi gastronomiczne i stacje paliw, są to bowiem sfery dobrze rozwijające się w Koszalinie, niewymagające wspomagania;

- fundusz poręczeniowy - fundusz poręczeń kredytowych ma na celu wspieranie przedsięwzięć gospodarczych, zmniejszanie bezrobocia i tworzenie nowych miejsc pracy poprzez udzielanie poręczeń przedsiębiorcom lub osobom podejmującym działalność gospodarczą. W 2002 r. przy KARR S.A. powstał Oddział Zachodniopomorskiego Regionalnego Funduszu Poręczeń Kredytowych Spółka z o.o. w Szczecinie, obejmujący m.in. miasto Koszalin. O udzielenie poręczenia $\mathrm{z}$ tego funduszu mogą ubiegać się MSP, które prowadzą lub podejmują działalność gospodarczą, maja siedzibę lub prowadzą działalność w woj. zachodniopomorskim, w wyniku udzielonego poręczenia tworzą nowe lub utrzymują istniejące miejsca pracy. Poręczenia mogą być udzielane na kredyty i pożyczki przeznaczone na sfinansowanie zakupu produkcyjnych środków trwałych, środków obrotowych oraz wyposażenia;

- działania informacyjno-promocyjne. W ramach promowania przedsiębiorczości miasto uczestniczy w prezentacjach gospodarczych, na których lokalne firmy mogą przedstawiać swój potencjał innowacyjny i gospodarczy. Ponadto pod honorowym patronatem prezydenta miasta odbywają się szkolenia, konkursy i targi dla MSP. W celu pozyskania inwestorów opracowano oferty inwestycyjne miasta Koszalina. Udostępnia się zainteresowanym różnego rodzaju materiały promocyjne: foldery, broszury, filmy wideo, oferty inwestycyjne w internecie. Miasto dysponuje własną stronę internetową oraz materiałami promocyjnymi na płytach CD. Podejmuje się działania mające na celu zapewnienie przedsiębiorcom informacji o warunkach realizacji przedsięwzięć, pomoc w załatwianiu formalności związanych z działalnością gospodarczą, promocję przedsiębiorstw, pomoc w uzyskiwaniu środków pomocowych dla podmiotów gospodarczych, organizowanie misji gospodarczych oraz przygotowywanie terenów pod działalność gospodarczą;

- utworzenie Kompleksu „Koszalin” w ramach Słupskiej Specjalnej Strefy Ekonomicznej. Stwarzając na 22 ha dogodne warunki powstawania i rozwoju lokalnych firm oraz przyciagania inwestorów zewnętrznych, poprzez całkowite zwolnienie z podatku od nieruchomości oraz zwolnienie z podatku dochodowego w zależności od poniesionych nakładów inwestycyjnych i liczby utworzonych nowych miejsc pracy;

- uruchomienie Centrum Biznesu Koszalin. Podjęto działania zmierzające do uruchomienia w obiektach położonych w centrum miasta (w dawnej siedzibie oddziału NBP) Centrum Biznesu Koszalin, skupiającego w jednym miejscu różnego rodzaju instytucje, banki i organizacje prowadzące działalność na rzecz wspierania przedsiębiorczości i pozyskiwania zewnętrznych inwestorów.

\section{Realizacja programu (Vademecum przedsiębiorcy, 2004 r.)}

W celu wspierania MSP, przeciwdziałania bezrobociu poprzez udzielanie pomocy osobom rozpoczynającym działalność gospodarczą oraz tworzenia nowych miejsc pracy, miasto powołało Fundację Centrum Innowacji i Przedsiębiorczości. Swoje zadania Fundacja realizuje poprzez działalność:

- Ośrodka Wspierania Przedsiębiorczości - zajmującego się organizacją szkoleń, kursów i seminariów dla osób bezrobotnych, zagrożonych bezrobociem oraz początkujących i działających na rynku przedsiębiorców, w zakresie podstawowych informacji dotyczących prowadzenia działalności gospodarczej;

- Funduszu Rozwoju Przedsiębiorczości - udzielającego wsparcia finansowego w postaci kredytów bezrobotnym, absolwentom, małym przedsiębiorstwom, zamierzającym otworzyć własną działalność lub inwestującym w rozwój. Fundusz współpracuje z Kanadyjsko-Polską Fundacją Przedsiębiorczości; 
- Koszalińskiego Inkubatora Przedsiębiorczości Sp. z o.o. - pomagającej w rozpoczynaniu działalności gospodarczej poprzez wynajem na preferencyjnych warunkach lokali i samochodów oraz udostępnianie urządzeń biurowych. Nowo założona firma może przebywać w inkubatorze 3-5 lat;

- Regionalnego Centrum Informacji Europejskiej - zajmującego się problematyką Unii Europejskiej, w tym również możliwościami skorzystania z funduszy unijnych oraz funkcjonowania przedsiębiorstw na rynku europejskim.

W 2002 r. Fundacja Centrum Innowacji i Przedsiębiorczości uzyskała Certyfikat Krajowego Systemu Usług dla Małych i Średnich Przedsiębiorstw, w ramach usług szkoleniowych i finansowych, co wskazuje na wysoki poziom jakości jej usług. Ponadto, w ramach struktury organizacyjnej tej fundacji, miasto powołało Centrum Biznesu, stanowiące uzupełnienie dotychczasowych działań prowadzonych przez Fundację na rzecz przedsiębiorców. Centrum Biznesu, w Koszalinie oferuje kompleksowy system usług i doradztwa dla regionalnych oraz międzynarodowych partnerów biznesowych i inwestorów, m.in.: profesjonalne doradztwo i wsparcie początkujących przedsiębiorców oraz firm już działających, kompleksową obsługę inwestorów krajowych i zagranicznych, tworzenie biznesowych więzi kooperacyjnych, gromadzenie, przetwarzanie i rozpowszechnianie międzynarodowych ofert współpracy, promowanie koszalińskiej przedsiębiorczości, udział w przedsięwzięciach proinwestycyjnych, misjach gospodarczych, targach, wystawach i konferencjach.

Koszalińska Izba Przemysłowo-Handlowa realizuje program promowania w społeczeństwie dobrych pragmatycznych rozwiązań i kreowania etycznych wzorców przedsiębiorcy i przedsiębiorstwa, poprzez organizację konkursu „Koszaliński Denar - Nagroda Gospodarcza Roku”. Nazwa konkursu nawiązuje do czasów świetności Koszalina, kiedy przedsiębiorczość i zasobność jego mieszkańców pozwalały bić własną monetę, a miasto należało do Związku Miast Hanzeatyckich. Konkurs obejmuje teren działania Izby, czyli woj. zachodniopomorskie, ze szczególnym naciskiem na tereny dawnego woj. koszalińskiego. „Koszaliński Denar” został wpisany w kalendarz Koszalińskich Dni Techniki, organizowanych od wielu lat przez Naczelną Organizację Techniczną. Nagrody i wyróżnienia są przyznawane w 4 kategoriach: mikroprzedsiębiorstwa, małe, średnie i duże przedsiębiorstwo. Izba zaprasza samorządy lokalne: gminy, miasta i powiaty do przyznawania przedsiębiorcom własnych wyróżnień.

Potwierdzeniem realizacji programu są wyniki w ogólnopolskich rankingach miast (www.koszalin.pl). Koszalin awansował o 19 miejsc w rankingu ogólnopolskiego Tygodnika Samorządowego „Wspólnota”. W 2004 r. Koszalin zajmował 35 miejsce wśród miast na prawach powiatu o najwyższych dochodach, a w rankingu przeprowadzonym za 2005 r. uzyskał wysokie 16 . miejsce. W rankingu wzięto pod uwagę wykonanie budżetu za 2005 r., wzrost dochodów ogółem i wysokość środków pozyskanych z Unii Europejskiej w przeliczeniu na mieszkańca. Do wykazanych realnie dochodów dodane zostały skutki obniżek stawek, ulg podatkowych, zwolnień i umorzeń podatkowych. W ten sposób ustalono faktyczny potencjał dochodowy. Ponadto Koszalin zajął 6. miejsce wśród miast na prawach powiatu w rankingu samorządów przygotowanym przez „Rzeczpospolita”. Gazeta oceniła przychody gmin, wzrost nakładów na inwestycje, ilość pozyskiwanych środków z funduszy unijnych, stopę bezrobocia, współpracę z organizacjami pozarządowymi i funkcjonowanie urzędu. ,Zajęcie wysokich miejsc przez nasze miasto w rankingach to potwierdzenie przyjętego na początku obecnej kadencji kierunku rozwoju miasta. W Koszalinie widać wzrost gospodarczy, widać spadek bezrobocia, przybywa nowych zakładów pracy, a co najważniejsze tworzone są nowe miejsca pracy" - komentował wyniki rankingu prezydent Koszalina Mirosław Mikietyński (www.koszalin.pl). 


\section{Inne inicjatywy}

Od uchwalenia Strategii minęło kilka lat. Od 2001 r. zmieniła się sytuacja międzynarodowa, a Koszalin stanął przed koniecznością dopasowania swojego najważniejszego dokumentu do wymogów Unii Europejskiej oraz zmian społeczno-gospodarczych zachodzących w Koszalinie i jego okolicy. Te uwarunkowania spowodowały konieczność opracowania nowego dokumentu integrującego system zarządzania miastem. Nowa strategia uwzględnia kilkuletni plan najważniejszych działań rozwojowych miasta - Plan Rozwoju Lokalnego Miasta Koszalina na lata 2005-2007. Pierwsza edycja Planu jest oparta na aktualizacji Strategii i ocenie konkurencyjności miasta. Plan obejmuje lata 2005-2007. Corocznie będzie aktualizowany (wprowadzanie do realizacji nowych projektów) na kolejne 3 lata. Plan obejmuje 60 projektów zgrupowanych w 12 programach dotyczących spraw najistotniejszych dla rozwoju Koszalina. Nazwy programów odpowiadają ich tematyce: „Gospodarny Koszalin”, „Infrastruktura dla rozwoju”, „Miasto równych szans”, „Razem można więcej” (Plan Rozwoju..., 2005).

\section{Podsumowanie}

Priorytetem dla miasta są działania w sferze gospodarczej. Dotyczy to także celów strategicznych, z których głównym jest rozwój gospodarczy. Kluczem do rozwoju Koszalina jest koncentracja działań w sferze gospodarczej, ukierunkowana na przyciąganie inwestorów i rozwój przedsiębiorczości. Wspieranie tych działań jest zasadniczym zadaniem władz lokalnych, które są odpowiedzialne za podtrzymanie aktywności gospodarczej, przyrost liczby miejsc pracy i umacnianie bazy podatkowej. Trwały wzrost gospodarczy nie jest jednak możliwy bez inwestycji. Dlatego samorząd Koszalina tworzy możliwie dogodne warunki rozwoju przedsiębiorczości, sprawność gospodarki w zasadniczy sposób wpływa bowiem na jakość życia i tempo rozwoju społeczeństwa (www.koszalin.pl).

\section{Literatura}

1. Kraśnicka T., Wokót pojęcia przedsiębiorczości, „Przegląd Organizacji” 6/2002

2. Miszczor M., 15 lat Koszalińskiej Izby Przemysłowo-Handlowej, „Moment - regionalny magazyn społeczno-gospodarczy" III/2005

3. Plan Rozwoju Lokalnego Miasta Koszalina na lata 2005-2007, Stowarzyszenie Rozwoju Gospodarczego Gmin, Koszalin 2005

4. Uchwała Rady Miejskiej w Koszalinie z 29.03.2001 r. w sprawie uchwalenia Strategii Rozwoju Koszalina

5. Uchwała Rady Miejskiej w Koszalinie z 22.02.2002 r. w sprawie uchwalenia programu wspierania przedsiębiorczości na lata 2002-2005

6. Vademecum przedsiębiorcy, 2004, R. Zdrojewski (red.), Agencja Wydawnicza Millenium, Koszalin

7. www.koszalin.pl., 10.10.2006.

\section{Programs of Development of Enterprise in Koszalin}

Work in economic sphere is the priority of Koszalin. The key to development of Koszalin is the focus on economic sphere - on attraction the investors and the development of enterprise. Principle task of the provincial government, obliged to support the economic activity and the increase of workplaces, is to favor these works. The local council of Koszalin creates favorable environment for development of enterprise by initiation different programs of support for city's enterprise. 


\section{Janusz Ustupski}

Zakład Geografii Regionalnej

Instytut Geografii

Akademia Pedagogiczna w Krakowie

\section{Przedsiębiorczość w otoczeniu Tarnowa}

Prawie siedemnastoletni okres funkcjonowania gospodarki wolnorynkowej w Polsce stwarza sytuację, w której konieczne są systematyczne badania nad rozwojem przedsiębiorczości w poszczególnych regionach. W ostatnich latach w wielu miejscowościach obserwujemy dynamiczny rozwój sektora małych i średnich przedsiębiorstw (MSP). Powstają ośrodki, które wpływają na rozwój procesów przedsiębiorczości w otoczeniu i z upływem czasu zaczynają oddziaływać na obszary dalej położone, co stwarza dogodne warunki rozwoju przedsiębiorczości w całym regionie. Wraz ze studentami Wyższej Szkoły Biznesu w Tarnowie ${ }^{1}$ autor podjął próbę analizy rozwoju przedsiębiorczości w rejonie Tarnowa, z uwzględnieniem jej aspektu przestrzennego. Przedsiębiorczość w ujęciu przestrzennym to funkcjonowanie przedsiębiorstw i firm na tle walorów naturalnych i antropogenicznych regionu. Przedsiębiorczość, pobudzana i wspomagana przez władze samorządowe i stowarzyszenia lokalne, przejawia się działaniami zmierzającymi do udoskonalenia produkcji, usług, systemu dystrybucji oraz wzrostu efektywności poszczególnych podmiotów gospodarczych.

Uznając, że badania nad przedsiębiorczością przedsiębiorstw i firm w regionach są uzasadnione, można sformułować następujące problemy badawcze:

- Jakie czynniki wpływają na rozwój przedsiębiorczości?

- W jakich dziedzinach występują przejawy przedsiębiorczości w firmach i przedsiębiorstwach? Czy są widoczne oznaki jej ograniczania?

- Jakie wnioski dotyczące charakteru przedsiębiorczości rozwijającej się w konkretnym regionie można wyciagnąć na podstawie analizy poszczególnych przypadków rozwoju przedsiębiorstw w gminach?

Celem niniejszego opracowania jest zatem próba identyfikacji czynników wpływających na rozwój przedsiębiorczości w regionie. Na podstawie badań pilotażowych można wskazać czynniki rozwoju przedsiębiorstw i firm działających w bliskim otoczeniu Tarnowa. Analizy przypadków umożliwią dokonanie uogólnień i weryfikację hipotez dotyczących możliwości rozwoju przedsiębiorczości firm w gminach okalających Tarnów.

\section{Tarnów jako ośrodek wspierania aktywności mieszkańców w działalności gospodarczej}

Lokalizacja Tarnowa na skrzyżowaniu ważnych europejskich szlaków handlowych jest jedną z jego najmocniejszych stron umożliwiających rozwój przedsiębiorczości. Międzynarodowa trasa E4 (Zgorzelec - Wrocław - Katowice - Kraków - Tarnów - Rzeszów - Medyka) krzyżuje się w mieście z szosą krajową Warszawa - Kielce - Nowy Sącz. Najbliższe lotniska międzynarodowe znajdują się w odległości około 80 km od Tarnowa, w Balicach pod Krakowem i w Jasionce pod

\footnotetext{
${ }^{1}$ W badaniach uczestniczyli studenci: J. Burzawa, R. Mroczek, T. Kluza.
} 
Rzeszowem. W bezpośrednim sąsiedztwie miasta będzie przebiegać autostrada. Węzeł oraz zjazd z autostrady, zlokalizowane w pobliżu północno-zachodniej części Tarnowa, przyczynią się do lepszej dostępności miasta. Od południowej strony bezpiecznie i szybko można się dostać do centrum lub ominąć je dzięki niedawno wybudowanej południowej obwodnicy. Atutami Tarnowa są tranzytowe położenie i bliskość przejść granicznych. Od granicy z Ukrainą dzieli Tarnów $180 \mathrm{~km}$, od granicy ze Słowacją - $100 \mathrm{~km}$, od granicy z Niemcami - $500 \mathrm{~km}$. Znaczenie Tarnowa określa jego centralne położenie w Małopolsce, ułatwiające dostęp do rynków w tej części kraju.

Lokalny klimat inwestycyjny to najważniejszy czynnik wpływający na rozwój przedsiębiorczości. Składają się nań: pomoc władz miasta i instytucji biznesowych w zakresie doradztwa i usług dla przedsiębiorców, pomoc w zakresie finansowania działalności gospodarczej i inwestycyjnej oraz miejscowy system udogodnień podatkowych w formie m.in. niższych podatków od nieruchomości i opłat za dzierżawę terenu. Ważną inicjatywą wspierającą przedsiębiorczość jest tworzenie specjalnych stref ekonomicznych, w których stosowane są różne formy udogodnień mających na celu ułatwienie chętnym założenia i prowadzenia działalności gospodarczej.

W ramach lokalnych programów Powiatowy Urząd Pracy oraz Urząd Miasta Tarnowa przygotowały program dla bezrobotnych pod nazwą Mikroinkubator Przedsiębiorczości. Jego celem jest stworzenie sprzyjających warunków powstawania i rozwoju małych firm. W ramach programu mogą być organizowane firmy usługowe, wytwórcze, usługowo-handlowe i handlowe. Uczestnicy programu mogą skorzystać bezpłatnie z pomocy w zakresie:

- indywidualnego poradnictwa dotyczącego ogólnych zasad tworzenia własnej firmy i oceny szans powodzenia przedsięwzięcia;

- doradztwa w zakresie przepisów podatkowych oraz ubezpieczeń społecznych i zdrowotnych,

- pożyczek udzielanych w ramach Funduszu Pracy na rozpoczęcie działalności gospodarczej;

- możliwości wynajmu na preferencyjnych warunkach finansowych lokali położonych na terenie miasta Tarnowa, będących własnością urzędu miasta. Preferencje obejmujązniżki od stawki wywoławczej czynszu: w pierwszym roku działalności-75\%,w drugim roku-50\%, w trzecim roku-25\%;

- jednorazowe dotacje na rozpoczęcie działalności gospodarczej, w tym na pokrycie kosztów pomocy prawnej, konsultacji i doradztwa w wysokości nie większej niż pięciokrotne przeciętne wynagrodzenie ${ }^{2}$.

Na uwagę zasługuje opracowany w Urzędzie Miasta Tarnowa projekt pod nazwą Kompleksowa Obsługa Inwestora, skierowany do przedsiębiorców. Wychodzi on naprzeciw potrzebie tworzenia jak najmniej skomplikowanych procedur postępowania administracyjnego w sprawach związanych z działalnością gospodarczą, zarówno przedsiębiorców lokalnych, jak i inwestorów zewnętrznych. Program obejmuje:

- inwestycje pozwalające na stworzenie co najmniej piętnastu nowych stałych miejsc pracy;

- inwestycje związane z powstawaniem nowych lub modernizacją i adaptacją istniejących obiektów w rozumieniu prawa budowlanego;

- inwestycje związane z wprowadzaniem nowoczesnych technologii.

W Tarnowie rozwój przedsiębiorczości jest wspierany przez funkcjonowanie specjalnej strefy ekonomicznej. Tarnowski Klaster Przemysłowy „Plastikowa Dolina” S.A. jest podstrefą Specjalnej Strefy Ekonomicznej w Krakowie. Liczy 39,07 ha terenu w pełni uzbrojonego w media. Celem przedsięwzięcia było stworzenie warunków zachęcających przedsiębiorców interesujących się branżą chemiczną do lokalizacji nowych zakładów produkcyjnych w Tarnowie.

${ }^{2}$ Mikroinkubator przedsiębiorczości, http://www.tarnow.pl/biznes w tarnowie/inkubator/index.php, 11.09.2001 r. 
Nowym projektem, przeznaczonym dla osób, które chcą prowadzić własną działalność gospodarczą, jest program skierowany do wszystkich mieszkańców woj. małopolskiego pod hasłem „Winnice Małopolski”. Jest to program Małopolskiej Agencji Rozwoju Regionalnego.

\section{Organizacja usług i doradztwa wspierającego rozwój małych i średnich przedsiębiorstw w Tarnowie i jego okolicach}

Do najważniejszych instytucji wpierających przedsiębiorczość w otoczeniu Tarnowa możemy zaliczyć: Izbę Przemysłowo-Handlową, Wszechnicę Edukacyjna, Małopolski Instytut Samorządu Terytorialnego i Administracji, Tarnowską Agencję Rozwoju Regionalnego, Polską Agencję Rozwoju Przedsiębiorczości, Izbę Rzemieślniczą Małej i Średniej Przedsiębiorczości, Koło Terenowe Polskiego Stowarzyszenia Chrześcijańskich Przedsiębiorców, Ośrodek Innowacji NOT, Krajowy System Usług dla Małych i Średnich Przedsiębiorstw, Korporację Ubezpieczeń Kredytów Eksportowych.

- Izba Przemysłowo-Handlowa w Tarnowie działa od 1992 r. jako Samorząd Gospodarczy, który na zasadzie dobrowolności zrzesza podmioty gospodarcze z dawnego woj. tarnowskiego. Do Izby należą małe i średnie firmy prowadzące działalność gospodarczą w sferze produkcji, handlu i usług. Do zadań Izby należą: reprezentowanie interesów firm członkowskich, promowanie gospodarki regionu tarnowskiego, kształcenie zawodowe poprzez organizowanie szkoleń, kursów, rozpowszechnianie informacji gospodarczej, kojarzenie podmiotów gospodarczych, wydawanie katalogów, organizowanie targów, konkursów i misji gospodarczych, integrowanie członków Izby oraz kształtowanie i upowszechnianie zasad etyki w biznesie. Poprzez taki zakres zadań Izba wpływa na kształtowanie gospodarki na terenie miasta, gminy i powiatu. ${ }^{3}$

- Tarnowska Agencja Rozwoju Regionalnego jest członkiem Krajowego Systemu Usług - sieci regionalnych ośrodków wspierania biznesu, świadczących usługi doradcze, szkoleniowe, informacyjne, finansowe i inne małym i średnim przedsiębiorstwom. TARR świadczy usługi doradczo-szkoleniowe firmom tarnowskim w zakresie marketingu i sprzedaży, zarządzania zasobami ludzkimi, finansów, podatków itd. Uruchomił również Tarnowski Inkubator Przedsiębiorczości, którego celem jest wspieranie powstających i istniejących przedsiębiorstw poprzez udostępnianie taniej powierzchni lokalowej oraz pakietu bezpłatnego doradztwa biznesowego. ${ }^{4} \mathrm{~W}$ ramach TARR funkcjonuje Fundusz Poręczeń Kredytowych, skierowany przede wszystkim do mikro- oraz małych i średnich przedsiębiorców. Pomoc finansowa udzielana jest drobnym przedsiębiorcom niezależnie od fazy rozwoju, począwszy od założenia po jej funkcjonowanie i rozwój. Dotyczy przedsiębiorstw, które znajdują się na terenie powiatu tarnowskiego i powiatów sąsiednich. Fundusz udziela poręczeń kredytowych małym i średnim przedsiębiorstwom za pośrednictwem banków i innych instytucji finansujących.

- Izba Rzemieślnicza Małej i Średniej Przedsiębiorczości w Tarnowie udziela pomocy instruktażowej i doradczej, zwłaszcza w odniesieniu do problemów prawnych, podatkowych, ekonomicznych, finansowych oraz zasad bezpieczeństwa i higieny pracy. Jej zadaniami są również promocja i marketing wyrobów oraz usług małych i średnich przedsiębiorstw. Izba udziela pomocy zrzeszonym w niej organizacjom przy urządzaniu wystaw, giełd, targów i konkursów. ${ }^{5}$

- Koło Terenowe Polskiego Stowarzyszenia Chrześcijańskich Przedsiębiorców. Do podstawowych zadań Stowarzyszenia należy reprezentowanie przedsiębiorców i pracodawców

\footnotetext{
${ }^{3}$ Izba Przemystowo-Handlowa w Tarnowie, http://www.chamber-tamow.com.pl/izba, $12.06 .2006 \mathrm{r}$.

${ }^{4}$ Tarnowska Agencja Rozwoju Regionalnego, http://www.tarr.tarnow.pl/index.php=tarr/informacje, 12.06.2006 r.

${ }^{5}$ Izba Rzemieślnicza oraz Małej i Średniej Przedsiębiorczości, http://www.tarnow.pl/biznes_w_tarnowie, 12.06.2006 r.
} 
deklarujących wiarę chrześcijańską, a także poradnictwo prawne, marketingowe itp., działalność charytatywna i kulturalna. Z inicjatywy Stowarzyszenia przyjeżdżają do Tarnowa holenderscy specjaliści w dziedzinie zarządzania i pomagają w prowadzeniu małego i średniego biznesu ${ }^{6}$.

- Ośrodek Innowacji NOT w Tarnowie świadczy usługi doradcze w zakresie pozyskiwania funduszy Unii Europejskiej. Dotychczas z jego usług skorzystało 85 firm. Ośrodek szkoli przedsiębiorców oraz rolników prowadzących działalność agroturystyczną; współpracuje z gminami oraz Towarzystwem Agrarnym w Tarnowie ${ }^{7}$.

- Małopolski Instytut Samorządu Terytorialnego i Administracji posiada akredytację Krajowego Systemu Usług dla Małych i Średnich Przedsiębiorstw w zakresie usług doradczych i informacyjnych dla przedsiębiorców. Ma wiele propozycji dla przedsiębiorców, m.in. jest wykonawcą projektów Polskiej Agencji Rozwoju Przedsiębiorczości: „Wstęp do jakości”, „Przygotowanie do działania na rynku europejskim”, „Program Rozwoju Przedsiębiorstw” i „Program Rozwoju Przedsiębiorstw Eksportowych”.

Prowadzący działalność gospodarczą lub zamierzający ją rozpocząć mogą także skorzystać z pomocy instytucji ogólnopolskich mających oddziały w Tarnowie: Polskiej Agencji Rozwoju Przedsiębiorczości, Krajowego Systemu Usług dla Małych i Średnich Przedsiębiorstw oraz Korporacji Ubezpieczeń Kredytów Eksportowych ${ }^{8}$. Do głównych zadań PARP należą: wspieranie rozwoju sektora małej i średniej przedsiębiorczości, rozwój eksportu, rozwój regionalny, wykorzystanie nowych technik oraz technologii, tworzenie nowych miejsc pracy oraz przeciwdziałanie bezrobociu. PARP prowadzi również Krajowy System Usług dla Małych i Średnich Przedsiębiorstw.

\section{Przedsiębiorczość w Tarnowie oraz w wybranych gminach w jego okolicy}

Wśród tarnowskich podmiotów gospodarczych przeważa sektor prywatny. Największa liczba podmiotów gospodarczych została zarejestrowana w 2003 r. Liczbę podmiotów zarejestrowanych w 2005 r. według sekcji Polskiej Klasyfikacji Działalności (PKD) przedstawia tab. 1.

Tab. 1. Liczba jednostek gospodarczych zarejestrowanych w Tarnowie (według wybranych sekcji PKD) w 2005 r.

\begin{tabular}{|c|l|c|}
\hline Lp. & \multicolumn{1}{|c|}{ Sekcja } & $\begin{array}{c}\text { Liczba zarejestrowanych } \\
\text { jednostek gospodarczych }\end{array}$ \\
\hline 1. & $\begin{array}{l}\text { Handel detaliczny i hurtowy oraz naprawy pojazdów samocho- } \\
\text { dowych, motocykli, artykułów użytku osobistego i domowego }\end{array}$ & 3768 \\
\hline 2. & $\begin{array}{l}\text { Obsługa nieruchomości, wynajem i usługi związane z prowa- } \\
\text { dzeniem działalności gospodarczej }\end{array}$ & 1841 \\
\hline 3. & Przetwórstwo przemysłowe & 919 \\
\hline 4. & Budownictwo & 847 \\
\hline 5. & Transport, gospodarka magazynowa i łączność & 768 \\
\hline 6. & Pośrednictwo finansowe & 489 \\
\hline 7. & Hotele i restauracje & 212 \\
\hline 8. & Rolnictwo, lowiectwo i leśnictwo & 69 \\
\hline
\end{tabular}

Źródło: dane Urzędu Miasta Tarnowa

${ }^{6}$ Polskie Stowarzyszenie Chrześcijańskich Przedsiębiorców, http://www.wsd.tarnow.pl/stowarzyszenia, 12.06.2006 r.

${ }^{7}$ Sieć Ośrodków Innowacji NOT, http://innowacje.not.org.pl/437-42b986b21e5f6.htm, 14.06.2006 r.

${ }^{8}$ Por. Moduly tematyczne, http://www.mistia.org.pl/mistia/index2.htm, 13.06.2006 r. 
W Tarnowie najwięcej podmiotów gospodarczych zajmuje się handlem detalicznym i hurtowym, naprawami pojazdów samochodowych, motocykli, artykułów użytku osobistego i domowego. Drugie miejsce zajmują: obsługa nieruchomości, wynajem i usługi związane z prowadzeniem działalności gospodarczej. Trzecim popularnym rodzajem działalności gospodarczej jest przetwórstwo przemysłowe.

W gminie Pilzno przedsiębiorczość od dawna jest związana z rzemiosłem, które mimo przemian gospodarczych i kryzysów politycznych przetrwało i stanowi podstawę współczesnej przedsiębiorczości. Przykładem mogą być zakłady, które powstały w drugiej połowie XX w.: Piekarnia Drobińskich, Zakład stolarski „Limba” i Cukiernia D. Desoń.

Rozwój sektora przemysłu prywatnego to szansa rozwoju miasta i gminy. W $1998 \mathrm{r}$. w gminie Pilzno zanotowano 620 tzw. podmiotów gospodarczych, 31.12.2004 r. prowadziło działalność 701 podmiotów gospodarczych, a rok później zarejestrowano 778 przedsiębiorstw, co daje 2244 miejsca pracy w gminie, w tym 1428 w samym Pilźnie.

Podobnie jak w całym kraju, w gminie Pilzno po 1990 r. wiele zakładów rzemieślniczych przekształciło się w małe i średnie przedsiębiorstwa prywatne, które dają zatrudnienie miejscowej ludności. Skoncentrowane są w samym Pilźnie, gdzie infrastruktura jest najlepiej rozwinięta, a zapotrzebowanie na usługi - największe. Poza Pilznem, na terenach wiejskich, przedsiębiorcy działają jednoosobowo.

Na terenie gminy Pilzno w 2005 r. prowadziło działalność 778 podmiotów gospodarczych.

Tab. 2. Liczba podmiotów gospodarczych w gminie Pilzno według branż

\begin{tabular}{|c|l|c|c|}
\hline Lp. & \multicolumn{1}{|c|}{ Rodzaj branży } & $\begin{array}{c}\text { Liczba podmiotów } \\
\text { gospodarczych } \\
\text { w 2004 r. }\end{array}$ & $\begin{array}{c}\text { Liczba podmiotów } \\
\text { gospodarczych } \\
\text { w 2005 r. }\end{array}$ \\
\hline 1. & Handel & 247 & 231 \\
\hline 2. & Produkcja wyrobów metalowych & 25 & 24 \\
\hline 3. & Produkcja i naprawa maszyn rolniczych & 2 & 2 \\
\hline 4. & Przetwórstwo mięsne & 1 & 1 \\
\hline 5. & Piekarnictwo i cukiernictwo & 5 & 5 \\
\hline 6. & Produkcja mebli i wyrobów z drewna & 30 & 31 \\
\hline 7. & Gastronomia i hotelarstwo & 15 & 16 \\
\hline 8. & Transport & 108 & 31 \\
\hline 9. & Naprawy samochodów & 27 & 253 \\
\hline 10. & Inne & 241 & \\
\hline
\end{tabular}

Źródło: dane Urzędu Gminy Pilzno

Wśród podmiotów gospodarczych w latach 2004 i 2005 przeważały przedsiębiorstwa zajmujące się handlem, transportem i produkcją mebli oraz wyrobów z drewna. W handlu panuje tendencja spadkowa. Wysokie czynsze oraz duża konkurencja sprawiają, że na rynku utrzymują się tylko ci przedsiębiorcy, którzy potrafią znaleźć odpowiednie źródła zaopatrzenia, dostosować działalność do potrzeb rynku i umiejętnie organizować dystrybucję wyrobów.

W gminie Skrzyszów w końcu 2005 r. zarejestrowanych było 578 podmiotów gospodarczych (tab. 3). Najwięcej podmiotów prowadzi działalność handlową, wiele jest przedsiębiorstw budowlanych i transportowych. 
Tab. 3. Liczba podmiotów gospodarczych w gminie Skrzyszów według branż

\begin{tabular}{|c|l|c|}
\hline Lp. & \multicolumn{1}{|c|}{ Branża } & $\begin{array}{c}\text { Liczba podmiotów } \\
\text { gospodarczych w 2005 r. }\end{array}$ \\
\hline 1. & Handel & 218 \\
\hline 2. & Gastronomia & 3 \\
\hline 3. & Piekarnictwo & 2 \\
\hline 4. & Cukiernictwo & 2 \\
\hline 5. & Przetwórstwo mięsne & 2 \\
\hline 6. & Transport & 30 \\
\hline 7. & Budownictwo & 95 \\
\hline 8. & Stolarstwo & 12 \\
\hline 9. & Inne & 214 \\
\hline
\end{tabular}

Źródło: dane Urzędu Gminy Skrzyszów

Najpoważniejszą barierą rozwoju przedsiębiorstw jest brak środków finansowych na modernizację. Wśród małych i średnich firm utrzymuje się tendencja finansowania rozwoju przede wszystkim z własnych środków. Taką postawę wywołują uwarunkowania makroekonomiczne, które określają rynkowe warunki funkcjonowania przedsiębiorstw na terenie gminy, oraz czynniki wewnętrzne, przede wszystkim wielkość majątku przedsiębiorstwa. Trudna sytuacja spowodowana jest spadkiem zapotrzebowania na usługi i produkty.

Pod względem rozwoju technologicznego małe i średnie przedsiębiorstwa pozostają w tyle za dużymi firmami. Wprowadzenie do produkcji nowego lub zmodernizowanego wyrobu czy nowej lub zmodernizowanej technologii wiąże się z poważnymi wydatkami, zbyt wysokimi, jak na możliwości małych i średnich firm.

Małe przedsiębiorstwa cechuje niedostateczny poziom wiedzy o prowadzeniu przedsiębiorstwa oraz umiejętności praktycznego jej zastosowania. Około 50\% małych i średnich przedsiębiorstw w gminie ma dostęp do internetu, ale nieliczne to wykorzystują.

\section{Czynniki wpływające na rozwój przedsiębiorczości w rejonie Tarnowa}

Czynniki zidentyfikowane w trakcie badań pilotażowych, które stwarzają dogodne warunki dla rozwoju przedsiębiorczości w Tarnowie, to:

- dogodne położenie Tarnowa jako ośrodka rozwoju przedsiębiorczości w regionie; przedsięwzięcia zmierzające do poprawy warunków dostępności komunikacyjnej; bliskość Krakowa i Rzeszowa;

- lokalny klimat wokół rozwoju przedsiębiorczości; wyniki analizy upoważniają do stwierdzenia, że w rejonie Tarnowa stworzono dogodne warunki inwestycyjne rozwoju małych i średnich przedsiębiorstw. Działa dziesięć organizacji zajmujących się doradztwem i usługami w tej dziedzinie. Na pobudzenie przedsiębiorczości w latach 2003-2005 przeznaczono ponad 700 tys. zł. Stworzono system udzielania pożyczek finansowych i zniżek przy wynajmie lokali przeznaczonych na działalność gospodarczą. W wyniku tych działań - na liście najlepszych miejsc do inwestowania w Polsce w kategorii miast powyżej 100 tys. mieszkańców, Tarnów zajmuje siódme miejsce; 
- tradycje w przemyśle chemicznym, maszynowym, szklarskim; bogate tradycje rzemieślnicze zarówno w Tarnowie, jak i w gminach otaczających miasto;

- utworzenie Tarnowskiego Klastra Przemysłowego „Plastikowa Dolina” oraz Małopolskiego Rynku Hurtowego;

- rozwój sieci szkolnictwa wyższego opartego na dorobku i kadrze uczelni krakowskich;

- atrakcje turystyczne Tarnowa i okolic;

- cykliczne tradycyjne imprezy kulturalne, targowe i wystawiennicze.

\section{Rodzaje działalności gospodarczej w gminach}

W gminach, które podlegały analizie, przeważają przedsiębiorstwa zajmujące się handlem detalicznym i hurtowym, naprawą pojazdów samochodowych, motocykli oraz artykułów użytku osobistego i domowego. W dalszej kolejności należy wymienić obsługę nieruchomości, wynajem i usługi związane z prowadzeniem działalności gospodarczej i przetwórstwa przemysłowego. W gminie Pilzno przeważają przedsiębiorstwa handlowe, transportowe oraz produkujące meble i wyroby z drewna. W gminie Skrzyszów najwięcej podmiotów prowadzi działalność handlową; liczne są przedsiębiorstwa budowlane i transportowe.

Najbardziej zróżnicowana działalność występuje w Tarnowie, gdzie przeważają przedsiębiorstwa świadczące usługi oraz zajmujące się przetwórstwem przemysłowym. W otoczeniu Tarnowa zdecydowanie przeważa aktywność w handlu, transporcie, budownictwie i rzemiośle.

\section{Podsumowanie}

Badania, o których mowa, miały charakter pilotażowy. Głównym ich celem była analiza rozwoju przedsiębiorczości w gminach położonych w pobliżu Tarnowa. Obecnie prowadzone są badania nad rozwojem przedsiębiorczości w gminach: Brzesko, Lisia Góra, Tuchów, Wierzchosławice, Wojnicz i Żabno. W toku dalszych badań będzie można w sposób kompleksowy podejść do zjawiska przedsiębiorczości w całym rejonie.

Należy przyjąć, że rodzajów przedsiębiorczości jest tyle, ile badanych firm. Widoczne są charakterystyczne dla konkretnych rejonów typy inicjatyw przedsiębiorczych wyróżnianych na podstawie rodzaju działalności oraz skali przedsięwzięć. Niewielka liczba przebadanych gmin nie upoważnia jednak do wysuwania daleko idących wniosków. Największą trudność w rozwoju przedsiębiorczości - jak się wydaje w świetle przeprowadzonych badań - sprawiają: planowanie, motywowanie i systematyzacja działań przedsiębiorczych oraz niedostateczny kapitał społeczny i intelektualny. Trudności wynikają także z polityki państwa, które pomimo zapewnień o promocji przedsiębiorczości, nadal nie oferuje dogodnych warunków do jej rozwoju.

\section{Enterprise Development in the Area of Tarnow}

The author introduces the results of carried out in Tarnow and its adjoining area a pilotage research into the enterprise development. The analysis concerns the factors that decide about enterprise development in this area, and presents a range of activities to which the inhabitants show the biggest commitment. In the final part conclusions of the research up to the present time are presented. 


\section{Janusz Machowski}

Wydział Geografii i Studiów Regionalnych

Uniwersytet Warszawski

\section{Płocki Park Przemysłowo-Technologiczny - projekt pobudzenia przedsiębiorczości lokalnej}

Przedsiębiorczość, rozumiana jako umiejętność dostrzegania i wykorzystywania nowych możliwości na różnych polach działania, które dają szanse osiągania większych korzyści niż dotychczas uzyskiwane, stała się koniecznością w rozwijającej się w Polsce gospodarce rynkowej. $\mathrm{Z}$ dniem akcesji do Unii Europejskiej Polska została włączona w nurt programów zapewniających realizację strategii lizbońskiej, która stwarza szanse szybszego rozwoju gospodarczego.

Możliwości pobudzenia innowacyjności i przedsiębiorczości, rozwoju nauki i badań podnoszących konkurencyjność gospodarki, stworzyły fundusze strukturalne Unii, wspierające uboższe i bardziej zacofane regiony i społeczności lokalne.

W miarę pogłębiania się podziału pracy i specjalizacji współczesne przedsiębiorstwa wydzielają ze swej działalności podstawowej działalność badawczo-rozwojową. Przejmują ją firmy pośredniczące między nauką a gospodarką, specjalizujące się w opracowywaniu nowych technologii czy sposobów wdrażania innowacji. Podmioty realizujące programy wsparcia innowacyjności i szeroko rozumianej przedsiębiorczości szczególnie w sektorze małych i średnich przedsiębiorstw (MSP) są określane jako ośrodki innowacji i przedsiębiorczości.

Geneza ośrodków innowacji jest związana z uczelniami amerykańskimi poszukującymi dodatkowych dochodów z komercjalizacji osiagnięć naukowych. Bazujące na konkretnym terenie, z koncepcją zagospodarowania i rozwoju obejmującą aktywność naukowo-badawczą oraz produkcyjną, powiązane z lokalną lub regionalną administracją oraz instytucjami wspierania przedsiębiorczości, organizacje tego typu są określane jako parki: technologiczne, naukowe, badawcze, naukowo-badawcze, naukowo-technologiczne, przemysłowo-technologiczne, technopolie itp.

Parki technologiczne są najbardziej koncepcyjnie i organizacyjnie rozwiniętym typem ośrodków innowacji. Za pierwszy park technologiczny uważa się utworzony w 1948 r. Bohanson Research Park w Menlo Park w Stanach Zjednoczonych. Najbardziej znanym tego typu przedsięwzięciem jest powołany w 1951 r. (przy Uniwersytecie Stanforda w Kalifornii) Stanford Research Park, który następnie rozrósł się w słynną Dolinę Krzemową. Obecnie działa na świecie ponad 800 tego typu przedsięwzięć, które powstały w prawie wszystkich krajach rozwiniętych.

W latach 60. i 70. XX w. pojawiły się tzw. inkubatory technologiczne-ośrodki innowacji mniej kosztowne i nastawione głównie na doradztwo, gromadzenie informacji i wspieranie technologiczne przedsiębiorstw.

Pierwsze prace studyjne nad adaptacją instytucji parku technologicznego $\mathrm{w}$ gospodarce polskiej zostały podjęte w drugiej połowie lat 80 . XX w. przez zespół prof. Bohdana Gruchmana w Wyższej Szkole Ekonomicznej w Poznaniu. Za pierwszy polski park technologiczny należy uznać Poznański Park Naukowo-Technologiczny powstały w 1995 r. w ramach działalności 
statutowej i gospodarczej Fundacji Uniwersytetu im. Adama Mickiewicza w Poznaniu. Na początku powstawania parków w Polsce brak było zrozumienia dla idei ich tworzenia i brakowało środków finansowych oraz wsparcia rzeczowego ze strony przedsiębiorstw i władz regionów. Sytuacja zmieniła się radykalnie po uzyskaniu dostępu do funduszy strukturalnych UE. Środki unijne sprawiły, że w Polsce powstało około 50 inicjatyw utworzenia parków przemysłowych na bazie restrukturyzowanych przedsiębiorstw i technologicznych, opartych na ośrodkach naukowo-badawczych. Ich liczba wciąż wzrasta.

W ramach Sektorowego Programu Operacyjnego - Wzrost Konkurencyjności Przedsiębiorstw, lata 2004-2006, działanie 1.3 „Tworzenie korzystnych warunków dla rozwoju firm”, Europejski Fundusz Rozwoju Unii Europejskiej współfinansuje ośrodki innowacji w formie parków przemysłowych, parków naukowo-technologicznych oraz inkubatorów technologicznych.

Park przemysłowy to zespół wyodrębnionych nieruchomości, w którego skład wchodzi co najmniej nieruchomość wraz z infrastrukturą techniczną pozostałą po restrukturyzowanym lub likwidowanym przedsiębiorstwie, utworzony na podstawie umowy cywilno-prawnej, której jedną ze stron jest jednostka samorządu terytorialnego, stwarzający możliwość prowadzenia działalności gospodarczej przedsiębiorstwom, szczególnie małym i średnim.

Park technologiczny to zespół wyodrębnionych nieruchomości wraz z infrastrukturą techniczną, utworzony w celu dokonywania przepływu wiedzy i technologii pomiędzy jednostkami naukowymi a przedsiębiorstwami. Przedsiębiorcom wykorzystującym nowoczesne technologie oferowane są usługi w zakresie doradztwa w tworzeniu i rozwoju przedsiębiorstw, transferu technologii oraz przekształcania wyników badań naukowych i prac rozwojowych w innowacje technologiczne. Tworzy się także korzystne warunki prowadzenia działalności gospodarczej przez korzystanie z nieruchomości i infrastruktury technicznej na zasadach umownych.

Inkubator technologiczny to wyodrębniona organizacyjnie, budżetowo i lokalowo jednostka, która początkującym przedsiębiorcom z sektora małych i średnich przedsiębiorstw zapewnia pomoc w uruchomieniu i prowadzeniu firmy oferującej produkt lub usługe powstałą w wyniku wdrożenia nowej technologii.

Mimo wielu podobieństw (misja, cele, formy działania), parki bardzo się między sobą różnią. Praktycznie każdy z nich ma swoją specyfikę, wynikającą z lokalnych uwarunkowań, typu gospodarki i tradycji przemysłowych oraz potencjału środowiska naukowego.

Bardzo ciekawa inicjatywa powstała pod koniec 2003 r. w Płocku. Restrukturyzujący się Polski Koncern Naftowy ORLEN S.A., największe polskie przedsiębiorstwo rafineryjno-petrochemiczne (firma notowana na giełdach w Warszawie i Londynie), oraz przedstawiciele miasta Płock, na którego terenie mieści się siedziba koncernu, podpisali wzajemne zobowiązania i ustalili zasady współpracy w związku z przygotowaniem i wdrożeniem projektu Płockiego Parku Przemysłowo-Technologicznego. Usytuowany w centrum Polski, w północnej części Płocka, w sąsiedztwie Zakładu Produkcyjnego PKN ORLEN S.A., dobrze skomunikowany z siecią drogową i kolejową (potencjalnie także z rzeczną i powietrzna), Płocki Park Przemysłowo-Technologiczny miałby:

- zapewniać rozwój gospodarczy i społeczny miasta i regionu w dłuższym okresie przez zwiększenie udziału inwestorów zewnętrznych oraz tworzenie nowych, trwałych miejsc pracy, co wpłynęłoby na podniesienie poziomu życia mieszkańców;

- podnieść konkurencyjność PKN ORLEN S.A. i przedsiębiorstw regionu w skali europejskiej, dzięki lepszemu wykorzystaniu potencjału ludzkiego i materialnego; uczynić konkurencyjnymi przedsiębiorstwa działające w Parku;

- umożliwić współdziałanie w procesie restrukturyzacji Koncernu - tworzenie miejsc pracy, redukcję kosztów oraz rozwój spółek z grupy kapitałowej PKN ORLEN S.A. 
W celu realizacji tego wspólnego przedsięwzięcia, 14.07.2004 r. ustanowiono podmiot zarządzający pod nazwą Płocki Park Przemysłowo-Technologiczny SA (z kapitałem założycielskim w wysokości 1000000 zł), w którym po połowie objęły udziały: Miasto Płock i PKN ORLEN S.A. Wymagany wkład własny oraz pozostałe koszty inwestycji (koszty niekwalifikowane) miały stanowić grunty i środki pieniężne, wniesione wspólnie przez Miasto Płock i PKN ORLEN S.A. do podmiotu zarządzającego Parkiem. Zgodnie z przyjętymi założeniami, zasadniczym źródłem finansowania pierwszego etapu powstawania Parku miały być środki z funduszy strukturalnych UE, które mogły stanowić do 75\% kosztów kwalifikowanych inwestycji. Założenia finansowe powstania Parku w partnerstwie publiczno-prywatnym pozwoliły na ubieganie się o środki na sfinansowanie projektu pod nazwą „Pierwszy etap budowy infrastruktury technicznej, materialnej Parku Przemysłowego w Płocku" w ramach Europejskiego Funduszu Rozwoju Regionalnego w wyniku działania 1.3 Sektorowego Programu Operacyjnego - Wzrost Konkurencyjności Przedsiębiorstw, lata 2004-2006. Starania uwieńczone zostały pełnym sukcesem; w wyniku konkursu prowadzonego za pośrednictwem Agencji Rozwoju Przemysłu S.A. Płocki Park Przemysłowo-Technologiczny S.A. uzyskał dofinansowanie projektu w wysokości 39375000 zł (ze środków Europejskiego Funduszu Rozwoju Regionalnego oraz budżetu państwa). Łącznie z wkładem jednostki samorządu terytorialnego Miasto Płock budżet przedsięwzięcia wyniósł $45000000 \mathrm{zł}$. Pierwszymi inwestycjami w ramach realizacji projektu były: wybudowanie systemów sieci wodociagowej, kanalizacyjnej, centralnego ogrzewania oraz infrastruktury telekomunikacyjnej (przy użyciu światłowodu) na potrzeby Płockiego Parku Przemysłowo-Technologicznego, a także systemu dróg wewnętrznych Parku Przemysłowego. Zrewitalizowane obiekty byłego Zespołu Szkół Ochrony Środowiska w Płocku przy ul. Zglenickiego 42 przekształcono w Centrum Administracyjne Płockiego Parku Przemysłowo-Technologicznego. W Centrum Administracyjnym Parku zlokalizowano instytucje administrujące projektem, udostępniono odpowiednie powierzchnie biurowe dla firm - lokatorów Parku i zapewniono wspólne powierzchnie użytkowe dla funkcji wystawienniczych, reprezentacyjnych i szkoleniowych.

Obecnie w Centrum Administracyjnym składającym się z 4 budynków o powierzchni około $5000 \mathrm{~m}^{2}$ zgrupowane są głównie firmy logistyczne, informatyczne, administracyjne i prawne: Orlen Projekt S.A., Orlen Administracja Sp. z o.o., Orlen Księgowość Sp. z o.o., Orlen Biuro Podatków, Elektrobudowa S.A. (Oddział Płock), Lumena Park Sp. z o.o., Henczke Budownictwo Sp. z o.o., INES S.A., Automatic System Engineering Sp. z o.o., Centrum Komercjalizacji Technologii Sp. z o.o., Bertschi Poland Sp. z o.o., Stangpol Sp. z o.o., Eco-Invest S.A., Orlen Biuro Informatyki, PCC Rokita S.A., BW. GASTRO. Część zlokalizowanych w Parku przedsiębiorstw to firmy należące do liczącej 76 spółek i osiągającej najwyższe dochody w kraju Grupy Kapitałowej PKN ORLEN S.A. lub z nią współpracujące.

Płocki Park Przemysłowo-Technologiczny oferuje ulgi i zachęty dla przyszłych lokatorów - przedsiębiorców:

- zwolnienia z podatku od nieruchomości na okres od 1 roku do 5 lat w zależności od liczby nowo utworzonych miejsc pracy;

- dostępność funduszy UE - możliwość uzyskania dodatkowych punktów w trakcie procesu aplikacyjnego przez przedsiębiorcę - lokatora prowadzącego swoją działalność w Parku;

- specjalistyczne szkolenia i kursy prowadzone przez powołaną do tego instytucję Centrum Edukacji Sp. z o.o., stale współpracującą z Parkiem.

Projekt zakłada funkcjonowanie Parku jako zespołu trzech ściśle powiązanych ze sobą i współpracujących konglomeratów: parku przemysłowego, parku technologicznego i parku naukowo- 
-badawczego. Określenie ,park przemysłowo-technologiczny” oznacza, że na terenie Parku z jednej strony priorytetem jest restrukturyzacja obszaru przemysłowego, a z drugiej - rozwój nowoczesnych technologii z próbami kształtowania elementów innowacyjnych, co ewoluuje w kierunku parku technologicznego. Park w obecnej postaci jest parkiem przemysłowym, a naturalny jego profil został zdefiniowany przez podstawową działalność PKN ORLEN S.A.

Obszar Płockiego Parku Przemysłowo-Technologicznego wykorzystuje tereny strefy ochronnej Zakładu Produkcyjnego PKN ORLEN S.A. i obejmuje powierzchnię 200,4 ha .To największa powierzchnia spośród parków tego typu w Polsce. Park dysponuje najwyższym wśród parków istniejących w Polsce kapitałem zakładowym (od 31.08.2006 r. - 50460860 zł, z udziałem po 50\% akcjonariuszy założycieli - miasta Płock i PKN ORLEN S.A.). Baza surowców i produktów, jaką oferują PKN ORLEN S.A. i firmy należące do Grupy Kapitałowej, pozwala na prowadzenie działalności w bardzo różnych branżach przemysłu. Stwarza to możliwość lokalizacji w Parku firm produkujących komponenty, produkty i półprodukty m.in. w branżach: chemicznej, farmaceutycznej, papierniczej, gumowej, farb i lakierów, włókienniczej, tworzyw sztucznych i samochodowej.

Szczególną rolę odgrywa Basell Orlen Polyolefins Sp. z o.o., będąca spółką joint venture. Utworzona w 2003 r. przez PKN ORLEN S.A. i Basell Europe Holdings B.V. spółka (udział po 50\%) jest jedynym polskim producentem poliolefin, dysponującym zakładami o światowej skali, produkującymi polipropylen i polietylen na bazie unikatowych technologii należących wyłącznie do firmy Basell. Przekazując licencje na najnowocześniejsze na świecie technologie i prawa do korzystania ze swych znaków firmowych, Basell stworzył ogromne możliwości rozwoju tej gałęzi przemysłu w Polsce. Zapewniając surowce do produkcji, urządzenia i usługi na swym terenie, PKN ORLEN S.A. zyskał najwyższej jakości produkty.

Poważnym inwestorem, jakiego pozyskał Płocki Park Przemysłowo-Technologiczny, jest firma PCC Rokita S.A. z siedzibą w Brzegu Dolnym, będąca jedną z większych firm chemicznych w Polsce, zaopatrująca w produkty przemysł tworzyw sztucznych, kosmetyczny i chemii gospodarczej. Jej strategicznym akcjonariuszem (90\% akcji) jest niemiecka firma PCC AG z siedzibą w Duisburgu.

30.01.2006 r. zawarto porozumienie, dzięki któremu powstanie nowa inwestycja przemysłowa o wartości nie niższej niż 40000000 zł i zostaną stworzone co najmniej 32 stałe miejsca pracy. PCC Rokita uruchomi jedną ze swych wytwórni w bezpośrednim sąsiedztwie Zakładu Produkcyjnego PKN ORLEN S.A., który zobowiązał się do wybudowania i uruchomienia rurociągu. Będzie nim dostarczał surowce na potrzeby wytwórni. Wartość tej umowy szacowana jest na 350000000 zł. Inwestycja została zlokalizowana w jednej z ośmiu stref, na które dzieli się powierzchnia Parku, z przeznaczeniem wyłącznie pod inwestycje i działalność spółki PCC Rokita .

Zgodnie z miejscowym planem zagospodarowania przestrzennego (Uchwała nr 299/XVI/03 Rady Miasta Płock z 28.10.2003 r.), teren Parku został podzielony na strefy funkcjonalne. Strefy I i II zostały przeznaczone do prowadzenia działalności produkcyjnej, strefy III i VII - do działalności usługowo-produkcyjnej i usługowo-biurowej, a strefy IV, V i VI - do działalności usługowo-produkcyjnej.

W 2006 r. zostały oddane do użytku strefy uzbrojone w ramach projektu „Pierwszy etap budowy infrastruktury technicznej, materialnej Parku Przemysłowego w Płocku”. W miarę realizacji inwestycji sukcesywnie refundowane są koszty ponoszone przez wykonawców. Rozległa gama surowców i produktów wytwarzanych przez PKN ORLEN S.A. i współpracujące z nim firmy stwarza ogromne możliwości dynamicznego rozwoju tej części Parku - Parku Przemysłowego. Pierwszy etap tworzenia Parku Przemysłowego ma się zakończyć w 2008 r. 
Park Technologiczny, którego powstanie jest przewidziane do 2019 r. w ramach II etapu rozwoju, ma realizować zadania z zakresu transferu nowoczesnych technologii oraz inkubacji przedsiębiorstw innowacyjnych, podobnie jak Ośrodek Badawczo-Rozwojowy Przemysłu Rafineryjnego w Płocku oraz Centrum Komercjalizacji Technologii znajdujące się na terenie Parku.

W tym przypadku bardzo pomocne wydają się być doświadczenia Basell Orlen Polyolefins Sp. z o.o., a zwłaszcza najnowocześniejsze technologie oferowane przez tę firmę oraz jej bardzo pozytywny stosunek do idei powstania projektu Parku (firma określa siebie jako partnera w jego tworzeniu, a działania traktuje jako pewnego rodzaju misję).

Etap trzeci rozwoju Płockiego Parku Przemysłowo-Technologicznego, czyli tworzenie Parku Naukowo-Badawczego, jest przewidziany głównie na lata 2019-2028. Park Naukowo-Badawczy ma w przyszłości wykorzystywać potencjał płockich wyższych uczelni. Kształcą one aktualnie około 10 tys. studentów, m.in. w Szkole Nauk Technicznych i Społecznych (filia Politechniki Warszawskiej), Szkole Wyższej im. Pawła Włodkowica i Państwowej Wyższej Szkole Zawodowej, na kierunkach: inżynieria środowiska, informatyka, technologia chemiczna, zarządzanie i marketing, finanse i rachunkowość przedsiębiorstw, studia językowe i ekonomia.

W 2004 r. prezydent Płocka, prezes PKN ORLEN S.A. oraz rektor Politechniki Warszawskiej zawarli trójstronne porozumienie o współpracy w zakresie działalności naukowo-badawczej w ramach projektu tworzenia Płockiego Parku Przemysłowo-Technologicznego. W 2006 r. zostało ono przedłużone na kolejne 3 lata. Porozumienie uwzględnia profil Parku i podmiotów go tworzących w programach kształcenia uczelni i zapewnia możliwość wykonywania prac naukowo-badawczych oraz ekspertyz dzięki modernizacji bazy naukowej. Jednym z przykładów tej współpracy jest realizacja projektu Centrum Doskonałości CERED - Redukcja Wpływu Przemysłu Przetwórczego na Środowisko Naturalne, przez filię Politechniki Warszawskiej.

Projekt Parku Przemysłowo-Technologicznego umocnił współdziałanie PKN ORLEN i miasta Płock na rzecz rozwoju regionu, pobudzając lokalny potencjał naukowo-badawczy związany z chemią i takimi dziedzinami, jak ochrona środowiska, gospodarka odpadami i recykling, logistyka, usługi finansowe i naukowe, informatyka i telekomunikacja. Tworzenie Parku zmobilizowało do działania nie tylko głównych udziałowców projektu. Aby promować lokalnych przedsiębiorców i pozyskiwać inwestorów, Płocki Park Przemysłowo-Technologiczny prezentowany był przez Polską Agencję Informacji i Inwestycji Zagranicznych m.in. przedstawicielom misji dyplomatycznych w Polsce oraz uczestnikom polsko-chińskiego forum biznesu.

W celu zwiększenia atrakcyjności inwestycyjnej, miasto Płock rozpoczęło modernizację dróg i zleciło zbudowanie bezprzewodowej sieci informatycznej wykorzystującej szerokopasmowy system radiowy WiMax oraz miejskiej sieci teleinformatycznej pozwalającej na wymianę informacji i elektroniczny obieg dokumentów pomiędzy jednostkami administracji miejskiej. Będą one dostępne także na terenie Parku.

Tworząc Płocki Park Przemysłowo-Technologiczny, kierowano się filozofią działania, która koncentruje środki finansowe na najbardziej efektywnych projektach i przedsięwzięciach w sektorze przedsiębiorstw, instytucji naukowo-badawczych oraz otoczenia biznesu i przyczynia się do pobudzenia lokalnej przedsiębiorczości. Praktyka potwierdza te możliwości.

Płocki Park Przemysłowo-Technologiczny w partnerstwie publiczno-prywatnym dobrze promuje idee przedsiębiorczości; może być przykładem dla tego typu inicjatyw.

Poszczególne inicjatywy tworzenia parków technologicznych czy przemysłowo-technologicznych odzwierciedlają specyfikę lokalnego środowiska naukowego i biznesu, typ gospodarki i tradycje przemysłowe oraz kulturowe uwarunkowania przedsiębiorczości. Nie ma jednego uniwersalnego modelu rozwoju gwarantującego sukces takiego przedsięwzięcia. 
Według autora opracowania powodzenie takiej inicjatywy zależy od wielu czynników, z których najważniejsze to:

1. odpowiedni poziom finansowania - znaczny kapitał założycielski pozwala na wstępne działania związane z powstawaniem i rozwojem parku, w tym rozwój infrastruktury i stworzenie przyszłym lokatorom dogodnych warunków prowadzenia działalności;

2. partnerstwo publiczno-prywatne (optymalny wydaje się równy udział w finansowaniu przedsięwzięcia przez obu partnerów) pozwalające na wsparcie finansowe do 75\% kosztów kwalifikowanych inwestycji Parku ze środków funduszy strukturalnych Unii Europejskiej;

3. jasna strategia rozwoju, oparta na działaniach promujących wzrost konkurencyjności oraz budowę marki zarówno przedsiębiorstw, jak i regionu. W tych działaniach wiodącą rolę powinien odgrywać partner prywatny;

4. oparte na zasadach synergii porozumienie o współpracy w zakresie działalności naukowo-badawczej i wdrożeniowej z lokalnymi uczelniami i ośrodkami badawczymi;

5. zaufanie i bezpośrednie zaangażowanie partnerów zwiększające skuteczność działań oraz kompetencja w działaniu, zwłaszcza podczas udziału w konkursach o przyznanie wsparcia publicznego dla organizowanego przedsięwzięcia.

Stworzenie ośrodka, w którym innowacyjne projekty naukowo-badawcze będą wspierały przedsiębiorczość i procesy gospodarcze oparte na nowoczesnych technologiach, to cel długofalowy. Powinno się również tworzyć priorytety na okresy krótko- i średnioterminowe, oparte na wiodących w parkach branżach, co pozwoli na efektywne wykorzystywanie zaangażowanych środków finansowych.

Największym zagrożeniem realizacji takich inicjatyw mogą być zmiany władz, zarówno przedsiębiorstw, jak i władz publicznych, co nie sprzyja ciągłości działań.

Wydaje się jednak, że stworzone przez Unię Europejską możliwości finansowego wspierania ze środków funduszy strukturalnych pozwolą tego typu ośrodkom promującym przedsiębiorczość i innowacyjność w Polsce rozwijać się bez przeszkód.

\section{Literatura}

1. Benko G., 1993, Geografia technopolii, PWN, Warszawa

2. Dzierżanowski M., Szultka S., Tamowicz P., Wojnicka E., 2005, Analiza stanu i kierunków rozwoju parków naukowo-technologicznych, inkubatorów technologicznych i centrów transferu technologii $w$ Polsce, PARP, Warszawa

3. Innowacyjność 2006. Stan innowacyjności, metody wspierania, problemy badawcze, 2006, A. Żołnierski (red.), PARP, Warszawa

4. Matusiak K.B., 1998, Ośrodki innowacji i przedsiębiorczości [w:] K.B. Matusiak, E. Stawasz (red.), Przedsiębiorczość i transfer technologii. Polska perspektywa, Łódź/Żyrardów

5. Matusiak K.B., Matusiak M., 2005, Potencjat i zasoby parków technologicznych [w:] K.B. Matusiak (red.) Ośrodki innowacji w Polsce, PARP, SOOIPP, Poznań/Warszawa

6. Matusiak K.B. (red.), 2005, Innowacje i transfer technologii. Stownik pojęć, PARP, Warszawa

7. Ocena możliwości rozwojowych polskich Parków Przemysłowych. Raport dla ARP, 2006, IPI - The Institute for Industrial Promotion, Warszawa

8. Parki naukowe i technologiczne. Polska perspektywa, 1999, B.M. Marciniec, J. Guliński (red.), Wydawnictwo Poznańskie, Poznań 


\section{Adresy internetowe}

1. www.arp.pl

2. www.parp.gov.pl

3. www.paiz.gov.pl

4. www.pppt.pl

5. www.orlen.pl

6. www.ump.pl

7. www.pi.gov.pl

8. www.sooiip.org.pl

9. www.stim.org.pl

\section{The Płock Industrial and Technological Park - Program for Nascent Local Entrepreneurship}

A measure "Establishing Environment Conducive to Enterprises Development" was one of strategic goals of the Sectoral Operational Program "Improvement of competitiveness of the economy, 2004-2006". This measure will be compatible with a development of the enterprises and entrepreneurship in technology and industrial parks.

Despite industrial and technology parks have similar goals, these facilities are different. Each park has its own unique nature because of its regional, cultural and economic conditions as well as available growth potential.

The initial profile of The Płock Industrial and Technological Park - created in July 2004/ /shareholders: PKN ORLEN /50\%/ and City of Płock /50\%/ - was defined by the basic operation of PKN ORLEN and will benefit from financial and technological potential of this company.

This program will activate the local $R \& B$ potential connected with the chemical industry and related fields, such as: environmental protection, waste treatment and recycling, logistics as well as financial and banking services, IT, and telecommunications. 


\section{Beata Namyślak}

Uniwersytet Wrocławski

\section{Przestrzenne aspekty funkcjonowania zagranicznych podmiotów przemysłowych we Wroclawiu i w okolicach}

Na początku lat 90. XX w. Polska stała się atrakcyjnym miejscem lokat kapitału zagranicznego. Niedługie uczestnictwo Polski w międzynarodowym przepływie dóbr i usług wystarczyło jednak, aby obcy kapitał obecny na polskim rynku przeszedł swoistą ewolucję, kreując nowy obraz gospodarki i dostosowując ją do trendów światowych. Inwestycje zagraniczne na polskim rynku pobudzają modernizację struktury gospodarczej, przyspieszają procesy prywatyzacyjne, przyczyniają się do tworzenia nowych miejsc pracy oraz nowoczesnego zarządzania i organizacji produkcji. Obecność kapitału zagranicznego w gospodarce to również zapowiedź wzbogacania asortymentu towarów i usług na rynku krajowym, wdrażania nowych technologii oraz intensyfikacji wymiany handlowej z zagranicą.

Napływ kapitału zagranicznego stał się w ostatnich latach jednym z tematów badawczych w geografii ekonomicznej. Geografowie opisują przede wszystkim zmiany funkcjonalno-przestrzenne pod wpływem napływu inwestycji z zagranicy. Analizowane są przepływy większej, średniej i małej skali. Jednostkami odniesienia w tych badaniach są najczęściej województwa, rzadziej miasta, gminy czy powiaty.

Artykuł powstał na podstawie badania ankietowego, którego celem było ukazanie przestrzennych aspektów funkcjonowania podmiotów zagranicznych reprezentujących przetwórstwo przemysłowe, zarejestrowanych we Wrocławiu oraz w sąsiadujących z gminą Wrocław powiatach: wrocławskim, oleśnickim, oławskim, średzkim, trzebnickim i wołowskim. Celem badania było uzyskanie odpowiedzi na następujące pytania:

1. Czy w miejscu siedziby firmy prowadzona jest również działalność produkcyjna?

2. Jakie motywy zadecydowały o lokalizacji podmiotu i jakie bariery najbardziej utrudniają prowadzenie działalności?

3. Jak dużą część produkcji firma przeznacza na eksport? Jakie są kierunki eksportu i importu? Gdzie zlokalizowani sąjej odbiorcy i dostawcy na obszarze kraju?

4. Jak kształtuje się układ powiązań pomiędzy ankietowanymi firmami a ich kooperantami?

Jako przedmiot badań wzkazano podmioty reprezentujące górnictwo i kopalnictwo (sekcja C) oraz działalność produkcyjną (sekcja D). Ankietowane podmioty wybrano z krajowego rejestru podmiotów gospodarczych REGON zgodnie ze stanem z 20.10.2004 r. Wzięto pod uwage podmioty będące $\mathrm{w}$ całości własnością zagraniczną oraz podmioty z przewagą własności zagranicznej. Ze zbioru odrzucono firmy w stanie likwidacji i w stanie upadłości. Następnym kryterium była wielkość podmiotów mierzona liczbą pracujących. Ze względu na zamiar zbadania jedynie istotnych podmiotów oraz krótką żywotność spółek najmniejszych, odrzucono podmioty zatrudniające do 9 osób. W ten sposób do analizy zakwalifikowano 131 podmiotów. Na obszarze Wrocławia 
ankietę przeprowadzono w formie wywiadu w okresie od grudnia 2004 r. do stycznia 2005 r $^{1}$, a podmioty zlokalizowane poza granicami miasta ankietowano listownie od października do grudnia 2005 r. Łącznie zebrano 40 odpowiedzi, stopa zwrotu osiagnęła zatem 30,53\%.

\section{Charakterystyka ankietowanych podmiotów}

Analizowane podmioty zostały założone (w przypadku greenfield investments) lub stały się własnością kapitału zagranicznego w latach 1990-2004. Nie zaobserwowano dominacji roku czy okresu kilku następujących po sobie lat, w których liczba zarejestrowanych podmiotów byłaby zdecydowanie większa. Nieznacznie przeważa liczba spółek, które powstały w latach 1996, 1998, 2000 i 2003 (po 3-4 podmioty w każdym roku).

Uwzględniając liczbę pracujących, ankietowane podmioty można podzielić na dwie grupy: podmioty małe, zatrudniające do 99 osób - 15 spółek oraz podmioty duże, liczące 250-499 pracujących - 15 firm. Sześć jednostek reprezentuje klasę podmiotów średniej wielkości, czyli zatrudniających 100-249 osób. Jedynie cztery podmioty zatrudniają więcej niż 500 osób. Największy zakład zatrudnia 1500 osób. Warto dodać, że w granicach Wrocławia odpowiedzi udzielały głównie małe i średnie przedsiębiorstwa, a na obszarze sąsiednich powiatów - przede wszystkim duże podmioty. Spośród 40 firm 26 to inwestycje nowe (greenfield), pozostałe to dawne krajowe przedsiębiorstwa, które po prywatyzacji stały się całkowicie lub w większości własnością zagraniczna. Prawie wszystkie podmioty zlokalizowane poza Wrocławiem to nowe inwestycje.

Pod względem rodzaju działalności nie stwierdzono dominacji konkretnych rodzajów działalności produkcyjnej. Właściwie prawie każda z firm reprezentuje inną gałąź przemysłu, m.in. produkcję odzieży, urządzeń telekomunikacyjnych, elektrycznych, materiałów budowlanych, tworzyw sztucznych, akcesoriów samochodowych, sprzętu AGD, maszyn wykorzystywanych w rolnictwie, a także wydobycie i przetwórstwo surowców kopalnych. Rozproszenie widoczne jest również w charakterystyce podmiotów według kraju pochodzenia kapitału, kapitał pochodzi bowiem z 11 krajów (10 krajów europejskich i Stanów Zjednoczonych). Zauważalna jest przewaga liczebna podmiotów niemieckich (9), brytyjskich (6), a także francuskich, włoskich i amerykańskich (po 4).

Starano się ustalić, czy w miejscu, w którym zlokalizowana jest siedziba spółki, prowadzona jest także działalność produkcyjna. Dość powszechnie uważa się, że miejsce lokalizacji spółek polskich i zagranicznych nie pokrywa się z miejscem faktycznego prowadzenia działalności. Zakłada się bowiem, że firmy lokalizują swoje siedziby w jednej z metropolii, a działalność prowadzą poza granicą miasta, gdzie koszty produkcji są mniejsze. Uzyskane dane nie potwierdzają jednak tej prawidłowości. Na 29 ankietowanych podmiotów we Wrocławiu - aż w 24 przypadkach działalność prowadzona jest również we Wrocławiu. W pięciu przypadkach działalność prowadzona jest w innej miejscowości. Trzy zakłady przemysłowe wskazały miejscowości położone w odległości do 30 km od Wrocławia, w gminie Twardogóra, w Środzie Śląskiej i w okolicach Świętej Katarzyny. Dwie spółki trudniące się wydobyciem surowców skalnych mają zakłady w województwach: dolnośląskim (Mietków, Strzegom, Pilce, Bolęcin), opolskim (Paczków) i łódzkim (Bełchatów, Łowicz, Łódź i Radomsko). W wypadku 11 firm zlokalizowanych poza granicami Wrocławia lokalizacja siedziby i miejsce produkcji pokrywały się.

\footnotetext{
${ }^{1}$ Ankietę we Wrocławiu przeprowadzili studenci - członkowie Koła Naukowego Studentów Geografii Uniwersytetu Wrocławskiego.
} 


\section{Czynniki decydujące o lokalizacji inwestycji oraz czynniki stanowiące barierę dla inwestorów}

Jednym z badanych zagadnień była hierarchia czynników zachęcających do inwestowania na badanym obszarze. Pytanie miało charakter otwarty; respondent mógł podać dowolną odpowiedź. Nie limitowano również liczby odpowiedzi. Uzyskane odpowiedzi podzielono na trzy klasy według częstości występowania (tab. 1). Pierwszą klasę (A) stanowią czynniki wymienione przynajmniej 7 razy, drugą (B) - cechy, które wymieniono 5 lub 6 razy, trzecią $(\mathrm{C})$ - cechy, które wskazano 3 lub 4 razy, czwartą zaś (D) - cechy, które wskazał 1 respondent lub dwu.

Tab. 1. Czynniki, które zadecydowały o lokalizacji inwestycji we Wrocławiu lub w jego okolicach

\begin{tabular}{|c|c|}
\hline Klasa & Czynnik \\
\hline A & $\begin{array}{l}\text { - bliskość ważnych dróg krajowych i międzynarodowych } \\
\text { - bliskość granicy zachodniej }\end{array}$ \\
\hline B & $\begin{array}{l}\text { - lokalizacja przedsiębiorstwa prywatyzowanego } \\
\text { - bliskość rynków zbytu } \\
\text { - bliskość kraju pochodzenia inwestora } \\
\text { - podaż taniej siły roboczej }\end{array}$ \\
\hline $\mathrm{C}$ & $\begin{array}{l}\text { - bliskość kooperanta/dostawcy } \\
\text { - niskie koszty produkcji } \\
\text { - brak konkurencji } \\
\text { - bliskość granicy południowej } \\
\text { - wykwalifikowana kadra } \\
\text { - lotnisko } \\
\text { - podaż obiektów gospodarczych (hale, magazyny) oraz podaż terenów } \\
\text { przeznaczonych na działalność gospodarczą }\end{array}$ \\
\hline $\mathrm{D}$ & $\begin{array}{l}\text { - złoża surowca } \\
\text { - wcześniejsze kontakty z przedsiębiorcami we Wrocławiu } \\
\text { - wzrost konkurencyjności regionu } \\
\text { - wyższe uczelnie } \\
\text { - otwartość władz miasta } \\
\text { - reorganizacja przedsiębiorstwa, utworzenie nowej jednostki we Wrocławiu } \\
\text { - możliwość zatrudnienia kobiet } \\
\text { - przypadek }\end{array}$ \\
\hline
\end{tabular}

Źródło: opracowanie autorki

Badania wyraźnie ukazały znaczenie uwarunkowań przestrzennych jako podstawowych determinant atrakcyjności inwestycyjnej miasta. Bliskość granicy zachodniej oraz infrastruktura transportowa okazały się czynnikami wymienianymi najczęściej. Dużą liczbę wskazań uzyskały także inne odpowiedzi nawiązujące do położenia geograficznego, jak bliskość rynków zbytu i bliskość kraju pochodzenia inwestora. Przynajmniej pięć razy wymieniono lokalizację atrakcyjnego zakładu, który stał się z czasem własnością kapitału zagranicznego, oraz podaż taniej siły roboczej w regionie dolnośląskim. Wszystkie te odpowiedzi odnoszą się tylko do uwarunkowań egzogenicznych i nie nawiązują do nowych koncepcji lokalizacji przemysłu, opierających się na tzw. czynnikach nienamacalnych (m.in. Martin 2003, Huggins 1997, Klasik 2002). Wniosek ten jest dość niepokojący. Takie cechy, jak wykształcona kadra czy obecność uczelni wyższych giną wśród rzeszy tradycyjnych czynników lokalizacji przemysłu, jak bliskość surowców, kooperanta, granic. O zaawansowanych technologiach nie wspomniano w żadnej z firm.

Spółki, które stały się własnością kapitału zagranicznego, wymieniały lokalizację atrakcyjnych zakładów jako ważny czynnik świadczący o potencjale gospodarczym miasta. Można 
jednak założyć, że ranga tego czynnika dla ogółu inwestorów z czasem maleje, ze względu na coraz krótszą listę zakładów przemysłowych atrakcyjnych dla inwestorów. Ważne jest również to, że miasto o znacznym potencjale gospodarczym umożliwia podmiotom działającym na jego terenie tworzenie sieci powiązań gospodarczych (dostawa materiałów, usługi spedycyjne, logistyczne).

Odpowiedzi odwołujące się do czynników społecznych jako determinant atrakcyjności inwestycyjnej zebrały mniejszą liczbę wskazań niż czynniki przestrzenne i gospodarcze. Rynek pracy we Wrocławiu otrzymał różne opinie, szczególnie w kwestii kwalifikacji siły roboczej. Z ankiety wynika również, że w dalszym ciągu koszty pracy w Polsce uznawane są za niskie, czyli za korzystne z punktu widzenia inwestora. Interesujące jest, że (aż) trzy firmy z różnych branż skarżą się na brak chęci do pracy i związane z tym kłopoty z pozyskaniem nowych pracowników.

Dostrzeżono również podaż wolnych terenów i obiektów. Cecha ta staje się powoli atutem Wrocławia na tle pozostałych metropolii Polski. Wrocław posiada bowiem relatywnie dużo terenów niezagospodarowanych lub zagospodarowanych częściowo. Luki w zabudowie miasta są przeważnie pozostałością po zniszczeniach wojennych. Tereny te doskonale nadają się pod obiekty usługowe lub produkcyjne. Podaż wolnych obiektów to częściowo wynik słabej kondycji dawnych dużych fabryk, które obecnie próbują się ratować, wynajmując lub sprzedając budynki.

Czterech respondentów podkreśliło znaczenie braku konkurencji na rynku. Ta cecha okazała się ważna dla inwestorów wytwarzających materiały budowlane i części do produkcji samochodów. Zwrócono również uwagę na lokalizację lotniska jako elementu świadczącego o atrakcyjności inwestycyjnej miasta.

Pojedyncze wskazania dotyczyły m.in. znaczenia wcześniejszych kontaktów z przedsiębiorcami działającymi we Wrocławiu. Jedna firma z branży elektrycznej uznała za ważną możliwość zatrudnienia kobiet. Niestety, nie rozszerzono tej wypowiedzi. W dwóch przypadkach uznano, że o lokalizacji zakładu we Wrocławiu zadecydowała reorganizacja strukturalna firmy, a nawet przypadek.

Oprócz motywów sprzyjających lokalizacji inwestycji zagranicznych w mieście, badano również bariery (tab. 2). Nie sugerowano odpowiedzi, nie limitowano ich liczby. Uzyskane odpowiedzi podzielono na cztery klasy według częstości występowania. Podziału na klasy dokonano w taki sam sposób, jak w przypadku czynników zachęcających do lokalizacji.

Tab. 2. Czynniki stanowiące barierę dla inwestorów działających we Wrocławiu i okolicach

\begin{tabular}{|c|c|}
\hline Klasa & Czynnik \\
\hline A & - słabo rozwinięta infrastruktura drogowa, brak autostrad \\
\hline B & $\begin{array}{l}\text { - mała ilość połączeń lotniczych } \\
\text { - zmienność przepisów } \\
\text { - brak wykwalifikowanej kadry (zarówno pracowników umysłowych, } \\
\text { jak i fizycznych) } \\
\text { - biurokracja, opieszałość urzędów } \\
\text { - zbyt wysokie koszty pracy }\end{array}$ \\
\hline $\mathrm{C}$ & $\begin{array}{l}\text { - brak kadry chętnej do pracy } \\
\text { - zbyt częste kontrole Państwowej Inspekcji Sanitarnej, Urzędu Skarbowego } \\
\text { i innych urzędów } \\
\text { - zbyt wysoka cena lokali w centrum miasta }\end{array}$ \\
\hline $\mathrm{D}$ & $\begin{array}{l}\text { - brak informacji o innych podmiotach, co ogranicza możliwość podjęcia współpracy } \\
\text { - zbyt mała liczba hoteli } \\
\text { - niewydolny system towarowych przewozów kolejowych } \\
\text { - słaba sytuacja finansowa polskich przedsiębiorstw, uniemożliwiająca współpracę } \\
\text { i zmuszająca do poszukiwania zagranicznych partnerów }\end{array}$ \\
\hline
\end{tabular}


W tej kategorii pojawiło się mniej odpowiedzi niż w pytaniu poprzednim. Kilku respondentów (siedmiu z Wrocławia, po jednym z Brzegu Dolnego, Oławy i ze Środy Śląskiej) ominęło to pytanie, nie podając wyjaśnienia. Możliwe, że nie dostrzegli żadnych przeszkód w prowadzeniu działalności w rejonie Wrocławia, możliwe też, że w pośpiechu zaniechali odpowiedzi na to pytanie (przedostatnie $\mathrm{w}$ ankiecie).

Respondenci wskazywali na bariery o zasięgu lokalnym i krajowym. Najpoważniejszą barierą o charakterze lokalnym okazała się słabość infrastruktury transportowej. Z ankiety jednoznacznie wynika, że większość problemów jest pochodną niedoskonałości systemu transportowego. Pojawił się cały zestaw zażaleń odwołujących się głównie do niezadowalającej ilości i jakości dróg. Niektóre problemy charakteryzowano dość dokładnie, np.: zbyt wąska droga prowadząca do lotniska we Wrocławiu, brak dobrego dojazdu do autostrady A-4 (głos z Oleśnicy), uciążliwy przejazd przez centrum Wrocławia, paraliżujące ruch remonty ważnych dróg, np. ul. Henryka Sienkiewicza. Wspomniano także o zbyt małej liczbie połączeń lotniczych z dużymi miastami Polski i Europy oraz o złych rozwiązaniach w zakresie towarowych przewozów kolejowych.

Poza tym właściwie wymieniono tylko trzy cechy, które dotyczą miasta i okolic Wrocławia. Pierwszą są zbyt wysokie koszty wynajmu/kupna lokali w centrum Wrocławia, drugą - słaba infrastruktura hotelowa w rejonie Oleśnicy, a trzecią - brak wykwalifikowanej kadry pracowników umysłowych i fizycznych, chętnej do pracy.

Pozostałe cechy, jak twierdzili sami respondenci, dotyczą całego kraju. Znalazły się wśród nich opieszałość urzędników, biurokracja oraz zmienność przepisów. Pojawiły się również skargi na zbyt częste kontrole Państwowej Inspekcji Sanitarnej, Urzędu Skarbowego i innych urzędów oraz na brak informacji o innych podmiotach, co ogranicza możliwość współpracy. Zwrócono uwagę na słabą sytuację finansową polskich przedsiębiorstw, która uniemożliwia współpracę i zmusza do poszukiwania innych, na ogół zagranicznych partnerów.

Wreszcie kilka uwag ogólnych. Tylko raz wspomniano o działalności samorządów lokalnych, których pomoc - szczególnie na etapie rozpoczynania działalności, np. przy przygotowywaniu gruntów pod zabudowę - jest niezbędna. Nie bez znaczenia jest z pewnością fakt, że to największa z ankietowanych firm (około 1500 pracowników) podała ten motyw. Najwięksi inwestorzy są szczególnie ważni dla regionów i częściej mogą liczyć na przychylność władz. Zastanawia, czy działalność samorządów jest dobrze oceniana również przez mniejsze podmioty. Standard życia w mieście okazał się czynnikiem nieistotnym. Można zatem wnioskować, że mimo zmiennej koniunktury na rynku przetwórstwa przemysłowego inwestorzy nie obawiają się problemów ze zbytem towarów. Częściowo jest to efekt orientacji proeksportowej, którą reprezentuje znaczna część respondentów. Nie zwrócono również uwagi na poziom rozwoju instytucji zaliczanych do otoczenia „okołobiznesowego”, co może świadczyć o zadowalającym poziomie dostępności tych usług. Jeszcze kilka lat temu powszechnie narzekano na ich brak.

Wobec zachodzących przemian zastanawiająca jest rola odległości w przestrzeni wśród czynników decydujących o atrakcyjności inwestycyjnej miast. W literaturze przedmiotu zagadnienie to jest przedmiotem dyskusji. W obliczu postępującej globalizacji istotność tego czynnika jest podawana w wątpliwość, dostrzega się bowiem spadek znaczenia odległości fizycznej jako bariery oddziaływania w przestrzeni (m.in. Dziemianowicz 1997, Domański 2001). Na tym tle zwracają uwagę wnioski z badania ankietowego, z których wynika, że relacje odległościowe mają nadal silną pozycję. Zaprezentowany obraz uzmysławia, że do sukcesu Wrocławia i jego okolic w przyciągnięciu kapitału zagranicznego przyczyniły się głównie egzogeniczne czynniki rozwoju. 


\section{Rynki zbytu. Kierunki eksportu i importu}

Udział eksportu w działalności firm ukazuje tab. 3. Z danych wynika, że niektórzy z inwestorów zaopatrują tylko rynek wewnętrzny. Eksportu nie prowadzi 7 spółek. Jeśli podmioty decydują się na eksport, to zazwyczaj przewyższa on znacznie sprzedaż produktów na rynku krajowym. W 26 firmach eksport przekracza 50\%, w tym w 19 przekracza 75\% produkcji. Pięciu respondentów uznało, że produkuje tylko na potrzeby rynków zagranicznych. Grupa firm eksportujących powyżej 75\% produkcji jest bardzo różnorodna i składają się na nią producenci: wyrobów ze stali, z metalu, armatury sanitarnej, odzieży, części samochodowych, maszyn i urządzeń elektrycznych, opakowań oraz urządzeń rolniczych i telekomunikacyjnych.

Tab. 3. Udział eksportu w działalności firmy

\begin{tabular}{|c|c|}
\hline Udzial eksportu & Liczba podmiotów \\
\hline $75-100 \%$ & 19 \\
\hline $50-74 \%$ & 7 \\
\hline $26-49 \%$ & 2 \\
\hline $1-25 \%$ & 5 \\
\hline Brak eksportu & 7 \\
\hline
\end{tabular}

Źródło: opracowanie autorki

Kolejnym badanym zagadnieniem było określenie rynków zbytu analizowanych podmiotów oraz wskazanie lokalizacji dostawców surowców i półproduktów stosowanych w produkcji. Obydwa kierunki przepływu badano na płaszczyźnie krajowej i międzynarodowej. W przypadku wymiany handlowej w obrębie Polski respondenci wskazywali miasta, do których kierowane są produkty lub w których zlokalizowani są dostawcy. W przypadku wywozu towarów za granicę i przywozu towarów z zagranicy respondenci wymieniali nazwy krajów. Sześciu respondentów udzieliło zbyt ogólnej odpowiedzi, twierdząc, że rynkiem zbytu jest obszar całego kraju. Pozostali wymieniali miasta lub regiony. Miejsca zbytu towarów w Polsce zlokalizowane są we wszystkich 16 województwach. Duże znaczenie w tej kwestii odgrywa odległość, najwięcej wskazań dotyczyło bowiem woj. dolnośląskiego, w dalszej kolejności województw: śląskiego, wielkopolskiego i mazowieckiego (ryc. 1). Najrzadziej (1-2 razy) wskazywano województwa: pomorskie, zachodniopomorskie, podlaskie, warmińsko-mazurskie, małopolskie i lubuskie. Ogólnie można stwierdzić, że ankietowane spółki mają bardziej intensywne połączenia handlowe z podmiotami znajdującymi się w Polsce południowej niż w północnej. Jest to szczególnie widoczne na ryc. 2, przedstawiającej lokalizację dostawców. Wskazano tylko siedem regionów, a wśród nich ponownie najczęściej województwa dolnośląskie i śląskie a także woj. małopolskie. Dostawcy z woj. śląskiego to przeważnie producenci stali i komponentów wykorzystywanych do produkcji maszyn i urządzeń.

Najwięcej produktów kierowanych jest do Wrocławia, Warszawy i Poznania. Do podmiotów funkcjonujących we Wrocławiu wysyłane są m.in. części do automatów tokarskich, urządzenia dla przemysłu mleczarskiego, artykuły budowlane, części spawane do pojazdów, opakowania, odzież, surowce skalne. W kategorii „lokalizacja dostawców” wyraźnie dominuje Wrocław. Z kilkunastu pozostałych miast tylko Warszawę, Bydgoszcz i Katowice wskazano dwukrotnie.

W analizie zagranicznych rynków zbytu najbardziej zwraca uwagę nasilenie kontaktów z Niemcami (ryc. 3 i 4). Aż 27 respondentów spośród 33 eksportujących sprzedaje towary do Niemiec, a 19 firm spośród 26 importujących sprowadza towary z Niemiec. Oprócz tej jednej cechy wspólnej, obrazy uzyskane na rysunkach różnią się znacznie. W kategorii eksportu na kolejnych 
Ryc. 1. Rynki zbytu w Polsce

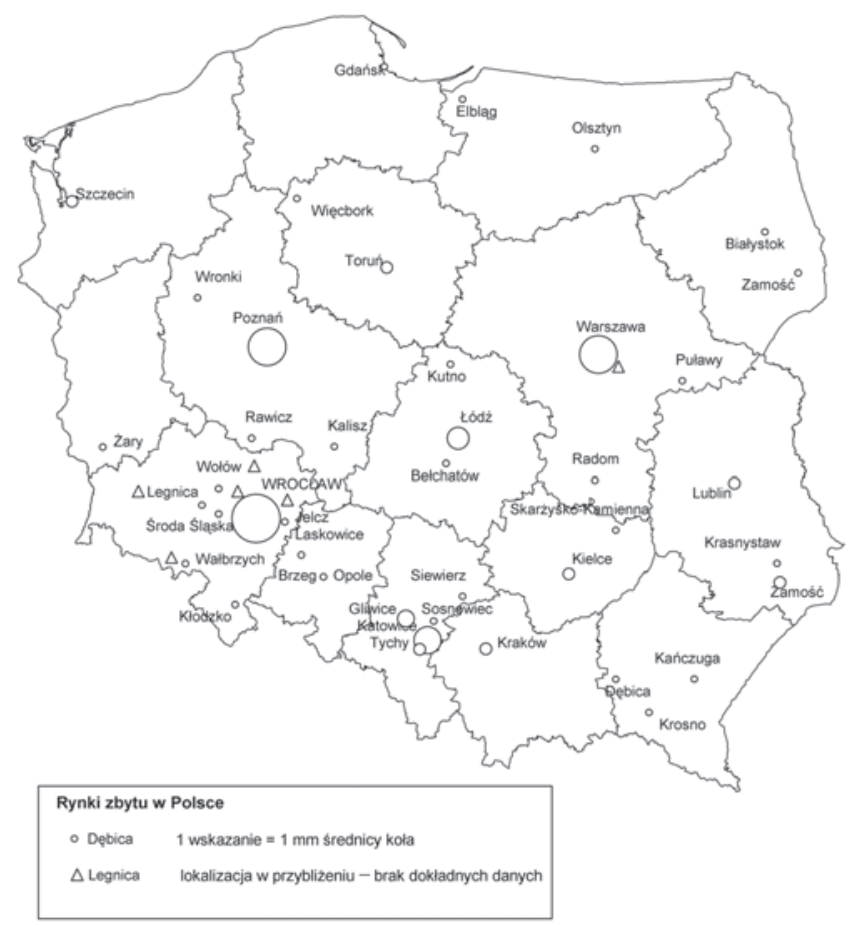

Źródło: opracowanie autorki

Ryc. 2. Lokalizacja dostawców surowców/półproduktów

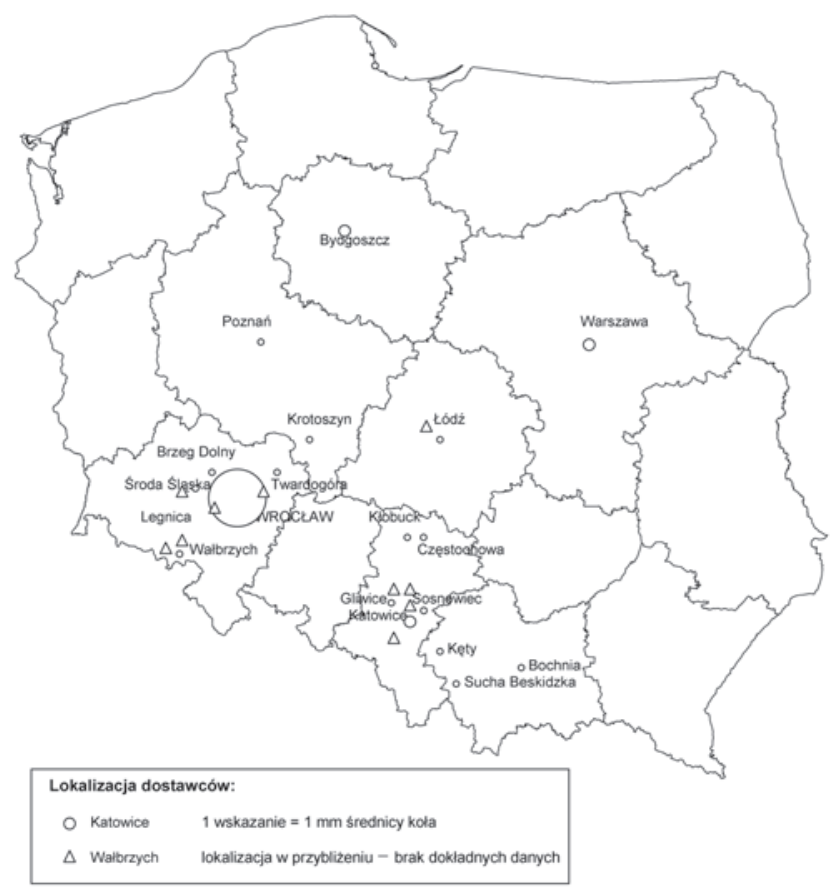

Źródło: opracowanie autorki 
Ryc. 3. Rynki zbytu analizowanych podmiotów gospodarczych

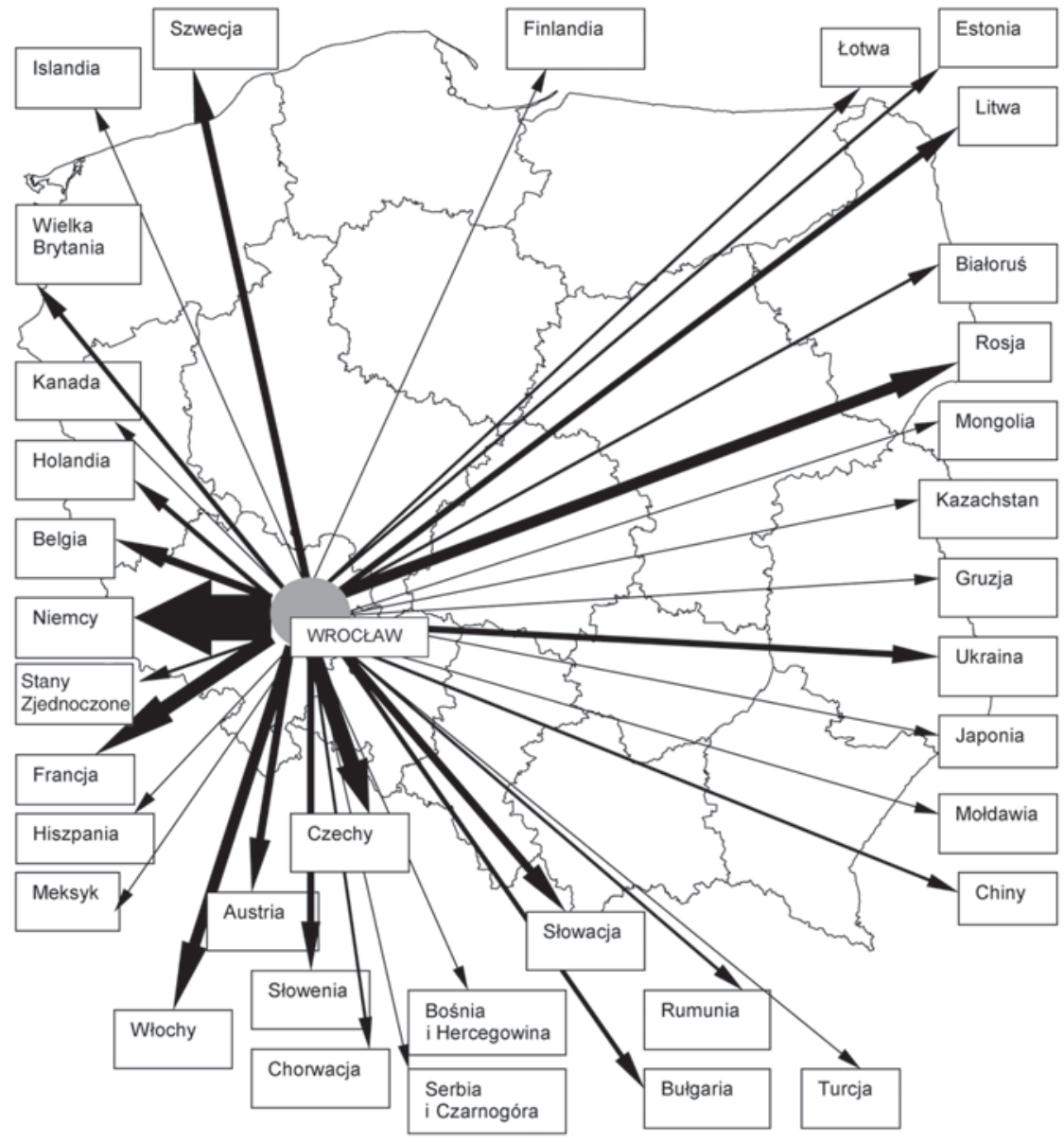

Zagraniczne rynki zbytu

Japonia

1 wskazanie $=0,3 \mathrm{~mm}$ grubosci strzałki

Źródło: opracowanie autorki

miejscach znalazły się: Francja, Włochy, Rosja, Austria i Czechy, a według importu: Holandia, Włochy, Francja i Belgia. Zwraca również uwagę różnica w liczbie krajów. Eksport trafia do 35 państw, a import pochodzi z 21 państw. Jest ponadto znaczna różnica $\mathrm{w}$ intensywności tych powiązań. Respondenci wskazywali na ogół więcej krajów, do których eksportują niż z których importują towary. Najważniejsza jednak różnica dotyczy kierunków powiązań. Eksport odbywa się właściwe w każdym kierunku, a szczególnie na zachód i wschód. Najmniej powiązań dotyczy północnej części kontynentu. Importowano zaś z zachodniej, północnej i południowej Europy, a nawet z dalekich krajów azjatyckich, ale nie z Europy Wschodniej. Podstawową zatem różnicą jest eksport na rynki wschodnioeuropejskie, bez importu z tej części kontynentu. Potwierdza się powszechnie uznawane twierdzenie, że inwestorzy lokalizują swoje oddziały w Polsce, aby stąd dalej eksportować towary na rynki wschodnie. 
Ryc. 4. Lokalizacja dostawców surowców/półproduktów
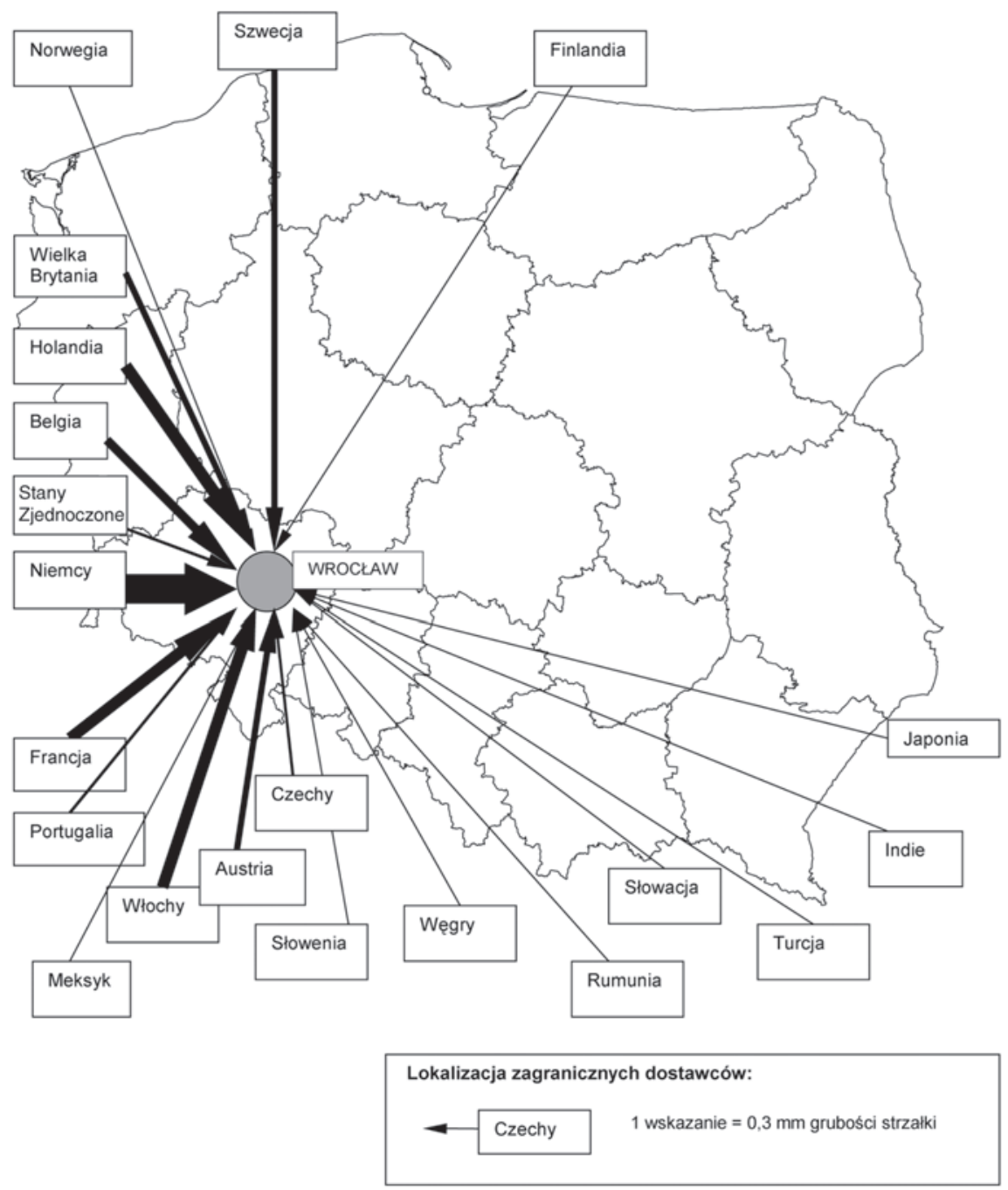

Źródło: opracowanie autorki

\section{Powiązania kooperacyjne}

W badaniu 29 na 40 respondentów uznało, że kooperuje z co najmniej jednym podmiotem. Respondenci uznali niemal jednogłośnie, że w powiązaniach kooperacyjnych najważniejsze są jakość towarów i utrwalone układy powiązań, gwarantujące bezpieczną współpracę. Z tego powodu w wielu odpowiedziach pominięto lokalizację kooperanta, ograniczając informacje do nazwy firm i/lub branży produkcji. Jeśli jednak respondent postanowił wymienić lokalizację kooperanta, to w niektórych wypadkach były to firmy działające w odległych rejonach. Wymieniano takie miasta, jak Rumia, Lublin i Pasłęk, co jest potwierdzeniem wniosku, że odległość w tej kategorii nie jest najważniejsza.

Kilkakrotnie wskazywano huty stali (Górny Śląsk), betoniarnie (Górny Śląsk, Dolny Śląsk, województwa łódzkie i wielkopolskie). Wymieniono znanych producentów na polskim rynku: Amicę Wronki, Polar, Electrolux (sprzęt AGD), Cermag (armatura sanitarna), Siemens (sprzęt elektroniczny), Hutmen (hutnictwo i przetwórstwo metali nieżelaznych) i stocznie, m.in. w Szczecinie. Pewna część 
podmiotów współpracuje z różnymi producentami opakowań ze szkła, z metalu lub z innych tworzyw. Wspomniano również o centrach dystrybucyjnych w kraju i za granicą oraz o firmach consultingowych. Duża część powiązań kooperacyjnych łączy podmioty o podobnym profilu produkcji, np. zakład zajmujący się produkcją wielowrzecionowych automatów tokarskich kooperuje z firmami zajmującymi się obróbką skrawaniem i wytwarzającymi drobne podzespoły wykorzystywane w produkcji automatów tokarskich, a producent odzieży kooperuje ze spółkami szwalniczymi.

Współpraca z zagranicznymi kooperantami okazała się dość słaba. Tylko siedmiu respondentów wymieniło zagranicznego kooperanta. Były to zakłady produkujące sprzęt telekomunikacyjny, części do samochodów, tworzywa sztuczne, maszyny i urządzenia elektryczne. Dwie firmy wymieniły kilku zagranicznych kooperantów, zaznaczając, że nie współpracują z firmami w Polsce. Przeważnie wymieniano firmy z krajów Europy Zachodniej - Niemiec, Włoch, a także ze Stanów Zjednoczonych i z Meksyku. Uzyskane wyniki są raczej negatywną przesłanką, mówią bowiem o słabych powiązaniach polskiego rynku z rynkami międzynarodowymi.

\section{Konkluzje}

Z powyższych rozważań wynikają następujące wnioski:

1. Wyniki ankiety nie potwierdzają hipotezy zakładającej, że miejsce lokalizacji spółek zagranicznych często nie pokrywa się z miejscem faktycznie prowadzonej działalności.

2. Na atrakcyjność inwestycyjną miasta najsilniej wpływają uwarunkowania przestrzenne. Korzystne położenie geograficzne oraz infrastruktura transportowa okazały się najczęściej wymienianymi cechami. Rola poszczególnych czynników decydujących o lokalizacji inwestycji na świecie podlega zmianom: od dominującej roli czynników egzogenicznych do wzrostu znaczenia endogenicznych czynników sprawczych (m.in. Pietrzyk 2000, Markowski, Marszał 1998, Namyślak 2003). Tym samym motywy lokalizacji kapitału we Wrocławiu należą do nurtu tradycyjnego, przestarzałego. Odpowiedzi odwołujące się do czynników społecznych jako determinant atrakcyjności inwestycyjnej zebrały znacznie mniejszą liczbę wskazań niż czynniki przestrzenne. Rynek pracy we Wrocławiu był różnie oceniany przez respondentów, szczególnie w kwestii kwalifikacji siły roboczej. Z ankiety wynika również, że koszty pracy w Polsce nadal uznawane są za niskie, czyli za korzystne z punktu widzenia inwestora.

3. Wśród ankietowanych podmiotów dominuje orientacja proeksportowa: $65 \%$ zakładów eksportuje więcej niż połowę wytwarzanych towarów, a około $47 \%$ eksportuje więcej niż trzy czwarte produkowanych dóbr. Zarówno w eksporcie, jak i w imporcie najczęściej wskazywano Niemcy, a także Włochy i Francję. Podstawową różnicą jest eksport na rynki wschodnie, bez importu z tej części kontynentu. W skali kraju najbardziej zwracają uwagę powiązania z podmiotami zlokalizowanymi w województwach dolnośląskim i śląskim.

4. Ze względu na niepełne dane nie udało się zbudować schematu powiązań kooperacyjnych. Respondenci zaznaczyli, że w powiązaniach tego rodzaju najważniejsze są jakość towarów i utrwalone układy powiązań, gwarantujące bezpieczną współpracę, nie zaś odległość. Z tego powodu w wielu odpowiedziach pominięto lokalizację kooperanta, ograniczając informacje do nazwy firm i/lub branży produkcji. Wiele powiązań łączy podmioty o podobnym profilu produkcji. Większość odpowiedzi, czyli wymienianych kooperantów, nie powtarzała się. Wyjątkiem są huty stali na Górnym Śląsku, betoniarnie oraz centra dystrybucji.

Współpraca z zagranicznymi kooperantami okazała się dość słaba. Zaledwie kilka razy wymieniono firmy z krajów Europy Zachodniej. Uzyskane wyniki mogą świadczyć o wolnym tempie włączania spółek z udziałami kapitału zagranicznego funkcjonujących we Wrocławiu w międzynarodowe sieci kooperacji. 


\section{Literatura}

1. Domański B., 2001, Deformacje metodologiczne i ideologiczne w badaniach przeksztatceń przestrzeni gospodarczej Europy Środkowej i Wschodniej [w:] Koncepcje teoretyczne i metody badań geografii społeczno-ekonomicznej i gospodarki przestrzennej, H. Rogacki (red.), Bogucki Wydawnictwo Naukowe, Poznań

2. Dziemianowicz W., 1997, Kapitat zagraniczny a rozwój regionalny i lokalny w Polsce, Europejski Instytut Rozwoju Regionalnego i Lokalnego, 21(54), Warszawa

3. Huggins R., 1997, Competitiveness and the Global Region. The Role of Networking [w:] Innovation, Networks and Learning Regions?, J. Simmie (red.), Regional Policy and Development 18, Regional Studies Association, London

4. Klasik A., 2002, Strategia konkurencyjna regionu [w:] Problemy transformacji struktur regionalnych i konkurencyjność regionów w procesie integracji europejskiej, A. Klasik, Z. Zioło (red.), Wyższa Szkoła Informatyki i Zarządzania, Rzeszów

5. Markowski T., Marszał T., 1998, Konkurencyjność regionów jako element polityki przestrzennej [w:] Wspótczesne problemy rozwoju regionalnego, T. Marszał, M. Opałło (red.), Biuletyn KPZK PAN, z. 180

6. Martin A., 2003, A Study on Factors of Regional Competitiveness; University of Cambridge, Cambridge

7. Namyślak B., 2003, Zróżnicowanie poziomu konkurencyjności regionów na tle rozmieszczenia inwestycji zagranicznych $w$ Polsce [w:] Zarzadzanie rozwojem regionalnym i lokalnym, T. Markowski (red.), Biuletyn KPZK PAN, z. 221

8. Pietrzyk I., 2000, Konkurencyjność regionów w ujęciu Komisji Europejskiej [w:] Polityka regionalna i jej rola w podnoszeniu konkurencyjności regionów, M. Klamut, L. Olszewski (red.), Wydawnictwo Akademii Ekonomicznej we Wrocławiu, Wrocław

\section{Spatial Aspects of Running Foreign Industrial Manufactures in Wroclaw and Neighborhoods}

The article is based on a survey purposed to show spatial aspects of running foreign industrial manufactures registered in Wrocław and adjoining districts: Wrocław, Oleśnica, Oława, Środa Śląska, Trzebnica, and Wołowski. The goal of the survey was finding answers to following questions: Is a production in progress in the site of entity? What motivated them for such localization? What barriers are the most encumbering for making business? How much of production is exported? What are directions of sale and sources of supply? What are relation between surveyed organizations and their partners? 


\title{
Przedsiębiorczość na obszarach
}

\author{
wiejskich
}




\section{Joanna Buks}

\section{Agnieszka Otlowska}

Zakład Polityki Społecznej i Regionalnej

Instytut Ekonomiki Rolnictwa i Gospodarki Żywnościowej - PIB

\section{Rozpowszechnienie nierolniczej działalności gospodarczej na obszarach wiejskich}

Obszary wiejskie tradycyjnie wiązane były wyłącznie z rolnictwem i traktowane jako miejsce wytwarzania produktów żywnościowych. Wieś dawała zatrudnienie większości jej mieszkańców. Transformacja gospodarcza i postęp technologiczny spowodowały zmiany także w rolnictwie. Produkcja w małych gospodarstwach przestała być opłacalna, zmniejszyła się liczba miejsc pracy zarówno w rolnictwie, jak i poza nim. Wielu mieszkańców wsi zostało zmuszonych do poszukiwania nowych źródeł zarobkowania. Część z nich podjęła próbę prowadzenia własnej pozarolniczej działalności gospodarczej.

Głównym celem badania było określenie poziomu rozpowszechnienia nierolniczej działalności gospodarczej na terenach wiejskich oraz identyfikacja szans i barier rozwoju przedsiębiorczości mieszkańców wsi w zakresie podejmowania nierolniczej działalności gospodarczej na wsi. Badania, w formie ankiety, przeprowadzili pracownicy Zakładu Polityki Społecznej i Regionalnej w II kwartale 2006 r. Objęto nimi 76 wsi w całym kraju. Miejscowości zostały dobrane tak, by były reprezentatywne ze względu na strukturę rolnictwa.

Rozmieszczenie wsi, które zostały objęte badaniem oraz wydzielone dla celów pracy badawczej makroregiony zostały zaprezentowane na ryc. 1 .

Ryc. 1. Podział przestrzenny badanych wsi

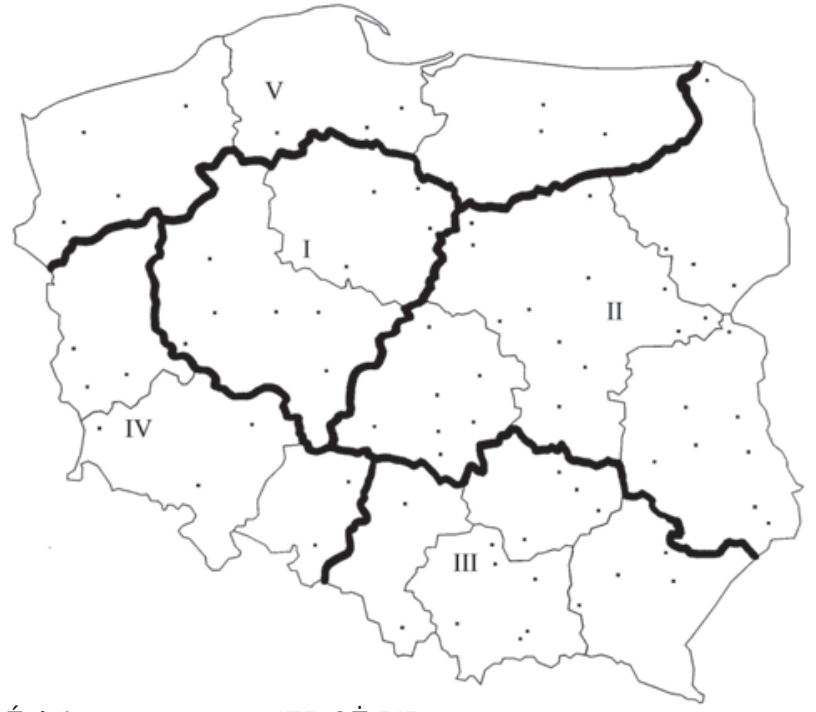

$\square$ - wieś objęta badaniem

Makroregiony: I - środkowozachodni (województwa: kujawsko-pomorskie, wielkopolskie); II - środkowowschodni (województwa: łódzkie, mazowieckie, lubelskie, podlaskie); III - południowo-wschodni (województwa: świętokrzyskie, małopolskie, podkarpackie, śląskie); IV - południowo-zachodni (województwa: opolskie, lubuskie, dolnośląskie); V - północny (województwa: zachodniopomorskie, pomorskie, warmińskomazurskie)

Źródło: opracowanie IERiGŻ-PIB 


\section{Rozpowszechnienie działalności nierolniczej}

Rozwój przedsiębiorczości stanowi element wielofunkcyjnego rozwoju obszarów wiejskich, dzięki któremu polska wieś ma szansę stać się bardziej atrakcyjna jako miejsce życia i pracy. Jest to zagadnienie bardzo ważne, podjęto zatem badania w celu określenia stanu i perspektyw rozwoju nierolniczej działalności gospodarczej na obszarach wiejskich, w wyniku których odnotowano 638 działających podmiotów gospodarczych na terenie 76 ankietowanych wsi. Na jedną wieś przypadało średnio 8 firm prowadzących działalność nierolniczą, ale najczęściej w badanych wsiach funkcjonowało 3-7 podmiotów gospodarczych. Odnotowano również wieś, w której działały 44 firmy, oraz dwie wsie, w których nikt nie prowadził nierolniczej działalności gospodarczej.

Tab. 1. Podmioty gospodarcze działające na obszarach wiejskich

\begin{tabular}{|c|c|c|}
\hline \multirow[b]{2}{*}{ Makroregion } & \multicolumn{2}{|c|}{ Podmioty gospodarcze dzialające na obszarach wiejskich } \\
\hline & struktura procentowa & $\begin{array}{c}\text { średnio na } 1 \text { wieś } \mathrm{w} \text { badanym } \\
\text { makroregionie }\end{array}$ \\
\hline Ogółem & 100 & 8,4 \\
\hline I - środkowozachodni & 11,1 & 7,1 \\
\hline II - środkowowschodni & 37,6 & 7,7 \\
\hline III - południowo-wschodni & 22,3 & 8,9 \\
\hline IV - południowo-zachodni & 13,9 & 9,9 \\
\hline V-północny & 15,1 & 9,6 \\
\hline
\end{tabular}

Źródło: opracowanie zespołu badawczego na podstawie ankiet

We wsiach makroregionów środkowozachodniego, środkowowschodniego i południowo-wschodniego najczęściej występowało 2-5 podmiotów prowadzących nierolniczą działalność gospodarczą (odpowiednio: $30 \%, 42 \%$ i $38 \%$ populacji). W makroregionie południowo-zachodnim odnotowano najwięcej wsi, w których funkcjonowało 6-10 i 11-20 firm (po 33\% ogółu). Najbogatsze w podmioty prowadzące nierolniczą działalności gospodarczą były wsie makroregionu północnego. Niemal w 40\% z nich prowadzono 11-20 firm.

Badania ankietowe i zebrany materiał statystyczny pozwoliły prześledzić główne kierunki pozarolniczej działalności gospodarczej na terenach wiejskich. Niemal 47\% podmiotów gospodarczych funkcjonujących na wsiach prowadziło działalność handlową, ponad 38\% - działalność usługową, 10\% - działalność produkcyjną, a w 5\% - działalność mieszaną.

W tab. 2 przedstawiono zróżnicowanie przestrzenne w rozpowszechnieniu rodzajów działalności. W makroregionie północno-zachodnim, w odróżnieniu od pozostałych, największy udział procentowy (blisko 44\%) przypadał na działalność o charakterze usługowym. Można przypuszczać, że było to spowodowane położeniem przygranicznym.

Spośród podmiotów związanych z handlem niemal $24 \%$ zajmowało się sprzedażą gazu w butlach. Ten rodzaj działalności nie wymaga nakładów finansowych ani specjalnych powierzchni magazynowych, dlatego jest bardzo popularny. Osoby zajmujące się działalnością handlową równie często prowadziły sklepy spożywczo-przemysłowe i sklepy spożywcze. Zazwyczaj na te cele były wykorzystywane budynki wchodzące w skład gospodarstw domowych. Znaczną część wyposażenia tych placówek stanowiły akcesoria dostarczane przez producentów czy dystrybutorów towarów, więc również i w tych przypadkach koszty rozpoczęcia działalności nie były wysokie. Na ryc. 2 przedstawiono strukturę podmiotów prowadzących działalność handlową wg rodzaju działalności.

Z ogólnej liczby podmiotów ponad 9\% stanowiły pozostałe placówki handlowe, do których zaliczono: sklepy przemysłowe, sklepy z odzieżą i obuwiem, sklepy wielobranżowe, sklepy z artykułami 
Tab. 2. Rodzaje działalności gospodarczej w makroregionach

\begin{tabular}{|l|c|c|c|c|}
\hline \multirow{2}{*}{\multicolumn{1}{|c|}{ Makroregion }} & \multicolumn{4}{|c|}{ Rodzaj dzialalności (w \%) } \\
\cline { 2 - 5 } & handlowa & produkcyjna & usługowa & mieszana \\
\hline Ogółem & $\mathbf{4 6 , 7}$ & $\mathbf{9 , 7}$ & $\mathbf{3 8 , 3}$ & $\mathbf{5 , 3}$ \\
\hline I - środkowozachodni & 49,3 & 7,1 & 38,0 & 5,6 \\
\hline II - środkowowschodni & 43,7 & 9,7 & 39,3 & 7,3 \\
\hline III - południowo-wschodni & 50,4 & 9,6 & 37,0 & 3,0 \\
\hline IV - południowo-zachodni & 37,1 & 14,6 & 43,8 & 4,5 \\
\hline V - północny & 56,2 & 7,3 & 32,3 & 4,2 \\
\hline
\end{tabular}

Źródło: opracowanie zespołu badawczego na podstawie ankiet

Ryc. 2. Struktura podmiotów gospodarczych według rodzaju działalności handlowej

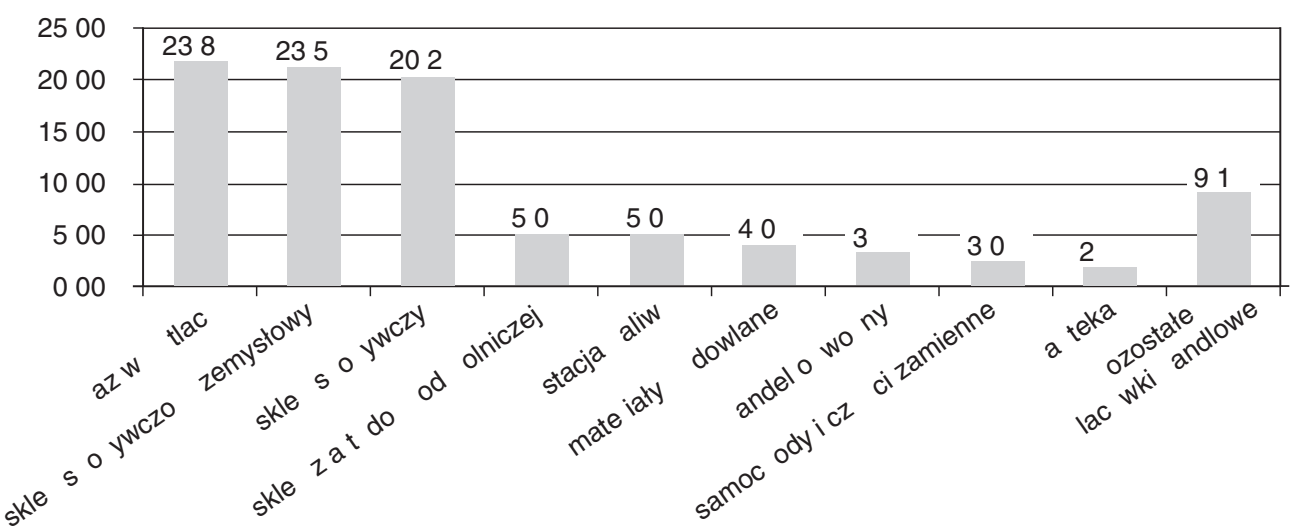

Źródło: opracowanie zespołu badawczego na podstawie ankiet

papierniczo-biurowymi, kioski, kwiaciarnie, punkty skupu złomu. Odnotowano także obecność: hurtowni porcelany, szkła i sztućców, hurtowni sprzętu komputerowego, sklepów meblowych, podmiotów zajmujących się skupem, sprzedażą nowego i używanego sprzętu AGD i RTV oraz dojrzewalni bananów.

Kolejnym kierunkiem pod względem ilości pozarolniczej działalności gospodarczej na terenach wiejskich było świadczenie różnego rodzaju usług. Najbardziej rozpowszechnione firmy usługowe, stanowiące więcej niż połowę wszystkich podmiotów prowadzących działalność tego typu, to: remontowo-budowlane, transportowe, motoryzacyjne oraz gastronomiczno-hotelowe. Strukturę procentową podmiotów prowadzących działalność usługową przedstawia ryc. 3 .

Pozostałe punkty świadczyły usługi z zakresu: renowacji antyków, naprawy sprzętu AGD, poligrafii, galwanizacji i korepetycji. Odnotowano także pojedyncze przypadki: farbiarni, usług mechanizacyjno-rolniczych, regeneracji i ostrzenia pił, siłowni sportowej, punktu spawania tworzyw, usług kosmetyczno-fryzjerskich dla zwierząt oraz twórczości ludowej. Rzadziej występowały podmioty zajmujące się działalnością produkcyjną (ryc. 4). Działalność o tym charakterze wymaga wiedzy technicznej i ciagłej jej aktualizacji, dlatego nie jest tak popularna jak inne. Najwięcej zakładów produkcyjnych zajmowało się wytwarzaniem materiałów budowlanych (ceramiki budowlanej, metalowych elementów montażowych oraz ogrodzeń i bram). Firmy produkujące artykuły przemysłowe wytwarzały przede wszystkim znicze, zabawki i pomoce naukowe. 
Ryc. 3. Struktura podmiotów gospodarczych według rodzaju działalności usługowej

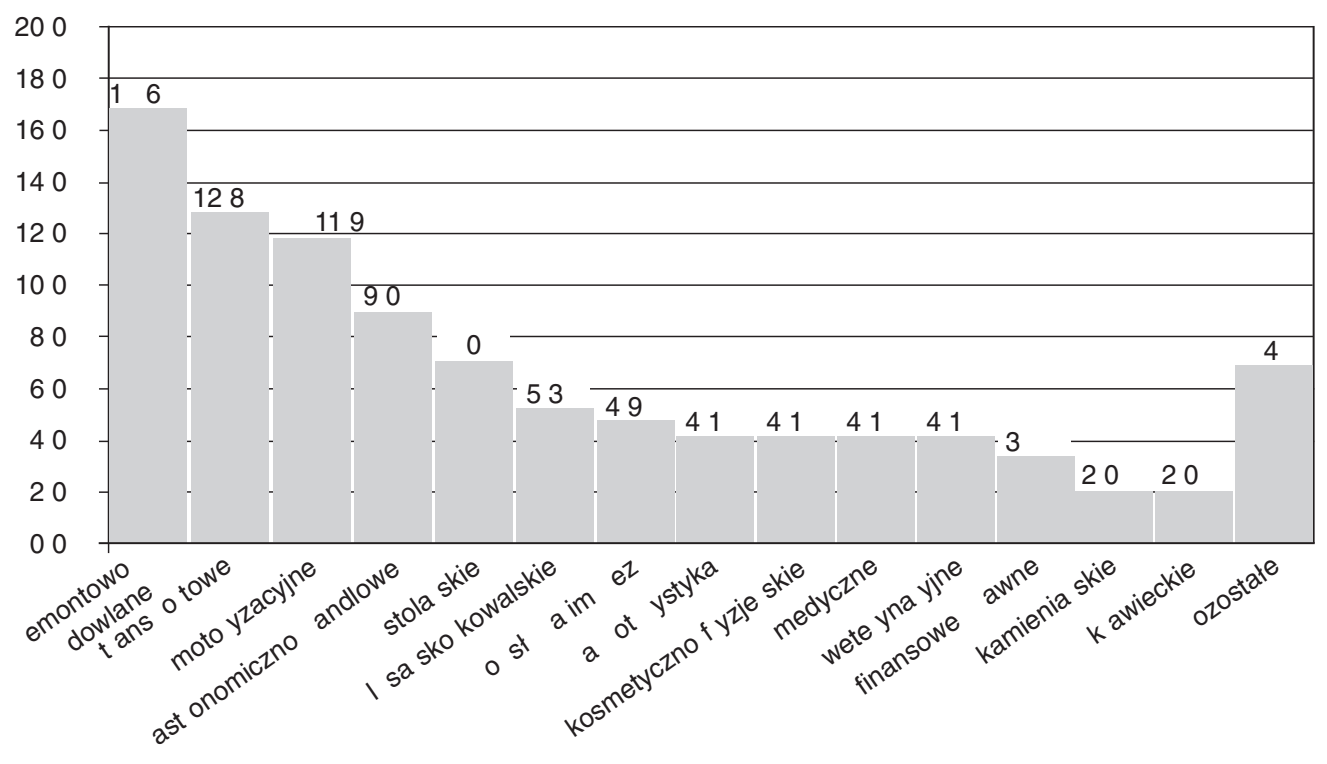

Źródło: opracowanie zespołu badawczego na podstawie ankiet

Odnotowano również obecność zakładów produkujących opakowania plastikowe, papier toaletowy, urządzenia oświetleniowe, włókniny na ścierki, dywaniki łazienkowe i zegary ścienne. Podmioty produkujące artykuły spożywcze to przede wszystkim piekarnie i cukiernie. Do pozostałych zakładów produkcyjnych zaliczono zakład produkcji bryczek konnych i wytwórnie kajaków.

Ze względu na trudności w określeniu głównego kierunku działalności niektórych podmiotów gospodarczych, zaliczono je do grupy firm prowadzących działalność mieszaną. Większość $\mathrm{z}$ tych firm charakteryzowała się sezonowością działania, a były to podmioty zajmujące się: skupem i przetwórstwem płodów rolnych, usługami leśnymi i tartacznymi, sprzedażą artykułów remontowo-budowlanych wraz ze świadczeniem usług w tym zakresie.

Ryc. 4. Struktura podmiotów gospodarczych prowadzących działalność produkcyjną według rodzaju działalności

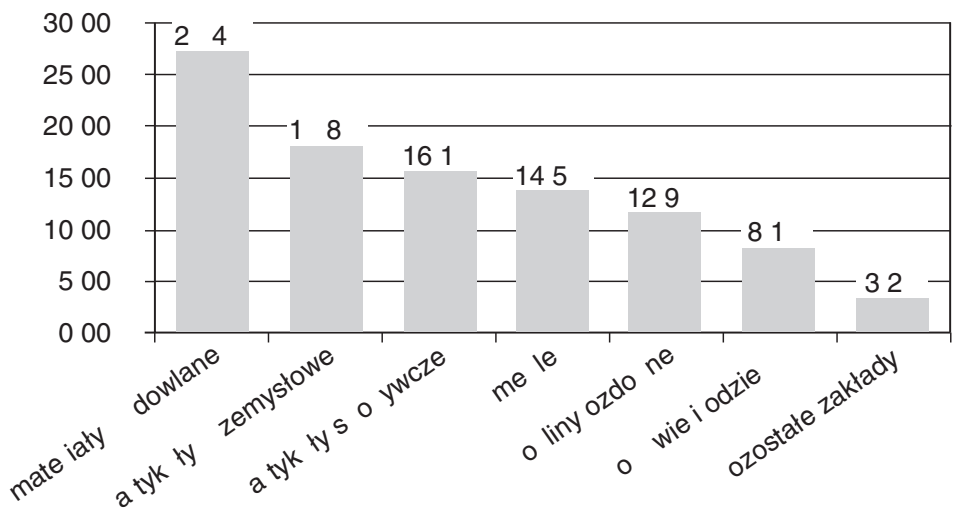

Źródło: opracowanie zespołu badawczego na podstawie ankiet 
Siedziba i rozmieszczenie punktów sprzedaży firmy są ważne z wielu względów. Badania wykazały, że mieszkańcy wsi do prowadzenia działalności najczęściej wykorzystywali budynki znajdujące się w gospodarstwach domowych (blisko 77\%). Można to uznać za zjawisko pozytywne, ponieważ rolnicy wykorzystują posiadany potencjał, a tym samym unikają kosztów związanych z wynajmem budynków czy budową siedzib. Jeśli jednak gospodarstwo znajduje się w miejscu, do którego z różnych względów trudno dojechać, potencjalni nabywcy nie będą chcieli poświęcać czasu na dotarcie do firmy. Takiemu przedsiębiorcy może być również trudnej pozyskać odpowiednio wyszkoloną kadrę pracowniczą, moga go także nie obejmować preferencyjne przepisy lokalne czy podatkowe.

Badani przedsiębiorcy działali głównie na rynkach lokalnych - ponad $68 \%$ (wieś, okoliczne wsie, gmina). Na terenie powiatu działalność prowadziło ponad $13 \%$ podmiotów, a na obszarze województwa - ponad 6\%. Zasięgiem krajowym charakteryzowało się blisko $8 \%$ podmiotów, a międzynarodowym - tylko ponad $4 \%$.

\section{Charakterystyka osób prowadzących nierolniczą dzialalność gospodarczą}

Powszechne jest przekonanie, że przedsiębiorczość to droga do rozwoju gospodarczego kraju, zmniejszenia bezrobocia i wzrostu dobrobytu. Jednak samo przeświadczenie nie wystarczy, aby poprawić warunki życia ludzi i stan gospodarki. Za każdą decyzją o rozpoczęciu działalności, stworzeniu nowego artykułu czy usługi - zawsze stoi człowiek. Podjęto zatem próbę analizy struktury demograficzno-społecznej osób zaangażowanych w powstawanie firm na wsi.

Jednoosobową nierolniczą działalność gospodarczą prowadziły 623 osoby; stanowiło to ponad 97\% ogółu odnotowanych przypadków tej działalności. Podmioty prowadzone przez dwie osoby odnotowano w 15 przypadkach; zazwyczaj był to tzw. biznes rodzinny (działalność wspólna małżonków, rodzeństwa, rodziców i dzieci) i firmy założone przez wspólników. Właścicielami lub współwłaścicielami badanych podmiotów gospodarczych w ponad $64 \%$ przypadków byli mężczyźni, a tylko w 36\% - kobiety. Przedsiębiorczych mężczyzn było zatem niemal dwukrotnie więcej niż kobiet. Przedmiotem analizy był również wiek osób aktywnych w zakładaniu i rozwijaniu firm. Najczęściej w nierolnicze przedsięwzięcia gospodarcze angażowały się osoby w wieku 36-55 lat (68,1\% badanej populacji), a średni wiek osób prowadzących pozarolniczą działalność gospodarczą na terenach wiejskich wynosił prawie 44 lata; był taki sam w grupie mężczyzn i w grupie kobiet. Najwięcej przedsiębiorczych kobiet liczyło 50 lat, a mężczyzn - 40 lat.

Wpływ płci i wieku na gotowość do podejmowania przedsiębiorczych inicjatyw jest znaczący. Kolejną cechą uznaną za ważną było wykształcenie. W gospodarce rynkowej to wiedza decyduje o sukcesie przedsiębiorcy, dlatego wykształcenie ma istotny wpływ na wzrost liczby i rodzaj prywatnych podmiotów. Wśród prowadzących nierolniczą działalność gospodarczą przeważały osoby z wykształceniem średnim i policealnym (ponad 45\%) oraz zasadniczym zawodowym (niemal 39\%). Istnieje zatem potrzeba rozwijania, szczególnie wśród osób młodych, aktywnego planowania własnej kariery zawodowej. Ludzie, którzy wiedza, z czym wiąże się działalność gospodarcza, w sposób bardziej świadomy oceniają swoje sukcesy i porażki. Społeczeństwo, szczególnie z obszarów wiejskich, musi zacząć dostrzegać w pozarolniczej działalności gospodarczej szanse na własny awans zawodowy i materialny.

Trudna sytuacja ekonomiczna tradycyjnych gospodarstw rolnych zmusza ich właścicieli do poszukiwania dodatkowych źródeł dochodów. Jednym z nich jest nierolnicza działalność gospodarcza, z której wpływy stanowią znaczną część budżetu gospodarstwa domowego. Dlatego też prawie $46 \%$ osób prowadzących nierolniczą działalność gospodarczą na terenach wiejskich było jednocześnie właścicielami gospodarstw rolnych. W niemal $40 \%$ przypadków były to gospodarstwa małe, o powierzchni 1,00-3,00 ha. 


\section{Przedsiębiorczość wiejska w opinii sołtysów}

Sołtys - osoba reprezentująca mieszkańców wsi - najlepiej znająca ich sytuację, potrzeby, możliwości i aspiracje. Za interesujące uznano więc opinie sołtysów i ich oceny dotyczące przedsiębiorczości na obszarach wiejskich. Udzielili oni wyczerpujących odpowiedzi na liczne pytania zawarte w ankiecie, obrazujące stan i możliwości rozwoju przedsiębiorczości na wsi.

Wizja przyszłości wsi w ocenie jej mieszkańców to istotny aspekt rozwoju przedsiębiorczości, uzależniony w dużym stopniu od ich inwencji i zaangażowania. To m.in. od mieszkańców wsi zależy, w jakim kierunku rozwinie się ich wieś i jaki wygląd uzyska za 5, 10 czy 15 lat.

Ponad $72 \%$ ankietowanych przyszłość swojej wsi wiązało wyłącznie z rolnictwem, co oznacza, że występuje nadal bardzo silne przywiązanie do tradycyjnie postrzeganego modelu wsi. Niestety, niemal $20 \%$ ankietowanych nie widziało perspektyw dla rozwoju swojej wsi. Znaczna część ankietowanych wskazała agroturystykę jako najodpowiedniejszy sposób dywersyfikacji źródeł zarobkowania (tab. 3). Oznacza to, że coraz większa grupa mieszkańców wsi ma świadomość korzyści z tego rodzaju działalności. Agroturystyka pozwala pełniej wykorzystać majątek gospodarstwa rolnego i jest komplementarna do produkcji rolniczej.

Tab. 3. Przyszły rozwój wsi w ocenie sołtysów

\begin{tabular}{|l|c|}
\hline \multicolumn{1}{|c|}{$\begin{array}{c}\text { Odpowiedzi* respondentów na pytanie: z czym według } \\
\text { respondentów związana jest szansa rozwoju wsi? }\end{array}$} & \% odpowiedzi \\
\hline Z rolnictwem & 72,4 \\
\hline Nie widzę perspektyw dla swojej wsi & 19,7 \\
\hline Z rozwojem usług & 17,1 \\
\hline$Z$ rozwojem przedsiębiorczości & 14,5 \\
\hline$Z$ rozwojem turystyki, agroturystyki & 14,5 \\
\hline$Z$ rozwojem zakładów produkcyjnych & 9,2 \\
\hline
\end{tabular}

*Uwaga. Istniała możliwość podania więcej niż jednej odpowiedzi, dlatego suma odsetek jest większa od 100.

Źródło: opracowanie zespołu badawczego na podstawie ankiet

Z rolnictwem - jako szansą rozwoju swojej wsi - utożsamiali się prawie wszyscy respondenci. Wśród mieszkańców makroregionu środkowozachodniego równie często występowała opinia, że przed wsią nie rysują się żadne wyraźne perspektywy. Natomiast największy odsetek sołtysów wskazujących na przedsiębiorczość jako właściwy kierunek rozwoju odnotowano we wsiach makroregionu północnego (30,8\%).

Wskazując typy działalności mające szansę na rozwój w danej wsi, ankietowani informowali o zaobserwowanych potrzebach. W makroregionach południowo-zachodnim i środkowo-zachodnim najczęściej za perspektywiczną uważano działalność usługową, a w makroregionie środkowowschodnim - działalność handlową i agroturystykę.

Ważnym czynnikiem sprzyjającym powstawaniu nowych działalności jest rozbudowana infrastruktura techniczna. Według respondentów 46,1\% wsi leży w pobliżu obiektów mogących wpłynąć na rozwój przedsiębiorczości: ponad jedna piąta w okolicach aglomeracji miejskiej, $18,4 \%$ - w pobliżu dużego zakładu pracy, ponad $13 \%$ - blisko dróg ekspresowych, szybkiego ruchu i autostrad (tab. 4).

W ujęciu regionalnym największe szanse na rozwój przedsiębiorczości związane z atrakcyjnym położeniem mają wsie makroregionu południowo-zachodniego, gdzie sprzyja mu bliskość: miasta $(33,3 \%)$, dużego zakładu pracy $(22,2 \%)$, przejść granicznych $(22,2 \%)$ i dróg ekspresowych $(11,1 \%)$. Najwięcej w tym makroregionie jest wsi położonych atrakcyjnie dla turystów $(11,1 \%)$. Najmniejsze 
szanse wynikające z położenia mają mieszkańcy wsi makroregionów środkowowschodniego i północnego, gdzie żaden z tego typu obiektów nie znajduje się w bliskiej okolicy badanych wsi.

Tab. 4. Ocena wpływu położenia wsi na rozwój przedsiębiorczości (\% odpowiedzi)

\begin{tabular}{|l|c|c|c|c|c|c|}
\hline \multirow{2}{*}{ Makroregion } & \multicolumn{3}{|c|}{ Na rozwój przedsiębiorczości wplywa bliskie położenie: } \\
\cline { 2 - 7 } & $\begin{array}{c}\text { dróg } \\
\text { ekspreso- } \\
\text { wych, } \\
\text { szybkiego } \\
\text { ruchu, } \\
\text { autostrad }\end{array}$ & $\begin{array}{c}\text { przejść } \\
\text { granicz- } \\
\text { nych }\end{array}$ & $\begin{array}{c}\text { specjalnej } \\
\text { strefy } \\
\text { ekono- } \\
\text { micznej }\end{array}$ & $\begin{array}{c}\text { dużego } \\
\text { zakładu } \\
\text { pracy }\end{array}$ & miasta & $\begin{array}{c}\text { atrakcji } \\
\text { turystycz- } \\
\text { nych, } \\
\text { miejsc } \\
\text { kultu } \\
\text { religijnego }\end{array}$ \\
\hline Ogółem & $\mathbf{1 3 , 2}$ & $\mathbf{3 , 9}$ & $\mathbf{1 , 3}$ & $\mathbf{1 8 , 4}$ & $\mathbf{2 1 , 1}$ & $\mathbf{2 , 6}$ \\
\hline I - środkowozachodni & 20,0 & 0,0 & 0,0 & 30,0 & 20,0 & 0,0 \\
\hline II - środkowowschodni & 12,9 & 3,2 & 0,0 & 16,1 & 9,7 & 0,0 \\
\hline III - południowo-wschodni & 12,5 & 0,0 & 6,3 & 18,8 & 37,5 & 6,3 \\
\hline IV - południowo-zachodni & 11,1 & 22,2 & 0,0 & 22,2 & 33,3 & 11,1 \\
\hline V - północny & 10,0 & 0,0 & 0,0 & 10,0 & 20,0 & 0,0 \\
\hline
\end{tabular}

Źródło: opracowanie zespołu badawczego na podstawie ankiet

Wstąpienie Polski do UE otworzyło nowe możliwości aktywizacji gospodarczej obszarów wiejskich, które w europejskiej polityce zajmują bardzo ważną rolę. Nowe instrumenty wspierające przedsiębiorczość wiejska, jakie pojawiły się wraz z członkostwem w UE, stanowią dużą szansę rozwoju terenów wiejskich, ale także wyzwanie dla mieszkańców wsi. Stopień znajomości instrumentarium pomocy strukturalnej oraz praktyczna wiedza o procedurach przyznawania środków to całkiem nowe czynniki rozwoju przedsiębiorczości na obszarach wiejskich. W rok po wejściu Polski do Unii Europejskiej tylko w niespełna 1/4 badanych wsi poziom wiedzy mieszkańców o Unii Europejskiej jest ich zdaniem zadowalający. W tych wsiach jako główne źródło informacji o UE wskazywano: ośrodki doradztwa rolniczego, oddziały Agencji Restrukturyzacji i Modernizacji Rolnictwa oraz gminne centra informacji. Przeważającą grupę stanowią wsie, w których poziom wiedzy o możliwościach wynikających z członkostwa w UE jest niedostateczny. Jako przyczynę najczęściej wskazywano brak instytucjonalnego źródła informacji w każdej gminie oraz brak spotkań szkoleniowo-informacyjnych na terenie wsi.

Niewystarczający poziom informacji skutkuje niewielką aktywnością w pozyskiwaniu funduszy z UE na założenie i rozwój działalności gospodarczej. Jedynie w nieco ponad jednej piątej badanych wsi odnotowano przypadki korzystania ze wsparcia działalności pozarolniczej. Mniej niż połowa respondentów znała przypadki zainteresowania mieszkańców wsi pozyskaniem środków na cele pozarolnicze. Wynika z tego, że kapitał założycielski dla nowych przedsięwzięć gospodarczych pochodzi ze środków własnych, a w niewielkim tylko stopniu ze źródeł zewnętrznych o charakterze instytucjonalnym (kredytów bankowych czy wsparcia z funduszy europejskich).

Niski poziom informacji o UE i nowych instrumentach polityki strukturalnej wspierających przedsiębiorczość sprawia, że mieszkańcy wsi ostrożnie wypowiadają się o obecnych i przyszłych możliwościach pozyskiwania środków na zakładanie i rozwój działalności pozarolniczej na obszarach wiejskich. Mimo że 45\% badanych przedstawicieli wsi jest zdania, że po wejściu do UE w Polsce wzrosły możliwości rozwoju przedsiębiorczości wiejskiej, to pozytywną opinię o przyszłych możliwościach rozpowszechnienia się nierolniczej działalności gospodarczej na obszarach wiejskich odnotowano jedynie w jednej trzeciej badanych wsi. Mieszkańcy wsi mają 
świadomość możliwości pozyskiwania środków wsparcia na rozwój przedsiębiorczości, lecz uważają je za niedostępne dla przeciętnego człowieka z powodu skomplikowanych procedur i biurokracji towarzyszących ubieganiu się o dofinansowanie. Jednocześnie panuje przekonanie, że tylko młodzi wykształceni ludzie w przyszłości będą w stanie skutecznie wykorzystywać możliwości pozyskania funduszy na rozpoczęcie i rozwój małej przedsiębiorczości.

Za szanse rozwoju nierolniczej działalności gospodarczej ankietowani najczęściej uważają członkostwo Polski w Unii Europejskiej. Respondenci wierza, że poprawa poziomu wykształcenia mieszkańców wsi przyczyni się do wzrostu zainteresowania innym źródłem zarobkowania niż rolnictwo. Za największe zagrożenia rozwoju przedsiębiorczości wiejskiej uważają przede wszystkim: skomplikowane procedury zakładania działalności gospodarczej, nadmierny fiskalizm państwa wobec przedsiębiorstw oraz trudności w pozyskiwaniu zewnętrznych środków na rozpoczęcie i rozwój małej i średniej przedsiębiorczości. Spośród czynników pośrednio wpływających na aktywizację obszarów wiejskich, za najważniejsze uważają działania informacyjno-szkoleniowe gminy oraz innych instytucji lokalnych, wpływające na poziom wiedzy mieszkańców, oraz skalę inwestycji w infrastrukturę społeczno-techniczna, zwłaszcza podstawową, czyli wiejskie drogi.

Analiza wstępnych wyników badań pozwala na sformułowanie następujących wniosków:

- niemal 4\% mężczyzn i tylko 2\% kobiet spośród ankietowanych mieszkańców wsi w wieku powyżej 18 roku życia prowadzi nierolniczą działalność gospodarczą;

- najczęściej występującymi podmiotami gospodarczymi na terenach wiejskich są:

- w działalności handlowej - sprzedaż gazu w butlach,

- w działalności usługowej - usługi remontowo-budowlane,

- w działalności produkcyjnej - produkcja materiałów budowlanych;

- niemal połowa prowadzących nierolniczą działalność gospodarczą posiada gospodarstwo rolne;

- w badanych wsiach więcej niż połowa ankietowanych określiła poziom przedsiębiorczości ludności jako średni;

- niemal trzy czwarte respondentów wiąże przyszłość wsi głównie z rolnictwem;

- głównymi barierami rozwoju nierolniczej działalności gospodarczej na wsi są: brak kapitału, skomplikowane procedury zakładania przedsiębiorstw i wysokie koszty jej prowadzenia;

- należy zwiększyć intensywność kampanii informacyjnej o możliwościach zewnętrznego finansowania działalności pozarolniczej na wsi

\section{Development of Non-agricultural Economic Activity in Rural Areas}

Rural entrepreneurship and enterprise development can stimulate local economic growth, engage young people, and recreate community's vitality. A lively, growing rural community will encourage further growth of the regions and entrepreneurship is one of the leveraging instruments for unify a disproportion in socio-economic development of Polish regions.

The paper analyses the development of non-agricultural economic activity on rural areas and shows the chances and barriers for rural entrepreneurship's increase.

Research conducted in 76 villages shows that the most popular non-rural economic activity on rural areas is trading and most of the activities have local extent. Lack of the funds for launching a company is the great barrier to further development of rural entrepreneurship and structural policy instruments can be a chance to improve this situation. 


\section{Mariusz Chądrzyński}

Katedra Ekonomii i Polityki Gospodarczej

Szkoły Głównej Gospodarstwa Wiejskiego

\section{Glówne bariery rozwoju i funkcjonowania małych i średnich przedsiębiorstw na obszarach wiejskich województwa lódzkiego}

Przedsiębiorczość jest siłą, która w dużym stopniu może się przyczynić do rozwoju społeczno-gospodarczego obszarów wiejskich. Poważnym problemem jest rozpoczęcie działalności gospodarczej, ale czasami jeszcze większym - jej utrzymanie i rozwijanie. Duże możliwości działania daje cały sektor agrobiznesu, ze względu na niezaspokojony popyt ${ }^{1}$. Ta kategoria popytu stanowi niszę rynkową, która może zostać wykorzystana przez nowe podmioty gospodarcze. Rozpoczęcie i prowadzenie działalności gospodarczej w każdych warunkach wiąże się z pokonywaniem wielu barier. Te bariery, jeśli zostaną źle zidentyfikowane, mogą być przyczyną zakończenia działalności, natomiast prawidłowe ich określenie umożliwia właściwe użycie posiadanych zasobów, środków i wiedzy w celu ich przezwyciężenia.

\section{Metodyka badań}

W niniejszym opracowaniu wykorzystano wyniki badania ankietowego, dotyczącego uwarunkowań i perspektyw rozwoju sektora małych i średnich przedsiębiorstw (MSP) na obszarach wiejskich woj. łódzkiego, przeprowadzonego w 2003 r. W badaniu uczestniczyło 250 wylosowanych, a następnie celowo dobranych małych i średnich przedsiębiorstw działających na terenach wiejskich tego województwa.

\section{Bariery rozwoju i funkcjonowania sektora MSP na terenach wiejskich}

Bariery ograniczające prowadzenie działalności gospodarczej można zdefiniować jako takie uwarunkowania wewnętrzne i zewnętrzne środowiska biznesu, które osłabiają dynamikę powstawania nowych przedsiębiorstw, zmniejszają możliwości rozwoju firm istniejących lub przyspieszają upadanie drobnej przedsiębiorczości (Sawicka 2000). Przedsiębiorcy napotykają różne trudności; każdy z nich może wskazać inny czynnik, w zależności od stopnia rozwoju, skali działania i lokalizacji. Są to bariery i ograniczenia²:

- finansowe;

- rynkowe;

- związane z wytwórczością;

\footnotetext{
${ }^{1}$ Termin „niezaspokojony popyt” można rozumieć dwojako: jako popyt zgłoszony, a więc efektywny, który z różnych powodów nie może zostać zaspokojony, i jako popyt potencjalny, który można uświadomić poprzez odpowiednio prowadzoną działalność marketingową.

${ }^{2}$ Grupy czynników hamujących rozwój i funkcjonowanie przedsiębiorczości opracowano na podstawie raportów PARP i J. Sawicka, 2000, Założenie i prowadzenie małego przedsiębiorstwa, Wydawnictwo SGGW, Warszawa, a także projektu badawczego pod kierownictwem J. Sawickiej: Aktywizacja zawodowa kobiet wiejskich ze szczególnym uwzględnieniem drobnej przedsiębiorczości.
} 
- organizacyjne;

- związane z dostępnością do informacji, doradztwa, edukacji;

- infrastrukturalne;

- związane z rynkiem pracy i jego regulacją;

- związane z polityką fiskalną;

- administracyjne i prawne;

- wewnętrzne środowiska przedsiębiorców.

Jedną z ważniejszych barier jest brak lub utrudniony dostęp do kapitału początkowego pozwalającego rozpocząć działalność gospodarczą. Podstawowym źródłem finansowania działalności gospodarczej MSP są środki własne. Często nie wystarczają one na właściwy rozwój przedsiębiorstwa i działalność inwestycyjną na odpowiednim poziomie. Należy zgodzić się ze stwierdzeniem J. Sawickiej, że główne przyczyny takiego stanu rzeczy to wysoki koszt pożyczonego kapitału, brak odpowiedniej liczby banków specjalizujących się w obsłudze małych i średnich firm oraz mała dostępność kredytów preferencyjnych, a często niewiedza przedsiębiorców o ich istnieniu (brak informacji).

Istotną barierą rozwoju przedsiębiorczości są czynniki rynkowe, które - źle ocenione lub pominięte przez przedsiębiorcę - mogą się stać przyczyną trudności w funkcjonowaniu firmy lub doprowadzić do jej upadku. Jeszcze przed rozpoczęciem działalności należy oszacować popyt efektywny i potencjalny na produkty lub usługi, które przyszły przedsiębiorca zamierza wytwarzać. Jest to ważne z punktu widzenia opłacalności działalności gospodarczej. Często rola tego czynnika jest umniejszana w praktyce. W trakcie prowadzenia firmy przedsiębiorcy przywiązują ogromną rolę do określenia popytu, jednak nie zawsze dysponują odpowiednią wiedza, aby to we właściwy sposób zrobić. Metoda oparta na własnym doświadczeniu sprawdza się bardzo często, jednak poparcie jej naukowymi podstawami daje większe prawdopodobieństwo właściwego określenia popytu zarówno efektywnego, jak i potencjalnego.

Nie należy zapominać o barierze rynkowej, jakąjest konkurencja. Badania empiryczne (m.in. wykonywane przez IERiGŻ) dowodzą, że przedsiębiorcy małą uwagę poświęcają zagadnieniom konkurencji, a skupiają się na czynniku opłacalności swojej działalności (Sikorska 2001). Konkurencyjność własnej firmy oraz rozpoznanie otoczenia konkurencyjnego przekładają się na ostateczny wynik ekonomiczny przedsiębiorstwa. Konkurencja jako element rzeczywistości gospodarczej jest zauważana przez przedsiębiorców dopiero wówczas, gdy dotykają ich bardziej konkretne działania konkurencji. Jest to szczególnie istotne, jeśli w okolicy znajdują się duże firmy. Konkurencja może ograniczać lub utrudniać wejście na rynki zbytu, utrudniać dostęp do dostawców.

Kolejne bariery to bariery wejścia, szczególnie zróżnicowanie produktów, potrzeby kapitałowe, drożność i struktura kanałów dystrybucji. Z tymi barierami muszą walczyć przedsiębiorstwa, które chcą wejść z działalnością na dany rynek czy do danej branży (Piasecki 1999). Zagrożeniem dla sektora MSP, szczególnie w warunkach postępującej globalizacji gospodarki światowej, jest brak sieci powiązań kooperacyjnych i współpracy między małymi i dużymi przedsiębiorstwami. Ta współpraca może ułatwić przystosowanie małych i średnich przedsiębiorstw do warunków konkurencji na globalnym rynku.

Grupa czynników ograniczających rozwój małej i średniej przedsiębiorczości zaliczana do barier wytwórczych ma pewne powiązanie z barierami finansowymi. Do najważniejszych barier w tym zakresie można zaliczyć niski stopień nowoczesności wyposażenia przedsiębiorstw, niezadowalający stan parku maszynowego, stosowanie przestarzałych technologii. Związane jest to z ograniczonym dostępem do kapitału inwestycyjnego. 
Do barier organizacyjnych zalicza się trudności w funkcjonowaniu przedsiębiorstwa jako organizacji, m.in. kierowanie, delegowanie uprawnień, kontrolę, wyróżnienie formalne działów funkcjonalnych. Często kłopoty z organizacją są związane z niskim poziomem wiedzy w tym zakresie u osób rozpoczynających działalność gospodarczą. Trudnością-szczególnie podczas rozpoczynania działalności gospodarczej - jest wybór formy prawnej dla działalności oraz formy rozliczania się z urzędem skarbowym.

Pewne czynniki zaliczane do barier organizacyjnych związane są z brakiem informacji, doradztwa i edukacji. Te czynniki nabierają znaczenia na obszarach wiejskich ze względu na słabszy na wsi niż w mieście rozwój infrastruktury technicznej i społecznej. Dlatego też powstają inkubatory i agroinkubatory przedsiębiorczości, których zadaniem jest poprawa informacji, doradztwa, edukacji, jednak ich liczba jest niewystarczająca. Osoba pragnąca podjąć działalność gospodarczą często nie wie, gdzie zgłosić się po poradę w tej sprawie. Poprawić tę sytuację może informacja i edukacja propagująca przedsiębiorczość. Warto ją rozpoczynać już w szkole, a następnie kontynuować w formie różnych kursów. Jakkolwiek trafne jest powiedzenie, że jeśli ktoś szuka, to znajdzie, jednak można ułatwić te poszukiwania dzięki szerszej informacji.

Bariery związane z infrastruktura, wymieniane przez przedsiębiorców-praktyków najczęściej, to zły stan dróg i słaby rozwój sieci telekomunikacyjnej na obszarach wiejskich.

Kolejnymi barierami są: niestabilność prawa, częste zmiany polityki fiskalnej oraz sztywność kodeksu pracy. Od 2003 r. obowiązuje znowelizowany kodeks pracy, który w zamyśle ustawodawcy miał być korzystny dla pracodawców i skłaniać ich do tworzenia nowych miejsc pracy. W opinii pracodawców zawiera on wiele dobrych rozwiązań prawnych, dotyczących m.in. nowych zasad zwolnień grupowych, okresów zatrudniania pracowników, umowy o zastępstwo. Jednak dla wielu przedsiębiorców nadal barierą są duże obciążenia podatkowe i parapodatkowe, kształtujące wysokie koszty pracy.

Przedsiębiorcy dostrzegają wiele czynników ograniczających również w prawie podatkowym, m.in. wspomniany wcześniej zbyt wysoki poziom obciążeń podatkowych, represyjność systemu podatkowego, niejasność i nieczytelność przepisów, zmienność prawa podatkowego (zasady naliczania podatku i stosowania ulg były często zmieniane, nawet corocznie).

Istotną barierę rozwoju przedsiębiorczości stanowią czynniki związane z wewnętrznym środowiskiem przedsiębiorców. Chodzi głównie o małą solidarność i dezintegrację środowiska przedsiębiorców, niechęć do podejmowania wspólnych inicjatyw i do kooperacji, czego skutkiem jest brak silnych organizacji reprezentujących interesy środowiska przedsiębiorców, szczególnie przedsiębiorców z obszarów wiejskich (Sawicka 2000). Do tej grupy czynników ograniczających można również zaliczyć wysokie ryzyko kupieckie jako następstwo braku etyki i niesolidności części przedsiębiorców.

Biorąc pod uwagę środowisko wewnętrzne przedsiębiorców, należy również wspomnieć o nich samych jako o podmiocie należącym do tego środowiska i kształtującym je. Większość osób podejmujących działalność gospodarczą musi mieć pewne predyspozycje osobowościowe, m.in. skłonność do podejmowania ryzyka, komunikatywność, szeroko pojętą otwartość zarówno na ludzi, jak i wszelkiego rodzaju nowości techniczne, produkcyjne, organizacyjne. Nie wszyscy też zdają sobie sprawę, że te cechy należy rozwijać. Wielu osobom potrzebny jest wzorzec do naśladowania. Istotną rolę w tej dziedzinie mogą odgrywać inkubatory przedsiębiorczości, agroinkubatory, ośrodki doradztwa rolniczego i inne instytucje informacyjno-doradcze oraz liderzy przedsiębiorczości.

\section{Bariery i czynniki wpływające niekorzystnie na działalność gospodarczą}

W świetle wyników badań empirycznych, wśród małych i średnich przedsiębiorstw działających na obszarach wiejskich woj. łódzkiego najczęściej występujące bariery w prowadzeniu 
własnej działalności gospodarczej to częste zmiany w systemie podatkowym, uciążliwe dla 80\% ankietowanych. Duże trudności sprawiają także zatory płatnicze (prawie 70\%) oraz ograniczony dostęp do źródeł finansowania działalności gospodarczej (ponad 50\%).

Ryc. 1. Najczęściej występujące bariery w prowadzeniu działalności gospodarczej (w \%)

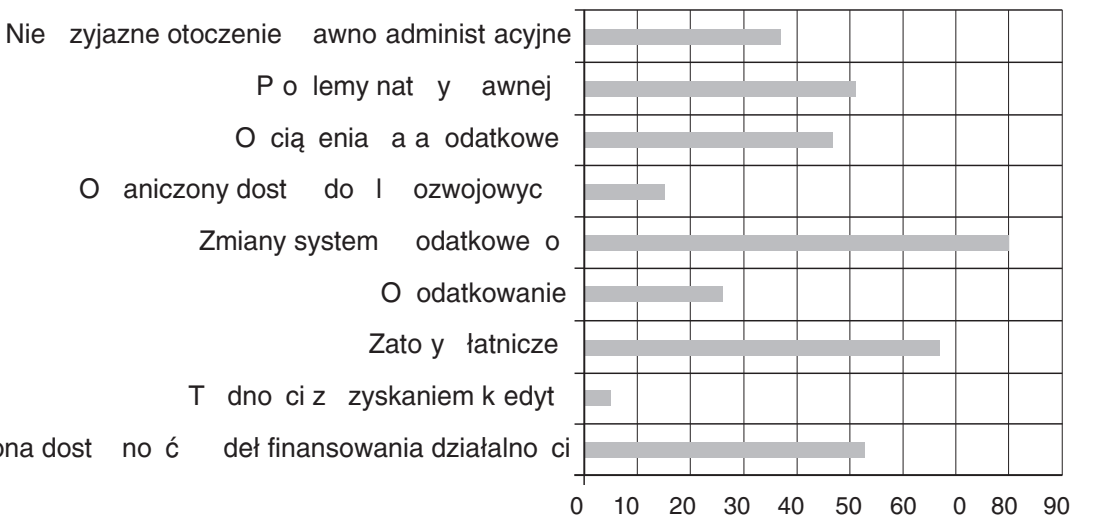

Uwaga. Suma $>100 \%$, gdyż ankietowani mogli wybrać więcej niż 1 odpowiedź

Źródło: opracowanie autora na podstawie badań empirycznych

Dla więcej niż połowy badanych istotną barierę stanowiły problemy natury prawnej, takie jak niestabilność, zmienność i niezrozumiałość systemu prawnego, nieskuteczność wymiaru sprawiedliwości. Na kolejnym miejscu wskazywano obciążenia o charakterze parapodatkowym związane z pracą i składki na ubezpieczenia społeczne. Natomiast problemy natury fiskalnej i zły rozwój infrastruktury, a także niekorzystny system opodatkowania nie stanowiły bariery w funkcjonowaniu ankietowanych przedsiębiorstw. Podobne bariery były wymieniane przez ankietowanych w projekcie badawczym Aktywizacja zawodowa kobiet wiejskich ze szczególnym uwzględnieniem drobnej przedsiębiorczości, prowadzonym w SGGW w latach 1996-1997 pod kierunkiem J. Sawickiej (Sawicka 1998).

Ryc. 2. Czynniki wpływające niekorzystnie na rozwój pozarolniczej działalności gospodarczej na terenach wiejskich (w \%)

Brak wykwalifikowanej siły roboczej

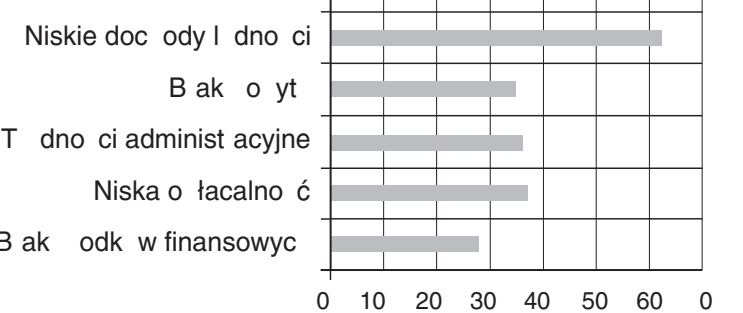

Uwaga. Suma > 100\%, gdyż ankietowani mogli wybrać więcej niż 1 odpowiedź.

Źródło: opracowanie autora na podstawie badań empirycznych 
Do barier rozwoju przedsiębiorczości można również zaliczyć czynniki, które w opinii ankietowanych przedsiębiorców wpływały niekorzystnie na rozwój pozarolniczej działalności gospodarczej na terenach wiejskich (ryc. 2). Czynnikiem najbardziej niekorzystnym były niskie dochody ludności, ograniczające potencjalny popyt w rejonie działania badanych przedsiębiorstw. Na niską opłacalność działalności gospodarczej, trudności natury administracyjnej, czyli biurokrację, oraz mały popyt na oferowane produkty i usługi wskazało ponad $35 \%$ badanych przedsiębiorców. Na niewystarczający popyt zwróciły uwagę wszystkie przedsiębiorstwa średnie i większość firm jednoosobowych.

\section{Podsumowanie}

Prowadząc działalność gospodarczą, przedsiębiorca styka się z różnorodnymi barierami. Często są one dla danej jednostki nie do pokonania i wymuszają zakończenie działalności. Najważniejsze jest prawidłowe zidentyfikowanie pojawiających się barier oraz właściwe dobranie środków do ich przezwyciężenia. Bariery i ograniczenia, jakie spotykają małe i średnie przedsiębiorstwa, można dzielić w zależności od poziomu rozwoju, lokalizacji i skali prowadzonej działalności gospodarczej. Gradacja barier jest uzależniona od specyfiki działalności.

Najczęściej występującymi barierami były zmiany systemu podatkowego, zatory płatnicze oraz ograniczona dostępności źródeł finansowania. Wśród czynników niekorzystnie wpływających na rozwój pozarolniczej działalności gospodarczej na terenach wiejskich, za najistotniejsze respondenci uznali niskie dochody ludności, które ograniczają lokalny popyt. Prowadzenie jakiejkolwiek działalności wiąże się z barierami w jej rozpoczynaniu, funkcjonowaniu i rozwoju. Najważniejsze jednak jest takie podejście do ich pokonywania, aby przyczyniały się one do pozytywnego rozwoju działalności.

\section{Literatura}

1. Aktywizacja zawodowa kobiet wiejskich poprzez rozwój drobnej przedsiębiorczości, t. II, Funkcjonowanie matych i średnich przedsiębiorstw prowadzonych przez kobiety, 1998, J. Sawicka (red.), Fundacja ROZWÓJ SGGW, Warszawa

2. Ekonomika i zarzqdzanie mała firma, 1999, B. Piasecki (red.), Wydawnictwo Naukowe PWN, Warszawa-Łódź

3. Sikorska A., 2001, Przedsiębiorczość na wsi w świetle ankiety IERiGŻ 2000, Komunikaty, raporty, ekspertyzy, z. 472, Wydawnictwo IERiGŻ, Warszawa

4. Założenie i prowadzenie małego przedsiębiorstwa, 2000, J. Sawicka (red.), Wydawnictwo SGGW, Warszawa

\section{The Main Barriers for Development and Performance of Small and Medium-sized Enterprises (SMEs) in Rural Areas of Kódź Province}

The contents of the report touches the problem of prospects and threats for development of the sector of small and medium enterprises in the rural area. The following problems are described: some groups of factors that constitute barriers to business of SME sector in rural areas. 


\section{Renata Rettinger}

Zakład Geografii Regionalnej

Instytut Geografii

Akademia Pedagogiczna w Krakowie

\section{Gospodarstwa farmerskie jako forma aktywizacji gospodarczej obwodu lwowskiego}

Uzyskanie przez Ukrainę niezależności politycznej zapoczątkowało trudny okres przebudowy jej struktury ekonomicznej i unowocześniania większości sfer życia społeczno-gospodarczego. Warunki, w jakich dokonują się zmiany, są jednak bardzo skomplikowane. Kraj stanowił wcześniej część ZSRR, w ramach którego spełniał określone funkcje gospodarcze i był silnie zespolony więzami produkcyjnymi z całą gospodarką radziecką. Gwałtowne zerwanie tych powiązań w wyniku rozpadu ZSRR doprowadziło do powstania wielu ograniczeń normalnego funkcjonowania państwa i spowodowało konieczność restrukturyzacji jego gospodarki. Największe problemy pojawiły się w przedsiębiorstwach przemysłowych kooperujących w okresie istnienia ZSRR $\mathrm{z}$ wieloma fabrykami, rozsianymi nieraz po całym kraju. Nieprzypadkowo więc w tych dziedzinach gospodarki Ukrainy regres jest największy i zmiany restrukturyzacyjne są mało widoczne.

Szczególnie skomplikowana sytuacja występuje w ukraińskim rolnictwie, które w ciągu zaledwie kilku ostatnich lat drastycznie ograniczyło produkcję roślinną oraz hodowlę, co stało się przyczyną poważnych problemów ogólnonarodowych związanych z dostawą produktów żywnościowych na rynek wewnętrzny i na eksport.

Tymczasem doświadczenia państw Europy Środkowej dowodzą, że dla początkowego okresu przechodzenia od gospodarki centralnie sterowanej do gospodarki rynkowej niezmiernie istotne jest uzyskanie w miarę stabilnej sytuacji w zakresie zaopatrzenia kraju w podstawowe artykuły żywnościowe. W tych krajach, podobnie jak na Ukrainie, wydatki na żywność pochłaniają bowiem około $50 \%$ ogółu wydatków, a w rodzinach o niskich dochodach - nawet $75 \%$. Sukcesy w budowie nowych struktur gospodarczych w Polsce, Czechach i na Węgrzech są w znacznym stopniu związane z relatywnie korzystną sytuacją w rolnictwie, dzięki której własna produkcja zaspokaja potrzeby żywnościowe i stanowi ważny produkt eksportowy. W stosunku do tych krajów sytuacja w rolnictwie Ukrainy, podobnie zresztąjak i Rosji, jest o wiele mniej korzystna. Potrzebne są zdecydowane reformy ustrojowe i strukturalne w samym rolnictwie oraz w innych ogniwach gospodarki żywnościowej.

Jednak zarówno uwarunkowania zewnętrzne, jak i wewnętrzne takich zmian są bardzo skomplikowane, nie udało się bowiem skutecznie ograniczyć trwającego od 1991 r. kryzysu, który negatywnie wpływa na rolnictwo Ukrainy i praktycznie uniemożliwia restrukturyzację kolektywnych gospodarstw, stanowiąca podstawowy warunek szerszych zmian w gospodarce kraju. Kryzys doprowadził do zasadniczej zmiany sposobu gospodarowania w rolnictwie. Rozpad ZSRR stworzył zupełnie nową sytuację dla ukraińskiego rolnictwa zarówno pod względem funkcji produkcyjnych, jak i warunków techniczno-ekonomicznych i społecznych, w jakich rolnicze przedsiębiorstwa muszą działać. Gwałtowny wzrost inflacji sparaliżował działalność inwestycyjną oraz proces odradzania technologicznego i strukturalnego gospodarstw rolnych. 
W ocenach dotychczasowych zmian na Ukrainie zwraca się uwagę na to, że istniejący kryzys gospodarczy odzwierciedla się w największym stopniu w rolnictwie, a przeprowadzone reformy nie wpływają aktywizująco na gospodarstwa rolne. Temu kryzysowi można nawet przypisać znaczny wpływ na produkcję rolnicza, skutkujący jej spadkiem. Spadek jest największy spośród wszystkich krajów byłego ZSRR i dotyczy wszystkich podstawowych dziedzin rolnictwa. W latach 1990-2000 zbiory zbóż na Ukrainie spadły z prawie $48 \mathrm{mln}$ ton do niewiele ponad $23 \mathrm{mln}$ ton, tzn. o ponad $52 \%$, a przeciętne plony o $47 \%$, do $19,3 \mathrm{~g} /$ ha, tzn. do poziomu, który notowano w tym kraju na początku lat 60 . XX w. Wtedy jednak tutejsze rolnictwo znajdowało się w stadium powojennej odbudowy, zużywało niewiele nawozów i środków ochrony roślin, było bardzo słabo zmechanizowane. W $2005 \mathrm{r}$. zanotowano stosunkowo wysokie zbiory $-37 \mathrm{mln}$ ton, co było spowodowane bardzo dobrymi warunkami pogodowymi w tym roku. Spośród pozostałych roślin zwiększyły się jedynie zbiory ziemniaków (o 33\%) oraz kukurydzy (o 108\%). Spadek produkcji zbóż spowodował ogromny regres w hodowli, zwłaszcza trzody chlewnej, owiec i drobiu. Zwierzęta należały w dużej części do gospodarstw przyzagrodowych. Hodowano je, wykorzystując do tego celu chleb kupowany po bardzo niskich cenach. W 2005 r. hodowano na Ukrainie zaledwie 6,4 mln sztuk trzody chlewnej (w 1990 r. około $20 \mathrm{mln}$ - spadek o 68\%). Podobna sytuacja powstała hodowli bydła: w 1990 r. hodowano 24,6 mln sztuk, a w 2005 r. 6,9 mln sztuk (spadek o 72\%).

\section{Prawne podstawy rozwoju gospodarstw farmerskich na Ukrainie}

Od momentu uzyskania niepodległości, w gospodarce Ukrainy widoczny jest brak konsekwentnie realizowanych reform gospodarczych. Połowiczne i jedynie deklarowane reformy dotyczą także rolnictwa ukraińskiego, w którym dokonano powierzchownej restrukturyzacji kolektywnych gospodarstw rolnych (Grykień 2006). Podstawowym problemem jest brak regulacji prawnych, który ogranicza w znacznym stopniu powstawanie nowych form gospodarowania ziemia, a przede wszystkim stanowi barierę dla funkcjonowania oficjalnego rynku ziemi.

Aktualna struktura agrarna jest wynikiem wprowadzenia w grudniu 1999 r. Dekretu Prezydenta Ukrainy „O potrzebie zastosowania natychmiastowych zabiegów w celu przyspieszenia reform w rolnictwie". Zgodnie z tym dokumentem nastapiły istotne zmiany typu społeczno-gospodarczego i organizacyjnego. Ważny krok zrobiono w kierunku sformowania nowej struktury organizacyjnej sektora rolnego. Obecnie niemal wszystkie podmioty prowadzące działalność gospodarczą w rolnictwie tworzone są na zasadach prywatnej własności ziemi i innych środków produkcji, m.in. towarzystwa gospodarcze, rolnicze spółdzielnie produkcyjne, przedsiębiorstwa prywatne dzierżawiące ziemię. Dekret umożliwił wydzielenie - z jednolitego obszaru - części ziemi grupom właścicieli w celu organizacji wspólnego zagospodarowania, przekazania go w dzierżawę lub zagospodarowania w inny sposób (na przykład sprzedaży). Z dekretu wynika także rozporządzenie, że ,podczas zawierania umowy o dzierżawie ziemi, podstawą prawną jest certyfikat dający prawo do własności ziemi. Jest on dokumentem, który potwierdza prawo dzierżawcy do zarządzania, korzystania i rozporządzania wyznaczonym kawałkiem ziemi”. Dzięki tym przepisom umożliwiono tworzenie działek ziemskich o nowych strukturach, które zostały utworzone na bazie gospodarstw społecznych metodą dzierżawy części ziemi, bez konieczności ich parcelowania.

W 1991 r. na Ukrainie państwowa własność ziemi stanowiła prawie 100\% użytków rolnych. Konstytucja przewiduje trzy formy własności: prywatną, państwową i komunalną. Podstawy prawne tworzenia gospodarstw farmerskich zostały zawarte w kodeksie rolnym. Nieruchomości rolne niezbędne do prowadzenia gospodarstw farmerskich przekazywane są na własność lub w użytkowanie z gruntów państwowego ,zapasu” ziemi. W przypadku kołchozów i sowchozów dawnym pracownikom mogą być przekazywane nieruchomości rolne z areału tych jednostek. Powierzchnia nowo tworzonego gospodarstwa nie powinna przekraczać 50 ha użytków rolnych i 100 ha powierzchni ogólnej 


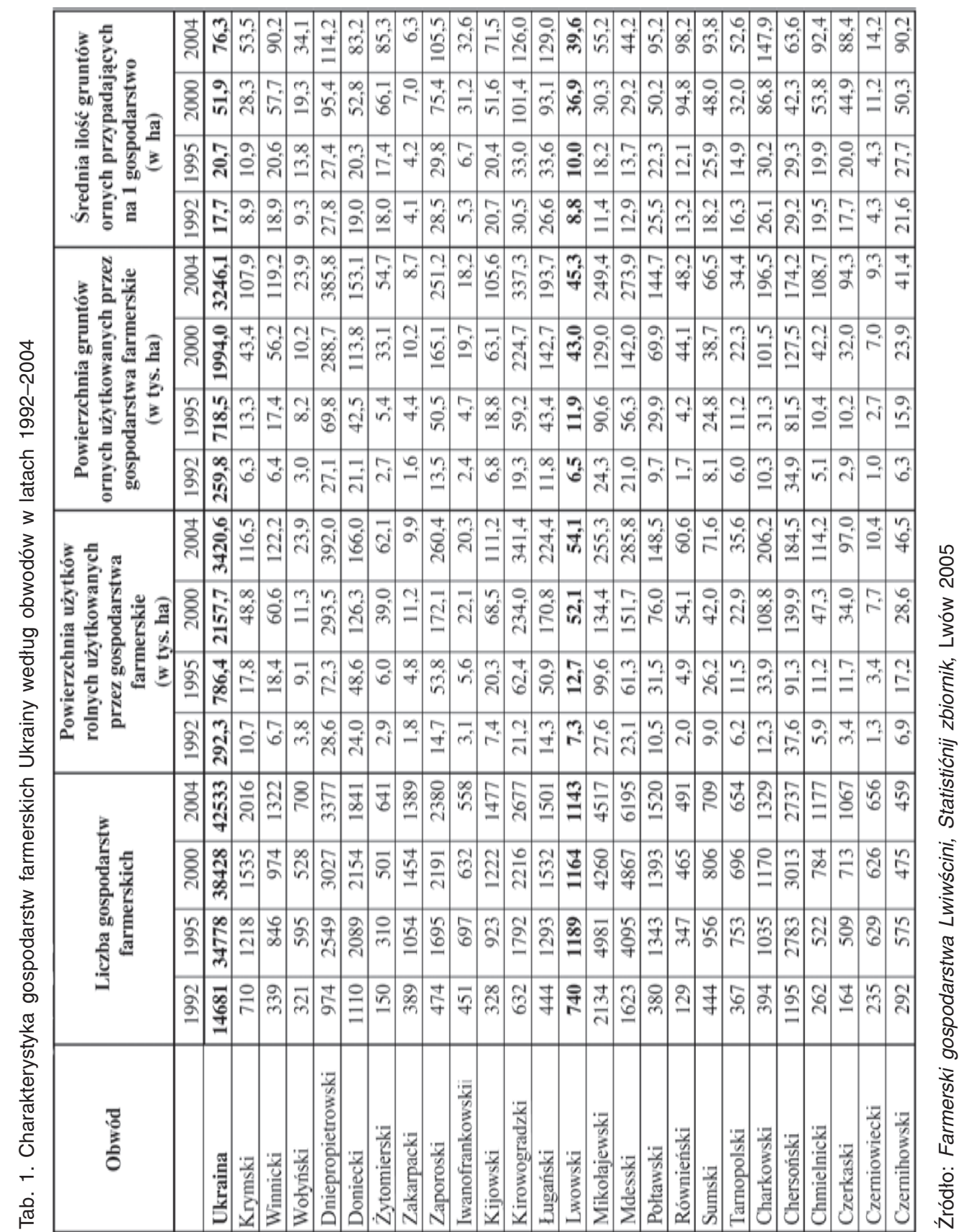


(w tym działka przyzagrodowa). W wielu regionach Ukrainy dopuszczalne są pewne odstępstwa od tej reguły, ponieważ ostateczną wielkość gospodarstwa określają rady rejonowe lub wiejskie po uwzględnieniu regionalnej specyfiki rolnictwa oraz możliwości zagospodarowania ziemi. W skład gruntów gospodarstw farmerskich wchodzą bezpłatne działki, których wielkość jest określana odrębnie dla każdej miejscowości; pozostałą część nabywa się odpłatnie (Grykień 2006).

Prawo do tworzenia gospodarstw farmerskich mają obywatele Ukrainy, którzy ukończyli 18 lat. Pierwszeństwo przysługuje mieszkańcom wsi mającym kwalifikacje do pracy w rolnictwie. W praktyce są to głównie członkowie likwidowanych rolniczych spółdzielni produkcyjnych oraz ich domownicy. Do obowiązków właścicieli należy zarejestrowanie gospodarstwa farmerskiego w radzie. W ten sposób właściciel uzyskuje status osoby prawnej. Nowe gospodarstwa są na okres trzech lat zwolnione od opłaty za ziemię, lecz nie mogą to być gospodarstwa dzielone.

\section{Zmiany w liczbie oraz powierzchni gospodarstw farmerskich}

Proces tworzenia gospodarstw farmerskich na Ukrainie rozpoczął się w $1991 \mathrm{r}$. W pierwszym roku powstało ich 81, a w 1993 r. funkcjonowało już 20 tys. gospodarstw. Obecnie na terytorium Ukrainy zarejestrowanych jest 42,5 tys. gospodarstw farmerskich. Stagnacja w tworzeniu nowych jednostek trwała w drugiej połowie lat 90. XX w. (tab. 1).

Niemal od początku reform obserwuje się znaczne różnice w przestrzennym przebiegu zjawiska prywatyzacji rolnictwa, szczególnie zaś powstawania i rozwoju gospodarstw farmerskich. Najwięcej gospodarstw farmerskich jest w obwodach: odesskim (około 6,2 tys.), mikołajewskim (4,5 tys.) oraz dniepropietrowskim (3,3 tys.). Najmniejszą liczbę gospodarstw tego typu odnotowano w obwodach: czernihowskim, rówieńskim, iwanofrankowskim, czerniowieckim, tarnopolskim i żytomierskim. Jest prawidłowością, że tego typu gospodarstwa nie powstają tak licznie w obwodach charakteryzujących się słabszymi warunkami przyrodniczymi. Należą do nich obszary północnej części kraju (Polesie), zachodniej oraz południowo-zachodniej (Karpaty). W obwodzie lwowskim w 2004 r. funkcjonowały 1143 gospodarstwa farmerskie, a w latach 1995-2004 liczba ta ulegała niewielkim wahaniom (tab. 1).

Gospodarstwa farmerskie otrzymały w użytkowanie 3,4 mln użytków rolnych, z czego 95\% stanowią grunty orne (tab. 1). Ziemie użytkowane przez gospodarstwa farmerskie stanowią zaledwie 8,4\% użytków rolnych i 9,9\% gruntów ornych Ukrainy. Średnia wielkość gospodarstwa farmerskiego w 2004 r. wynosiła 80,4 ha (w 1992 r. około 19,9 ha). Największe gospodarstwa występują we wschodniej i południowo-wschodniej części Ukrainy (strefa stepowa). W obwodzie charkowskim średnia wielkość gospodarstwa to 155,2 ha, w ługańskim - 149,1 ha, w kirowogradzkim - 127,5 ha, w dniepropietrowskim - 116,1 ha. Najmniejsze gospodarstwa powstały w obwodach: zakarpackim - 7,1 ha, czerniowieckim - 15,9 ha, wołyńskim - 34,1 ha, iwanofrankowskim - 36,4 ha. W obwodzie lwowskim średnia wielkość gospodarstwa farmerskiego wynosi 47,3 ha i jest prawie dwukrotnie mniejsza niż średnia krajowa.

Przestrzenne zróżnicowanie liczby i wielkości gospodarstw farmerskich w obwodzie lwowskim przedstawia tab. 2. Największa liczba tych gospodarstw działa w rejonach sokalskim, pustomyckim i żółkiewskim, a najmniejsza w rejonach skolskim i turskim (najdalej na południe wysunięte rejony obwodu lwowskiego). Największe gospodarstwa położone są w rejonach: samborskim (153,7 ha), buskim (92,0 ha), żydaczewskim, sokalskim i stryjskim. Najmniejsze gospodarstwa są charakterystyczne dla rejonów położonych na obszarze Karpat (skolski i turski).

Struktura zasiewów w gospodarstwach farmerskich obwodu lwowskiego przedstawia się następująco: 71,6\% gruntów ornych przeznacza się pod uprawy zbożowe, 16,3\% pod uprawy pastewne, 2,9\% pod buraki cukrowe, 2,5\% pod ziemniaki, 2,1\% pod uprawę lnu, a 1,4\% - pod sady owocowe. W przypadku gospodarstw farmerskich zauważa się specjalizację w zakresie 


\begin{tabular}{|c|c|c|c|c|c|c|c|c|c|c|c|c|c|c|c|c|c|c|c|c|c|}
\hline 产 & 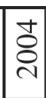 & 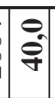 & 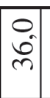 & $\begin{array}{l}0 \\
\infty \\
0\end{array}$ & 임 & 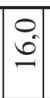 & m. & $\begin{array}{l}0 \\
\text { î }\end{array}$ & $\begin{array}{l}0 \\
\dot{m} \\
\dot{m}\end{array}$ & $\begin{array}{l}0 \\
\text { j. } \\
\text {. }\end{array}$ & $\frac{0}{m}$ & 이 & ते & $\stackrel{0}{\infty}$ & $\begin{array}{c}0 \\
m\end{array}$ & ה & $c$ & $\begin{array}{l}0 \\
0 \\
0\end{array}$ & \begin{tabular}{l}
8 \\
\multirow{2}{*}{} \\
0
\end{tabular} & $\circ$ & $\begin{array}{l}0 \\
2 \\
2\end{array}$ \\
\hline 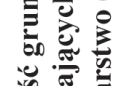 & ঃ্ & 穴 & 0 & $\frac{0}{m}$ & $\ddot{0}$ & : & $\begin{array}{l}0 \\
\dot{t}\end{array}$ & $\begin{array}{l}0 \\
0 \\
m\end{array}$ & $\begin{array}{l}0 \\
F \\
F\end{array}$ & \begin{tabular}{l|l}
0 & \\
ते
\end{tabular} & $\begin{array}{l}0 \\
\therefore \\
=\end{array}$ & $\begin{array}{l}0 \\
\text { in } \\
\text { in }\end{array}$ & $\begin{array}{ll} & 0 \\
0 & 0\end{array}$ & $\begin{array}{l}0 \\
= \\
=\end{array}$ & $\frac{0}{m}$ & $\begin{array}{l}0 \\
\vdots \\
2 \\
2\end{array}$ & :iil & 5 & $\begin{array}{l}0 \\
0 \\
1\end{array}$ & $\therefore$ & $\begin{array}{l}0 \\
0 \\
+ \\
+\end{array}$ \\
\hline & $\stackrel{2}{2}$ & 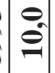 & 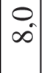 & $\begin{array}{l}0 \\
\infty\end{array}$ & $\ddot{0}$ & $\therefore$ & i & $\therefore$ & $\begin{array}{l}0 \\
\stackrel{2}{2}\end{array}$ & $\stackrel{0}{=}$ & $=$ & :- & $\therefore$ & $\stackrel{\circ}{\circ}$ & $\begin{array}{l}a^{\circ} \\
\sigma^{2}\end{array}$ & $\stackrel{0}{ \pm}$ & i. & $=0$ & 0 & 아. & 0 \\
\hline & ๙ิ & $a$ & $\therefore$ & $\therefore$ & बे & $\begin{array}{l}0 \\
0\end{array} \mid$ & $\stackrel{0}{0}$ & $\therefore$ & $\stackrel{\circ}{\circ}$ & $\begin{array}{c}0 \\
\infty \\
\infty\end{array}$ & $\begin{array}{l}0 \\
=\end{array}$ & $\begin{array}{l}0 \\
\mathrm{i}\end{array}$ & 임 & ㅇ. & $\stackrel{0}{\varrho}$ & $\infty$ & î. & i. & $\mid \begin{array}{l}0 \\
n\end{array}$ & ᄋी & 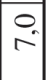 \\
\hline 胥 & $\begin{array}{l}\text { ठे } \\
\text { ¿ }\end{array}$ & 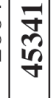 & $\Xi$ & 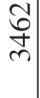 & 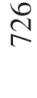 & 年 & 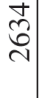 & $\begin{array}{l}\infty \\
\sigma \\
\sigma\end{array}$ & ลે & 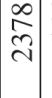 & ?. & $\frac{5}{6}$ & $\begin{array}{c}7 \\
\text { s }\end{array}$ & 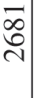 & $\begin{array}{c}m \\
n \\
n\end{array}$ & $\begin{array}{l}\hat{n} \\
\infty \\
\infty \\
\end{array}$ & $\underline{0}$ & ई & 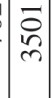 & & $\stackrel{0}{0}$ \\
\hline 毛嵒 & ঠి & $\mid$ & & $\curvearrowleft$ & & 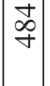 & $\bar{\sigma}$ & 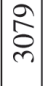 & & $\begin{array}{c}\infty \\
2 \\
n \\
-\end{array}$ & 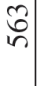 & $\stackrel{ }{0}$ & $\frac{?}{\infty}$ & - & 尺 & $\begin{array}{l}\text { dे } \\
0 \\
0\end{array}$ & & & $\mid \begin{array}{l}0 \\
\hat{0} \\
i \\
n\end{array}$ & $\bar{\sigma}$ & 寻 \\
\hline
\end{tabular}

कo

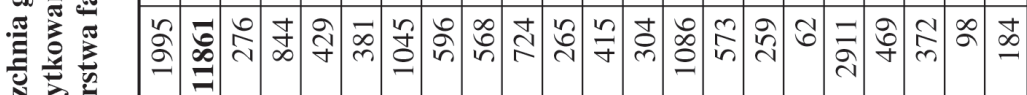

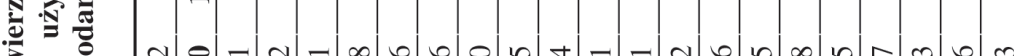

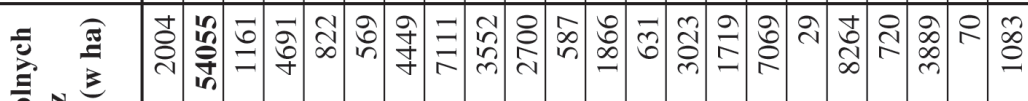
잉

安范

可

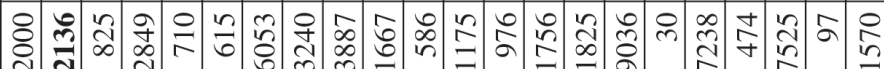

철

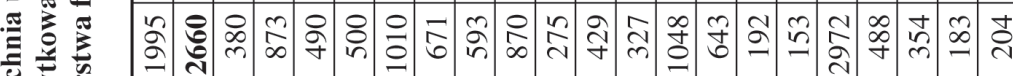

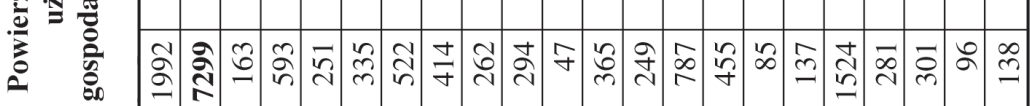

ปั

递

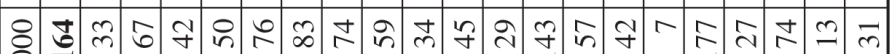
N

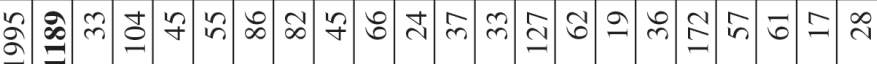

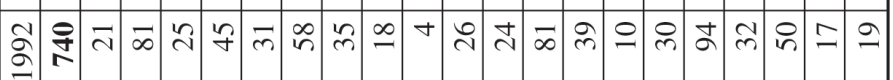


uprawy zbóż, gospodarstwa przyzagrodowe zaś mają bardziej zróżnicowaną strukturę zasiewów: $33,9 \%$ przeznacza się pod uprawę zbóż; $28,9 \%$ pod uprawy pastewne, a 27,3\% pod ziemniaki.

Analizując rolę gospodarstw farmerskich w produkcji rolnej obwodu lwowskiego należy stwierdzić, że od początku lat 90. XX w. obserwuje się tendencję wzrostu w zakresie zarówno produkcji roślinnej, jak i zwierzęcej. Udział gospodarstw farmerskich w zbiorach poszczególnych roślin w obwodzie lwowskim w 2004 r. przedstawia się następująco: zboża 8,5\%, buraki cukrowe 7,7\%, len $40,1 \%$, ziemniaki $0,5 \%$, owoce $1,4 \%$.

Jeszcze mniejszą rolę odgrywają gospodarstwa farmerskie w zakresie produkcji zwierzęcej. Udział w pogłowiu głównych zwierząt gospodarskich jest bardzo niski: bydło 1,3\%, trzoda chlewna $1,8 \%$, owce i kozy $0,7 \%$, drób $1,5 \%$, konie $0,6 \%$.

Należy się zastanowić, dlaczego gospodarstwa farmerskie w zachodniej części Ukrainy, a w szczególności w obwodzie lwowskim, odgrywają tak niewielką rolę zarówno w produkcji roślinnej, jak i zwierzęcej. Wcześniejsza analiza wykazała, że występuje tam stosunkowo niewielka liczba gospodarstw farmerskich. Liczba nowo powstających gospodarstw farmerskich jest w dużej mierze uzależniona od ilości ziemi we władaniu gospodarstw przyzagrodowych w poszczególnych obwodach czy rejonach. W zachodniej części Ukrainy ludność wiejska posiada duże ilości gruntów rolnych użytkowanych w ramach gospodarstw przyzagrodowych, co może świadczyć o jej mniejszym zainteresowaniu tworzeniem od podstaw nowych gospodarstw, a w szczególności gospodarstw farmerskich, które podlegają odrębnym przepisom prawnym i fiskalnym. Drugim ważnym czynnikiem jest zachowanie na tych terenach tradycji chłopskiego gospodarowania na roli w odróżnieniu od obszarów wschodniej części, wcześniej zsowietyzowanej (Grykień 2006).

\section{Podsumowanie}

Na Ukrainie powstawanie indywidualnych gospodarstw rolnych odbywało się poprzez nadawanie pracownikom sowchozów i kołchozów tytułów własności ziemi, które mogły stanowić podstawę indywidualnego gospodarowania. Niestety, skomplikowana sytuacja legislacyjna oraz ekonomiczna spowodowały brak zainteresowania tą formą gospodarowania na obszarach wiejskich.

Znaczenie gospodarstw farmerskich jako nowej formy gospodarowania w rolnictwie jest na Ukrainie niewielkie i niewspółmierne do oczekiwań społeczeństwa. Główną barierą rozwoju jest brak kapitału, infrastruktury gospodarczej, zabudowań gospodarczych oraz środków produkcji (siły pociągowej, maszyn rolniczych, nawozów sztucznych i środków ochrony roślin). Ograniczenia wynikają także z niepewnego klimatu politycznego, częstych zmian w aktach prawnych odnoszących się do własności ziemi, czego skutkiem są poczucie niepewności i brak stabilności. To zaś ogranicza podejmowanie decyzji inwestycyjnych związanych z tworzeniem nowych gospodarstw rolnych - farmerskich.

Zmiany w polityce rolnej kraju powinny doprowadzić do stworzenia na wsi gospodarki wielosystemowej, ukierunkowanej na rzeczywistego właściciela i gospodarza ziemi. Zakres, tempo i jakość reformy rolnej zależą bezpośrednio od doskonalenia stosunków agrarnych. Szczególne znaczenie ma odtworzenie naturalnych związków łączących rolnika z ziemią, czyli właścicielem środków produkcji i konsumentem wypracowanych zysków. Indywidualne gospodarstwa rolne (przyzagrodowe, farmerskie) borykają się z dużymi trudnościami związanymi z niedostatkiem kapitału ograniczającym rozwój mechanizacji i budownictwa gospodarczego, ale także z brakiem pomocy prawnej ułatwiającej ich funkcjonowanie oraz poradnictwa naukowego w zakresie organizowania prywatnej działalności gospodarczej. Równocześnie należy stwierdzić, że w okresie transformacji, w związku z narastającymi problemami, znacznie lepiej radzi sobie sektor prywatny niż uspołeczniony. 


\section{Literatura}

1. Bański J., 1999., Obszary problemowe w rolnictwie Polski., „Prace Geograficzne” 172/1999, IGiPZ PAN, Wrocław

2. Bański J., 2003., Współczesne i przyszłe zmiany w strukturze przestrzennej obszarów wiejskich - wybrane zagadnienia., Studia Obszarów Wiejskich PTG, t. IV, Warszawa

3. Grykień S., 2006., Przekształcenia w rolnictwie Europy Środkowo-Wschodniej ze szczególnym uwzględnieniem nowych krajów zwiazkowych Niemiec, Polski i Ukrainy, Studia Geograficzne Uniwersytetu Wrocławskiego, Wrocław

4. Jaworowski P., 2003., Wybrane problemy przedsiębiorczości na obszarach wiejskich [w:] Obszary wiejskie w Polsce a integracja z Uniq Europejskq, C. Sobków, M. Zarębski (red.), Wydawnictwo Adam Marszałek, Toruń

5. Kołodziejczak A., 2003., Rola rolnictwa w perspektywie rozwoju społeczno-gospodarczego obszarów wiejskich w Polsce, Studia Obszarów Wiejskich PTG, t. IV, Warszawa

6. Rettinger R., 1998., Rola sektora prywatnego w rolnictwie Ukrainy, Rocznik Naukowo-Dydaktyczny WSP, Prace Geograficzne XVII, Kraków

\section{Farms as a Form of Economic Activation in Lwow District}

The article outlines economic changes in rural areas of Ukraina and especially focuses on the operating new, private farms. Individual farms in Ukraina came into being when workers from sovkhozy and kolkhozy got titles to the lands and were able to the individual farming. Unfortunately they were not interested in this form of farming because of complicated situation in a law and economy. Farms as the new form of agriculture in Ukraina are not important and do not fulfill expectations of the society. Lacks of capital, economic infrastructure, buildings, means of production (tractors, machines, fertilizers, plant pharmaceutics) is the main barrier to the development. Also unsteady political climate and frequent changes in property law are the restrictions that result a sense of incertitude and a lack of stability. Consequently it restricts decisions to investments in new farms. 



\section{Kapitał społeczny}

\section{w przedsiębiorczości}




\section{Monika Borowiec}

Zakład Przedsiębiorczości i Gospodarki Przestrzennej

Instytut Geografii

Akademia Pedagogiczna w Krakowie

\section{Rola szkolnictwa wyższego w podnoszeniu jakości kapitału ludzkiego}

W procesie wkraczania w informacyjną fazę rozwoju cywilizacyjnego i kształtowania gospodarki opartej na wiedzy wzrasta znaczenie problematyki szkolnictwa wyższego jako podstawowej bazy ekonomicznej biegunów rozwoju, czynnika wzrostu społeczno-gospodarczego i kulturowego oraz podnoszenia konkurencyjności układów lokalnych, regionalnych, krajowych i międzynarodowych. Zwiększające się znaczenie wiedzy jako zasobu produkcji powoduje, że w różnej skali układów przestrzennych czynnikiem determinującym wzrost konkurencyjności są kapitał ludzki oraz infrastruktura edukacyjna i naukowa, które przyspieszają rozwój nowoczesnych dziedzin gospodarki. W układach doceniających wiedzę i tworzących nowe struktury przestrzenne wokół aglomeracji zaznacza się wzrost innowacyjności i rozwój gałęzi przemysłu opartego na nowoczesnych technologiach (Pakulska 2005).

W świetle tych przesłanek należy przyjąć, że ważnym czynnikiem rozwoju aglomeracji jest rozwój instytucji edukacyjnych, który warunkuje poprawę jakości zasobów kapitału ludzkiego. „Kapitał ludzki ma ogromne znaczenie dla rozwoju regionalnego systemu innowacyjnego i decyduje o konkurencyjności zintegrowanego regionu miejskiego" (Kuciński, Kudłacz, Markowski, Ziobrowski 2002). Przyjmuje się również, że,,wiedza i technika zawsze były niezbędnymi katalizatorami przemian cywilizacyjnych. Obecnie, kiedy nasilają się procesy globalizacyjne, fundamentalną rolę odgrywa kreacja i praktyczne wykorzystanie wiedzy, a kapitał ludzki jest czynnikiem, bez którego nie jest możliwe osiągnięcie trwałego i wysokiego tempa rozwoju gospodarczego" (Janc 2003).

Wzrasta zatem rola wiedzy, kwalifikacji i postaw przedsiębiorczych nie tylko w wymiarze jednostkowym, które umożliwiają uzyskanie wysokiej pozycji na rynku pracy, ale przede wszystkim zwiększa się ich znaczenie jako czynnika rozwoju społecznego i aktywizacji gospodarczej różnej skali układów przestrzennych.

Przyjmuje się, że przyczyną głębokich przeobrażeń w strukturze i działalności szkół wyższych jest szybkie przechodzenie krajów z przemysłowego do informacyjnego etapu cywilizacyjnego (Kluczyński 1984, 1991). Proces ten charakteryzuje się:

- wzrostem możliwości generowania i przekazywania informacji oraz przyspieszeniem postępu naukowo-technicznego;

- uznaniem wiedzy i inteligencji za podstawowe zasoby gospodarki;

- nieustannym wzrostem znaczenia edukacji, zwłaszcza szkolnictwa wyższego, w związku z powstawaniem nowych zawodów wymagających wysokich kwalifikacji;

- koniecznością posiadania rozległej wiedzy w celu tworzenia i wykorzystywania informacji;

- dominowaniem miejsc pracy związanych z wytwarzaniem, transformacją i wykorzystaniem informacji. 
Można więc przyjąć, że wykształcenie będzie się liczyć nie ze względu na wartość samą w sobie, lecz jako inwestycja, zarówno z perspektywy społecznej, jak i jednostkowej, a współczesne tendencje rozwoju cywilizacyjnego prowadzą do wdrażania gospodarki opartej na wiedzy. Podstawową rolę w tym procesie odgrywa system szkolnictwa, który współdecyduje o innowacyjności gospodarki (Domański 2000, Rozkrut 2001). Można wnosić, że jakość funkcjonowania systemu nauki i szkolnictwa jest czynnikiem decydującym o kierunkach i poziomie rozwoju gospodarczego i społecznego państw.

Z istotnym zwiększeniem roli wykształcenia w określaniu szans na rynku pracy w Polsce wiąże się także rozwój gospodarki rynkowej. Szkoły wyższe muszą więc dostosować się do konieczności przygotowania dla gospodarki, nauki, oświaty i kultury określonych grup pracowników o nastawieniu innowacyjnym oraz kadr specjalistów do nowych zawodów lub przeobrażających się specjalności. Struktura społeczeństwa i struktura gospodarki wzajemnie się warunkują, ponieważ powstawanie nowych lub rozwój pewnych dziedzin działalności ekonomicznej wywołuje zapotrzebowanie na nowe kwalifikacje i zawody, a z kolei określona struktura społeczno-zawodowa determinuje potencjał modernizacyjny społeczeństwa. Rozumiany jest on jako zdolność i skłonność do konfrontacji oraz do przyjmowania wyzwań, jakie stawia przed nim proces zmian. Możemy przyjąć, że jest on pochodną systemu kształcenia, zależy bowiem od poziomu wykształcenia (tzn. im wyższe wykształcenie, tym większe możliwości sprostania wyzwaniom cywilizacyjnym i rozumienia zmieniającej się rzeczywistości).

Wielu autorów uważa, że wykształcenie jest ważnym elementem wzrostu społeczno-gospodarczego i traktowane jest jako istotny czynnik wpływający na jakość i wydajność pracy. Podkreślają to głównie przedstawiciele ekonomiki kształcenia, która najlepiej rozwinięta jest w krajach o wysokim poziomie rozwoju społeczno-gospodarczego ${ }^{1}$.

Inwestowanie w edukację i naukę staje się jedną z najistotniejszych i najefektywniejszych, a także najtańszych form inwestycji. T.W. Schultz $(1963,1976)$, który jest uznawany za autora koncepcji kapitału ludzkiego, określa ekonomiczną opłacalność nakładów na oświatę; w wyniku badań przyjmuje tezę, że inwestycje w wykształcenie są znacznie bardziej opłacalne niż inwestycje w kapitał rzeczowy, a szybkość rozwoju produkcji zależy od wysoko wykwalifikowanej kadry.

W literaturze przeważa podejście, że kapitał ludzki to wiedza produkcyjna, umiejętności i wykształcenie jednostek. Na kapitał ludzki składają się: zdolność do innowacji, wysoki poziom edukacji, zdolność do współpracy, umiejętność organizacji, zdolność systemu społecznego do odtwarzania i rozwoju kapitału ludzkiego (Markowski 1996).

M. Kabaj (1997) przytacza wyniki badań nad czynnikami wzrostu gospodarki Stanów Zjednoczonych, które dowodza, że 58\% wzrostu jej produktywności było efektem zwiększenia kwalifikacji kadr. Ponadto podaje wyniki badań przeprowadzonych przez Europejską Komisję Gospodarczą w Genewie, które wykazują że na tempo wzrostu gospodarki krajów Europy Zachodniej największy wpływ wywarły wiedza i postęp techniczny. Podobnie badania Banku Światowego podkreślają główną rolę wykwalifikowanej pracy w rozwoju gospodarczym i szacują, że udział zasobów kapitału w globalnym bogactwie wynosi 16\%, zasobów naturalnych $20 \%$, a zasobów ludzkich $64 \%$. Oznacza to, że inwestowanie w człowieka jest najważniejszym czynnikiem wzrostu i postępu społeczno-gospodarczego.

Również F. Harbison i Ch.A. Mayers (1964) w wyniku badań empirycznych stwierdzili, że rozwój gospodarczy w dużym stopniu zależy od rozmiarów i właściwego wykorzystania kapitału ludzkiego. Doszli oni do następujących wniosków:

${ }^{1}$ Badania w krajach wysoko rozwiniętych wskazują, że wzrost wykształcenia ludności w wieku produkcyjnym o $1 \%$ powoduje wzrost gospodarczy o $0,02-0,07$ p.p. (Pakulska 2005). 
- istnieje bezpośrednia zależność między stanem oświaty a poziomem rozwoju ekonomicznego państwa;

- wysokie nakłady na kształcenie są niezbędnym warunkiem rozwoju gospodarczego, a w przypadku państw słabo rozwiniętych - warunkiem przezwyciężenia zacofania;

- we wszystkich badanych państwach ludzie zdają sobie sprawę, że wykształcenie jest podstawą uzyskania pracy i osiagnięcia sukcesu w życiu.

Cywilizacja informacyjna jest cywilizacją szybkich zmian. Oznacza to konieczność reagowania na nowe uwarunkowania, a siłą motorycznąjej rozwoju jest jakość zasobów kapitału ludzkiego (Wasilewski, Kwiatkowski, Kozłowski 1997). „Współczesne wyzwania cywilizacyjne stawiają nowe, wysokie zdania w zakresie edukacji i przygotowania do pełnienia określonych ról zawodowych" (Zioło 1999). Edukacja powinna przygotowywać ludzi do adaptacji do nowych warunków pracy, tak aby mogli oni w sposób racjonalny wpływać na struktury, które w przyszłości będą podlegać przemianom.

Według W.R. Pawlaka (2001) każdy absolwent powinien mieć świadomość, że wiedza uzyskana podczas edukacji nie wystarczy na przyszłość, a zatem należy przyjąć, że konieczne będzie ciagłe jej aktualizowanie i będzie ona weryfikowana na rynku pracy. Sukces w rozwoju intelektualnym, czy to na poziomie jednostki, uczelni, przedsiębiorstwa, instytucji, czy to na poziomie organizacji będzie polegał na umiejętności korzystania z rozwijającej się wiedzy, łączenia jej różnych obszarów i praktycznego, szybkiego jej stosowania.

Oznacza to, że w obecnym procesie edukacyjnym główny nacisk należy stawiać nie tylko na wiedzę merytoryczna, ale i na umiejętności budowania warsztatu naukowego, który w dalszym okresie umożliwi podjęcie racjonalnych działań z zakresie dokształcania i systematycznego doskonalenia zawodowego.

W niniejszych rozważaniach przyjmujemy, że aglomeracje miejskie - będące zarazem ośrodkami akademickimi - na etapie cywilizacji informacyjnej mają do odegrania wiodącą rolę jako ogniska przemian i przyszłego rozwoju. Realizację przeważającej części potrzeb w zakresie kształcenia na poziomie wyższym i w zakresie badań gwarantuje ośrodek akademicki, będący zasadniczym miejscem koncentracji nauki w regionie. Dobrze rozwinięty ośrodek akademicki może zapoczątkować rozwój nowych form relacji środowiska naukowego z gospodarka, nie tylko miasta i regionu, ale także całego kraju. Można zatem wnosić, że jakość zasobów intelektualnych społeczeństwa w układach regionalnych w poważnym stopniu jest uzależniona od rozmieszczenia ośrodków szkolnictwa wyższego i ich dostępności oraz przestrzennego oddziaływania. Istotne w tym procesie jest zmniejszanie luki edukacyjnej między obszarami wiejskimi a miastami, jak bowiem zauważa E. Rydz (2006), w okresie transformacji gospodarki narodowej pogorszył się dostęp do szkolnictwa na wszystkich poziomach, zwłaszcza do szkolnictwa wyższego, co wynika nie tylko z istnienia barier systemowych i kulturowych, ale przede wszystkim - z istnienia barier ekonomicznych.

Częściową egzemplifikację tego szczególnie ważnego problemu przeprowadzono na przykładzie przestrzeni edukacyjnej woj. podkarpackiego.

Liczba uczelni w poszczególnych województwach jest zróżnicowania i waha się od 6 w woj. opolskim do 94 w woj. mazowieckim, a liczba studentów w uczelniach waha się odpowiednio od 36,8 tys. do 346,9 tys. (Borowiec 2006). W strukturze krajowej pod względem liczby uczelni i studentów wiodącą rolę odgrywa woj. mazowieckie, w którym znajduje się 24,1\% uczelni i studiuje 18,8\% studentów. Drugą pozycję zajmuje woj. śląskie, w którym jest 9,5\% uczelni i 10,9\% studentów, a następne - woj. małopolskie i woj. wielkopolskie, w których działa po 8,0\% uczelni, a studentów jest odpowiednio 9,6\% i 8,3\%. Woj. dolnośląskie skupia 8,7\% studentów i 7,4\% uczelni. Te pięć województw w strukturze sieci krajowej odgrywa główną rolę, skupiając 222 uczelnie (56,9\%) i 1,1 mln studentów (56,2\%).

Na tym tle potencjał edukacyjny woj. podkarpackiego jest stosunkowo niewielki, co wynika $\mathrm{z}$ jego rozwoju w zasadzie dopiero w latach powojennych. O niskiej pozycji szkolnictwa wyższego 
Tab. 1. Studenci i szkoły wyższe woj. podkarpackiego na tle polskich województw w 2004 r.

\begin{tabular}{|c|c|c|c|c|c|c|c|c|}
\hline \multirow[b]{2}{*}{ Województwa } & \multicolumn{4}{|c|}{ Liczba } & \multicolumn{4}{|c|}{ Struktura } \\
\hline & $\begin{array}{l}\text { studentów } \\
\text { ogólem }\end{array}$ & $\begin{array}{c}\text { szkól } \\
\text { wyższych }\end{array}$ & $\begin{array}{l}\text { filii i wydziałów } \\
\text { zamiejscowych }\end{array}$ & $\begin{array}{c}\text { punktów } \\
\text { konsultacyjnych }\end{array}$ & $\begin{array}{c}\text { studentów } \\
\text { ogólem }\end{array}$ & $\begin{array}{c}\text { szkół } \\
\text { wyższych }\end{array}$ & $\begin{array}{c}\text { punktów } \\
\text { konsultacyjnych }\end{array}$ & $\begin{array}{l}\text { filii i wydziałów } \\
\text { zamiejscowych }\end{array}$ \\
\hline Ogółem & 1846464 & $390 *$ & 105 & 72 & 100,00 & 100,00 & 100,00 & 100,00 \\
\hline Mazowieckie & 346860 & 94 & 16 & 3 & 18,79 & 24,1 & 4,17 & 15,24 \\
\hline Śląskie & 200421 & 37 & 13 & 5 & 10,85 & 9,49 & 6,94 & 12,38 \\
\hline Małopolskie & 177361 & 31 & 2 & 10 & 9,61 & 7,95 & 13,89 & 1,90 \\
\hline Dolnośląskie & 160686 & 29 & 8 & 5 & 8,7 & 7,44 & 6,94 & 7,62 \\
\hline Wielkopolskie & 152789 & 31 & 14 & 2 & 8,27 & 7,95 & 2,78 & 13,33 \\
\hline Lódzkie & 124462 & 25 & 7 & 5 & 6,74 & 6,41 & 6,94 & 6,67 \\
\hline Lubelskie & 101104 & 18 & 10 & 1 & 5,48 & 4,62 & 1,39 & 9,52 \\
\hline Pomorskie & 91237 & 25 & 3 & 7 & 4,94 & 6,41 & 9,72 & 2,86 \\
\hline Zachodniopomorskie & 88045 & 18 & 4 & 18 & 4,77 & 4,62 & 25 & 3,81 \\
\hline Kujawsko-pomorskie & 83422 & 15 & 6 & 1 & 4,52 & 3,85 & 1,39 & 5,71 \\
\hline Podkarpackie & 77453 & 17 & 6 & $\mathbf{5}$ & 4,19 & 4,36 & 6,94 & 5,71 \\
\hline Warmińsko-mazurskie & 58854 & 8 & 5 & 1 & 3,19 & 2,05 & 1,39 & 4,76 \\
\hline Świętokrzyskie & 56962 & 14 & - & 2 & 3,08 & 3,59 & 2,78 & - \\
\hline Podlaskie & 50642 & 15 & 8 & 1 & 2,74 & 3,85 & 1,39 & 7,62 \\
\hline Lubuskie & 39393 & 7 & 3 & 5 & 2,13 & 1,79 & 6,94 & 2,86 \\
\hline Opolskie & 36773 & 6 & - & 1 & 1,99 & 1,54 & 1,39 & - \\
\hline
\end{tabular}

* Bez szkół resortu obrony narodowej oraz resortu spraw wewnętrznych i administracji

Źródło: opracowanie autorki na podstawie Rocznika statystycznego województw, GUS, Warszawa 2004,

i Rocznika statystycznego Rzeczpospolitej Polskiej, GUS, Warszawa 2004 
tego województwa w kraju świadczy niewielki udział szkół wyższych i studentów kształcących się na jego obszarze w stosunku do ogólnej ich liczby w Polsce. W 2004 r. w woj. podkarpackim działało 17 uczelni, które stanowiły 4,3\% ogólnej liczby szkół wyższych w Polsce (tab. 1). Oprócz nich funkcjonowało 6 filii i wydziałów zamiejscowych oraz 5 punktów konsultacyjnych różnych uczelni (odpowiednio 6,9\% i 5,7\%). Woj. podkarpackie w skali kraju pod względem liczby uczelni zajmuje 10 miejsce. Wyprzedzająje woj. zachodniopomorskie i woj. lubelskie, w których działa po 18 uczelni, a za nim znajdują się woj. kujawsko-pomorskie i woj. podlaskie (po 15 uczelni).

Pod względem liczby studentów woj. podkarpackie (77,5 tys. studentów) zajmuje 11 pozycję (4,2\% ogólnej liczby studentów w Polsce). Wyprzedza je woj. kujawsko-pomorskie (84,3 tys. studentów), a za nim znajduje się woj. warmińsko-mazurskie (58,9 tys. studentów).

W latach transformacji gospodarki narodowej w woj. podkarpackim zaczęły powstawać niepaństwowe szkoły wyższe. Najstarszą na Podkarpaciu uczelnią niepaństwową, utworzoną w 1995 r., jest Wyższa Szkoła Administracji i Zarządzania w Przemyślu, która jako jedyna niepubliczna uczelnia w tym regionie ma uprawnienia magisterskie (na kierunku administracja). W $1996 \mathrm{r}$. powstały trzy kolejne niepaństwowe szkoły wyższe: Wyższa Szkoła Informatyki i Zarządzania w Rzeszowie, Wyższa Szkoła Zarządzania w Rzeszowie oraz Wyższa Szkoła Społeczno-Gospodarcza w Tyczynie, w 1997 r. powstała Wyższa Szkoła Ekonomiczna w Stalowej Woli, w 1999 r. - Wyższa Szkoła Gospodarki i Zarządzania w Mielcu, w 2000 r. - Wyższa Szkoła Inżynierii Rolniczej i Zarządzania w Ropczycach, a w 2001 r. - Wyższa Szkoła Gospodarcza w Przemyślu oraz Wyższa Szkoła Hotelarstwa i Turystyki w Lesku.

Łącznie w tych dziewięciu niepaństwowych szkołach wyższych kształci się 19,7 tys. studentów, co stanowi 27,8\% wszystkich studentów woj. podkarpackiego (tab. 2).

Tab. 2. Szkolnictwo wyższe w woj. podkarpackim w 2003 r.

\begin{tabular}{|l|c|c|c|c|}
\hline \multirow{2}{*}{ Ośrodek akademicki } & \multicolumn{2}{|c|}{ Liczba } & \multicolumn{2}{c|}{ Struktura } \\
\cline { 2 - 5 } & szkól wyższych & studentów & szkół wyższych & studentów \\
\hline Rzeszów & 4 & 47819 & 5,48 & 12,24 \\
\hline Przemyśl & 3 & 6854 & 4,11 & 1,75 \\
\hline Jarosław & 1 & 8206 & 1,37 & 2,10 \\
\hline Krosno & 1 & 2637 & 1,37 & 0,67 \\
\hline Tyczyn & 1 & 1359 & 1,37 & 0,35 \\
\hline Stalowa Wola & 1 & 1083 & 1,37 & 0,28 \\
\hline Tarnobrzeg & 1 & 934 & 1,37 & 0,24 \\
\hline Ropczyce & 1 & 605 & 1,37 & 0,15 \\
\hline Sanok & 1 & 556 & 1,37 & 0,14 \\
\hline Mielec & 1 & 543 & 1,37 & 0,14 \\
\hline Lesko & 1 & 282 & 1,37 & 0,07 \\
\hline Ogółem & $\mathbf{1 6}$ & $\mathbf{7 0 8 7 8}$ & $\mathbf{2 1 , 9 2}$ & $\mathbf{1 8 , 1 4}$ \\
\hline $\begin{array}{l}\text { Ogółem w poludniowo- } \\
\text {-wschodniej Polsce* }\end{array}$ & $\mathbf{7 3}$ & $\mathbf{3 9 0 7 5 3}$ & $\mathbf{1 0 0 , 0 0}$ & $\mathbf{1 0 0 , 0 0}$ \\
\hline
\end{tabular}

*Przyjmuje się, że obszar południowo-wschodniej Polski obejmuje województwa: podkarpackie, małopolskie, lubelskie i świętokrzyskie.

Źródło: opracowanie autorki na podstawie Rocznika statystycznego województwa podkarpackiego 2003 , Rocznika statystycznego województwa świętokrzyskiego 2003, Rocznika statystycznego województwa lubelskiego 2002 i Rocznika statystycznego województwa małopolskiego 2003 
Ryc. 1. Szkoły wyższe w woj. podkarpackim w 2002 r.

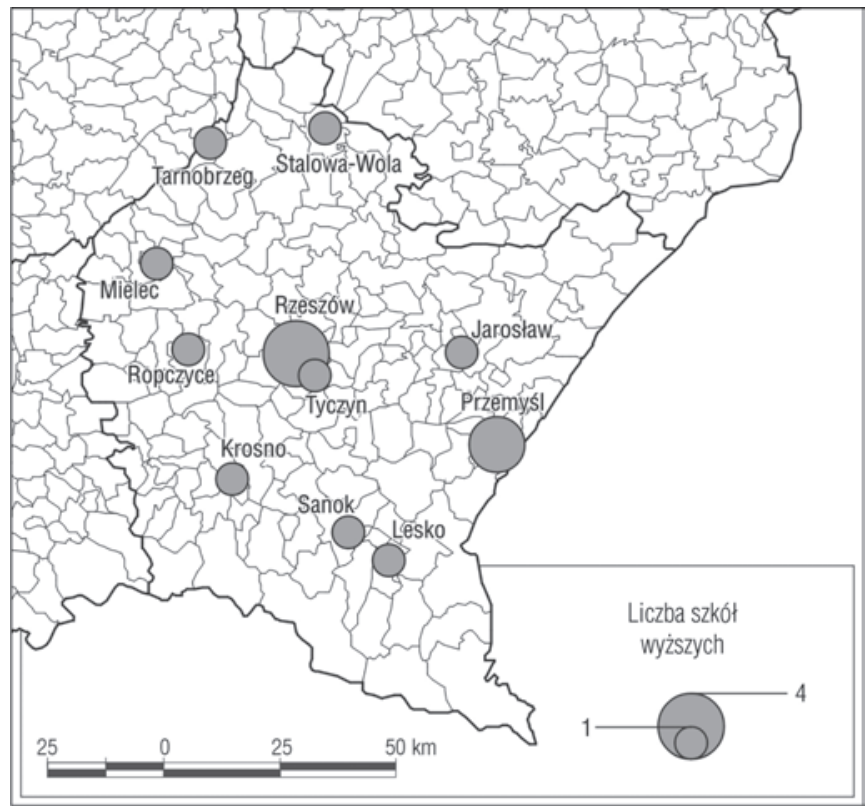

Źródło: opracowanie autorki na podstawie tab. 2

Ponadto w 1998 r. powołano Państwową Szkołę Wyższą w Jarosławiu, w 1999 r. Państwową Wyższą Szkołę Zawodową w Krośnie, a w 2001 r. Państwowe Wyższe Szkoły Zawodowe w Sanoku, Przemyślu i Tarnobrzegu, w których kształci się 13 tys. studentów (18,3\% ogólnej liczby studentów w województwie). Najwięcej z nich studiuje w Państwowej Wyższej Szkole Zawodowej w Jarosławiu, gdzie kształci się 8,2 tys. studentów (aż 63,1\% studentów tego typu szkół w woj. podkarpackim).

Ośrodki szkolnictwa wyższego w woj. podkarpackim charakteryzują się zróżnicowanym potencjałem edukacyjnym, na co wskazuje liczba uczelni wahająca się w poszczególnych ośrodkach akademickich od jednej do czterech i liczba studentów - od 0,3 tys. do 47,8 tys. Podstawowe znaczenie wśród ośrodków w woj. podkarpackim ma ośrodek rzeszowski, gdzie w czterech uczelniach (Uniwersytet Rzeszowski, Politechnika Rzeszowska, Wyższa Szkoła Informatyki i Zarządzania i Wyższa Szkoła Zarządzania) kształci się 67,5\% ogólnej liczby studentów woj. podkarpackiego (ryc. 1). Kolejne miejsce zajmuje Przemyśl; w trzech szkołach wyższych (Wyższa Szkoła Administracji i Zarządzania, Państwowa Wyższa Szkoła Zawodowa, Wyższa Szkoła Gospodarcza) studiuje 9,7\% ogółu studentów województwa. Te dwa ośrodki akademickie skupiają łącznie 77,1\% studentów. W kolejnych dziewięciu ośrodkach działa po jednej uczelni wyższej kształcącej na poziomie zawodowym. Łącznie skupiają one 22,9\% studentów województwa, najwięcej Jarosław, następnie Krosno, Tyczyn, Stalowa Wola oraz Tarnobrzeg, Ropczyce, Sanok, Mielec i Lesko.

Ośrodek jarosławski wypełnia znaczną lukę w województwie w zakresie dostępu młodzieży do studiów wyższych. Dzięki lokalizacji Państwowej Wyższej Szkole Zawodowej (PWSZ) w tym mieście studia wyższe podjęło 10,6\% studentów woj. podkarpackiego i aż 63,1\% studentów tego typu szkół. Analiza zasięgu oddziaływania tej uczelni wskazuje na jej charakter subregionalny. W roku akademickim 2004/2005 9,4 tys. studentów tej uczelni rekrutowało się z 366 gmin, znajdujących się na obszarze 15 województw ${ }^{2}$. Z woj. podkarpackiego pochodziło 78,1\% studentów, kolejną

\footnotetext{
${ }^{2}$ Opracowanie na podstawie pracy magisterskiej K. Kozak: Ksztattowanie się i rola PWSZ w Jarosławiu w otoczeniu regionalnym, wykonanej pod kierunkiem prof. dr. hab. Z. Zioło.
} 
Tab. 3. Przestrzenne oddziaływanie Państwowej Wyższej Szkoły Zawodowej w Jarosławiu w 2005 r.

\begin{tabular}{|c|c|c|c|}
\hline Województwo & Gmina & Liczba studentów & Struktura studentów \\
\hline \multicolumn{2}{|l|}{ Ogółem } & 9373 & 100,00 \\
\hline \multicolumn{2}{|c|}{ Ogółem Polska południowo-wschodnia } & 9189 & 98,04 \\
\hline \multicolumn{2}{|l|}{ Woj. podkarpackie } & 7323 & 78,13 \\
\hline \multicolumn{2}{|l|}{ Woj. lubelskie } & 1710 & 18,24 \\
\hline \multicolumn{2}{|l|}{ Pozostałe } & 340 & 3,63 \\
\hline \multirow[t]{11}{*}{ Woj. podkarpackie } & Jarosław & 1834 & 19,57 \\
\hline & Przemyśl & 915 & 9,76 \\
\hline & Przeworsk & 515 & 5,49 \\
\hline & Lubaczów & 321 & 3,42 \\
\hline & Leżajsk & 273 & 2,91 \\
\hline & Lańcut & 234 & 2,50 \\
\hline & Dębica & 234 & 2,50 \\
\hline & Radymno & 208 & 2,22 \\
\hline & Stalowa Wola & 196 & 2,09 \\
\hline & Wiązownica & 126 & 1,34 \\
\hline & Kańczuga & 114 & 1,22 \\
\hline \multicolumn{2}{|l|}{ Ogółem } & 4970 & 53,02 \\
\hline \multirow[t]{4}{*}{ Woj. lubelskie } & Tomaszów Lubelski & 276 & 2,94 \\
\hline & Zamość & 245 & 2,61 \\
\hline & Biłgoraj & 221 & 2,36 \\
\hline & Hrubieszów & 144 & 1,54 \\
\hline \multicolumn{2}{|l|}{ Ogółem } & 886 & 9,45 \\
\hline
\end{tabular}

Źródło: opracowanie autorki na podstawie pracy magisterskiej K. Kozak: Kształtowanie się i rola PWSZ $w$ Jarosławiu $w$ otoczeniu regionalnym, wykonanej pod kier. prof dr. hab. Z. Zioło

pozycję zajmowało woj. lubelskie (18,2\%) (tab. 3). W uczelni przeważają osoby pochodzące z Jarosławia. Rekrutuje się z niego 1,8 tys. studentów, którzy stanowią 19,6\% studentów uczelni (ryc. 2). Kolejne pozycje zajmują większe sąsiadujące ośrodki: Przemyśl i Przeworsk, z których łącznie rekrutuje się 1,4 tys. studentów; stanowią oni 15,3\% ogólnej liczby. Te trzy miasta w najpoważniejszym stopniu są obszarem oddziaływania uczelni; pochodzi z nich 3,2 tys. studentów, którzy stanowią 34,9\% ogólnej liczby studentów PWSZ w Jarosławiu.

Ważną rolę w zakresie rekrutacji studentów PWSZ w Jarosławiu na obszarze woj. podkarpackiego odgrywają również gminy, z których pochodzi powyżej 200 studentów: Lubaczów (321), Leżajsk (273), Łańcut (243), Dębica (234) i Radymno (208). Rekrutuje się z nich 1,0 tys. studentów (11,1\% ogólnej ich liczby).

Zasięg oddziaływania uczelni obejmuje także południową część woj. lubelskiego. Największe znaczenie mają: Tomaszów Lubelski (276), Zamość (245) i Biłgoraj (221). Rekrutuje się z nich 742 studentów, którzy stanowią 7,9\% ogólnej ich liczby. Ze wspomnianych 11 miast pochodzi 5,3 tys. studentów, czyli 56,4\% ogólnej liczby studentów PWSZ w Jarosławiu. 
Ryc. 2. Przestrzenne oddziaływanie Państwowej Wyższej Szkoły Zawodowej w Jarosławiu w 2005 r.

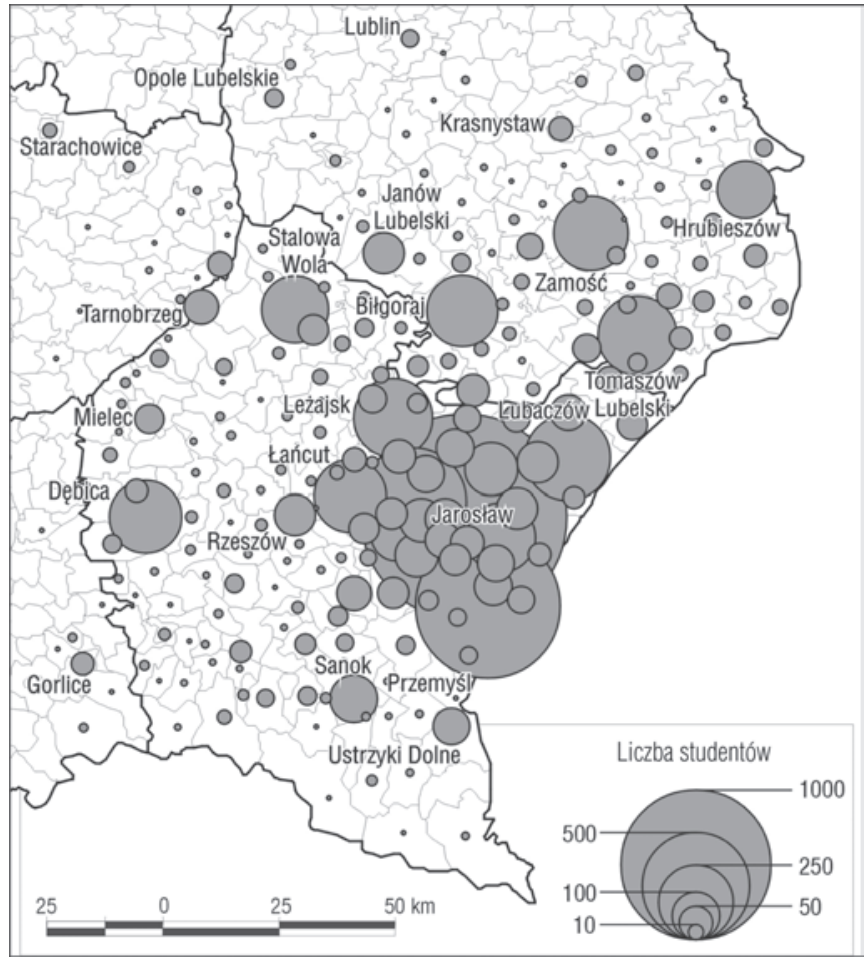

Źródło: opracowanie autorki na podstawie tab. 3

Wyrazem relacji między udziałem studentów a udziałem jednostek osadniczych, z których rekrutują się studenci PWSZ w Jarosławiu, jest wskaźnik koncentracji osadniczej studentów wynoszący 0,690, co wskazuje na wysoki stopień ich skupienia przestrzennego. Należy podkreślić, że zbliżenie uczelni do miejsca zamieszkania studentów w znacznym stopniu wpłynęło na decyzje o podjęciu studiów przez osoby, które ze względów ekonomicznych i znaczną odległość do głównego ośrodka akademickiego nie byłyby w stanie podjąć edukacji na poziomie wyższym.

Rozwój ośrodka jarosławskiego, a także pozostałych ośrodków akademickich woj. podkarpackiego, które zwiększają dostępność do szkolnictwa wyższego, nawiązuje do założeń Strategii Lizbońskiej, która kładzie szczególny nacisk na podniesienie poziomu edukacyjnego społeczeństwa. W konsekwencji nowe, dynamicznie rozwijające się ośrodki akademickie stają się centrami kultury zwiększającymi jakość kapitału ludzkiego w układach lokalnych i regionalnych, przyspieszają zatem ich aktywizację gospodarczą.

\section{Literatura}

1. Borowiec M., 2006, Rola szkolnictwa wyższego w ksztaltowaniu metropolii [w:] Rzeszowski i Krakowski Obszar Metropolitalny, Z. Makieła, R. Fedan (red.), KSW w Krakowie, Kraków

2. Domański R., 2000, Miasto innowacyjne, Wydawnictwo Naukowe PWN, Warszawa

3. Harbison F., Mayers Ch., 1964, Education, Manpower and Economic Growth, McGraw-Hill, New York

4. Janc K., 2003, Rola nauki i techniki we współczesnym świecie [w:] Geograficzne aspekty globalizacji i integracji europejskiej, M. Śmigielska, J. Słodczyk (red.), PTG Uniwersytet Opolski, Opole 
5. Kabaj M., W kierunku gospodarki opartej na wiedzy [w:] „Polityka Społeczna” 4/1997

6. Kluczyński J., 1984, Prognoza rozwoju szkolnictwa wyższego, PWN, Warszawa

7. Kluczyński J., 1991, Prognozy i uwarunkowania rozwoju szkolnictwa wyższego w Polsce, Instytut Polityki Naukowej i Szkolnictwa Wyższego, Wydawnictwo Naukowe PWN, Warszawa-Łódź

8. Kuciński K., Kudłacz T., Markowski T., Ziobrowski Z., 2002, Zintegrowany rozwój aglomeracji a konkurencyjność przestrzeni, Studia PAN PKZK, T.CXI, Warszawa

9. Markowski T., 1996, Wspieranie konkurencyjności w polityce rozwoju regionalnego [w:] Strategiczne wyzwania dla rozwoju regionalnego Polski, Friedrich Ebert Stifung, Przedstawicielstwo w Polsce, Warszawa

10. Pakulska T., 2005, Kapitat ludzki w Polsce w warunkach gospodarki informacyjnej [w:] J. Brdulak (red.), Rozwój elementów i infrastruktury życia społeczno-gospodarczego, Warszawa

11. Pawlak W.R., Zarzadzanie wiedza, czyli nowe wyzwania [w:] „Problemy Jakości” 10/2001

12. Rozkrut M., 2001, Rozwój nauki i szkolnictwa a postęp gospodarczy-Polska a Unia Europejska [w:] „Zeszyty Naukowe Uniwersytetu Szczecińskiego” 318/2001, „Prace Katedry Ekonometrii i Statystyki" 10/2001

13. Rydz E., 2006, Przemiany struktur społeczno-gospodarczych w okresie transformacji systemowej na Pomorzu Środkowym, PAP w Słupsku, Słupsk

14. Schultz T.W., 1963, The Economic Value of Education, Columbia University Press, New York

15. Schultz T.W., 1976, Investment in Human Capital, The Free Press, New York

16. Wasilewski L., Kwiatkowski S., Kozłowski J., 1997, Nauka i technika dla rozwoju. Polska na tle Europy, konteksty, miary, tendencje, Redakcja Wydawnictw Ośrodka Przetwarzania Informacji, Warszawa

17. Zioło I, Wybrane atuty wartości edukacyjnej wyższej szkoły niepaństwowej (wyniki badań sondażowych prowadzonych $w$ WSiZ z siedziba w Rzeszowie [w:] Problemy przemian układów regionalnych, Z. Zioło (red.), „Zeszyty Naukowe” 3/2999, rok III (11), cz. II, Wydawnictwo Wyższej Szkoły Informatyki i Zarządzania w Rzeszowie

\section{The Role of Educational System in Improving the Quality of the Intellectual Resources}

The foundation of competitiveness in present economies becomes innovations that determine the development of knowledge based economy. First of all, the innovations are generated by the academic centers. During the process of formation of information society, knowledge and science become essential factors leading to the improvement of the intellectual potential of societies, which influences on the competitiveness of national and regional systems. The development of scientific and educational functions makes possible to improve it thanks to the intellectual resources. The development of higher educational systems should be an essential element of formation the regional development poles and increase of the competitiveness of the regional system. The aim of conducted research was to determine the range of the territorial influence of PWSZ located in Jarosław. The author underlines the role of educational system in the development of the Podkarpackie Province. 


\section{Nadine Bednarz}

Ośrodek Doradztwa Metodycznego

i Doskonalenia Nauczycieli w Legnicy

\section{Czy uczenie się przez całe życie jest postawą przedsiębiorczą}

\section{Kapitał ludzki a edukacja}

Kapitał ludzki definiuje się jako zasób wiedzy, umiejętności, zdrowia i energii witalnej zawarty w danym społeczeństwie. Ponieważ jednak kapitał ludzki jest cechąjakościową danej osoby, nie może on być przedmiotem obrotu rynkowego i zmieniać właściciela. Można go jednak powiększać drogą inwestycji, zwanych inwestycjami w człowieka. W szerokim ujęciu, do inwestycji tworzących zasób kapitału ludzkiego zalicza się wszystkie te inwestycje, które mogą wpływać na poprawę jakościowych cech pracy ludzkiej, czyli inwestycje w zdrowie, ochronę środowiska i kulturę.

Cechą charakterystyczną kapitału ludzkiego jest to, że pozostaje on w stałym związku z dokonującymi się na świecie przemianami w nauce i technice. W literaturze można spotkać wąską i szeroką interpretację tego terminu. W ujęciu wąskim kapitał ludzki jest ujmowany, po pierwsze, jako efekt inwestycji w oświatę i kształcenie, ucieleśniony w cechach jakościowych dostępnego w gospodarce zasobu pracy. Cechy kapitału ludzkiego kształtowane są przez nakłady na szeroko rozumiane badania i prace rozwojowe, gdyż większość z nich wiąże się z procesami typu „uczenie przez działanie" i „uczenie przez naukę" ". W ujęciu szerokim do nakładów czy też inwestycji tworzących zasób kapitału ludzkiego zalicza się również inwestycje w zdrowie, ochronę środowiska, kulturę, gdyż podobnie jak oświata oddziałują one na poprawę cech jakościowych pracy ludzkiej.

Przede wszystkim jednak kapitał ludzki interpretowany jest jako efekt inwestycji w oświatę i kształcenie. Podkreśla się, że kapitał ludzki:

- wywiera ważny wpływ na konkurencyjność gospodarek, ich zdolności absorpcyjne w dziedzinie przyswajania i wdrażania światowych osiagnięć naukowych, technicznych, organizacyjnych, kulturowych itp.;

- sprzyja kształtowaniu nowoczesnej infrastruktury techniczno-organizacyjnej, informacyjnej itp.;

- korzystnie oddziałuje na przemiany instytucjonalne;

- sprzyja propagowaniu i rozpowszechnianiu się nowoczesnych wzorców konsumpcji, jakości życia i wzorów etyczno-moralnych.

Edukacja rozumiana jest jako wychowanie, wykształcenie, nauka ${ }^{2}$ oraz proces zdobywania wiedzy. Ma ogromną wartość dla człowieka zarówno w wymiarze kapitału, który wnosi on na rynek pracy, jak i w dalszym jego osobistym rozwoju, niezwiązanym z ekonomicznymi perspektywami. Pojedynczy człowiek, jako jednostka uzyskująca wykształcenie, nie bierze pod uwagę tzw. efektów zewnętrznych wykształcenia, wyrażających się m.in. tym, że wzrost wykształcenia

${ }^{1}$ B. Fiodor, 2001, Polityka państwa a powiększanie zasobów kapitalu ludzkiego w Polsce w latach dziewięćdziesiatych [w:] J. Jagas (red.), Produktywność i wydajność w okresie transformacji gospodarki polskiej, Wydawnictwo Uniwersytetu Opolskiego, Opole.

${ }^{2}$ Stownik języka polskiego, Wydawnictwo Naukowe PWN, Warszawa 1998. 
zwiększa nie tylko wydajność jego samego, lecz także wydajność, współpracowników. Efekty zewnętrzne sprawiają, że w teorii ekonomii edukacja jest zaliczana do grupy dóbr społecznie pożądanych. Oznacza to, że państwo powinno zachęcać obywateli do kształcenia się, czyniąc je dostępnym dla wszystkich ${ }^{3}$. Edukacja jest więc ważną inwestycją warunkującą rozwój gospodarki każdego państwa; jest czynnikiem stymulującym wzrost gospodarczy, badania i innowacje, konkurencyjność oraz aktywne postawy obywatelskie.

Kształcenie w warunkach konkurencyjności spełnia wiele funkcji:

1. Funkcja dochodowa - wykształcenie staje się warunkiem osiagnnięcia sukcesów ekonomicznych. Następuje dywersyfikacja dochodowa społeczeństwa, zmieniają się proporcje dochodów w różnych zawodach. Praca specjalistów najwyższej klasy jest szczególnie premiowana.

2. Funkcja zatrudnieniowa - istnieje ścisły związek między poziomem wykształcenia a możliwością uzyskiwania dodatkowych kwalifikacji w zawodach, na które jest zapotrzebowanie. Osobom o najwyższych kwalifikacjach najłatwiej przystosować się do wymogów rynku pracy.

3. Funkcja efektywnościowa - osoby o najwyższych kwalifikacjach cechują się wyższą wydajnością pracy.

4. Funkcja kreacyjna - szeroko rozumiana innowacyjność i dynamizm ekonomiczny są efektami aktywności zawodowej specjalistów. Konkurencyjność w skali międzynarodowej wynika w największym stopniu z kreatywności i poziomu innowacyjności społeczeństwa.

5. Funkcja społeczno-wychowawcza - obejmuje proces kształtowania pożądanych społecznie wzorców i zachowań, wdrażanie do dorosłego życia, nauczanie zasad komunikacji społecznej.

6. Funkcja kulturowa - polegająca na kształtowaniu świadomości narodowej, historycznej i społecznej, propagowaniu wzorców kultury, upowszechnianiu języków obcych i poprawnej polszczyzny. ${ }^{4}$

Proces wzrostu społeczno-gospodarczego jest ściśle związany z rozwojem jakościowym kapitału ludzkiego, a ten wymaga podjęcia działań dotyczących formalnych możliwości kształcenia na wszystkich szczeblach, łącznie ze szkoleniem w czasie pracy. Jakość kapitału ludzkiego i jego kreowanie to wynik działań zbiorowych o charakterze instytucjonalnym oraz motywacji indywidualnych. Dlatego też ważną rolę odgrywa:

- kształcenie oferowane przez formalny system edukacji narodowej;

- kształcenie i doskonalenie zawodowe w trakcie zatrudnienia;

- kształcenie ustawiczne.

W dużym uproszczeniu cele ekonomiczne edukacji można sprowadzić do przygotowania kadr kwalifikowanych o poziomie wykształcenia i strukturze zawodowej, które powinny odpowiadać zmiennym w czasie potrzebom gospodarki.

Zadania w dziedzinie edukacji są w dużej mierze zdeterminowane przez sytuację demograficzną, stan infrastruktury w dziedzinie oświaty i kształcenia, liczebność i poziom kwalifikacji nauczycieli oraz ustawodawstwo dotyczące obowiązku szkolnego. Do niedawna Polska była jednym z krajów o najwyższym współczynniku przyrostu naturalnego. W ostatnim dziesięcioleciu współczynnik ten malał i w 2001 r. wyniósł 0,5 na 1000 mieszkańców. Z badań tendencji demograficznych wynika, że systematycznie zmniejsza się liczba dzieci i młodzieży w wieku przedszkolnym i szkolnym. W sposób radykalny rośnie udział ludności w wieku emerytalnym w ogóle ludności i będzie to trend długookresowy. ${ }^{5}$

\footnotetext{
${ }^{3}$ A. Baran., Edukacja w Polsce wobec zmian systemowych i demograficznych, ,Polityka Społeczna” 5-6/2004. ${ }^{4}$ L. Cybulski, 1999, Edukacja a konkurencyjność regionów [w:] M. Klamut (red.), Konkurencyjność regionów, Wyd. AE we Wrocławiu, Wrocław.

${ }^{5}$ Strategia rozwoju edukacji 2007-2013, MEiN, Warszawa 2005.
} 
Zmiany demograficzne wywierają silną presję na rynek pracy i wymuszają zmiany w strukturze popytu i podaży usług edukacyjnych.

Oczekuje się, że zmiany w systemie oświaty doprowadzą do:

- upowszechnienia wykształcenia średniego;

- uwzględnienia w programach kształcenia treści dostosowanych do potrzeb rynku pracy;

- wprowadzenia do wszystkich szkół ponadpodstawowych zagadnień dotyczących życia gospodarczego i aktywnego zachowania się na rynku pracy;

- wprowadzenia do szkół problematyki orientacji zawodowej uczniów i poradnictwa zawodowego;

- uświadomienia roli i znaczenia kształcenia ustawicznego „uczenia się przez całe życie”.

W Polsce dokonał się znaczny postęp w poziomie wykształcenia ludności. Polacy traktują wykształcenie jak jedną z podstawowych dróg do zaspokojenia aspiracji i osiąnnięcia wyższego statusu materialnego i społecznego. Wzrost motywacji do kontynuowania nauki wyraźnie widać w grupie osób młodych, zwłaszcza w wieku 25-34 lat. Generalnie, wyższy poziom wykształcenia w dużym stopniu przekłada się na wyższy wskaźnik zatrudnienia. Najbardziej zagrożone bezrobociem są osoby o niższym poziomie wykształcenia. Przeważająca część bezrobotnych ma więc wykształcenie podstawowe lub zasadnicze zawodowe. W 2003 r. stopa bezrobocia w grupie ludności z wykształceniem wyższym wynosiła 7,6\%, a wśród osób z wykształceniem zasadniczym zawodowym $24,0 \% .{ }^{6}$ Te dane dowodza, że wykształcenie może chronić przed wykluczeniem z rynku pracy. Oznacza to, że bardzo ważne są długofalowe działania zmierzające do poprawy poziomu wykształcenia społeczeństwa.

W 1999 r. rozpoczęto w Polsce wieloletnią, kompleksową reformę programów i metod pracy dydaktyczno-wychowawczej oraz struktury ustroju szkolnictwa. Reforma ma być drogą do podniesienia poziomu edukacji społeczeństwa przez upowszechnienie wykształcenia średniego i wyższego oraz wyrównywanie szans edukacyjnych.

\section{Ksztalcenie a aktywność zawodowa}

Istotne zmiany zachodzą w tzw. kształceniu ustawicznym. Warunkiem realizacji idei budowania społeczeństwa opartego na wiedzy jest nadanie w Polsce odpowiedniej rangi powszechnie rekomendowanej w ostatnich latach koncepcji uczenia się przez całe życie. Ta koncepcja (OECD - Paryż 1996) obejmuje rozwój indywidualny i rozwój cech społecznych we wszystkich formach i wszystkich kontekstach - w systemie formalnym i nieformalnym, tzn. w szkołach i placówkach kształcenia zawodowego, uczelniach i placówkach kształcenia dorosłych oraz w ramach kształcenia incydentalnego, czyli w domu, w pracy i w społeczności. Podkreśla się w niej potrzebę przygotowywania i zachęcania wszystkich dzieci do nauki przez całe życie, już od wczesnego wieku. Koncepcja ta ukierunkowuje działania w taki sposób, by zapewnić odpowiednie możliwości wszystkim - osobom dorosłym, pracującym i bezrobotnym, które muszą przekwalifikować się lub podnieść swoje kwalifikacje.

Powszechna idea budowania społeczeństwa opartego na wiedzy zmieniła stosunek do kształcenia, wywołując wzmożone zainteresowanie problematyką edukacyjną, a przede wszystkim kształceniem ustawicznym. Tendencja ta znajduje odzwierciedlenie zarówno w dokumentach międzynarodowych, jak i krajowych, które wytyczają priorytety i kierunki działań w tym zakresie. $\mathrm{Z}$ całą pewnością należy wymienić w tym miejscu Memorandum Komisji Wspólnot Europejskich dotyczqce kształcenia ustawicznego z 30 października 2000 r., Deklarację Kopenhaska oraz przyjętą przez Radę Ministrów 8 lipca 2003 r. Strategię Rozwoju Ksztatcenia Ustawicznego do roku 2010.

${ }^{6}$ Strategia rozwoju edukacji 2007-2013, MEiN, Warszawa 2005. 
Ostatnio wyraźnie widać zmiany w kształceniu dorosłych. Liczba osób dokształcających się średnio rocznie w Polsce w ostatnich latach wynosi 1,2-1,5 mln osób, czyli około 9\% pracujących w gospodarce (w UE około 20\%). Wprawdzie odnotowuje się tendencję rosnąca, ale wiele należy jeszcze zmienić. W tym zakresie Polska musi dostosować się do Strategii Lizbońskiej, w której Unia Europejska zawarła priorytety dotyczące koncepcji „uczenia się przez całe życie”. Komisja Europejska zobowiązała się wspierać współpracę w tej dziedzinie przez stworzenie spójnej strategii oraz podejmowanie wspólnych działań pozwalających na lepsze wykorzystanie środków w celu rozwoju kształcenia ustawicznego dostępnego dla wszystkich. ${ }^{7}$

Edukacja ustawiczna to zasada kształcenia organizująca nowy proces aktywnego poznania oraz stałego rozwoju intelektualnego i kulturalnego. Podstawową ideą kształcenia ustawicznego jest zachowanie ciagłości i systematyczności procesu uczenia się, co zapewnia stały rozwój i chroni przed zdezaktualizowaniem się zdobytej wiedzy. Kształcenie ustawiczne jest zgodne z potrzebami nowoczesnego społeczeństwa; uwzględnia przemiany czasu, wartości rynku oraz rytm indywidualnej egzystencji.

Współczesna idea uczenia się przez całe życie nawiązuje do wcześniejszych definicji kształcenia ustawicznego. Kształcenie ustawiczne to kompleks procesów oświatowych: formalnych, nieformalnych i incydentalnych, które niezależnie od treści, poziomu i metod umożliwiają uzupełnianie wykształcenia w formach szkolnych i pozaszkolnych, dzięki czemu osoby dorosłe rozwijają swoje zdolności, wzbogacają wiedzę, doskonalą kwalifikacje zawodowe lub zdobywają nowy zawód, zmieniają swoje postawy. Trzeba zaznaczyć, że w Polsce kształcenie ustawiczne jest utożsamiane z ideą uczenia się przez całe życie, która bezpośrednio jest łączona ze strategicznym celem przyjętym przez Radę Europejską (Lizbona 2000). Porównując definicję „kształcenia ustawicznego" przyjętą w Polsce z definicją ,kształcenia przez całe życie” przyjętą w Unii Europejskiej można stwierdzić, że idea kształcenia przez całe życie znaczy coś więcej. Według definicji podanej w Rezolucji Rady Unii Europejskiej z 27 czerwca 2002 r. „(...) pojęcie lifelong learning (uczenie się przez całe życie) powinno dotyczyć uczenia się od fazy przedszkolnej do późnej emerytalnej, włączając w to całe spektrum uczenia się formalnego (w szkołach i innych placówkach systemu edukacji), pozaformalnego (w instytucjach poza systemem edukacji) i nieformalnego (naturalnego). Ponadto, powinno się ono odnosić do wszelkiej, trwającej przez całe życie, aktywności uczenia się, mającej na celu rozwój wiedzy, kompetencji i umiejętności w perspektywie osobistej, obywatelskiej, społecznej oraz zorientowanej na zatrudnienie. Zasadniczym odniesieniem w tym względzie powinna być osoba jako podmiot uczenia się, co podkreślać ma znaczenie prawdziwej równości szans i jakości w procesie uczenia się". W polskich realiach, mówiąc o „,(..) kształceniu ustawicznym - należy przez to rozumieć kształcenie w szkołach dla dorosłych, a także uzyskiwanie, uzupełnianie wiedzy ogólnej, umiejętności i kwalifikacji zawodowych w formach pozaszkolnych (formy uzyskiwania i uzupełniania wiedzy ogólnej, umiejętności i kwalifikacji zawodowych w placówkach i ośrodkach będących jednostkami organizacyjnymi systemu oświaty) przez osoby, które spełniły obowiązek szkolny" (Ustawa o systemie oświaty, art. 3 pkt 17). Położenie akcentu na integrację wyróżnionych form kształcenia sprawia, że proces kształcenia ustawicznego zyskuje nowy, całościowy charakter.

Komplementarne traktowanie kształcenia formalnego, nieformalnego i incydentalnego - przy uwzględnieniu standardów kwalifikacji zawodowych - umożliwia przenikanie się struktur organizacyjnych systemu edukacji, ułatwia zdobywanie i uznawanie kwalifikacji zawodowych. Jest

\footnotetext{
${ }^{7}$ M. Budzyńska, 2004, Koncepcja ksztatcenia ustawicznego w Unii Europejskiej jako jeden ze sposobów realizacji Strategii Lizbońskiej, Urząd Komitetu Integracji Europejskiej, Warszawa (publikacja w wersji elektronicznej).
} 
to również płaszczyzna do szerokiej wymiany doświadczeń natury merytorycznej, metodycznej i organizacyjnej. To także krok w kierunku budowania otwartego i elastycznego systemu edukacji, rzeczywistego wspierania aktywności poznawczej i przedsiębiorczości, prowadzących do zwiększania szans zatrudnienia na współczesnym rynku pracy. Dynamizm przemian zmusza współczesnego człowieka do realizowania w praktyce idei uczenia się przez całe życie. Edukacja ustawiczna staje się jednym z najlepszych sposobów sprostania wyzwaniom wynikającym z gwałtownego rozwoju technologicznego, globalizacji czy przeobrażeń społecznych i ekonomicznych. Warunki nowej rzeczywistości wymuszają na jednostce konieczność nieustannego podnoszenia kwalifikacji i ciagłego poszerzania wiedzy wraz z eksplorowaniem zastanego otoczenia, w celu przystosowania się do zmieniającego się w szybkim tempie świata. Ciągła konieczność aktualizacji zdobytej wiedzy staje się jednym z najważniejszych wyzwań cywilizacyjnych, jakie stawia przed człowiekiem społeczeństwo oparte na wiedzy. W kontekście tych wyzwań współczesności edukację XXI w. należy postrzegać jako proces, który trwa całe życie.

\section{Literatura}

1. Baran A., Edukacja w Polsce wobec zmian systemowych i demograficznych, „Polityka Społeczna” 5-6/2004

2. Budzyńska M., 2004, Koncepcja ksztatcenia ustawicznego w Unii Europejskiej jako jeden ze sposobów realizacji Strategii Lizbońskiej, Urząd Komitetu Integracji Europejskiej, Warszawa (publikacja w wersji elektronicznej, scholaris.pl)

3. Cybulski L., 1999, Edukacja a konkurencyjnossć regionów [w:] M. Klamut (red.), Konkurencyjność regionów, Wyd. AE we Wrocławiu, Wrocław

4. Fiodor B., 2001, Polityka państwa a powiększanie zasobów kapitalu ludzkiego w Polsce w latach dziewięćdziesiatych [w] J. Jagas (red.), Produktywność i wydajność w okresie transformacji gospodarki polskiej, Wydawnictwo Uniwersytetu Opolskiego, Opole

5. Słownik języka polskiego, Wydawnictwo Naukowe PWN, Warszawa 1998

6. Strategia rozwoju edukacji 2007-2013, MEiN, Warszawa 2005

\section{Is a Lifelong Learning an Entrepreneurial Attitude?}

The main thesis of the article is connected with the constant attempts to the implementation a new educational system in Poland. Some new opportunities have occurred since Poland entered the European Union as we can now make use of other countries' experience in the reforming area. Nowadays we are dealing with a new term in Poland i.e. lifelong learning. According to the author such a view on the education has its roots in constant changes in Polish society and economy. Open trade economy has influenced Polish scholar system - the trainees/ /students are focused on being successful on the market, especially on the job market. Traditional educational system in Poland was enriched by elements of entrepreneurship. The author describes Polish education as an investment, which is a condition of economic, scientific and social development. Constant or lifelong learning is therefore described as a social and economic phenomenon. 


\title{
Maciej Tokarski \\ Andrzej Tokarski
}

Katedra Rachunkowości

Wyższa Szkoła Bankowa w Toruniu

\section{Funkcjonowanie Akademickiego Inkubatora Przedsiębiorczości przy Wyższej Szkole Bankowej w Toruniu}

\begin{abstract}
Akademickie inkubatory przedsiębiorczości(AIP) to wielki projekt ostatnich lat, realizowany przez Fundację AIP z inicjatywy Studenckiego Forum BCC, zmierzający do rozwoju przedsiębiorczości wśród polskiej młodzieży. AIP są tworzone we współpracy z najlepszymi w kraju szkołami wyższymi, dzięki czemu wykorzystują wiedzę zarówno kadry naukowej tych uczelni, jak i praktyków gospodarczych skupionych w największej w Polsce organizacji pracodawców - Business Centre Club. Obecnie na najlepszych uczelniach całej Polski działa 16 współpracujących ze sobą akademickich inkubatorów przedsiębiorczości ${ }^{1}$. To połączenie teorii i praktyki przekłada się na sukces podmiotów uczestniczących w projekcie. Z drugiej strony działalność w ramach inkubatora pomaga jego beneficjentom pokonywać biurokratyczne bariery, przechodzić przez zawiłe procedury oraz unikać licznych innych pułapek ${ }^{2}$. Umożliwia młodym przedsiębiorcom kontrolowane starcie z otaczającą rzeczywistością gospodarczą. Ideą inkubatora jest umożliwienie młodym, kreatywnym i ambitnym ludziom założenia własnej firmy przy minimalnych nakładach finansowych, by po okresie inkubacji mogli samodzielnie funkcjonować w normalnych warunkach gospodarczych, wykorzystując zdobyte w inkubatorze doświadczenia oraz niezbędną wiedzę prawniczą, ekonomiczną itd.
\end{abstract}

\section{Działalność AIP}

Akademickie inkubatory przedsiębiorczości są jednostkami organizacyjnymi Fundacji AIP, tworzonymi we współpracy ze szkołami wyższymi ${ }^{3}$. Udzielają one pomocy działającym w ich

\footnotetext{
${ }^{1}$ Jeden z nich działa przy Wyższej Szkole Bankowej w Toruniu.

${ }^{2}$ Szerzej o barierach sektora MSP w Polsce - patrz: raporty o kondycji małych i średnich przedsiębiorstw w Polsce w latach 2000-2005, wydawane przez Polską Konfederację Pracodawców Prywatnych „Lewiatan”, Warszawa 2000-2005, a także M. Tokarski, 2006, Prawno-ekonomiczne bariery rozwoju małych i średnich przedsiębiorstw na przyktadzie województwa kujawsko-pomorskiego [w:] Zarzqdzanie podmiotami i procesami gospodarczymi, J. Wiśniewski (red.), Wyższa Szkoła Bankowa w Toruniu, Toruń ${ }^{3}$ Obecnie na najlepszych uczelniach całej Polski działa 16 współpracujących ze sobą akademickich inkubatorów przedsiębiorczości: AIP przy Uniwersytecie Gdańskim, AIP przy Akademii Ekonomicznej im. O. Langego we Wrocławiu, AIP przy Wyższej Szkole Bankowej w Toruniu, AIP przy Wyższej Szkole Ekonomii i Informatyki w Krakowie, AIP przy Śląskiej Wyższej Szkole Zarządzania im. gen. J. Ziętka w Katowicach, AIP przy Wyższej Szkole Informatyki Stosowanej i Zarządzania w Warszawie, AIP przy Uniwersytecie Warszawskim, AIP przy Szkole Głównej Gospodarstwa Wiejskiego, AIP przy Wyższej Szkole Komunikacji i Zarządzania w Poznaniu, AIP przy Społecznej Wyższej Szkole Przedsiębiorczości i Zarządzania w Łodzi, AIP przy Politechnice Częstochowskiej, AIP przy Szkole Głównej Handlowej, AIP przy Wyższej Szkole Gospodarki w Bydgoszczy, AIP przy Wydziale Ekonomicznym Uniwersytetu w Białymstoku, AIP przy Wyższej Szkole Informatyki i Zarządzania w Rzeszowie, AIP przy Górnośląskiej Wyższej Szkole Przedsiębiorczości im. K. Goduli w Chorzowie.
} 
obrębie podmiotom na mocy obowiązującego regulaminu oraz umowy z beneficjentem. Osoba wnioskująca o pomoc AlP jest zobowiązana do wniesienia na rzecz inkubatora jednorazowej symbolicznej opłaty, której wysokość ustalana jest przez dyrektora AIP. W okresie inkubacji koszty związane z rozwojem firmy pokrywa w większości Fundacja AIP. Wysokość opłat pobieranych od osób działających w inkubatorze jest ustalana na koniec miesiąca przez dyrektora AIP i jest stosowna do świadczonej pomocy, przy czym na wniosek beneficjenta dyrektor AIP może podjąć decyzję o częściowym lub całkowitym zwolnieniu z opłat.

W wypadku osób prowadzących działalność gospodarczą i korzystających z pomocy inkubatora opłata obejmuje do $10 \%$ przychodu osiaganego z działalności gospodarczej objętej pomocą. Zmienia się ona z upływem czasu w sposób przewidziany w umowie. Wpływy z opłat mają docelowo pokryć 30\% kosztów funkcjonowania AIP.

Pomoc AIP jest udzielana maksymalnie przez dwa lata. W tym czasie beneficjent jest zobowiązany do realizowania przedłożonego dyrektorowi AIP indywidualnego planu działania. Beneficjent zobowiązany jest także, na mocy umowy, do poddania nadzorowi Fundacji wykorzystywania środków powierzonych przez Fundację oraz zasobów przyznanych z dotacji, subwencji lub innych form pomocy uzyskanych przy udziale Fundacji. Wszyscy beneficjenci muszą także składać na ręce dyrektora AIP comiesięczne raporty z postępów w realizacji swojego przedsięwzięcia.

Działalność w inkubatorze jest nastawiona na utworzenie przez beneficjenta firmy, dlatego też AIP pomaga zakładać jednoosobowe działalności gospodarcze, spółki cywilne i spółki osobowe prawa handlowego. Forma prawna jest zawsze dobierana odpowiednio do wielkości przedsięwzięcia. Osoba działająca w inkubatorze może w każdej chwili opuścić inkubator, ale nie może w nim przebywać dłużej niż dwa lata.

Akademickie inkubatory przedsiębiorczości czynnie realizują ideę przedsiębiorczości i samodzielności także poprzez tzw. biznesy własne. Jest to działalność gospodarcza podejmowana przez dany AIP, której dochód jest przeznaczany na rozszerzanie działalności inkubatora oraz jego modernizację i wprowadzanie usprawnień. Biznesy własne pozwalają inkubatorom na uniezależnienie finansowe od Fundacji AIP i podejmowanie bardziej kosztochłonnych działań na rzecz promocji przedsiębiorczości.

\section{Przyjmowanie beneficjentów}

Przyjmowanie nowych uczestników projektu AIP odbywa się z reguły metodą konkursu na najlepsze biznesplany, który odbywa się raz w roku ${ }^{4}$ Wyłaniane są wówczas najlepsze pomysły, które dostają szansę realizacji w inkubatorach w całym kraju. Ponadto zwycięzcy otrzymują nagrody pieniężne i inne, które mają ułatwić start firmy w inkubatorze.

Szczegóły organizacji konkursu oraz warunki składania prac zawarte są w regulaminie konkursu, z którym zobowiązani są zapoznać się wszyscy nadsyłający prace. Regulamin dostępny jest na stronie www.inkubatory.pl. Po zakwalifikowaniu pomysłu do realizacji osoba, która go złożyła, sporządza wraz z dyrektorem AIP tzw. indywidualny plan działania, który zawiera szczegółowy opis realizacji projektu oraz przewidywane koszty i przychody. Następnie zawiera z AlP umowę, na mocy której uzyskuje pomoc.

Aby wziąć udział w konkursie (uprawnieni są wszyscy chętni, którzy nie ukończyli 30 lat), należy swój pomysł na działalność gospodarczą opisać na (maksymalnie) trzech stronach A4 i przesłać wraz z wypełnionym formularzem (dostępnym w serwisie www.inkubatory.pl w zakładce „konkurs”) pod adresem: konkurs@inkubatory.pl. Nie ma wymogu, by prace konkursowe

\footnotetext{
${ }^{4}$ Więcej informacji można znaleźć w internecie pod adresem: www.inkubatory.pl.
} 
były kompletnymi biznesplanami, ale powinny one zawierać jego elementy: opis projektu, metody jego realizacji oraz koszty finansowe jego wdrożenia.

Prace poddawane są dwustopniowej ocenie.

- W pierwszym etapie rady inkubatorów, w których skład wchodzą przedstawiciele władz uczelni, dyrektorzy inkubatorów oraz przedsiębiorcy z BCC, wybierają najlepsze pomysły, które kwalifikują do realizacji w inkubatorze.

- Wyłonione prace ocenia Kapituła, złożona z ekspertów z Business Centre Club oraz przedsiębiorców. Kapituła wyłania kilka najlepszych biznesplanów i nagradza ich twórców stypendiami pieniężnymi na rozwój firmy. Nagrody są fundowane przez patronów AIP: ministra gospodarki prezesa BCC oraz mecenasów AIP.

W efekcie około 100 autorów najlepszych biznesplanów rozpoczyna realizację swoich wymarzonych pomysłów, zakładając firmy w AIP.

Jak rozpocząć działalność w inkubatorze poza konkursem? Należy złożyć stosowny wniosek wraz z opisem przedsięwzięcia gospodarczego na ręce dyrektora AIP, w którym chce się rozpocząć działalność. Dyrektor AIP - na wniosek zainteresowanego podmiotu i z jego udziałem - przygotowuje szczegółowy biznesplan przedsięwzięcia. Biznesplan i wniosek ocenia rada AIP. Po uzyskaniu pozytywnej oceny wniosku i biznesplanu podmiot starający się o przyznanie pomocy zostaje zaproszony na rozmowę kwalifikacyjną z dyrektorem AIP, której celem jest ostateczna ocena przedsięwzięcia. Po tej rozmowie dyrektor AIP podejmuje decyzję o zakwalifikowaniu podmiotu do pomocy AIP i o podpisaniu z nim stosownej umowy przedwstępnej, a po wniesieniu opłaty wpisowej następuje podpisanie umowy z Fundacją Akademickie Inkubatory Przedsiębiorczości.

\section{Kto może skorzystać z pomocy AIP}

O przyznanie pomocy AIP wystapić może każda osoba, która nie ukończyła 30 lat, a w szczególności studenci i absolwenci szkół wyższych mający pomysł na rozpoczęcie własnej działalności gospodarczej. Osoby takie prowadzą własny biznes w inkubatorze na tzw. zasadzie pionu, tzn. nie zakładają własnych firm, lecz działają na rachunek i ryzyko inkubatora.

Uczestnikami inkubatora mogą być też osoby posiadające własną firmę, ale chcące skorzystać z pomocy AIP. Takie osoby działają w inkubatorze na własny rachunek i ryzyko.

\section{Świadczenia na rzecz beneficjentów sieci AIP}

Akademicki inkubator przedsiębiorczości udziela beneficjentom szeroko zakrojonej pomocy przy tworzeniu, organizowaniu i prowadzeniu działalności gospodarczej.

- Osoba prowadząca działalność gospodarczą w ramach inkubatora początkowo nie musi zakładać własnej firmy (działanie na zasadzie pionu w inkubatorze) i ponosić związanych z tym kosztów.

- Uczelnia, przy której funkcjonuje dany inkubator, udostępnia wyposażone w odpowiednie urządzenia biurowe (meble, komputer z dostępem do internetu, drukarka itd.) pomieszczenia przeznaczone do prowadzenia działalności gospodarczej.

- Ksiegowość podmiotów funkcjonujących w obrębie inkubatorów prowadzi biuro rachunkowe.

- Beneficjenci mogą liczyć na bezpłatne porady prawnopodatkowe najlepszych kancelarii prawnych w kraju, współpracujących z AlP.

- Beneficjenci mogą korzystać z systemu szkoleń z zakresu autoprezentacji, zarządzania, a także prawa gospodarczego, marketingu itd.

- Fundacja zapewnia beneficjentom dostęp do prasy specjalistycznej. 
- Fundacja pomaga beneficjentom w pozyskiwaniu funduszy na inwestycje oraz w promocji i reklamie, głównie poprzez współpracę ze specjalistycznymi agencjami PR i marketingowymi.

- W trakcie inkubacji każda osoba może liczyć na bieżącą pomoc dyrektora AIP.

- Fundacja, która czynnie wspiera i koordynuje działalność inkubatorów w całym kraju, sprawuje nad wszystkimi beneficjentami opiekę merytoryczną, pomaga w zdobywaniu funduszy dla większych przedsięwzięć i doradza im w kwestiach reklamy w mediach.

- Dzięki aktywnym kontaktom z firmami zrzeszonymi w BCC, Fundacja pomaga beneficjentom pozyskiwać pierwszych kontrahentów.

Wszyscy beneficjenci mogą liczyć na promocję swojej strony internetowej poprzez portal inkubatory.pl oraz inne media oraz dzięki posługiwaniu się znakiem akademickiego inkubatora przedsiębiorczości. Raz w roku organizowane są targi firm z inkubatorów i tworzy się ich ranking.

\section{Akademicki Inkubator Przedsiębiorczości przy Wyższej Szkole Bankowej w Toruniu ${ }^{5}$}

Akademicki Inkubator Przedsiębiorczości przy Wyższej Szkole Bankowej w Toruniu już od października 2004 r. stwarza szansę młodym ambitnym osobom, dając możliwość tworzenia nowych miejsc pracy absolwentom i studentom oraz inspirując współpracę między środowiskami naukowo-badawczymi a przedsiębiorcami. Nad jego działaniami czuwa Rada Inkubatora pod przewodnictwem Doroty Dąbrowskiej, wicekanclerza Wyższej Szkole Bankowej w Toruniu. W skład Rady wchodzą również przedstawiciele czołowych firm toruńskich: Wojciech B. Sobieszak, prezes CPP Toruń-Pacific, Kanclerz Loży Toruńskiej BCC Kazimierz Herba, prezes Torfarm S.A. W AIP w Toruniu z powodzeniem funkcjonują 4 firmy o różnych profilach ${ }^{6}$. Działają one na regionalnym toruńskim rynku oraz na rynkach ogólnopolskim i międzynarodowym. Od czasu powstania AIP w Toruniu już ponad 30 osób na zasadzie współpracy i wolontariatu miało możliwość zdobyć doświadczenie przy tworzeniu i rozwijaniu firmy.

Oprócz podstawowej działalności związanej z obsługą istniejących firm, AIP przy Wyższej Szkole Bankowej realizuje również :

- programy stażowe - we współpracy z Powiatowym Urzędem Pracy;

- programy stypendialne - we współpracy z Europejskim Funduszem Socjalnym;

- projekty zadań publicznych:

1. „Przeciwdziałanie bezrobociu i wspieranie przedsiębiorczości” ze środków Urzędu Miasta Torunia,

2. „Konwent Akademickiej Przedsiębiorczości” ze środków Urzędu Marszałkowskiego Województwa Kujawsko-Pomorskiego;

\footnotetext{
${ }^{5}$ Warto wspomnieć, że 14.09.2006 r. Rada Miasta Torunia zadecydowała jednogłośnie o utworzeniu Centrum Promocji Przedsiębiorczości i Projektów Zintegrowanych, czyli inkubatora przedsiębiorczości. Toruńskie Centrum ułatwi start małym i średnim przedsiębiorstwom. $Z$ jego usług skorzystają zarówno dopiero co powstałe firmy, jak i osoby, które właśnie przymierzają się do działalności gospodarczej. Preferowane będą firmy niewymagające wielkiego kapitału początkowego, działające głównie w branży usługowej. Toruński inkubator ma być największym takim przedsięwzięciem w kraju. Jego stworzenie pochłonie 23,5 mln zł. Pieniędzy miasto poszuka w funduszach europejskich. Jeśli chodzi o formę własności, to w $100 \%$ będzie to instytucja gminna. W ten sposób miasto wesprze drobnych przedsiębiorców. Plan na najbliższe trzy lata jest prosty: Centrum stworzy warunki do powstania 120 niewielkich firm. Dzięki nim zatrudnienie znajdzie 500 osób. Do 2010 r. projekt nie będzie przynosił zysku. Dopiero po tym czasie miasto spodziewa się zwrotu nakładów [za:] D. Wójcicki, Powstanie inkubator, „Gazeta Wyborcza”, dodatek lokalny, 15.09.2006 r.

${ }^{6}$ Stan w końcu września 2006 r.; dane uzyskane od Dyrektora AIP w Toruniu.
} 
- cykle konferencji z udziałem wybitnych dydaktyków oraz przedsiębiorców z regionu toruńskiego;

- cykle szkoleń mających na celu podnoszenie kwalifikacji osób bezrobotnych oraz studentów w zakresie:

1. komunikacji w biznesie,

2. podstaw negocjacji,

3. podstaw autoprezentacji,

4. podstaw rachunkowości oraz prawa gospodarczego.

Można stwierdzić, że Akademicki Inkubator Przedsiębiorczości przy Wyższej Szkole Bankowej w Toruniu nie stosuje szkolenia młodzieży poprzez nudne, monotonne, nieefektywne warsztaty, lecz stwarza młodym osobom szansę zakładania własnych firm z możliwością konsultacji kadry naukowej oraz lokalnych przedsiębiorców, bez ryzyka związanego z działalnością.

\section{Sukcesy akademickich inkubatorów przedsiębiorczości w Polsce}

AIP działają krótko (od 2004 r.), ale mająjuż niewątpliwe sukcesy:

1. jest to pierwsza sieć w Europie Środkowo-Wschodniej współpracujących ze sobą 16 akademickich inkubatorów przedsiębiorczości;

2. dzięki AIP powstało już ponad 150 firm prowadzonych przez młodych ludzi;

3. firmy z AIP w 2005 r. wygenerowały niemal 2 mln zł przychodu;

4. ponad 800 młodych osób zgłosiło chęć działania w AIP (uczestnicy konkursu na biznesplany w AIP);

5. ogólnopolska kampania promująca akademicką inicjatywę na przełomie października i listopada 2005 r. zgromadziła 18 patronów medialnych-największych polskich mediów oraz prawie 100 mediów zaangażowanych w całej Polsce;

6. AIP we współpracy z Powiatowym Urzędem Pracy przekazały młodym osobom w całej Polsce ponad 70 bezzwrotnych dotacji na założenie własnych firm, w wysokości 12000 zł każda;

7. Parlament Studencki RP za najlepszą inicjatywę 2005 r. przyznał AIP-om tytuł Studenckiej Inicjatywy 2005.

\section{Literatura}

1. Sprawozdanie z działalności AIP przy WSB w Toruniu

2. Tokarski M., 2006, Prawno-ekonomiczne bariery rozwoju matych i średnich przedsiębiorstw na przykładzie województwa kujawsko-pomorskiego [w:] Zarzadzanie podmiotami i procesami gospodarczymi, J. Wiśniewski (red.), Wyższa Szkoła Bankowa w Toruniu, Torun

3. Wójcicki D., Powstanie inkubator, „Gazeta Wyborcza”, dodatek lokalny, 15.09. 2006 r.

4. Zarzqdzanie podmiotami i procesami gospodarczymi, 2006, J. Wiśniewski (red.), Wyższa Szkoła Bankowa w Toruniu, Torun

\section{Adresy internetowe}

1. www.inkubatory.pl

2. www.torun.inkubatory.pl

3. www.sfbcc.org.pl 


\section{An Operation of Academic Incubator of Enterprise Based on the Banking School in Toruń}

The Academic "Incubator" of Enterprise (AIE) originated in the Torun Banking School in October 2004 was initiated by the school and the foundation called Academic Incubators of Enterprise (former "Enterprise Above Divisions")

Now there are 16 cooperating AIEs at the best Polish graduate schools which aim for the development of enterprise among Polish young people.

The article shows the operation of AIE and its importance for students of Kujawsko-Pomorskie Province. 


\section{Krystian Sowislok}

II Liceum Ogólnokształcące w Zabrzu

\section{Zachowania młodzieży na współczesnym rynku pracy w Polsce}

Współczesna młodzież w Polsce w wieku 19-26 lat staje się bardziej aktywna i dynamiczna. Nie szuka, jak jeszcze kilka lat temu, usprawiedliwienia swojej bierności i niepowodzeń w otaczającej rzeczywistości, ale raczej w sobie. Spada systematycznie liczba osób nieuczących się i niepracujących, a w latach 2002-2005 dwukrotnie wzrosła grupa jednocześnie uczących się i pracujących, do około 24\% ogółu młodych w wieku 19-26 lat (Raport AIG OFE i „Gazety Wyborczej" - Młodzi 2005).

Ryc. 1. Co należy robić, żeby zwiększyć swoje szanse na rynku pracy (zmiana w czasie)

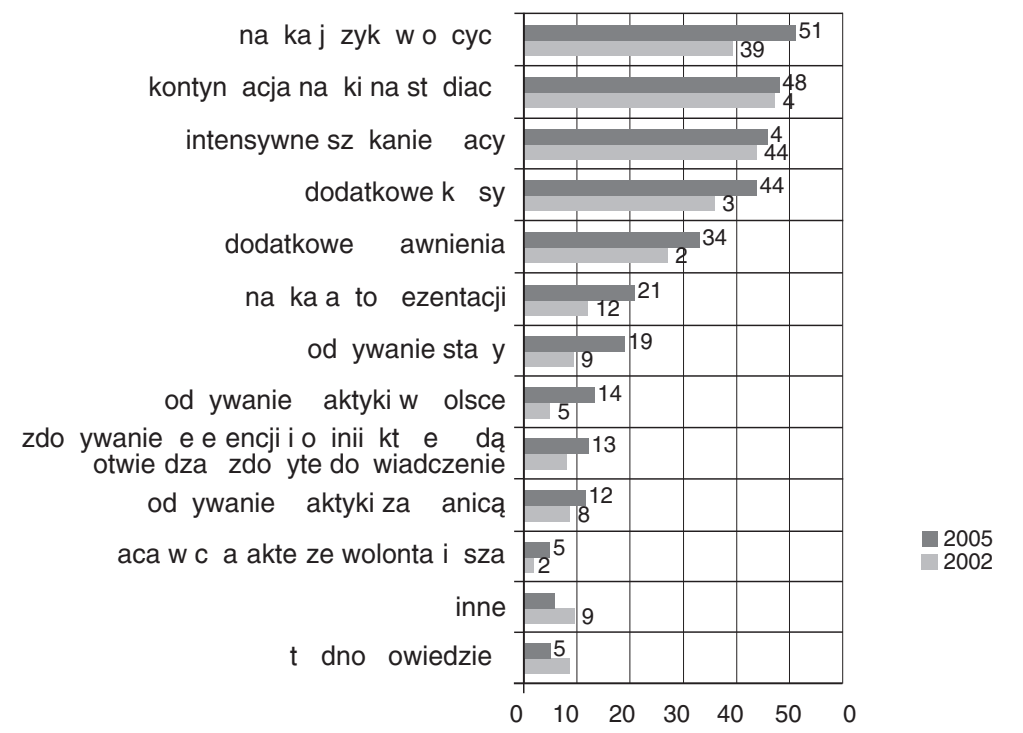

Źródło: opracowanie autora na podstawie Raportu AIG OFE i „Gazety Wyborczej” - Młodzi 2005

Powyższe dane pokazują, że młodzi ludzie starają się zdobywać ciągle nowe doświadczenia i umiejętności; nie poprzestają na tym, co maja, chcą się dalej rozwijać. Robią to zwykle w sposób planowy i przemyślany. Na pierwszym miejscu stawiają naukę języków obcych; przywiązują większą wagę niż dawniej do ciągłego dokształcania się, uczestnictwa w kursach i szkoleniach oraz uzyskiwania dodatkowych uprawnien, licencji i tytułów. Modną formą aktywności wśród młodzieży jest wolontariat. W ostatnich latach stale rośnie procent osób w wieku 19-25 lat podejmujących pracę jako wolontariusze. Obecnie stanowią oni najliczniejszą grupę wiekową wolontariatu. 
Tab.1. Struktura wiekowa wolontariuszy (w \%)

\begin{tabular}{|l|c|c|c|c|}
\hline \multirow{2}{*}{ Wiek } & \multicolumn{4}{|c|}{ Wolontariusze } \\
\cline { 2 - 5 } & $\mathbf{2 0 0 1}$ & $\mathbf{2 0 0 2}$ & $\mathbf{2 0 0 3}$ & $\mathbf{2 0 0 4}$ \\
\hline Poniżej 25 lat & 8,1 & 11,9 & 22,5 & 23,8 \\
\hline 26-35 lat & 7,8 & 9,6 & 19,4 & 16,3 \\
\hline 36-45 lat & 10,4 & $13,6 \%$ & 18,6 & 17,2 \\
\hline 46-55 lat & 14,5 & 13,6 & 20,5 & 18,0 \\
\hline Powyżej 55 lat & 10,1 & 7,1 & 8,3 & 15,0 \\
\hline
\end{tabular}

Źródło: opracowanie autora na podstawie raportu z badań Wolontariat, filantropia i 1\% (Gumkowska, Herbst, Wygnański 2004)

Młodzi ludzie w ramach wolontariatu uczą się współdziałania z innymi i zdobywają doświadczenie zawodowe, i to z reguły, jak twierdzą oni sami, w przyjemnej i pożytecznej formie. W trakcie badań ankietowych podkreślają, że praca w charakterze wolontariusza zwiększa ich szanse na rynku pracy.

Wśród zdobywanych doświadczeń przeważają pozytywne, ale realia polskiego rynku pracy, różne warunki i stosunki pracy powodują że młodzież gromadzi również doświadczenia negatywne. Do takich należą: praca „w nadgodzinach” bez dodatkowego wynagrodzenia, opóźnianie, zmniejszanie, a nawet brak wynagrodzenia, odmowa udzielenia przysługującego urlopu. Zdarzają się także mobbing i zwolnienia z pracy bez podania przyczyny. Takim negatywnym zjawiskiem jest również, stosowane nagminnie przez pracodawców w Polsce, zatrudnianie młodych ludzi bez jakiejkolwiek umowy - „na czarno”. Taką pracę najczęściej wykonują osoby najsłabiej wykształcone. Zdarza się, że w swojej pracy zawodowej nigdy nie zetknęli się z inną formą zatrudnienia.

Ryc. 2. Podejmowanie pracy „na czarno” według poziomu wykształcenia (w \% ogółu młodych podejmujących pracę)

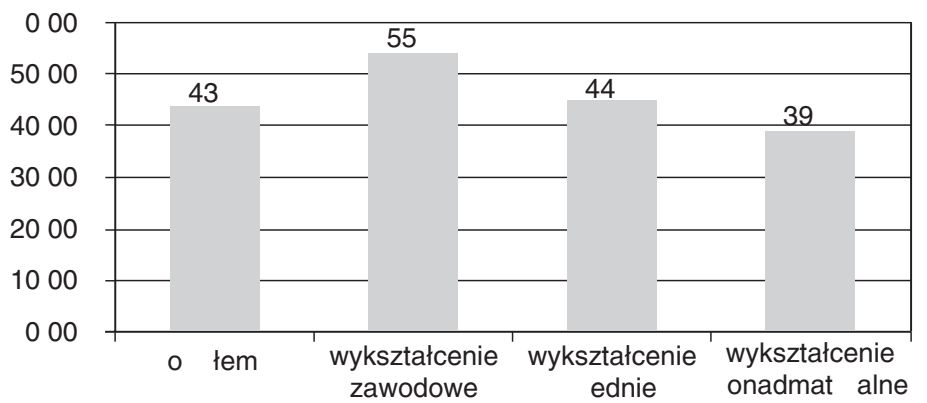

Źródło: Raport AIG OFE i „Gazety Wyborczej” - Młodzi 2005

Z przedstawionego wykresu wynika, że $43 \%$ respondentów podejmujących pracę pracowało „na czarno”. W grupie respondentów legitymujących się wykształceniem zawodowym, bez umowy o pracę było zatrudnionych 55,0\%, z wykształceniem średnim (odpowiednio) 44,0\%, z wykształceniem ponadmaturalnym $-39,0 \%$.

Własne doświadczenia związane z rynkiem pracy mobilizują młodzież do samodzielnego poznawania przepisów prawa pracy. Duży wpływ na taki stan rzeczy mają media coraz częściej pokazujące przykłady bezprawnych praktyk niektórych pracodawców oraz pozytywne dla pracowników 
rozstrzygnięcia sądowe. Młodzi napotykają także problemy, z którymi bez dobrej znajomości praw i obowiązków pracowniczych nie mogą sobie poradzić. Sięgają wobec tego do kodeksu pracy, po specjalistyczne czasopisma i wydawnictwa.

Znacznie częściej niż nad zjawiskami negatywnymi, młodzi zastanawiają się nad cechami idealnej pracy. Są zdecydowani i bardzo konkretni. Uważają, że idealna praca powinna być interesująca, gwarantować bezpieczeństwo zatrudnienia, dawać możliwość rozwoju i awansu, ale przede wszystkim powinna być dobrze płatna.

Pewnym wzorcem kariery zawodowej dla młodych ludzi jest przedsiębiorca, który założył firmę i dzięki niej może żyć razem z całą rodziną znacznie lepiej niż osoba pracująca na posadzie „u kogoś”. Taki model wybrałaby prawie połowa z nich. Chęć otwarcia własnej firmy w ciagu najbliższych pięciu lat częściej deklarują osoby z wyższym wykształceniem, podkreślają jednak, że największą przeszkodą jest brak pieniędzy. Fundusze, które można otrzymać w ramach programów wspierania samozatrudnienia przez młodzież, są niewystarczające; przydałby się też własny „,wkład”. Poza tym podnoszone bywają kwestie wysokich kosztów prowadzenia firmy, które w związku z tym traktowane sąjako jedna z poważniejszych barier przedsiębiorczości młodych.

Ryc. 3. Zmienność intencji założenia własnej firmy (w \%)

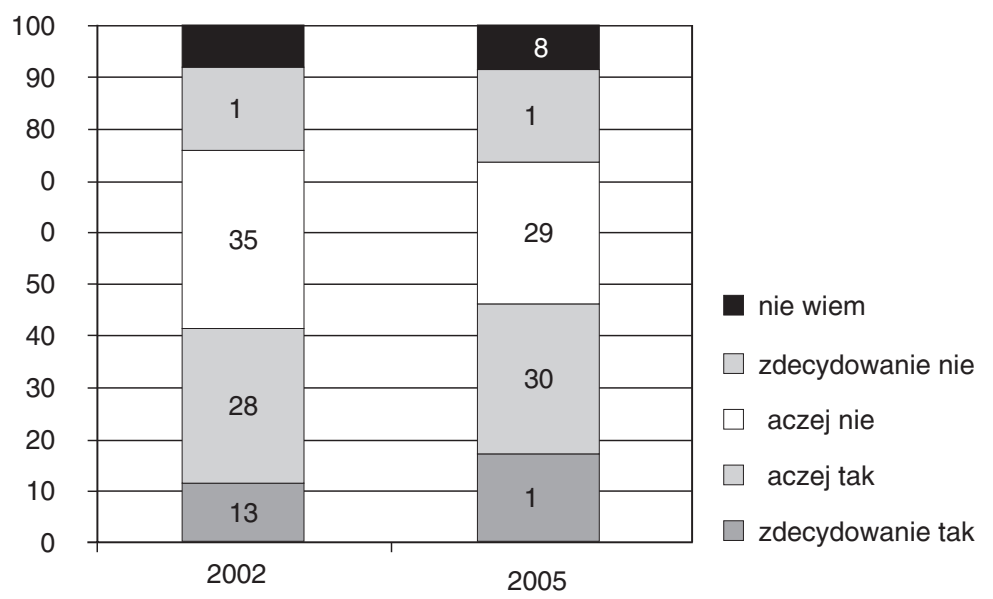

Źródło: Raport AIG OFE i „Gazety Wyborczej” - Młodzi 2005

Z wykresu wynika, że deklaracje założenia firmy wykazują stosunkowo niską zmienność w czasie; porównanie wyników z lat 2002 i 2005 pokazuje, że pozytywne deklaracje wykazują niską tendencję wzrostową (różnice 2-4\%).

Z analizy Raportu Młodzi 2005 wynika zatem, że obecnie młodzi ludzie swoją aktywność zawodową starają się realizować nieco inaczej niż jeszcze w niedalekiej przeszłości. Więcej z nich stara się podejmować pracę na czas określony, dorywczą, na zlecenie lub umowę o dzieło, mniej niż w przeszłości - na umowę stała, na czas nieokreślony. Duże znaczenie w takim podejściu ma fakt, że wzrost aktywności łączony jest z nauką; młodzież widzi konieczność ustawicznego kształcenia, zdobywania nowych umiejętności i poznawania nowych technologii. Korzystają z nadarzających się szans, ale dostrzegają także negatywne zjawiska na polskim rynku pracy, co mobilizuje ich do szukania rozwiązań, aby poradzić sobie w trudnych sytuacjach. Taka postawa może prowadzić w przyszłości do zmian standardów zachowań w relacjach pomiędzy uczestnikami rynku pracy, które obecnie nie są chlubą naszego kraju. Niezbędne jest odbudowanie właściwych więzi w załogach pracowniczych firm i przedsiębiorstw oraz tworzenie nowoczesnych 
struktur organizacyjnych. Są przesłanki, że wraz z młodym pokoleniem wchodzącym na rynek pracy do takich zmian powoli może dochodzić.

\section{Metodyka własnych badań wśród młodzieży}

Na przełomie lat 2005 i 2006, wzorując się na autorach Raportu Młodzi 2005, przeprowadzono podobne badania wśród młodzieży klas maturalnych II Liceum Ogólnokształcącego w Zabrzu, w celu oceny roli zabrzańskich lokalnych instytucji w przeciwdziałaniu bezrobociu młodzieży. Miały one m.in. odpowiedzieć na pytanie: „Jak współczesna młodzież radzi sobie na rynku pracy i jakie sa jej plany edukacyjne i zawodowe?"

Charakter badanych problemów, a więc postaw młodzieży na rynku pracy oraz oceny przedsięwzięć edukacyjnych przygotowujących do dorosłego, w tym zawodowego życia, jest zmienny i zależy od wielu czynników zewnętrznych. Można do nich zaliczyć instytucjonalne i prawne bariery rozwoju przedsiębiorczości i tworzenia nowych miejsc pracy na danym terenie oraz ilość i jakość przedsięwzięć podejmowanych w celu aktywizacji młodzieży i przygotowania jej do wejścia na rynek pracy. Wreszcie - wiedza o faktach społecznych może wywierać bezpośredni wpływ na świadomość ludzi, którzy się z nią zetkną, kształtować ich światopogląd i system wartości, skłaniać ich, poprzez wpływ na ich postawy, do określonych zachowań (Nowak 1985). W przypadku badanego problemu istotne są także indywidualne predyspozycje uczniów. Wydaje się, że nie tylko jednostki kształtują obraz danej zbiorowości, ale pewne fakty społeczne oddziałują na jednostki i kształtują ich postawy. Jest to stanowisko między skrajnym indywidualizmem a holizmem, które zakłada, że cechy całości społecznych są zależne od cech części je współtworzących, a cechy części od całości przez te części współtworzonej (Sołoma 2002).

Badania miały również potwierdzić hipotezy, że przedsięwzięcia skierowane do młodzieży wpływają na zwiększenie przedsiębiorczości i aktywności na rynku pracy, a młodzi ludzie zdają sobie sprawę, jakie wymagania są przed nimi stawiane, mają swoje marzenia i jasne ścieżki rozwoju własnej kariery.

Badanie przeprowadzono metodą ilościową. Dzięki dotarciu do wyników zaprezentowanych wyżej podobnych badań możliwe było wykorzystanie metody porównawczej, którą stosuje się często w badaniach zjawisk życia społecznego w celu ustalenia cech i zachowań podobnych, identycznych lub odmiennych dla grup o zbliżonych charakterystykach. Jako technikę badawczą wykorzystano anonimową ankietę audytoryjną. Kwestionariusz ankiety zawierał zbiór dziewięciu pytań, które dotyczyły doświadczeń zawodowych, wyobrażeń na temat zatrudnienia i pożądanych cech pracy oraz planów życiowych po maturze badanych uczniów.

Wybór próby reprezentacyjnej opierał się na zasadach doboru celowego. Dobór celowy to świadomy dobór obiektów do próby badanej ze względu na to, że spełniają one określonego rodzaju kryteria (Sołoma 2002).

Badania przeprowadzono wśród uczniów klas trzecich II Liceum Ogólnokształcącego w Zabrzu, którzy są typowymi przedstawicielami młodzieży miasta. Są, co bardzo istotne dla poznania badanych problemów, kolejnym rocznikiem kończącym naukę w liceum po wprowadzeniu przedmiotu podstawy przedsiębiorczości do programu szkół ponadgimnazjalnych. Ponadto w czasie edukacji uczestniczyli w innych formach szkolenia i warsztatach związanych z rynkiem pracy.

\section{Prezentacja rezultatów badań}

Badani uczniowie mają w większości osiemnaście lat; praca i życie zawodowe dopiero przed nimi. Okazuje się jednak, że większość z nich - 66\% - ma już za sobą pierwsze doświadczenia zawodowe. Szczegółowe dane na ten temat prezentuje ryc. 4. 
Na wzrost aktywności młodzieży wpływa kilka czynników. Na polskim rynku zachodzą przeobrażenia w kierunku preferowania pracy w niepełnym wymiarze czasu oraz formy zatrudnienia na podstawie umów czasowych. Jest to z reguły niekorzystne dla osób o ustabilizowanym statusie życiowym, które oczekują stałego zatrudnienia. Tę lukę wypełniają młodzi ludzie łączący naukę z pracą. Młodzież z reguły chce zarobić na dodatkowe ,zachcianki”, takie jak nowy telefon komórkowy, modna odzież, kosmetyki czy popołudnie z przyjaciółmi w pubie. Młodzież pracuje także dlatego, że tak robią rówieśnicy, koleżanki i koledzy, którzy są zresztą „źródłem” kontaktów i sposobem dotarcia do ewentualnego pracodawcy.

Ryc. 4. Podejmowanie pracy przez uczniów II LO w Zabrzu (w \%)

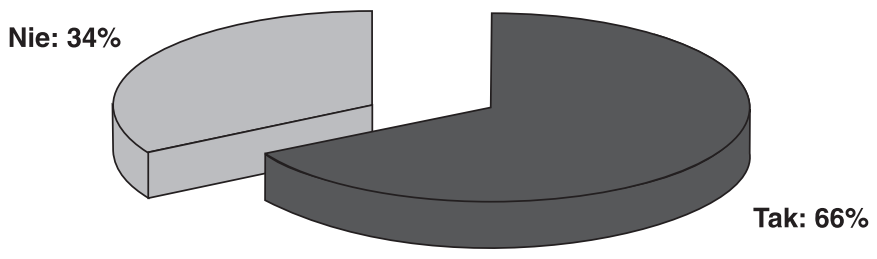

Źródło: opracowanie autora

Liberalizacja na rynku pracy ma jednak nie tylko plusy. To, że praca w niepełnym wymiarze godzin, dorywcza, jest łatwiej dostępna, wiąże się z omijaniem przez niektórych pracodawców przepisów prawa i zatrudnianiem młodych ludzi bez umowy - „na czarno”.

Ryc. 5. Formy zatrudnienia badanych ( $w \%)$

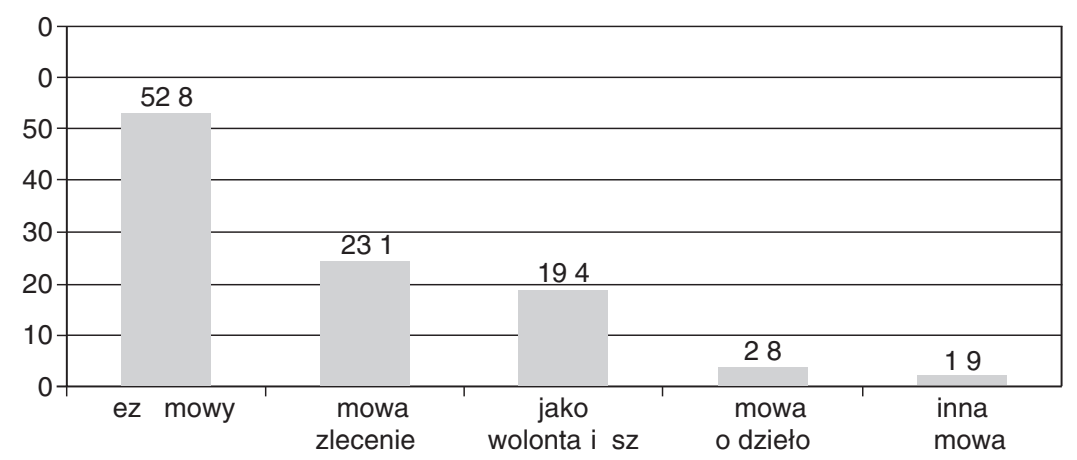

Źródło: opracowanie autora

Więcej niż połowa uczniów - 57, czyli 52,8\% spośród tych, którzy dotychczas pracowali, było zatrudnionych bez umowy, więcej niż 1/4 - 25 uczniów, czyli 27,8\%, pracowało po podpisaniu umów zleceń, o dzieło i o pracę. Młodzież z reguły podejmuje pracę w handlu (hostessy promujące wyroby znanych marek w supermarketach), usługach i w wolontariacie - 21 uczniów, czyli $19,5 \%$ ogółu pracujących. Należy podkreślić, że w wolontariacie może podjąć pracę tylko osoba pełnoletnia, a 18 lat ankietowani ukończyli dopiero w 2005 r., jest to więc chyba dobry wynik.

Młodzi ludzie zdają sobie sprawę z tego, że aby stać się bardziej atrakcyjnymi dla potencjalnych pracodawców, muszą - oprócz doświadczeń - zdobywać kolejne umiejętności i uprawnienia.

Zdaniem uczniów najważniejsze są kontynuowanie nauki (studia) i znajomość języków obcych, konieczna m.in. w związku z otwarciem unijnych rynków pracy oraz dużą liczbą przedstawicielstw firm zagranicznych i przedsiębiorstw krajowych kooperujących z firmami zagranicznymi, 
Ryc. 6. Czynniki zwiększające szanse młodych ludzi na rynku pracy - według uczniów II LO w Zabrzu

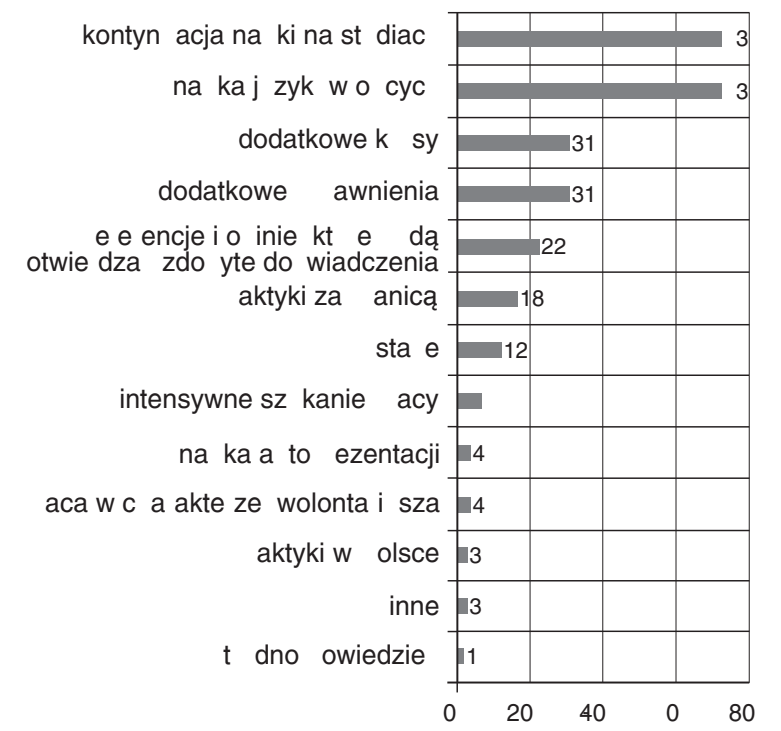

Źródło: opracowanie autora

wymagających od pracowników biegłego posługiwania się językami obcymi. Te odpowiedzi (można było zaznaczyć trzy) wybrało 73\% ankietowanych. Podkreślono również duże znaczenie dodatkowych kursów - 31\% odpowiedzi, zdobywania dodatkowych uprawnień - 31,2\% odpowiedzi, referencji i opinii potwierdzających dotychczasowe doświadczenie - 22,2\% odpowiedzi. Młodzi ludzie są świadomi, że w związku z rosnącymi wymaganiami i konkurencją niełatwo jest obecnie zdobyć pracę. Aby przyszła praca spełniała ich oczekiwania, muszą się stale rozwijać.

Wolontariat jest jedną z dróg budowania własnej pozycji na rynku pracy. Uczniowie decydują się na pracę wolontariusza przede wszystkim po to, aby pomagać innym i zrobić coś pożytecznego. Kolejne najczęściej wskazywane powody są związane z planowaniem przyszłej kariery zawodowej. Dotyczą nabywania umiejętności współpracy z ludźmi, zdobywania doświadczenia zawodowego i uatrakcyjnienia własnego CV. Obecnie w Centrum Wolontariatu w Zabrzu pracuje ponad 150 wolontariuszy. Centrum nie prowadzi dokładnych statystyk z podziałem na grupy wiekowe, ale z uzyskanych danych wynika, jaki udział w wolontariacie mają uczniowie i studenci, a więc najprawdopodobniej osoby znajdujące się w grupie wiekowej 18-25 lat. Stanowią oni 24\% (37 osób) ogółu wolontariuszy w Zabrzu. Jest to porównywalna wielkość do udziału w wolontariacie tej grupy wiekowej w Polsce w 2004 r. (por. tab. 2).

Wizerunek idealnej pracy na podstawie odpowiedzi uczniów jest jasny i konkretny. Przede wszystkim powinna być dobrze płatna. Poza tym istotne jest, aby była interesująca i zgodna z wybranym zawodem, dawała możliwość dalszego rozwoju i aby panowała w niej miła atmosfera. Zważywszy na młody wiek ankietowanych, ciekawe, że duże znaczenie ma dla nich również stałość zatrudnienia. Przyczyną może być to, że do tej pory, podejmując pracę, spotykali się z łamaniem praw pracowniczych, np. brakiem umowy o pracę, opóźnieniami w wypłacaniu wynagrodzenia lub obniżeniem wynagrodzenia, złym traktowaniem przez przełożonych. Zdają sobie sprawę, że aby mogli się bronić przed takim traktowaniem, muszą lepiej poznać przepisy prawa pracy. 
Ryc. 7. Źródła informacji o prawie pracy (w \%) - według uczniów II LO w Zabrzu

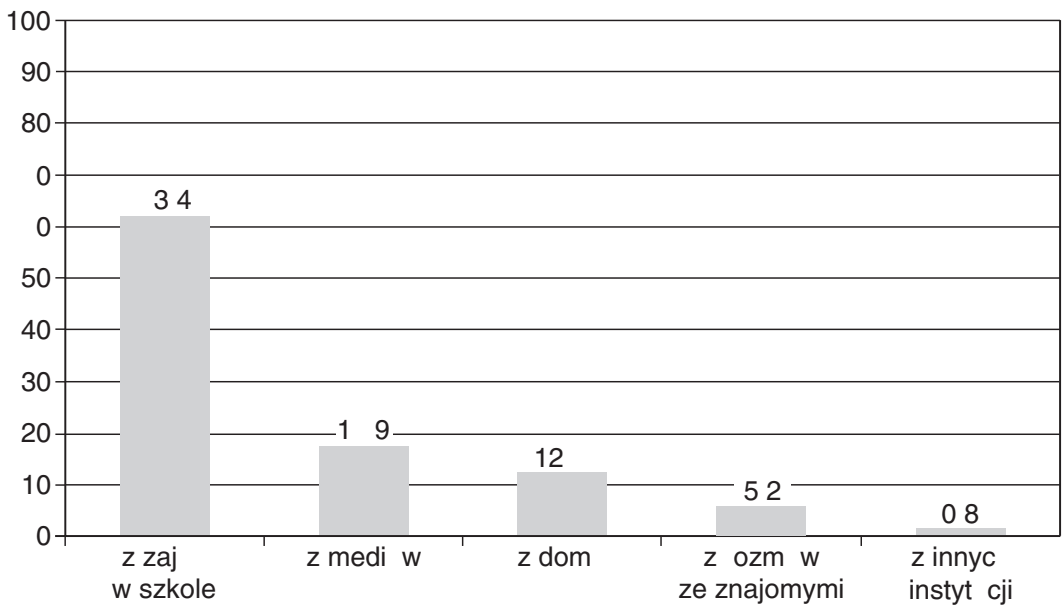

Źródło: opracowanie autora

Przedstawiony stan rzeczy próbują, zdaniem uczniów, zmienić przede wszystkim nauczyciele przedmiotu podstawy przedsiębiorczości, w którego programie mieszczą się zagadnienia dotyczące m.in. umów o pracę oraz praw i obowiązków pracownika i pracodawcy. Uczniowie przyznają że przepisy prawa pracy najczęściej poznają na zajęciach w szkole $(63,4 \%)$. Niektórzy wymieniają jako źródło informacji media (17,9\%) lub dom (12,7\%).

Ryc. 8. Czynniki decydujące o zatrudnieniu w Polsce - według uczniów II LO w Zabrzu

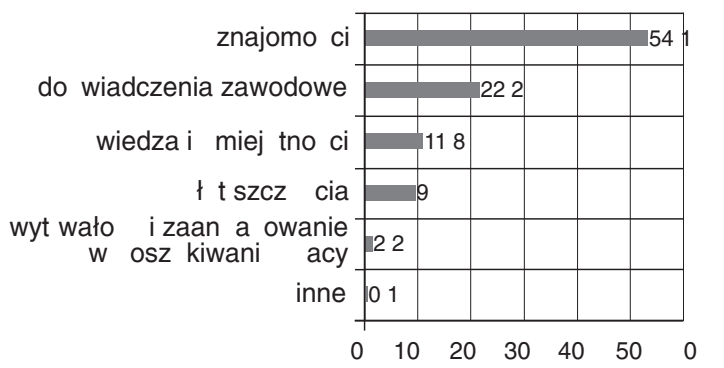

Źródło: opracowanie autora

Opinie młodych ludzi o czynnikach decydujących w Polsce o zatrudnieniu nie są pozytywne. Więcej niż połowa uczniów $(54,1 \%)$ uważa, że o zatrudnieniu decydują znajomości. Uczniowie wyjaśniali, że większość zaznaczała tą odpowiedź nie dlatego, że rodzina czy znajomi ,załatwiają” im pracę, ale że sąźródłem informacji o miejscach pracy i dzięki ich wskazówkom mogą łatwiej dotrzeć do potencjalnego pracodawcy. Oprócz omawianej wyżej odpowiedzi niektórzy ankietowani podkreślili również istotną rolę doświadczenia zawodowego (22,2\%) oraz wiedzy i umiejętności (11,8\%).

\section{Plany życiowe badanych po maturze}

Ankietowani, tegoroczni maturzyści, planują dalszą edukację. Wiedzą że na razie ich wartość na rynku pracy jest bardzo niska, ponieważ traktuje się ich jak pracowników niewykwalifikowanych, bez zawodu. Część z nich myśli o podjęciu pracy równocześnie z nauką. 
Ryc. 9. Plany badanych uczniów dotyczące łączenia po maturze dalszej edukacji z pracą

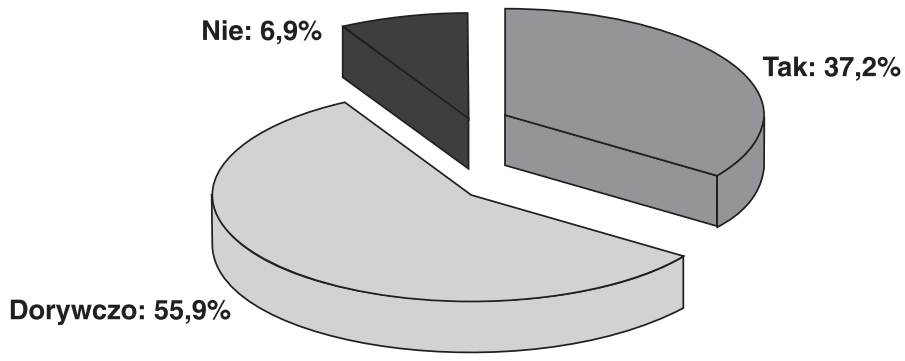

Źródło: opracowanie autora

Osób, które chciałyby pogodzić naukę z praca, jest ponad jedna trzecia (37,2\%). Najwięcej $(55,9 \%)$ jest takich, którzy chcieliby pracować dorywczo, żeby zaspokoić potrzeby, których koszty przekraczają wysokość kieszonkowego otrzymywanego od rodziców. W tej grupie są również uczniowie, którzy zaspokajają swoje ambicje dzięki wolontariatowi i pomocy innym ludziom. Niewielu spośród ankietowanych nie myśli o łączeniu nauki z pracą $(6,9 \%)$.

Mimo że ankietowani są dopiero osiemnastolatkami, ostatnie pytanie dotyczyło możliwości założenia w przyszłości własnej firmy. Nie określono w ankiecie, czy te plany mają być realizowane w ciągu najbliższych pięciu czy nawet dziesięciu lat. Ważne było, czy przy obecnej wiedzy i przygotowaniu merytorycznym rozważają taką możliwość.

Założenie własnej firmy zdecydowanie zadeklarowała niemal jedna czwarta uczniów. Największą grupę stanowią niezdecydowani: raczej tak - 16,3\%, raczej nie $-27,9 \%$, nie wiem $-33,6 \%$ (łącznie ponad 77\%). Potwierdza to wysuwaną już tezę, że dla tych młodych ludzi jest jeszcze za wcześnie na podjęcie jednoznacznej decyzji w tej sprawie.

Ryc. 10. Zainteresowanie badanych uczniów podjęciem działalności gospodarczej (w \%)

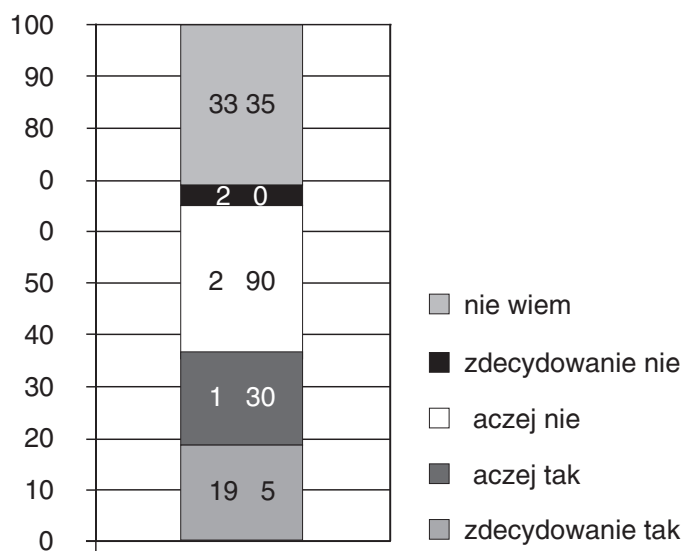

Źródło: opracowanie autora

\section{Porównanie wyników badań autora z wynikami podobnych badań przeprowadzonych w kraju}

Od wielu lat bezrobocie młodzieży jest w Polsce bardzo niepokojącym zjawiskiem. Taka sytuacja, czyli samo istnienie problemów społecznych, zdaniem S. Nowaka wyznacza problematykę badań socjologicznych (1985). Problem bezrobocia młodzieży szczególnej wagi nabiera obecnie, kiedy na rynek pracy wchodzi wyż demograficzny połowy lat 80. XX w. Dzięki badaniom 
uzyskujemy możliwość rozszerzenia wiedzy o przejawach życia społecznego i wzbogacenia jej o nowe dane i wynikające z nich wnioski (Sztumski 1979). Na początku niniejszej pracy przedstawiono opinie młodzieży z całego kraju dotyczące rynku pracy w Polsce, oparte na danych Raportu AIG OFE i „Gazety Wyborczej” - Młodzi 2005, a w dalszej części omówiono zbliżone tematycznie i ze względu na wiek ankietowanych opinie uczniów klas maturalnych II Liceum Ogólnokształcącego w Zabrzu. Możliwe jest więc przeprowadzenie analizy porównawczej.

Przekonania młodzieży o tym, co należy robić w celu zwiększenia swoich szans na zatrudnienie, są podobne, niezależnie od miejsca zamieszkania i wieku. W porównywanych badaniach młodzi ludzie podkreślają, że trzeba się kształcić, doskonalić znajomość języków obcych i uczestniczyć w kursach i szkoleniach, aby zdobyć dodatkowe umiejętności i uprawnienia. Jedyną poważną różnicąjest znaczenie intensywnego poszukiwania pracy: w Raporcie Młodzi 2005 na trzeciej pozycji, wśród uczniów II LO w Zabrzu - na ósmej. Wyjaśnienie jest chyba proste. Taką strategię trzeba stosować, poszukując pracy stałej, a zatrudniając się dorywczo, młodzi ludzie korzystają z kontaktów rodzinnych lub koleżeńskich.

W analizie badań podkreślany był kilkakrotnie problem zatrudniania pracowników „,na czarno" oraz to, że uczniów liceum na rynku pracy uważa się za niewykwalifikowaną siłę roboczą. Najczęściej pracodawcy zatrudniają ich bez umowy o pracę. Wynik badania ankietowego autora (52,8\%) nie odbiega od statystyk krajowych w tej kwestii (55\%).

Przedstawiona sytuacja wywołuje zachowania obronne młodych ludzi. Starają się oni lepiej poznać przepisy prawa pracy. Część młodzieży, za jaką uważa się osoby w wieku 18-25 lat, nie miała jeszcze takiej możliwości zdobywania wiedzy nt. prawa pracy, jaką mają obecni uczniowie szkół ponadgimnazjalnych uczestniczący w zajęciach z przedsiębiorczości. Uczniowie klas maturalnych II LO w Zabrzu podkreślają że najwięcej informacji o prawie pracy uzyskują w szkole, w ramach zajęć z podstaw przedsiębiorczości (63,4\%). Ich starsi koledzy muszą sobie radzić sami, korzystając z mediów czy prasy lub sięgając po kodeks pracy.

Każdy, nie tylko młody człowiek, chciałby wykonywać pracę zgodną z zainteresowaniami i - co najważniejsze - dobrze płatną. To samo podkreślają ankietowani młodzi ludzie w Polsce i uczniowie II LO w Zabrzu. Ważne są dla nich także gwarancja zatrudnienia, możliwości rozwoju i awansu oraz koleżeńska atmosfera w miejscu pracy.

Większość młodych ludzi marzy o karierze przedsiębiorcy, która kojarzy im się z niezależnością i zarabianiem dużych pieniędzy. Żeby jednak podjąć decyzję o rozpoczęciu własnej działalności gospodarczej, trzeba nie tylko chęci, ale również predyspozycji, sprzyjających warunków i pewnej dojrzałości. Tej ostatniej - przede wszystkim, choć nie tylko - ankietowanym uczniom jeszcze brakuje. Stąd na pytanie o gotowość do założenia własnej firmy duża część niezdecydowanych odpowiadała ,nie wiem”. Jest ona większa niż w przypadku odpowiedzi na to pytanie osób ze starszych grup wiekowych uwzględnionych w Raporcie Młodzi 2005.

Z przedstawionych porównań wynika, że poglądy i marzenia dotyczące pracy zawodowej uczniów klas maturalnych II LO w Zabrzu pokrywają się z ogólnie panującymi wśród młodzieży w Polsce. Widać oczywiście ich mniejsze doświadczenie w poruszaniu się po rynku pracy, ale w pewnych sprawach mają przewagę. Mogąjuż teraz w czasie zajęć z podstaw przedsiębiorczości uzyskać wiele istotnych informacji i nabyć umiejętności, które starsze koleżanki i koledzy muszą zdobywać samodzielnie.

Zwiększa się liczba tych, którzy pierwsze zawodowe doświadczenia zbierająjeszcze w czasie edukacji i to nawet na szczeblu ponadgimnazjalnym. Są przy tym świadomi konieczności kształcenia się i ciagłłego zdobywania nowych umiejętności, uprawnień i doświadczeń. Wykazują aktywność nie tylko w podejmowaniu pracy zarobkowej. Często swoje ambicje zaspokajają bezinteresownie, pomagając ludziom jako wolontariusze. Z opinii młodzieży poznanych w trakcie 
badań oraz analizy wyników badań prowadzonych w Polsce przez różne instytucje wynika, że młodzi ludzie coraz lepiej radzą sobie na rynku pracy. Można również stwierdzić, że stają się, zgodnie z intencjami nauczycieli przedsiębiorczości i przedmiotów ekonomicznych oraz wszystkich innych osób odpowiedzialnych za edukację w tym zakresie, bardziej przedsiębiorczy.

\section{Literatura}

1. Gumkowska M., Herbst J., Wygnański J., 2004, Wolontariat, filantropia i 1\%, Stowarzyszenie Klon/ /Jawor, www.klon.org.pl

2. Nowak S., 1985, Metodologia badań społecznych, PWN, Warszawa

3. Raport AIG OFE i „Gazety Wyborczej”-Młodzi 2005, 2005, www.gazeta.pl/praca

4. Sołoma L., 2002, Metody i techniki badań socjologicznych, Wyższa Szkoła Pedagogiczna, Olsztyn

5. Sztumski J, 1979, Wstęp do metod i technik badań społecznych, Uniwersytet Śląski, Katowice

\section{Youths' Behaviors on the Current Labour Market in Poland}

Young people are becoming more and more active on the labour market these days. The number of young adults who are studying and working at the same time is increasing. These statements are confirmed by research done all over Poland and the survey conducted among the last-year students of The Second Comprehensive School in Zabrze.

Young people acquire their first job experience during their education, after completing grammar school course. They treat their careers very seriously in a planned and unhurried manner. They are conscious of the necessity of further education, especially mastering foreign languages and getting more skills and experience. A national research and my own survey come to the conclusion that young people seem to be performing better and better on the labour market and becoming, in compliance with our intentions, more and more entrepreneurial. 


\section{Kazimierz Nowak}

Zespół Szkół Przemysłu Spożywczego

w Krakowie

\section{Start młodzieży na rynku pracy}

Gospodarka każdego kraju za najważniejsze zadanie stawia sobie odpowiedni wzrost gospodarczy, stabilne ceny i pełne zatrudnienie. Realizacja tych zadań związana jest z realizacją celów społecznych, takich jak ${ }^{1}$ :

- wolność ekonomiczna,

- efektywność ekonomiczna,

- sprawiedliwość ekonomiczna,

- bezpieczeństwo ekonomiczne.

Nierówność społeczna to sytuacja, gdy ludzie są nierówni sobie nie z powodu jakichkolwiek cech cielesnych czy psychicznych, lecz z powodu przynależności do różnych grup, zajmowania różnych pozycji społecznych albo nierównego dostępu do społecznie cenionych dóbr. Raczej nie mówi się o nierówności wówczas, gdy różnica w dostępie do tych dóbr jest nieznaczna.

J.J. Rousseau wyróżnia dwa rodzaje nierówności: naturalną lub przyrodzoną, ustanowioną przez naturę i polegającą na różnicach wieku, sił, zdrowia, zalet umysłu czy duszy, oraz obyczajową, polityczną albo społeczną, zależną od czegoś w rodzaju umowy; albo jest ona zgodnie ustanowiona przez ludzi, albo moc swą przynajmniej czerpie z tej zgody. ${ }^{2}$ Źródłem nierówności drugiego rodzaju są fakty społeczne nieodznaczające się naturalnością, lecz będące czymś sztucznym, ustanowionym.

Zagrożenia wywołane przez nierówności mają zarówno wymiar społeczny, gdyż dotyczążycia mniejszych lub większych zbiorowości ludzkich, jak i wymiar indywidualny, dotyczą bowiem losów i perspektywy życia jednostek. ${ }^{3}$

Największe zagrożenie nierówności stwarzają człowiekowi jako jednostce społecznej, gdyż krępująjego inicjatywę, tłumią jego wolność, nie pozwalają na to, by mógł suwerennie stanowić o sobie.

\section{Charakterystyka polskiego rynku pracy wśród młodzieży}

Polski rynek pracy charakteryzuje się najwyższym bezrobociem w Unii Europejskiej. Dotyczy ono przede wszystkim ludzi młodych. Zgodnie z ustawą z 20.04.2004 r. o promocji zatrudnienia i instytucjach rynku pracy, obowiązującą od 1.06.2004 r. (Dz.U. Nr 99, poz.1001, z późn. zm.), stopę bezrobocia podaje się z uwzględnieniem pracujących w gospodarstwach indywidualnych

\footnotetext{
${ }^{1}$ T. Buczyńska, 2000, Makroekonomia, WS PWN, Warszawa-Łódź.

${ }^{2}$ J.J. Rousseau, Rozprawa o pochodzeniu i podstawach nierówności między ludźmi, thum. H. Elzenberg [w:] Trzy rozprawy z filozofii spolecznej, PWN, Warszawa 1956.

${ }^{3}$ K. Sosenko, A. Węgrzecki, Nierówność jako kategoria interdyscyplinarna, „Zeszyty Naukowe” 1/2003, Uniwersytet Rzeszowski.
} 
Ryc. 1. Stopa bezrobocia w wybranych krajach Unii Europejskiej w 2005 r. (przeciętnie w roku)

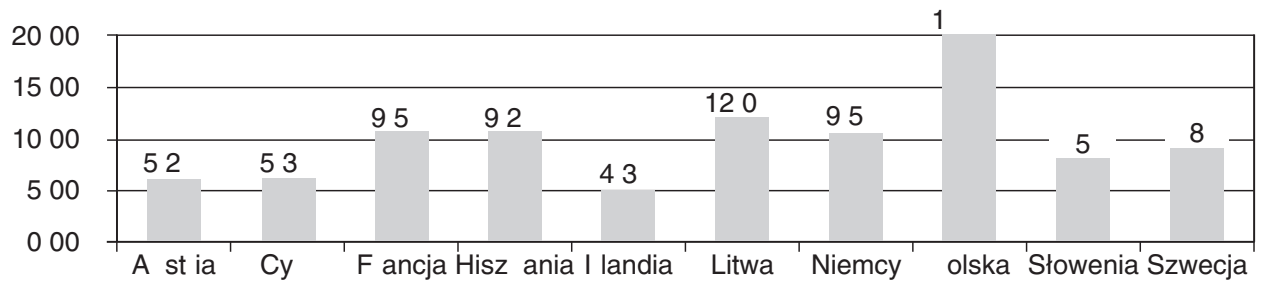

Źródło: Mały Rocznik Statystyczny, GUS, Warszawa 2006

w rolnictwie. Od 1.06.2004 r. za bezrobotnego nie uważa się osoby odbywającej przygotowanie zawodowe w miejscu pracy. ${ }^{4}$ Stopę bezrobocia w wybranych krajach UE przedstawia ryc. 1.

Bezrobocie w Polsce ma charakter strukturalny; w 80\% wynika z uwarunkowań instytucjonalnych, które wywołują ograniczenie popytu na pracę, małą elastyczność rynku pracy, wysokie pozapłacowe koszty pracy, utrzymywanie jednolitej stawki płacy minimalnej wobec dużych zróżnicowań na regionalnych rynkach pracy.

Pomimo dotkliwego bezrobocia, wiele czynników powoduje ograniczenie liczby osób zainteresowanych podjęciem pracy. Najważniejsze z nich związane są z charakterem polityki społecznej i wysokim poziomem dostępności pozapłacowych źródeł dochodów oraz charakterem regulacji i negocjacji płacowych w gospodarce.

Ryc. 2. Struktura zatrudnienia młodych (15-24 lata) według poziomu wykształcenia w IV kwartale 2005 r.

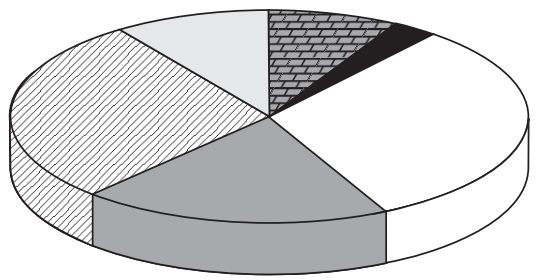
国 wyższe 9,8\%
policealne $3,8 \%$
zawodowe rednie $31,4 \%$
og Inokształcące 19,4\%
zasadnicze zawodowe $23,8 \%$
$\square$ gimnazjalne i podstawowe $11,8 \%$

Źródło: Mały Rocznik Statystyczny, GUS, Warszawa 2006

Niezwykle ważną rolę w ograniczaniu podaży pracy odgrywają ograniczenia przestrzenne i jakościowe na rynku pracy. Ograniczenia przestrzenne wiążą się z niską mobilnością terytorialną siły roboczej, a jakościowe są następstwem niskich kwalifikacji dużej części poszukujących pracy oraz luk w systemie edukacji.

Autorzy Rekomendacji Polskiego Forum Strategii Lizbońskiej do Narodowego Planu Reform 2005-2008 podkreślają że polityka społeczna, której celem jest ograniczanie ubóstwa, opiera się głównie na redystrybucji dochodów. Wprawdzie świadczenia dla bezrobotnych zmniejszają ubóstwo w kraju, gdyż otrzymują je ubodzy, to jednak na skutek negatywnego wpływu kosztów polityki socjalnej na sytuację na rynku pracy, w wyniku transferów, tworzy się nowe ubóstwo związane z wykluczeniem z rynku pracy. Niski stopień zatrudnienia powoduje wzrost ubóstwa, natomiast wzrost zatrudnienia sprzyja zmniejszaniu ubóstwa, zwłaszcza wśród młodych. Szczególnie niskie stopy zatrudnienia dotyczą osób młodych, wchodzących na rynek pracy.

${ }^{4}$ Maty Rocznik Statystyczny, GUS, Warszawa 2006

${ }^{5}$ Polskie Forum Strategii Lizbońskiej. Wzrost gospodarczy i zatrudnienie, 2005, Warszawa-Gdańsk. 


\section{Polityka kształcenia a rynek pracy}

Reforma edukacji zapoczątkowała proces dostosowywania polskiego szkolnictwa do potrzeb gospodarki i rynku pracy. W praktyce okazało się, że idee reformy są lepsze od ich wykonania. Złożyło się na to kilka czynników:

- brak konsekwencji w realizacji reform,

- niepełna decentralizacja,

- wprowadzanie i wycofywanie nowej matury,

- połowiczna reforma systemu prawnego odnoszącego się do wykonywania zawodu nauczycielskiego.

Z tych względów przekształcenia systemu edukacji w Polsce muszą być kontynuowane, aby poprawić jakość kształcenia i dostosować je do potrzeb gospodarki. Zasadniczym problemem, który należy rozwiązać, jest polityka kształcenia zawodowego. W krajach UE odbywa się ono zwykle poza systemem szkolnym. Szybkie tempo postępu technicznego powoduje, że wiedza techniczna dezaktualizuje się, a absolwenci szkół zawodowych, jak żadna inna grupa, są narażeni na bezrobocie. W tej sytuacji jest konieczne stopniowe ograniczanie stosowania tej formy edukacji i zastępowanie jej przekazywaniem wiedzy zawodowej w ramach formalnej edukacji w szkole średniej lub po zakończeniu kształcenia.

Kolejną kwestią jest polityka dokształcania skoordynowana z polityką edukacyjną. Dokształcanie poza systemem szkolnym powinno być dopasowane treścią i formą do tego, czego się uczy bądź nie uczy w szkole. ${ }^{6}$ Dokształcanie winno też wyrównywać szanse grup wcześniej upośledzonych w dostępie do kształcenia, a także zapobiegać wykluczaniu i długotrwałemu bezrobociu.

W Polsce aktywni zawodowo dokształcają się rzadziej aniżeli w krajach tzw. starej Unii. Dlatego też edukacja i kształcenie ustawiczne muszą przejmować realizację zadań państwa w zakresie pomagania w wychodzeniu z ubóstwa i wyrównywania szans.

Oprócz regulacji rynkowej procesów dokształcania istotna jest interwencja państwa, której elementy mogą obejmować dotacje lub zbliżone rozwiązania niwelujące nierówności. Ofertę dokształcania należy kierować do grup najsłabszych na rynku pracy, osób nisko wykwalifikowanych, bezrobotnych oraz zagrożonych bezrobociem z powodu dezaktualizacji kwalifikacji zawodowych. Taka polityka dokształcania prowadzi do zmniejszania nierówności i wykluczania oraz ogranicza długotrwałe bezrobocie bardziej efektywnie niż polityka redystrybucji.

W celu osiągnięcia efektywności w pracy szkół konieczne jest zwiększenie ich konkurencji o ucznia, ale należy też poprawić jakość pracy tych szkół. Konieczna jest deregulacja rynku pracy nauczycieli poprzez zmianę lub likwidację Karty Nauczyciela, zniesienie pensum i wprowadzenie właściwych zasad awansu, dzięki którym najlepsi nauczyciele będą mieli możliwość szybkiego osiagania kolejnych szczebli kariery.

W polityce edukacyjnej należy położyć nacisk na kompensowanie nierówności edukacyjnych wynikających ze zróżnicowania kulturowego i materialnego środowisk uczniów. Wyrównanie szans powinno więc następować poprzez douczanie i dokształcanie.

\section{Zatrudnienie młodych ludzi warunkiem integracji społecznej}

W wypadku młodych ludzi osiągnięcie niezależności finansowej i realizacja indywidualnych aspiracji są możliwe poprzez zatrudnienie. Rządzący, którzy nie są w stanie zaoferować młodym ludziom wstępu na rynek pracy, ryzykują ich marginalizację i degenerację społeczną. Otwarcie rynku pracy dla młodych ludzi przyczynia się do stabilności społecznej, która uważana jest za

${ }^{6}$ Polskie Forum Strategii Lizbońskiej. Wzrost gospodarczy i zatrudnienie, Warszawa-Gdańsk 2005. 
podstawę dobrobytu i rozwoju ekonomicznego. Bezrobocie postrzegane jest jako naruszenie praw młodego człowieka.

Młodzi ludzie są bardzo wrażliwi na oferty rynku pracy. Chcą mieć poczucie, że kierunek, który obrali, prowadzi do znalezienia miejsca w świecie pracy w perspektywie długoterminowej. Praca oznacza dla nich zdobycie statusu osoby dorosłej, szacunek wobec samego siebie, wobec pieniędzy i niezależność finansową oraz możliwość rozwoju kontaktów społecznych. ${ }^{7}$ Szanse ich pojawienia się na rynku pracy zwiększają: dobre wykształcenie, umiejętności praktyczne oraz nauka za granicą.

Obecnie młodzi ludzie potrzebują więcej czasu, aby osiągnąc stabilną pozycję na rynku pracy. Dobre wykształcenie nie zawsze gwarantuje znalezienie pracy, ponieważ bardzo wzrosła konkurencja w tej dziedzinie. Sukces na rynku pracy coraz bardziej zależy od okoliczności i doświadczenia młodego człowieka.

Trudności finansowe i rozczarowania, często połączone z problemami osobistymi, prowadzą do zaburzeń psychicznych i życia na marginesie społeczeństwa. Wśród młodzieży rośnie poczucie niesprawiedliwości pokoleniowej oraz świadomość wpływu zmian demograficznych na systemy społeczny, zdrowotny i emerytalny. Zwłaszcza systemy emerytalne zależą od chęci i możliwości młodych ludzi do ich finansowania, ich zatrudnienie warunkuje dobrobyt rodziców i dziadków.

Według młodych ludzi, przejście z etapu kształcenia do etapu pracy powinno być łatwiejsze. Brak strategicznych inicjatyw państwowych lub prywatnych mających na celu wspieranie integracji społecznej osób, które mają trudności ze znalezieniem pracy lub dyskryminowanych na rynku pracy, to główny problem młodych ludzi.

Postęp technologiczny (komputeryzacja) coraz częściej staje się nową formą alienacji społecznej. Nieznajomość nowych technologii doprowadza do biedy w wieku dorosłym.

\section{Ksztaltowanie postaw przedsiębiorczych wśród młodych}

Upowszechnianie postaw przedsiębiorczych w życiu codziennym, w szkole, pracy i w domu, może okazać się pomocne w przezwyciężaniu barier i rozwijaniu wiary w siebie, a także przy tworzeniu nowych i lepszych miejsc pracy. W większości krajów UE młodzi ludzie mają skłonność do zakładania własnych firm; przejmują oni firmy swych rodziców lub krewnych albo tworzą własne. Własna firma jest dla młodego człowieka sposobem na osiagnięcie autonomii i elastyczności, rozpoczęcie kariery zawodowej, wdrożenie innowacyjnych technik działania i nowego stylu zarządzania.

Funkcjonujące w niektórych krajach UE, w tym także w Polsce, systemy edukacyjne nie przygotowują należycie młodych ludzi do wyzwań rynku pracy. Jest rozbieżność pomiędzy prywatnym światem pracy a publicznym sektorem edukacyjnym. Budowanie pomostów między tymi sektorami może złagodzić trudności związane z długością czasu trwania edukacji i nakładami finansowymi na naukę.

Dostęp do rynku pracy dla młodego człowieka jest coraz trudniejszy i wzrastają wymagania związane z wiedza, doświadczeniem zawodowym, elastycznością geograficzną oraz osobistą.

W kwestii legislacji należy poczynić wszelkie działania, aby nadążać za tempem zmian na rynku pracy.

Zadaniem rządów poszczególnych krajów Unii oraz Komisji Europejskiej powinno być dążenie do pełnego zatrudnienia we wszystkich krajach UE. Aby osiagnąć ten stan, młodzi ludzie proponują kilka rozwiązań: skrócenie czasu pracy, wykorzystanie skrócenia czasu pracy do

${ }^{7}$ Biała Księga Komisji Europejskiej. Nowe impulsy dla młodzieży, Komisja Wspólnot Europejskich, Bruksela 2001. 
wspierania integracji na rynku pracy, zapewnienie młodzieży minimalnej płacy i wsparcia finansowego na dokończenie edukacji, poprawienie i poszerzenie publicznych programów w zakresie zatrudnienia.

Coraz częściej młodzi ludzie korzystają z niestałych form zatrudnienia, jak praca studentów, praca sezonowa, praca tymczasowa, staże, kontrakty krótkoterminowe. W myśl obowiązującej od 2004 r. ustawy o pracy tymczasowej, po 12 miesiącach zatrudnienia tymczasowego pracodawca powinien podpisać z pracownikiem umowę o pracę, a pracownik powinien otrzymywać takie samo wynagrodzenie, jak inni wykonujący tę samą pracę. ${ }^{8}$ Jednak młodzi ludzie często są wykorzystywani, otrzymują niskie płace i z reguły częściej niż doświadczeni pracownicy ulegają wypadkom przy pracy.

W szeregu rodzajów działalności zatrudnionych jest procentowo dużo młodzieży, np. w restauracjach fast food, firmach kurierskich, telepracy czy przy roznoszeniu ulotek reklamowych.

Niskie wynagrodzenia zmuszają młodych ludzi do pozostawania w zależności finansowej od rodziców, dziadków czy innych bliskich osób. Niezależność zdobywają oni dopiero w wieku trzydziestu lat lub po jego przekroczeniu. To wpływa także na możliwość i warunki zakładania rodziny oraz wychowywania dzieci.

\section{Zawody deficytowe i nadwyżkowe a bezrobocie wśród młodzieży w woj. małopolskim}

Według statystyk Wojewódzkiego Urzędu Pracy w Krakowie bezrobocie w Małopolsce spada. W końcu czerwca 2006 r. najniższą w kraju stopę bezrobocia odnotowano w woj. małopolskim $-12,3 \%$ (mazowieckie-12,8\%, wielkopolskie-12,9\%).

Woj. małopolskie ma również najniższą stopę napływu bezrobotnych $-0,9 \%$.

Spośród bezrobotnych osoby do 25 roku życia stanowiły w 2006 r. 41,4\% ogólnej liczby nowo zarejestrowanych.

Podobnie jak w poprzednich latach, największa grupa bezrobotnych ma wykształcenie zasadnicze zawodowe $-31,6 \%$ ogółu bezrobotnych zarejestrowanych w urzędach pracy, policealne i średnie zawodowe-22,1\%, średnie ogólnokształcące - 8,4\%, a wyższe - 5,4\%. Pozostałe 32,5\% bezrobotnych to osoby z wykształceniem gimnazjalnym i niższym. ${ }^{9}$

Najliczniejszą grupę bezrobotnych stanowią osoby pozbawione kompetencji zawodowych, co utrudnia im wejście na rynek pracy. Wśród zawodów o największym spadku liczby bezrobotnych wymieniane są następujące: murarz, sprzedawca, ślusarz, robotnik budowlany, pracownik biurowy, kucharz, krawiec i kierowca samochodu osobowego. ${ }^{10}$ Do zawodów o największym napływie bezrobotnych należą: pielęgniarka, handlowiec, kucharz małej gastronomii, asystent ekonomiczny, pedagog i specjalista administracji publicznej. Zawody, w których bezrobocie utrzymuje się najdłużej, są związane z czynnościami nieskomplikowanymi, wykonywanymi najczęściej przez pracowników nisko wykwalifikowanych oraz robotników przemysłowych i rzemieślników.

W małopolskich urzędach pracy odnotowano także takie zawody, na które przedsiębiorcy zgłosili oferty mimo braku zarejestrowanych osób bezrobotnych. Są to: doręczyciel, urzędnik podatkowy, informator handlowy, technik teleinformatyk, aktor cyrkowy. Duże zapotrzebowanie występuje także na informatyków, elektrotechników, biotechnologów i nauczycieli języków obcych, głównie języka angielskiego. W końcu 2005 r. 230 zawodów zaliczono do deficytowych. ${ }^{11}$

\footnotetext{
${ }^{8}$ Ustawa z dnia 9 lipca 2003 r. o zatrudnianiu pracowników tymczasowych, Dz.U. z 22.09.2003 r., Nr 166, poz. 1608 .

${ }^{9}$ Ranking zawodów deficytowych i nadwyżkowych w woj. matopolskim w 2005 r., Raport Wojewódzkiego Urzędu Pracy w Krakowie, Kraków 2006.

${ }^{10}$ Miesięczna informacja o bezrobociu w Polsce w czerwcu 2006 r., GUS, Warszawa 2006.

${ }^{11}$ Ranking zawodów deficytowych i nadwyżkowych ..., op. cit.
} 


\section{Wnioski}

1. Polska należy do najbiedniejszych krajów rozszerzonej Unii Europejskiej (PKB na mieszkańca według parytetu siły nabywczej wynosi około $45 \%$ średniej unijnej).

2. Polityka rozwojowa Polski powinna się opierać na stosunkowo młodej i coraz lepiej wykształconej sile roboczej, dobrych perspektywach dla rozwoju przedsiębiorczości, docenianym w świecie potencjale naukowym i kulturowym oraz stale rozwijającym się rynku.

3. Do kierunków zapewniających absolwentom wyższych studiów dobrą pracę zalicza się informatykę, biotechnologię, elektrotechnikę, filologię angielską.

4. Polityka gospodarcza państwa stymulująca inwestycje o wysokich efektach zewnętrznych i wspierająca ekspansję gospodarki opartej na wiedzy przyczynia się do ograniczania nierówności i służy pomnażaniu dobrobytu społecznego.

5. Konsekwencją nierówności społecznych typu frustrującego, głównie w zakresie dostępu do wykształcenia na poziomie gwarantującym konkurencyjność na współczesnym rynku pracy, są różnego typu straty o charakterze nie tylko społecznym, ale także ekonomicznym, np. niższy poziom wzrostu gospodarczego danego kraju.

6. Nierówności społeczne typu aktywizującego wyzwalają energię społeczną w kierunku pokonania ubóstwa i prowadzą do koncentrowania się na przedsięwzięciach produktywnych.

7. Młodym ludziom należy ułatwić dostęp do rynku pracy poprzez tworzenie odpowiednich bodźców materialnych i odpowiedni system dostosowawczy do wymogów rynku.

\section{Literatura}

1. Begg D., 2003, Makroekonomia, PWE, Warszawa

2. Biała Ksiega Komisji Europejskiej, Nowe impulsy dla młodzieży europejskiej, 2001, Bruksela

3. Buczyńska T., 2000, Makroekonomia, WS PWN, Warszawa-Łódź

4. Maty Rocznik Statystyczny, 2006, GUS, Warszawa

5. Polskie Forum Strategii Lizbońskiej. Wzrost gospodarczy i zatrudnienie, 2005, Warszawa-Gdańsk

6. Sosenko K., Węgrzecki A., Nierówności jako kategoria interdyscyplinarna, „Zeszyty Naukowe” 1/2003, Uniwersytet Rzeszowski

7. Woźniak M.G., 2003, Nierówności społeczne a wzrost gospodarczy. Zarys problematyki, Katedra Ekonomii Uniwersytetu Rzeszowskiego, Rzeszów

8. Woźniak M.G., 2004, Wzrost gospodarczy, Wydawnictwo AE w Krakowie, Kraków

9. Założenia Narodowego Planu Rozwoju na lata 2007-2013, 2004, Warszawa

\section{Young People's Start on a Labour Market}

Poland belongs to the group of the poorest countries in European Union (country's gross growth per capita according to the purchasing power constitutes about $45 \%$ of the union's average).

The development policy of our country should be based on the young and better educated people, on good perspectives for the development of enterprise, on scientific and cultural potential highly valued by the whole world and a continuously developing market.

The fields in which the graduates of the universities may find good jobs in the future include: computer science, biotechnology, electrical engineering, English philology. 
National economic policy, stimulating the investments with good external effects and supporting the expansion of the knowledge based economy, contributes to the reduction of inequalities and the increase of social wealth.

The inequalities lead to social losses and lower growth of the country's profit.

A mitigating the inequalities releases social energy used to fight against poverty and make people focus on the productive activities and initiatives.

Young people should have better access to the job market. It is possible thanks to the creation a proper financial stimuli and a relevant system of adaptation to the market requirements. 


\section{Postawa przedsiębiorcza}

i wizerunek przedsiębiorcy 


\section{Pawel Żukowski}

Wyższa Szkoła Biznesu

i Administracji w Łukowie

\section{Wizerunek osobowościowy współczesnego menedżera w przedsiębiorstwie}

W globalizującej się i integrującej gospodarce przedsiębiorstwa różnego rodzaju, zwłaszcza gospodarcze, żeby odnosić sukcesy w swojej działalności, muszą być sprawnie zarządzane i umieć współpracować z wieloma instytucjami, spełniać oczekiwania swoich klientów i partnerów, a także uważnie analizować postępowanie konkurencji na rynku. Uwarunkowania te i oczekiwania są jednak zmienne w czasie, a często pozostają ze sobą w sprzeczności, co dodatkowo utrudnia i komplikuje zarządzanie przedsiębiorstwami. Wymagania stawiane współczesnym menedżerom mają więc charakter wielowymiarowy i są coraz wyższe (Armstrong 2007, Penc 2001, Żukowski 2006). Z tych względów menedżer powinien umieć rozpoznawać, analizować i rozwiązywać złożone problemy organizacyjno-zarządcze oraz podejmować właściwe decyzje związane ze sprawnym funkcjonowaniem i rozwojem współczesnego przedsiębiorstwa. Zarządzanie wymaga od niego przede wszystkim asertywności, kreatywności i przedsiębiorczości, rozwijania w sobie właśnie tych cech, a jednocześnie odwagi, wytrwałości i zdolności inspirowania innych pracowników do działania, a także tolerancji wobec różnych kultur i kosmopolityzmu. Od sprawności pracy personelu menedżerskiego zależą w głównej mierze sukcesy rynkowe przedsiębiorstwa. Ze względu na ciagle zmieniające się różnorodne elementy otoczenia oraz konieczność szybkich, a nawet natychmiastowych reakcji, praca kierownicza jest szczególnie trudna i odpowiedzialna. Wymaga ona od menedżera określonych predyspozycji psychotechnicznych, szczególnej osobowości, wiedzy i umiejętności oraz doświadczenia, a także uwzględniania uznawanego systemu wartości. O sukcesie menedżera, a tym samym przedsiębiorstwa, decydują również jakość wykształcenia, stałe podnoszenie umiejętności kierowniczych i gotowość do ciągłego poszerzania wiedzy ogólnej, co stanowi poważny i cenny, tzw. kluczowy zasób współczesnego przedsiębiorstwa. Należy zaznaczyć, że w przedsiębiorstwie profesjonalny menedżer spełnia co najmniej następujące role: interpersonalną (nawiązywanie i utrzymanie kontaktów z innymi ludźmi), informacyjną (zbieranie, przetwarzanie i przekazywanie informacji) i decyzyjną (dysponowanie zasobami przedsiębiorstwa) oraz negocjacyjną (umiejętności prowadzenia negocjacji) (Armstrong 2004, Kubik 2005, Stoner, Wankel 2001).

W tej pracy poświęcamy uwagę przede wszystkim typologii menedżerów i ich cechom osobowym (osobowości).

\section{Typologia menedżerów}

Na temat cech osobowych menedżerów i stawianych im wymagań istnieje wiele poglądów i opinii, a także naukowych opracowań. Wynikają z nich istotne różnice dotyczące postulowanych modeli osobowości menedżera i jego zachowania.

Amerykański psycholog zarządzania H. Leavitt zaproponował bardzo użyteczną typologię menedżerów: 
- menedżer wizjoner - jest to osoba śmiała, charyzmatyczna, oryginalna, często ekscentryczna, błyskotliwa i bezkompromisowa; proponuje całkowite zerwanie z przeszłością i wejście na nowe tereny działania; jest obdarzony intuicją inspirującą zwolenników i często kieruje się wyczuciem (instynktem);

- menedżer analityk - zajmuje się liczbami i faktami, a nie opiniami; jest racjonalista, rachmistrzem i kontrolerem; widzi świat w barwach czarnych i białych; uważa, że na wszystko jest właściwa odpowiedź; potrafi za pomocą liczb i rachunkowości (finansowo) kontrolować olbrzymie korporacje; jest systematyczny i ma umiejętność wykorzystywania systemów kontroli;

- menedżer wykonawca - jest pragmatykiem odnoszącym sukcesy w działaniu, we wdrażaniu planów i projektów oraz w rozwiązywaniu trudności; z reguły nieobciążony skłonnością do wizjonerstwa czy nadmiernej analizy, dąży do podporządkowania podwładnych swojej woli.

Praktyka zarządzania wykształciła też pewne europejskie wzorce osobowe menedżerów:

- menedżerowie odważni - są dobrze przygotowani, ambitni, identyfikują się z przedsiębiorstwem i zmierzają do pożądanej jego odnowy; dążą do zaprezentowania się jako kierownicy wartościowi, dojrzali; ich odwaga wynika z wiedzy, umiejętności i kompetencji kierowniczych oraz doświadczenia;

- menedżerowie wyzywający - są niezadowoleni z istniejącego stanu rzeczy, przeciwstawiają się istniejącej strukturze działań w przedsiębiorstwie, pragną zmian, odnowy, sąjednak przeciwnikami przekazywania swoich kompetencji innym pracownikom;

- menedżerowie niezadowoleni - oddalają się od przedsiębiorstwa, odrzucają zastany (istniejący) porządek rzeczy, lecz nie są zdolni do wypracowania programu zmian na lepsze, nie mają ambicji ani większej chęci działania, nie identyfikują się z przedsiębiorstwem, utrzymują wobec niego dystans i odgradzają się od panujących w nim trudności;

- menedżerowie konformiści - akceptują przedsiębiorstwo w zastanym kształcie i porządku rzeczy, uważają istniejące rozwiązania za najkorzystniejsze (optymalne), bronią porządku przedsiębiorstwa i chcą, aby było takie samo w przyszłości; ich motywacją jest dążenie do bycia akceptowanym w przedsiębiorstwie (por. Penc 2001).

Zgodnie z opiniami wielu specjalistów wymagania wobec menedżerów ciągle rosną. W związku z tym formułuje się zespoły cech, których spełnienia wymaga się od menedżera. Na przykład, amerykańska firma doradztwa personalnego Kom i Ferry - na podstawie badań przeprowadzonych w grupie około 1500 amerykańskich, japońskich i europejskich menedżerów o najwyższych kwalifikacjach - uważa, że menedżerowie muszą być przede wszystkim entuzjastami, powinni inspirować, dodawać otuchy, być otwarci i kreatywni oraz dawać przykład etycznego postępowania. Zdaniem jej ekspertów, idealnym menedżerem jest kosmopolita ze świetnym wykształceniem ogólnym, tolerancyjny wobec różnych kultur, sprawny w pracy zespołowej, o niezależnym sposobie myślenia.

\section{Osobowość menedżera}

Osobowość każdego człowieka, jako wartość niepodzielna i jedyna w swoim rodzaju, jest zorganizowaną strukturą cech indywidualnych, wyznawanych wartości i określonych postaw, przejawiających się w sposobie zachowania. Decyduje ona o umiejętności przystosowania się, adaptacji danej jednostki do otoczenia (społeczeństwa). Osobowość tworzy zintegrowaną całość takich zasadniczych grup elementów, jak:

- cechy fizyczne,

- temperament,

- uzdolnienia intelektualne,

- zainteresowania i zamiłowania, 
- wyznawany system wartości,

- przejawiane postawy społeczne,

- sposoby wyrażania myśli, styl bycia i inne cechy (por. Stoner, Wankel 2001).

Temperament jest zespołem cech zachowania człowieka, przejawiającym się siłą i szybkością reagowania na różne sytuacje. W dużym stopniu kreuje on osobowość menedżera. Uzdolnienia intelektualne obejmują cały zespół umiejętności intelektualnych, np. rozwinięte poczucie humoru umożliwia szybkie chwytanie przenośni czy aluzji. Zainteresowania i zamiłowania związane są z ludzką aktywnością, wyznaczają jej kierunek i wpływają na powodzenie w pracy zawodowej. System wartości tworzy wiele elementów należących do zagadnień filozoficznych. Sposoby wyrażania myśli i styl bycia przejawiają się w relacjach z innymi ludźmi.

Wymienione wyżej właściwości nie wyczerpują oczywiście wszystkich cech osobowości składających się na wzorzec idealnego menedżera. Należy je uzupełnić jeszcze wieloma innymi cechami, jak: silna wola, prawy charakter, szczerość i godność osobista, spostrzegawczość i kreatywność, a także ambicja, zdyscyplinowanie, punktualność. Zintegrowana i pozytywnie oceniana osobowość menedżera jest ważnym źródłem jego władzy. Wpływ menedżera na inne osoby związany jest w istotny sposób z cechami jego charakteru. Jak jednak dana osobowość sprawdza się w określonej grupie pracowniczej, zależy w dużym stopniu od uznawanego systemu wartości, cech osobowości jej uczestników, ich potrzeb i oczekiwań, a także warunków, w jakich grupa funkcjonuje, m.in. warunków zarządzania.

Zgodnie z opinią E. H. Scheina (2001), liderzy powinni mieć następujące cechy:

- wysoki poziom percepcji i zrozumienia otaczającej rzeczywistości i samych siebie;

- wysoki poziom motywacji, umożliwiający aktywną partycypację w procesie uczenia się i zmian;

- wielką siłę emocjonalną, pozwalającą pokonywać niepokoje i trudności;

- umiejętność analizy przesłanek kulturowych, identyfikacji tych rozwiązań, które mają rację bytu i tych, które funkcjonują niewłaściwie, a także analizy procesów rozwijających kulturę organizacji pracy;

- chęć i umiejętność angażowania innych pracowników i pozyskiwania ich aktywnego udziału w rozwiązywaniu problemów i wykonywaniu zadań;

- chęć i umiejętność dzielenia się władzą i uprawnieniami do kontroli zgodnie z wiedzą i umiejętnościami ludzi (przekazywanie kompetencji).

W studium opracowanym przez Międzynarodową Agencję Pośrednictwa Menedżerów (TASA) w Brukseli, na podstawie ankiety rozesłanej do najlepszych menedżerów różnych narodowości i zawodów, ustalono, że dobry menedżer powinien:

- być komunikatywny, doskonale informować;

- być praktykiem znającym realia - dzięki talentowi i praktycznemu doświadczeniu;

- być zdolny do stworzenia systemu z tego, co dobrze funkcjonuje;

- być wizjonerem o nieustającej motywacji, kimś, kto potrafi skupić wokół siebie zespół ludzi przekształcających jego wizję w rzeczywistość;

- wyczuwać zmiany i odpowiednio na nie reagować;

- podejmować decyzje, które mogą okazać się słuszne dopiero w przyszłości;

- utrzymywać równowagę między poszanowaniem podwładnych a konsekwencjami podejmowanych decyzji;

- być cierpliwy, zdolny do wysłuchiwania innych i chętny do udzielania pomocy;

- być otwarty na wszystkie pomysły i poglądy;

- umiejętnie reprezentować organizację na zewnątrz. 
Na uwagę zasługuje to, że cechy osobowe (osobowość) menedżerów w poszczególnych krajach różnią się od siebie. Na przykład, dla Amerykanów najważniejsza jest kondycja fizyczna i psychiczna, a dla Belgów i Francuzów nie ma ona większego znaczenia, natomiast umiejętność wzbudzania zaufania zajmuje u nich jedno z pierwszych miejsc, a u Amerykanów - ostatnie miejsce. Różni się także mentalność menedżerów. Brytyjczycy zaczynają spotkanie od ogólnej pogawędki, Francuzi traktują porządek dzienny jako ogólną inspirację, Niemcy zaś uważają za oczywiste, że trzeba się trzymać programu i natychmiast przystępować do rzeczy. Wśród menedżerów niemieckich Francuzi uchodzą za chaotycznych i niedostatecznie systematycznych, choć szczególnie efektywnych w rozwiązywaniu problemów techniki, zwłaszcza automatyzacji. Wszystkich zachodnich menedżerów cechuje wysoki poziom profesjonalizmu.

Nie wypracowano jeszcze solidnej osobowościowej charakterystyki polskich menedżerów. Trudno jest też stwierdzić, czy są oni dobrze przygotowani do podjęcia wyzwań, jakie stoją przed polską kadrą zarządzającą $\mathrm{w}$ warunkach globalizacji i integracji, choć podjęto pewne próby oceny tego przygotowania. Badania cech osobowych (osobowości) polskich menedżerów przeprowadzone przez naukowców (psychologów) z Uniwersytetu Wrocławskiego pozwoliły określić (wyodrębnić) następujące ich słabości:

- niechęć do brania na siebie odpowiedzialności,

- powolność w podejmowaniu decyzji,

- spora emocjonalność w stosunkach międzyludzkich,

- brak ducha innowacyjności,

- mała elastyczność działania,

- preferowanie poczucia bezpieczeństwa,

- stosunkowo mała skuteczność i efektywność działania [por. Witkowski (red.), 1996].

Słabości te są jednak równoważone przez inteligencję, kreatywność, zdolność do adaptacji nowych metod i technik zarządzania oraz chęcią uczenia się i doskonalenia. Jednak te zalety widoczne są zwłaszcza w przedsiębiorstwach typu joint venture, w mniejszym zaś stopniu dotyczą menedżerów przedsiębiorstw państwowych. Inne badania wykazały, że u menedżerów jest bardzo silnie widoczna cecha dominacji i osiagnięć, z których ostatnia nie zawsze bywa efektywnie realizowana. Polski menedżer - według tych badań - jest mało kreatywny, preferuje standardowe, nawykowe rozwiązania; nieliczni zdobywają się na twórcze, nowatorskie, dość ryzykowne, ale właściwe decyzje. Preferowanie sprawdzonych schematów działania może powodować niezdolność do przewidywania następstw aktualnych sytuacji w przyszłości. Jeszcze inne badania dowodzą, że menedżer ceni sobie pewność zatrudnienia, stabilizację pracy w przedsiębiorstwie, w której ma szansę na osiągnięcie sukcesu. Chce mieć wyraźnie określone zadania, zakres kompetencji i odpowiedzialności za ich realizację. Chce, by jego rola ograniczała się do określania zadań i kontroli ich wykonania. Kontakty z przełożonym nie mają dla niego większego znaczenia, a swoje zadania realizuje przy pomocy dobrego zespołu pracowników, w którym ma szeroką autonomię. Menedżer pragnie osiąnąć sukces, niemierzony jednak pozycją w strukturze przedsiębiorstwa czy poziomem dochodów, ale stopniem rzeczywistego współprzyczyniania się do sukcesu całego przedsiębiorstwa (Kubik 2005, Probst, Raub, Romhardt 2004, Żukowski 2006).

Nowoczesne zarządzanie przedsiębiorstwem wymaga menedżerów odważnych, zmierzających do lepszej organizacji, wprowadzających zmiany, potrafiących szybko reagować na ich pojawienie się oraz wykorzystujących je do podejmowania nowych, ryzykownych działań (Drucker 1994). Obecnie w zarządzaniu szczególnego znaczenia nabiera chęć podejmowania ryzyka i ponoszenia za nie odpowiedzialności. Menedżer powinien wprowadzać zmiany; musi planować swoją przyszłość i przyszłość swojego przedsiębiorstwa długofalowo. Musi umieć przewidywać i oceniać przyszłe 
wydarzenia, stan rzeczy i jego skutki. Zarządzanie wymaga twórczej i inspirującej pomysłowości oraz przedsiębiorczości, energii i wyobraźni, a nade wszystko dbałości, aby wszyscy pracownicy zmierzali w pożądanym kierunku i realizowali założone cele i wynikające z nich zadania.

P.F. Drucker za najważniejszą cechę menedżera uważa efektywność. W jego rozumieniu efektywność jest wypadkową dwóch cech: sprawności (robienie rzeczy we właściwy sposób) i skuteczności (robienia właściwych rzeczy). Chociaż sprawność jest ważna, podstawowe znaczenie dla przedsiębiorstwa ma jednak skuteczność. Od menedżera wymaga się więc, aby jego działalność była jednocześnie skuteczna i sprawna. Skuteczność oznacza w tym wypadku umiejętność wyboru właściwego celu (przedmiotu działania) i metod jego realizacji, m.in. w najkorzystniejszy sposób koncentrowania na nim zasobów materialno-energetycznych i informacyjnych oraz wysiłku ludzkiego. Sprawni menedżerowie odznaczają się umiejętnością przyjmowania różnych postaw, które w zależności od okoliczności potrafią skutecznie wykorzystać. P.F. Drucker, oprócz efektywności, wyróżnia inne cechy składające się na osobowość menedżera:

- dobrą organizację czasu własnej pracy,

- osobistą aktywność,

- umiejętność współpracy z ludźmi (zarówno podwładnymi, jak i przełożonymi),

- komunikatywność,

- ciągłe samodoskonalenie,

- umiejętność podejmowania decyzji kierowniczych (Drucker 1994, Kubik 2001).

W jego rozumieniu efektywność pozostaje jednak w pewnym dystansie do wysokiej inteligencji, wyobraźni i wiedzy. Oznacza to, że samo posiadanie tych trzech atrybutów nie jest gwarancją skuteczności, choć na pewno stanowią one podstawowe składniki we wzorcu osobowości menedżera. Z podejściem P.F. Druckera zgadzają się J.A. F. Stoner i Ch. Wankel (2001).

Do skuteczności odwołuje się również M. Armstrong. Twierdzi on, że w celu wykształcenia tej cechy należy:

- zrozumieć, co robią skuteczni,

- obserwować skutecznych,

- analizować własne zachowania,

- uczyć się wszystkiego, co jest dostępne na temat technik zarządzania (Armstrong 2007, Bjerke 2004).

Na wiele cech dobrego menedżera wskazuje M. Armstrong, ujmując je jako zalecenia. Są one wynikiem zarówno jego własnych badań, jak i rozważań innych autorów. Wymienia następujące: znajomość podstawowych faktów, właściwą wiedzę zawodową, stałą wrażliwość na to, co się dzieje, umiejętności analityczne, umiejętności rozwiązywania problemów, umiejętności podejmowania decyzji, umiejętności dokonywania oceny, zalety i umiejętności towarzyskie, odporność emocjonalną, wolę działania, predyspozycje do twórczego myślenia (wyobraźnię), gibkość umysłową, ustalone nawyki i umiejętności uczenia się, wiedzę o samym sobie, gotowość do podejmowania ryzyka, umiejętność inspirowania entuzjazmu, twardość i stanowczość, asertywność, tzn. domaganie się respektowania swoich praw w taki sposób, aby nie naruszać praw innych osób, wyrażanie własnych potrzeb, chęci, opinii, odczuć i przekonań w bezpośredni i szczery sposób, myślenie lateralne, innowacyjność, logiczne, jasne myślenie, komunikatywność i dar przekonywania (Armstrong 2004, Bjerke 2004).

Oprócz wyżej wymienionych cech (rekomendacji), menedżer powinien wykazywać zmysł praktyczny oraz dużą elastyczność w pracy kierowniczej. Zmienne warunki tej pracy wymagają dużej energii, wytrwałości w działaniu oraz aktywności. Bierność i poddawanie się okolicznościom oceniane są negatywnie. Menedżer powinien być spostrzegawczy i mieć umiejętność obserwowania faktów, obiektywnego badania przyczyn i wyciągania wniosków. 
Z uwagi na tak liczne cechy osobowe wymieniane przy identyfikacji wzorów osobowościowych menedżerów przez różnych autorów, często podejmowane są próby ustalenia najważniejszych cech, jakimi powinien odznaczać się menedżer. Wobec tak dużej liczby cech pożądanych rodzi się pytanie o najważniejsze z nich. Sądzę, że za dodatnie cechy osobowe, tworzące osobowość menedżera zbliżoną do idealnej, można, z pewnym uproszczeniem, uznać:

- twórczą wyobraźnię i inwencję, szeroki horyzont myślowy,

- umiejętność przewidywania przyszłych zdarzeń, stanów rzeczy i ich skutków,

- zdolności przywódcze,

- odwagę, zdecydowanie i zdolność podejmowania decyzji, nawet ryzykownych, stosownie do okoliczności,

- nieprzeciętną energię, silną wolę i stałość charakteru,

- komunikatywność oraz umiejętności wzbudzania zaufania i przekonywania,

- umiejętność pracy w zespole i współdziałania z nim, poczucie więzi grupowej oraz poświęcenie dla przedsiębiorstwa,

- inteligencję, przejawiającą się umiejętnością wyboru właściwego postępowania w nieprzewidzianych sytuacjach,

- elastyczność w działaniu, takt i życzliwość,

- inicjatywę i przedsiębiorczość, przejawiającą się poszukiwaniem nowych rozwiązań oraz podejmowaniem nowych przedsięwzięć,

- poczucie osobistej odpowiedzialności,

- uczciwość, sprawiedliwość i poszanowanie prawa,

- stałe doskonalenie umiejętności kierowniczych i poszerzanie wiedzy ogólnej,

- zdolność jasnego i zwięzłego wyrażania myśli,

- tolerancyjność wobec różnych kultur, kosmopolityzm.

Niezbędne są też profesjonalizm (kwalifikacje zawodowe, kompetencje menedżerskie) i wysoki poziom etyczny. Uważa się, że umiejętność postępowania z ludźmi i podnoszenie efektywności pracy zespołowej to $85 \%$ sukcesu w pracy zawodowej menedżera.

Jaka powinna być osobowość idealnego menedżera? Wydaje się, że jednoznacznej odpowiedzi nie ma, zwłaszcza w polskich warunkach. Wzorcowemu menedżerowi przypisuje się różne, bardzo pozytywne cechy, łącznie z tym, że musi on mieć zarówno autorytet formalny, jak i nieformalny (osobisty), oparty na wiedzy, umiejętnościach i racjonalności postępowania. Musi on mieć osobowość „wartą” tego, by go słuchać (Rachwał, Rachwał 2005).

\section{Podsumowanie}

Jakkolwiek w procesie zarządzania przedsiębiorstwem cechy osobowe menedżera są bardzo ważne, to jednak w kształceniu i doskonaleniu menedżerów nie można koncentrować się wyłącznie na osobowości i jej wzbogacaniu. Cechy osobowe, wiedza i umiejętności oraz sprawność intelektualna często decydują o właściwym postępowaniu menedżera z ludźmi, jego reakcjach. Jednak to nie wszystko. Sukces menedżera zależy w dużej mierze od tego, w jakim stopniu potrafi on pogodzić swoje wrodzone i wykształcone cechy osobowe z oczekiwaniami przełożonych i podwładnych. Ponadto dotychczasowe badania i doświadczenia nie pozwoliły ustalić właściwego zestawu cech osobowych (osobowości) - czy szerzej: wzorca - idealnego menedżera, odnoszącego prawdziwe sukcesy w działalności kierowniczej. Teoria cech kierowniczych jest zawodna i jak dotąd nie została potwierdzona empirycznie. Długie listy różnorodnych cech osobowych i profesjonalnych menedżera nie wystarczają do wyboru skutecznego, sprawnego i efektywnego kierownika, niezbędny jest jeszcze jego wysoki poziom etyczny (Kietliński, Martinez-Reyes, Aleksyn 2004, Penc 2001). 
Osiagnięcie przez menedżera prawdziwego sukcesu (nie tylko finansowego) wymaga także znajomości i stosowania w pracy kierowniczej zasad etyczno-moralnych. W zarządzaniu bowiem, w którym złem jest dać się przyłapać, a nie w którym złem jest postępowanie niezgodne z zasadami etycznymi, nigdy nie osiagnie się prawdziwego i pełnego sukcesu. Prawdziwy sukces w biznesie osiagają ci menedżerowie, którzy mają wiedzę, umiejętności, doświadczenie i odwagę, ale zarazem są uczciwi i przyzwoici, a w swojej pracy zarządczej kierują się uznawanymi zasadami etycznymi (Rachwał 2005).

\section{Literatura}

1. Armstrong M., 2007, Jak być lepszym menedżerem, Oficyna Ekonomiczna ABC, Warszawa

2. Armstrong M., 2004, Zarzadzanie zasobami ludzkimi, Oficyna Ekonomiczna, Warszawa

3. Bjerke B., 2004, Kultura a style przywództwa, Oficyna Ekonomiczna, Kraków

4. Drucker P. F., 1994, Menedżer skuteczny, Akademia Ekonomiczna, Kraków

5. Kietliński K., Martinez-Reyes V., Aleksyn T., 2004, Etyka w biznesie i zarzq̨dzaniu, Oficyna Ekonomiczna, Kraków

6. Kubik K., 2005, Menedżer w przedsiębiorstwie przyszłości, Dom Organizatora TNOiK, Toruń

7. Penc J., 2001, Wizerunek menedżera przyszłości, „Ekonomika i Organizacja Przedsiębiorstwa”, 8/2001

8. Probst G., Raub S., Romhardt K., 2004, Zarzadzanie wiedza w organizacji, Oficyna Ekonomiczna, Warszawa

9. Psychologiczne czynniki sukcesu w zarzadzaniu, S. Witkowski (red.), 1996, Wydawnictwo Uniwersytetu Wrocławskiego, Wrocław

10. Rachwał. M., Rachwał. T., 2005, Wartości moralne podstawa prawdziwego sukcesu menedżera [w:] Rola przedsiębiorczości w podnoszeniu konkurencyjności społeczeństwa i gospodarki, Z. Zioło, T. Rachwał (red.), seria: Przedsiębiorczość - Edukacja nr 2, Wydawnictwo Nowa Era, Zakład Przedsiębiorczości i Gospodarki Przestrzennej Instytutu Geografii Akademii Pedagogicznej w Krakowie, Warszawa-Kraków

11. Schein E.H., 2001, Przywództwo a kultura organizacji, PWE, Warszawa

12. Stoner J., Wankel Ch., 2001, Kierowanie, PWE, Warszawa

13. Żukowski P., 2006, Podstawy nauk o zarzqdzaniu, Oficyna Wydawnicza Politechniki Rzeszowskiej, Rzeszów

\section{Profile of Modern Manager in a Company}

To succeed in a global and integrated economy, various organizations - especially in business - need the efficient management and be able to cooperate with a lot of institutions; also they need to fulfill expectation of their partners and customers as well as carefully study the activities of their competitors. Additional complication and difficulties for the company management result from continuous changes in above conditions and expectations that sometimes are even contradicted. Requirements for the modern managers are multidimensional and strict. So the article emphasizes a typology of managers and their personal attributes. These attributes as well as a knowledge and skills and an intellectual mastery show whether manager is able to communicate with people and properly react - all of these traits fundamentally affect company success. If you look for competent and efficient manager long questionnaires with various personal and managerial attributes are not enough; also high ethical level is essential. Only these managers reach real success who besides having the knowledge, the skills, the courage, and the experience they are also honest and solid; and respected moral values direct their works. 


\section{Pawel Czapliński}

Instytut Geografii

Akademia Pomorska w Słupsku

\section{Prasowy wizerunek przedsiębiorców}

Jak wynika z badań ${ }^{1}$ przeprowadzonych przez Instytut Badania Opinii, Rynku i Konsumpcji GfK Polonia na zlecenie „Rzeczpospolitej”, opinie Polaków o przedsiębiorcach są pełne sprzeczności. Według respondentów przedsiębiorca to człowiek zamożny i wykształcony, ale jego postawa etyczna pozostawia wiele do życzenia (Biały 2006).

Zamożność i wykształcenie można uznać za przejaw pracowitości, aktywności, konsekwencji i solidności, które powszechnie są uznawane za zalety. Kiedy jednak poddajemy wnikliwej analizie zamożność przedsiębiorców, ujawnia się funkcjonujący w polskiej opinii społecznej stereotyp. Według J. Szredera (2006) sprowadza się on do następującego schematu myślowego: Przedsiębiorca to człowiek majętny, ale jego zamożność wynika z chciwości i uzależnienia od potrzeby bogacenia się. Wielkość majątku przedsiębiorcy jest wypadkową oszustw i mataczenia, ewentualnie dobrego urodzenia i szczęśliwego zbiegu okoliczności. Niezależnie od tego, który wariant przyjmiemy, za dużym majątkiem musi się kryć wyzysk pracowników mający znamiona przestępstwa; nie dopuszcza się myśli, że wysoki poziom zamożności można osiagnąć uczciwą droga.

Wyniki badań przeprowadzonych przez T. J. Stanleya i W.D. Danko, opublikowane w książce Sekrety amerykańskich milionerów, wskazują, że znaczna część respondentów (milionerów), ponad $75 \%$, to osoby żyjące na niższym poziomie niż pozwala na to ich status. Nie kupują oni najdroższych ubrań; jeżdżą w 80\% własnymi, ale niekoniecznie nowymi i drogimi samochodami; są oszczędni, co miesiąc spłacają swoje karty kredytowe, nie zadłużają się w bankach, a 40\% z nich nie zaciąga kredytów hipotecznych. Badania pokazały także, że poziom wykształcenia, choć istotny, nie musi stanowić podstawy sukcesu, gdyż tylko około połowy badanych przedsiębiorców ukończyło studia wyższe, a 90\% skończyło szkołę średnią, w której większość z nich była ,typowymi średniakami” (Stanley, Danko 1998).

Należy jednak postawić pytanie, czy wyniki badań przeprowadzonych w Stanach Zjednoczonych można odnieść do polskich przedsiębiorców. Wydaje się, że nie do końca. W rozważaniach należy bowiem wziąć pod uwagę moment historyczny - etap rozwoju społeczno-gospodarczego. Po jego uwzględnieniu rysują się wyraźne różnice dotyczące np. czasu trwania, skali oraz formy i zasad gospodarki rynkowej. Istnieją też wyraźne różnice między obydwoma krajami w strukturze społecznej. Ocena wykształcenia jako czynnika sukcesu w biznesie również budzi wątpliwości, wydaje się bowiem, że w warunkach polskich wykształcenie biznesmenów może nie osiaggać wartości uzyskiwanych w Stanach Zjednoczonych. Nie bez znaczenia pozostaje także wielkość zgromadzonego majątku. Dodatkowo na negatywny obraz przedsiębiorcy w Polsce mają wpływ inne istotne czynniki, takie jak: formy i stosunki własnościowe związane m.in. z mało

${ }^{1}$ Badania ankietowe zostały przeprowadzone 3-5.02.2006 r. na ogólnopolskiej reprezentatywnej próbie 958 dorosłych Polaków. 
czytelnymi procesami prywatyzacyjnymi przedsiębiorstw państwowych oraz liczne związki świata polityki i biznesu (Kaczmarczyk 2003).

Jak dowodzą badania nad zamożnością amerykańskich grup etnicznych ${ }^{2}$, polscy emigranci stanowią jedną z najbogatszych grup narodowościowych w Stanach Zjednoczonych. Na przykład w Chicago prawie połowa budynków czynszowych jest własnością osób o polskich korzeniach $^{3}$. Można zatem przyjąć, że Polacy majązdolność szybkiego dostosowywania się do nowych warunków społeczno-gospodarczych i umiejętność przetrwania w biznesie (Bereta 2006). Dlatego też stereotyp zamożnego przedsiębiorcy, który zbudował fortunę na nieuczciwości, może ulec zmianie, kiedy zostaną w Polsce stworzone odpowiednie warunki działalności gospodarczej. Tym samym, jak wskazuje D. Stefański (2006), potencjalnie każdy będzie mógł zostać milionerem, gdyż: „,...) nie udało mu się [komunizmowi] wytępić wśród Polaków przedsiębiorczości”.

W. Kozek (2006) twierdzi, że w opiniach Polaków widać inne zaszłości z poprzedniej epoki, gdyż tempo procesu przekształcania ich świadomości jest bardzo powolne ${ }^{4}$. Być może znaczący wpływ na tempo tych procesów ma również świat polityki, który podtrzymuje i wykorzystuje, a przez to utrwala stereotypy. Przykładem jest stereotyp prywatnego przedsiębiorcy zwanego pogardliwie prywaciarzem, który przetrwał zmiany ustrojowe. Być może dlatego właśnie polscy biznesmeni są często wymieniani przy okazji informacji o aferach gospodarczych. Nie bez znaczenia pozostaje także udział przedstawicieli świata biznesu w przesłuchaniach sejmowych komisji śledczych. Ale im więcej znamy przedsiębiorców, tym bardziej rzeczywisty i czytelny jest ich obraz w naszej świadomości.

Za paradoks należy uznać to, że chociaż Polacy marzą o karierze przedsiębiorcy dla siebie lub swoich dzieci (70\% zapytanych Polaków poparłoby zamiary swojego dziecka, aby zostać biznesmenem), to biznesmenów nie darzą sympatią. Jak wynika ze szczegółowych ustaleń Instytutu GfK Polonia, większą niechęć do biznesmenów deklarują mężczyźni niż kobiety. Dotyczy to zwłaszcza mężczyzn w średnim wieku i to niezależnie od statusu zawodowego. W ujęciu przestrzennym największą niechęcią odznaczają się mieszkańcy południowej i środkowo-wschodniej części Polski.

Z badań zaprezentowanych w „Rzeczpospolitej” należy także wnosić, że najbardziej negatywnie jest oceniany stosunek polskich przedsiębiorców do pracowników. Aż $60 \%$ procent respondentów uważa, że prywatni przedsiębiorcy nie przywiązują większej wagi do dbałości o pracowników. Natomiast użyteczność przedsiębiorców dla społeczeństwa sprowadza się do twierdzenia: „,bo tworzą miejsca pracy”. I to pewnie dlatego - jak podkreśla A. Biały - „właściciel dużej firmy cieszy się znacznie większym prestiżem niż właściciel mniejszej, niż ten, który zwykle nie zatrudnia innych, jak sklepikarz czy taksówkarz". Tylko jedna trzecia Polaków uważa, że polscy biznesmeni uczciwie płacą podatki i przestrzegają prawa. Chęć sprostania konkurencji może więc wiązać się z wejściem w szarą strefę.

W ocenie wizerunku prywatnego przedsiębiorcy widać jednak pozytywne zmiany. O prawie połowę wzrosła liczba pozytywnych opinii na temat uczciwości i pracowitości biznesmenów. Do takich wniosków dochodzi A. Biały, porównując wyniku sondażu przeprowadzonego przez GfK z bardzo podobnym sondażem przeprowadzonym przez S. Augustyniaka w 2004 r. ${ }^{5}$ Obecnie

\footnotetext{
${ }^{2}$ Badania nad zamożnością amerykańskich grup etnicznych prowadzone są na University of California w Los Angeles.

${ }^{3} \mathrm{~W}$ rankingu nie uwzględniono osób narodowości żydowskiej. Przypisano je do kraju, z którego wyemigrowały. ${ }^{4}$ Prof. W. Kozek jest dyrektorem Instytutu Socjologii UW. Wypowiedź ukazała się w „Rzeczpospolitej” 20.02.2006 r.

${ }^{5}$ S. Augustyniak, 2004, Świadomość ekonomiczna i wizerunek biznesu, ISP, Warszawa.
} 
prywatny przedsiębiorca nie jest jeszcze zbyt często dobrze oceniany. Ta ocena jednak się zmienia, a biznesmen staje się nie tylko pozytywnym, ale także pożądanym i trwałym elementem polskiej rzeczywistości. Należy podkreślić, że biznesmen musi zabiegać i zabiega o pozytywny wizerunek, każdy funkcjonujący na rynku podmiot potrzebuje bowiem społecznego uwiarygodnienia, społecznej akceptacji. Wydaje się, że doskonałymi narzędziami, które obecnie można w tym celu wykorzystać, są prasa, radio i telewizja. Warto także zwrócić uwagę na to, że jeżeli za pośrednictwem mediów dociera do nas dużo informacji przedstawiających przedsiębiorców oraz ich firmy w negatywnym świetle, to zazwyczaj zaczynamy sądzić, że te negatywne przykłady dowodzą powszechności zjawiska i dotyczą wszystkich. Badania „Rzeczpospolitej” to właśnie pokazuja.

Bolesław Bok, wiceprezes zarządu Forum Odpowiedzialnego Biznesu', twierdzi, że: „,...) biznesmeni, o których często piszą media, cieszą się niższym zaufaniem niż zwykli menedżerowie i przedsiębiorcy. Czy kształtowanie, często niezasłużonego, negatywnego wizerunku biznesu w świadomości społecznej może prowadzić niczym samospełniająca się przepowiednia do ograniczania ich działalności w Polsce? Chyba nie o to chodzi. Zwiększająca się frustracja może prowadzić do społecznej niechęci wobec gospodarki rynkowej w ogóle"7.

Czy jednak nie jest to kolejny stereotyp? Frustracją i niechęcią nie da się zmieniać polskiej gospodarki.

Wizerunek przedsiębiorców nie zmienia się z dnia na dzień. Stanowi pewne kontinuum. Współczesny wizerunek polskich przedsiębiorców stanowi kontynuację propagandy uprawianej jeszcze w systemie gospodarki sterowanej centralnie, w której czasem łączono negatywny stereotyp przedsiębiorcy z treściami antysemickimi. I chociaż od dawna ten stereotyp nie ma odzwierciedlenia w rzeczywistości, to nadal funkcjonuje w świadomości społecznej (Szczepocka 2006).

W świetle wszystkich omówionych wyżej faktów uznano za konieczne przeprowadzenie badań na temat medialnego wizerunku przedsiębiorców na przykładzie subregionu słupskiego. Wyniki tych badań są zbieżne z wynikami podobnych badań przeprowadzonych przez R. Szczepockąw 2006 r. ${ }^{8}$ i wskazują że dziennikarze nie mają skłonności do pisania o złych przedsiębiorcach.

Jak wynika z analizy zawartości „Dziennika Bałtyckiego”, ukazującego się w edycji słupskiej 6 razy w tygodniu na terenie województw pomorskiego i zachodniopomorskiego (dawniej: słupskiego), procentowy udział artykułów o przedsiębiorcach i przedsiębiorstwach mających wydźwięk pozytywny jest wyższy niż procent pozytywnych artykułów w ich ogólnej liczbie.

Badania objęły kwietniowe, majowe i czerwcowe wydania „Dziennika Bałtyckiego” z 2006 r. Łącznie w 74 wydaniach ukazało się 49 artykułów dotyczących przedsiębiorców z dawnego woj. słupskiego, czyli średnio w tygodniu ukazywały się 4 artykuły na ten temat.

Nieznaczna część artykułów (8, czyli 16,3 \%) miała charakter wybitnie informacyjny, neutralny. Zabarwienie pozytywne stwierdzono w 26 artykułach stanowiących 53,1\%, natomiast artykułów przedstawiających przedsiębiorców w negatywnym świetle (często piętnujących jakieś elementy ich działalności) było 15 (30,6\%).

Nieco inaczej przedstawia się problem ekspozycji dobrych i złych treści. Informacje negatywne zdecydowanie częściej pojawiały się na pierwszych stronach. Zwykle też były obszerniejsze.

\footnotetext{
${ }^{6}$ Forum Odpowiedzialnego Biznesu powstało w 2000 r. jako organizacja pozarządowa zajmująca się społeczną odpowiedzialnością biznesu, czyli kształtowaniem właściwych relacji firm ze społeczeństwem. ${ }^{7}$ Wypowiedź zamieszczona w „Rzeczpospolitej”, 20.02.2006 r.

${ }^{8}$ Wyniki badań nad artykułami „Kuriera Szczecińskiego” w marcu 2006 r. zostały opublikowane w materiałach pokonferencyjnych Przedsiębiorca i jego odbiór społeczny, Z.A. Walo (red.), Słupsk 2006.
} 
Najważniejszym celem badań była jednak identyfikacja wizerunków przedsiębiorców w mediach. W tym celu poddano analizie jakościowej i ilościowej zawartość „Dziennika Bałtyckiego” edycji słupskiej w okresie od 1 kwietnia do 30 czerwca 2006 r. Zidentyfikowano 2 grupy obrazów słupskich (subregionu słupskiego) przedsiębiorców: negatywną i pozytywną (ryc. 1).

Ryc. 1. Typy przedsiębiorców subregionu słupskiego

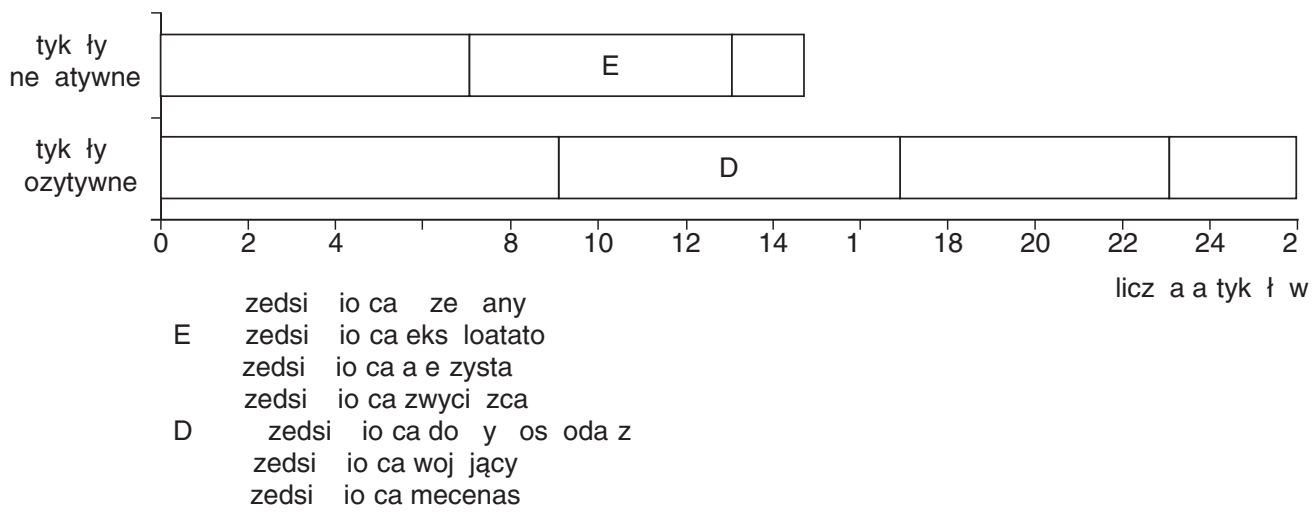

Źródło: opracowanie autora

\section{Grupę negatywną tworzą:}

- Przedsiębiorca przegrany - przedsiębiorca, którego firma została postawiona w stan upadłości, likwidacji, a majątek trwały niszczeje. Dodatkowo podaje się informacje o pracownikach zwolnionych na skutek likwidacji zakładu. Przykładami mogą być doniesienia prasowe na temat Fabryki Obuwia „Alka” oraz Zakładu Urządzeń Okrętowych „Sezamor” ze Słupska.

- Przedsiębiorca eksploatator - przedsiębiorca, który wykorzystuje pracowników, ogranicza wynagrodzenia albo je wstrzymuje, zmusza pracowników do pracy po godzinach. Przykładem jest sprawa traktowania pracowników sieci sklepów „Biedronka” w Bytowie i Lęborku.

- Przedsiębiorca aferzysta - przedstawiany w materiałach jako osoba winna nadużyć i afer gospodarczych, oszustw i korupcji. Tego typu informacji nie pojawia się dużo, ale są one łatwo zauważalne, gdyż publikowane są zwykle na pierwszych stronach, np. sprawa wyłudzenia kredytów przez przedsiębiorcę z Sycewic.

\section{W grupie pozytywnej znaleźli się:}

- Przedsiębiorca zwycięzca - przedsiębiorca, który odniósł sukces. Bez trudu podaje informacje o wynikach ekonomicznych przedsiębiorstwa, nowych inwestycjach, wprowadzaniu nowych produktów, np. artykuł o właścicielach lęborskiego Przedsiębiorstwa Produkcji Farmaceutyczno-Kosmetycznej „Profarm”. Do tej grupy zalicza się także artykuły, które dotyczą uzyskania przez przedsiębiorcę różnego rodzaju dowodów uznania, np. nagród, certyfikatów, jak w przypadku właściciela firmy „Plastmet” z Widzina, który otrzymał nagrodę biznesmena roku.

- Przedsiębiorca dobry gospodarz - osoba (grupa osób), której przypisuje się zasługi w restrukturyzacji firmy. W publikacjach przedstawione są całościowo bądź wyrywkowo procesy restrukturyzacji przedsiębiorstw, wskazuje się jednocześnie dalszy kierunek zmian mających przynieść ostateczny sukces. Można to zaobserwować na przykładzie słupskich sklepów „Społem” PSS. 
- Przedsiębiorca wojujący - przedsiębiorca walczący z nieudolnością machiny urzędniczej i z niejasnymi przepisami prawnymi, skarbowymi, technicznymi itp. W większości przypadków media stają w obronie przedsiębiorcy, jak w przypadku właściciela majątku upadłej stoczni „Ustka”.

- Przedsiębiorca mecenas - przedsiębiorca, który jawi się jako mecenas, sponsor, darczyńca czy fundator. Takie artykuły pokazują wrażliwość na potrzeby innych oraz chęć uczestniczenia w życiu społeczności lokalnych. Przykładem może być wspomniany wyżej właściciel firmy „Profarm” z Lęborka. Wydaje sięjednak, że jest to przykład dobrze działającej w firmie komórki public relations, która tworzy pozytywny wizerunek firmy i jej właściciela.

Jak sugeruje R. Szczepocka (2006), analizując zawartość prasy „(..) można zauważyć dość wyraźny podział wśród publikacji dotyczących przedsiębiorstw. W jednej grupie znajdują się te, które w swojej działalności korzystają z pomocy osób posiadających wiedzę i umiejętności z zakresu public relations (zarówno własnych pracowników, jak i wynajętych agencji), w drugiej przedsiębiorstwa, które takiego wsparcia nie mają". Badania wskazują, że do tej drugiej grupy należy zdecydowana większość firm.

Reasumując, można założyć, że lektura doniesień medialnych wydaje się być obecnie jedną z najważniejszych elementów badań zachowań rynkowych przedsiębiorców, w tym ich wizerunku. Dotyczy to w dużej mierze prasy. Siła przyzwyczajenia, względna trwałość i dostępność powodują, że to właśnie prasa odgrywa dzisiaj ważną rolę w kreowaniu wizerunku przedsiębiorcy. Należy jednak zauważyć, że częstym zjawiskiem jest niska rzetelność publikacji prasowych, która może wynikać m.in. z braku kompetencji osób piszących lub z relatywnie niegroźnych konsekwencji, np. prawnych, za pisanie nieprawdy. Czasem dochodzi nawet do manipulacji informacją w celu osiagnięcia nowych celów rynkowych - poprzez np. zwalczanie lub też świadome wprowadzanie w błąd konkurencji.

Zaobserwowane obrazy słupskich przedsiębiorców, ze względu na stosunkowo mały obszar badań, wysoki stopień rozpoznania przez autora i stosunkowo dużą liczbę uwzględnionych artykułów, wydają się być obiektywne. Nie można jednak całkowicie wykluczyć wspomnianego powyżej aspektu manipulacji informacją.

Na przykładzie kreowanych wizerunków przedsiębiorców można ustalić, na jakim etapie transformacji znajduje się przedsiębiorstwo i jaka jest jego kondycja ekonomiczna. Można też określić, czy w przedsiębiorstwie są osoby odpowiedzialne za public relation czy też nie, i czy dzięki nim następuje poprawa wizerunku, która jest warunkiem niezbędnym do dalszego funkcjonowania (Bochniarz 2006).

W czasach, kiedy informacja zaczyna być jednym z najważniejszych zasobów, należy także pamiętać o tym, że zła informacja szybko się rozprzestrzenia, szybko utrwala i długo zalega w pamięci. Można zatem przyjąć, że w przekazie medialnym z powodzeniem funkcjonuje prawo Kopernika-Greshama9 (Zychowicz 2001). Może to oznaczać albo nagły sukces, albo też gwałtowne obniżenie się warunków działalności przedsiębiorstwa, aż do jego upadku.

R. Szczepocka (2006) pisze: „Aby być lubianym przez media, trzeba im poświęcać czas i uwagę. Trzeba z nimi współpracować, a nie ich unikać".

Wzajemne relacje media - przedsiębiorca muszą więc być świadome, zaplanowane i stałe. Tylko takie zabiegi mogą obalić ciągle żywe w społeczeństwie stereotypy przedsiębiorców.

\footnotetext{
${ }^{9}$ Prawo Kopernika-Greshama to zasada mówiąca, że jeśli jednocześnie istnieją dwa rodzaje pieniądza, pod względem prawnym równowartościowe, ale jeden z nich jest postrzegany jako lepszy, ten „lepszy” pieniądz będzie gromadzony, a w obiegu pozostanie głównie ten „gorszy” (gorszy pieniądz wypiera lepszy pieniądz).
} 


\section{Literatura}

1. Augustyniak S., 2004, Świadomość ekonomiczna i wizerunek biznesu, ISP, Warszawa

2. Bereta J., 2006, Bogaty jak Polak, „Ozon”, 16.03.2006 r.

3. Biały A., 2006, Bogaty, wyksztatcony, ale nielubiany, „Rzeczpospolita”, $20.02 .2006 \mathrm{r}$.

4. Bochniarz H., 2006, Wizerunek przedsiębiorców w spoleczeństwie, Raport: Odpowiedzialny biznes w Polsce w 2005 r., M. Jagielska, B. Rok (red.), Forum Odpowiedzialnego Biznesu, Warszawa

5. Kaczmarczyk A., 2003, Twarze sejmowej komisji, ,Tygodnik Powszechny”, 16.03.2003 r.

6. Stanley T.J., Danko W.D., 1998, Sekrety amerykańskich milionerów, Warszawa

7. Stefański D., 2006, Kogo nie psuja pieniqdze, „Inwestor finansowy - miesięcznik WGI dla inwestorów", www.fundi.pl, 8.01.2007 r.

8. Szczepocka R., 2006, Czy media lubiq przedsiębiorców? [w:] Przedsiębiorca i jego odbiór społeczny, Z.A. Walo (red.), Słupsk

9. Szreder J., 2006, Portret przedsiębiorcy - wyobrażenia a rzeczywistość [w:] Przedsiębiorca i jego odbiór społeczny, Z.A. Walo (red.), Słupsk

10. Zychowicz Z., 2001, Głos w dyskusji nad przyjęciem uchwały Senatu Rzeczypospolitej Polskiej w sprawie Sprawozdania Krajowej Rady Radiofonii i Telewizji z rocznej działalności, 83. posiedzenie Senatu RP

\section{The Entrepreneur's Image in a Press}

Recently the image of an entrepreneur - that is still a subject of numerous stereotypes - has evolved. Despite the fact that the consciousness-transforming processes take a long time in the reference to Poles - one of the obvious factors is the world of politics - the growth of positive opinions about the honesty and industriousness of businessmen can be observed. In addition, the career of an entrepreneur is more and more desirable - in the parents' view also for the children.

According to the research based on the example of Słupsk subregion, the entrepreneur's image in the press is not homogenous. The groups of negative and positive attitudes are easily distinguished. The presented types of entrepreneurs are distinctly varied, but their recognition should be analyzed not stochastically, but as a process connected to the ongoing adaptation of economic subjects to the transforming environment. 


\section{Krystian Sowislok}

II Liceum Ogólnokształcące w Zabrzu

\section{Współczesny przedsiębiorca}

Kim na współczesnym rynku jest przedsiębiorca? Jakimi cechami powinien się charakteryzować? Przedsiębiorca powinien łączyć funkcje:

1. założyciela-organizatora,

2. kierującego-zarządzającego,

3. ponoszącego odpowiedzialność społeczną, finansową i prawną za swoją działalność.

Jeżeli przyjmie się takie założenia, to można stwierdzić, że nie jest przedsiębiorcą ani zawodowy menedżer zatrudniony do prowadzenia firmy, ani właściciel przedsięwzięcia, ponieważ nie spełnia drugiego z wymienionych warunków. Nie można też nazwać przedsiębiorcą kogoś, kto nie ponosi ryzyka, gdyż w dzisiejszych czasach nie ma przedsiębiorczości, która byłaby od niego wolna. Obecne realia gospodarcze są znacznie bardziej wymagające od tych, które panowały na początku lat 90 . XX w. i które umożliwiły dynamiczny wzrost liczby przedsiębiorstw w różnych dziedzinach produkcji i usług, co przełożyło się na niespotykany w Polsce i w innych państwach dawnego bloku wschodniego wzrost gospodarczy. Ale wtedy wachlarz cech niezbędnych przedsiębiorcy, w porównaniu z dzisiejszymi wymaganiami, był takim (posłużmy się określeniami zaczerpniętymi z motoryzacji) „,standardem" - ,tańszą wersją”. Aby obecnie zaistnieć na rynku gospodarczym, potrzeba ,szeregu dodatków” zapewniających ,komfort jazdy”- czyli atrybutów mogących zapewnić powodzenie.

Zadaniem nauczycieli przedmiotu ,podstawy przedsiębiorczości” jest wskazanie uczniom tego, co jest ważne dla przedsiębiorcy, co i jak robić, aby to osiagnać, żeby w niedalekiej przyszłości kształtować rzeczywistość życia gospodarczego w Polsce. Oczywiście, jak w każdej dziedzinie i w każdym środowisku, ludzie są mniej lub bardziej chętni do akceptowania i przyswajania rzeczy nowych i często wymagających dużego wysiłku. Niektórych uczniów można oceniać jako przedsiębiorczych, inni tacy nigdy nie będą. Ktoś mógłby powiedzieć, że bez tego przedmiotu tak by się stało, ale dzięki niemu podejmowanie przez uczniów pewnych działań w przyszłości będzie może nie oczywiste, ale jednak łatwiejsze, bo częściowo już poznane.

Współczesny przedsiębiorca to człowiek łączący w sobie cechy organizatora, menedżera i przywódcy. Takie są wymagania teraźniejsze, ale przyszłość może je zwiększyć.

Do cech, które można uznać za niezbędne u współczesnego przedsiębiorcy, pogrupowanych w zależności od trzech funkcji wymienionych wyżej, można zaliczyć:

\section{Cechy związane z organizowaniem.}

- „Duch przedsiębiorczości”, potrzeba działania (tworzenia) - przedsiębiorca to człowiek, w którym wyzwala się „,duch przedsiębiorczości”, potrzebujący konkretnego działania. Rozwój gospodarczy zależy od ducha przedsiębiorczości wyzwalającego boom gospodarczy (Schumpeter 1960). W razie kryzysu liczy się szybkość dostosowania się do nowych wymagań, które inni będą powielać, naśladować.

- Kreatywność - zdolność tworzenia czegoś nowego, oryginalnego, twórczego. Realizowany pomysł jest nowością na rynku, jest odmienny od wykorzystywanych przez innych 
przedsiębiorców. Należy jednak pamiętać, że efektywna strategia produktu musi zręcznie łączyć wprowadzanie nowych produktów z istnieniem dawnych, aby przedsiębiorstwo mogło najlepiej spożytkować swoje szczególne zasoby (Kramer 2000).

- Optymizm - wiara w powodzenie swojego przedsięwzięcia, dostrzeganie jego pozytywnych stron.

2. Cechy menedżerskie, powiązane bezpośrednio z zarządzaniem. Jest to chyba najważniejsza grupa cech, decydująca o przetrwaniu i rozwoju, teraźniejszości i przyszłości przedsiębiorstwa, o powodzeniu całego przedsięwzięcia.

- Zarządzanie zasobami ludzkimi - współczesny przedsiębiorca stawia ludzi na pierwszym miejscu, szanuje ich i ufa im, potrafi zaakceptować ich słabości, sprawia, że dobrowolnie mu się podporządkowują, podejmują decyzje, które on tylko koordynuje. Z tej cechy wypływają umiejętności niezbędne w zarządzaniu: przewodzenie i motywowanie. Motywowanie do strategii, aby być najsilniejszym z potężnych (Drucker 2004).

- Zarządzanie czasem - osoba decydująca się zostać przedsiębiorcą musi sobie zdać sprawę, że jest się nim przez 24 godziny na dobę, 7 dni w tygodniu. Czas jest zasobem, ale - w przeciwieństwie do wielu innych zasobów - nie można go kupić ani zmagazynować, dlatego przedsiębiorca musi go umieć jak najlepiej wykorzystać.

- Wizjonerstwo - współczesny przedsiębiorca powinien mieć umiejętność wyobrażenia sobie swoich planów, zamierzeń, co jeszcze wzmaga chęć osiągnięcia wyznaczonych celów.

- Uporczywe dążenie w wybranym kierunku - ale warto zaznaczyć, choć brzmi to nieco przewrotnie, że powinno ono być elastyczne. Nie może się odbywać za wszelką cenę. Zdarzają się sytuacje, kiedy pewnych działań należy zaniechać albo zmienić ich kierunek lub natężenie. Czasem upór może doprowadzić do nieodwracalnych szkód w przedsiębiorstwie lub w jego szeroko pojętym otoczeniu, co może się ujemnie odbić na samym przedsiębiorcy. Należy stosować strategię polegającą na formułowaniu zbioru długofalowych celów przedsiębiorstwa i ich modyfikacji, w zależności od zmian zachodzących w otoczeniu, określaniu zasobów i środków niezbędnych do osiagnięcia tych celów oraz sposobów postępowania zapewniających optymalne ich rozmieszczenie i wykorzystanie, aby było możliwe elastyczne reagowanie na wyzwania rynku i zapewnienie przedsiębiorstwu warunków egzystencji i rozwoju (Penc 1994).

- Umiejętność wykorzystania informacji - bardzo ważna cecha, zważywszy na zalewające nas ze wszystkich stron informacje. Człowiek przedsiębiorczy to osoba, która w natłoku informacji potrafi wypatrzyć przysłowiową, ,czterolistną koniczynę”, umie ją zanalizować, przetworzyć i z korzyścią zastosować w swoim przedsiębiorstwie. Przyjmuje się przy tym ogólne założenie, że informacja nie ma ceny zerowej, w związku z czym obowiązuje rygor oszczędnego gospodarowania jej zasobami (Kramer 2000).

- Myślenie systemowe - zdolność wykorzystania wiedzy z różnych dziedzin oraz umiejętność wiązania pewnych zjawisk i informacji w celu ich zastosowania w swojej działalności.

- Innowacja, czasami „myślenie na opak” - podejmowanie w pewnych sytuacjach decyzji wbrew przyjętym regułom. Przyszłość należy do ludzi wychodzących poza schematy. Podstawą przedsiębiorczości jest zmysł innowacyjny (Drucker 1991).

- Etyka - mimo że umieszczona na końcu listy, jest bardzo ważna we współczesnym biznesie. Nie można jej kupić ani sprzedać, ale należy do aktywów przedsiębiorstwa. To, czy przedsiębiorca się nią kieruje, czy też nie, wpływa pośrednio na wyniki finansowe firmy. W Europie Zachodniej w niektórych kręgach biznesu panuje opinia, że jeżeli przedsiębiorca nie kieruje się ogólnie przyjętymi regułami moralnymi, jest głupcem i przegrał walkę przed jej podjęciem. Nieetyczne postępowanie w gospodarce rynkowej to krótkowzroczność, która prędzej czy później kończy się porażką zawodową, a czasem i osobistą przedsiębiorcy. 
Tych cech - atrybutów menedżera - można wymienić więcej, np. dynamizm czy zdecydowanie. Poza tym trzeba wspomnieć o zasobie wiedzy fachowej. Menedżer powinien dysponować wiedzą o prawach i mechanizmach gospodarki rynkowej, o kształtowaniu się rynku nabywcy, praktycznym zastosowaniu i realizacji strategii marketingowych.

\section{Cechy związane z ponoszeniem ryzyka.}

- Odpowiedzialność - przedsiębiorstwo funkcjonuje w określonym otoczeniu i nieodpowiedzialne decyzje (szczególnie jeżeli dotyczą przedsiębiorstw dużych) mogą prowadzić do problemów społecznych, a także wpływać negatywnie na wizerunek przedsiębiorstwa. Może to doprowadzić do osłabienia jego pozycji na rynku, a nawet do upadłości.

- Ryzyko finansowe - niewłaściwe decyzje (inwestycje) finansowe mogą doprowadzić do utraty płynności finansowej, a także do upadłości przedsiębiorstwa. Konieczne jest porównanie kosztów ryzyka z korzyściami, które można odnieść, podejmując je (Cohen 1998).

- Ryzyko prawne - ściśle powiązane ze wspomnianymi wcześniej. Nieodpowiedzialne i niewłaściwe decyzje (głównie finansowe) mają często finał w sądzie.

Jak widać, ta ostatnia grupa cech to zagrożenia czyhające na współczesnego przedsiębiorcę. Jeżeli jednak ma on atrybuty wymienione w pkt. 1 i 2 i potrafi je wykorzystać, to poradzi sobie z przeciwnościami.

Podsumowując-wydaje się, że najważniejsze nie jest przekazanie młodym ludziom jak największej ilości wiedzy podręcznikowej, lecz wskazanie im, jak zdobywać ważne umiejętności i kształtować cechy niezbędne współczesnemu przedsiębiorcy. Istotne jest również to, aby tematy i zagadnienia kształtujące przedsiębiorczość u młodych ludzi wprowadzać już we wczesnych etapach nauki.

\section{Literatura}

1. Cohen G.N.,1998, Biznesplan doskonaty, Business Press, Warszawa

2. Drucker P.F., 1991, Innowacja i przedsiębiorczość. Praktyka i zasady, PWE, Warszawa

3. Drucker P.F., 2004, Natchnienie i fart, czyli innowacja i przedsiębiorczość, Studio Emka, Warszawa

4. Kramer T., 2000, Podstawy marketingu, Polskie Towarzystwo Ekonomiczne, Warszawa

5. Penc J., 1994, Strategie zarzqdzania, Agencja Wydawnicza „Placet”, Warszawa

6. Schumpeter J., 1960, Teoria rozwoju gospodarczego, PWN, Warszawa

\section{An Entrepreneur for Modern Times}

This paper tries to show an image and define qualities vital to a modern entrepreneur. The requirements for entrepreneurs are very high. An entrepreneur must be both a founder and organizer, as well as manager and leader. In order to play these roles well one should possess certain qualities and abilities. It is necessary to have so called "spirit of enterprising", to be creative and innovative, which will let us find a niche on the market and prosper in the competitive world. Furthermore, it is vital to be able to manage the personnel and time - an important resource in our times. Also, we should be able to interpret and use the accessible information and our knowledge that should be constantly broadened. It is important to have the sense of responsibility, as there is no enterprise without financial and legal risk.

Above list shows that this set of qualities and abilities is hard to develop. The teachers' task, who give Introduction to Enterprising lesson, is to show young people what qualities are necessary for a modern entrepreneur, and what to do in order to develop them. Today's students should decide on the shape of tomorrow economy in Poland. 


\section{Tomasz Tadeusz Brzozowski}

Katedra Ekonomii Wyższej Szkoły Handlowej we Wrocławiu

Centrun Kształcenia Ustawicznego przy Zakładzie Karnym nr 1 we Wrocławiu

Autorskie Licea Artystyczne ALA we Wrocławiu

\section{„Przedsiębiorczość" - pojęcie polisemiczne czy niewłaściwie rozumiane? Próba systematyzacji}

\section{Jadwidze i Tadeuszowi Brzozowskim poświęcam}

Problem poruszony w niniejszych rozważaniach odnosi się w głównej mierze do treści wyczerpujących pojęcie ,przedsiębiorczości” oraz tego, co pod tym określeniem w powszechnym odczuciu rozumiemy. To, na pozór łatwe zadanie, podczas pogłębionej analizy wybranych definicji i wypowiedzi wielu autorów, wcale nie okazuje się już takie proste. Badacze obszarów ekonomii traktują zakres słowa „przedsiębiorczość” albo nazbyt wąsko, albo zbyt szeroko, nie zawsze dookreślając, co rzeczywiście pod tym pojęciem rozumieją. Odnosi się to do wypowiedzi zarówno pisemnych, jak i ustnych. Ponieważ problem dotyczy jednego z najważniejszych pojęć w dziedzinach ekonomii, logistyki i psychologii, ze wszech miar zasługuje na zainteresowanie lub przynajmniej próbę rozwiązania.

Zamiarem autora nie jest stworzenie jakiejś nowej, zamkniętej definicji przedsiębiorczości. Nie zajmuje go także próba odpowiedzi na pytanie, kto to jest człowiek przedsiębiorczy, jakie cechy go określają, wreszcie czym jest duch przedsiębiorczości itd. Chodzi o to, aby dostrzec problem zbytniej rozległości semantycznej definicji.

Używając pojęcia ,przedsiębiorczość”, ekonomiści i badacze struktury rynku, psycholodzy i socjologowie posługują się tym samym słowem, jednak wkładają weń różne, czasem sprzeczne treści. Śledząc publikacje z tych dziedzin, można odnieść wrażenie, że pojęcie ,przedsiębiorczość" stanowi quasi-protezę lub słowo-wytrych dla oznaczenia różnych, bliżej nieokreślonych zagadnień. Skąd taki stan rzeczy? Składa się nań wiele przyczyn, począwszy od obniżenia logicznej kultury publikacji, przez brak odczuwania potrzeby dogłębnej analizy pojęcia, które czasem występuje jako dodatkowe, sekundarne, na chęci świadomego pozostawienia wieloznaczności kończąc. Żeby nie pozostawiać wrażenia jedynie krytycznego stanowiska wobec zastanej rzeczywistości, w niniejszym tekście podjęto próbę przedstawienia propozycji nowej definicji, która jednak nie może być ścisła z uwagi na zbyt bogate treści zawarte $\mathrm{w}$ określeniu „przedsiębiorczość", których objętość oraz różnorodność wykazują cechy redundantne. Miałaby to zatem być definicja obejmująca możliwie szerokie spektrum zagadnień, po to, aby na jej bazie utworzyć - na użytek własny publikującego - dodatkowe wyjaśnienia, których charakter mógłby przybrać status subdefinicji, pozwalających z polisemicznego pojęcia ,przedsiębiorczość” wydobyć istotne, skonkretyzowane i jednoznaczne treści oraz znaczenia.

Przyglądając się losowo wybranym definicjom słownikowym pojęcia „,przedsiębiorczość”, można zauważyć, że w części są one ze sobą zbieżne, w części zaś się różnią. Oto kilka przykładów: „»Przedsiębiorczość« - zdolność do tego, żeby być przedsiębiorczym, posiadanie ducha inicjatywy; obrotność, rzutkość, zaradność [przy czym »przedsiębiorczy« to mający ducha inicjatywy, skory do podejmowania różnych spraw, zwłaszcza w dziedzinie przemysłu i handlu; pomysłowy, zaradny, rzutki]"1.

${ }^{1}$ Komputerowy słownik języka polskiego PWN, PWN, Warszawa 2004. 
Przedsiębiorczość jest podstawą rozwoju gospodarczego, dążeniem do ciągłej zmiany i doskonalenia produkcji, wymiany i konsumpcji, stwarzania nowych, lepszych możliwości zaspokajania potrzeb i funkcjonowania przedsiębiorstw. Można ją określić jako wszelkie działania i przedsięwzięcia, związane z dążeniem do zysku i ponoszeniem ryzyka, polegające na wytwarzaniu, oferowaniu, dostarczaniu i sprzedawaniu produktów i usług uznanych za korzystne do zaspokajania potrzeb oraz przyczyniających się do funkcjonowania krajowej czy międzynarodowej gospodarki. Przedsiębiorczość nie polega głównie na uzyskiwaniu maksimum korzyści z wykorzystywania tego, co istnieje, lecz na ciągłym stwarzaniu czegoś nowego - jest ona innowatorstwem. Rozwój przedsiębiorczości, jako podstawy ekspansji gospodarczej krajów europejskich i pozaeuropejskich, jest związany z tymi okresami historii gospodarczej, w których powstawały warunki do gromadzenia kapitału handlowego, przemysłowego i bankowego i w których mogła się rozwijać ludzka zdolność do racjonalnego gospodarowania. Miejscami występowania przedsiębiorczości są przede wszystkim przedsiębiorstwa, lecz także gospodarstwa domowe, instytucje administracyjne i cały rynek, a więc sfera codziennych kontaktów tych, którzy kupują z tymi, którzy wytwarzają i sprzedają. Przedsiębiorczość jest indywidualną cechą ludzkiej osobowości wyróżniającej się inteligencją, innowacyjnością, umiejętnością dostrzegania uwarunkowań i związków zachodzących między zjawiskami gospodarczymi a zdolnością do organizowania działalności handlowej, przemysłowej i usługowej, zapewniającej przewagę dochodów nad kosztami ich uzyskania. Przedsiębiorczość jest nowatorstwem polegającym na poszukiwaniu odmienności w porównaniu z tym, co robią inni, znajdowaniu bardziej skutecznych sposobów działania na rynku, dających wyższą użyteczność produktów i usług oraz większą efektywność gospodarowania. Jest ona ze swej natury działalnością konkurencyjną w stosunku do postępowania innych przedsiębiorstw. Zdaniem A. Isachsena i C. Hamiltona jest ona ekonomicznym „pulsem” społeczeństwa, który odmierza rytm i sposób zaspokajania potrzeb. Przedsiębiorczość zapewnia koordynację decyzji ekonomicznych zgodnie z najlepiej pojętym interesem uczestników rynku. Dzieje się tak dlatego, że człowiek ekonomiczny, jako konsument, znając wysokość cen i własnych dochodów, kieruje się jak najwyższą użytecznością, a człowiek ekonomiczny, jako producent, znając wysokość cen i własne możliwości produkcyjne, dąży do jak najwyższego zysku, wykorzystując efektywnie posiadane zasoby. C. Kent uważa, że przedsiębiorczość jest w najbardziej pozytywnym znaczeniu procesem samoniszczącym, ponieważ nowe pomysły przyciągają imitatorów, którzy - nasycając rynek - eliminują krótkookresowe zyski; nowe działania przedsiębiorcze, niszcząc stare rynki i produkty, dostarczają nowych, korzystnych dla nabywców wartości. Przedsiębiorczość jest podstawą i warunkiem innowacyjnego rozwoju gospodarki, podnoszenia jakości życia społeczeństwa oraz indywidualnej zamożności. Zapewnia wzrost dochodów ludności, zwłaszcza przedsiębiorczych jednostek i zespołów gospodarczych, stałe zwiększanie i doskonalenie podaży towarów i usług, wzrost zatrudnienia, potencjału i konkurencyjności krajowej gospodarki na rynkach światowych. ${ }^{2}$

Kolejna definicja przedsiębiorczości mówi, że „,»przedsiębiorczość» to także zachowanie człowieka lub organizacji polegające na poszukiwaniu i stosowaniu nowych rozwiązań wymagających więcej energii, inicjatywy i pomysłowości oraz umiejętnego oszacowania koniecznych nakładów (czasu, wysiłku, środków) i możliwych do osiągnięcia korzyści w obszarze występujących ograniczeń i możliwości, a także skłonność do brania na siebie ryzyka i odpowiedzialności za swoje decyzje i działania. Zachowanie przedsiębiorcze zależy od osobistej dyspozycji człowieka (ludzi) do działania (posiadanie ducha inicjatywy, pomysłowości, zaradności itp.) oraz

${ }^{2}$ Na podstawie: T. Sztucki, Encyklopedia marketingu (wersja komputerowa), Wydawnictwo Placet, Warszawa 1998. 
woli jego działania wynikającej z cech charakteru (np. potrzeba rywalizacji, robienia lepiej od innych, wykazania się nieprzeciętnymi umiejętnościami itp.) oraz z istniejącego systemu motywacji. W przedsiębiorstwie przedsiębiorczych kierowników może jedynie kreować i kształtować obowiązujący w kraju system zarządzania. System ten bowiem przenosi wartości, normy i ideały do praktyki, w której następuje rozstrzygnięcie, czy jest przedsiębiorczość, czy też jej nie ma. Zobacz również: skłonność do innowacji, wrażliwość na zmiany, inwencja, aspiracje, sublimacja"3.

Przytoczone definicje wskazują na różnorodność interpretacyjną pojęcia ,„przedsiębiorczość”. Trudno się nie zgodzić z niektórymi z nich, ale jeżeli autorzy twierdzą, że przedsiębiorczość z jednej strony to: zdolność do tego, żeby być przedsiębiorczym, dążenie do ciągłej zmiany, doskonalenie produkcji, wymiany i konsumpcji, stwarzanie nowych, lepszych możliwości zaspokajania potrzeb i funkcjonowania przedsiębiorstw, działania i przedsięwzięcia, polegające na dążeniu do zysku, z drugiej zaś ciagłe stwarzanie czegoś nowego, innowatorstwo, indywidualna cecha ludzkiej osobowości, zdolność do organizowania działalności handlowej, działalność konkurencyjna, ekonomiczny „puls” społeczeństwa, proces samoniszczący, podstawa i warunek innowacyjnego rozwoju gospodarki, indywidualnej zamożności, zachowanie człowieka lub organizacji, wreszcie skłonność do innowacji, wrażliwość na zmiany - to mimo pozornych podobieństw, są to przecież różne kwestie. Zdolność, indywidualna cecha osobowości czy skłonność to przecież nie to samo co doskonalenie, wymiana czy konsumpcja. Czym innym jest działalność konkurencyjna, czym innym wrażliwość na zmiany. Przecież świat naszych odczuć oraz skłonności nie jest tym samym co świat działania, stwarzania, zaspokajania i organizowania. Zdziwienie musi więc budzić przemieszanie sfery uczuć, towarzyszących człowiekowi jako obserwatorowi i uczestnikowi zmian zachodzących w gospodarce, ze sferą świadomego czynu oraz działania. Choć obie są ze sobą semantycznie powiązane, to logikę świadomości i logikę myśli wiele dzieli od logiki czynu.

Podjęcie działania, czyli świadomego i zaplanowanego wysiłku na rzecz wprowadzenia zmiany w otaczającej podmiot rzeczywistości, jest skutkiem uprzedniego odczucia pewnego braku. Świadomość tego braku skłania człowieka do uznania stanu, który - oddziałując na podmiot - budzi w nim określone pragnienie. Pragnienie uzupełnienia uznanego braku staje się źródłem odczuwania potrzeby, wyzwala zatem w podmiocie chęć oraz wolę działania w celu osiagnięcia stanu znoszącego potrzebę. Jeżeli przejście od rzeczywistości zastanej, tej, która wpływa na podmiot, nakazując mu podjąć działanie, do rzeczywistości jako wyniku tego działania jest udane, to można mówić o skutecznym działaniu i osiągnięciu pożądanego skutku. Jeśli zaś nowa rzeczywistość (będąca skutkiem uprzedniej aktywności podmiotu) ujawnia kolejne braki lub uchybienia, nie można powiedzieć, że działanie to było skuteczne, gdyż nasze pragnienie nie zostało zaspokojone, lecz wywołało uczucie kolejnej potrzeby zaprowadzenia zmiany w otaczającym podmiot świecie. Wynika z tego, że przejście od konstatacji i uświadomienia sobie potrzeby do popartego aktem wolitywnym świadomego działania nie zachodzi automatycznie. W owym przeskoku jest bowiem coś magicznego, coś, czego nasza racjonalność nie potrafi uchwycić. Ów moment, nazywając go gestem alfa $(\alpha)$, miał na myśli Stanisław Brzozowski, polski filozof przełomu XIX i XX w., propagator aktywnej postawy człowieka w świecie i autor „filozofii pracy”. $\mathrm{W}$ jednym z głównych pism filozoficznych podjął on problem owego przejścia od momentu zastanej rzeczywistości do nowego stanu, stanu po dokonanej pracy: „Musimy swemu życiu nadać pewien specyficzny $\alpha$ kierunek, aby przedmiot został tym, czym go mieć chcieliśmy, aby na miejsce I-szej formy życia wystąpiła ta właśnie II-a [...] $\alpha$ - musi być $\alpha$, aby z I stało się II. [...] Mamy stworzyć akt, gest $\alpha$, aby z I stało się II. $\alpha$ jest tym gestem, tym zaklęciem, na skutek

${ }^{3}$ Penc L., Leksykon biznesu (wersja komputerowa), Wydawnictwo Placet, Warszawa 1997. 
którego świadomość nasza konstatuje zmianę - oznaczoną tu przejściem od I do II" ${ }^{4}$. Z naszych rozważań wynika, że czym innym jest odczuwać brak, zrodzić potrzebę, czym innym zaś podjąć wysiłek. Nie można więc umieścić znaku równości między sferą możności a sferą aktu. Choć działanie wynika z potrzeby, a aktywność jest odpowiedzią na potrzebę, związek między elementami tej relacji nie jest oczywisty.

Rozróżnienie to jest istotne z punktu widzenia filozofii czynu oraz pracy ${ }^{5}$. Po wielekroć możemy zaobserwować, a jeśli chcemy, bez trudu jesteśmy w stanie sobie wyobrazić sytuację, w której negatywne przecież poczucie braku, rodzące potrzebę, wcale nie wyzwala działania, pozwalając podmiotowi na pozostanie na poziomie świadomości owego braku. Wystąpienie więc działania po uprzednim skonstatowaniu braku nie jest momentem koniecznościowym. Gdy podejmuje się działanie, warto zwrócić uwagę na fakt, że negatywność braku może prowadzić do pozytywnego uzupełnienia oraz pozytywnej zmiany. Jednak problem samej decyzji o podjęciu bądź zaniechaniu działania pozostaje swoistą tajemnicą. W świetle przedstawionych rozważań można stwierdzić, że z punktu widzenia logiki czynu obejmowanie pojęciem ,przedsiębiorczość” znaczeniowo odległych wyrażeń, takich jak ,zdolność”, „dążenie”, „działanie”, „,przedsięwzięcie”, rodzi chaos semantyczny, myląc porządki: czynny z pasywnym i aktywny z biernym.

W obowiązujących podręcznikach do nauki przedmiotu w ,podstawy przedsiębiorczości” dla szkół ponadgimnazjalnych można znaleźć definicję, że przedsiębiorczość jest zespołem określonych cech osobowości człowieka, pozwalających mu aktywnie uczestniczyć w życiu społecznogospodarczym. W ślad za tym zakłada się, że tzw. człowiek przedsiębiorczy potrafi kreować nowe potrzeby dla siebie oraz innych, a także potrafi je zaspokajać, i to niezależnie od warunków otoczenia. ${ }^{6}$

Jedna z definicji osobowości brzmi: osobowość jest systemem regulacji i integracji psychicznej, który składa się ze zbioru cech indywidualnych oraz zbioru reakcji zachodzących między nimi. W psychologii praktycznej osobowość rozpatruje się jako strukturę cech. Cecha osobowości jest to względnie trwała właściwość człowieka ${ }^{7}$, niedostępna bezpośredniej obserwacji, lecz stanowiąca rzeczywistą podstawę różnic indywidualnych w postępowaniu i zachowaniach. Jeśli więc przyjać, że cech jednej osobowości może być wiele (zespół), to po pierwsze, nie wiemy, co w definicji przedsiębiorczości oznacza słowo „określone”, bo pojęcie to nie zostało doprecyzowane i dostatecznie wyjaśnione, a po drugie, rodzi się wątpliwość, czy przedsiębiorczość jest zespołem cech osobowości zmiennym czy jednak trwałym, jak chce tego definicja psychologiczna. Jeśli uznać tę ostatnią za uzasadnioną, to przedsiębiorczość nie mogłaby być zespołem cech stałych, ponieważ wiemy, że ducha przedsiębiorczości można w człowieku wzbudzić. Dzieje się tak pod wpływem rozwoju, edukacji, przykładu, osiągnięcia sukcesu itd. Musiałaby to więc być cecha zmienna, a psycholodzy mówią o cesze względnie ${ }^{8}$ trwałej. W człowieku można ducha

\footnotetext{
${ }^{4}$ S. Brzozowski, Idee. Wstęp do filozofii dojrzałości dziejowej, Wydawnictwo Literackie, Kraków 1990. ${ }^{5} \mathrm{O}$ strukturze czynu, jego składnikach oraz rodzajach zob.: M. Borowski, O składnikach czynu, „Przegląd Filozoficzny” 3/1923; O rodzajach czynu, „Przegląd Filozoficzny” 4/1923; T. Kotarbiński, Czyn, Lwów 1937; T. Kotarbiński, O istocie sprawstwa, „Przegląd Filozoficzny” 1925, r. XXVIII.

${ }^{6}$ Z. Makieła, T. Rachwał, 2005, Podstawy przedsiębiorczości. Podręcznik dla liceum ogólnokształcacego, liceum profilowanego i technikum, Nowa Era, Warszawa, s. 9.

${ }^{7}$ Por. J. Ekel, J. Jaroszyński, J. Ostaszewska, 1965, Mały słownik psychologiczny, Warszawa, s. 94.

${ }^{8}$ Słowo „względnie” wydaje się być użyte celowo, nie wnosi jednak do definicji nic, co by mogło uczynić ją bardziej konkretną i jednoznaczną. Termin służy za swoisty „bezpiecznik”, pozwalający na pewną dowolność interpretacyjną.
} 
przedsiębiorczości wzbudzić, ale i zagłuszyć lub spowodować jego utratę, nie może ona zatem być trwałą cechą osobowości.

Rozważmy inny przykład: ktoś jest człowiekiem przedsiębiorczym (cokolwiek miałoby to oznaczać), potrafiącym wykazać aktywność wobec otaczającego go świata jedynie w sytuacji sprzyjającej jego pomysłom i planom, kiedy zaś warunki są odmienne lub zgoła niesprzyjające, niewykazującym żadnej aktywności. Czy takiego człowieka nazwiemy przedsiębiorczym? Zgodnie $\mathrm{z}$ definicją $\mathrm{w}$ podręczniku, osoba przedsiębiorcza potrafi zaspokajać potrzeby niezależnie od warunków otoczenia. Jak rozwiązać ten problem? Wygodnie chyba byłoby przyjąć, że przedsiębiorczość jest postawą wobec otaczającej rzeczywistości, charakteryzującą się aktywnościąi działaniem na rzecz zmiany swoich warunków życia, postawą zmienną i zależną od stopnia edukacji, świadomości, doświadczenia, a także od warunków. Poza nawiasem pozostawmy chwilowo kwestię skuteczności działań, a także stopień tej aktywności oraz działania. Będzie on zależał od wykształcenia, doświadczenia oraz indywidualnych predyspozycji. Jeżeli przyjmiemy, że człowiek przedsiębiorczy potrafi wykorzystać każde warunki, aby zmienić swoją sytuację na lepszą, to będzie to charakteryzować kogoś, kto ma określone umiejętności ekonomiczne, rachunkowe, bankowe itd. Umiejętności - jak się wydaje - nie muszą mieć wiele wspólnego z przedsiębiorczościąjako aktywną postawą wobec świata. Warto więc chyba pokusić się o próbę sformułowania definicji wyjściowej, definicji o dużym stopniu ogólności, której zakres objąłby zarówno cechy osobowości, charakteru, jak i konkretne umiejętności, wiedzę, doświadczenie. Określniki takie pozwolą na wzbogacenie tego jednak wieloznacznego - pojęcia o konkretne informacje. Ponadto, sformułowanie takiej definicji wyjściowej wymusiłoby na autorach wypowiedzi, chcących zachować porządek myśli, ścisłość oraz klarowność wywodu, ujednoznacznienie pojęcia. Oczekiwano by od nich dodatkowych informacji w formie dopowiedzenia, jakie konkretne treści kryją się za pojęciem „przedsiębiorczość”. Skutek przyjęcia i powszechnej akceptacji takiej definicji wyjściowej bez wątpienia uporządkowałby terminologię nauk ekonomicznych i gospodarczych, w których pojęcie „przedsiębiorczość” odgrywa jeśli nie najważniejsza, to na pewno doniosłą rolę.

Problem ze zdefiniowaniem pojęcia ,przedsiębiorczość” dotyczy także zagadnienia samej aktywności. Gdybyśmy przyjęli zaproponowaną wersję definicji wyjściowej, że przedsiębiorczość jest postawą wobec otaczającej rzeczywistości, charakteryzującą się aktywnością i działaniem na rzecz zmiany swoich warunków życia, postawą zmienną i zależną m.in. od stopnia edukacji, świadomości, doświadczenia, a także od warunków, to wciąż pozostaje do wyjaśnienia, co rozumiemy pod pojęciem aktywności. Czy aktywność można stopniować? Czy można mówić o różnych rodzajach aktywności? O jaką aktywność chodzi w zaproponowanej definicji? W odpowiedzi na pierwsze pytanie oddajmy głos Tadeuszowi Kotarbińskiemu, rozpatrującemu te kwestie z punktu widzenia prakseologii: „(...) z jednej strony jest prawdą że sam fakt czynu nie podlega różnicom stopniowania: po prostu wywarto impuls dowolny, albo nie; był czyn albo nie było czynu. $\mathrm{Z}$ drugiej strony jednak zachowanie się czynne może być bardziej lub mniej czynne (...). Po drugie, czyn czynowi nie jest równy co do stopnia aktywności: podobnie i mróz np., chociaż - skoro niżej zera - zawsze i po prostu, a nie bardziej lub mniej mróz, bywa jednak bardziej lub mniej siarczysty". ${ }^{9}$ Chociaż czyn i aktywność można stopniować czy to pod względem włożonej energii, czy np. pod względem intensyfikacji siły, nam chodzi o aktywność w ogóle; aktywność, którą podejmuje człowiek kierujący się chęcią zmiany zastanych warunków. Będzie on chciał polepszyć sytuację, w jakiej tkwił, zanim podjął wysiłek mający doprowadzić do zmiany. Celowo nie dookreślamy tu stopnia aktywności i skuteczności podjętego wysiłku, bo - jak ustaliliśmy - kwestia skuteczności podjętego wysiłku to problem leżący poza obszarem definicji wyjściowej.

${ }^{9}$ T. Kotarbiński, 1937, Czyn, Polskie Towarzystwo Filozoficzne, Lwów, s. 9. 
To, że jeden podmiot, wyzwalając impuls do działania, osiąga więcej niż inny, wcale nie oznacza, że temu drugiemu odmówimy miana człowieka przedsiębiorczego. Możemy co najwyżej mówić o bardziej lub mniej skutecznej (udanej) aktywności.

Odpowiadając na pytanie o zróżnicowanie form aktywności, można stwierdzić: prawdąjest, że mamy do czynienia z różnymi jej formami, podobnie jak istnieje podział w obrębie samego czynu. Możemy go bowiem, za Tadeuszem Kotarbińskim, podzielić na czyn prosty i czyn złożony. Należy się zgodzić, że aktywność ma różne formy, począwszy od zwykłego, prostego wysiłku mięśniowego, na wysiłku intelektualnym kończąc. Wysiłkiem intelektualnym jest np. myślenie, które nie zawsze kojarzy się z aktywnością czy przedsiębiorczością. A jednak. Nie tylko przejawy życia praktycznego kwalifikują czyn jako aktywność. Okazuje się, że również proces myślenia nosi taką cechę: „Niemniej jednak i samo myślenie też jest swego rodzaju czynem. Czyż nie bywa pracą? Częstokroć bardzo trudną pracą... Czyż nie wymaga wysiłku? Czy nie wiąże się stale i w sposób konieczny ze współczesnymi napięciami mięśni, towarzyszącymi umyślnemu skupianiu uwagi? Czy nie osiagamy drogą namysłu pewnych skutków, wyników, dzieł w postaci rozwiązań problemów?". ${ }^{10} \mathrm{~W}$ naszej wyjściowej definicji przedsiębiorczości chodzi o postawę cechującą się aktywnością i działaniem w sensie bardzo ogólnym. Szczegółowe dookreślenie, o jaką aktywność autorowi chodzi, powinno się znaleźć w jednej z subdefinicji będących formą doprecyzowania definicji wyjściowej. W definicji bazowej chodzi o wyraźne wskazanie na aktywność jako nie-bierność, o postawę dynamiczną jako nie-statyczną.

Kolejna kwestia odnosząca się do problemu rozumienia przedsiębiorczości jako postawy wobec otaczającej nas rzeczywistości, charakteryzującej się aktywnością i działaniem na rzecz zmiany swoich warunków życia, związana jest ze skupianiem uwagi na zmianie swoich (cudzych?) warunków życia i abstrahowaniu od tego, czy ma to być zmiana na lepsze, czy na gorsze. Jeżeli przyjąć, że przedsiębiorczość to postawa aktywności na rzecz polepszenia zastanej rzeczywistości i warunków, to w jakich kategoriach umieścimy tych, którzy podejmując np. ryzyko inwestycyjne, giełdowe, rynkowe, bankowe, wskutek zmiennych czynników ponoszą fiasko finansowe? Czy są to ludzie przedsiębiorczy, czy może nieudacznicy? Nasze rozumienie przedsiębiorczości jako aktywnej postawy nie zakłada tylko i wyłącznie rozwiązania pozytywnego z punktu widzenia rachunku ekonomicznego. Zresztą porażka wcale nie musi być skutkiem złego kroku podmiotu przedsiębiorczego; równie często bywa skutkiem zmiennej i niestabilnej sytuacji rynkowej. Należy zatem odróżnić ogół działań podjętych przez aktywny podmiot, które to działania mają w zamierzony sposób doprowadzić do zmiany warunków przez ten podmiot zastanych, od skuteczności owych działań. W definicji wyjściowej najważniejszym elementem jest moment samej aktywności podmiotu przedsiębiorczego, a skutki tej aktywności nie zawsze są z góry znane i przewidywalne. Akcentując dynamizm i chęć podjęcia działania, definicja wyjściowa podkreślałaby akt wolitywny podmiotu, który jest odpowiedzią na niezgodę podmiotu na aktualny stan, na zastane warunki życia. Wtedy więc przy tworzeniu definicji wyjściowej nie interesuje nas zakres skuteczności działań podjętych przez podmiot bądź podmioty, ich przebieg, środki itd. Te - istotne przecież - informacje, jako dodatkowe, wpływające na dokładny opis procesu od fazy decyzyjnej, przez realizację aż do osiagnięcia rezultatu - winny się znaleźć w tzw. subdefinicjach lub informacjach dodatkowych. Od autora zetem zależą: ilość dodatkowych informacji, ich ścisłość i konkretyzacja, zakres i objętość.

Wreszcie ostatnia kwestia. Przedsiębiorczość to postawa, jaką przyjmuje się wobec otaczającej rzeczywistości. Charakteryzuje ją aktywność i działanie podmiotu na rzecz zmiany swoich warunków życia. Jest postawą zmiennąi zależną od stopnia edukacji, świadomości, doświadczenia,

${ }^{10}$ Ibidem, s. 8 . 
a także od warunków. To ostatnie zdanie, jak sądzę, jest potrzebne po to, aby zwrócić uwagę na element elastyczny ${ }^{11} \mathrm{i}$ dynamiczny, nierozłącznie zawarty w podmiocie przedsiębiorczym. Przedsiębiorczość nie zawsze jest postawą, z którą przychodzi się na świat. Gdyby tak w istocie było, nauczanie przedsiębiorczości w szkołach, jak też krzewienie i wskazywanie aktywnych sposobów funkcjonowania jednostki w przestrzeni wolnorynkowej, wyzwalanie inicjatyw przedsiębiorczych - byłyby pozbawione sensu. Przedsiębiorczość jako postawę można zatem kształtować, rozwijać i doskonalić. Nabywanie doświadczeń choćby poprzez wykształcenie, praktykę itd. wiedzie ku stwierdzeniu, że ta postawa jest lub może być zmienna. Pozostawmy na boku problem zależności stopnia przedsiębiorczości od wykształcenia, wcześniejszych doświadczeń, przykładu. Są to interesujące kwestie, ale chyba bardziej dla psychologii i socjologii, niż dla metodologii nauk ekonomicznych. Warto dodać, że zmienność postaw w relacjach do rzeczywistości może dotyczyć zarówno wzmocnienia aktywności, jak też jej zmniejszenia. Jeśli jest cechą zmienną, należy do sfery zachowań z punktu widzenia przedsiębiorczości zarówno pozytywnych, jak i niepożądanych. Zahamowanie lub utrata aktywności przez podmiot na pewno wpłynie na jego kwalifikację. Taki podmiot będzie cechowała mniej wyraźna postawa przedsiębiorcza bądź jej brak. Bez groźby popadnięcia w pułapkę logiczną możemy orzekać o kimś, jako o człowieku charakteryzującym się mocniejszą, bardziej wyrazistą (aktywną) lub słabszą postawą przedsiębiorcza.

Reasumując, należy przypomnieć propozycję stworzenia definicji wyjściowej o dużym stopniu ogólności, tworzoną po to, aby mieściła maksymalnie liczne i potencjalne informacje szczegółowe, które, jeśli tekst bądź wypowiedź mają być spójne i mieć walory komunikatu naukowego, byłyby rozwinięte i dookreślone w tzw. subdefinicjach. Umożliwiałyby one uzyskanie bardziej szczegółowych informacji w obrębie jednego przypadku jej użycia. Istota propozycji zbudowania definicji wyjściowej i tworzenia na konkretny użytek subdefinicji leży w fakcie, że wielu autorów pod pojęciem ,przedsiębiorczość” rozumie różne treści, czasem z zupełnie różnych sfer, niekiedy sprzeczne, co wykazały przytoczone wyżej przykłady definicji. Niech zatem określeniem „przedsiębiorczość”, skoro jest to pojęcie nazbyt bogate i polisemiczne, oznacza się bardzo ogólne cechy, po to, aby w dalszych wywodach, za pomocą definicji pomocniczych, każdy autor mógł doprecyzować, co - jego zdaniem i w jego rozumieniu - wchodzi w zakres tego metapojęcia, wyrażonego definicją wyjściową. Sytuacja taka wymusiłaby na posługujących się tym terminem potrzebę uściślenia własnych definicji. Zyskałyby na tym komunikaty (jednoznaczność) i wewnętrzna spójność wywodu, uniknięto by także chaosu semantycznego i przemieszania różnych treści w obrębie pozornie tego samego pojęcia.

\section{Literatura}

1. Bauman Z., 2006, Praca, konsumpcjonizm i nowi ubodzy, Wyd. WAM, Kraków

2. Borowski M., O rodzajach czynu, „Przegląd Filozoficzny” 4/1923

3. Borowski M., O sktadnikach czynu, „Przegląd Filozoficzny” 3/1923

${ }^{11}$ Pojęciem elastyczności w kontekście pozyskiwania środków posługuje się Z. Bauman. Analizując kwestie zatrudnienia w czasach ponowoczesnych, wskazuje on na zmienną aktywność podmiotów pracy, które częściej wybierają formy zatrudnienia takie jak praca dorywcza, w niepełnym wymiarze godzin, na czas określony. Kiedy nie można liczyć na stabilną, ciągłą pracę, elastyczny podmiot (co sytuuje go pośród tych, których określa postawa przedsiębiorcza) decyduje się na krótkotrwałe, czasem efemeryczne formy zatrudnienia. Świadczy to o jego stałej gotowości do uczestnictwa w życiu gospodarczym. Zob. Z. Bauman, Praca, konsumpcjonizm i nowi ubodzy, Wyd. WAM, Kraków 2006. 
4. Brzozowski S., 1990, Idee. Wstęp do filozofii dojrzałości dziejowej, Wydawnictwo Literackie, Kraków

5. Ekel J., Jaroszyński J., Ostaszewska J., 1965, Mały słownik psychologiczny, Warszawa

6. Komputerowy słownik języka polskiego, 2004, PWN, Warszawa

7. Kotarbiński T., 1937, Czyn, Polskie Towarzystwo Filozoficzne, Lwów

8. Kotarbiński T., O istocie sprawstwa, „Przegląd Filozoficzny” 1925, r. XXVIII

9. Makieła Z., Rachwał T., 2005, Podstawy przedsiębiorczości. Podręcznik dla liceum ogólnoksztatcacego, liceum profilowanego i technikum, Nowa Era, Warszawa

10. Sztucki T., 1998, Encyklopedia marketingu (wersja komputerowa), Wydawnictwo Placet, Warszawa

11. Penc L., 1997, Leksykon biznesu (wersja komputerowa), Wydawnictwo Placet, Warszawa.

\section{Enterprise - Ambiguous or Misunderstood Concept? Attempt of Systematize}

The concept of enterprise has its own settled and consolidated position in economics and other allied sciences nowadays. Without "enterprise", one of the most important term, there is no debate in the area of economics, logistics and even politics.

Accordingly it is worth to focus on the issue of enterprise and its significance.

All the available literature on enterprise takes into consideration many options of the idea of enterprise.

A wide range of meanings seems to set out to define enterprise more precisely. To solve that problem means to compose terminology of science, to set an interchangeable meaning for enterprise. No doubt, it will influence the term to be more expressive.

The author of the article describes in outline the context of enterprise, trying to show both variance and similarity in the enterprise based on some definitions. The enterprise concept is a subject of considerable debate although the article might contribute a number of studies towards liability to have a good grasp of the meanings of enterprise. 
Anita Paszko-Janowska

Akademia Ekonomiczna w Poznaniu

\section{Osobowość, motywacja, przedsiębiorstwo rodzinne. Wybrane aspekty przedsiębiorczości}

\section{Problemy z przedsiębiorczością}

Niemiecki psychiatra Wolfgang Rutz prowadził badania nad reakcją mieszkańców postkomunistycznych państw bałtyckich na nową sytuację ekonomiczną i polityczną po zmianach z początku lat 90 . XX w. ${ }^{1}$ Stwierdził, że narody te przechodzą ostry kryzys tożsamości. Popadając w sytuacje skrajne, ludzie dają dowody wielkiej odwagi lub stają się skłonni do rezygnacji czy kierowania się zasadą przyjemności. Ta ambiwalencja przejawia się z jednej strony otwartością na nowość, z drugiej prowadzi do utraty tożsamości i rodzi poszukiwania egzystencjalne. Rutz zauważył pewne objawy, które określa jako pozytywne: zdolność do improwizowania, tolerancję dla ryzyka, brak ustalonej struktury działania, elastyczność. Zauważył także pewne objawy negatywne wynikające z sytuacji kryzysowej. Znajdując się w stanie niepewności, ludzie przyjmują postawę oczekiwania, starają się nie brać na siebie odpowiedzialności (gdyż postrzegająjąjako niebezpieczną), przestrzegać ścisłej społecznej hierarchii, naśladując wzorce autorytarne. Są podejrzliwi i niespójni w zachowaniach. Jego zdaniem podobne reakcje można było zauważyć także i w Polsce (Mikulski Pomorski 1999).

Problemy wynikające z nowej sytuacji, w jakiej znaleźliśmy się po 1989 r., są skutkiem zmian, traumy, jaką przechodzi społeczeństwo. Max Weber ${ }^{2}$ nazwałby to problemami z, ,duchem przedsiębiorczości”, my możemy nazwać wpływem socjalizacji³ na jednostki, ich osobowość i kulturę.

Człowiek jest istotą społeczna; jego rozwój psychiczny, motywy, działania, postawy podlegają przemożnemu wpływowi czynników społecznych. Natura ludzka to zespół trwałych zdolności człowieka i jego sił motorycznych, zmuszających go nie tylko do zaspokajania potrzeb biologicznych, ale także do aktywnego przystosowania do środowiska społecznego i kulturalnego. ${ }^{4}$ O przedsiębiorczości decyduje nie absolutny, uzyskany już poziom osiagnięć, lecz zakodowana w społeczeństwie potencja, dążność do osiagania. Niezwykle istotna jest rola rodziny w kreowaniu osobowości jednostki i jej wpływ na przedsiębiorczość. Rodzina jest podstawową instytucją, w której odbywa się proces socjalizacji. ${ }^{5}$ Człowiek nie ma natury ludzkiej przy urodzeniu;

\footnotetext{
${ }^{1}$ Za: J. Mikulski Pomorski, 1999, Niepokój a potrzeba ładu: współczesna polska transformacja wobec zmiany świadomości [w:] Imponderabilia wielkiej zmiany, P. Sztompka (red.), Wydawnictwo Naukowe PWN, Warszawa-Kraków.

${ }^{2}$ Zob. M. Weber,1994, Etyka protestancka a duch kapitalizmu. Wyd. Test, Lublin.

${ }^{3}$ Socjalizacja to proces, dzięki któremu jednostka wdraża się do sposobu życia swojej grupy i szerszego społeczeństwa przez uczenie się reguł i idei zawartych w kulturze. Socjalizacja początkowo dokonuje się w rodzinie, a następnie w innych grupach pierwotnych - rówieśniczych i sąsiedzkich. Później szkoła, kościół, uczelnia. Następnie cała gama innych grup zawodowych, terytorialnych, rekreacyjnych (patrz P. Sztompka 2003, J. Szczepański 1970).

${ }^{4}$ J. Szczepański, 1970, Elementarne pojęcia socjologii, PWN, Warszawa.

${ }^{5}$ P. Sztompka, 2003, Socjologia, Wyd. Znak, Kraków.
} 
nabywa jej przez współżycie społeczne. Osobowość człowieka jest wytworem społeczeństwa i jego kultury, ukształtowanym w procesie socjalizacji. Popędy, które stanowią cechę gatunkową człowieka, są modyfikowane przez nabyte w toku socjalizacji umiejętności panowania nad nimi, przez wartości, idee, postawy, nawyki itp. W każdym człowieku te impulsy biopsychiczne oraz postawy, nawyki, idee, dążenia są zorganizowane, zintegrowane, stanowią jeden system i ten dynamiczny, zorganizowany system stanowi osobowość człowieka. ${ }^{6}$ Rodzina jest najważniejszym pasem transmisyjnym, który służy przekazywaniu wzorców kulturowych następnemu pokoleniu. Przekazuje przeważnie część kultury dostępną warstwie społecznej i grupom, w których znajduję się sami rodzice. Jest to mechanizm socjalizowania dziecka w kategoriach celów kulturowych i obyczajów charakterystycznych dla tego wąskiego kręgu grupy społecznej. Ten proces jest mimowolny; dziecko, obserwując codzienne zachowania i luźne rozmowy rodziców, jest wystawione na oddziaływanie społecznych prototypów. Równie istotna jest projekcja ambicji rodzicielskich na dziecko. Wobec osobistej „porażki” albo ograniczonego „sukcesu” wielu rodziców tłumi swe początkowe cele, wartości i odracza dalsze wysiłki, próbując zastępczo osiągnąć cel poprzez dzieci. ${ }^{7}$ Dlatego motywacja często pomaga w osiaganiu sukcesu, w działaniach przedsiębiorczych.

Społeczeństwo złożone z ludzi motywowanych do twórczej aktywności i zdolnych do uczenia się dzięki nieustannym ludzkim działaniom, stale się przekształca, następuje rozwój. Decydują o tym cztery rodzaje czynników:

- cechy osobowości jednostek, dominujący typ osobowości (na społeczeństwo aktywne muszą się składać jednostki twórcze, innowacyjne, zorientowane na osiągnięcia, cechujące się znaczną wiedza, wyobraźnią i realizmem; mające poczucie autonomii, integralności i niezależności);

- właściwości struktur społecznych, warunków, w których ludzie podejmują działania (społeczeństwo aktywne musi otwierać pole do swobodnej, twórczej aktywności, motywować i dawać możliwości ekspresji);

- panujący w społeczeństwie stosunek do tradycji, przeszłości (społeczeństwo aktywne jest zakorzenione w przeszłości, ciagłości historycznej, czerpie z niej siły i środki do dalszego rozwoju);

- wizja oczekiwanej przyszłości (w społeczeństwie aktywnym panują optymizm i nadzieja, poczucie mocy, przekonanie, że przyszłość zależy od ludzkich działań, a nie zrządzeń opatrzności) ${ }^{8}$

Przyjrzyjmy się bliżej kwestii osobowości, przedsiębiorczości rodzinnej oraz motywacji, które są ważnymi aspektami przedsiębiorczości.

\section{Osobowość a przedsiębiorczość}

Starając się zrozumieć rolę przedsiębiorczości w aktywizacji gospodarczej, nie można zapomnieć o wadze poznania zachowań jednostki i jej osobowości jako siły sprawczej przedsiębiorczości. To właśnie osobowość wpływa na sposób radzenia sobie z sytuacjami kryzysowymi. Niektórzy ludzie są spokojni i bierni, inni zaś hałaśliwi i agresywni. Osobowość jest kombinacją cech psychicznych. Psychologowie definiują osobowość jako względnie stały wzorzec emocji, motywów i postępowania odróżniający jednego człowieka od drugiego. ${ }^{9}$

Na podstawie wszechstronnych badań psychologicznych zidentyfikowano 16 podstawowych cech osobowości. Stwierdzono, że owe 16 cech stanowi trwałą i niezmienną podstawę

${ }^{6}$ J. Szczepański, op. cit.

${ }^{7}$ R.K. Merton, 2002, Teoria socjologiczna i struktura spoleczna, Wydawnictwo Naukowe PWN, Warszawa.

${ }^{8}$ P. Sztompka, op. cit.

${ }^{9}$ S.A. Rathus, 2004, Psychologia wspótczesna, GWP, Gdańsk. 
zachowań, umożliwiającą przewidywanie zachowania jednostki w określonych sytuacjach, dzięki ustaleniom ich wagi w danym kontekście. ${ }^{10}$

Jednym z najbardziej rozpowszechnionych kwestionariuszy osobowości jest wskaźnik typów Myersa-Briggsa (MBTI). Typy osobowości klasyfikuje się jako: ekstrawertyczne lub introwertyczne (E lub I), poznawcze lub intuicyjne ( $\mathrm{S}$ lub N), myślące lub uczuciowe (T lub E) oraz obserwujące lub oceniające (P lub J). Kombinacje tych określeń tworzą 16 typów osobowości. INTJ to wizjonerzy; zwykle mają oryginalne pomysły i wielki zapał do realizacji własnych zamierzeń. Takich ludzi charakteryzuje się jako sceptycznych, krytycznych, niezależnych, zdecydowanych i często upartych. ESTJ to organizatorzy. Są praktyczni, realistyczni, trzeźwo myślący; mają wrodzony talent do interesów lub uzdolnienia techniczne. Lubią organizować pracę i nią kierować. ENTP to konceptualiści. Są szybcy, błyskotliwi i wszechstronnie uzdolnieni. Zazwyczaj są skuteczni w rozwiązywaniu niekonwencjonalnych problemów, lecz zaniedbują czynności rutynowe. Według opublikowanej niedawno książki przedstawiającej 13 współczesnych biznesmenów, którzy doprowadzili do potęi najbogatsze firmy, m.in.: Apple Computer, Federal Express, Honda Motors, Microsoft, Sony i Prince Club, wykazano, że cała trzynastka należała do typu NT (czyli osób intuicyjnych i myślących). Innym modelem jest pięcioskładnikowy model osobowości nazywany ,wielką piątką". Składnikami wielkiej piątki są: ekstrawersja, ugodowość, sumienność, stabilność emocjonalna i otwartość na doświadczenia. Badania nad ,wielką piątką” nie tylko umożliwiły tworzenie jednolitych opisów osobowości, ale również przyczyniły się do odkrycia ważnej relacji pomiędzy wymiarami osobowości a osiagnięciami zawodowymi. Ekstrawersja pozwala np. oczekiwać dobrych wyników na stanowiskach kierowniczych, podobnie otwartość na doświadczenia. Sumienność jest prognostykiem osiagnięć zawodowych we wszystkich grupach, a stabilność emocjonalna nie ma na nie wpływu. Innymi podstawowymi atrybutami osobowości są: umiejscowienie kontroli, autorytaryzm, makiawelizm, samokontrola, skłonność do ryzyka oraz osobowość typu A. Niektórzy ludzie sądzą, że sami kształtują swój los, inni uważają się za pionki w grze, są przekonani, że to co im się przytrafia, jest tylko sprawą szczęścia lub zrządzeniem losu. Osoby skrajnie autorytarne wykazują sztywność umysłu, osądzają innych, są przesadnie układne wobec przełożonych i lekceważą podwładnych, na zmiany reagują niechęcią i obawą. Jednostka mająca silne skłonności makiawelistyczne posługuje się manipulacją zachowuje dystans emocjonalny i wierzy, że cel uświęca środki. Osoby o znacznym stopniu samokontroli są wrażliwe na sygnały z zewnątrz i umieją dopasować swoje zachowanie do różnych sytuacji. Ludzie różnią się skłonnością do podejmowania ryzyka. Natomiast osobowość typu A to ludzie nastawieni na rywalizację.

Ludzie mają różne osobowości. Najlepiej zbadaną teorią zgodności zawodu jest model sześciu typów osobowości: realistyczny, badawczy, społeczny, konwencjonalny, przedsiębiorczy, artystyczny. Typ osobowości przedsiębiorczy preferuje działalność werbalną, dającą możliwość oddziaływania na innych i zdobywania władzy. Jest pewny siebie, ambitny, energiczny, władczy. Typ realistyczny preferuje aktywność fizyczną wymagającą umiejętności, siły i koordynacji. Jest nieśmiały, rzetelny, wytrwały, zrównoważony, ugodowy, praktyczny. Typ badawczy preferuje zajęcia związane z myśleniem, organizowaniem i rozumieniem. Jest analityczny, oryginalny, dociekliwy, niezależny. Typ osobowości konwencjonalny preferuje czynności zgodne z regułami, uporządkowane i jednoznaczne. Jest ugodowy, skuteczny, praktyczny, pozbawiony wyobraźni, nieelastyczny. Typ artystyczny preferuje zadania niejednoznaczne i niesystematyczne, które umożliwiają ekspresję twórczą. Jest obdarzony wyobraźnią, nieuporządkowany, idealistyczny, emocjonalny, niepraktyczny. Typ społeczny preferuje działalność związaną z pomaganiem i wychowaniem. Jest towarzyski, życzliwy, uspołeczniony, wyrozumiały. ${ }^{11}$

${ }^{10}$ S.P. Robbins, 2001, Zasady zachowania w organizacji, Wyd. Zysk i S-ka, Poznań.

${ }^{11}$ Ibidem. 
Rola osobowości w zakładaniu i prowadzeniu własnej działalności gospodarczej ma znaczenie. Niepewność rynku, potrzeba podjęcia ryzyka, umiejętności przewodzenia, oto niektóre czynniki mające wpływ na przedsiębiorczość.

Czy każdy przedsiębiorca musi być dobrym przywódcą? Skuteczne przywództwo odgrywa zasadniczą rolę w gospodarce, $\mathrm{w}$ administracji oraz w rozmaitych grupach i organizacjach, które kształtują styl życia, pracy i zabawy. Przywództwo jest to umiejętność oddziaływania na grupę w dążeniu do określonych celów. Źródłami takiego wpływu mogą być: ${ }^{12}$

1. formalna pozycja kierownika,

2. uczucie,

3. kompetencje fachowe, wiedza,

4. osobowość,

5. charyzma.

Wskazano sześć cech wyróżniających przywódcę spośród innych ludzi. Są to: zapał i ambicja, chęć kierowania innymi i wywierania wpływu, uczciwość i rzetelność, pewność siebie, inteligencja oraz rzetelna wiedza techniczna związana z zakresem odpowiedzialności. Wbrew powszechnej opinii, przywództwo nie zawsze musi być ważne. Wpływ przywództwa mogą neutralizować np. cechy pracowników: doświadczenie, kwalifikacje, kompetencje zawodowe oraz potrzeba niezależności.

\section{Przedsiębiorczość rodzinna}

Ważnym aspektem w funkcjonowaniu gospodarki jest przedsiębiorczość rodzinna. Rodzina jest środowiskiem sprzyjającym zachowaniom przedsiębiorczym. Można przypuszczać, że firmy rodzinne stanowią dosyć wysoki odsetek polskiego sektora małych i średnich przedsiębiorstw. Konieczność utrzymania rodziny wywiera poważny wpływ na decyzję o założeniu firmy. Przedsiębiorczość jest ważnym aspektem większości firm rodzinnych, a firma rodzinna często wspiera wysiłki jej członków do działań przedsiębiorczych. ${ }^{13} \mathrm{~W}$ Stanach Zjednoczonych firmy rodzinne stanowiły pod koniec XX w. około $90 \%$ z 15 mln przedsiębiorstw. Jedna trzecia spośród największych 500 firm amerykańskich była własnością rodzin. W Stanach Zjednoczonych firmami rodzinnymi są takie przedsiębiorstwa (marki), jak: Cargill, Mariett, Levi-Strauss, Mars Candy, Tyson Foods, Hallmark. Na kontynencie europejskim źródłem przedsiębiorczości rodzinnej są gospodarki rynkowe Europy Zachodniej. Najwyższy poziom aktywności firm rodzinnych występował pod koniec XX w. we Włoszech (99\%), podobnie w Niemczech ( $80 \%$ firm było kontrolowanych przez rodziny). W Wielkiej Brytanii 76\% z 8 tys. największych przedsiębiorstw było w posiadaniu lub pod kontrolą rodziny. Po 1989 r. wiele firm rodzinnych powstało w Europie ŚrodkowoWschodniej, zwłaszcza w Polsce, Czechach, na Wegrzech. ${ }^{14}$ Badacze są zdania, że firmy rodzinne są podstawą tworzenia stabilnej gospodarki. Przedsiębiorstwo rodzinne jest bardziej skłonne do „reinwestycji w siebie” w celu utrzymania, utrwalenia i pomnożenia majątku dla przyszłych pokoleń. Firma rodzinna jest zdolna do przeprowadzenia długookresowych inwestycji i skutecznie opiera się presji osiaggania krótkookresowych korzyści. W literaturze podkreśla się, że w obecnym okresie transformacji w Polsce sektor małych i średnich przedsiębiorstw, w tym firm rodzinnych, odgrywa ważną rolę ze względu na:

\footnotetext{
${ }^{12}$ Zarzqdzanie. Teoria i praktyka, 1995, A. Koźmiński, W. Piotrowski (red.), Wydawnictwo Naukowe PWN, Warszawa.

${ }^{13}$ J. Jeżak, W. Popczyk, A. Winnicka-Popczyk, 1995, Przedsiębiorstwo rodzinne, Difin, Warszawa.

${ }^{14}$ Ibidem.
} 
- aktywny udział w procesie zmian struktury przemysłowej kraju;

- produkcję towarów i usług, na które popyt jest niewielki lub bardzo zmienny;

- ugruntowanie się zasad rynkowych w postawach ludzi i pojawienie się konkurencji;

- zmniejszenie bezrobocia powstającego w związku z kurczeniem się sektora publicznego. ${ }^{15}$

Jednym z poważnych motywów w zakładaniu firmy rodzinnej jest kwestia zaufania. Ryzyko i obawy związane z nowym przedsięwzięciem są tak duże, że łatwiej jest współdziałać i przezwyciężać problemy z kimś, komu ufamy. Zaufanie oznacza przeświadczenie, że druga strona nie będzie oszukiwać w słowach, działaniach i decyzjach. Pojęcie pozytywnego przeświadczenia zakłada wiedzę o drugim człowieku. Zaufanie jest związane z przeszłością i tworzy się na podstawie istotnych, chociaż ograniczonych doświadczeń. Wymaga czasu, nabywania i gromadzenia doświadczeń. Trudne jest natychmiastowe zaufanie komuś, o kim nic nie wiemy. W sytuacji skrajnej, w przypadku całkowitej niewiedzy, można ryzykować, ale nie: ufać. Dlatego zaufanie jest jednym z powodów zakładania firm rodzinnych, rozwoju przedsiębiorczości rodzinnej. ${ }^{16}$ F. Fukujama dość obszernie analizuje kwestię zaufania lub jego braku w gospodarowaniu. Według niego kapitał społeczny ma poważny wpływ na charakter gospodarki przemysłowej, którą dane społeczeństwo jest w stanie stworzyć. Jeżeli pomiędzy wspólnikami danego przedsięwzięcia istnieje wzajemne zaufanie wynikające z uznawania tych samych norm kodeksu etycznego, to prowadzenie interesów jest mniej kosztowne. Kapitał ten może być cechą najmniejszej i najbardziej podstawowej grupy społecznej, jaką jest rodzina; można go rozpatrywać w skali całego narodu lub w obrębie wszystkich grup pośrednich. ${ }^{17}$

\section{Motywacja w przedsiębiorczości}

Podstawową cechą człowieka, który poradzi sobie w życiu, jest motywacja do poszerzania wiedzy, a co za tym idzie - umiejętności w działaniu. Dziś nikt nie wątpi, że podstawą tych działań jest wychowanie dziecka w rodzinie, ale niezwykle istotne jest również kształcenie postaw studentów, wskazywanie im ,ścieżek”. By wychować młode pokolenie do sukcesu i przedsiębiorczości, trzeba dążyć do rozwijania wielu cech osobowości młodych ludzi, przez:

- pobudzanie motywacji i aspiracji,

- rozwijanie zainteresowań i zdolności,

- wyzwalanie aktywności i własnej twórczości,

- przekazywanie wartości ponadczasowych,

- kształtowanie samodzielności,

- kształtowanie stabilnej samooceny. ${ }^{18}$

Maslow uważał, że ludzi od zwierząt odróżnia zdolność do samourzeczywistnienia, czyli inicjowania przez samego człowieka dążenia do stania się osobą, którą mógłby się stać, realizując w pełni swój potencjał. Jego zdaniem potrzeba samourzeczywistnienia jest równie ważna u ludzi jak głód. To ta potrzeba popycha ludzi do zostania pianistami, dyrektorami wielkich przedsiębiorstw czy pisarzami. Sformułował on tezę, że potrzeby ludzkie tworzą pewną hierarchię, od potrzeb fizjologicznych aż do potrzeby samourzeczywistnienia. Wierzył, że naturalna droga rozwoju

\footnotetext{
${ }^{15}$ Ibidem.

${ }^{16}$ S.P. Robbins, op. cit.

${ }^{17}$ Zob. F. Fukujama, 1997, Zaufanie. Kapitat społeczny a droga do dobrobytu, PWN, Warszawa-Wrocław.

${ }^{18}$ J. Jeżak, W. Popczyk, op. cit.
} 
człowieka wiedzie od zaspokajania potrzeb podstawowych do coraz wyższych pięter w hierarchii, na którą składają się następujące rodzaje potrzeb:

1. potrzeby fizjologiczne,

2. potrzeby bezpieczeństwa,

3. potrzeby przynależności i miłości,

4. potrzeby szacunku i dowartościowania,

5. potrzeby samourzeczywistnienia.

Maslow uważał także, że ludzie są motywowani przez świadomą potrzebę osobistego rozwoju. ${ }^{19}$ Krytycy teorii Maslowa wskazują natomiast na to, że zróżnicowanie poszczególnych osób jest zbyt duże, aby dla wszystkich można było zasadnie postulować tę samą hierarchię motywów. Psychologowie humanistyczni podkreślają, że ludzie są w stanie wytrzymać ból, głód i wiele innych napięć, by osiagnąć stan samourzeczywistnienia. Motywacja jest bardzo ważnym aspektem w rozwoju przedsiębiorczości. Motywy zakładania własnej działalności gospodarczej mogą być różne: bezrobocie, chęć zysku, chęć zostania panem własnego losu, chęć samorealizacji, chęć dokonania czegoś ważnego w życiu, potrzeba szacunku, uznania czy objęcie firmy otrzymanej w spadku. Jednakże niezwykle istotne jest to, by wykształcić w młodych umysłach chęć dokonania tych właśnie rzeczy, podjęcia ryzyka i odpowiedzialności za siebie i innych. Jest to zadanie, które stoi przede wszystkim przed rodziną, ale również przed szkołami i wykładowcami uczelni wyższych, którzy - dając podbudowę teoretyczną - nie powinni zapominać o zachęcaniu młodych ludzi do robienia rzeczy wielkich. Nauczać i motywować, sprawiać, by bycie przedsiębiorczym stało się modne, to zadanie, przed którym stoi edukacja. Ważną rolę pełnią też środki masowego przekazu, zwłaszcza telewizja.

Poruszane w tym artykule kwestie osobowości, zaufania, przywództwa, powstawania firm rodzinnych, motywów działania, nie wyczerpują kwestii przedsiębiorczości. Jesteśmy na początku drogi, którą sami tworzymy. Możemy wzorować się na drodze, którą przeszli inni, jednak nasza jest niepowtarzalna i musimy ją sami pokonać. Przedsiębiorczość jest zjawiskiem złożonym, ale nie można zapominać, że to człowiek jest twórcą przedsiębiorstwa. Ma swoje aspiracje, problemy, wizje, plany. Swoje marzenia i problemy. W tym zmaganiu z rzeczywistością może pomóc wsparcie rodziny, które jest pierwszym etapem rozwoju człowieka, jego osobowości, i może być czynnikiem zarówno motywującym, jak i hamującym rozwój.

\section{Literatura}

1. Fukujama F., 1997, Zaufanie. Kapital społeczny a droga do dobrobytu, Wydawnictwo Naukowe PWN, Warszawa-Wrocław

2. Imponderabilia wielkiej zmiany, 1999, P. Sztompka (red.),Wydawnictwo Naukowe PWN, Warszawa-Kraków

3. Jeżak J., Popczyk W., Winnicka-Popczyk A., 2004, Przedsiębiorstwo rodzinne, Difin, Warszawa

4. Merton R.K., 2002, Teoria socjologiczna i struktura społeczna, Wydawnictwo Naukowe PWN, Warszawa

5. Rathus S.A., 2004, Psychologia wspótczesna, GWP, Gdańsk

6. Robbins S.P., 2001, Zasady zachowania w organizacji, Zysk i S-ka, Poznań

${ }^{19}$ S.A. Rathus, op. cit. 
7. Szczepański J., 1970, Elementarne pojęcia socjologii, PWN, Warszawa

8. Sztompka P., 2003, Socjologia, Znak, Kraków

9. Zarzqdzanie. Teoria i praktyka, 1995, A. Koźmiński, W. Piotrowski (red.), Wydawnictwo Naukowe PWN, Warszawa

\section{Personality, Motivation and Family Business in Enterprise}

Poland has short experience in the free market economy. We have just been learning to "taking the matters in our own hands" to face new reality. One of the problems we face at the beginning of the way to market economy is enterprise. We have to dare "begin something new". The question is: Does a personality, safety and motivation have influence on enterprise? Is establishing family business a necessary evil or a mean of manage new reality? Can you make enterprise fashionable and what does depend on us?

There are no simple answers to those questions. The subjects touched in this article indicate certain question of enterprise that is worth observing. 


\section{Przedsiębiorczość}

\section{w funkcjonowaniu przedsiębiorstw}




\section{Pawel Żukowski}

Zakład Organizacji i Zarządzania

Wyższa Szkoła Zarządzania i Administracji w Opolu

\section{Model i symulacja dynamiki systemu zarządzania organizacją gospodarczą (ujęcie modelowe)}

Sprawne i efektywne zarządzanie organizacją gospodarczą w warunkach rynkowych wymaga analizy dynamiki systemu zarządzania. Stanowi ona podstawę integracji takich obszarów działalności, jak: rynek, zaopatrzenie, produkcja, dystrybucja, inwestycje, prace badawcze i rozwojowe. W miarę kompleksowe podejście do rozpatrywanego problemu wymaga skupienia uwagi na tych składnikach i współzależnościach, które są istotne dla pożądanej właściwości systemu. Podstawowymi elementami takiej analizy są: poszukiwanie analogii, budowa modeli oraz symulacja. Rozważając bowiem jakikolwiek konkretny system, człowiek dąży w istocie do stworzenia w swym umyśle modelu wyjaśniającego zachowanie się obserwowanego systemu (Ansoff 1995, Forrester 1961, Grudzewski, Hejduk 2004, Thompson, Strickland 1993, Żukowski 1990). Systemy konkretne bywają często bardzo złożone; trudno określić ich rzeczywistą strukturę i właściwości. Staramy się wtedy wyjaśnić ich funkcjonowanie na zasadzie analogii między jakimś systemem, który znamy, a systemem badanym. Istotą analogii są relacje równoważności między dwoma systemami. Jeśli ta równoważność obejmuje pewien zbiór elementów i czynników istotnych dla interesujących badającego właściwości wyjaśnianego systemu, to mówi się o dobrej analogii, w przeciwnym wypadku - o analogii złej lub pozornej. Ocena, czy rozpatrywana analogia jest dobra czy zła, nie jest sprawą ani prostą, ani łatwą, szczególnie w wypadku bardziej złożonych systemów, a akceptacja niewłaściwej jest często kosztowna. Jedną z metod eliminowania niewłaściwych analogii jest zdobywanie wiedzy o nich metodą symulacji. Narzędziem umożliwiającym symulację są modele, które powinny odwzorowywać interesujące zależności i właściwości systemu w stopniu wystarczającym dla założonego zakresu badań. Jednocześnie konstrukcja modelu powinna pozwalać na przeprowadzenie badań z możliwością ich powtórzenia w różnych warunkach pracy organizacji gospodarczej [Grudzewski (red.) 1985, Grudzewski, Hejduk 2004, Penc 2006b, Thompson, Strickland 1993, Żukowski 2006].

Analiza dynamiki systemu zarządzania, według J.W. Forrestera (1961), jest metodą badań charakterystyk informacyjnych sprzężeń zwrotnych w działaniu organizacji gospodarczej. Służy ona poznaniu interakcji struktury organizacyjnej na wzmocnienia (w zakresie wytycznych działania) i opóźnienia (w zakresie decyzji i współdziałania), od których wzajemnego oddziaływania zależą sprawność i efektywność pracy całej organizacji. Analizuje się głównie współzależności i oddziaływania między strumieniami: materiałów, zamówień, zleceń, produkcji, wyposażenia, personelu, pieniędzy i innych wielkości - na różnych poziomach i w różnej skali zarządzania (Grudzewski, Hejduk 2002, Penc 2006a, Wagner 1980). Celem podstawowym matematycznoekonomicznego opisu dynamiki systemu zarządzania organizacją gospodarczą, w ujęciu modelowym, jest zobrazowanie metodyki i cech budowy tego typu modeli. Model ten reprezentuje w sposób uproszczony dowolną organizację gospodarczą (produkcyjną). Główną 
uwagę zwraca się na analizę przyczyn fluktuacji zachodzących procesów (określonych wielkości) obserwowanych przy skokowych zmianach, w warunkach rynkowych, potoku zamówień na produkty finalne. Taka analiza powinna eksperymentalnie ujawniać przybliżone ilościowe współzależności między strukturą organizacyjną i wytycznymi działania a stabilnością pracy organizacji gospodarczej. Wyniki symulacji na modelu wskażą pewne właściwości dynamiki zachowania się organizacji gospodarczej (kształtowania się charakterystycznych i interesujących badacza wielkości) w trakcie jej pracy (Forrester 1961, Penc 2000, Żukowski 1990).

\section{Ogólny opis modelu, wytyczne dzialania}

W opisie symboliczno-analogowym przyjętej do rozważań modelowej organizacji gospodarczej (ryc. 1) wyróżniono pięć kluczowych działów i wydziałów, które są reprezentowane przez następujące wielkości (ich poziomy): DS - portfel zamówień (liczba przyjętych zamówień na produkty finalne), DZ - liczba zleceń zakupu materiałów z działu zaopatrzenia, MM - zawartość surowców, materiałów i półfabrykatów w magazynie materiałów, $\mathrm{PR}$ - wielkość produkcji wydziału (zakładu) produkcyjnego i MP - wielkość zapasów produkcji finalnej w magazynie. Sformułowano też niezbędne wytyczne (reguły) działania. Oto wytyczne dla personelu kierowniczego:

1. wielkość produkcji, a ściślej: wielkość zleceń produkcyjnych $(Z P R)$ powinna być taka, aby zapewnić $k$-krotnie wyższy poziom produkcji finalnej w magazynie produktów $(M P)$ w stosunku do uśrednionej liczby przychodzących z rynku zamówień $(Z S)$ na produkty finalne (np. współczynnik wzmocnienia $k=3$ tygodnie). Warunek ten jest spełniany przez przesyłanie do wydziału (zakładu) produkcyjnego $(P R)$ zleceń produkcyjnych $(Z P R)$, stanowiących sumę złożoną z uśrednionej liczby przyjmowanych zamówień $(Z S)$ na produkty finalne i różnicy $\left(S_{l}\right)$ między pożądaną zawartością produktów finalnych w magazynie produktów a jego rzeczywistym stanem. Wielkość $Z P R$ wyznaczymy z formuły:

$Z P R=Z S+S_{1}$

gdzie:

ZS - uśredniona liczba przyjmowanych zamówień,

$\mathrm{S}_{1}$ - zmienna pomocnicza.

Pożądana zawartość produktów finalnych w magazynie produktów $(k \times Z S)$ to iloczyn uśrednionej wielkości zamówień produktów finalnych $(Z S)$ i współczynnika wzmocnienia $(k)$. Współczynnik $k$ określa liczbę tygodni, w ciągu których pożądana zawartość produktów finalnych w magazynie produktów $(M P)$ byłaby wystarczająca do ich wysyłki odbiorcom z prędkością równą średniej prędkości napływania zamówień z rynku. Zmienną pomocniczą $S_{1}$ zatem obliczy się ze wzoru:

$\mathrm{S}_{1}=k \cdot Z S-M P$

gdzie:

$k$-współczynnik wzmocnienia,

$M P$ - faktyczna ilość produktów finalnych w magazynie produktów.

2. w przypadku, gdy poziom materiałów i półfabrykatów w magazynie materiałów $(M M)$, zabezpieczający produkcję, spada poniżej poziomu określonego przez portfel przyjętych zamówień $(D S)$, należy wstrzymać przyjmowanie nowych zamówień na produkty finalne (ZDS); wykorzystuje się tu zmienną pomocniczą $S_{2}$ (ryc. 1);

3. podobnie, jak w wytycznej 2, gdy zawartość materiałów (półfabrykatów) w magazynie materiałów $(M M)$ spadnie poniżej pewnej, z góry określonej wartości (Min), należy wstrzymać przesyłanie zleceń produkcyjnych $(Z Z R)$ do wydziału (zakładu) produkcyjnego $(P R)$; wykorzystuje się tu z kolei zmienną pomocniczą $S_{3}$ (Żukowski 1990, Żukowski, Winnicki, Grabowiecka 2000) (ryc. 1). 
Zmienna pomocnicza $S_{3}$ wyraża różnicę między aktualną zawartością materiałów i półfabrykatów w magazynie materiałów $(M M)$ a pewnym jego zapasem minimalnym (Min). Zmienną pomocniczą $S_{3}$ obliczy się ze wzoru:

$S_{3}=M M-M i n$

4. wielkość strumienia zleceń na zakup materiałów i półfabrykatów $(Z D Z)$ wysyłanych do działu zaopatrzenia $(D Z)$ musi być równa wielkości strumienia zamówień z rynku sprzedaży na produkty finalne $(R K)$, napływających do działu sprzedaży;

5. w przepustowości informacyjnej prac biurowych czasy przejścia zostały odpowiednio oznaczone: $T Z S$ - czas przejścia niezbędny do uśredniania zamówień na produkty finalne, $T D Z$ - czas przejścia niezbędny do zakupu materiałów, $T P R$ - czas przejścia niezbędny do produkcji, TDS - czas przejścia niezbędny do dystrybucji, $T M P$ - czas przejścia niezbędny do realizacji wytycznej 1 .

\section{Matematyczny opis dynamiki systemu zarządzania}

Z rynku sprzedaży produktów finalnych płyną dwa strumienie (ryc. 1); jeden z nich niesie zamówienia na produkty finalne, drugi zaś - informacje o ich wielkości.

Na pierwszym stanowisku decyzyjnym, oznaczonym na ryc. 1 przez poziom $R K$, opisuje się wielkość napływających z rynku zamówień na produkty finalne. Wielkość $R K$ ma charakter skokowy; można ją wyliczyć ze wzoru:

$R K=R K_{0}+Z F \cdot 1(T)$

gdzie:

$R K_{0}$ - początkowa liczba zamówień na produkty finalne,

$Z F$ - liczba napływających do organizacji z rynku zamówień na produkty finalne.

Drugie stanowisko decyzyjne, poziom $Z D S$, reguluje dopływ zamówień na produkty finalne, które można przyjąć ze względu na istniejące zabezpieczenie materiałowe (realizacja wytycznej 2 z wykorzystaniem zmiennej $S_{2}$ ), i jednocześnie koryguje informację o wielkości strumienia tych zamówień przez skierowanie informacji do „uśredniania” zamówień $(Z S)$. Działanie drugiego stanowiska decyzyjnego określa funkcja $F^{*}$ w postaci:

$$
F^{*}= \begin{cases}1, & g d y M M \geq D S \\ 0, & g d y M M<D S\end{cases}
$$

Wielkość $Z D S$ wyliczany z zależności:

$Z D S=F^{*} \cdot R K$

Stanowisko decyzyjne 3, poziom $D S$ (portfel zamówień), określa liczbę przyjętych zamówień na produkty finalne. Wielkość $D S$ obliczymy ze wzoru:

$D S=D S_{0}+T(Z D S-Z M P)$

gdzie:

$D S_{0}$ - poprzednia liczba zamówień na produkty finalne,

$T$ - przedział czasu,

$Z D S$ - wielkość strumienia przyjętych zamówień na produkty finalne,

$Z M P$ - wielkość strumienia zrealizowanych zamówień na produkty finalne.

Stanowisko decyzyjne 4, poziom $Z M P$, reguluje:

- wielkość wysyłki zamówionych produktów finalnych z magazynu $(M P)$,

- wielkość odpowiadającego tej wysyłce odpływu załatwionych zamówień z portfela zamówień na produkty finalne do archiwum. 
Ryc. 1. Symboliczno-analogowy model zarządzania organizacją gospodarczą

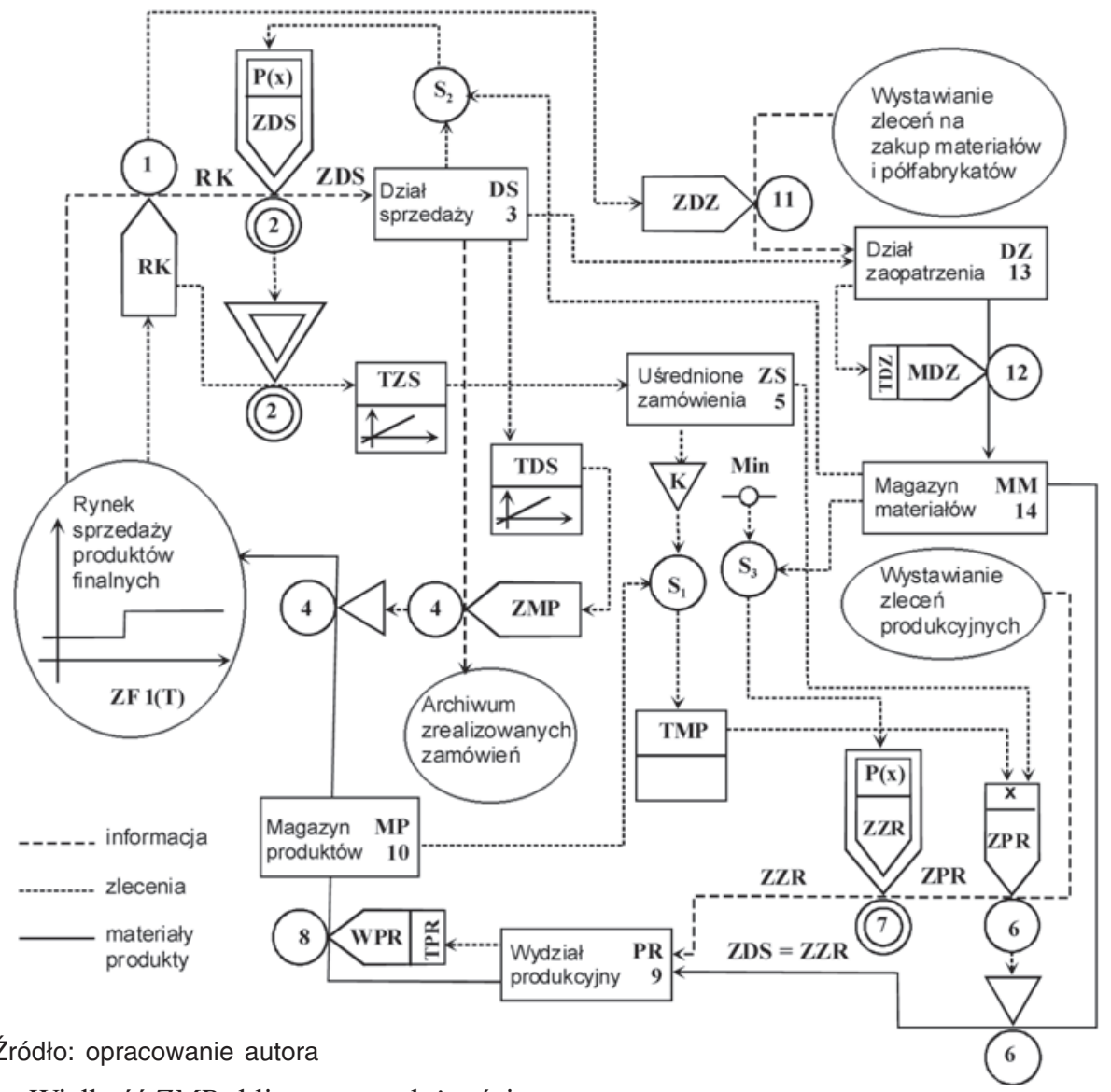

Wielkość ZMP obliczymy z zależności:

$Z M P=D S / T D S$

$D S$ - portfel przyjętych zamówień na produkty finalne,

$T D S$ - czas realizacji zamówienia na produkt finalny (jest wartością stałą, np. 1 tydzień).

Stanowisko decyzyjne 5, poziom $Z S$ (uśrednianie napływających zamówień na produkty finalne), reprezentuje średnią wielkość strumienia napływających z rynku zamówień na produkty finalne $R K$ (z uwzględnieniem korekcyjnego działania 2 stanowiska decyzyjnego - ZDS). Wielkość $Z S$ wyliczymy z formuły:

$Z S=Z S_{0}+T\left(Z D S-Z S_{0}\right)$

gdzie:

$Z S_{0}$ - poprzednia liczba uśrednienia zamówień na produkty finalne,

$T$ - przedział czasu,

$Z D S$ - wielkość strumienia przyjętych zamówień na produkty finalne.

Stanowisko decyzyjne 6, poziom ZPR, reguluje (wykorzystując zmienną pomocniczą $\mathrm{S}_{1}$, zgodnie z wytyczną 1):

- wielkość przepływu zleceń produkcyjnych przesyłanych do wydziału (zakładu) produkcyjnego,

- wielkość strumienia materiałów i półfabrykatów przesyłanych do produkcji $(P R)$, a pobieranych z magazynu materiałów $(M M)$. 
Wielkość strumienia zleceń produkcyjnych $(Z P R)$ jest równa sumie średniej wielkości napływających zamówień na produkty finalne $(Z S)$ oraz poprawce wyrażonej ilorazem wielkości pomocniczej $S_{1}$ i czasu przejścia $T P R$. Wielkość $Z P R$ wyliczymy ze wzoru:

$$
Z P R=Z S+S_{1} / T P R
$$

Stanowisko decyzyjne 7, poziom $Z Z R$, zapewnia realizację 3 wytycznej działania, odcinając dopływ zleceń produkcyjnych przesyłanych do wydziału produkcyjnego, gdy stan materiałów lub półfabrykatów w magazynie materiałów $(M M)$ spadnie do zapasu minimalnego (Min). Działanie stanowiska 7 określa funkcja $P^{*}$ w postaci:

$$
P^{*}= \begin{cases}1, & g d y S_{3} \geq D S \\ 0, & g d y S_{3}<D S\end{cases}
$$

Wielkość ZZR zaś określi się z zależności:

$$
Z Z R=P^{*} \cdot Z S R
$$

Stanowisko decyzyjne 8, poziom $W P R$, stanowi element przepustowości wykładniczej pierwszego rzędu i określa czas przejścia potrzebny na produkcję. Przyjmuje się, że ten czas (TPR) jest wartością stałą (np. 2 tygodnie), a elementem akumulującym przepustowość jest zawartość portfela zleceń produkcyjnych $(P R)$. Wielkość $W P R$ obliczymy z zależności:

$$
W P R=P R / T P R
$$

Stanowisko decyzyjne 9, poziom $P R$, określa aktualną wielkość portfela zleceń produkcyjnych. Ta wielkość jest równa sumie poprzedniej wielkości zleceń produkcyjnych $\left(P R_{0}\right)$ i akumulowanej różnicy między napływem nowych zleceń produkcyjnych do wydziału $(Z Z R)$ a ich odpływem, równoważnym wielkości produkcji $(W P R)$.

$$
P R=P R_{0}+T(Z Z R-W P R)
$$

Stanowisko decyzyjne 10, poziom $M P$, reguluje zawartość magazynu produktów finalnych; stan magazynu tych produktów jest zasilany strumieniem produkcji (WPR) z wydziału (zakładu) produkcyjnego, a wyjściem jest strumień produktów finalnych $(Z M P)$ wysyłanych przez dział sprzedaży zgodnie z zamówieniami klientów. Różnica między tymi strumieniami jest akumulowana w magazynie produktów finalnych $(M P)$. Wielkość $M P$ określa się ze wzoru:

$$
M P=M P_{0}+T(W P R-Z M P)
$$

gdzie:

$M P_{0}$ - poprzednia zawartość magazynu produktów finalnych.

Stanowisko decyzyjne 11, poziom $Z D Z$, określa wielkość strumienia zamówień (zleceń zakupu) materiałów i półfabrykatów przez dział zaopatrzenia i - zgodnie z wytyczną działania 4 - równa się strumieniowi zamówień na produkty finalne $(R K)$.

Wielkość $Z D Z$ równa jest więc $R K$ :

$$
Z D Z=R K
$$

Stanowisko decyzyjne 12, poziom $M D Z$, reprezentuje strumień materiałów i półfabrykatów zakupionych i dostarczonych do magazynu materiałów $(M M)$ przez dział zaopatrzenia. Wielkość tego strumienia jest regulowana na podstawie liczby zleceń na zakup materiałów i półfabrykatów zakumulowanej w zaopatrzeniu $(D Z)$. Wielkość $M D Z$ określamy z zależności:

$$
M D Z=D Z / T D Z
$$


gdzie:

$T D Z$ - czas przejścia potrzebny na zakup materiałów i półfabrykatów; przyjmuje się go jako wielkość stałą (np. 2 tygodnie).

Stanowisko decyzyjne 13, poziom $D Z$, akumuluje różnicę między napływającym strumieniem zleceń zakupu materiałów i półfabrykatów (ZDZ) a strumieniem ich odpływu, czyli realizacji. Ta ostatnia wielkość jest równoważna strumieniowi materiałów i półfabrykatów zakupionych przez zaopatrzenie $(M D Z)$ i przekazanych do magazynu materiałów $(M M)$. Wielkość $D Z$ wyliczamy ze wzoru:

$D Z=D Z_{0}+T(Z D Z-M D Z)$

gdzie:

$D Z_{0}$ - poprzednia liczba zleceń zakupu materiałów i półfabrykatów.

Stanowisko decyzyjne 14, poziom $M M$, akumuluje różnicę między strumieniem zakupionych materiałów i półfabrykatów $(M D Z)$ a strumieniem ich odpływu do produkcji $(Z P R)$. Wielkość $M M$ określamy ze wzoru:

$M M=M M_{0}+T(M D Z-Z P R)$

gdzie:

$M M_{0}$ - początkowy poziom materiałów i półfabrykatów w magazynie.

\section{Interpretacja wyników symulacji}

W symulacji, wykorzystując zbudowany model, zbadano zachowanie się organizacji gospodarczej wówczas, gdy zamówienie na produkty finalne wzrasta o ZF $=40$ jednostek/tydzień przy początkowym poziomie materiałów w magazynie $\mathrm{MM}_{0}=270$ jednostek (ryc. 2).

Ryc. 2. Wyniki symulacji w przypadku wzrostu zamówienia o 40 jednostek/tydzień przy początkowym poziomie materiałów w magazynie 270 jednostek

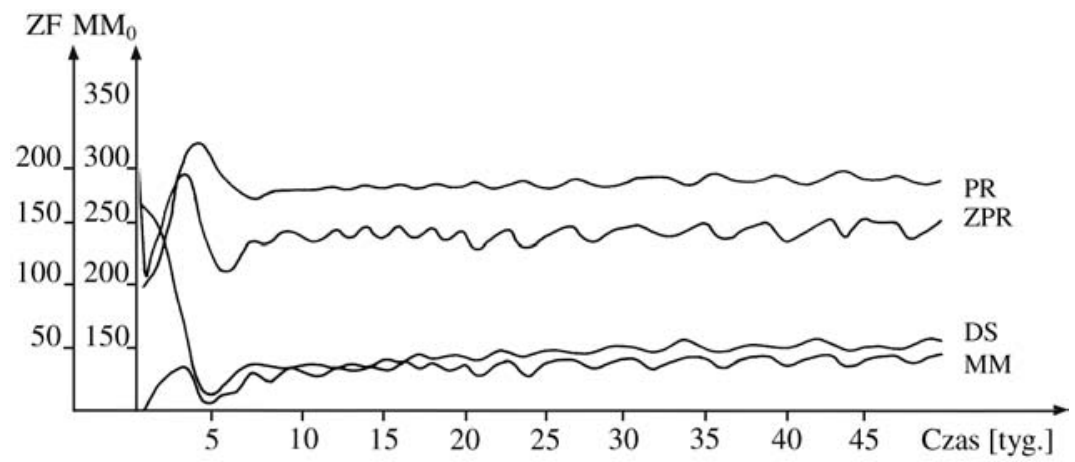

Z wyniku symulacji przedstawionego na wykresie (ryc. 2) płynie wniosek, że przy skokowym wzroście zamówienia na produkty finalne o $Z F=40$ jedn./tydzień zaburzenia przejściowe w pracy opisanej organizacji gospodarczej, wyrażające się wahaniem poziomu produkcji $(P R)$, oraz przepływu zleceń i materiałów na produkcję $(Z P R)$, są obserwowane jeszcze w 35 . tygodniu pracy, przy czym rozpiętość wahań sięga około 10\% średniej ich wartości. Wykres ten wykazuje ponadto przyczynę nadmiernego wydłużania się okresu zaburzeń przejściowych w pracy badanej organizacji gospodarczej. Na wykresie (ryc. 2) widać przenikanie się krzywych wielkości $M M$ i $D S$, co-zgodnie z wytycznymi działania 2 i 3 - powoduje okresowe wstrzymanie przyjmowania 
zamówień na produkty finalne. Efekt ten jest równoważny rynkowym zmianom (wahaniom) wielkości zamówień na produkty finalne; wprowadza on dodatkowe zaburzenia w pracy organizacji gospodarczej. Te zaburzenia - wbrew pozorom - nie są wywołane, jak pokazują wyniki obliczeń (symulacji), przyczynami zewnętrznymi, pochodzącymi z rynku, lecz okolicznościami wewnętrznymi zależnymi głównie od wielkości zamówienia na produkty finalne $(Z F)$ i zapasu początkowego materiałów i półfabrykatów w magazynie $\left(M M_{0}\right)$ (Żukowski, Prusak 1999, Żukowski, Winnicki, Grabowiecka 2000).

\section{Podsumowanie}

Opisany wyżej model dynamiki systemu zarządzania organizacją gospodarczą został zweryfikowany przez porównanie uzyskanych wielkości modelowych z danymi rzeczywistymi pewnego zakładu meblarskiego. Wyniki symulacji na modelu pokazują, że przy skokowym wzroście zamówień na produkty finalne obserwuje się przejściowe zaburzenia w pracy zakładu, wyrażające się przede wszystkim zmianami wielkości produkcji i poziomu przepływu materiałów do produkcji. Te zaburzenia zanikają w różnym okresie, którego długość zależy od wielkości zamówienia na produkty finalne $(Z F)$ i zapasu początkowego materiałów i półfabrykatów w magazynie $\left(M M_{0}\right)$.

Model dynamiki systemu zarządzania organizacją ma znaczenie praktyczne, pozwala bowiem przewidzieć ewentualny okres (w tygodniach) zaburzenia w organizacji gospodarczej w przypadku przyjęcia nadesłanej wielkości zamówienia (oferty) na produkty finalne, przy znanej wielkości początkowej zapasów materiałów i półfabrykatów w magazynie.

\section{Literatura}

1. Ansoff H.I., 1995, Zarzqdzanie strategiczne, PWE, Warszawa

2. Badania operacyjne $w$ organizacji i zarzqdzaniu, 1985, W. Grudzewski (red.), PWE, Warszawa

3. Forrester J.W., 1961, Industrial dynamics, Massachusetts Institute of Technology Press, Cambridge

4. Grudzewski W.M., Hejduk I.K., 2002, Przedsiębiorstwo przyszłości-wizja strategiczna, Difin, Warszawa

5. Grudzewski W.M., Hejduk I.K., 2004, Metody projektowania systemów zarzq̨dzania, Difin, Warszawa

6. Penc J., 2006a, Encyklopedia zarzq̨dzania, Akademica, Łódź

7. Penc J., 2000, Kreatywne kierowanie, AW Placet, Warszawa

8. Penc J., 2006b, Podstawy nowoczesnego zarzqdzania, Akademica, Łódź

9. Rue L.W., Holland Ph.G., 1986, Strategic Management: Concepts and Experiences, McGraw-Hill Book Co., New York

10. Thompson A.A., Stricland A.J., 1992, Strategy Formulation and Implementation, Richard D. Irwin, Cambridge

11. Thompson A.A. jun., Strickland A.J., 1993, Strategic Management: Concepts and Cases, Richard D. Irwin, Boston

12. Wagner H.M., 1980, Badanie operacyjne, PWE, Warszawa

13. Żukowski P., Postrojenije i issliedowanije dinamiczieskoj modieli uprawlenija miebielnym priedprijatijem (sistiemnyj podchod), „Lesnoj Żurnał” 2/1990

14. Żukowski P., Prusak Z., 1999, Design and Analysis of the Dynamic Management Model of a Manufacturing Company [In:] The $15^{\text {th }}$ International Conference on Production Research: Manufacturing for a Global Market (Ed. M.T. Hillery \& H.J. Lewis), University of Limerick, Limerick (Ireland)

15. Żukowski P., Winnicki K., Grabowiecka R., 2000, The Management Model of an Agriculture Company. [In:] Проблемы упраления агропромылиленным комплексом России (Problemy zarzqdzania agroprzemysłowym kompleksem Rosji), m. III - Теория и практика упраления предприятиями АПК, Российская академия сельскохозяйственых наук, Всероссийский научно-исследовательский институт экономики сельского хозяйства, Санкт-Петербург

16. Żukowski P., 2006, Podstawy nauk o zarzadzaniu, Oficyna Wydawnicza Politechniki Rzeszowskiej, Rzeszów 


\section{Model of Dynamic and Simulation of the Management System in Business Organization}

This work describes dynamic model and simulation of a manufacturing company that manage operations, and analysis the reasons for changing processes inside the company in accordance with a change in the stream of incoming orders for finished products. Results of computer simulation of the designed model, show some dynamic characteristics within different divisions of the entire manufacturing company throughout duration of the production process. In the model of a production facility, different departments were taken into account. The departments are involved in activities related to flow of information, materials and prefabricated elements, production, products storage, and shipment. 


\section{Krzysztof Rejman}

Katolicki Uniwersytet Lubelski Jana Pawła II

Wydział Zamiejscowy Nauk o Społeczeństwie w Stalowej Woli

Państwowa Wyższa Szkoła Zawodowa

im. ks. Bronisława Markiewicza w Jarosławiu, Instytut Turystyki i Rekreacji

\section{Wpływ innowacyjności na efektywność współczesnych przedsiębiorstw}

Efektywność organizacji nie jest pojęciem jednoznacznym. Można znaleźć różne podejścia do jej istoty, sposobu wyrażania i mierzenia. W polskiej literaturze z zakresu teorii organizacji i zarządzania to pojęcie jest bardzo szeroko stosowanie. Niektórzy zastępująje terminem „sprawność” (Pszczołowski 1978). Zdaniem J. Zieleniewskiego (1972), na sprawność składają się skuteczność i korzyść, rozumiana także jako ekonomiczność (Zieleniewski 1972). T. Kotarbiński (1965), oprócz skuteczności i ekonomiczności, wymienia jeszcze: prostotę, udatność, czystość, energiczność, dokładność, pewność, niezawodność - jako cechy sprawności.

Niezwykle istotnym czynnikiem, który przyczynia się do wzrostu efektywności organizacji, jest innowacyjność. Termin ten, dotychczas bardzo rzadko stosowany, coraz częściej jest używany w literaturze przedmiotu nie tylko z zakresu zarządzania, ekonomii czy marketingu, ale także w codziennym słownictwie. Należałoby zatem przypomnieć jego znaczenie, aby głębiej zrozumieć rolę innowacyjności w procesie funkcjonowania przedsiębiorstwa. W bogatej literaturze zachodniej „,termin innowacja używany bywa w znaczeniu rzeczowym i czynnościowym” (Targalski 1999) i oznacza wprowadzenie czy też wdrożenie czegoś nowego, dotychczas niespotykanego, oraz zmodyfikowanie już istniejącego zjawiska, jakim może być produkt lub technologia (Penc 1995).Zakres tego pojęcia jest bardzo szeroki. Zdaniem H.G. Barutta, innowacja to wszelka nowa myśl, ponieważ jest ona inna od dotychczas istniejących (Targalski 1999). „Innowacja, jako synonim zmian techniki, stanowi od zarania dziejów nauki obiekt jej badań" (Kasprzyk 1980). Jest to nowy, szerszy kierunek wiedzy, który w ostatnich latach stanowi niewątpliwie przedmiot poważnego zainteresowania naukoznawstwa jako zespołu nauk o nauce. P. Drucker innowację definiuje jako szczególne narzędzie przedsiębiorców, za pomocą którego mają oni okazję do podjęcia nowej, dotychczas nieznanej działalności gospodarczej lub do świadczenia nowych usług. Jego zdaniem jest to raczej pojęcie ekonomiczne lub społeczne niż techniczne. U podstaw tezy mówiącej, że nauka stanowi obecnie główną siłę napędową rozwoju społeczno-gospodarczego działająca przez przekształcenie osiagnięć naukowych w innowacje, a następnie realizację założonych celów społeczno-gospodarczych w drodze praktycznego rozwoju, leży właśnie innowacja.

Pobudzanie ducha innowacyjności i kreatywności wymaga stworzenia odpowiedniej atmosfery i - jak twierdzą Meyer i Purser - wiąże się ze zrozumieniem potrzeb i problemów nabywców, czyli klientów (Koźmiński, Piotrowski 1998). W znacznie węższym ujęciu C. Freemana, o innowacji możemy mówić dopiero po pierwszym handlowym wprowadzeniu (zastosowaniu) nowego produktu, procesu, systemu lub urządzenia. Niedociągnięciem tej teorii jest jednak to, że nie precyzuje ona skali, w jakiej powinno nastąpić to pierwsze handlowe wprowadzenie (Koźmiński, Piotrowski 1998). 


\section{Znaczenie innowacyjności w podnoszeniu efektywności organizacji}

Lata 80. XX w. bardzo ożywiły gospodarkę, zwłaszcza w krajach rozwiniętych, gdyż był to okres powstawania i wdrażania wielu innowacji. Miało to konsekwencje także w postaci zmniejszenia bezrobocia i rozwoju nowych, nieznanych wcześniej firm. W tym okresie w zakresie innowacyjności technologicznej szczególnie intensywnie rozwijały się przedsiębiorstwa małe i średnie. Nowość, która miała mniejszy zasięg, szybciej się adaptowała, zwłaszcza w nowym otoczeniu. Współcześnie nowym i bardzo dobrym rynkiem rozwoju innowacji są państwa, które wstąpiły do UE, przyjęły wypracowane w niej standardy i uczestniczą w jednolitym rynku europejskim. Do tych państw zalicza się Polskę. Rynek ten jest bardzo chłonny w dziedzinie nowości rynkowych i łatwo przyswaja sobie to, czego jeszcze nie zna.

Innowacja jest bardzo ważnym czynnikiem stymulującym rozwój przedsiębiorstwa. Ciągłe wdrażanie nowości pozwala współczesnej organizacji szybko się rozwijać. Zdarza się, że przedsiębiorstwa wprowadzające innowacje unikają niebezpieczeństw wynikających z działań konkurencji i potrafią wykorzystać pojawiające się szanse rynkowe w taki sposób, który gwarantuje uzyskanie przewagi konkurencyjnej.

Analitycy twierdzą, że to właśnie innowacja jest źródłem przedsiębiorczości. „Aby być innowacyjnym, przedsiębiorca musi także współpracować z otoczeniem” (Ansoff 1985). Współczesne otoczenie biznesu podlega ciągłym, intensywnym zmianom, dlatego należy je stale badać i analizować. Przedsiębiorstwo, aby nadążyć za zmianami w otoczeniu, musi wprowadzać innowacje. Zwłaszcza duże organizacje mają szanse wykorzystać te zmiany w otoczeniu, gdyż to właśnie one posiadają środki finansowe niezbędne do realizacji planów innowacyjnych. Natomiast małym przedsiębiorstwom, które nie posiadają dużych zasobów finansowych, łatwiej jest wyszukiwać wśród własnej kadry pracowniczej innowatorów, bo ich zaplecze pracownicze jest o wiele węższe. Otoczenie jest często bodźcem, który pozwala przedsiębiorstwu odnaleźć drogę do zwiększenia atrakcyjności i skuteczności. Ponadto częste wdrażanie nowości zwiększa możliwość zatrudniania nowych pracowników, co zmniejsza bezrobocie.

Innowacja jest coraz ważniejszym przedmiotem badań wielu naukowców nie tylko z zakresu zarządzania. Proces zarządzania innowacjami jest, ,zjawiskiem powstawania, dojrzewania i upowszechniania tych idei technicznych, praktycznemu zastosowaniu których towarzyszą określone skutki ekonomiczno-społeczne. W procesach nowatorstwa duże znaczenie odgrywa również czas tzw. cykl życia innowacji, który trwa od rozpoczęcia prac badawczych do chwili realizowania nowości” (Bogdaniecki 1998). Nowatorstwo pozwala na osiągnięcie przewagi konkurencyjnej, która zapewnia komfort działania, bezpieczny rozwój firmy i jest źródłem sukcesu rynkowego.

Z punktu widzenia skuteczności zarządzania innowacjami najważniejsza jest kontrola nad procesem powstawania i wprowadzania pomysłów, gdyż nie wszystkie są trafne i twórcze. Dużą rolę odgrywają różnego rodzaju alianse, czyli stowarzyszenia, związki i powiązania (Machaczka 1998).

Innowacyjność odgrywa bardzo ważną rolę, ponieważ pozwala przedsiębiorstwu zdobyć pozycję rynkową oraz doświadczenia, które wpłyną korzystnie na jego rozwój. Należy podkreślić, że współczesne przedsiębiorstwo swoje funkcjonowanie oraz sukces opiera na nowościach.

$\mathrm{Z}$ marketingowego punktu widzenia proces innowacyjności w przedsiębiorstwie jest jednym z najważniejszych czynników rozwoju i podnoszenia konkurencyjności jego produktów. Wpływa on nie tylko na jakość wyrobów, ale również na estetykę i elegancję wykończenia stanowisk pracy. Innowacyjne przedsiębiorstwa przyciągają do siebie inwestorów krajowych i zagranicznych, a to z kolei poprawia ich konkurencyjność na rynku.

W dobie zaawansowanych technologii konkurencyjność odgrywa znaczącą rolę w funkcjonowaniu przedsiębiorstwa. Konkurencja jest punktem wyjścia i jedną z podstawowych przesłanek umiędzynarodowionego zarządzania (Koźmiński 1999). „Konkurencja stanowi podstawowy 
mechanizm napędowy gospodarki rynkowej” (Ciupa 1997), a w wąskim znaczeniu sprowadza się do zdobywania przewagi nad innymi. Konkurencyjność można traktować jako gotowość do podjęcia określonych działań z myślą o przyszłości. Oznacza to, że firma zdobywa szansę na osiągnięcie przewagi w przyszłym współzawodnictwie firm.

\section{Bariery na drodze wprowadzania innowacji w organizacjach}

Współczesne społeczeństwo boi się zmian, ale po ich wdrożeniu nowości szybko zostają wchłonięte. W ostatnich latach rozwój technologii informacyjnej i szybki przepływ informacji pozwolił wielu przedsiębiorstwom zapobiec powstawaniu różnych barier we wdrażaniu innowacji. Nowoczesne rozwiązania telekomunikacyjne opierają się na zaawansowanych technikach gromadzenia, przetwarzania i przesyłania danych, dlatego też rozwój telefonii, sieci internetowej i różnego typu sieci telekomunikacyjnych ułatwia przewidywanie zmian w otoczeniu i sprzyja minimalizacji ryzyka działalności gospodarczej. Bardzo popularne, zwłaszcza w produkcji i wymianie informacji, są komputery sterujące praca, tzw. serwery. To właśnie one ułatwiły modernizację przepływu informacji i przyspieszyły realizację założonego celu w zakresie wprowadzania innowacji. Wymaga to oczywiście zakupu odpowiedniego sprzętu komputerowego. Rozwiązaniem bardzo przydatnym do przepływu informacji może być internet. Dzięki niemu możliwa jest współpraca przedsiębiorstw. Skuteczność i sprawność finansowa organizacji oraz jakość produktów w coraz większym stopniu będzie zależeć od stosowania nowoczesnych technologii informacyjnych, w tym internetu.

Innowacyjność, chociaż jest zjawiskiem korzystnym dla przedsiębiorstwa, napotyka na różnego rodzaju bariery. Często tkwią one w mentalności pracowników, ze względu na specyficzne przyzwyczajenie załóg do dotychczas stosowanych metod działania, które utrudnia wdrażanie nowości. Ponadto wszelka zmiana technologiczna jest kojarzona ze zwolnieniami. Wprowadzenie innowacji do przedsiębiorstwa jest więc trudnym zadaniem, które wymaga pokonania wielu przyzwyczajeń załogi. Czynnik ludzki odgrywa zatem znaczącą rolę we wprowadzaniu innowacji. Bariery w ich wdrażaniu wynikają także z funkcjonowania w ramach przestarzałych struktur organizacyjnych i ze stereotypów myślenia (bariera biurokratyczna). Podstawą zarządzania efektywnością pracy jest stworzenie takiego procesu zarządzania, który wspierałby realizację strategii ekonomicznej organizacji przez integrację dążeń jednostek i przedsiębiorstwa. Skuteczny system zarządzania powinien rozwijać w pracownikach poczucie wartości celu, który należy osiagnaćc. System ten powinien skutecznie poprawiać jakość pracy całej organizacji i odpowiednio wynagradzać pracującą w niej kadrę. Obowiązkiem współczesnej organizacji jest tworzenie pracownikom możliwości rozwoju. Rozwój ten gwarantuje nie tylko osobiste zadowolenie pracowników, ale także właściwe spełnienie wymagań przedsiębiorstwa. Wprowadzanie innowacji powinno zawsze uwzględniać aspekt personalny, ponieważ tylko takie podejście gwarantuje właściwy rozwój organizacji.

Dodatkowymi barierami we wdrażaniu innowacji są: brak odpowiednich środków finansowych (bariera ekonomiczna) oraz - czasem - nieprzewidywalne zachowania pracowników (bariera psychologiczna). Ta ostatnia utrudnia tworzenie i wprowadzanie innowacji oraz osłabia efekt planowanych przedsięwzięć w przedsiębiorstwie. Chociaż w przedsiębiorstwie stale wdrażane są zmiany i innowacje technologiczne, to poziom ich dofinansowania nie zmienia się. Warunkiem budowania innowacyjności przedsiębiorstw jest wzrost nakładów na działalność badawczo-rozwojową. Realizacja tych działań mogłaby angażować środki budżetowe, regionalne, prywatne oraz pomocnicze, głównie z funduszy Unii Europejskiej. Wydaje się, że przedsiębiorstwa powinny otrzymywać dotacje bądź preferencje w trakcie udziału w programach związanych z wdrażaniem innowacyjnych projektów, gdyż przyczynia się to do wzrostu innowacyjności 
i podnoszenia konkurencyjności całej gospodarki. Pomoc tego typu nie powinna być umarzana. Przedsiębiorstwo powinno być zwolnione z oprocentowania, jeśli innowacja zakończyła się niepowodzeniem. Jest to tzw. projekt eliminacji połowy ryzyka. Takie działania pozwoliłyby organizacji prężnie się rozwijać i zdobywać przewagę konkurencyjna.

Głównym czynnikiem utrudniającym innowacyjność przedsiębiorstwa są więc trudności w pozyskiwaniu środków na sfinansowanie procesu wdrażania innowacji i prowadzenia kosztownych prac badawczo-rozwojowych. Badania te rzadko są finansowane kredytem bankowym, gdyż banki z reguły udzielają kredytu na ten cel na warunkach rynkowych. Koszt takiego kredytu jest zbyt wysoki. Dlatego dla przedsiębiorstw często zysk jest jedynym źródłem finansowania nowych inwestycji. Pomoc finansowa w zakresie wdrażania innowacji to nie tylko dotacje gotówkowe, ale również zwolnienia podatkowe i tzw. wakacje podatkowe. W celu zwiększania innowacyjności przedsiębiorstw i - w konsekwencji - całej gospodarki wydaje się konieczne wprowadzenie specjalnych grantów na innowacje, które spełniałyby funkcję quasi-dotacji.

W rozwijaniu innowacyjności gospodarki i poszczególnych przedsiębiorstw dużą rolę odgrywa nowoczesny system edukacyjny, który powinien sprzyjać wdrażaniu innowacji. Należy więc skupić się na nowych możliwościach nauczania. Rozwiązaniem mogłoby być umożliwienie uzdolnionej młodzieży wyprzedzania toku nauczania przez ,przeskakiwanie” klas (w szkołach średnich i wyższych). Powinny powstać nowe ścieżki nauczania. Studentom szkół wyższych należy umożliwić indywidualizację toku nauczania, aby można było wykorzystać ich potencjał innowacyjny. Przedsiębiorstwa, przez współpracę ze studentami, mogłyby wówczas korzystać z innowacyjnej wiedzy. Bardzo ważne dla rozwoju przedsiębiorstwa jest więc wspieranie praktyk studenckich.

Istotne są również ulgi podatkowe na naukę. Skromne środki przeznaczone na szkolnictwo wyższe oznaczają także ograniczenie wzrostu liczby studentów w uczelniach publicznych. Tę lukę częściowo wypełnia szkolnictwo niepubliczne, pojawia się jednak problem odpłatności za studia.

Barierą w podnoszeniu poziomu innowacyjności przedsiębiorstw jest również to, że małe i średnie firmy nie stać na to, aby ich pracownicy uczestniczyli w płatnych kursach i różnego typu szkoleniach, mających na celu zwiększanie kompetencji.

Konieczne staje się opracowanie i wdrożenie specjalnych programów proinnowacyjnych, które nie będą narzucać konkretnych rozwiązań i działań, lecz pozostawią przedsiębiorstwom dużą swobodę. Takimi pożądanymi działaniami są: wsparcie finansowe i gwarancje, programy i projekty badawcze, promocje i informacje, różnego typu kursy i szkolenia, doradztwo prawne oraz konsultacje z zastosowaniem internetu.

\section{Literatura}

1. Ansoff H.J., 1985, Zarzadzanie strategiczne, PWE, Warszawa

2. Bogdaniecki J., 1998, Zarzadzanie innowacjami, SGH, Warszawa

3. Ciupa S.W., 1997, Umowa o zakazie konkurencji w prawie pracy, C.H. Beck, Warszawa

4. Kasprzyk S., 1980, Innowacje od koncepcji do produkcji, CRZZ, Warszawa

5. Kotarbiński T., 1965, Traktat o dobrej robocie, Ossolineum, Wrocław

6. Kotler P., 1999, Marketing. Analiza. Planowanie. Wdrażanie i kontrola, Wyd. Felberg SJA, Warszawa

7. Koźmiński A.K., Piotrowski W., 1998, Zarzqdzanie - teoria i praktyka, Wydawnictwo Naukowe PWN, Warszawa

8. Koźmiński A.K., 1999, Zarzqdzanie - teoria i praktyka, Wydawnictwo Naukowe PWN, Warszawa

9. Machaczka J., 1998, Zarządzanie rozwojem organizacji, Wydawnictwo Naukowe PWN, Warszawa-Kraków

10. Okoń-Hordyńska E., 1998, Narodowy system innowacji w Polsce, AE, Katowice

11. Penc J., 1995, Strategia zarzadzania, Placet, Warszawa 
12. Poznański K., 1979, Innowacje w gospodarce kapitalistycznej, PWN, Warszawa

13. Pszczołowski T., 1978, Mała encyklopedia prakseologii i teorii organizacji, Ossolineum, Wrocław 14. Stawiasz E., 1999, Innowacje a mała firma, Wydawnictwo Uniwersyteckie, Łódź

15. Stoner J. A. F., 1998, Kierowanie, PWE, Warszawa

16. Targalski J., 1999, Przedsiębiorczość i rozwój firm, AE, Kraków

17. Zieleniewski J., 1972, Organizacja i zarzqdzanie. PWN, Warszawa

\section{An Impact of an Entrepreneurship on a Performance of Modern Companies}

The term of innovation is a supplement to such fields as economics, psychology and marketing. There is a conviction among scientists that "structuralized innovation is institutionalization and sanctioning in the organizing structure which is constantly tending to offer purchasers new and better products". It is also thought that innovation is a creation of a new and valuable phenomenon on the assumption a certain level of personal financial and social risk, but also with an assumption financial compensation or satisfaction. The main problem with introducing research in an enterprise is an existing gap between the stage of research and using commercial projects. This gap should be filled and this is the task of the firms that specialize in supporting the development. In our times innovation is an indispensable element of the activity of all enterprises in the area of competitiveness. A lot of academic publications have been adressed to this issue, the present article is a reference to the discussion on this problem. 


\author{
Jacek Strojny \\ Wyższa Szkoła Informatyki i Zarządzania w Rzeszowie \\ Politechnika Rzeszowska \\ Magdalena Berezowska \\ Wyższa Szkoła Informatyki i Zarządzania w Rzeszowie
}

\title{
Przedsiębiorczość jako determinanta konkurencyjności organizacji zorientowanej projektowo
}

\section{Zmiana i wynikająca z niej niepewność jako determinanty rozwoju}

Wśród określeń najpełniej charakteryzujących świat, w którym funkcjonują współczesne organizacje, najważniejszym jest zmiana. Nie ulega wątpliwości, że jest ona czymś powszechnym, wszechobecnym, czymś, czego organizacje nie mogą uniknąć.

Szukając odpowiedzi na pytanie, czym jest zmiana, warto sięgnąc po propozycje, których liczne przykłady można znaleźć w literaturze przedmiotu. Z. Mikołajczyk i K. Zieniewicz pod pojęciem zmiany rozumieją proces ,,przeobrażeń, zmieniających istotę rzeczy lub zjawisk”. Można zatem powiedzieć, że jeśli w jakimś „systemie czy układzie społecznym powstają nowe elementy składowe lub znikają elementy dotychczas występujące, lub jeżeli powstają nowe stosunki między tymi elementami czy znikają stosunki dotychczas istniejące, mówimy, że system ten ulega zmianie"(Karwińska, Mikułowki-Pomorski, Pacholski 2002).

Biorąc pod uwagę natężenie zmian, można wyróżnić trzy podstawowe stany otoczenia: 1. stabilizacja; 2. zmienność; 3. burzliwość (Stoner, Wankel 1996). Pierwszy z wymienionych w klasyfikacji stanów - otoczenie stabilne - charakteryzuje się niewielkim natężeniem zmian nagłych i nieoczekiwanych. Pozwala to na planowanie rozwoju firmy w długim horyzoncie czasowym. W takiej sytuacji również na poziomie organizacji obserwuje się stagnację i rozwój ewolucyjny. Znacznie większe wymagania stawia otoczenie zmienne, w którym skala zmian jest duża. Jednocześnie są one efektem trwałych tendencji, co daje możliwość przewidywania kierunku zmian. Oczywiście firmy muszą wdrażać programy zmian wewnątrzorganizacyjnych. Jednak prawidłowo zbudowany system monitoringu otoczenia pozwala ograniczyć ryzyko błędów. Najwięcej wyzwań dla zarządzających organizacją stwarza otoczenie burzliwe. Zmiany mają w nim dużą skalę, w dodatku pojawiają się bez wyraźnych tendencji. Często mają one charakter rewolucyjny, wynikający z innowacyjności wyrobu lub procesu. W takiej sytuacji organizacja musi jednocześnie przedsięwziąć dwa typy działań. Po pierwsze, należy usprawnić proces monitorowania otoczenia. Po drugie, konieczne jest wykazanie elastyczności proaktywnej, czyli wyprzedzanie zmian, a nawet ich kreowanie. Te dwa atrybuty organizacji mogą decydować o zdolności przedsiębiorstwa do zbudowania przewagi konkurencyjnej. Pozwalają one kierującym na niwelowanie niepewności decyzyjnej wynikającej ze zmienności otoczenia.

${ }^{1}$ Z. Mikołajczyk, K. Zieniewicz, 1999, Zarzadzanie małym przedsiębiorstwem [w:] Ekonomika i zarzadzanie mata firma, B. Piasecki (red.), Wydawnictwo Naukowe PWN, Warszawa [za:] J. Majchrzak, 2002, Zarzadzanie zmianami w przedsiębiorstwie, Wyd. AE w Poznaniu, Poznań. 
Ryc. 1. Rodzaje otoczenia firmy

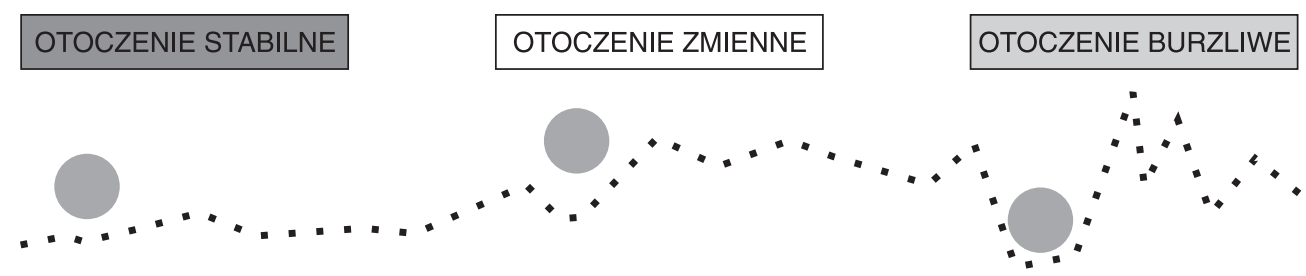

Źródło: opracowanie autorów na podstawie: Stoner, Wankel 1996

Sam stopień zmienności nie wystarcza jednak, aby skutecznie opisać zewnętrzne warunki funkcjonowania organizacji. Zmienność mówi bowiem tylko o tym, w jakim stopniu otoczenie jest stabilne, a w jakim burzliwe. Ważny jest także stopień jednorodności. Chodzi o zidentyfikowanie czynników (elementów) kształtujących sytuację w otoczeniu. Jednorodność wskazuje zatem, czy otoczenie jest proste, czy złożone. Dopiero oba te wymiary łącznie pozwalają określić poziom niepewności wynikający z sytuacji w otoczeniu. Właśnie ta niepewność jest zjawiskiem determinującym funkcjonowanie organizacji i wymuszającym na nich stosowanie rozwiązań zwiększających elastyczność (np. zarządzania projektowego).

Ryc. 2. Zmienność i jednorodność jako atrybuty otoczenia firmy

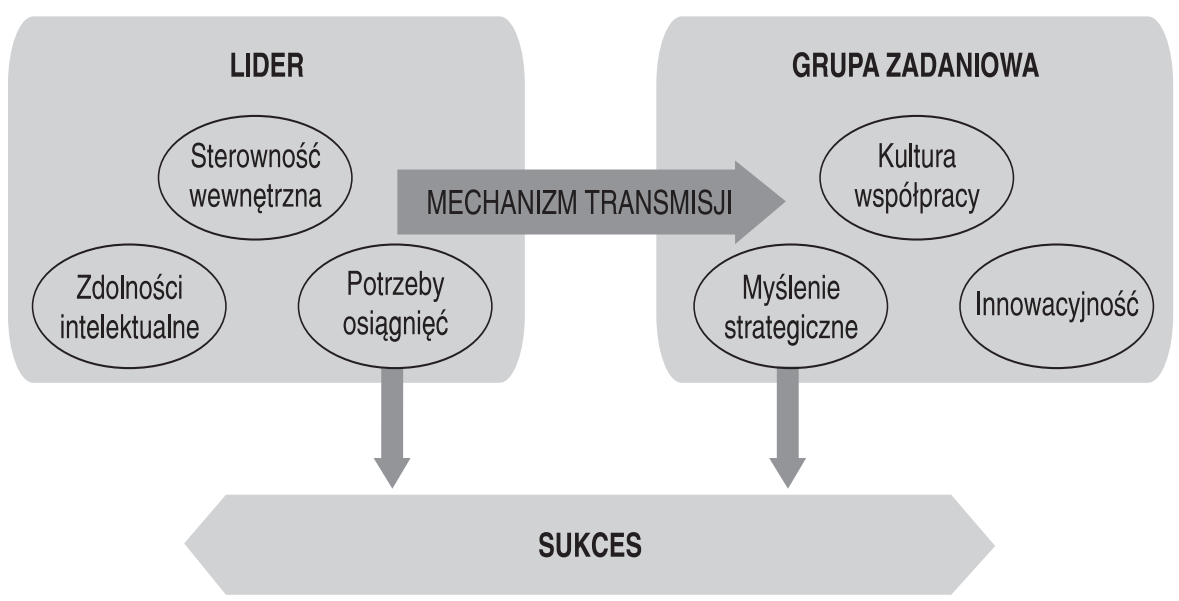

Źródło: opracowanie autorów na podstawie: J.D. Thompson, 1967, Organizations in Action, McGraw-Hill, New York [za:] R.W. Griffin, 1999, Podstawy zarządzania organizacjami, Wydawnictwo Naukowe PWN, Warszawa

Przyczyn zmienności i niepewności otoczenia jest wiele. R.B. Kuc (2004) próbuje je wymienić, wskazując na cztery podstawowe źródła zmian: 1. globalizacja i internalizacja konkurencji; 2 . deregulacja procesów i zmniejszenie barier ekspansji; 3. dojrzewanie rynków; 4. przyspieszenie postępu naukowego (techniki i technologii). Można stwierdzić, że przyczyną omawianych tendencji jest globalizacja. Zjawisko to jest przedmiotem zainteresowania wielu dyscyplin naukowych. Na potrzeby niniejszego artykułu wystarczy stwierdzić, że jest to zjawisko złożone i wielowymiarowe, tzn. ujawnia się w wielu obszarach życia społeczno-gospodarczego, szczególnie 
w technice i technologii, kulturze oraz gospodarce. ,W dziedzinach związanych z gospodarką do jej cech zaliczano integrowanie, scalanie i wzajemne przenikanie prowadzonej w skali międzynarodowej działalności na różnych poziomach: produkcji, dystrybucji i handlu, co w rezultacie niosło wzrost międzynarodowej współzależności systemu gospodarczego" (Nowakowski, Wajszczuk 2003).

\section{Przedsiębiorczość jako atrybut organizacji konkurencyjnej}

Zmienność, niepewność, globalizacja - te terminy są wymieniane przez wielu autorów przy okazji rozważań na temat zarządzania współczesnym przedsiębiorstwem. Jest to zrozumiałe, ponieważ za tymi terminami kryją się determinanty, które stwarzają nowe wyzwania.

Warunki, w jakich przychodzi się rozwijać współczesnym przedsiębiorstwom, powodują konieczność zmiany sposobów konkurowania, a co za tym idzie - także zmiany strategii organizacji (Kasiewicz 1999). J. Machaczka (2004) dostrzega ten problem, podkreślając, że tylko dzięki innowacyjności, jakości, elastyczności i dynamice firmy mogą przetrwać i się rozwijać. Inny autor J. Penc (2001) - mówi o coraz większym nacisku na innowacyjność, elastyczność, efektywność i szybkość wprowadzania nowych rozwiązań. S. Kasiewicz (1999) stwierdza, że w zglobalizowanej gospodarce konkurencyjność organizacji wymaga budowania proaktywnej reakcji przedsiębiorstwa na zmiany w otoczeniu.

Wszyscy wymienieni autorzy są zgodni w kwestii konieczności wdrażania nowego modelu konkurowania. Model ten powinien zwiększać elastyczność organizacji. „Elastyczność rozumiana także jako zwinność, mobilność stanowi powszechnie akceptowaną cnotę i pożądaną cechę współczesnego przedsiębiorstwa w warunkach konkurencji globalnej (...)" (Osbert-Pociecha 2004). Ta cecha jest zatem miarą pozwalającą na określenie stopnia adaptacyjności organizacji (Holstein-Beck 1997).

Dzięki elastyczności jest zatem możliwe skuteczne przeprowadzanie zmian organizacyjnych. Zjawisko to obejmuje szereg procesów dostosowujących organizację do wymagań stawianych przez otoczenie [Szplit (red.) 1996]. Istotą tych procesów jest zastąpienie stanu istniejącego stanem odmiennym, ale jednocześnie podnoszącym przedsiębiorstwo na wyższy poziom rozwoju (Kurek 2001). Wynika stąd postulat, że te zmiany, które są projektowane i realizowane w ramach współczesnych organizacji, powinny mieć charakter innowacyjny i tworzyć nową jakość funkcjonowania (Penc 2005).

Wprowadzenie do rozważań pojęcia ,innowacje” daje podstawę do wysunięcia tezy, że podstawowym atrybutem organizacji konkurencyjnej jest przedsiębiorczość. Jak słusznie stwierdza W. Janik (2003), zjawiska innowacji i przedsiębiorczości są ze sobą nierozerwalnie związane. O znaczeniu i sukcesie przedsiębiorczości ,,przesądza (zatem) tworzenie innowacji oraz doskonalenie wyrobów i ich rynkowe wykorzystanie, czyli dobry interaktywny marketing i nowe lub udoskonalone wyroby wprowadzane po to, by lepiej zaspokoić potrzeby klientów i pokonać konkurencję przewagą wartości” (Stopczyńska, Karkowski 2003).

Czymże zatem jest ta przedsiębiorczość? Odpowiedź nie jest łatwa. Mimo że uczeni są zgodni co do roli przedsiębiorczości w życiu społeczno-gospodarczym, różnią się w rozumieniu tego pojęcia. Widoczne jest to szczególnie wówczas, gdy bierze się pod uwagę wielość jego definicji. Przedsiębiorczość nie jest bowiem zjawiskiem jednolitym. W. Janasz (2004) określa ją nawet jako kategorię wielowymiarową, wyjaśnianą za pomocą różnych zmiennych. Jej wyjaśnianie wymaga zatem również podejścia interdyscyplinarnego.

Dzięki temu możliwe jest zrozumienie zjawiska przedsiębiorczości z punktu widzenia różnych dziedzin nauki: 1. psychologii; 2. socjologii; 3. ekonomii; 4. organizacji i zarządzania. Tworzą się w ten sposób cztery wymiary przedsiębiorczości, przedstawione na ryc. 3 . 
Ryc. 3. Przedsiębiorczość jako zjawisko wielowymiarowe

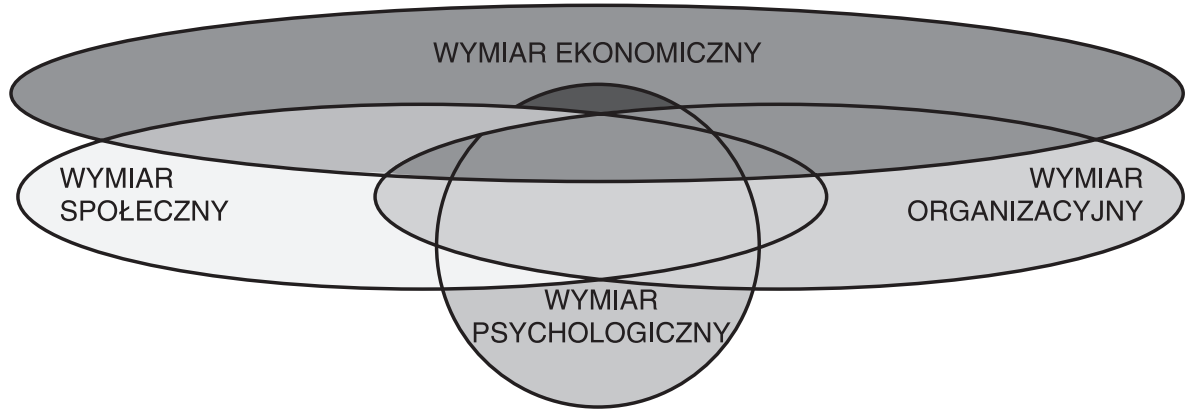

Źródło: opracowanie autorów

W ujęciu psychologicznym przedsiębiorczość może być rozumiana ,jako cecha określonych osób, które są skłonne i zdolne inicjować oraz realizować nowe, odważne działania" (Zaleśkiewicz 2004). A. Francik (1994) wyraża się podobnie, określając przedsiębiorczość jako swego rodzaju cechę danej osoby albo sposób, w jaki ona się zachowuje. „W tym nurcie mieści się określenie przedsiębiorczości, przyjmujące, że jest to cecha osobowości charakteryzująca postawy i zachowania ludzkie, polegająca na zdolności i chęci ponoszenia ryzyka, skłonności do zachowań innowacyjnych oraz podejmowania działań w celu wykorzystania nadarzających się szans i okazji”" (Kożuch 2001). M. Bratnicki (2002) dodaje, że przedsiębiorcze nastawienie umysłu pozwala na tworzenie wartości, na uzyskanie korzyści z niepewności (nieokreśloności).

T. Listwan (2004) stwierdza, że ludzka, indywidualna przedsiębiorczość znajduje odzwierciedlenie w takich działaniach, jak inicjowanie projektów gospodarczych, kreatywne rozwiązywanie problemów, podejmowanie ryzyka, wykorzystywanie okazji czy elastyczne dostosowywanie organizacji do warunków otoczenia. W podobnym duchu przedsiębiorczość rozumie T. Kraśnicka (2002), nazywając ją działaniem menedżerskim i wykonawczym, polegającym na wykorzystywaniu okazji i ponoszeniu ryzyka, które w efekcie przynosi korzyści. To podkreślanie wartości dodanej czy efektywności uzyskiwanej dzięki działalności przedsiębiorczej jest charakterystyczne dla ujęcia ekonomicznego.

Już w tych definicjach podkreśla się, że przedsiębiorczość może być nie tylko cechą człowieka, ale także cechą organizacji [Lichtarski (red.) 1999]. Aby jednak tak było, aby skutecznie wykorzystywać szanse i wprowadzać innowacyjne zmiany, wymagane jest zarządcze podejście do przedsiębiorczości. Jak zauważa J.D. Antoszkiewicz (2002), można zatem mówić o przedsiębiorczym zarządzaniu, które ujawnia się odpowiednią polityką w następujących obszarach: 1. klimat przedsiębiorczy; 2. kultura organizacji; 3. wspomaganie samokształcenia; 4. przeciwdziałanie barierom rozwoju. Takie rozumienie przedsiębiorczości wynika z podejścia organizacyjnego.

W rozumieniu społecznym, ,przedsiębiorczość to umiejętne i społecznie akceptowane, a przy tym ukierunkowane na rozwój, funkcjonowanie jednostek i grup ludzkich w ramach gospodarki rynkowej" (Kożuch 2001).

Niezależnie od wymiaru, który jest podstawą definiowania, bezdyskusyjne wydaje się to, że w każdym rozumieniu przedsiębiorczość traktowana jest jako podstawowy atrybut podnoszący konkurencyjność we współczesnym świecie. W związku z tym można zaproponować ogólną definicję, która niejako łączy wszystkie te podejścia. Przedsiębiorczość jest to zatem względnie trwała kompetencja osoby, grupy, organizacji lub systemu gospodarczego, która przejawia się dynamicznym reagowaniem na zjawiska pojawiające się w otoczeniu i przynosząca efekt w postaci przejścia na wyższy poziom rozwoju. 


\section{Budowanie przedsiębiorczości w organizacji projektowej}

Przedsiębiorczość jest zjawiskiem, które występuje w różnego rodzaju organizacjach, szczególnie w tych, które są zorientowane projektowo. Realizacja projektów w ramach specjalnie powołanych zespołów zadaniowych może bowiem być traktowana jako przejaw przedsiębiorczości. Na pewno powoływanie takich zespołów jest rozwiązaniem zwiększającym elastyczność i ułatwiającym wprowadzanie zmian organizacyjnych.

W ramach organizacji projektowych wyodrębniane są grupy zadaniowe. Można je traktować jako pewien szczególny typ grupy społecznej. W literaturze wskazuje się, że są one powoływane w celu realizacji określonego zadania (Robbins 1998). Oczywiście wspólny cel jest podstawą tworzenia się wszystkich grup społecznych (Domachowski 1998), jednak w przypadku grupy zawodowej ten cel wynika z przyjętych planów rozwojowych organizacji, w ramach której grupa jest formowana. W przypadku zaawansowanych rozwiązań organizacyjnych ludzie mogą tworzyć zespoły projektowe, które dysponują także zbiorem zasobów wyodrębnionych na potrzeby konkretnego projektu (Lock D. 2003).

Problematykę zarządzania przedsiębiorczego można rozpatrywać z punktu widzenia kilku różnych perspektyw. Nie ulega wątpliwości, że przedsiębiorczość, nawet jako atrybut organizacji, warunkowana jest przede wszystkim przez czynnik ludzki. Należy jednak zwrócić uwagę, że oprócz ogólnych problemów związanych z funkcjonowaniem człowieka w organizacji, dostrzegalna jest pewna specyfika organizacji projektowej. Można powiedzieć, że praca w ramach zespołów zadaniowych stawia człowiekowi większe wymagania niż praca w organizacjach zarządzanych tradycyjnie, z kilku powodów, m.in.: 1. projekty cechują się dużą złożonością i niepowtarzalnością; 2. pracownicy muszą mieć wysokie kwalifikacje wejściowe; 3 . wymaga się umiejętności pracy zespołowej (Trocki, Grucza, Ogonek 2003). Oczywiście należy zwrócić uwagę na to, że w ramach zespołów funkcjonują zwykle osoby o wiedzy specjalistycznej i wysokich kompetencjach, co stwarza dodatkowe wyzwania, szczególnie liderom zespołów. Wydaje się zatem słuszna teza, że istotnym zagadnieniem dotyczącym budowania przedsiębiorczości jest zapewnienie skutecznego przywództwa projektowego. Chodzi tutaj o dobór lidera, który powinien się charakteryzować określonymi cechami przedsiębiorczymi. Po drugie, należy się zastanowić nad cechami grupy, jakie powinny zostać zapewnione, aby można ją było nazwać przedsiębiorczą. Trzecim elementem jest budowanie procesu transmisji przedsiębiorczości lidera na poziom grupy.

Warto również zwrócić uwagę na to, że dzięki przedsiębiorczości jest możliwe zbudowanie układu proaktywnego. Oznacza to, że jednostki, grupy czy organizacje cechujące się przedsiębiorczością potrafią nie tylko dostosowywać się do zmian w otoczeniu, ale też wyprzedzać, a nawet kreować zmiany. A wszystko po to, aby osiagnąć sukces, czyli zrealizować przyjęte cele.

Projekt wymaga szczególnego rodzaju przywództwa. Niepowtarzalność celów powoduje wzrost niepewności, a zróżnicowany skład zespołu stwarza duże wymagania względem kultury organizacyjnej i klimatu pracy (Heerkens 2003). Można zatem zaryzykować stwierdzenie, że wymagania względem przedsiębiorczości lidera projektu są większe, niż w przypadku przywódców funkcjonujących w ramach organizacji tradycyjnych.

Proponuje się, aby cechy przedsiębiorcze lidera opisać w postaci trzech podstawowych wymiarów: 1. potrzeby osiagnięć; 2. sterowność wewnętrzna; 3. zdolności intelektualne (Strojny 2006). Zastanawiając się nad pierwszym z wymienionych kryteriów, należy stwierdzić, że potrzeby osiągnięć wskazują kierunek rozwoju indywidualnego lidera. Ich przejawem jest dążenie zarówno do osiągnięcia sukcesu, jak i do spełnienia się w pracy; są nimi także skłonności do poprawy statusu materialnego czy do wywierania wpływu. Aby skutecznie zarządzać zespołem projektowym, lider musi mieć wszystkie te cechy. Człowiek nimi obdarzony skłonny jest do 
podejmowania walki, do konkurowania z innymi, ale także do bycia lepszym. Jednak niemożliwe jest podejmowanie konkretnych działań w celu osiagnnięcia sukcesu osobistego, jeżeli potrzebom osiagnięć nie towarzyszy sterowność wewnętrzna. Obejmuje ona grupę cech, które powodują, że lider wierzy w siebie, jest niezależny i odpowiedzialny, optymistycznie patrzy w przyszłość, a dzięki temu jest otwarty na zmiany i innych ludzi. Sterowność wewnętrzna daje więc poczucie bezpieczeństwa i pogodę ducha. Podstawowym źródłem przewagi - instrumentem konkurowania przywódcy - są jego zdolności intelektualne. Ważne są także takie cechy, jak inteligencja, kreatywność czy różnego rodzaju uzdolnienia do wykonywania określonych czynności.

Czym powinna się charakteryzować przedsiębiorcza grupa zadaniowa? Zidentyfikowano trzy podstawowe grupy cech: 1. myślenie strategiczne; 2. kultura współpracy; 3. innowacyjność. Pierwszy wymieniony wymiar - myślenie strategiczne - ma pewną specyfikę w przypadku organizacji zorientowanej projektowo. Otóż, cele ustalane są na poziomie całej organizacji. Zadaniem zespołu zadaniowego (jego celem) jest natomiast realizacja konkretnego projektu. Sytuację komplikuje to, że cele poszczególnych członków zespołu mogą być ustalane na podstawie celów macierzystych jednostek organizacyjnych. Może zatem rodzić się konflikt pomiędzy poszczególnymi celami. Grupa zadaniowa, aby sprawnie funkcjonować, musi więc być świadoma ogólnej wizji strategicznej i - mając tę wizję na uwadze - podejmować działanie w ramach konkretnego projektu. Ważne są oczywiście także umiejętności bezpośrednio związane z realizacją projektu, takie jak umiejętność monitorowania i budowania zasobu wiedzy strategicznej. Należy zauważyć, że w przewodzeniu grupą zadaniową mniej istotne są działania powodujące rozwój organizacji. Zespół zadaniowy ze względu na ograniczony czas jego funkcjonowania bazuje na wypracowanym ogólnym potencjale rozwojowym. Jednocześnie lider nie jest zwolniony z obowiązku patrzenia na organizację jako całość, powinien więc angażować się i na podstawie zdobytych doświadczeń wskazywać pożądane kierunki rozwoju. Znacznie większe pole działania dla lidera projektu pojawia się w przypadku kształtowania kultury organizacyjnej. Niezbędne jest stworzenie przyjaznego klimatu współpracy, zapewnienie częstych interakcji i skutecznej komunikacji. Skuteczne przewodzenie zespołom zadaniowym wymaga zapewnienia wysokiego stopnia samodzielności, zwłaszcza że pracownicy mają wiedzę ekspercką. Kultura organizacyjna oparta na współpracy powinna obejmować także klienta, czyli odbiorcę projektu. Taka potrzeba jest szczególnie widoczna właśnie w przypadku zarządzania projektowego, gdzie związek grupy zadaniowej z klientem i współpraca z nim są bardzo ścisłe. Dzięki odpowiednio zbudowanej kulturze udaje się osiaggnąć spójność wewnętrzną i wytworzyć ducha zespołu. Daje to członkom zespołu poczucie bezpieczeństwa i zwiększa prawdopodobieństwo pojawienia się ostatniej grupy cech, określanej mianem innowacyjności. To właśnie dzięki innowacyjnemu podejściu do projektu możliwe jest osiąnnięcie sukcesu. Niepowtarzalność problemów stojących przed poszczególnymi zespołami projektowymi wymusza konieczność wzbudzania innowacyjności. Nie jest to oczywiście zadanie proste. Wymaga od pracowników odpowiedniego poziomu kompetencji, kreatywności. Niezbędne są też nowoczesne technologie, umiejętność przygotowania nowego produktu czy zastosowania nowego procesu.

Trzeci element, od którego zależy skuteczność wyzwalania przedsiębiorczości w ramach grupy zawodowej, dotyczy mechanizmu transmisji, tzn. przełożenia przedsiębiorczości lidera na przedsiębiorczość grupy. Aby przywództwo było skuteczne, lider projektu musi opierać swoją pozycję na określonych źródłach władzy. Organizacja musi zapewnić odpowiedni zakres uprawnień, które lider projektu może wykorzystać w swojej pracy. Legitymizacja formalna jednak nie wystarcza; ważny jest także umiejętny dobór stylu zarządzania (poziomu centralizacji władzy) oraz instrumentów motywacyjnych. 
Przedstawioną koncepcję kształtowania przedsiębiorczości w ramach organizacji zorientowanej projektowo ilustruje schemat.

Ryc. 4. Proces budowania przedsiębiorczości w organizacji zorientowanej projektowo

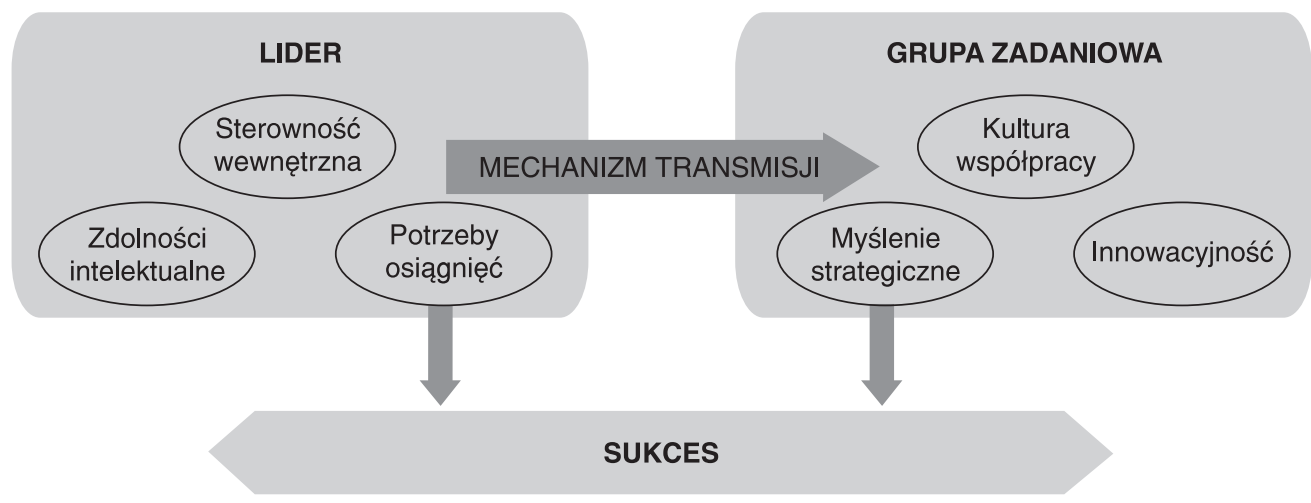

Źródło: opracowanie autorów

Warto spojrzeć na proponowany schemat jako na pewnego rodzaju układ proaktywny, w którym poszczególne cechy spełniają określone funkcje. Zarówno potrzeby osiągnięć na poziomie indywidualnym, jak i myślenie strategiczne na poziomie grupy zadaniowej wskazują kierunek działania. Pojedynczy człowiek będzie je skłonny podejmować, jeśli będzie wierzył w siebie (sterowność wewnętrzna), a grupa - jeśli będzie wewnętrznie spójna (jeśli wytworzy się kultura współpracy). Sukces będzie mógł zostać osiągnięty, jeśli jednostka ma odpowiednie zdolności intelektualne, które pozwolą jej zdobyć przewagę nad innymi. W przypadku grupy zadaniowej instrumentem, który pozwala zdobyć przewagę, jest innowacyjność.

\section{Literatura}

1. Antoszkiewicz J.D., 2002, Przedsiębiorczość w nowej roli [w:] Przedsiębiorczość i rozwój matych $i$ średnich przedsiębiorstw w XXI wieku, B. Piasecki (red.), Wydawnictwo UŁ, Łódź

2. Bratnicki M., 2002, Przedsiębiorczość i przedsiębiorcy współczesnych organizacji, Wydawnictwo AE w Katowicach, Katowice

3. Domachowski W., 1998, Przewodnik po psychologii spolecznej, Wydawnictwo Naukowe PWN, Warszawa

4. Francik A., 1994, Przedsiębiorczość a innowacje, „Zeszyty Naukowe” 444/1994, AE w Krakowie, Kraków

5. Griffin R.W., 1999, Podstawy zarzadzania organizacjami, Wydawnictwo Naukowe PWN, Warszawa

6. Heerkens G.R., 2003, Jak zarzadzać projektami, Wydawnictwo RM, Warszawa

7. Holstein-Beck M., 1997, Być albo nie być menedżerem, Infor, Warszawa

8. Innowacje w rozwoju przedsiębiorczości w procesie innowacji, 2004, W. Janasz (red.), Difin, Warszawa

9. Kapitał ludzki a kształtowanie przedsiębiorczości, 2004, M. Juchnowicz (red.), Poltext, Warszawa

10. Karwińska A., Mikułowki-Pomorski J., Pacholski M., 2002, Typy działań socjotechnicznych a funkcje organizacji, Wydawnictwo AE w Krakowie, Kraków

11. Kasiewicz S., 1999, Klasyfikacja wskaźników oceny zarzadzania współczesnym przedsiębiorstwem, „Organizacja i Kierowanie” 3/1999

12. Kożuch B., 2001, Pojęcie i istota przedsiębiorczości [w:] Praktyczne problemy przedsiębiorczości, H. Wnorowski, A. Letkiewicz (red.), Wydawnictwo Uniwersytetu w Białymstoku, Białystok

13. Kraśnicka T., 2002, Wokót pojęcia przedsiębiorczości, „Przegląd Organizacji” 6/2002 
14. Kuc B.R., 2004, Od zarzqdzania do przywództwa, Wydawnictwo Menedżerskie PTM, Warszawa

15. Kurek Z., 2001, Wprowadzenie do przedsiębiorczości, Olsztyńska Wyższa Szkoła Informatyki i Zarządzania im. prof. T. Kotarbińskiego, Olsztyn

16. Listwan T., 2004, Wplyw potencjatu kompetencyjnego menedżerów na jakość kapitalu ludzkiego [w:] Kapitał ludzki a kształtowanie przedsiębiorczości, M. Juchnowicz (red.), Poltext, Warszawa

17. Lock D., 2003, Podstawy zarzadzania projektami, PWE, Warszawa

18. Machaczka J., 2004, Zmiana organizacji jako zjawisko wielowymiarowe, „Przegląd Organizacji” 12/2004

19. Majchrzak J., 2002, Zarzadzanie zmianami w przedsiębiorstwie, Wydawnictwo AE w Poznaniu, Poznań

20. Nowakowski M.K., Wajszczuk J.J., 2003, Globalizacja i biznes. Powrót do źródet i wartości, „Organizacja i Kierowanie" 4/2003

21. Osbert-Pociecha G., 2004, Elastyczność organizacji - atrybut pożq̨dany a niezidentyfikowany, „Organizacja i Kierowanie" 2/2004

22. Penc J., 2005, Role i umiejętności menedżerskie, Difin, Warszawa

23. Penc J., 2001, Zarzqdzanie w nowej ekonomii, „Przegląd Organizacji” 11/2001

24. Podstawy nauki o przedsiębiorstwie, 1999, J. Lichtarski (red.), Wydawnictwo AE im. O. Langego we Wrocławiu, Wrocław

25. Praktyczne problemy przedsiębiorczości, 2001, H. Wnorowski, A. Letkiewicz (red.), Wydawnictwo Uniwersytetu w Białymstoku, Białystok

26. Przedsiębiorczość i rozwój małych i średnich przedsiębiorstw w XXI wieku, 2002, B. Piasecki (red.), Wydawnictwo Uniwersytetu Łódzkiego, Łódź

27. Przedsiębiorczość w Polsce w perspektywie z integracja Europejska, 2003, M. Trocki, K. Krajewski (red.), Instytut Przedsiębiorczości i Samorządności, Warszawa

28. Psychologia ekonomiczna, 2004, T. Tyszka (red.), GWP, Gdańsk

29. Robbins S.P., 1998, Zachowania w organizacji, PWE, Warszawa

30. Stoner J.A.F., Wankel Ch., 1996, Kierowanie, PWE, Warszawa

31. Stopczyńska K., Karkowski T., 2003, Wykorzystanie aplikacji CRM w kreowaniu pozycji konkurencyjnej przedsiębiorstwa na rynkach zjednoczonej Europy [w:] Przedsiębiorczość w Polsce w perspektywie z integracjq europejskq, M. Trocki, K. Krajewski (red.), Instytut Przedsiębiorczości i Samorządności, Warszawa

32. Strojny J., Wielowymiarowość zwiazku między przedsiębiorczościa jako cechq osobowości a działaniem małej i średniej firmy, maszynopis pracy doktorskiej, AE w Krakowie

33. Szplit A. (red.), 1996, Leksykon przedsiębiorcy, Wydawnictwo Politechniki Świętokrzyskiej, Kielce

34. Trocki M., Grucza B., Ogonek K., 2003, Zarzqdzanie projektami, PWE, Warszawa

35. Zaleśkiewicz T., 2004, Przedsiębiorczość i podejmowanie ryzyka [w:] Psychologia ekonomiczna, T. Tyszka (red.), GWP, Gdańsk

\section{Entrepreneurship as a Determinant of Competitiveness for a Project-oriented Organization}

Authors start from a theoretical debate about a change, and consequent uncertainty, as a determinant of a company growth and they recognize entrepreneurship as a fundamental attribute of a competitive organization. According to the authors entrepreneurship is strictly related to the innovation of the company. The creation of innovation as well as products development and reasonable use of them on the market, i.e. good interactive marketing and new or enhanced product launched to better fulfill customers' needs and beat the competitors by value advantage - all of these decide on importance and success of the company. In the second part the authors explain how to build entrepreneurship in the project-oriented organization. 


\author{
Wanda Klepacka \\ Ilona Pietucha \\ Wydział Inżynierii Produkcji \\ Politechnika Warszawska
}

\title{
Ustawa o niektórych formach wspierania działalności innowacyjnej - narzędziem aktywizacji gospodarczej
}

W dniu 29.07.2005 r. Sejm RP uchwalił Ustawę o niektórych formach wspierania działalności innowacyjnej (Dz.U. Nr 179, poz. 1484). Jej treść zmieniła niektóre zapisy ustaw: o podatku rolnym (z 15.11.1984 r.), o jednostkach badawczo-rozwojowych (z 25.07.1985 r.), o podatkach i opłatach lokalnych (z 12.01.1991 r.), o podatku dochodowym od osób fizycznych (z 26.07.1991 r.), o podatku dochodowym od osób prawnych (z 15.02.1992 r.), o Bankowym Funduszu Gwarancyjnym (z 14.12.1994 r.), o utworzeniu Polskiej Agencji Rozwoju Przedsiębiorczości (z 9.11.2000 r.), o finansowym wspieraniu inwestycji (z 20.03.2002 r.), o podatku leśnym (z 30.10.2002 r.), o podatku od towarów i usług (z 11.03.2004 r.) i o zasadach finansowania nauki (z 8.10.2004 r.). Ustawa o niektórych formach wspierania działalności innowacyjnej weszła w życie 20.10.2005 r.

Na stronie internetowej Ministerstwa Gospodarki można przeczytać: „Ustawa jest ukierunkowana na powstrzymanie nasilających się od szeregu już lat negatywnych zjawisk, takich jak: spadek udziału nakładów na działalność badawczo-rozwojową w PKB, niska innowacyjność przedsiębiorstw, brak zachęt dla przedsiębiorstw do ponoszenia zwiększonych wydatków na innowacje. Cel główny ustawy to wzrost konkurencyjności i innowacyjności gospodarki poprzez wzrost nakładów sektora prywatnego na badania i rozwój oraz poprawa efektywności gospodarowania środkami publicznymi przeznaczonymi na prace badawczo rozwojowe $(B+R)$.

Ten cel zostanie zrealizowany poprzez 4 cele cząstkowe, zdefiniowane jako:

- rozwój prywatnego sektora badawczo-rozwojowego,

- poprawa efektywności wdrażania polityki innowacyjnej na poziomie krajowym i regionalnym,

- wzrost efektywności wykorzystywania środków publicznych przeznaczonych na działalność innowacyjną,

- zwiększenie zainteresowania działalnością innowacyjną podmiotów sektora prywatnego wyrażone wzrostem nakładów przedsiębiorstw na działalność badawczo-rozwojową. ${ }^{1}$

Narzędziami realizacji powyższych celów będą:

- nowy instrument finansowy w postaci kredytu technologicznego,

- nadawanie przedsiębiorcom statusu centrów badawczo-rozwojowych,

- zmiany w prawie podatkowym,

- rozszerzenie zadań Polskiej Agencji Rozwoju Przedsiębiorczości”.2

\footnotetext{
${ }^{1}$ http://www.mgip.gov.pl

${ }^{2}$ Ibidem.
} 
Ustawa realizuje jedynie niektóre z tych celów. Już w przepisach ogólnych (rozdział pierwszy) ustawodawca zdefiniował następująco regulacje określone w niniejszym akcie prawnym:

,Art. 1.

Ustawa określa:

1) niektóre formy wspierania działalności innowacyjnej, w szczególności zasady i tryb udzielania kredytu technologicznego i umarzania części tego kredytu;

2) zasady nadawania statusu centrum badawczo-rozwojowego". 3

Na podstawie treści przytoczonego artykułu można przypuszczać, że narzędzia przewidziane przez ustawodawcę nie są w stanie sprostać realizacji celów cząstkowych, w szczególności 2 i 3.

\section{Kredyt technologiczny}

W rozdziale drugim ustawy zostały określone zasady tworzenia, przyznawania i umarzania kredytu technologicznego. Ponadto ustawa lokuje Fundusz Kredytu Technologicznego w Banku Gospodarstwa Krajowego:

,Art. 3.

1. Kredyt technologiczny jest udzielany przez Bank Gospodarstwa Krajowego ze środków Funduszu Kredytu Technologicznego, o którym mowa w art. 9.

2. Kredyt technologiczny nie może być udzielany na realizację:

1) dużej inwestycji lub

2) inwestycji w sektorze hutnictwa żelaza i stali, włókien syntetycznych, górnictwa węgla i rybołówstwa oraz na działalność związaną z produkcją, przetwarzaniem i wprowadzaniem do obrotu produktów, o których mowa w Załączniku nr 1 do Traktatu ustanawiającego Wspólnotę Europejską,. ${ }^{4}$ W punkcie czwartym art. 3 zastrzega się, że: „Kredytu technologicznego nie udziela się przedsiębiorcy będącemu w trudnej sytuacji ekonomicznej lub w okresie restrukturyzacji realizowanej z udziałem pomocy publicznej, chyba, że jest mikroprzedsiębiorcą lub małym przedsiębiorcą w rozumieniu rozporządzenia Komisji (WE) nr 70/ /2001/WE z dnia 12 stycznia 2001 r. w sprawie zastosowania art. 87 i 88 Traktatu WE w odniesieniu do pomocy państwa dla małych i średnich przedsiębiorstw (Dz.Urz. WE L 10 z 13.01.2001), zmienionego rozporządzeniem nr 364/2004/WE z dnia 25 lutego 2004 r. (Dz.Urz. WE L 63 z 28.02.2004), zwanego dalej ,rozporządzeniem nr 70/2001”. 5

Z zapisów wcześniejszych omawianej ustawy wynika, że ,przedsiębiorca w trudnej sytuacji ekonomicznej" to taki:

a) którego wielkość niepokrytej straty z lat ubiegłych łącznie z wynikiem finansowym roku bieżącego przewyższa 50\% wartości kapitału zakładowego i wielkość straty w ostatnim roku obrotowym przewyższa 25\% wartości kapitału zakładowego - w przypadku spółki kapitałowej,

b) którego wielkość straty przewyższa 50\% wartości majątku spółki, stanowiącego mienie wniesione jako wkład lub nabyte przez spółkę i wielkość straty w ostatnim roku obrotowym przewyższa 25\% wartości tego majątku - w przypadku spółki niebędącej spółką kapitałową,

c) który spełnia kryteria kwalifikujące do wszczęcia wobec niego postępowania upadłościowego. ${ }^{6}$

\footnotetext{
${ }^{3}$ Art. 1 Ustawy z dnia 29 lipca 2005 r. o niektórych formach wspierania działalności innowacyjnej, Dz.U. Nr 179, poz. 1484.

${ }^{4}$ Art. 3 p. 1, ibidem.

${ }^{5}$ Art. 3 p. 4 , ibidem.

${ }^{6}$ Art. 2 ust. 13, ibidem.
} 
Zapisy ustawy dotyczące kredytu technologicznego przewidują możliwość umorzenia do 50\% wartości kredytu, z zastrzeżeniem, że wysokość kapitału kredytu technologicznego nie może przekroczyć kwoty 2 mln euro, a całkowita kwota umorzenia nie może przekroczyć 1 mln euro. Ustawa przewiduje również, że wysokość raty kredytu będzie wynosić $20 \%$ netto wartości wykazanej na fakturach sprzedaży innowacyjnych towarów lub usług powstałych w wyniku inwestycji.

\section{Centrum badawczo-rozwojowe}

Jak czytamy na stronie Ministerstwa Gospodarki: ,celem nadawania przedsiębiorcom statusu Centrum Badawczo-Rozwojowego jest rozwój prywatnego sektora badawczo-rozwojowego oraz wzrost popytu na usługi B+R przez powiązanie statusu Centrum z zachętami podatkowymi". ${ }^{7} \mathrm{Nie}$ wydaje się słuszne twierdzenie, że samo stworzenie regulacji prawnych umożliwiających przedsiębiorcom utworzenie centrum badawczo-rozwojowego generuje wzrost popytu na usługi $\mathrm{B}+\mathrm{R}$, choćby z tej przyczyny, że wyniki prac funkcjonujących obecnie jednostek badawczo-rozwojowych (JBR) w małym stopniu wpływają na tworzenie popytu na usługi $\mathrm{B}+\mathrm{R}$. Można przypuszczać, że konieczne jest zatem przekształcenie organizacyjne JBR oraz transformacja skostniałej ich struktury, a nade wszystko zbliżenie tematyki badań realizowanych w tych jednostkach do realnych potrzeb przedsiębiorstw oraz podniesienie jakości tych badań. Niestety nie jest to możliwe bez nakładów finansowych, chociażby na nowoczesną aparaturę pomiarową. Wracając do omawianej ustawy: w art. 14 przewidziane zostały warunki utworzenia centrum badawczo-rozwojowego: „Art. 12.

1. Przedsiębiorca niebędący jednostką badawczo-rozwojową może uzyskać status centrum badawczo-rozwojowego.

2. Status centrum badawczo-rozwojowego może uzyskać przedsiębiorca, o którym mowa w ust. 1:

1) którego przychody netto ze sprzedaży towarów, produktów i operacji finansowych za rok obrotowy poprzedzający rok złożenia wniosku, o którym mowa w ust. 6, wyniosły co najmniej równowartość w złotych 800000 euro przeliczoną według średniego kursu ogłaszanego przez Narodowy Bank Polski na ostatni dzień roku obrotowego poprzedzającego rok złożenia wniosku;

2) którego przychody netto ze sprzedaży wytworzonych przez siebie wyników badań lub prac rozwojowych stanowią co najmniej 50\% przychodów określonych w pkt 1 ;

3) który nie zalega z zapłatą podatków, składek na ubezpieczenia społeczne i składek na ubezpieczenie zdrowotne". ${ }^{8}$

W dalszych zapisach ustawy przewiduje się, że przedsiębiorca, który uzyskał status centrum badawczo-rozwojowego, będzie zwolniony z podatku od nieruchomości (w tym od nieruchomości rolnych i leśnych) wykorzystywanych do prowadzenia badań i prac rozwojowych.

\section{Nowe zadania Polskiej Agencji Rozwoju Przedsiębiorczości}

Przepisy zawarte w omawianej ustawie poszerzają zakres zadań realizowanych przez Polską Agencję Rozwoju Przedsiębiorczości (PARP). Do zadań Agencji należy:

1. działanie na rzecz realizacji założeń polityki innowacyjnej państwa,

2. wspieranie i promocja przedsięwzięć, w tym programów, centralnych i regionalnych, w zakresie rozwoju innowacyjności,

3. przygotowywanie i realizacja własnych programów działań wspierających działalność innowacyjna,

\footnotetext{
${ }^{7}$ www.mpig.gov.pl

${ }^{8}$ Art. 12 Ustawy z dnia 29 lipca 2005 r. o niektórych formach wspierania działalności innowacyjnej, Dz.U. Nr 179, poz. 1484.
} 
4. wspomaganie organów administracji rządowej i samorządowej w zbieraniu i przetwarzaniu danych o potrzebach gospodarki narodowej w zakresie innowacyjności,

5. wspieranie działalności instytucji otoczenia przedsiębiorstw działających na rzecz wzrostu innowacyjności przedsiębiorstw i gospodarki, takich jak: jednostki badawczo-rozwojowe, centra badawczo-rozwojowe, centra transferu technologii, inkubatory przedsiębiorczości i parki technologiczne,

6. współpraca międzynarodowa w zakresie promocji i rozwoju innowacyjności. ${ }^{9}$

\section{Zmiany w prawie podatkowym}

Niniejsza ustawa wprowadza również zmiany w obowiązującym prawie podatkowym. Dotyczą one przepisów o podatku dochodowym od osób fizycznych (PIT) i od osób prawnych. Zgodnie z treścią ustawy:

- przedsiębiorca może odliczyć od podstawy opodatkowania cenę zakupu nowej technologii od jednostek naukowych polskich lub zagranicznych w wysokości nie większej niż 50\% w przypadku mikro, małych i średnich przedsiębiorstw oraz $30 \% \mathrm{w}$ przypadku pozostałych przedsiębiorstw,

- wydatki na prace rozwojowe, niezależnie od wyniku, jakim się zakończyły, można w myśl przepisów ustawy zaliczyć w koszty,

- ulega skróceniu okres amortyzacji zakończonych prac rozwojowych z 36 do 12 miesięcy,

- wprowadza się 22\% stawkę podatku VAT na usługi naukowo-badawcze.

Wymienione zapisy ustawy zmieniające obowiązujące prawo podatkowe, zdaniem autorów niniejszego artykułu, częściowo służą realizacji czwartego celu cząstkowego ustawy.

\section{Nowelizacja Ustawy o niektórych formach wspierania działalności innowacyjnej}

19.05.2006 r. weszła w życie nowelizacja ustawy o niektórych formach wspierania działalności innowacyjnej. Zawarte w niej przepisy dotyczące podatków weszły w życie z datą wsteczną, 1.01.2006 r. Oto najważniejsze zmiany, jakie wprowadza omawiana nowelizacja:

- firmy mogą skorzystać z ulgi podatkowej, jeśli zakupią nową technologię od prywatnych instytutów naukowo-badawczych,

- wprowadzono jeden limit odliczenia podatkowego 50\% ceny nowej technologii niezależnie od tego, czy z ulgi korzysta małe, średnie czy duże przedsiębiorstwo (poprzednio stawki były zróżnicowane i wynosiły odpowiednio 50\% i 30\%),

- wydłużono comiesięczny termin przekazywania środków pieniężnych na fundusz innowacyjności z ostatniego dnia każdego miesiąca na 15 dzień następnego miesiąca,

- definicja „przedsiębiorcy w trudnej sytuacji ekonomicznej” została odniesiona do regulacji Unii Europejskiej (dzięki czemu uniknięto konieczności ponownej nowelizacji ustawy w związku $\mathrm{z}$ dostosowywaniem do prawodawstwa UE).

\section{Podsumowanie}

Jak wspomniano we wstępie, omawiana ustawa miała zapewnić wzrost konkurencyjności i innowacyjności gospodarki poprzez wzrost nakładów sektora prywatnego na badania i rozwój oraz poprawić efektywność gospodarowania środkami publicznymi przeznaczonymi na $B+R$. Według autorów niniejszego artykułu, ustawa o niektórych formach wspierania działalności

${ }^{9}$ Art. 24, ust. 1 b) Ustawy z dnia 29 lipca 2005 r. o niektórych formach wspierania działalności innowacyjnej, Dz.U. Nr 179, poz. 1484. 
innowacyjnej nie jest w stanie sprostać stawianym jej celom, ponieważ dotyczy bardzo wąskiego spektrum działań o charakterze regulacyjnym w zakresie podnoszenia innowacyjności i konkurencyjności polskiej gospodarki. Rzeczywisty wymiar efektów pracy legislatorów pracujących nad tą ustawą będzie można obserwować i ocenić poprzez analizę takich wielkości, jak:

- liczba powstałych centrów badawczo-rozwojowych;

- wyniki działalności centrów badawczo-rozwojowych (ekonomiczno-finansowe, naukowe),

- liczba udzielonych kredytów technologicznych;

- wielkość umorzenia kredytu technologicznego (łączna wartość i wartość średnia w przeliczeniu na jednego beneficjenta);

- wielkość odliczeń podatkowych z tytułu zakupu nowej technologii (łączna wartość i wartość średnia w przeliczeniu na jednego beneficjenta);

- stopień wywiązywania się PARP z zadań statutowych.

Niewątpliwie ustawa o niektórych formach wspierania działalności innowacyjnej jest odzwierciedleniem niektórych potrzeb MŚP $i$ transformacji sektora $B+R$, nie wystarczy ona jednak do realizacji celu głównego, jakim jest poprawa wskaźników innowacyjności naszego kraju.

Początkowo kredyt technologiczny nie cieszył się dużą popularnością wśród potencjalnych kredytobiorców. W pierwszym okresie składania wniosków (październik 2005 r.) złożono 30 wniosków, spośród których 18 zostało zaakceptowanych pod względem kryterium ,nowej technologii”. Zawarto 12 umów kredytowych na łączną kwotę 18,3 mln zł. W kwietniu 2006 r. w trakcie procedury kredytowej było już 120 wniosków na łączną kwotę $350 \mathrm{mln}$ zł.

\section{Literatura}

1. Ustawa z dn. 29 lipca 2005 r. o niektórych formach wspierania działalności innowacyjnej, Dz.U. Nr 179, poz. 1484

2. Ustawa z dnia 12 maja 2006 r. o zmianie ustawy o niektórych formach wspierania działalności innowacyjnej oraz niektórych innych ustaw, Dz.U. Nr 107, poz. 723

3. http://www.mgip.gov.pl

\section{Act of 29 July 2005 on Certain Forms of Support for Innovative Activities as a Tool for Economic Stimulation}

Development of Knowledge-Based Economy (KBE) depends on numerous factors and the most important is the cultural and organizational/technological transformation of the economy. The key factor in creating KBE in Poland is the stimulation of corporate innovation. One of the actions aimed for enhancing innovation in Polish economy is the enactment of regulations that facilite the development of small and medium-sized businesses.

On July 29th, 2005, Polish Sejm passed the Act on Certain Forms of Support for Innovative Activities (Dz.U. Nr 179, poz. 1484). Its main goals are: first, to stimulate economic competitiveness and innovation by raising expenditures of private sector on research and development, and second, to increase the effectiveness of managing public resources allotted for research and development. The Act is designed to encourage entrepreneurs to coparticipate in stimulating innovation processes in Polish economy by taking part in funding and realization of scientific research. 


\section{Agnieszka Pichur}

Katedra Przedsiębiorczości i Innowacji

Akademia Ekonomiczna w Krakowie

\section{Elektroniczne wspieranie przedsiębiorczości. Wyniki badań empirycznych}

Wynalazki wprowadzają rewolucyjne zmiany w różnych sferach życia, a tempo tych zmian rośnie. Zaobserwowane zjawisko opisał J. Schumpeter i nazwał je koncepcją fal rozwoju gospodarczego (fal innowacji). Według Schumpetera doświadczamy napływu już piątej fali w rozwoju gospodarczym. Jest to etap dynamicznego rozwoju technologii informatycznych wspomagających komunikowanie się i przesyłanie danych. Dynamika rozwoju tych technologii decyduje o tempie rozwoju gospodarki. W powiązaniach społecznych i ekonomicznych przestaje mieć znaczenie odległość geograficzna. Sami zauważamy, że znaczenie ma sprawne komunikowanie się oraz przetwarzanie, przesyłanie i przechowywanie informacji. Są one konsekwencją ogromnego postępu wiedzy. Duże znaczenie wiedzy w rozwoju gospodarczym nie jest czymś nowym, jednak w warunkach budowy gospodarki opartej na wiedzy jej rola jako głównego czynnika oddziałującego na strukturę produkcji i postęp gospodarczy rośnie. To, czego doświadczamy, opisuje też A. Toffer i nazywa falami przemian. Jego metaforę fal można wykorzystać do opisu dyfuzji technologii komunikacyjnej jako fali „,burzącej dotychczasowy cywilizacyjny układ”. Jak zauważają Tofflerowie: „Nie będzie nowej gospodarki bez nowego społeczeństwa, a nowego społeczeństwa bez nowych instytucji” (Toffler, Toffler 2000). Wobec mogącego budzić niepokój stanu rzeczy warto przypomnieć słowa P. Druckera, że w społeczeństwie przedsiębiorczym ludzie wobec ogromnego wyzwania powinni wykorzystać je jako okazje (Drucker 1992). Otoczeni zmianami sposobów komunikowania się, zdobywania wiedzy, pracy czy nawet spędzania wolnego czasu stajemy przed wyzwaniem potraktowania tego wszystkiego jako rynkowej szansy. Przedsiębiorczość w wielu definicjach objaśniana jest właśnie przez takie działania, jak wyszukiwanie, rozpoznawanie, tworzenie czy wykorzystywanie rynkowych okazji (np. P. Drucker, J. Timmons, H. Stevenson, L. Jarillo). Wynika z tego prosta myśl, że przedsiębiorczość to przeciwieństwo bierności, że przejawia się ona działaniem. Przedsiębiorcy (czy osoby przedsiębiorcze) to ci, którzy oddają się kolejnej fali zmian, wyczekująjej i wykorzystająjej siłę.

\section{Test na przedsiębiorczość}

Kształtowanie społeczeństwa przedsiębiorczego, czyli takiego, w którym przedsiębiorczość staje się udziałem znacznej jego części, jest podstawą budowania konkurencyjnej gospodarki. W takim rozumieniu kształtowanie przedsiębiorczości odnosi się do pobudzania prywatnej inicjatywy, zachęcania do tworzenia planów przedsięwzięć gospodarczych, w których zawarte są pomysłowość i innowacje. Społeczeństwo przedsiębiorcze to takie, które potrafi dostrzec i wykorzystać rynkowe okazje, a rynkowe okazje wynikająze zmian. Dynamiczne zmiany oraz adaptacja wynalazków „piątej fali” są więc niewątpliwie trudnym testem przedsiębiorczości społeczeństwa i testem dla gospodarki. 
Kiedyś zakładano, że czego człowiek nie nauczył się mniej więcej do dwudziestego pierwszego roku życia, tego nie nauczy się już nigdy, a to, czego się nauczył, wystarczy mu do końca życia. Są to założenia systemu czeladniczego, „społeczeństwa tradycyjnego”, a nie „przedsiębiorczego" (Drucker 1992).

W dokumentach Komisji Unii Europejskiej dotyczących rozwoju społeczno-gospodarczego czytamy o dokształcaniu się poprzez całe życie (long life learning). „Dokształcanie” polega na zdobywaniu nowej wiedzy i umiejętności, które pozwolą nie tylko wykonywać jakieś zadania i działać efektywniej, ale funkcjonować w społeczeństwie. Dokształcanie się przez całe życie oznacza potrzebę uczenia się, następnie oduczania i ponownego uczenia. „Paradoksalnie, w ewoluującym z prędkością światła świecie biznesu coraz większego znaczenia nabiera umiejętność zapominania" (Ridderstrale, Nordstron 2001).

Dzięki obserwacjom i pierwszym doświadczeniom łatwo jest przewidzieć, że w warunkach ciagłych nowinek technicznych i komunikacyjnych, o sukcesie gospodarczym ludzi i społeczności będzie decydowała skłonność do ciągłego uczenia się. Co więcej „(...) prawdziwa natura wiedzy oznacza jej szybką zmianę. Umiejętności naszych rąk nie mają takiego tempa zmian (...). I nawet najlepszy system szkolnictwa, nawet o najdłuższym programie, nie przygotuje studentów na wszystkie zmiany" (Drucker 1989). Oznacza to też świadomość potrzeby samodzielnego dokształcania się. Wyzwaniem jest nie tylko stawianie czoła zmianom i traktowanie ich jako rynkowych okazji. Jest nim także ciągłe uczenie się i stosowanie nauczania nowych metod - nowej technologii ${ }^{1}$ - technologii informatyczno-komunikacyjnej.

Nowy test na przedsiębiorczość wskazuje więc tych, którzy - wykorzystując informatycznie zaawansowane technologie - potrafią tak ukierunkować swoją „odnawialną” wiedzę i umiejętności, aby były one pomocne w identyfikowaniu i eksploatowaniu rynkowych okazji.

\section{Internetowe zasoby przedsiębiorczości}

Wynalazki mogą być wynikiem celowych poszukiwań lub przypadku, jednak pomysły na przekształcanie rzeczywistości zawsze rodzą się w ludzkim umyśle. Taka była historia internetowej sieci. Na początku internet był tylko ideą. Następnie stał się urzeczywistnionym wynalazkiem testowanym dla wojskowości i obronności. Internet na dobre zadomowił się w wielu sferach życia współczesnego człowieka. Nie budzi już emocji jako nowość. Został skomercjalizowany. Słowo ,internet” jest pojemne - to innowacja techniczna, to społeczność, to ogólnie dostępne zapisane w hipertekście informacje, to też handel czy rynek. Najdonioślejsze jednak słowo przypisane ogólnoświatowej sieci komputerowej to „internetowe zasoby”. „Zasób nie istnieje, dopóki człowiek nie znajdzie zastosowania dla czegoś, co występuje w przyrodzie i nie nada mu w ten sposób wartości ekonomicznej” (Drucker 1989). Zastosowanie internetu odnajdujemy w przedsiębiorstwach, szkołach, fundacjach, instytucjach publicznych. Informacje zgromadzone na stronach internetowych mają wartość ekonomiczną. Taką wartość ma internet jako kanał komunikacyjny, sieć sprzedaży czy marketingu. W kontekście rozważań o przedsiębiorczości, na internet należy patrzeć przede wszystkim jako na zasoby. Przedsiębiorczość wynika z rozpoznawania, wykorzystywania rynkowych okazji, a te mogą być właśnie zagospodarowywane poprzez zastosowanie różnych unikatowych zasobów oraz ich kombinacji.

\footnotetext{
${ }^{1}$ Objaśnienie słowa „technologia” wskazuje, że jest to „sztuka wykonywania czegokolwiek zgodnie z jakimiś wypracowanymi regułami, obowiązującymi w społeczeństwach stojących na pewnym poziomie cywilizacji”. Mówienie więc o technologii społeczeństwa informacyjnego oznacza sztukę wykonywania codziennych, społecznych zadań oraz przeświadczenie, że opisywany sposób realizacji tych zadań świadczy o poziomie rozwoju cywilizacji, tzw. cywilizacji informacyjnej.
} 
Zastosowanie internetu w przedsiębiorstwach oznacza nie tylko możliwość korzystania z dodatkowej, elektronicznej platformy sprzedaży czy pracy. Ważne jest to, że stał się on elementem otoczenia biznesu. Zgromadzone w nim i udostępniane odpłatnie lub bezpłatnie informacje stają się platformą elektronicznego wspierania przedsiębiorczości. Internet jest dodatkowym elementem wspierającym rynkowe działania przedsiębiorców i potencjalnych przedsiębiorców jako:

- elektroniczny ekosystem biznesu umożliwiający współpracę i wymianę informacji między uczestnikami tego ekosystemu,

- nowa platforma wymiany zapisanych w formie elektronicznej informacji i usług internetowych, które tematycznie wpisują się w działania zwane wspieraniem przedsiębiorczości.

Specyfika internetu jako medium komunikacyjnego sprawia, że może on być skutecznym narzędziem organizacji systemu wspierania przedsiębiorczości (instytucje publiczne), a także innych organizacji komercyjnych, pomocnym w realizacji zadań z zakresu promocji przedsiębiorczości i edukacji przedsiębiorców. Przedsiębiorcy na różnych etapach rozwoju firmy zgłaszają zapotrzebowanie na pewne usługi wspierające rozpoczynanie, a następnie prowadzanie działalności gospodarczej. D. Evans i Th. Volery (2001) stworzyli typologię internetowych usług, które uznali za wspierające przedsiębiorców na różnych etapach budowania przedsiębiorstwa. Wspieranie przedsiębiorczości poprzez internet dotyczy takich obszarów, jak: gromadzenie informacji, budowanie sieci współpracy, doradztwo, ekspertyzy oraz szkolenia i edukacja.

Obecnie najcenniejszym zasobem w rękach przedsiębiorców jest wiedza. W gospodarce opartej na wiedzy kartą przetargowąjest stan posiadania i zdobywania wiedzy i kwalifikacji. Zaproponowane przez Evansa i Volery’ego działania wspierające przedsiębiorczość poprzez internet mają charakter informacyjno-edukacyjny. Oczywista wydaje się wspierająca rola internetu w gromadzeniu informacji, ponieważ wciąż pozostaje on największą biblioteką świata. Każda osoba, każda organizacja może uczestniczyć w tworzeniu treści dostępnych poprzez sieć komputerową. Z tego też względu można mówić o nadmiarze informacji czy chaosie informacyjnym. Rozważając rolę internetu we wspieraniu informacją, można wskazać na pierwsze zadanie stojące przed instytucjami systemu wspierania przedsiębiorczości: systematyzowanie informacji (tych, które udostępnia organizacja na swoich stronach www, jak i tych, do których należy odesłać przedsiębiorcę) w bogatym zbiorze informacji hipertekstu. Serwisy internetowe adresowane do przedsiębiorców powinny pełnić rolę bibliotekarzy-administratorów i osób zarządzających zasobami informacyjnymi. Strony internetowe mające informacyjnie wspierać przedsiębiorców mogą umożliwiać: dostęp do usystematyzowanych, skatalogowanych informacji, z możliwością ich selekcjonowania, wyszukiwania według wybranego klucza, dostęp do wiarygodnych i aktualnych informacji gospodarczych, interakcję z innymi użytkownikami (kontakt z pracownikami, doradcami, partnerami poprzez pocztę elektroniczną czy listy i fora dyskusyjne), interakcję komputerową (uzyskiwanie elektronicznych wersji dokumentów, przeszukiwanie baz adresów partnerów rynkowych, wypełnianie wniosków i formularzy on line).

Choć wspieranie się internetem w poszukiwaniu informacji może rodzić ich nadmiar, jest to naturalne źródło informacji. Internet jest substytutem centrali telefonicznej czy książki telefonicznej.

Organizacje, tworząc internetowe serwisy i tematycznie strukturalizowane zbiory elektronicznych zasobów, dostarczając własne materiały informacyjne i usługi, pełnią rolę bibliotekarzy, ale mogą także pełnić rolę nauczycieli. Nie jest jeszcze oczywiste poszukiwanie w internecie elektronicznych szkoleń. Edukacja, szkolenie medialne pozbawione bezpośredniej interakcji osobowej, wydaje się zubożone. Możliwość wykorzystania ruchomego obrazu, dźwięku, komunikacja z natychmiastowym sprzężeniem zwrotnym przybliżają edukację medialną do bezpośredniej. Możliwość interakcji maszynowej w odniesieniu do udostępnionych na stronach www materiałów 
dydaktycznych zapewnia aktywny udział w szkoleniu i zwiększa ilość informacji gromadzonych w pamięci długookresowej (Stern 1999). W odniesieniu do szkoleń skierowanych do przedsiębiorców, Evans i Volery wskazują, że skuteczne elektroniczne szkolenia to takie, które oferują kursy tematycznie przygotowane i adaptowane do konkretnych wymagań grup przedsiębiorców oraz możliwość indywidualnego kontaktu z konsultantem.

\section{Praktyka wspierania przedsiębiorców poprzez internet}

W odpowiedzi na wyzwania budowy gospodarki opartej na wiedzy, w polityce wobec małych i średnich przedsiębiorstw zawarte zostały zadania związane z tworzeniem przyjaznego środowiska przedsiębiorczości poprzez przekazywanie informacji, podnoszenie poziomu wiedzy przez pomoc doradczo-szkoleniową. W programie rządu polskiego znalazły się zadania związane z rozwojem systemów informacji wspomagających działalność gospodarczą poprzez internet, organizowaniem seminariów, szkoleń, wydawaniem informatorów, przekazywaniem informacji za pośrednictwem środków masowego przekazu, internetu, tworzeniem i rozwijaniem internetowych baz danych dotyczących regulacji prawnych obowiązujących w Unii Europejskiej, możliwości eksportowych, warunków prowadzenia działalności gospodarczej.

W raporcie o usługach wspierających przedsiębiorstwa, przygotowanym w 2003 r., została sformułowana lista rekomendacji dla polskiego modelu wspierania przedsiębiorczości (Usługi wspierajace mikroprzedsiębiorstwa, małe przedsiębiorstwa i samozatrudnionych. Raport końcowy, Global Partners, Warszawa 2003). Rekomendacje dotyczyły stworzenia oferty internetowych szkoleń dla małych firm: wprowadzenie takich zmian procedur, które pozwalałyby na włączenie istniejącej oferty do pakietu e-usług oraz przygotowanie modułów szkoleniowych dla przedsiębiorców.

Od października do grudnia 2004 r. prowadzone było badanie sondażowe dotyczące korzystania przez przedsiębiorców z zasobów internetu. W tym czasie elektroniczny kwestionariusz ankiety był losowo wyświetlany internautom przez firmę badawczą specjalizującą się w badaniach internetu i badaniach poprzez internet - Gemius SA. Dysponuje ona systemem monitorującym, który pozwala na analizę zachowań internautów na witrynach internetowych. $Z$ tych witryn zostały wyselekcjonowane serwisy o treściach poświęconych działalności gospodarczej, na których miał być emitowany kwestionariusz ankiety. Analiza uzyskanych w ten sposób danych pozwoliła udzielić odpowiedzi na pytanie: W jaki sposób internet jest wykorzystywany jako narzędzie zdobywania informacji z zakresu wspierania przedsiębiorczości?

W ocenie użytkowników internetowych materiałów edukacyjnych z zakresu przedsiębiorczości dzięki dostępowi do tych zasobów następuje wzrost kompetencji przedsiębiorców. Większość obecnych lub przyszłych przedsiębiorców uznała, że informacje czy usługi, które oferują serwisy internetowe, przynoszą im wiele korzyści. Według 52,3\% respondentów szczególnie przydatne były one w zakresie podnoszenia kwalifikacji czy poszerzania wiedzy (ryc. 1). Internetowe serwisy przeznaczone dla przedsiębiorstw przez 27,6\% respondentów zostały uznane za pomocne w kontaktach z urzędnikami czy wybranymi instytucjami, a 23,4\% respondentów dzięki nim skorzystało z pomocy ekspertów.

Właściciele przedsiębiorstw wskazywali, że serwisy internetowe są najbardziej pomocne w podnoszeniu własnych kwalifikacji i poszerzaniu wiedzy. Jednak nie byli oni grupa, która najbardziej podkreślała tę korzyść. Najczęściej wskazywali na nią studenci oraz osoby wykonujące prace dorywcze.

Ankietowani ocenili również, jakie są najistotniejsze korzyści z treści i bezpłatnych usług dostępnych w internecie i wskazali najważniejsze problemy przy korzystaniu z takich zasobów. Za najważniejsze korzyści, jakie dają internetowe serwisy przedsiębiorstwom, respondenci uznali całodobowy dostęp do informacji i usług (55,3\% badanych) oraz oszczędność czasu na zbieranie 
Ryc. 1. W czym okazały się pomocne informacje czy usługi znajdujące się na serwisach internetowych

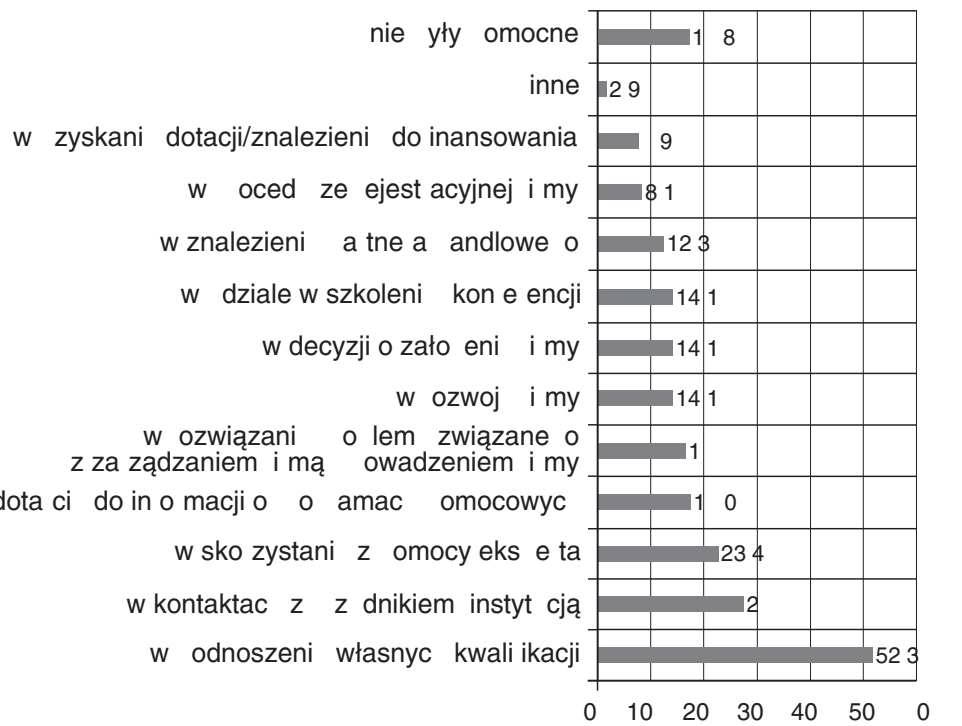

Źródło: opracowanie autorki na podstawie danych z badań własnych

informacji $(50,4 \%)$. Najmniej respondentów jako korzyść wymieniło ułatwienie dostępu do instytucji i urzędów czy kontakt z nimi (21,2\%) (ryc. 2). Tak niska ocena dostępu do instytucji i urzędów poprzez internet wynika zapewne z faktu, że strony większości urzędów nadal nie są zbyt często aktualizowane i mają charakter informacyjny, a nie interakcyjny.

Ryc. 2. Korzyści z internetowych treści i usług

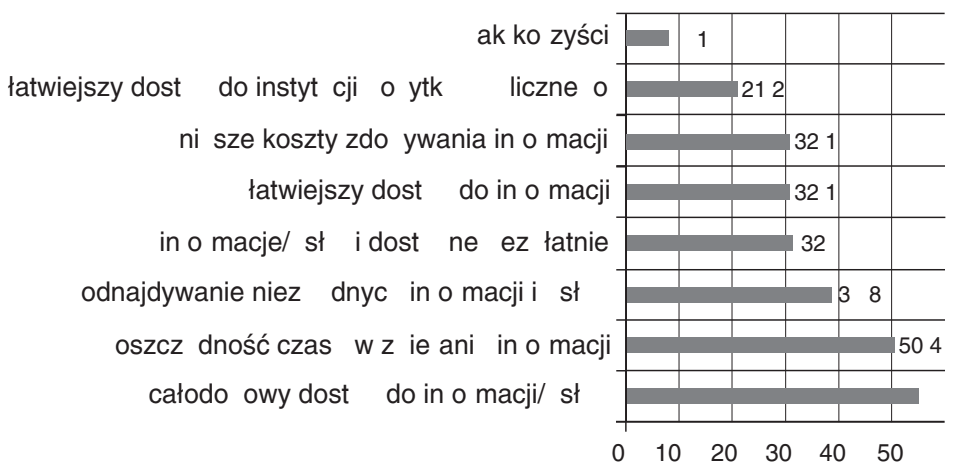

Źródło: opracowanie autorki na podstawie danych z badań własnych

Za najważniejszy problem związany z korzystaniem z zasobów i usług w internecie ankietowani uznali to, że instytucje i urzędy nie korzystają z internetu ( $47,1 \%$ badanych). Badani wskazali także na problemy ze znalezieniem serwisów $(37,3 \%)$ oraz na odpłatność za dostęp do treści i usług (30,4\% badanych) (ryc. 3$)$.

Zawartość stron internetowych jest pomocna w podnoszeniu kwalifikacji, ale internet ma przede wszystkim wartość informacyjną. W serwisach internetowych dla przedsiębiorstw badani najczęściej czytają różnego typu informacje (28,1\% badanych robi to codziennie, $25,4 \%$ - kilka 
Ryc. 3. Problemy przy korzystaniu z internetowych treści i usług

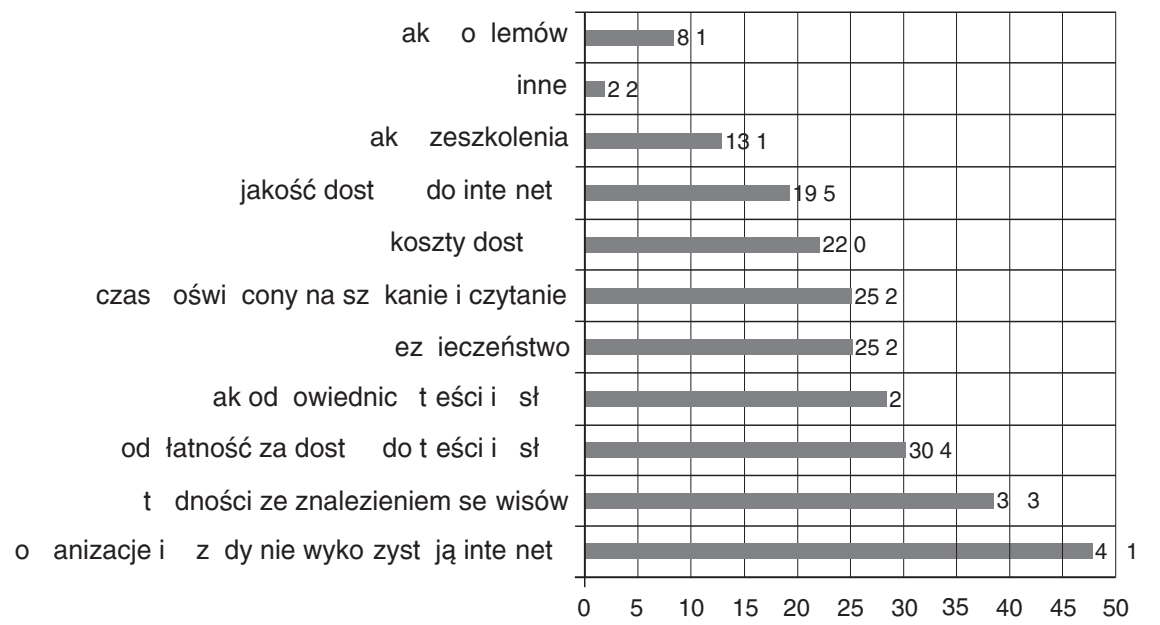

Źródło: opracowanie autorki na podstawie danych z badań własnych

razy w tygodniu) (ryc. 4). Najrzadziej ankietowani biorą udział w elektronicznych kursach czy szkoleniach: $72,9 \%$ badanych deklarowało, że nigdy nie brali w nich udziału, a 54,5\% ani razu nie wysłało poprzez internet urzędowych dokumentów. Okazuje się, że dużo popularniejsze jest ściagganie urzędowych formularzy i dokumentów. Przyczynąjest prawdopodobnie to, że serwisy urzędów i instytucji oferują możliwość czytania na ich stronach internetowych informacji, pobrania dokumentów i formularzy, natomiast rzadko istnieje możliwość ich wysłania do urzędu w postaci elektronicznej.

Ryc. 4. Częstotliwość i sposób korzystania z internetowych serwisów dla przedsiębiorstw

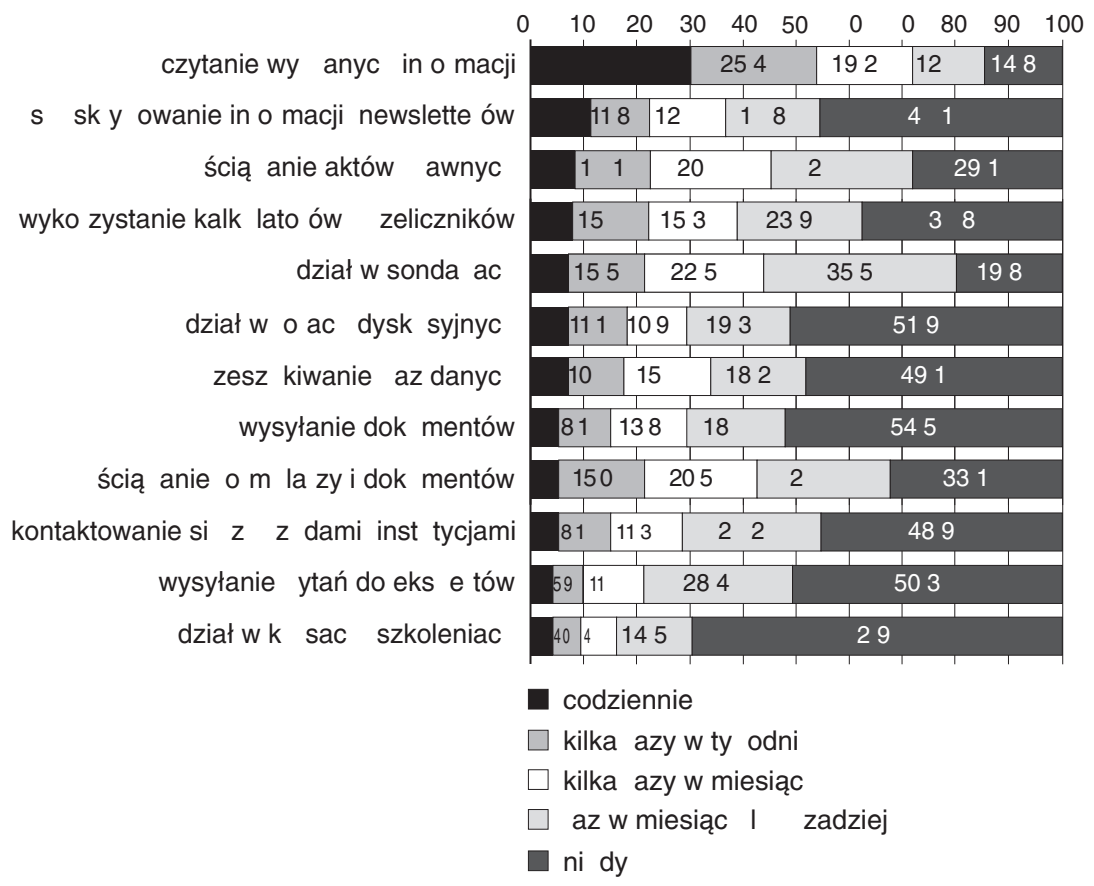

Źródło: opracowanie autorki na podstawie danych z badań własnych 
Ze sposobu wykorzystania internetowych treści i usług nie można wyciągać wniosków odnośnie do wartości edukacyjnej internetu, ale można ocenić jego wartość jako źródła informacji. Internet jest jednak medium, które daje możliwość realizacji zadań o charakterze informacyjno-szkoleniowym.

Polska Agencja Rozwoju Przedsiębiorczości, koordynująca i biorąca odpowiedzialność za rozwój usług wspierających przedsiębiorczość, proponuje zdobywanie wiedzy właśnie poprzez internet. We wrześniu $2005 \mathrm{r}$. na jej stronach internetowych pojawiły się cztery szkolenia dla przedsiębiorców oraz potencjalnych przedsiębiorców: Badanie rynku, Biznesplan, Fundusze strukturalne dla przedsiębiorstw, Jak założyć własna firmę. Do elektronicznych szkoleń została stworzona internetowa Akademia PARP (www.akademia.parp.gov.pl). Osoby, które ją odwiedziły, o internetowych nieodpłatnych szkoleniach dowiedziały się przede wszystkim ze stron internetowych Agencji oraz innych serwisów internetowych. Przemawia to za promowaniem szkoleń internetowych właśnie poprzez to medium (tab. 1).

Tab.1. Informacje o internetowych szkoleniach

\begin{tabular}{|l|l|c|}
\hline Z jakiego źródła dowiedział(a) się & od znajomych, rodziny & $11,65 \%$ \\
\cline { 2 - 3 } $\begin{array}{l}\text { Pan(i) o możliwości skorzystania ze } \\
\text { szkolenia? }\end{array}$ & w swoim zakładzie pracy & $3,64 \%$ \\
\cline { 2 - 3 } & z innego serwisu internetowego & $22,13 \%$ \\
\cline { 2 - 3 } & z prasy & $6,71 \%$ \\
\cline { 2 - 3 } & z radia lub telewizji & $1,27 \%$ \\
\cline { 2 - 3 } & ze strony internetowej PARP & $37,98 \%$ \\
\cline { 2 - 3 } & inne & $16,63 \%$ \\
\hline
\end{tabular}

Źródło: na podstawie danych Polskiej Agencji Rozwoju Przedsiębiorczości 2006

Internetowe szkolenia są tak samo ważne dla kobiet i dla mężczyzn. Osoby, które brały udział w szkoleniu, mieszkają w dużych miastach; są to przede wszystkim osoby z wyższym wykształceniem, młode, które dopiero rozpoczynają lub rozpoczęły karierę zawodową (tab. 2). Umiejętność korzystania z nowych mediów mają najczęściej osoby aktywne zawodowo, w wieku produkcyjnym, pełnosprawne, wykształcone. Internet może więc pogłębiać różnice społeczne, bo staje się niejako mnożnikiem posiadanej wiedzy i umiejętności oraz podnosi status osób, które w hierarchii społecznej sąjuż i tak wysoko.

Ze szkoleń internetowych dostępnych w elektronicznej Akademii korzystały przede wszystkim osoby pracujące na pełnym etacie, następnie osoby uczące się oraz przedsiębiorcy, choć tych było jedynie 12\% (tab. 2). Niewielu było użytkowników, którzy nie mają pracy. Szkolenia internetowe jako sposób aktywizacji zawodowej niepracujących mogą okazać się bardziej skuteczne, jeżeli te osoby zostaną „uposażone” w możliwość dostępu do internetu, gdyż w świetle badań miejsce pracy to dla Polaków główne miejsce korzystania z internetu. Brak pracy oznacza ograniczony dostęp do internetu.

Popularność szkoleń elektronicznych rośnie. Wzrasta liczba zarejestrowanych użytkowników Akademii. Największy przyrost użytkowników i uczestników szkoleń przypadł na pierwsze miesiące po uruchomieniu serwisu Akademii (tab. 3). Nie wszyscy odwiedzający Akademię uruchamiają programy szkoleniowe. Z grupy rozpoczynających naukę pozostaje nieduża liczba tych, którzy je kończą. Optymistyczne jednak jest to, że liczba kończących szkolenia rośnie.

Szkolenia dotyczące przedsiębiorczości to: Jak założyć własna firmę, Biznesplan oraz Badanie rynku. Ze wszystkich szkoleń najpopularniejsze jest Microsoft Office. Popularnością cieszą się także Badanie rynku oraz Jak założyć wtasna firmę (tab. 4). Niektóre z tych szkoleń można 
Tab. 2. Charakterystyka użytkowników szkoleń internetowych

\begin{tabular}{|c|c|c|}
\hline \multirow[t]{2}{*}{ Płeć } & Kobieta & $49,93 \%$ \\
\hline & Mężczyzna & $50,07 \%$ \\
\hline \multirow[t]{7}{*}{ Struktura wiekowa } & do 18 lat & $4,52 \%$ \\
\hline & od 19 do 25 lat & $31,80 \%$ \\
\hline & od 26 do 30 lat & $9,27 \%$ \\
\hline & od 31 do 40 lat & $19,16 \%$ \\
\hline & od 41 do 50 lat & $9,81 \%$ \\
\hline & od 51 do 60 lat & $4,96 \%$ \\
\hline & powyżej 61 lat & $0,48 \%$ \\
\hline \multirow[t]{6}{*}{ Miejsce zamieszkania } & poza terenem miejskim (na wsi) & $13,05 \%$ \\
\hline & w mieście do 20 tys. mieszkańców & $9,33 \%$ \\
\hline & w mieście od 20 tys. do 50 tys. mieszkańców & $13,59 \%$ \\
\hline & w mieście od 50 tys. do 100 tys. mieszkańców & $12,09 \%$ \\
\hline & w mieście od 100 tys. do 250 tys. mieszkańców & $12,99 \%$ \\
\hline & w mieście powyżej 250 tysięcy mieszkańców & $38,95 \%$ \\
\hline \multirow[t]{6}{*}{ Wykształcenie } & podstawowe & $3,80 \%$ \\
\hline & średnie & $17,30 \%$ \\
\hline & pomaturalne & $6,23 \%$ \\
\hline & zawodowe & $1,18 \%$ \\
\hline & licencjackie lub niepełne wyższe & $17,10 \%$ \\
\hline & wyższe & $54,38 \%$ \\
\hline \multirow[t]{8}{*}{ Aktywność zawodowa } & jestem na emeryturze/rencie & $1,05 \%$ \\
\hline & jestem na urlopie macierzyńskim/wychowawczym & $1,24 \%$ \\
\hline & nie pracuje/jestem osobą bezrobotną & $9,42 \%$ \\
\hline & pracuję na pełen etat & $45,79 \%$ \\
\hline & pracuję na umowę zlecenie/o dzieło & $5,35 \%$ \\
\hline & pracuję w niepełnym wymiarze godzin & $3,50 \%$ \\
\hline & $\begin{array}{l}\text { prowadzę własną firme/jestem właścicielem } \\
\text { lub współwłaścicielem }\end{array}$ & $11,83 \%$ \\
\hline & uczę się/studiuję & $21,82 \%$ \\
\hline
\end{tabular}

Źródło: na podstawie danych Polskiej Agencji Rozwoju Przedsiębiorczości 2006

odbyć w ciągu kilku godzin, inne trwają znacznie dłużej. Czasochłonność szkolenia bywa istotna przy podejmowaniu decyzji o jego rozpoczęciu.

Analizując problematykę szkoleń internetowych jako narzędzia wspierającego przedsiębiorczość, zwrócono uwagę na motywacje internautów do uruchomienia szkoleń Jak założyć własna firmę oraz Biznesplan (tab. 5 i 6 ).

Szkolenie o zakładaniu przedsiębiorstwa najchętniej rozpoczynali ci, którzy chcą bardzo szybko (w ciagu 3 miesięcy) założyć własną firmę (tab. 5). Biznesplan jest narzędziem potrzebnym nie tylko do planowania otwarcia przedsiębiorstwa, ale także do planowania kolejnych etapów 
Tab. 3. Liczba użytkowników szkoleń internetowych

\begin{tabular}{|l|c|c|c|c|c|c|}
\hline Charakterystyka & $\begin{array}{c}\text { Wrzesień } \\
\mathbf{2 0 0 5}\end{array}$ & $\begin{array}{c}\text { Listopad } \\
\mathbf{2 0 0 5}\end{array}$ & Luty 2006 & $\begin{array}{c}\text { Kwiecień } \\
\mathbf{2 0 0 6}\end{array}$ & $\begin{array}{c}\text { Czerwiec } \\
\mathbf{2 0 0 6}\end{array}$ & $\begin{array}{c}\text { Sierpień } \\
\mathbf{2 0 0 6}\end{array}$ \\
\hline $\begin{array}{l}\text { Liczba zarejestrowa- } \\
\text { nych użytkowników } \\
\text { szkoleń na Akademii } \\
\text { (LZU) }\end{array}$ & 3884 & 9550 & 16215 & 22798 & 28110 & 32027 \\
\hline $\begin{array}{l}\text { Zmianaw stosunku do } \\
\text { poprzedniego okresu } \\
\text { (\%) }\end{array}$ & - & $145,88 \%$ & $69,79 \%$ & $40,60 \%$ & $23,30 \%$ & $13,93 \%$ \\
\hline $\begin{array}{l}\text { Liczba osób, które } \\
\text { uruchomily szkolenia } \\
\text { (LOUS) }\end{array}$ & 2367 & 7380 & 12708 & 14939 & 19859 & 22952 \\
\hline $\begin{array}{l}\text { Zmianaw stosunku do } \\
\text { poprzedniego okresu } \\
\text { (\%) }\end{array}$ & - & $211,79 \%$ & $72,20 \%$ & $17,56 \%$ & $32,93 \%$ & $15,57 \%$ \\
\hline $\begin{array}{l}\text { Liczba osób, które } \\
\text { ukończyły szkolenia }\end{array}$ & 0 & 719 & 1261 & 1634 & 2033 & 2759 \\
\hline $\begin{array}{l}\text { Zmiana w stosunku } \\
\text { do poprzedniego } \\
\text { okresu (\%) }\end{array}$ & - & & $75,38 \%$ & $29,58 \%$ & $24,42 \%$ & $35,71 \%$ \\
\hline
\end{tabular}

Źródło: dane Polskiej Agencji Rozwoju Przedsiębiorczości 2006

rozwoju firmy. Prawie połowa ankietowanych chce poszerzyć wiedzę z tego zakresu, jedna czwarta tę wiedzę zamierza wykorzystać do otwarcia firmy (tab. 6.)

Uczestnicy internetowych szkoleń dotyczących biznesplanu także chcą rozpocząć działalność gospodarczą w ciagu 3 miesięcy. Można wnioskować, że internet jest medium „,pierwszej pomocy" informacyjnej i edukacyjnej.

Dzięki programom ePolska oraz Strategia Informatyzacji Rzeczpospolitej, Polska jest włączona w proces tworzenia wartościowych treści i usług społeczeństwa informacyjnego. W Polsce i w innych krajach Unii Europejskiej zgodnie z oczekiwaniami obywateli internet będzie coraz częściej wykorzystywany jako medium pozwalające na dotarcie do usług wspierających powstawanie

Tab. 4. Motywacje uczestników szkolenia Jak założyć własną firmę

\begin{tabular}{|l|c|}
\hline \multicolumn{1}{|c|}{ Nazwa szkolenia } & Liczba osób \\
\hline Jak założyć własną firmę & 299 \\
\hline Fundusze strukturalne dla przedsiębiorstw & 230 \\
\hline Biznesplan & 97 \\
\hline Badanie rynku & 541 \\
\hline Szkolenie bhp & 58 \\
\hline Zasady ubiegania się o zamówienia publiczne & 79 \\
\hline Microsoft Office & 729 \\
\hline Razem & $\mathbf{2 0 3 3}$ \\
\hline
\end{tabular}

Źródło: dane Polskiej Agencji Rozwoju Przedsiębiorczości, czerwiec 2006 
Tab. 5. Motywacje uczestników szkolenia Jak założyć własną firmę

\begin{tabular}{|l|c|c|}
\hline \multicolumn{3}{|c|}{ Dlaczego zainteresowal(a) się Pan(i) szkoleniem Jak zalożyć wlasna firmę? } \\
\hline Chcę poszerzyć swoją wiedzę w tym zakresie & 1867 & $35,29 \%$ \\
\hline Chcę założyć własną firmę & 3160 & $59,72 \%$ \\
\hline Chcę zmienić formę prawną przedsiębiorstwa & 40 & $0,76 \%$ \\
\hline Inne & 224 & $4,23 \%$ \\
\hline \multicolumn{2}{|c|}{ Kiedy planuje Pan(i) rozpocząć własną działalność gospodarczą? } \\
\hline Jeszcze nie wiem, kiedy & 475 & $15,03 \%$ \\
\hline Po skończeniu studiów/nauki & 354 & $11,20 \%$ \\
\hline W ciagu najbliższego roku & 1109 & $35,09 \%$ \\
\hline W ciągu najbliższych 3 miesięcy & 1222 & $38,67 \%$ \\
\hline
\end{tabular}

Źródło: dane Polskiej Agencji Rozwoju Przedsiębiorczości, sierpień 2006

i rozwój mikro-, małych i średnich przedsiębiorstw. Małe i średnie przedsiębiorstwa w Polsce mają dostęp do internetu i wykorzystują go do prowadzenia działalności gospodarczej. W polskich zasobach internetowych pojawia się coraz więcej informacji pozwalających poszerzać wiedzę przedsiębiorców i potencjalnych przedsiębiorców z zakresu prowadzenia firmy. Ze względu na swoją specyfikę, internet może być skutecznym środkiem służącym do przekazywania treści i usług o charakterze informacyjnym i szkoleniowym. Na podstawie analizy danych z badań, opinii przedsiębiorców oraz uczestników szkoleń można wnioskować, że internet może wspierać proces rozwoju przedsiębiorczości. Można wnioskować, że specjalnie przygotowywane internetowe serwisy stają się elementem systemu wpierania przedsiębiorczości. Internet jest substytutem centrali telefonicznej czy książki telefonicznej. Wydaje sięźródłem pierwszej pomocy informacyjnej.

Tab. 6. Motywacje uczestników szkolenia Biznesplan

\begin{tabular}{|l|c|c|}
\hline \multicolumn{3}{|c|}{ Dlaczego jest Pan(i) zainteresowany(a) szkoleniem Biznesplan? } \\
\hline Chcę poszerzyć swoją wiedzę z tego zakresu & 2633 & $48,79 \%$ \\
\hline Inne & 191 & $3,54 \%$ \\
\hline Ponieważ zamierzam rozpocząć działalność gospodarczą & 1384 & $25,64 \%$ \\
\hline $\begin{array}{l}\text { Ponieważ zamierzam starać się o uzyskanie finansowania } \\
\text { na projekt inwestycyjny }\end{array}$ & 497 & $9,21 \%$ \\
\hline $\begin{array}{l}\text { Ponieważ zamierzam starać się o uzyskanie finansowania } \\
\text { swojego pomysłu/projektu }\end{array}$ & 692 & $12,82 \%$ \\
\hline \multicolumn{2}{|c|}{ W jakim czasie planuje Pan(i) rozpocząć działalność gospodarczą/inwestycje? } \\
\hline Po skończeniu studiów/nauki & 177 & $6,93 \%$ \\
\hline Trudno powiedzieć & 237 & $9,28 \%$ \\
\hline W ciągu najbliższego roku & 680 & $26,61 \%$ \\
\hline W ciągu najbliższych 3 miesięcy & 941 & $36,83 \%$ \\
\hline W ciaggu najbliższych 6 miesięcy & 520 & $20,35 \%$ \\
\hline
\end{tabular}

Źródło: dane Polskiej Agencji Rozwoju Przedsiębiorczości, sierpień 2006 
Internet to wynalazek będący wynikiem kreatywności, a jego zastosowanie to oznaka przedsiębiorczości, choć często także lenistwa. Internet to również narzędzie wspierania przedsiębiorczości; informuje, jak założyć i prowadzić firmę. Należy oczekiwać, że w wielu urzędach już niedługo powszechne będzie zakładanie działalności gospodarczej poprzez internet. Rozwój przedsiębiorczości będzie następował w dużej mierze dzięki internetowi, ponieważ przedsiębiorczość jest sprawą praktyki (Drucker 1992).

\section{Literatura}

1. Drucker P., 1992, Innowacja i przedsiębiorczość, PWE, Warszawa

2. Drucker P., 1989, New Realities, Mandarin, London

3. Evans D., Volery Th., Online business development services for entrepreneurs: an exploratory study, "Entrepreneurship and Regional Development" 13/2001

4. Ridderstrale J., Nordstron K., 2001, Funky biznes, WIG-Press, Warszawa

5. Schumpeter J., 1995, Kapitalizm, socjalizm, demokracja, PWN, Warszawa

6. Stern J., 1999, Word Wide Web Marketing, JohnWiley\&Sons, New York

7. Toffler A., Toffler H., Cud klonowany, „Polityka”, 22.07.2000 r.

8. Toffler A., 1986, Trzecia fala, PIW, Warszawa

\section{On-line Business Support - Research Analysis}

The article highlights the catalyst role of technology and on-line services and their impact on entrepreneurship. This paper suggests that the Internet with its content is a powerful medium to provide the business development services needed by entrepreneurs (research networking, education/training). So far the Internet seems to be helpful, low-cost medium of communication that allows providers of support services to inform or to restitute that kind of services. The article presents an exploratory study of on-line business support services in Poland and first experience of on-line training. 
Katarzyna Świerczewska-Pietras

Kraków

\section{Przedsiębiorczość w sieci}

\section{Historia e-biznesu od powstania sieci}

Początki Internetu sięgają końca lat 60. XX w., kiedy powstał projekt o nazwie ARPANET. Projekt finansowany przez Agencję Zaawansowanych Projektów Badawczych Obrony Stanów Zjednoczonych (Defence Advanced Research Projects Agency - DARPA) miał służyć stworzeniu sieci komputerowej, która mogłaby przetrwać atak nuklearny, co wiązało się głównie z jej niezawodnością. Działanie sieci polegało przede wszystkim na możliwości przesyłania danych w przypadku ataku rakietowego, poprzez rozgałęzienie jej połączeń między komputerami; miała ona funkcjonować nawet mimo uszkodzenia jednej z jej części. Sukces projektu spowodował, że w 1975 r. sieć o nazwie ARPANET zaczęto stosować jako operacyjną, a nie eksperymentalną. Zanim to jednak nastąpiło, miały miejsce dwa godne uwagi wydarzenia w dziejach Internetu. Pierwsze z nich nastąpiło w 1971 r., kiedy to amerykański inżynier i programista Raymond S. Tomlinson, uczestniczący w budowaniu ARPANET, zastosował po raz pierwszy znak, @” do oddzielania nazwy odbiorcy od docelowego adresu. Pierwszy e-mail wysłany przez Tomlinsona „brzmiał”: QWERTY ${ }^{1}$. Jak utrzymywał sam autor, tekst pionierskiej wiadomości przesłanej drogą elektroniczną był zupełnie przypadkowy. Drugie wydarzenie nastąpiło w 1973 r. Wówczas to po raz pierwszy zostało zainicjowane międzynarodowe połączenie między Wielką Brytanią a Norwegią. W 1980 r. sieć ARPANET obejmowała już ponad 400 serwerów w Stanach Zjednoczonych (w tym serwery rządu, armii i uniwersytetów). W 1981 r. powstała CSNET, sieć przeznaczona dla naukowców niemających połączenia z ARPANET. W 1983 r. ARPA zdecydowała się oddzielić cześć wojskową MILNET od części cywilnej ARPANET, która od tej pory zaczęła działać samodzielnie, pod nazwą Internet. Sieć o nazwie Internet nie mogła jednak być używana do celów komercyjnych z uwagi na zakaz National Science Foundation. Prezydent Stanów Zjednoczonych George H.W. Bush zgodził się znieść ten zakaz dopiero w 1991 r. Rok wcześniej działalność zakończyła ARPANET. Dla użytkowników chcących rozmawiać na żywo Fin Jarkko Oikarinen stworzył w 1988 r. pierwszy internetowy czat o nazwie IRC (Internet Relay Chat), a w $1991 \mathrm{r}$. Timothy Berners-Lee z genewskiego laboratorium CERN stworzył podstawy HTML (HyperText Markup). Dnia 22 kwietnia 1993 r. powstała pierwsza graficzna przeglądarka o nazwie Mosaic. Osiem dni później CERN udostępnił bezpłatnie technologię Web. W 1994 r. powstała Yahoo, którą stworzyli David Filo i Jerry Yang. Twórca Mosaic, Marc Andreessen, w 1995 r. wprowadził kolejny program o nazwie Netscape Navigator. Warto również wspomnieć o pierwszym programie, który umożliwił porozumiewanie się poprzez sieć za pomocą głosu - Skype. Został wymyślony przez dwóch skandynawskich informatyków Niklasa Zennstroma i Janusa Friisa. Od razu zdobył popularność. W 2003 r. pojawiła się pierwsza publiczna wersja beta programu, który w pierwszym tygodniu ściagnęło 60 tys. użytkowników. Jak wynika z danych z sierpnia 2007 r.,

${ }^{1}$ http://pl.wikipedia.org/wiki/Ray_Tomlinson 
Skype ma ponad $220 \mathrm{mln}^{2}$ zarejestrowanych użytkowników na całym świecie, w tym ponad $7 \mathrm{mln}$ w Polsce, dzięki czemu Polska zajmuje trzecie miejsce po Stanach Zjednoczonych i Chinach, a w Europie miejsce pierwsze.

Rozwój Internetu w Polsce nastąpił dopiero pod koniec lat 80. XX w. Było to spowodowane przede wszystkim objęciem krajów z tzw. bloku wschodniego programem COCOM (Coordinating Committee for Multilateral Export Controls). Komitet, który skupiał 17 państw zachodnich, w tym Stany Zjednoczone i Japonię, miał za zadanie nie dopuścić, aby kraje bloku wschodniego miały dostęp do nowoczesnych technologii. Dopiero po upadku bloku komunistycznego po $1989 \mathrm{r}$. i odzyskaniu przez Polskę niepodległości, ograniczenia COCOM wobec Polski zostały zniesione. Dzięki temu Polska w 1990 r. uzyskała członkostwo w EARN (European Academic Research Network), europejskiej sieci łączącej ośrodki akademickie. W tym samym roku Uniwersytet Warszawski połączył sieć komputerów krajowych z siecią zagraniczną Uniwersytetu w Kopenhadze. W 1992 r. Telekomunikacja Polska udostępniła użytkownikom sieć pakietową POLPAK, a w 1993 r. na Wydziale Fizyki Uniwersytetu Warszawskiego został uruchomiony pierwszy polski serwer www. W tym samym roku przy Uniwersytecie Warszawskim powstała Naukowa Akademicka Sieć Komputerowa (NASK), która stała się monopolistą w dostępie do internetu i rejestracji domen internetowych. Jest ona nadal wiodącym operatorem sieci transmisji danych. W $1995 \mathrm{r}$. powstał pierwszy w Polsce portal internetowy o nazwie Wirtualna Polska, utworzyła się również Polska Społeczność Internetu, której zadaniem było propagowanie rozwoju internetu. Rok później internetową działalność rozpoczęło jedno z najbardziej popularnych obecnie multimedium w Polsce - portal Onet.pl.

Biznes w sieci zaczął rozkwitać od 1993 r., kiedy zaczęto przyjmować zamówienia na pizzę przez internet. Taką usługę jako pierwsza wprowadziła firma Pizza Hut. Powstał także pierwszy bank on-line. Dwa lata później Jeff Bezos założył Amazon.com. Początkowo była to księgarnia, której asortyment poszerzał się w miarę zapotrzebowania o inne towary, do których można zaliczyć przede wszystkim sprzęt komputerowy, DVD, sprzęt elektroniczny, żywność i meble. Bezos stworzył także internetowe radio o nazwie Radio HK. W 1995 r. powstał jeden z najpopularniejszych serwisów aukcji internetowych eBay. Dziesięć lat później firma zaczęła zdobywać polski rynek. W 1999 r., cztery lata po zniesieniu bezpłatnej rejestracji domen, za 7,5 mln dolarów sprzedano (kupioną w 1997 r. za 150 tys. USD) domenę business.com.

W Polsce biznes elektroniczny zaczął się rodzić w latach 90. XX w. Przedsiębiorcy tworzyli swoje pierwsze strony internetowe, traktując je jako wizytówki. Według źródeł, pierwszy sklep internetowy powstał już w 1996 r.; uruchomiła go firma Ternet ${ }^{3}$ z Warszawy, ale sklep szybko zakończył działalność. W sieci można jednak znaleźć firmy, które rozpoczęły działalność internetową wcześniej. Księgarnia nepo.pl na swojej stronie internetowej informuje, że sprzedaje swoje produkty w sieci od 1994 r. Według tygodnika „Time” pierwszy supermarket internetowy o nazwie ToTu do zamieszczania ofert stron internetowych i sklepów został założony w Polsce w $1997 \mathrm{r}$.

Handel internetowy staje się w Polsce coraz bardziej popularny również dzięki aukcjom internetowym. W 1999 r. Arjan Bakker stworzył Allegro - pioniera polskich aukcji, który jest wzorowany na amerykańskim e-Bay. Początkowo aukcje były bezpłatne, ale po pewnym czasie firma zdecydowała się wprowadzić opłaty za wystawianie przedmiotów, nie tracąc przy tym klientów. Jak wynika z danych firmy, Allegro liczy obecnie 6 mln użytkowników, a co 17 sekund rejestruje się nowe konto.

\footnotetext{
${ }^{2} \mathrm{http} / /$ skype. wiadomosc.info/index.php?s=\&mod=arts\&rid=4409

${ }^{3} \mathrm{http}: / /$ sklepy-internetowe.cogdziekupic.pl/historia_powstania

${ }^{4}$ http://pl.wikipedia.org/wiki/Sklep_internetowy
} 
Internet w Polsce ma już ponad 15 lat. Patrząc na wirtualny świat, można pomyśleć, że powstało w nim już wszystko i nic więcej się nie zmieści. Nie można jednak myśleć jak Charles H. Duell, który - pracując w biurze patentowym - stwierdził, że: „Wszystko, co było do wynalezienia, zostało już wynalezione". ${ }^{5}$ Było to w 1899 r., a od tej myśli minęło już 107 lat. W międzyczasie świat zmienił się o 180 stopni i zapewne będzie się zmieniał nadal.

\section{Internet w liczbach}

Według badań Millward Brown Group of Companies ${ }^{6}$, w Polce z dostępu do internetu korzysta 51,9\% mężczyzn i 48,1\% kobiet. Najwięcej użytkowników ma wykształcenie średnie (42,6\%). W strukturze wiekowej przeważa młodzież (15-24 lat; 37,9\%). Internauci najczęściej korzystają $\mathrm{z}$ sieci w domu $(73,4 \%)$; praca jest na drugim miejscu (30,8\%). Według raportu Głównego Urzędu Statystycznego: Wykorzystanie technologii informacyjno-telekomunikacyjnych w 2005 r., większość internautów korzysta z sieci w celu komunikowania się (30\% badanych) oraz wyszukiwania informacji o towarach i usługach (18\%). Czyta i pobiera czasopisma on-line, a także gra, pobiera gry i muzykę $14 \%$ internautów.

$\mathrm{Z}$ raportu Money.pl wynika, że łączna liczba internautów w Polsce wynosi $11 \mathrm{mln}$, z czego 3 mln robi zakupy w sieci. Poniższy wykres wskazuje, że użytkowników internetu z roku na rok przybywa.

Tab. 1. Odsetek Polaków korzystających z internetu

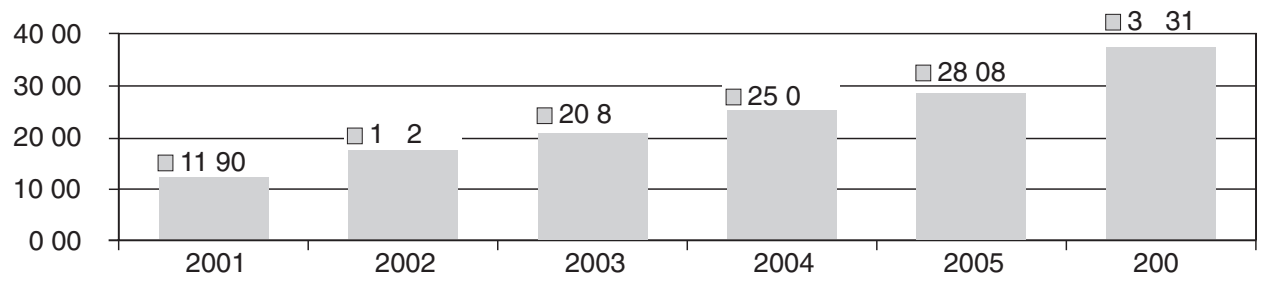

Źródło: Money.pl

Mimo wzrostu grupy internautów, dostęp do internetu jest ograniczony. Dlaczego? Jak wynika z badań Głównego Urzędu Statystycznego z kwietnia 2005 r., większość ankietowanych (39\%) odpowiedziała, że nie ma potrzeby korzystania z internetu, na drugim miejscu znalazły się zbyt wysokie koszty sprzętu, a na trzecim - zbyt wysokie koszty dostępu. Najbardziej zaskakuje wynik trzeciej grupy, ponieważ wskazuje, że Polska jest państwem, w którym dostęp do internetu jest jednym z najdroższych w Europie. Potwierdza to raport Centrum im. Adama Smitha: Ceny dostępu do Internetu w Polsce na tle wybranej grupy krajów europejskich III, IV kwartat 2005 i I kwartał 2006. Raport został podzielony na trzy grupy tzw. koszyków: LOW (użytkownicy początkujący lub mniej korzystający z internetu), MEDIUM (użytkownicy częściej korzystający) oraz HIGH (użytkownicy intensywnie korzystający z internetu). Przedstawiony wykres przekonuje o cenie, jaką płaci grupa użytkowników średnio intensywnie korzystających z dostępu do sieci.

Jak wynika z tego wykresu, najtańszy dostęp do internetu mają Wielka Brytania i Irlandia. Polska w tym zestawieniu znajduje się najwyżej, z ceną dochodzącą do 90 USD. Sytuacja ta wynika głównie z monopolu Telekomunikacji Polskiej, która poprzez reklamy zachęca do zakładania Neostrady już od kilkunastu złotych. Są to jednak najwolniejsze łącza, o małej przepustowości.

\footnotetext{
${ }^{5}$ Cytat pochodzi ze strony: http://www.cs.put.poznan.pl/mmasewicz/

${ }^{6}$ Dane z okresu czerwiec - sierpień $2006 \mathrm{r}$.
} 
Tab. 2. Zestawienie cen według parytetu siły nabywczej wyrażonej w USD w I kwartale 2006 r. (w koszyku MEDIUM)

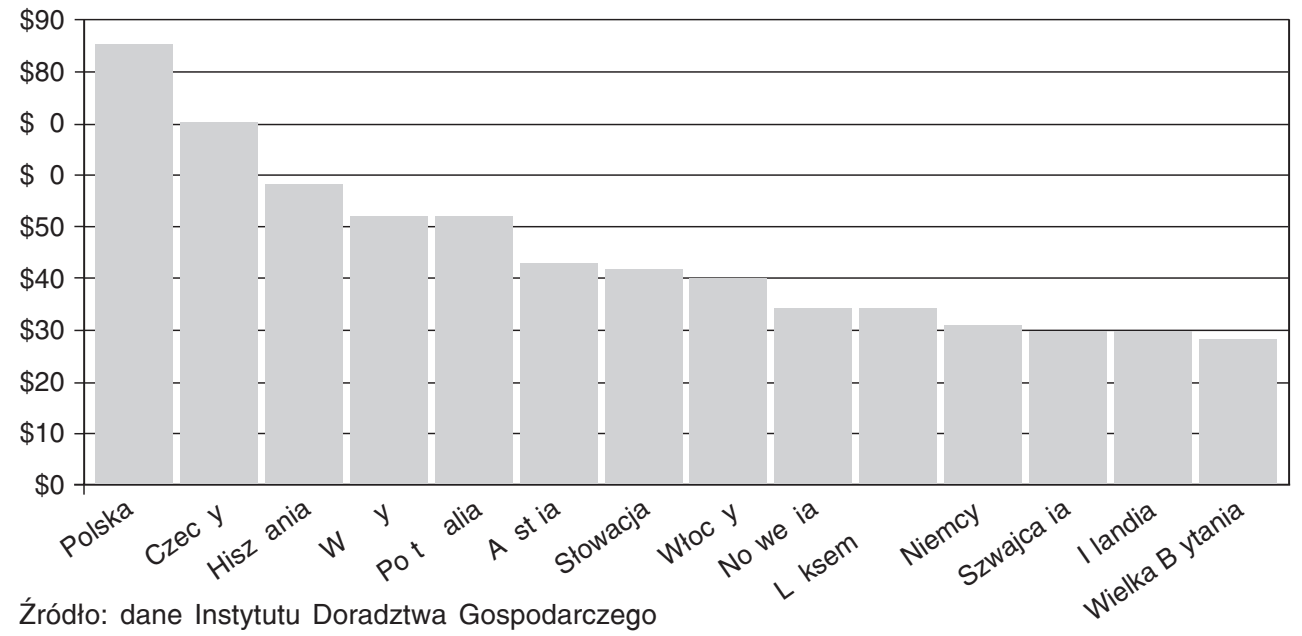

\section{Biznes z www, czyli e-commerce}

W 1997 r. handel elektroniczny został określony terminem e-commerce. „Według Światowej Organizacji Handlu (WTO) przez e-commerce należy rozumieć produkcję, reklamę, sprzedaż i dystrybucję produktów poprzez sieci teleinformatyczne. Instrumentami gospodarki elektronicznej są: telefon, telefax, telewizja, Elektroniczna Wymiana Danych (EDI) oraz Internet - najważniejszy i coraz częściej używany". ?

W Polsce coraz więcej przedsiębiorstw korzysta z internetu. W kwietniu 2005 r. GUS po raz pierwszy przeprowadził serię badań dotyczących wykorzystania technologii informacyjno-telekomunikacyjnych (ICT) na grupie 14000 przedsiębiorstw oraz badanie pilotażowe wykorzystania ICT w przedsiębiorstwach sektora finansowego na grupie 1500 przedsiębiorstw. Liczba pracujących w sektorach wyniosła od 10 do więcej osób. Jak wynika z raportu GUS: Wykorzystanie technologii informacyjno-telekomunikacyjnych w 2005 r., w Polsce 92\% firm posiada komputer, a dostęp do internetu ma 87\% firm. Najwięcej z internetu korzystają przedsiębiorstwa zajmujące się na co dzień informatyką (99\%), działalnością filmową, radiową i telewizyjną (98\%), obsługą nieruchomości i nauką (94\%), transportem, magazynowaniem i łącznością (91\%), handlem i naprawami (87\%), a także hotelarstwem, budownictwem i przetwórstwem przemysłowym (85\%). Firmy wykorzystują internet również do celów szkoleniowych (23\% badanych przedsiębiorstw) oraz do zamawiania towarów, płacenia za pomocą internetowych kont bankowych i porozumiewania się za pomocą e-maili.

\section{Jak rodziły się i rodzą fortuny e-biznesmenów}

Potentaci internetu znajdują się na listach najbogatszych ludzi świata. Wystarczy spojrzeć na najnowszy ranking magazynu „Forbes”, aby się o tym przekonać. Założyciele firmy Google, Sergey Brin i Larry Page, zajmują 12 i 13 pozycję na tej liście i są na niej najmłodszymi najbogatszymi ludźmi. W pierwszym kwartale 2006 r. obroty Google wzrosły o 25\%. W 2005 r. przychody firmy wyniosły 6,1 mld USD, a zysk - 2 mld USD. Majątek każdego z twórców Google szacuje się na około 12 mld USD. Twórca Amazon.com Jeffrey Bezos w najnowszym rankingu z 2006 r. znalazł się na 70 pozycji.

\footnotetext{
${ }^{7}$ www.mgip.gov.pl
} 
W Polsce również nie brak sieciowych gigantów. Można wymienić chociażby twórcę Allegro - Arjana Bakkera, Holendra, którego majątek szacowany jest na 220 mln zł. Na swój e-biznes Bekker wydał 30 tys. zł, a zaczynał w małym, dwupokojowym mieszkaniu. Obecnie firma zatrudnia kilkadziesiąt osób odpowiedzialnych za handel, marketing, bezpieczeństwo i obsługę klienta. Do Allegro należy $90 \%$ rynku aukcji internetowych.

Twórcy jednego z najbardziej popularnych portali internetowych onet.pl, Tomasz Kolbusz i Piotr Wilam, to pionierzy polskiego internetu, których majątek wyceniany jest na $200 \mathrm{mln}$ zł. W $2001 \mathrm{r}$. sprzedali oni swoje akcje koncernowi ITI za $100 \mathrm{mln}$ zł.

W Polsce, podobnie jak w Stanach Zjednoczonych, nie brak młodych i zdolnych. Przykładem są twórcy o2.pl - Jacek Świderski, Michał Brański i Krzysztof Sierota. W 2005 r. firma przyniosła im $11 \mathrm{mln}$ przychodu i $4 \mathrm{mln}$ zysku, a majątek założycieli wyniósł $60 \mathrm{mln}$ zł.

Firma Merlin.pl należy do najszybciej rozwijających się firm branży IT w Europie Środkowej. Założycielem i pomysłodawcą (na wzór amerykańskiego Amazon.com) jest Zbigniew Sykulski, którego majątek szacuje się na $40 \mathrm{mln}$ zł.

Warto również wspomnieć o innowacyjnych stronach internetowych, które często powstawały po to, aby można je było sprzedać z zyskiem. Jedną z nich jest tzw. serwis społecznościowy MySpace, stworzony w 2004 r. Pomysłodawcy MySpace stworzyli coś na miarę społeczności, której dali możliwość tworzenia swoich profili. Na stronie każdy może publikować, oceniać, komentować zamieszczone materiały, wymieniać się zdjęciami i adresami. Serwis od razu zyskał ogromną popularność. „MySpace.com ma ponad 140 mln użytkowników miesięcznie, którzy generują nawet 4,3 mld odsłon dziennie". ${ }^{8}$ Większość osób nie wyobraża sobie życia bez My-Space. Serwis został sprzedany za 580 mln dolarów koncernowi News Corp. W 2008 r. spółka prognozuje przychody na poziomie $800 \mathrm{mln}$ USD.

Podobnie przedstawia się sytuacja serwisu YouTube, umożliwiającego publikację filmów w sieci, który został kupiony przez Google w 2006 r. za 1,6 mld USD. W Polsce za kilkanaście tysięcy złotych powstał serwis Patrz.pl, który stanowi kopię amerykańskiego YouTube. Miesięcznie serwis notuje $15 \mathrm{mln}$ odwiedzin, a jego twórcy przewidują wzrost liczby wizyt. Jak informuje jeden z założycieli Patrz.pl, właściciele Gadu-Gadu oferowali za serwis pół miliona złotych. Jednak to za mało, ponieważ - jak mówi - potencjał zawarty w tym biznesie jest wart o wiele więcej. ${ }^{9}$

\section{Sklep internetowy}

Sklep internetowy to najczęściej spotykana forma e-commerce. Handel w sieci daje możliwość zakupu towarów o każdej porze dnia i nocy, a także w innym państwie, bez wychodzenia z domu. Sklepy internetowe oferują bogaty asortyment towarów, często w promocyjnych cenach, dogodne formy płatności oraz wizualne „dotknięcie” każdej rzeczy za pomocą zdjęć. Dzięki łatwej dostępności towarów w sklepach internetowych i możliwości ich zakupu poprzez sieć rodzi się nowy typ handlu elektronicznego, zwany Nową Ekonomią, która w handlu nie zna granic. Wystarczy wpisać przedmiot, który nas interesuje, w dowolnie wybranej wyszukiwarce, i czekać na rezultat. Tylko od nas zależy, czy wybierzemy sklep z Polski, czy zainteresuje nas oferta innego sklepu poza jej granicami.

\section{Jak tworzyć sklep internetowy?}

Sklep internetowy można stworzyć za pomocą szablonów, ale można również opracować własną aplikację. Przy tworzeniu sklepu należy przemyśleć pierwsze podstawowe kroki:

\footnotetext{
${ }^{8} \mathrm{http}: / /$ www.internetstandard.pl/news/119543.html

${ }^{9}$ Trzech zwyklych studentów i ich niezwykly serwis, „Rzeczpospolita”, gazeta/Ekonomia, 240/2006.
} 
1. Nazwa witryny - należy zastanowić się nad dobrze brzmiącą nazwą; najlepiej, by z czymś się kojarzyła.

2. Hasło - można wymyślić hasło reklamowe, które może zostać łatwo zapamiętane przez klientów, dzięki czemu przy skojarzeniu wrócą do nas przy następnych zakupach.

3. Misja witryny - co będziemy sprzedawać i w jaki sposób.

4. Cele witryny - co jest naszym celem, np.:

- zwiększenie sprzedaży,

- reklama i wyszukiwanie nowych kontaktów,

- przedstawienie aktualnej promocji i oferty,

- udzielenie pełnej informacji o oferowanych produktach.

5. Kto stanowi konkurencję - warto się zastanowić, jakich konkurentów mamy w sieci, i przygotować strategię działania.

6. Promocja witryny - witrynę możemy reklamować poprzez np.:

- pozycjonowanie,

- zgłoszenie w katalogach tematycznych (Onet, WP, Interna itd.),

- zgłoszenie w wyszukiwarkach (Google, Szukacz, Gooru),

- banery reklamowe.

7. Ustalamy nawigację serwisu - nawigacja jest jedną z najważniejszych rzeczy; należy się nad nią dobrze zastanowić. Jeżeli jest dobrze zaprojektowana, klient nie zniechęci się przy zakupie, ponieważ nie będzie musiał długo szukać interesującego go towaru. Jeżeli jest źle zrobiona, można się pożegnać z szybkim zyskiem ze sprzedaży.

8. Grafika-wygląd strony.

\section{Opinie internautów}

„Budując” sklep internetowy, warto się zastanowić nad możliwością wpisywania opinii kupujących. Według ,nowego raportu Jupiter Research, opinie o produktach czyta aż 77\% kupujących, a osoby, które opiniują produkty (pozytywnie lub negatywnie) na forach, wydają średnio o $22 \%$ więcej od tych, którzy tego nie robią. Według BizRate 57\% kupujących ceni sobie wyżej opinie innych kupujących niż opinie ekspertów". ${ }^{10}$ Dlatego ważne jest to, aby na stronie znalazły się nie tylko informacje o produktach, ale i o sklepie. Dzięki temu zdobywamy zaufanie klientów, którzy - opierając się na opinii innychwybierają nasz sklep. Opinia działa jak dobra reklama, którą należy wykorzystać. Rodzi się jednak pytanie: Czy należy umieszczać negatywne opinie? Według Wojciecha Kryciaka, autora książki: „Jak założyć skuteczny i dochodowy sklep internetowy”, powinno się moderować i usuwać opinie wulgarne bądź niezwiązane z produktem. Natomiast opinie, które odnoszą się krytycznie do danego produktu, powinny zostać zachowane. Autor uważa, że dzięki temu możemy zyskać szacunek klientów. Zaufanie możemy także zdobyć, podając nie tylko numer komórkowy w kontakcie ze sklepem, ale także dokładny adres i telefon stacjonarny. Przy zakupach w sieci jest to bardzo ważne; dzięki temu klienci mogą nawiązać z nami nie tylko wirtualny, ale także rzeczywisty kontakt.

\section{Na co zwracają uwagę klienci}

Można by sądzić, że klienci w pierwszej kolejności zwracają uwagę na cenę. Jednak w przypadku sklepów internetowych według raportu Money.pl więcej niż połowa kupujących (prawie $57 \%$ ) zwraca uwagę na szybką realizację przesyłki. Nie ma mowy o długim oczekiwaniu na zamówiony towar. Im krócej, tym lepiej. Byłoby najlepiej, gdyby przesyłka mogła się znaleźć u klienta następnego dnia po zamówieniu. Na drugim miejscu $(33,9 \%)$ znalazły się miła obsługa i profesjonalizm, dopiero na trzecim - cena $(24,8 \%)$.

\footnotetext{
${ }^{10} \mathrm{http}: / /$ ecommerce.blox.pl/html/1310721,262146,21.html?63116
} 


\section{Komunikacja}

Ważną rolę w komunikowaniu wirtualnym odgrywają telefon stacjonarny i adres firmy. Komunikować się z klientami można także za pomocą e-maili, komunikatorów (Gadu-Gadu, Tlen.pl) czy „dwóch w jednym”, czyli telefonu i komunikatora o nazwie Skype (warto w tym miejscu dodać, że $30 \%$ użytkowników Skypa to firmy ${ }^{11}$ ). Coraz częściej sklepy decydują się na ten krok, ponieważ rozmowy są tańsze i nie narażają klientów i sklepu na dodatkowe koszty związane z transakcja. Skype wychodzi naprzeciw przedsiębiorcom, rozszerzając ofertę ${ }^{12} \mathrm{o}$ :

- stronę internetową Skype dla Biznesu, przeznaczoną dla rozwoju przedsiębiorstwa;

- nowy certyfikowany sprzęt Skype firmy Plantronics;

- nowe cechy w panelu Skype for Business Control Panel (wcześniej Skype Groups), ułatwiające zarządzanie zgrupowanymi użytkownikami i usługami pre-paid.

Skype dla Biznesu jest dostępny w 18 językach, w tym oczywiście w języku polskim.

\section{Sprzedaż przez internet}

Spośród 11 mln użytkowników internetu w Polsce, 4 mln robi zakupy w sieci. W 2006 r. po raz drugi, we współpracy „Wprost” i Money.pl, powstał ranking sklepów internetowych i najlepiej sprzedających się produktów. Aby raport mógł powstać, wybrano i zbadano 15 kategorii towarów, do których zaliczono m.in.: muzykę, elektronikę użytkowa, sport i turystykę, odzież dla dziecka, komputery i oprogramowanie, a także militaria. Sklepy internetowe były oceniane według dwóch kategorii: funkcjonalności i ergonomii. Za funkcjonalność sklep mógł otrzymać 75\% punktów. Składały się na nią następujące podkategorie: asortyment i ceny - 18 pkt, informacje o produkcie $-18 \mathrm{pkt}$, biuletyn informacji, newsletter $-8 \mathrm{pkt}$, sposoby dostawy produktu $-8 \mathrm{pkt}$, warunki dostawy produktu $-8 \mathrm{pkt}$, dostępne sposoby płatności - $10 \mathrm{pkt}$, metody interakcji z klientem - 10 pkt, mapa serwisu, bonusy, komentarze - 20 pkt. Za ergonomię sklep mógł otrzymać 25\% punktów. Łatwość dotarcia do informacji była traktowana jak jedna z podstawowych kwestii, dlatego można było za nią dostać największą liczbę punktów, aż 50, poziom graficzny strony to kolejne 30 pkt, współpraca z przeglądarkami - 10 pkt, a obsługa rozdzielczości - również 10 pkt.

Według raportu, największy odsetek internautów kupił w sieci książki (14,23\% ogólnej liczby sprzedanych produktów). Na drugim miejscu znalazły się odzież i buty $(12,39 \%)$, trzecie miejsce zajęły telefony komórkowe oraz akcesoria. Zauważono, że rośnie zainteresowanie wszystkimi kategoriami produktów. Ryc. 3 ilustruje stopę wzrostu sprzedaży niektórych niszowych towarów w 2006 r. w porównaniu z 2005 r.

Ryc. 3. Porównanie sprzedaży produktów w latach 2005 i 2006

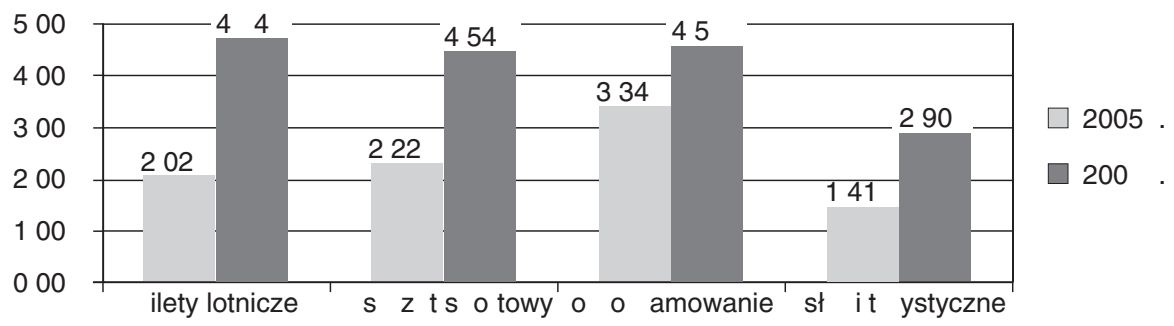

Źródło: opracowanie autorki na podstawie danych z raportu Money.pl

${ }^{11} \mathrm{http} / / /$ www.skyper.pl/nowosc/skype-30-proc-uzytkownikow-to-firmy

${ }^{12} \mathrm{http}: / /$ www.e-biznes.pl/inf/2006/16409, Skype_dla_malych_przedsiebiorstw.php 
Jak pokazuje wykres, sprzedaż w niektórych przypadkach wzrosła aż dwukrotnie, co świadczy o coraz większym zapotrzebowaniu na pożądane dobra i o łatwości dostępu do nich. Jest to o tyle dobry wynik, że według tygodnika „Wprost” Polacy są najwybredniejszymi klientami spośród dziesięciu narodów przebadanych przez Visa Europe. Są oszczędni, porównują ceny w różnych sklepach, kontrolują się podczas zakupów, zapoznają się z właściwościami produktów przed ich zakupem i są otwarci na nowe marki. Drugie miejsce w rankingu zajęli Francuzi". ${ }^{13}$ Coraz większą popularnością cieszą się porównywarki cenowe, które ułatwiają przeszukiwanie zasobów sklepowych w poszukiwaniu najtańszej oferty. Dzięki temu Polacy oszczędzają czas i pieniądze.

Jak wynika z danych tygodnika „Wprost” ${ }^{14}$, sprzedaż internetowa w Polsce w ostatnim roku wzrosła o 100\% (do 3,1 mld zł), o 100\% zwiększyła się także sprzedaż w sklepach internetowych (z 1 do 2 tys.). Nie przodujemy w dostępie do internetu, ale zakupy w sieci robimy już chętniej i znajdujemy się wśród krajów przodujących w tej dziedzinie w Europie. Częściej od nas zakupy robią tylko Brytyjczycy, Szwedzi i Niemcy.

W 2005 r. procent internautów wśród Polaków wynosił 17,5; w 2006 r. wzrósł do 25\%. Optymistyczna prognoza jest bardzo korzystna dla właścicieli sklepów internetowych, którzy ze swoim asortymentem mogą dotrzeć do prawie każdego internauty. To „prawie” wydobywa różnicę między miastem a wsią w dostępie do sieci. Różnica jest istotna, wynosi aż 60\%. Inwestorom telekomunikacyjnym nie opłaca się inwestować w małych miasteczkach i na wsiach z uwagi na wysokie koszty inwestycyjne i niskie przychody. Według raportu „ePolska” Ministerstwa Gospodarki za lata 2001-2006, ma się to zmienić. Jednym z planowanych kluczowych działań jest cel numer 4: „Teleinformatyka na obszarach wiejskich”, który ma się przyczynić do wzrostu liczby przedsięwzięć umożliwiających rozwój telekomunikacji na wsi oraz wspierania rozwoju społeczeństwa informacyjnego na terenach wiejskich. Już niedługo mieszkańcy wsi będą mogli swobodnie robić zakupy w sieci.

W Polsce zdecydowaną większość internetowych klientów stanowią mężczyźni, ale różnica w tej dziedzinie między mężczyznami a kobietami powoli zaczyna się zacierać. Wynika ona głównie z potrzeby dotknięcia i przymierzenia towaru, przez co kobiety na zakup decydują się rzadziej.

Ryc. 4. Porównanie sprzedaży produktów w latach 2005 i 2006

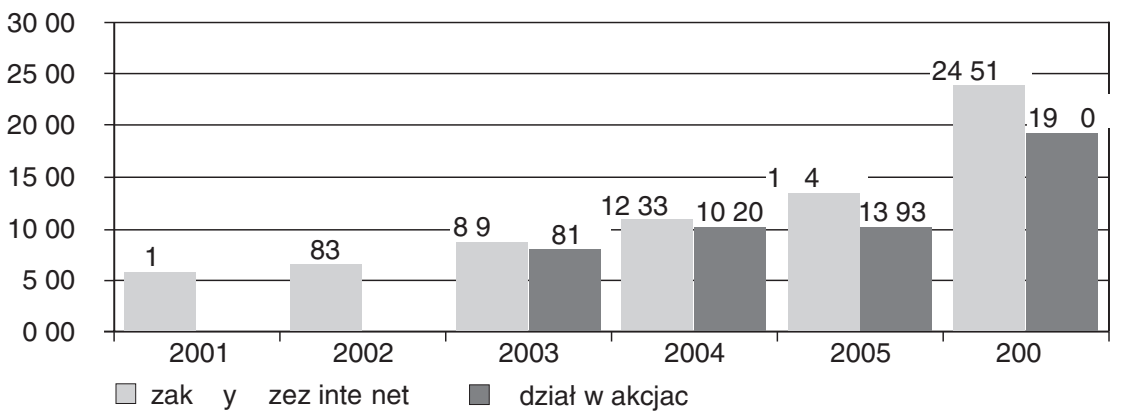

Źródło: Money.pl

Jedną z najpopularniejszych aukcji internetowych w Polsce jest Allegro. Według badań Megapanel Gemius/PBI, w sierpniu 2006 r. serwis miał jedną z największych liczbę odsłon, a liczba użytkowników wyniosła 6944 907. Allegro znalazło się na czwartej pozycji, po takich gigantach jak Google, Onet i Wirtualna Polska. Warto również wspomnieć, że za pośrednictwem Allegro w 2005 r. dokonano transakcji za ponad 1,5 mld zł.

\footnotetext{
${ }^{13} \mathrm{http}: / /$ www.wprost.pl/ar/?O=95333\&C $=57$

${ }^{14} \mathrm{http}: / /$ www.wprost.pl/ar/?O=95640
} 
Z raportu Money.pl i analizy 1172 opinii specjalistów z Ceneo.pl wynika, że z zakupów przez internet zadowolonych jest aż $82 \%$ internautów i tylko co 6 osoba ma problemy w sieci. To dobry i zachęcający wynik dla tych, którzy jeszcze nie robili zakupów w wirtualnym świecie.

\section{Bezpieczeństwo w sieci}

Bezpieczeństwo w sieci stało się istotne w 1988 r., w momencie zarażenia 6 tys. komputerów przez internetowego robaka (Internet Worm). Twórcą niebezpiecznego programu komputerowego był Robert Morris. Stworzył on samopowielający się kod, którego celem było wykazanie słabości systemów. W związku z tym wydarzeniem powstała organizacja CERT (Computer Emergency Response Team), która miała odpowiadać za bezpieczeństwo w sieci. Za straty wynoszące $10 \mathrm{mln}$ USD Morris został skazany na 3 lata obserwacji sądowej, 400 godzin pracy społecznej i grzywnę w wysokości 10 tys. USD. ${ }^{15}$

W Polsce instytucją odpowiedzialną za bezpieczeństwo w sieci jest CERT (Computer Emergency Response Team). ${ }^{16}$ CERT Polska jest zespołem powołanym do reagowania na zdarzenia naruszające bezpieczeństwo w sieci internetowej. CERT Polska działa od 1996 r. (do końca 2000 r. pod nazwą CERT NASK), a od 1997 r. jest członkiem FIRST (Forum of Incidents Response and Security Teams). W ramach tej organizacji współpracuje z podobnymi zespołami na całym świecie. Zespół CERT Polska działa w strukturach Naukowej i Akademickiej Sieci Komputerowej. Działalność zespołu jest finansowana przez NASK. Do głównych zadań zespołu należą:

- rejestrowanie i obsługa zdarzeń naruszających bezpieczeństwo sieci,

- alarmowanie użytkowników o wystąpieniu bezpośrednich dla nich zagrożeń, współpraca z innymi zespołami IRT (Incidents Response Team) w ramach FIRST,

- działania zmierzające do wzrostu świadomości dotyczącej bezpieczeństwa teleinformatycznego,

- badania i przygotowanie raportów dotyczących bezpieczeństwa polskich zasobów internetu,

- niezależne testowanie produktów i rozwiązań z dziedziny bezpieczeństwa teleinformatycznego,

- prace w dziedzinie tworzenia wzorców obsługi i rejestracji incydentów, a także klasyfikacji i tworzenia statystyk.

Do głównych zagrożeń w sieci należy zaliczyć: ${ }^{17}$

- uzyskanie przez osoby niepowołane dostępu do danych transmitowanych przez sieć lub przechowywanych w komputerach dołączonych do sieci,

- uzyskanie przez osoby niepowołane dostępu do innych zasobów (moc obliczeniowa komputerów itd.),

- utrata danych na skutek złośliwej ingerencji z zewnątrz,

- fałszerstwo danych (dotyczy zwłaszcza poczty elektronicznej, w której jest m.in. możliwość podszycia się pod innego nadawcę).

8 listopada 2001 r. Komitet Ministrów Rady Europy przyjął konwencję o cyberprzestępczości (ETS No. 185). 27 września 2006 r. konwencja została podpisana przez 43 sygnatariuszy, a 15 państw ją ratyfikowało. Polska podpisała konwencję 23 listopada 2001 r., ale dotychczas jej nie ratyfikowała. Konwencja zobowiązuje państwa-strony do zharmonizowania swoich przepisów karnych z przepisami konwencji w celu ujednolicenia zasad ścigania przestępstw komputerowych w skali ponadnarodowej oraz umożliwienia międzynarodowej współpracy krajowych organów ścigania. ${ }^{18}$

\footnotetext{
${ }^{15} \mathrm{http}: / /$ pl.wikipedia.org/wiki/Robak_Morrisa

${ }^{16} \mathrm{http}: / /$ www.cert.pl/index $3 . \mathrm{html}$ ?id=10

${ }^{17} \mathrm{http}: / /$ galaxy.uci.agh.edu.pl/ szymon/artykuly/iwp.html

${ }^{18} \mathrm{http}: / /$ www.pb.pl/content.aspx?sid=2284\& guid=80D20E88-CEA7-4027-B7FF-E139ABAF0B0B
} 
Przedsiębiorcy mogą spotkać się z łamaniem ich praw w internecie poprzez sprzedaż podrobionych towarów ze znakiem firmy, rejestrację domeny internetowej z zastrzeżonym znakiem firmy czy naruszeniem autorskich praw majątkowych. Internauci kupujący w sklepach internetowych czy na aukcjach obawiają się o bezpieczeństwo zawieranych transakcji, o brak przesyłki, brak zwrotu pieniędzy za zakupiony towar. Chociaż w większości klienci sieci są zadowoleni z zakupów, to jednak bywają ostrożni.

Popular Mechanics w 1949 r. stwierdził: „Już wkrótce komputery mogą ważyć nie więcej niż 1,5 tony". ${ }^{19}$ Czy ktoś, biorąc laptop do ręki, może sobie wyobrazić, jaki to musiał być komputer? Dzisiaj nikt się nad tym nie zastanawia. Komputer, internet to codzienna praca wielu z nas. Jeszcze 50 lat temu nikt nie zdawał sobie sprawy, że światem może zawładnać siła internetu, że będzie można tak łatwo porozumiewać się z przyjaciółmi, wysyłać listy pocztą elektroniczną, nie używając papeterii, sprawdzać poranną prasę, nie wychodząc z domu po gazety, czy robić zakupy. Obecnie świat rzeczywisty nie wyobraża sobie życia bez świata wirtualnego i nie mógłby już tak funkcjonować jak 50 lat temu. Internet to źródło informacji i otwarty rynek dla wszystkich firm. Wystarczy wpisać hasło, a z jego zasobów „wyskakuje” kilka tysięcy podstron na dany temat. Sam Bill Gates nie spodziewał się, że internet i komputery zawładną naszym życiem. Jeszcze w 1981 r. mówił: „640K powinno wystarczyć każdemu”.

Każda szanująca się firma ma już swój adres internetowy. Jest to najlepsza reklama, jaką firma może sobie sama zapewnić. Dzięki takim rozwiązaniom zyskuje możliwość globalnego rozwoju i pozyskiwania klientów z całego świata. Dlatego warto jest się rozwijać właśnie w sieci, budować swój wirtualny świat, który może przynieść zyski znacznie szybciej, niż świat rzeczywisty.

\section{Literatura}

1. Barrow C.,2006, Biznes w sieci, Felberg SJA, Warszawa

2. Ceny dostępu do Internetu w Polsce na tle wybranej grupy krajów europejskich III, IV kwartał 2005 i I kwartat 2006, Centrum im. Adama Smitha, Warszawa

3. Elektroniczna Gospodarka w Polsce, 2004, Raport przygotowany na zlecenie Ministerstwa Gospodarki i Pracy, Instytut Logistyki i Magazynowania, Poznań

4. Kociak W., Przeliorz K., 2006, Jak założyć skuteczny i dochodowy sklep internetowy, Helion, Gliwice

5. Raport „E-Polska” za lata 2001-2006, Ministerstwo Gospodarki

6. Trzech zwyktych studentów i ich niezwykty serwis, „Rzeczpospolita”, gazeta/Ekonomia, 240/2006

7. Wykorzystanie technologii informacyjno-telekomunikacyjnej w 2005 r., Główny Urząd Statystyczny, Warszawa 2006

\section{Adresy internetowe}

1.http://pl.wikipedia.org/wiki/Ray_Tomlinson

2. http://pl.wikipedia.org/wiki/Sklep_internetowy

3. http://pl.wikipedia.org/wiki/Robak_Morrisa

4. http://sklepy-internetowe.cogdziekupic.pl/historia_powstania

5. http://www.cs.put.poznan.pl/mmasewicz/

6. www.mgip.gov.p1/NR/rdonlyres/EC031149-D29D-477A-B6F2-8E96763BECE...

7. http://ecommerce.blox.pl/html/1310721,262146,21.html?63116

8. http://www.e-biznes.pl/inf/2006/16409,Skype_dla_malych_przedsiebiorstw.php

9. http://www.wprost.pl/ar/?O=95640

${ }^{19}$ Cytat pochodzi ze strony: http://www.cs.put.poznan.pl/mmasewicz/. 
10. http://www.cert.pl/index3.html?id=10

11. http://galaxy.uci.agh.edu.pl/ szymon/artykuly/iwp.html

12. http://www.pb.pl/content.aspx?sid=2284\&guid=80D20E88-CEA7-4027-B7FF-E139ABAF0B0B

13. http://skype.wiadomosc.info/index.php?s=\&mod=arts\&rid=4409

14. http://www.skyper.pl/nowosc/skype-30-proc-uzytkownikow-to-firmy

15. http://www.internetstandard.pl/news/119543.html

16. www.idg.pl

17. http://www.wprost.pl/ar/?O=95333\&C $=57$

18. http://www.wprost.pl/ar/?O=95640

19. www.money.pl

\section{Entrepreneurship on the Internet}

Entrepreneurship on the net makes the expansion possible in fields where in the real world very often it would be unworkable because of many obstacles and limiting factors like costs - which are quite simply to overcome on the net.

It is easy to set up a web site available to millions of people in the world who type the web site address or find what they are looking for in Google or via another search engine.

The Internet market is open to all ideas and hence we should take advantage thereof. The number of internet shops has increased by $100 \%$ against the numbers from last year. The number of buyers has increased as well. Thanks to the World Wide Web, e-mails and communicators, entrepreneurs have a chance to communicate with clients on a global scale.

It was merely not so long ago in 1977, when Ken Olson, the president and founder of the Digital Equipment Corp. Company stated, "there is no reason as to why anyone should want to have a computer at home". Today, most businesses, including most of us cannot imagine a life without a computer or the Internet that in the age of advanced technology has become a common work tool.

The work above presents the history of the Internet and the most important elements which have influenced its development and without which the virtual world would not have existed.

The thesis will present an in-depth look at the Internet's range and capacity, possibilities it creates, and also challenges the safety features Internet consumers face. Additionally it will provide explanations of the most important definitions used in the world of e-business. 
Jerzy Janczewski

Zespół Szkół w Żychlinie

\section{Uwarunkowania rozwoju przedsiębiorczości w małych warsztatach samochodowych}

Małe warsztaty należą do licznej grupy mikroprzedsiębiorstw. W literaturze takie mikrofirmy nazywane są lokomotywą przedsiębiorczości i stanowią jej synonim. W Polsce, po wstąpieniu do Unii Europejskiej, istnieją sprzyjające warunki rozwoju małych warsztatów samochodowych, a zatem i ich przedsiębiorczości. Wynikają one z dużego popytu na używane samochody i z unijnych dyrektyw wyzwalających konkurencyjność w motoryzacji. Ponadto małe warsztaty sąjuż w znacznym stopniu zakorzenione w warunkach gospodarki rynkowej; niektóre rodowodem sięgają czasów PRL-u, zdobyły doświadczenie i są uodpornione na czynniki hamujące przedsiębiorczość. Nauczyły się do perfekcji minimalizować koszty swej działalności. Barierami rozwoju małych warsztatów, a więc i rozwoju ich przedsiębiorczości, są przede wszystkim: niedostateczna wiedza i umiejętności z zakresu zarządzania, słabe wyposażenie techniczne i niewielkie możliwości finansowe. Od umiejętności pokonywania tych barier będzie w przyszłości zależała ich obecność na rynku.

\section{Rynek napraw w Polsce}

Analitycy zajmujący się rynkiem napraw samochodów najczęściej dzielą go na warsztaty niezależne, warsztaty autoryzowane przez producentów samochodów (typu dilerskiego) i warsztaty sieciowe (ryc. 1). Te ostatnie to warsztaty szybkiej obsługi, firm ubezpieczeniowych lub dużych hurtowni typu „,kierowniczego" lub warsztaty niezależne zrzeszone w sieci dystrybutorów i producentów części, tzw. właścicielskie. Ponadto na rynku napraw funkcjonują tzw. warsztaty garażowe typu „zrób to sam”, będące konsekwencją występowania szarej strefy oraz zamiłowania Polaków do samodzielnych napraw swoich pojazdów.

Ryc. 1. Rynek napraw w Polsce

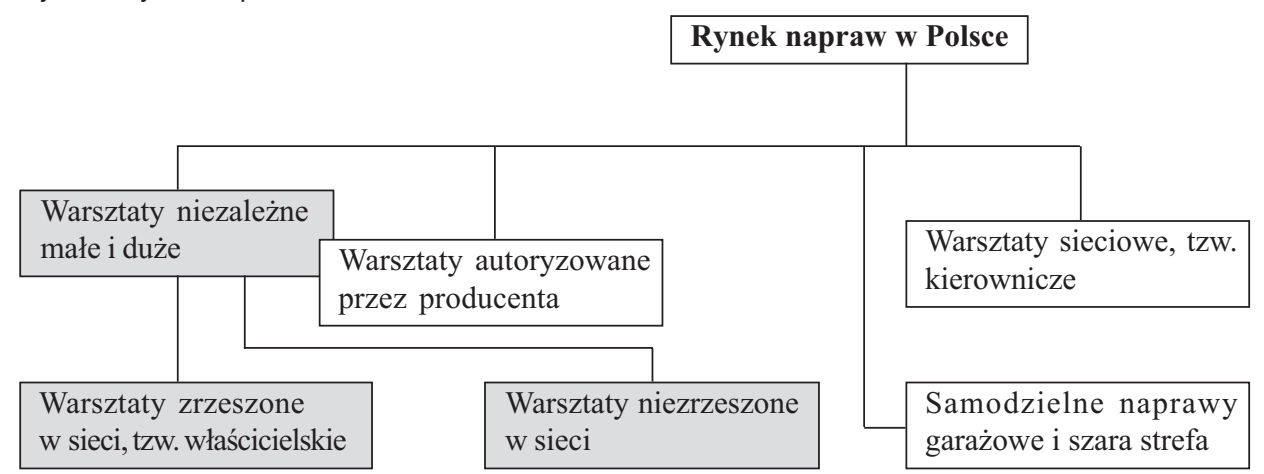

Źródło: opracowanie autora na podstawie: Inter Cars o sobie i o polskim rynku, „AutoExpert” 12/2004 
Podział rynku napraw w Polsce jest podobny do podziału tego typu przedsiębiorstw w pozostałych państwach Unii Europejskiej. Pewne różnice wynikają z przeszłości. Na polskim rynku są sklepy motoryzacyjne sprzedające części samochodowe, które oprócz warsztatów obsługują samodzielne naprawy garażowe i szarą strefę. W krajach tzw. „starej” Unii (UE-15) znajdują się również sklepy motoryzacyjne, ale ich oferta dotyczy głównie materiałów eksploatacyjnych - płynów, olejów, akumulatorów oraz akcesoriów - żarówek, dywaników, fotelików dla dzieci itp.

Tab. 1. Przedsiębiorstwa zajmujące się naprawami i obsługą pojazdów samochodowych w Polsce w 2005 r.

\begin{tabular}{|l|c|c|}
\hline \multicolumn{1}{|c|}{ Przedsiębiorstwa } & Szacunkowa liczba przedsiębiorstw & Udział (w \%) \\
\hline Warsztaty niezależne & 20000 & 82,0 \\
Warsztaty niezależne zrzeszone w sieci & 3000 & 12,3 \\
Razem warsztaty niezależne & 23000 & 94,3 \\
- warsztaty małe & 18300 & 75,1 \\
- warsztaty duże & 4700 & 19,3 \\
\hline Warsztaty autoryzowane & 1280 & 5,3 \\
Warsztaty sieciowe (kierownicze) & 100 & 0,4 \\
Ogółem & $\mathbf{2 4 3 8 0}$ & $\mathbf{1 0 0 , 0}$ \\
\hline
\end{tabular}

Źródło: opracowanie autora na podstawie materiałów: MotoFocus, InterCars, GIPA, Samar

Ryc. 2. Najważniejsze specjalizacje związane z eksploatacją współczesnego samochodu

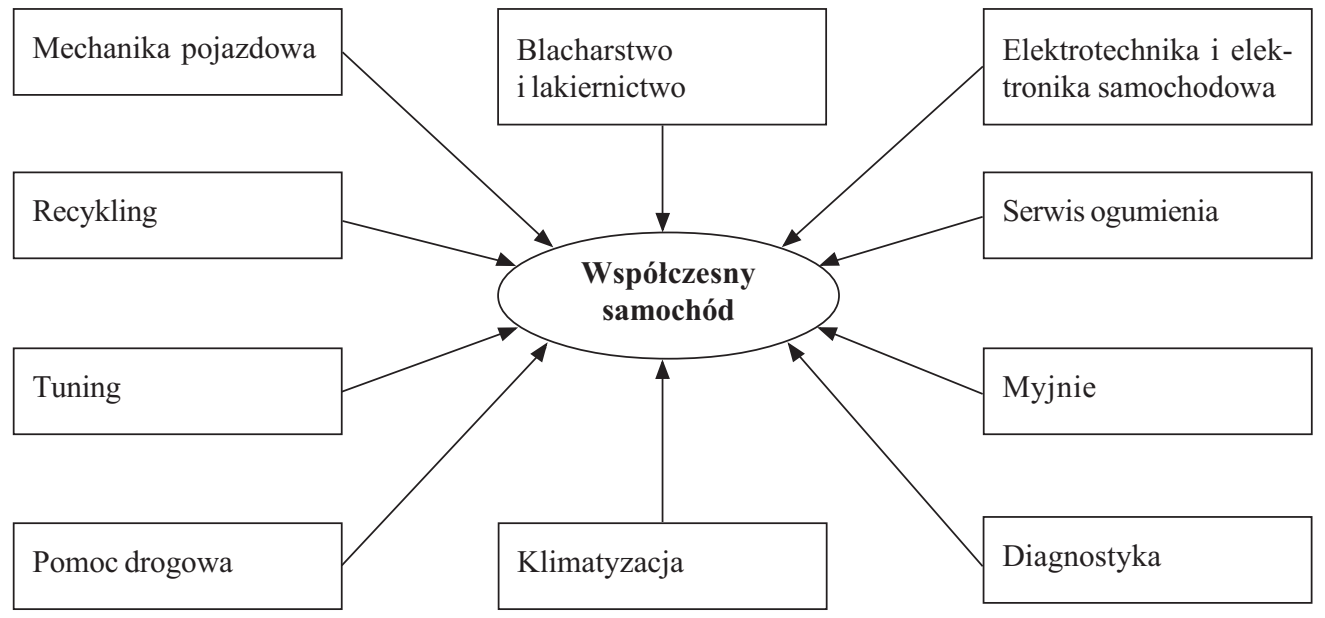

Źródło: opracowanie autora

Istotnym wyróżnikiem jest także sposób sprzedaży samochodów używanych; polską specjalnością są giełdy lub autokomisy. W krajach ,starej” Unii najczęstszym miejscem sprzedaży samochodu używanego jest salon dilera danej marki lub warsztat, w którym samochód był obsługiwany i naprawiany.

Najliczniejszą grupę przedsiębiorstw zajmujących się naprawami i obsługą samochodów stanowią małe warsztaty niezależne (tab. 1). Wykonują one naprawy pojazdów wielu marek; są słabiej wyposażone niż duże serwisy. Najczęściej dysponują jednym lub kilkoma stanowiskami. 
Ryc. 3. Wyposażenie warsztatów mechanicznych według ich wielkości

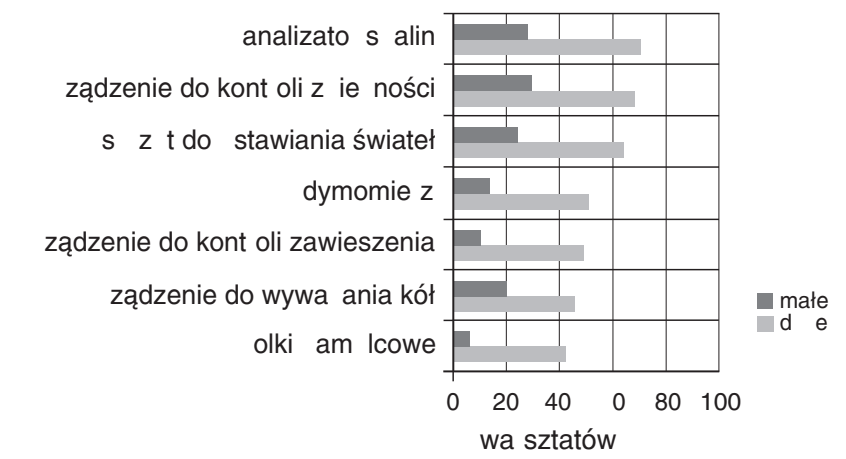

Źródło: opracowanie autora na podstawie: Badanie kanałów dystrybucji, GIPA, 12/2003

Oferują usługi w ograniczonym zakresie; naprawiają samochody starsze, mniej skomplikowane technicznie lub specjalizują się w jednej dziedzinie (ryc. 2). Wiele z nich, zwłaszcza blacharsko-lakierniczych, działa w szarej strefie (Steinbarth 2002). Niektóre lepiej wyposażone warsztaty niezależne, zwłaszcza duże, ale i niektóre małe, są zrzeszone w sieciach dystrybutorów lub producentów części samochodowych.

W Polsce według różnych szacunków (nie zawsze pełnych) działa około 25 tys. warsztatów świadczących usługi motoryzacjyjne. Tworzą one około 400 tys. stanowisk pracy. ${ }^{1}$ Są to dane orientacyjne; najbardziej prawdopodobne są szacunki firm Motofocus ${ }^{2}$ i Inter Cars (Gołąbek 2004), które przyjmują, że w Polsce działa około 20 tys. niezależnych warsztatów samochodowych, z czego $75 \%$ to warsztaty małe.

\section{Czynniki stymulujące lub hamujące przedsiębiorczość małych warsztatów}

W literaturze przedmiotu można znaleźć liczne przykłady analiz i badań czynników stymulujących lub hamujących przedsiębiorczość małych firm, które są wynikiem oddziaływania otoczenia na firmy. Rezultaty tych badań nie zawsze są porównywalne, zwłaszcza gdy postrzega się je przez pryzmat czasu, branży lub sektora. Różnie postrzegają je sami przedsiębiorcy. Wiele przytaczanych w literaturze czynników hamujących jest już drugiej rangi i ma znikome znaczenie dla przedsiębiorczości, choć niektóre wydają się uniwersalne i ponadczasowe. Ciagle bowiem to brak popytu, brak środków finansowych i koszty prowadzenia działalności postrzegane są w pierwszej kolejności jako bariery rozwoju małych firm. Są to bariery, które zapewne jeszcze długo (a może wcale) nie znikną. Można przyjąć, że lista zidentyfikowanych przeszkód utrudniających działalność i rozwój małych przedsiębiorstw w Polsce jest już pełna. Interesujące wydaje się wykonywanie takich analiz w ujęciu sektorowym, w którym wyraźnie uwydatniają się problemy branży.

W latach 2002 i 2003 pierwszoplanowymi barierami dla małych warsztatów niezależnych były podatki, małe obroty, koszty robocizny, przepisy prawne i biurokracja oraz brak pomysłu na dalszy rozwój warsztatu (Janczewski 2003). Większość tych barier pochodziła z zewnątrz firmy, a tylko jedna dotyczyła wnętrza warsztatów i wskazywała na bezradność kierownictwa w tworzeniu strategii dla dalszego rozwoju działalności. W tab. 2 przedstawione są najważniejsze czynniki stymulujące rozwój przedsiębiorczości w małych warsztatach samochodowych. Na podstawie

${ }^{1} \mathrm{Z}$ wypowiedzi organizatorów manifestacji w 2002 r., www.pim.org.pl, 29.03.2004 r.

${ }^{2}$ Rynek warsztatów w Polsce 2004/2005 - Raport, www.motofocus.pl, 12.03.2005 r.; Krótkie podsumowanie sieci warsztatowych, www.motofocus.pl, 9.06.2005 r. 
badań można uznać, że do grupy najważniejszych czynników wpływających na rozwój przedsiębiorczości w sektorze badanych przedsiębiorstw należą: czynniki rynkowe, uregulowania prawne oraz postęp techniczny w motoryzacji.

Problemy dotyczące zarządzaniem małymi warsztatami samochodowymi były przedmiotem badań GIPA (GIPA 2003). Miały ono na celu rozpoznanie problemów kierownictwa warsztatów niezależnych i autoryzowanych związanych z wykonywanym zawodem. Z badań wynikało, że dla warsztatów niezależnych, a więc i małych, najważniejszymi problemami w wykonywaniu zawodu były kłopoty z wyposażeniem, brak środków finansowych na jego zakupy, nienadążanie za postępem technologicznym oraz brak wykwalifikowanego personelu. Badania GIPA nie uwzględniały barier wynikających z zarządzania - niskiej skłonności warsztatów do tworzenia sieci i aliansów oraz do wykorzystania kreatywności pracowników, zdobywania wiedzy i braku strategicznego ,myślenia”.

Ryc. 4. Najważniejsze czynniki stymulujące lub hamujące przedsiębiorczość warsztatów samochodowych

\begin{tabular}{|l|l|}
\hline $\begin{array}{l}\text { Nieumiejętne zarządza- } \\
\text { nie, niska skłonność do } \\
\text { tworzenia sieci, aliansów, } \\
\text { zdobywania wiedzy }\end{array}$ \\
\hline $\begin{array}{l}\text { Rosnąca liczba używa- } \\
\text { nych samochodówi kon- } \\
\text { kurencja }\end{array}$ \\
\hline $\begin{array}{l}\text { Niski kapitał materialny } \\
\text { żemie warsztatu, poziom } \\
\text { wyszkolenia personelu }\end{array}$
\end{tabular}

Źródło: opracowanie autora

Przystąpienie Polski do Unii Europejskiej znacząco wpłynęło na poprawę sytuacji małych warsztatów samochodowych . Do najważniejszych elementów, które przyczyniły się do wzrostu przedsiębiorczości w małych warsztatach samochodowych, należał przede wszystkim napływ używanych samochodów z krajów UE. Likwidacja barier celnych, wprowadzenie dyrektywy GVO, przyjęcie dyrektywy o lotnych związkach organicznych LZO i ustawy o recyklingu samochodów wycofanych z eksploatacji - to również czynniki wpływające na rozwój tych przedsiębiorstw. Równie istotne były zmiany w prawie ubezpieczeniowym oraz działania dystrybutorów części i organizacji przedsiębiorców.

Najważniejszymi barierami hamującymi przedsiębiorczość małych warsztatów samochodowych są: niestabilna polityka podatkowa, trudności w pozyskaniu środków finansowych, koszty pracy, niewielki kapitał materialny i intelektualny warsztatów przejawiający się przestarzałym wyposażeniem i niskim poziomem wyszkolenia personelu, a także braki w zarządzaniu charakterystyczne dla większości małych firm. 
Analiza uwarunkowań rozwoju małych warsztatów samochodowych wskazuje na dużą różnorodność bodźców i barier przedsiębiorczości oraz na ich różne natężenie (tab. 2). Większość z nich nie zależy od przedsiębiorstw. Te same kwestie mogą być albo stymulatorami albo hamulcami dla przedsiębiorczości. Jednak po zbilansowaniu widać przewagę czynników stymulujących.

\section{Zasoby i zarządzanie jako najważniejsze determinanty rozwoju przedsiębiorczości małych warsztatów subregionu płockiego}

Większość małych warsztatów samochodowych subregionu płockiego (w którym przeprowadzono badania), podobnie jak i innych małych firm w Polsce, znajduje się w pierwszej fazie rozwoju, na etapie „narodzin i walki o przetrwanie”, inaczej: w fazie przedsiębiorczej. Faza ta trwa wiele lat; takie firmy to proste organizacje, w których właściciel sam formułuje cele i ustala zasady funkcjonowania. Podejmuje on decyzje, opierając się na własnej wiedzy i intuicji, niekiedy korzysta z zewnętrznego doradztwa. Właściciel małego warsztatu osobiście nadzoruje i ocenia pracowników według własnych, subiektywnych kryteriów. Z reguły realizuje strategię nastawioną na szybkie wykorzystanie pojawiających się szans. Często działa na zasadzie „straży pożarnej”. Pomija szanse, z których owoce można zebrać w bliżej nieokreślonej przyszłości. Rzadko potrafi wykorzystać szczególne szanse, które pozwoliłyby jego firmie wejść do następnej fazy rozwoju. Ta faza niekoniecznie musi przejawiać się rozwojem ilościowym. Mogą to być również zmiany jakościowe, do których należą zmiany w wyposażeniu i systemie zarządzania. Wiąże się to z powiększaniem kapitału materialnego i niematerialnego firmy.

Z badań autora wynika, że większość (62\%) małych warsztatów jest wyposażona tylko w podstawowe urządzenia i narzędzia do obsługi i naprawy samochodu: kanał, proste podnośniki, pistolet lakierniczy, narzędzia ręczne, rzadko narzędzia specjalistyczne. Nawet jeśli warsztat stać na zakup nowoczesnego sprzętu, to decyzję o zakupie odkłada się na bliżej nieokreślony termin. Narzędzia zmechanizowane, myjki do zespołów, podnośnik, sprzęt diagnostyczny i pozostałe nowoczesne wyposażenie obsługowo-naprawcze posiada około o $31 \%$ badanych firm. Jedynie $7 \%$ małych warsztatów (przeważnie te, które na mocy odpowiedniej ustawy prowadzą badania techniczne pojazdów) jest wyposażonych w sprzęt diagnostyczny na europejskim poziomie. Zaledwie kilka warsztatów blacharskich dysponuje kabiną lakierniczą i ramą naprawczą. Nie są to jednak urządzenia wykonane profesjonalnie.

Oprócz wyposażenia we właściwe narzędzia, na przedsiębiorczość małego warsztatu, a tym samym na jego zdolność do pokonywania barier, decydujący wpływ ma również wiedza właściciela i zatrudnionych przez niego pracowników. Stanowi ona o kapitale niematerialnym firmy. W badanych warsztatach przeważały osoby z wykształceniem średnim i zasadniczym zawodowym. Wśród właścicieli $67 \%$ osób miało wykształcenie średnie, a 24\% - wykształcenie zasadnicze, przeważnie o kierunku mechanik pojazdów samochodowych lub pokrewnym. Wyższe wykształcenie miało 8\%

Ryc. 5. Struktura wyposażenia małych warsztatów samochodowych

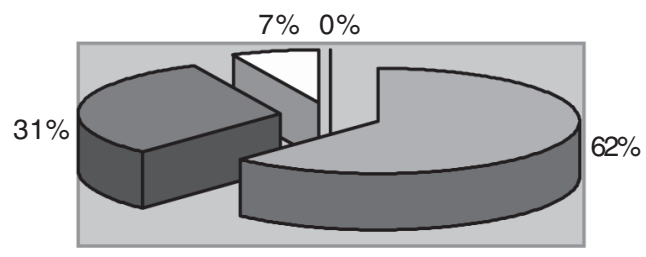

narzędzia podstawowe

narzędzia zmechanizowane, podnośnik

nowoczesny sprzęt diagnostyczny, rama naprawcza, kabina lakiernicza

Źródło: opracowanie autora na podstawie badań 
Tab. 2. Najważniejsze czynniki wpływające na przedsiębiorczość małych warsztatów samochodowych i ich natężenie

\begin{tabular}{|c|c|c|c|}
\hline \multirow{2}{*}{$\begin{array}{l}\text { Źródło } \\
\text { czynników }\end{array}$} & \multirow{2}{*}{$\begin{array}{l}\text { Najważniejsze czynniki pobudzające i hamujące } \\
\text { przedsiębiorczość małych warsztatów samochodowych }\end{array}$} & Bodziec & Bariera \\
\hline & & $\begin{array}{l}\text { natężenie } \\
\text { od } 1 \text { do } 3 \\
\end{array}$ & \begin{tabular}{|c|} 
natężenie \\
od - 1 do - 3
\end{tabular} \\
\hline \multirow[t]{5}{*}{ Rynek } & Rosnąca liczba używanych samochodów osobowych & +3 & \\
\hline & Szara strefa na rynku napraw & & -1 \\
\hline & Brak wykwalifikowanego personelu & & -1 \\
\hline & Konkurencja - ekspansja sieci warsztatowych & +3 & \\
\hline & $\begin{array}{l}\text { Oddziaływanie organizacji przedsiębiorców, producentów } \\
\text { i dystrybutorów części, placówek badawczych, szkoleniowych }\end{array}$ & +2 & \\
\hline \multirow[t]{2}{*}{ Finanse } & $\begin{array}{l}\text { Trudności z pozyskiwaniem środków na rozbudowę } \\
\text { i wyposażenie warsztatu }\end{array}$ & & -2 \\
\hline & Fundusze unijne, leasing, inne możliwości pozyskiwania finansów & +1 & \\
\hline \multirow[t]{4}{*}{ Polityka } & $\begin{array}{l}\text { Niekorzystna polityka podatkowa - zmiany w podatku od } \\
\text { używanych samochodów, zmiany akcyzy na paliwa, plany } \\
\text { likwidacji podatku zryczałtowanego, podatek VAT od zakupu } \\
\text { samochodów nowych przeznaczonych do działalności } \\
\text { gospodarczej }\end{array}$ & & -2 \\
\hline & $\begin{array}{l}\text { Silne lobby producentów samochodów, brak akceptacji } \\
\text { dla klauzuli napraw }\end{array}$ & & -3 \\
\hline & Koszty prowadzenia działalności & & -1 \\
\hline & Wsparcie dla małych przedsiębiorstw & +1 & \\
\hline \multirow[t]{4}{*}{ Prawo } & Wprowadzanie uregulowań GVO & +3 & \\
\hline & Zmiany w prawie ubezpieczeniowym & +1 & \\
\hline & Ustawa o samochodach wycofanych z eksploatacji & +1 & \\
\hline & Dyrektywa o lotnych związkach organicznych & +2 & \\
\hline Ekonomia & Poziom bezrobocia & +1 & \\
\hline Technika & Postęp techniczny w motoryzacji & +3 & \\
\hline \multirow{2}{*}{$\begin{array}{l}\text { Środowisko } \\
\text { naturalne }\end{array}$} & Rozwój sieci recyklingu samochodów & +1 & \\
\hline & Możliwości recyklingu produktowego & +2 & \\
\hline \multirow[t]{2}{*}{ Zasoby } & Niski kapitał materialny - wyposażenie warsztatu & & -2 \\
\hline & $\begin{array}{l}\text { Niski kapitał niematerialny - wykształcenie personelu, } \\
\text { certyfikaty jakości, specjalizacja }\end{array}$ & & -3 \\
\hline Zarządzanie & $\begin{array}{l}\text { Niedostateczna wiedza i umiejętności z zakresu zarządzania } \\
\text { - mała skłonność do stałego rozwoju własnych umiejętności } \\
\text { i zdobywania wiedzy, tworzenia sieci i aliansów, } \\
\text { wykorzystania kreatywności pracowników }\end{array}$ & & -3 \\
\hline Razem & & +24 & -18 \\
\hline
\end{tabular}

Źródło: opracowanie autora 
Ryc. 6. Struktura wykształcenia właścicieli warsztatów samochodowych

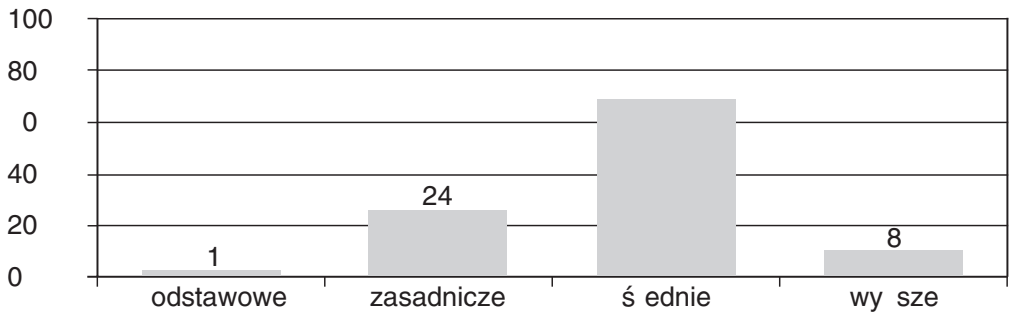

Źródło: opracowanie autora na podstawie badań

przedsiębiorców, a wykształcenie podstawowe - 1\%. Wśród pracowników także przeważało wykształcenie średnie (43\%) i zasadnicze zawodowe (43\%). Była także dość liczna grupa zatrudnionych z wykształceniem wyższym (14\%), głównie licencjackim, ale nietechnicznym.

Ryc. 7. Struktura wykształcenia pracowników małych warsztatów samochodowych

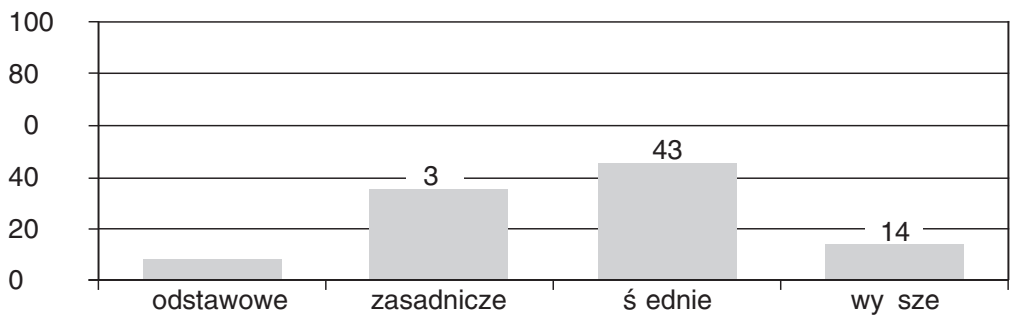

Źródło: opracowanie autora na podstawie badań

Kryterium jakości dla małego warsztatu określa, czy specjalizuje się on w wybranych usługach, czy posiada certyfikaty i autoryzacje producentów, czy wdraża uznane systemy jakości. Zdecydowana większość (86\%) małych warsztatów specjalizuje się w wybranych usługach, pozostali są „uniwersalni” i uważają, że w branży, w której działają, należy znać się na wszystkim. Większość wyspecjalizowanych umiejętności nie jest potwierdzona certyfikatami; małe warsztaty niezbyt o to dbają. Zapewne opierają się na opinii „złotej rączki”. Certyfikaty posiada jedynie $37 \%$ badanych warsztatów. Niewielka grupa, bo około 3\%, nie jest świadoma potrzeby jakiegokolwiek potwierdzania jakości usług. Wszystkie badane warsztaty nie mają autoryzacji producenta samochodów ani się o nią nie ubiegają. Żaden z nich nie uzyskał certyfikatu jakości, np. ISO.

Wiedza i umiejętności są istotnym kryterium oceny przedsiębiorczości każdej firmy (Dietl 2006). Umiejętności wyróżniające mały warsztat spośród otoczenia to przede wszystkim rezultat wykształcenia i wiedzy właściciela i pracowników. Wiedzy wymagają nie tylko nowoczesne modele samochodów, ale też nowe narzędzia i technologie. Stosunkowo niedawno, aby poprawnie naprawiać samochody, wystarczała znajomość budowy i zasad działania zespołów pojazdów i podstawowa wiedza z zakresu napraw mechanicznych i elektrycznych. Obecnie, aby zrozumieć budowę i funkcjonowanie większości zespołów, trzeba być również fachowcem w dziedzinie elektroniki; nie bez znaczenia jest złożoność urządzeń naprawczo-diagnostycznych. Niezbędna jest w warsztacie wiedza z zakresu zarządzania; dobrze zarządzany warsztat powinien przewidywać czas oraz zakres szkoleń doskonalących umiejętności pracowników. Charakterystycznymi cechami obrazującymi poziom poszerzenia wiedzy są częstotliwość dokształcania, poziom przeznaczanych na dokształcanie wydatków oraz formy dokształcania.

Z badań autora wynika, że istnieje grupa (28\%) małych warsztatów, która nie podnosi swoich kwalifikacji. Świadczy to, że w sektorze napraw samochodów mogą być tacy, którzy korzystają 
tylko z nabytej kiedyś wiedzy i nie widzą potrzeby jej aktualizowania. Głębsze badanie wykazało, że większość (52\%) właścicieli i pracowników małych warsztatów samochodowych dokształca się sporadycznie (od przypadku do przypadku), szczególnie wtedy, gdy zmusza ich do tego konieczność, np. brak informacji o budowie, zamiennikach lub danych regulacyjnych niezbędnych w naprawach i obsłudze samochodu. Pozostałe małe warsztaty przywiązują dużą wagę do dokształcania się: $35 \%$ czyni to systematycznie, a 13\% nastawia się na stałe dokształcanie. Wyniki badań autora są częściowo zbieżne z wcześniej cytowanymi badaniami GIPA, według których tylko $27 \%$ warsztatów niezależnych pomyślnie przechodzi przez szkolenia techniczne, a handlowe jeszcze mniej, bo zaledwie $8 \%$. Najmniej ze szkoleń korzystają warsztaty małe, jednostanowiskowe. Odwrotna sytuacja panuje w warsztatach autoryzowanych.

Zdobywanie wiedzy kosztuje. Z badań wynika, ze $42 \%$ małych warsztatów unika wydatków na dokształcanie. Zapewne nawet nie korzystają systematycznie z podstawowej prasy fachowej. Podobna liczba warsztatów (41\%) przeznacza niewielkie kwoty na dokształcanie się, ale oszczędza na takich wydatkach. Jedynie $17 \%$ badanych deklaruje, że na dokształcanie przewiduje pewien ułamek dochodu. Zdecydowana większość (62\%) małych warsztatów zdobywa informacje z popularnej prasy, z instrukcji, ulotek reklamowych lub od dostawców i kolegów z branży. Tylko 9\% uczęszcza na kursy lub studia podyplomowe, pozostali (29\%) czytają prasę i literaturę fachową, biorą udział w szkoleniach i korzystają z informacji w internecie.

Ryc. 8. Wydatki małych warsztatów samochodowych na dokształcanie

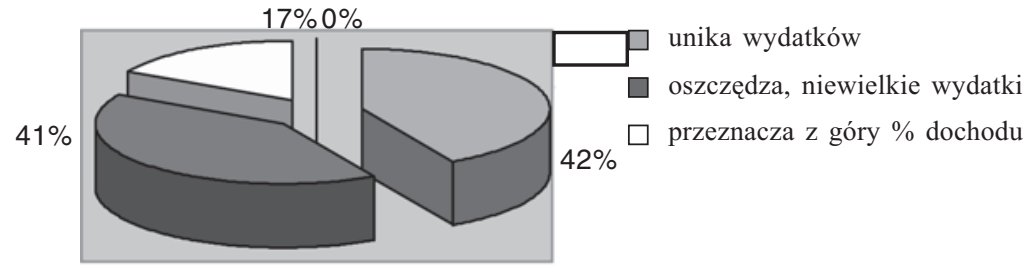

Źródło: opracowanie autora na podstawie badań

Ryc. 9. Formy dokształcania się personelu małych warsztatów samochodowych

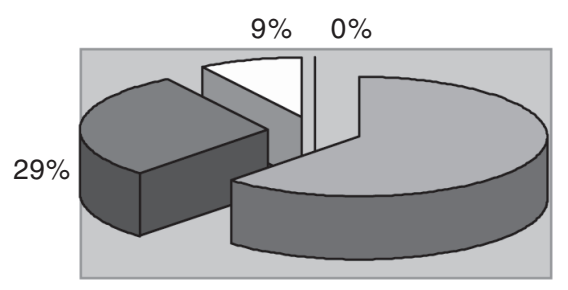

$\square$ popularna prasa, wiedza od dostawców

$\square$ szkolenia, fachowa prasa

$\square$ kursy, studia podyplomowe

Źródło: opracowanie autora na podstawie badań

Charakterystycznym przejawem przedsiębiorczości małych warsztatów jest współpraca z innymi firmami, także z konkurencyjnymi. Współpraca ta wyraża się m.in. przynależnością warsztatu do cechu, izby, sieci warsztatowej, tworzeniem nowych przedsiębiorstw lub innych aliansów strategicznych Małe warsztaty przeważnie działają w osamotnieniu (78\%). Na ,syndrom samotnika", oznaczający znikomą skłonność małych firm do współpracy z innymi, wskazuje H. Bieniok (Bieniok 2003). Syndrom samotnika w warsztatach zapewne wynika z ich głębokiego poczucia własnej niezależności i obawy przed utratą choćby kawałka tego przywileju. Jest to podejście niesłuszne, ogranicza bowiem możliwości rozwojowe firmy. Łączenie się w grupy pozwala na 
podział obowiązków; łatwiej wówczas nadążać za postępem w dziedzinie techniki i organizacji pracy. Rozwój różnego rodzajów sieci warsztatowych potwierdza korzyści ze stowarzyszania się. Wspólne akcje marketingowe, zespołowe szkolenia i zdobywanie wiedzy technicznej ułatwiają prowadzenie warsztatu. Można równolegle należeć do kilku stowarzyszeń, jeśli jest taka potrzeba.

Ryc. 10. Formy przynależności małych warsztatów samochodowych

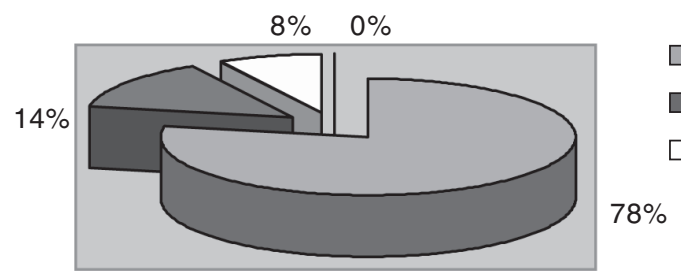

brak przynależności

cech, izba, inna forma

$\square$ sieć, tworzenie wspólnych przedsiębiorstw

Źródło: opracowanie autora na podstawie badań

Ryc. 11. System wynagradzania za pracę w warsztatach samochodowych

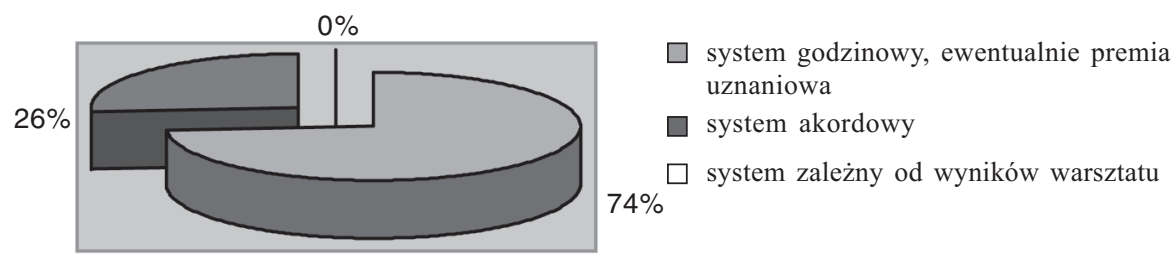

Źródło: opracowanie autora na podstawie badań

Aby warsztaty mogły zostać uznane za przedsiębiorcze, powinny wiązać wynagrodzenie za pracę z wynikami finansowymi, co skutecznie stymuluje przedsiębiorczość pracowników. Takie podejście uwalnia u zatrudnionych inicjatywę i zaradność. Niestety, w większości małych warsztatów nie stosuje się takiego systemu. Większość małych warsztatów (74\%) stosuje godzinowy system. Podstawą do wyliczenia stawki jest obowiązująca miesięczna płaca minimalna. Do tak konstruowanego systemu dochodzi premia uznaniowa, najczęściej wypłacana okazjonalnie. Pozostałe $26 \%$ warsztatów stosuje inny system płac niż godzinowy, np. prowizyjny lub zadaniowy.

\section{Podsumowanie}

Na podstawie badań własnych autora, których celem było rozpoznanie najważniejszych determinant rozwoju przedsiębiorczości małych warsztatów samochodowych subregionu płockiego, można stwierdzić, że większość małych warsztatów w niewielkim stopniu dostosowuje się do zmian otoczenia, w którym działa. Stosują one strategie bierne, nastawione na przetrwanie, a nie na rozwój; ich plany są krótkookresowe. Brak im długookresowej wizji rozwoju firmy i nastawienia marketingowego.

Małe warsztaty mają duże braki w wyposażeniu technicznym; wiele z nich korzysta tylko z podstawowych narzędzi ręcznych i tradycyjnego kanału; brakuje im nowoczesnego sprzętu diagnostycznego. Nie zabiegają o potwierdzenie jakości swoich usług. Dysponują niewielkimi zasobami niematerialnymi, do których należy zaliczyć niskie kwalifikacje personelu, który nie dokształca się systematycznie. Na zdobywanie wiedzy właściciele przeznaczają skromne środki i nie planują ich w swoich budżetach. Tylko kilka procent uczęszcza na szkolenia, kursy lub studia podyplomowe. Małe warsztaty w większości działają w osamotnieniu. Nie należą do cechu, sieci, organizacji przedsiębiorców, nie tworzą wspólnych przedsięwzięć. Marnotrawią zaradność i inicjatywę pracowników. 
Właściciele małych warsztatów oceniają swoją działalność w sposób subiektywny, przeceniają swoje kwalifikacje oraz możliwości działania swoich firm i uznają je za przedsiębiorcze, innowacyjne i konkurencyjne. Może to wynikać z niedostatecznej wiedzy marketingowej, braku umiejętności analizy otoczenia konkurencyjnego i analizy rynku, na którym działają. Pojawia się zatem potrzeba zaproponowania modelu oceny i analizy sektora małych warsztatów samochodowych dostosowanego do możliwości i poziomu wiedzy przedsiębiorców.

\section{Literatura}

1. Badanie kanałów dystrybucji, GIPA, 12/2003

2. Bieniok H., Ocena kondycji ekonomicznej oraz stopnia przedsiębiorczości i konkurencyjności małych $i$ średnich przedsiębiorstw prywatnych województwa ślaskiego [w:] H. Bieniok (red.], Przedsiębiorczość, konkurencyjność oraz kondycja małych i średnich przedsiębiorstw w obliczu integracji z Uniq Europejska, 2003, Wydawnictwo Akademii Ekonomicznej w Katowicach, Katowice

3. Dietl J., 2006, Przedsiębiorczość, Wyższa Szkoła Biznesu w Nowym Sączu, Nowy Sącz

4. Gołąbek T., Porzadek $i$ wielka improwizacja, „Świat Motoryzacji” 6/2004

5. InterCars o sobie i o polskim rynku, „AutoExpert” 12/2004

6. Janczewski J., Sytuacja małych przedsiębiorstw ustugowych sektora motoryzacyjnego, „Notatki Płockie" 3/196/2003

7. Janczewski J., 2003, Wybrane aspekty funkcjonowania matego przedsiębiorstwa branży motoryzacyjnej w dużym mieście i na rynku wiejskim [w:] M. Trocki, K. Krajewski (red.), Przedsiębiorczość w Polsce w perspektywie integracji z Uniq Europejska, IPiS, Warszawa

8. Steinbarth J., Traci budżet $i$ właściciele aut, „Gazeta Prawna” 199/2002

\section{Adresy internetowe}

1. Instytut Samar: www.samar.pl

2. Motofocus: www.motofocus.pl

3. Polska Izba Motoryzacji: www.pim.org.pl

\section{Conditions for Enterprise Development in Small Car Workshops}

The most important organizational and technical conditions for the development of the enterprise in small car workshops are presented in the report. Small workshops belong to the numerous group of small enterprises. In the literature of SMEs they are called the "smithy of the entrepreneurship" and make up their synonym. Small workshops are already considerably rooted in the environment of the market economy. Some of them were founded in the times of PRL, and possessed rich experiences. They have learned to perfectly minimalize the costs of their businesses.

After the access to EU favorable conditions for the development of the enterprise in small car workshops exist in Poland. They are the effect of the demand for used cars from western EU that liberated competitiveness in the auto industry.

Numerous conditions are results of weak management and equipment - they are the barriers to technical and financial opportunities. Generally the small workshops apply passive strategies directed to the survival. 


\section{Zbigniew Ożdżyński}

Zespół Szkół im. S. Staszica w Gąbinie

\section{Przedsiębiorczość a bezpieczeństwo ruchu drogowego}

Przedsiębiorczość jest pojęciem dobrze znanym, lecz różnie rozumianym przez ludzi różnych zawodów i o różnych zainteresowaniach. Najbardziej popularne definicje i koncepcje przedsiębiorczości stwierdzają, że polega ona na podejmowaniu wszelkich działań przynoszących korzyści w danej dziedzinie. Bezpieczeństwo ruchu drogowego to stan niezagrożenia jego uczestników. W celu zapewnienia bezpieczeństwa ruchu drogowego konieczne jest podejmowanie działań, które nie tylko utrzymają istniejący stan, ale przyczynią się do jego poprawy. Przedsiębiorczość w bezpieczeństwie ruchu drogowego należy zatem określić jako wszelkie działania prowadzące do jego poprawy.

\section{Stan bezpieczeństwa ruchu drogowego w Polsce}

W ostatnich latach nastąpił w Polsce szybki i dynamiczny rozwój motoryzacji. Za tym tempem nie nadąża rozwój infrastruktury drogowej. Poruszanie się po ulicach i drogach stało się najbardziej niebezpieczną czynnością współczesnego człowieka. Według Krajowego Programu Bezpieczeństwa Ruchu Drogowego Gambit 2005 [2], w latach 2000-2004 w wypadkach drogowych w Polsce:

- poniosło śmierć 29 tys. osób, co oznacza, że na drogach ginie około 5800 osób rocznie;

- rannych było 335 tys. osób, czyli około 67 tys. osób rocznie;

- koszty zdarzeń drogowych wyniosły prawie 150 mld zł, czyli 30 mld zł rocznie.

Ryc. 1. Liczba ofiar śmiertelnych wypadków drogowych w Polsce w latach 2000-2004

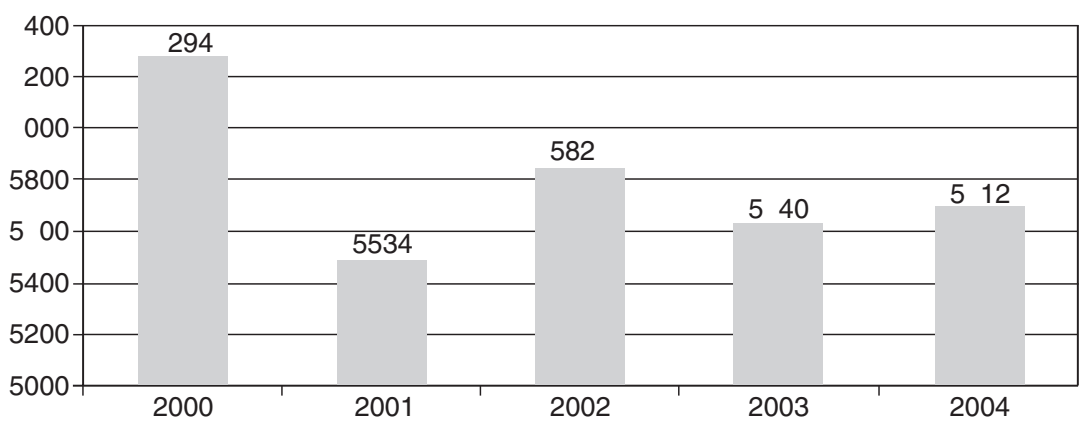

Źródło: opracowanie autora na podstawie Gambit 2005 oraz danych KG Policji, http://www.policja.pl/?dzial=8

W latach 2000-2003 liczba ofiar śmiertelnych w wypadkach drogowych malała średnio o 2,2\% rocznie; w 2003 r. wyniosła 5640. W 2004 r. wzrosła do 5712 osób (ryc. 1).

W 2003 r. podstawowe wskaźniki bezpieczeństwa ruchu drogowego w Polsce dotyczące ofiar śmiertelnych wynosiły (Gambit 2005):

- 14,7 ofiar śmiertelnych na 100 tys. mieszkańców,

- 3,5 ofiar śmiertelnych na 10 tys. pojazdów, 
- 31,6 ofiar śmiertelnych na 1 mld pojazdokilometrów,

- 11,2 ofiar śmiertelnych/100 wypadków.

Te wskaźniki kształtują się na poziomie notowanym w latach 70. XX w. w Szwecji, Holandii i Wielkiej Brytanii i są ponaddwukrotnie wyższe od obecnie notowanych (tab. 1). Grupami szczególnie wysokiego ryzyka śmierci w wypadku drogowym są piesi, dzieci, rowerzyści oraz młodzi kierowcy. Wskaźnik udziału ofiar śmiertelnych wśród niechronionych uczestników ruchu drogowego wynosi $46 \%$, w tym:

- piesi biorą udział w $33 \%$ wypadków i stanowią $34 \%$ ofiar śmiertelnych, podczas gdy podróże piesze to około $22 \%$ ogółu podróży;

- rowerzyści stanowią $12 \%$ ofiar śmiertelnych, podczas gdy podróże rowerem to zaledwie 1-2\% ogółu podróży.

W przeliczeniu na 100 tys. mieszkańców wskaźnik ten wynosi 6,8 ofiar i jest jednym z najwyższych w Europie.

Tab. 1. Wybrane wskaźniki bezpieczeństwa ruchu drogowego w wybranych krajach UE w 2003 r.

\begin{tabular}{|l|c|c|c|}
\hline \multicolumn{1}{|c|}{ Kraj } & $\begin{array}{c}\text { Liczba mieszkańców } \\
\text { (w mln) }\end{array}$ & $\begin{array}{c}\text { Liczba ofiar } \\
\text { śmiertelnych }\end{array}$ & $\begin{array}{c}\text { Wskaźnik liczby } \\
\text { ofiar śmiertelnych } \\
\text { na 100 tys. mieszk. }\end{array}$ \\
\hline Polska & 38,6 & 5640 & 14,7 \\
\hline Czechy & 10,3 & 1447 & 14,1 \\
\hline Francja & 59,2 & 6058 & 10,2 \\
\hline Niemcy & 82,2 & 6613 & 8,0 \\
\hline Holandia & 15,9 & 1028 & 6,4 \\
\hline Wielka Brytania & 59,8 & 3658 & 6,1 \\
\hline Szwecja & 8,9 & 530 & 5,9 \\
\hline
\end{tabular}

Źródło: Gambit 2005: http://www.krbrd.gov.pl/gambit/gambit_2005.htm, sierpień 2006 r.

Główne problemy bezpieczeństwa ruchu drogowego w Polsce to:

- niebezpieczne zachowania uczestników ruchu, związane z nieprzestrzeganiem przepisów ruchu, w tym: jazda z nadmierną prędkością, nietrzeźwość użytkowników dróg, niski stopień stosowania urządzeń bezpieczeństwa (pasy, urządzenia zabezpieczające dzieci, kaski ochronne), brak poszanowania praw innych uczestników ruchu;

- niska jakość infrastruktury drogowej, m.in.: brak wystarczającej hierarchizacji dróg i niedostosowanie ich do pełnionych funkcji, niebezpieczne obiekty w pasie drogowym, przejścia dróg tranzytowych przez miasta i miejscowości, obudowywanie dróg na znacznej ich długości, błędne rozwiązania skrzyżowań i przejść dla pieszych.

\section{Kierunki dzialań przedsiębiorczych w bezpieczeństwie ruchu drogowego}

Przedstawiony w krótkim zarysie stan bezpieczeństwa w ruchu drogowym w Polsce wskazuje na konieczność podjęcia natychmiastowych działań przedsiębiorczych w celu jego poprawy. Wspomniany program Gambit 2005 wyróżnia trzy podstawowe obszary działań: centralne, sektorowe oraz regionalne i lokalne - wraz z kierunkami i ich zakresem tematycznym.

Działania centralne polegają na stworzeniu odpowiednich aktów prawnych (ustaw), możliwości ich realizowania, finansowania oraz wskazania podmiotów odpowiedzialnych za ich realizację. Jako przykład może posłużyć ustawa Prawo o ruchu drogowym, stanowiąca podstawę do 
opracowania wielu rozporządzeń, np. rozporządzenia w sprawie szkolenia, egzaminowania i uzyskiwania uprawnień przez kierujących pojazdami, instruktorów i egzaminatorów czy rozporządzenia w sprawie znaków i sygnałów drogowych. Za działania centralne odpowiedzialne są Sejm i Senat.

Ryc. 2. Kierunki działań w obszarze centralnym

\section{DZIAŁANIA CENTRALNE}

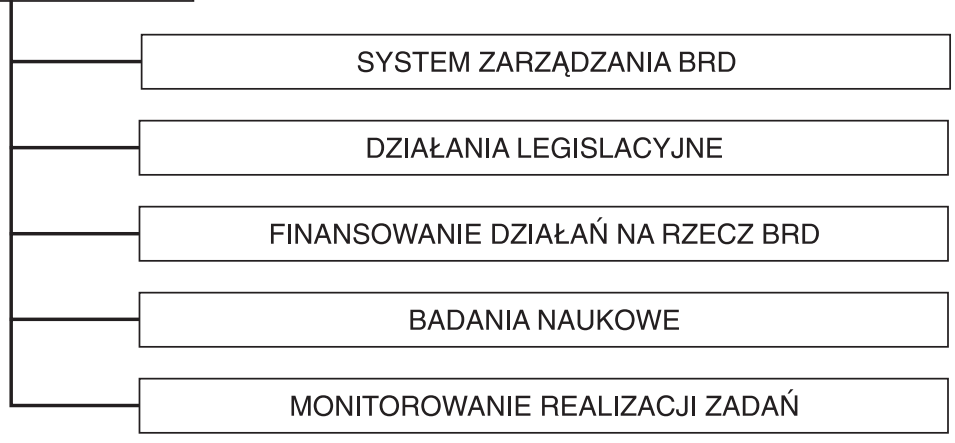

Źródło: opracowanie autora na podstawie Krajowego Programu Bezpieczeństwa Ruchu Drogowego 2005-2007-2013, Gambit 2005, przyjętego przez Radę Ministrów 19.04.2005 r., http://www.krbrd.gov.pl/gambit/gambit_2005.htm, sierpień 2006 r.

W wyniku działań sektorowych powstają akty wykonawcze w postaci rozporządzeń opracowywanych na podstawie ustaw. Za działania edukacyjno-propagandowe na tym poziomie są odpowiedzialni: Ministerstwo Edukacji Narodowej oraz - z ramienia Ministerstwa Transportu i Budownictwa - Krajowa Rada Bezpieczeństwa Ruchu Drogowego. Za stan dróg z ramienia Ministerstwa Transportu i Budownictwa odpowiedzialna jest Generalna Dyrekcja Dróg Krajowych i Autostrad.

Działania centralne i sektorowe dostosowane do potrzeb lokalnych przyjmują postać działań regionalnych i lokalnych prowadzonych na poziomie województw, powiatów i gmin, realizowanych w ramach formułowanych na tych poziomach programów bezpieczeństwa ruchu drogowego. Działania te powinny przede wszystkim odzwierciedlać lokalną specyfikę problemów i zagrożeń w następujących kierunkach:

- budowa regionalnych i lokalnych struktur bezpieczeństwa ruchu drogowego,

- edukacja w zakresie bezpieczeństwa ruchu drogowego,

- nadzór nad ruchem drogowym,

- inwestycje w infrastrukturę drogową i system ratownictwa drogowego.

Programy te powinny także realizować cele krajowe, z koniecznym wsparciem tych działań z poziomu centralnego.

\section{Działania przedsiębiorcze w edukacji}

Najważniejszym czynnikiem bezpieczeństwa w ruchu drogowym jest edukacja. Do priorytetów w tej dziedzinie należą działania dydaktyczne, wychowawcze i opiekuńcze. Ważną misją edukacji jest kształcenie bezpiecznych postaw oraz odpowiedzialności za przestrzeganie prawa i zachowanie na drogach. Dotyczy ona dzieci i młodzieży, a także rodziców, opiekunów i nauczycieli. Działania w tym zakresie prowadzą: Krajowa Rada Bezpieczeństwa Ruchu Drogowego, 
Rys. 3. Kierunki działań w obszarze sektorowym

\section{DZIAŁANIA SEKTOROWE}

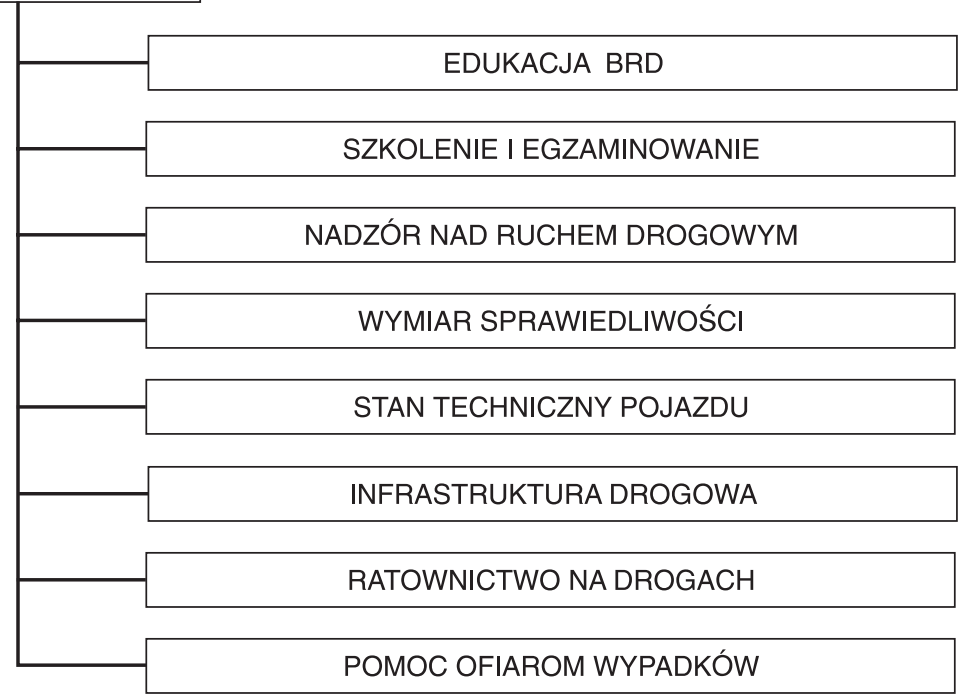

Źródło: opracowanie autora na podstawie Krajowego Programu Bezpieczeństwa Ruchu Drogowego 2005-2007-2013, Gambit 2005, przyjętego przez Radę Ministrów 19.04.2005 r., http://www.krbrd.gov.pl/gambit/gambit_2005.htm, sierpień 2006 r.

Wojewódzkie Ośrodki Ruchu Drogowego, Policja oraz Ministerstwo Edukacji Narodowej. Krajowa Rada Bezpieczeństwa Ruchu Drogowego prowadzi działalność edukacyjną głównie w formie analizy statystyk, szkolenia kadr bezpieczeństwa ruchu drogowego, medialnych kampanii edukacyjnych i akcji sezonowych. Wojewódzkie Ośrodki Ruchu Drogowego przeprowadzają egzaminy kandydatów na kierowców w zakresie wszystkich kategorii prawa jazdy, szkolenia kandydatów na instruktorów nauki jazdy, szkolenia kierowców na przewóz materiałów niebezpiecznych oraz reedukację kierowców. Policja, oprócz działalności statutowej, zajmuje się prewencją: przeprowadza liczne akcje uświadamiające oraz pogadanki w szkołach. Ministerstwo Edukacji Narodowej potraktowało zagadnienia bezpieczeństwa w ruchu drogowym marginesowo, wtłaczając je w ramy różnych przedmiotów. Tylko w nauczaniu zintegrowanym podstawowe treści bezpieczeństwa w ruchu drogowym mogą być przekazywane systematycznie. Na poziomie szkoły podstawowej i gimnazjum te treści są przekazywane na lekcjach techniki $\mathrm{i}$ - pośrednio - na pozostałych przedmiotach oraz jako program wychowawczy szkoły. Na kolejnych etapach edukacji - w klasach starszych szkoły podstawowej i w gimnazjum, obejmujących uczniów w wieku 10-16 lat, bezpieczeństwo w ruchu drogowym nie jest realizowane w ramach odrębnego przedmiotu. Realizacja odbywa się w sposób bezpośredni na lekcjach techniki oraz - pośrednio - na pozostałych przedmiotach, a także jako program wychowawczy szkoły. W praktyce edukacja dla bezpieczeństwa w ruchu drogowym została rozproszona na wiele różnych przedmiotów, a jej realizacja pozostawia wiele do życzenia ze względu na brak przygotowania kadry nauczycielskiej na wszystkich szczeblach nauczania, mimo że są to wspaniali pedagodzy. Nie jest to ich wina; system kształcenia nauczycieli pomija to zagadnienie. Jeśli do tego dodamy fakt, że nauka w wielu przypadkach odbywa się w klasie liczącej około 30 osób, to otrzymamy obraz współczesnego kształcenia nie tylko w tym zakresie. Co prawda nauczyciele mają możliwość 
dokształcania się w zakresie wychowania komunikacyjnego na poziomie studiów podyplomowych, ale kształtują one umiejętność nauczania przy założeniu, że nauczyciele znają przepisy ruchu drogowego. Z przytoczonych rozważań wynika, że:

- do dalszych etapów kształcenia w zakresie bezpieczeństwa w ruchu drogowym przechodzi młody człowiek mający mgliste pojęcie o podstawowych zasadach ruchu drogowego, bez wyrobionych nawyków bezpiecznego zachowania się na drodze;

- profesjonalne zajęcia z przepisów ruchu drogowego na szczeblach podstawowym i wyższym prowadzone są dopiero w ośrodkach szkolenia kierowców (OSK);

- OSK są podstawowym ogniwem w edukacji społeczeństwa w zakresie bezpieczeństwa w ruchu drogowym.

OSK może być prowadzony przez przedsiębiorcę lub szkołę ponadgimnazjalną kształcącą w specjalnościach samochodowych, co znacznie zawęża krąg chętnych. OSK prowadzony przez przedsiębiorcę stał się podstawowym ogniwem w edukacji społeczeństwa w zakresie bezpieczeństwa w ruchu drogowym. Strukturę organizacyjną, zakres działalności oraz cel edukacyjny OSK określa rozporządzenie w sprawie szkolenia, egzaminowania i uzyskiwania uprawnień przez kierujących pojazdami, instruktorów i egzaminatorów (Rozporządzenie Ministra Infrastruktury $\mathrm{z}$ dnia 27.10.2005 r.). To rozporządzenie określa m.in. wymagania $\mathrm{w}$ stosunku do podmiotów prowadzących szkolenie w zakresie wyposażenia dydaktycznego, warunków lokalowych, placu manewrowego i pojazdów przeznaczonych do szkolenia. Jest ono podstawą do stworzenia właściwej struktury organizacyjnej OSK (ryc. 4), zapewniającej osiąnnięcie celu edukacyjnego, czyli przygotowanie osób ubiegających się o uprawnienia do kierowania (prawo jazdy) do świadomego i bezpiecznego uczestnictwa w ruchu drogowym.

Oprócz statutowej działalności, OSK powinny prowadzić inne działania edukacyjne, poprzez nawiązanie współpracy z instytucjami, np. urzędami pracy, w celu organizacji kursu na prawo jazdy, czy ze szkołami, w celu organizacji imprez plenerowych lub prowadzenia lekcji otwartych z zakresu bezpieczeństwa w ruchu drogowym. Inne propozycje dotyczące działalności OSK to:

- rozszerzenie oferty edukacyjnej o kursy dla absolwentów OSK w celu doskonalenia nabytych umiejętności,

- publikacje prasowe popularyzujące bezpieczeństwo w ruchu drogowym.

\section{Działania przedsiębiorcze w zakresie budowy ,bezpiecznych pojazdów”}

Budowa „,bezpiecznych pojazdów” mieści się w szeroko rozumianym zakresie ich stanu technicznego. Pod tym pojęciem należy rozumieć nie tylko bezpieczeństwo kierowcy i pasażerów, ale także bezpieczeństwo pieszych i rowerzystów. W zakresie ochrony niechronionych uczestników ruchu proponowane są rozwiązania oparte na następujących koncepcjach:

1. ochrona w chwili zderzenia (bezpieczeństwo bierne):

- poduszki powietrzne dla niechronionych uczestników ruchu,

- wykorzystanie przedniej pokrywy (silnika lub bagażnika) jako stalowej ,poduszki” chroniącej pieszego,

- połączenie powyższych rozwiązań w jeden system;

2. ochrona przed zderzeniem (bezpieczeństwo czynne) oparta na komputerowych systemach rozpoznania przeszkód i kierowania ruchem pojazdu w celu ominięcia przeszkody lub zatrzymania go przed tą przeszkodą.

Nad rozwiązaniami dotyczącymi poduszek powietrznych chroniących pieszych pracuje wiele koncernów samochodowych i firm produkujących osprzęt. Na przykład szwedzka firma Autoliv proponuje system PPA (Pedestrian Protection Airbag), będący nietypową poduszką gazową, 
Ryc. 4. Struktura organizacyjna ośrodka szkolenia kierowców

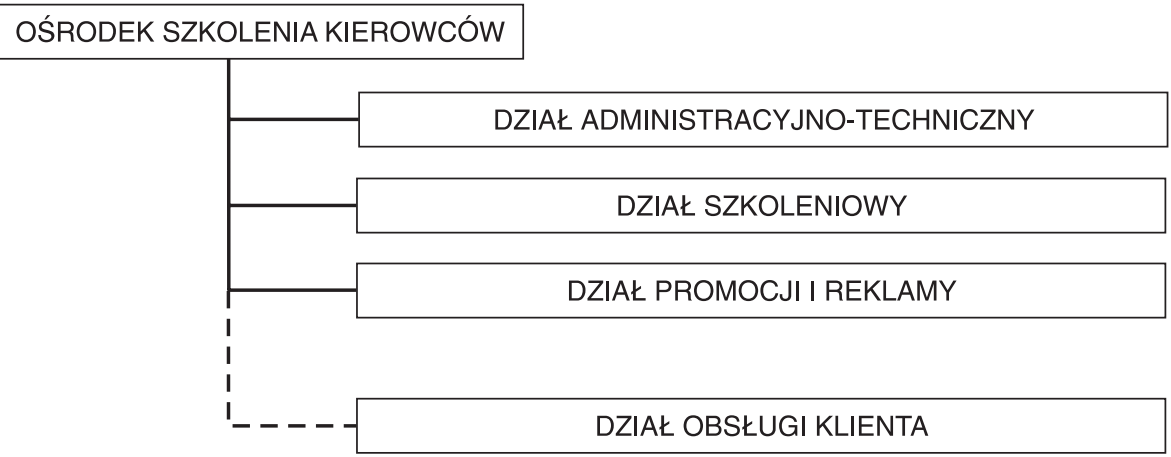

Źródło: opracowanie autora

która w chwili kolizji rozwija się na przedniej szybie (ryc. 5). Badania nad zaawansowanym systemem ochrony niechronionych uczestników ruchu opartym na komputerowych systemach rozpoznania i kierowania pojazdem prowadzone są przez koncern Daimler-Chrysler (ryc. 6).

Ryc. 5. System PPA w czasie próby zderzeniowej z manekinem

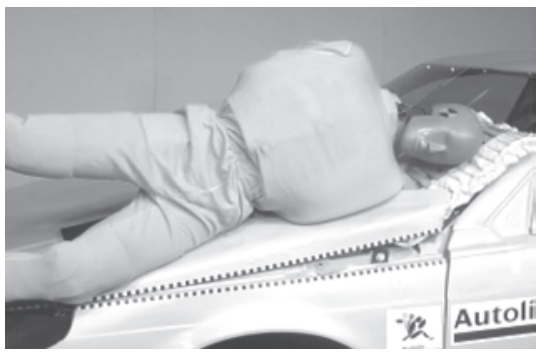

Źródło: Sobieraj (2002)

Ryc. 6. Komputerowy system analizy obrazu w czasie rzeczywistym podczas próby miejskiej

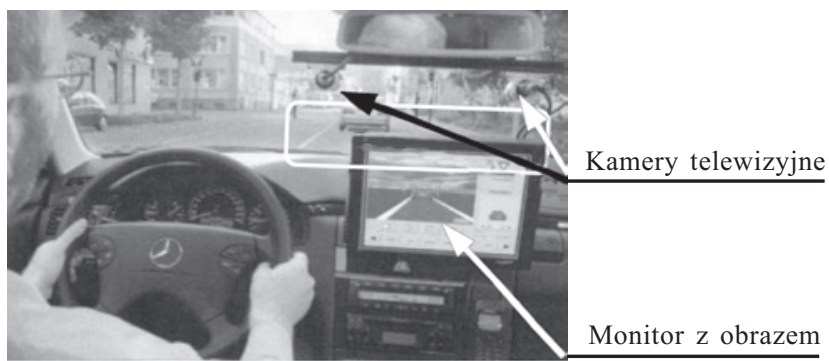

Źródło: Samochód, który widzi - http://moomin.w.interia.pl/samochod_widzi_.html 16.02.2005 


\section{Oczekiwane efekty podejmowanych dzialań przedsiębiorczych}

Rezultatów podejmowanych działań należy oczekiwać:

a) w zakresie edukacji,

b) w zakresie budowy „,bezpiecznych” pojazdów,

c) w zakresie rozwoju ,inteligentnej" infrastruktury drogowej.

Oto oczekiwane rezultaty w zakresie edukacji:

- świadomy i kulturalny uczestnik ruchu drogowego szanujący przepisy oraz prawa innych uczestników ruchu drogowego,

- uczestnik ruchu posiadający umiejętności i wiedzę z zakresu bezpieczeństwa w ruchu drogowym, technik kierowania oraz udzielania pierwszej pomocy,

- uczestnik ruchu znający i rozumiejący wpływ alkoholu lub innych podobnie działających środków na funkcje percepcyjne, podejmowane decyzje, czas reakcji i zachowanie, a także skutki wahań stanu emocjonalnego i zmęczenia,

- uczestnik ruchu znający rodzaje dróg oraz zagrożenia związane ze stanem ich nawierzchni, z uwzględnieniem warunków atmosferycznych i pory roku.

Oczekiwane rezultaty w zakresie budowy „bezpiecznych” pojazdów:

- pojazdy bezpieczne dla wszystkich uczestników ruchu drogowego,

- pojazdy ,inteligentne” korygujące niewielkie błędy w technice kierowania i niepozwalające na jazdę pod wpływem alkoholu,

Oczekiwane rezultaty w zakresie infrastruktury drogowej:

- „przyjazne” drogi, ,wybaczające” uczestnikom ruchu niewielkie błędy,

- „,inteligentna” infrastruktura ,wymuszająca” bezpieczne zachowania uczestników ruchu drogowego i jednocześnie ,wybaczająca” im niewielkie błędy.

Można zatem śmiało stwierdzić, że bez działań przedsiębiorczych trudno mówić o bezpieczeństwie w ruchu drogowym, a tym samym o jego poprawie. Jest to bowiem szerokie pole do działania dla osób kreatywnych, elastycznych, o wielkiej wyobraźni, jednym słowem dla osób przedsiębiorczych, mających wiedzę z zakresu bezpieczeństwa w ruchu drogowym, ekonomii oraz organizacji i zarządzania, gotowych do podejmowania decyzji z uwzględnieniem ryzyka. Przedsiębiorczość OSK w sektorze edukacji regionalnej i lokalnej jest co prawda ściśle określona rozporządzeniem (Rozporządzenie Ministra Infrastruktury z dnia 27.10.2005 r.), ale stwarza szerokie pole działania w licznych kierunkach.

Należy jednak pamiętać, że nawet najlepsze przepisy ruchu drogowego, najlepiej prowadzona edukacja, „,bezpieczne” pojazdy i ,przyjazne” drogi nie wymuszą bezpiecznych zachowań uczestników ruchu. Nie można nikogo do tego zmuszać, ale trzeba przekonywać do bezpiecznych zachowań na drodze, co przyniesie korzyści wszystkim uczestnikom ruchu drogowego. 


\section{Literatura}

1. Dane statystyczne KG Policji, http://www.policja.pl/?dzial=8, sierpień $2006 \mathrm{r}$.

2. Krajowy Program Bezpieczeństwa Ruchu Drogowego 2005-2007-2013 Gambit 2005, przyjęty przez Radę Ministrów 19 kwietnia 2005 r.

http://www.krbrd.gov.pl/gambit/gambit_2005.htm, sierpień $2006 \mathrm{r}$.

3. Rozporządzenie Ministra Infrastruktury z dnia 27 października 2005 r. w sprawie szkolenia, egzaminowania i uzyskiwania uprawnień przez kierujących pojazdami, instruktorów i egzaminatorów, Dz.U. Nr 217 poz. 1834 http://www.mt.gov.pl/article/transport_drogowy/akty_prawne/rozporzadzenia/article.php/id_item_tree/73064c79e8a4ca19415007c4b4f6defd/id_art/12518789634e4fbd2ab50071950f1833, sierpień 2006 r. (uaktualnienie adresu - październik 2007)

4. Samochód, który widzi, http://moomin.w.interia.pl/samochod_widzi_html, 16.02.2005 r.

5. Sobieraj W., Strefa przeżycia, „Auto Sukces” 4/02

\section{Entrepreneurship and Traffic Safety}

The article presents examples of activities and enterprising attitudes researched by the author in the field of the enterprise in the improvement of the road safety.

There are also presented the examples of enterprising activities of many institutions interested in this matter - from government-institutions, including the Department of the National Education, the Department of Transport and Building, the National Council of Traffic Safety, provincial Centres of Road Traffic, the Police and schools, to the over government institutions like European Parliament and Council and private driving schools.

The author presents the system of education about traffic safety - puts emphasis on activities of the driving schools - as an example of enterprising activities. The article gives examples of protecting pedestrians in road accidents. The article compares also the chosen indicators concerning traffic accidents in Poland and in chosen countries of the European Union in years 2000-2004. 


\section{Grażyna Voss}

Toruński Ośrodek

Doradztwa Metodycznego i Doskonalenia Nauczycieli

\section{Zestawienie zmian w skonsolidowanym kapitale własnym}

Zmiany warunków otoczenia, w których żyjemy, przynoszą codziennie ogromne ilości informacji. Ich użyteczność dla podmiotów gospodarczych jest bardzo zróżnicowana i zależy od wielu czynników. Terminowo dostarczana oraz rzetelna i kompletna informacja może być cennym elementem podejmowania decyzji ekonomicznych przez wszystkich zainteresowanych. Aby tak się stało, użytkownicy tych informacji muszą umieć prawidłowo odczytać i zinterpretować uzyskane wiadomości.

9 listopada 2000 r. uchwalona została ustawa o zmianie ustawy o rachunkowości (Dz.U. Nr 113, poz. 1186), która wprowadziła nowy element sprawozdania finansowego - zestawienie zmian w kapitale (funduszu) własnym. Pozwoli ono na odzwierciedlenie sytuacji majątkowej podmiotu gospodarczego i uzyskanie nowych informacji dotyczących dynamiki zmian w kapitałach własnych wykorzystywanych w zarządzaniu jednostka, a także przez użytkowników zewnętrznych. Dane zawarte w tym zestawieniu pozwolą określić rolę kapitału własnego w samofinansowaniu działalności przedsiębiorstwa oraz rentowność zainwestowanych kapitałów.

Skonsolidowane sprawozdanie sporządza jednostka dominująca, na podstawie sprawozdań poszczególnych jednostek należących do grupy kapitałowej. Zasady sporządzania sprawozdań są podobne jak w wypadku sporządzania sprawozdania finansowego dla indywidualnej jednostki. Sprawozdania finansowe koncentrują się przede wszystkim na rezultatach podjętych wcześniej decyzji. Badanie zmian w kapitale własnym na początek i koniec okresu obrachunkowego pozwala na oszacowanie przyrostu lub spadku aktywów netto jednostki, jej zasobności w ciągu roku. Ogólna zmiana stanu kapitału odpowiada łącznym stratom i zyskom wygenerowanym w wyniku działalności gospodarczej. Zestawienie zmian w kapitale własnym jest niezbędnym elementem sprawozdania finansowego, jednak dopiero przyszłość pokaże, w jakim stopniu zawarte w nim informacje będą wykorzystywane przez poszczególne grupy użytkowników.

Konsolidowanie sprawozdań finansowych jest procesem złożonym, szczególnie na gruncie polskim. Na jego złożoność wpływa stosunkowo krótki okres praktycznych zastosowań procedur konsolidacyjnych oraz niedostrzeganie znaczenia i możliwości wykorzystania skonsolidowanych sprawozdań finansowych w podejmowaniu decyzji gospodarczych. Postępujący rozwój rynku kapitałowego w Polsce, tworzenie się coraz liczniejszych złożonych struktur gospodarczych w postaci grup kapitałowych wymusza na użytkownikach sprawozdań finansowych ciągłe poszerzanie i aktualizację wiedzy. Dlatego coraz większego znaczenia nabiera kwestia zestawiania zmian w skonsolidowanym kapitale własnym.

Ocena wykorzystania zestawienia zmian w skonsolidowanym kapitale własnym - wyniki badań Badania odbyły się trójetapowo.

- Pierwszy etap został przeprowadzony w okresie od grudnia 2004 r. do stycznia 2005 r. wśród podmiotów gospodarczych sporządzających skonsolidowane sprawozdania finansowe. 
Przedsiębiorstwa zostały dobrane na podstawie zamieszczonych w „Rzeczpospolitej” z 17.11.2004 r. wyników finansowych i wybranych wskaźników za I - III kwartał 2004 r. 198 spółek sporządzających skonsolidowane sprawozdania. Formularze ankiet zostały wypełnione przez dyrektorów ds. ekonomiczno-finansowych, głównych księgowych, specjalistów ds. finansów, kierowników działów finansowych, specjalistów ds. konsolidacji i kontroli, kierowników controlingu. Wysłano 198 formularzy, zwrot uzyskano od 69 przedsiębiorstw; pełną przydatność (poprawnie wypełnione) spełniło 65 ankiet (zwrotność 32,83\%).

- Drugi etap badań przeprowadzono w okresie styczeń - luty 2005 r. wśród biegłych rewidentów. Formularz ankiety wysłano do 300 osób wybranych metodą losową spośród 2034 podmiotów. Uzyskano 88 ankiet, pełną przydatność (poprawnie wypełnione) spełniło 88 ankiet (zwrotność 29,33\%).

- Trzeci etap trwał od kwietnia do sierpnia 2005 r. Analizę przypadku przeprowadzono w trzech grupach kapitałowych, prowadzących różną działalność gospodarczą i sporządzających skonsolidowane sprawozdania finansowe na podstawie krajowych i międzynarodowych regulacji prawnych.

Wybór respondentów próby badawczej wynikał z tematyki badań. Miały one na celu przedstawienie opinii na temat wartości informacyjnej zestawienia zmian w skonsolidowanym kapitale własnym osób odpowiedzialnych za sporządzanie tego elementu sprawozdania finansowego oraz osób zajmujących się kontrolą sprawozdawczości finansowej. Wszystkie grupy badanych mają niezbędną wiedzę, a często również kilkuletnie doświadczenie w przygotowywaniu i badaniu zmian w kapitale własnym.

Skonsolidowane sprawozdania finansowe dostarczają użytkownikom informacji o wynikach działalności oraz o sytuacji majątkowej i finansowej całej grupy kapitałowej. Jednym z elementów tego sprawozdania jest zestawienie zmian w skonsolidowanym kapitale własnym, które sporządzane jest przez większość jednostek dopiero od dwóch lat i przedstawia dane dotyczące dynamiki zmian w bieżącym i poprzednim okresie obrachunkowym w skonsolidowanym kapitale własnym w grupie kapitałowej. Zestawienie to stanowi wtórne źródło informacji finansowych; jednocześnie jest uzupełnieniem i rozwinięciem danych zaprezentowanych w skonsolidowanym bilansie.

Wyniki badań pozwalają na wskazanie najważniejszych użytkowników skonsolidowanych sprawozdań finansowych oraz obszarów, w których informacje zaprezentowane w zestawieniu zmian w skonsolidowanym kapitale są najczęściej wykorzystywane. Do najczęściej wymienianych użytkowników skonsolidowanych sprawozdań zalicza się:

- zarząd jednostki dominującej,

- banki udzielające kredytu jednostce dominującej,

- akcjonariuszy/udziałowców jednostki dominującej,

- potencjalnych inwestorów.

Na podstawie badań opinii pracowników księgowości ustalono najważniejszych użytkowników zestawienia zmian w skonsolidowanym kapitale własnym, szeregując ich w kolejności od 1 do 11, według stopnia zapotrzebowania na informacje zawarte w sprawozdaniu finansowym. Wśród pracowników grup kapitałowych kolejność przedstawia tab. 1.

Również biegli rewidenci uporządkowali użytkowników według stopnia zapotrzebowania na informacje zawarte w skonsolidowanym kapitale własnym w kolejności przedstawionej w tab. 2 . 
Tab. 1. Najważniejsi użytkownicy zestawienia zmian w skonsolidowanym kapitale własnym w opinii pracowników służb finansowo-księgowych

\begin{tabular}{|l|c|}
\hline \multicolumn{1}{|c|}{ Użytkownik } & Średnia ważona \\
\hline Menedżerowie zarządzający jednostkami wchodzącymi w skład grupy & 4,52 \\
\hline Kontrahenci jednostki dominującej & 4,44 \\
\hline Zarząd jednostki dominującej & 3,87 \\
\hline Banki udzielające kredytu jednostce dominującej & 3,46 \\
\hline Banki udzielające kredytu jednostce podporządkowanej & 3,24 \\
\hline Kontrahenci grupy kapitałowej & 2,80 \\
\hline Udziałowcy/akcjonariusze jednostki dominującej & 2,58 \\
\hline Udziałowcy/akcjonariusze wchodzący w skład grupy & 2,25 \\
\hline Potencjalni inwestorzy & 2,21 \\
\hline Zarządy poszczególnych spółek wchodzących w skład grupy & 2,04 \\
\hline Menedżerowie zarządzający grupą & 1,94 \\
\hline
\end{tabular}

Źródło: opracowanie autorki na podstawie wyników badań opinii pracowników księgowości

Tab. 2. Najważniejsi użytkownicy zestawienia zmian w skonsolidowanym kapitale własnym w opinii biegłych rewidentów

\begin{tabular}{|l|c|}
\hline \multicolumn{1}{|c|}{ Użytkownik } & Średnia ważona \\
\hline Menedżerowie zarządzający grupą kapitałową & 3,98 \\
\hline Potencjalni inwestorzy & 3,79 \\
\hline Zarządy poszczególnych spółek wchodzących w skład grupy & 3,57 \\
\hline Udziałowcy/akcjonariusze jednostki dominującej & 3,41 \\
\hline Banki udzielające kredytu jednostce podporządkowanej & 3,05 \\
\hline Zarząd jednostki dominującej & 2,78 \\
\hline Banki udzielające kredytu jednostce dominującej & 2,70 \\
\hline Udziałowcy/akcjonariusze wchodzący w skład grupy & 2,31 \\
\hline Menedżerowie zarządzający jednostkami wchodzącymi w skład grupy & 2,00 \\
\hline Społeczeństwo lokalne & 2,00 \\
\hline Kontrahenci grupy kapitałowej & 1,79 \\
\hline Urzędy skarbowe & 1,60 \\
\hline Kontrahenci jednostki dominującej & 1,00 \\
\hline
\end{tabular}

Źródło: opracowanie autorki na podstawie wyników badań opinii biegłych rewidentów

Uwzględniając stopień zapotrzebowania na informacje zawarte w skonsolidowanym sprawozdaniu, każda grupa badanych wskazała innych użytkowników, co przedstawiono w tab. 3 .

Zdaniem pracowników służb finansowo-księgowych, najważniejszymi użytkownikami informacji zawartych w skonsolidowanym sprawozdaniu są menedżerowie zarządzający jednostkami wchodzącymi w skład grupy, kontrahenci i zarząd jednostki dominującej. Inna klasyfikacja została przedstawiona przez biegłych rewidentów, którzy - poza grupą kierowniczą jednostki dominującej 
Tab. 3. Najważniejsi użytkownicy zestawienia zmian w skonsolidowanym kapitale własnym w opinii pracowników służb finansowo-księgowych i biegłych rewidentów

\begin{tabular}{|c|c|}
\hline \multicolumn{2}{|c|}{ Najważniejsi użytkownicy w ocenie } \\
\hline pracowników służb finansowo-księgowych & biegłych rewidentów \\
\hline $\begin{array}{l}\text { Menedżerowie zarządzający jednostkami } \\
\text { wchodzącymi w skład grupy }\end{array}$ & Menedżerowie jednostki dominującej \\
\hline Kontrahenci jednostki dominującej & Potencjalni inwestorzy \\
\hline Zarząd jednostki dominującej & Udziałowcy/akcjonariusze jednostki dominującej \\
\hline
\end{tabular}

Źródło: opracowanie autorki na podstawie wyników badań opinii pracowników księgowości i biegłych rewidentów

- głównie skupili się na właścicielach wnoszących kapitał do jednostki oraz potencjalnych właścicielach, którzy są na etapie podejmowania decyzji inwestycyjnych (kapitałowych).

W pracy badawczej ustalono również kolejność najważniejszych obszarów, w których wykorzystywane są informacje zawarte w zestawieniu zmian w skonsolidowanym kapitale własnym. Wyniki badań opinii przedstawia tab. 4.

Tab. 4. Najważniejsze obszary wykorzystania informacji zawartych w zestawieniu zmian w skonsolidowanym kapitale własnym w opinii pracowników służb finansowo-księgowych

\begin{tabular}{|l|c|}
\hline \multicolumn{1}{|c|}{ Treść } & Średnia ważona \\
\hline Określenie bieżącej wartości firmy & 3,86 \\
\hline Analiza dynamika zmian aktywów netto & 3,65 \\
\hline Analiza sytuacji majątkowej i zdolności kredytowej & 3,62 \\
\hline Wpływ wyniku finansowego na wartość kapitałów własnych & 3,32 \\
\hline Aktualizacja wyceny składników majątkowych & 3,09 \\
\hline Polityka wypłaty dywidend i jej wpływ na wartość firmy & 2,96 \\
\hline Podjęcie decyzji strategicznych przez potencjalnych inwestorów & 2,67 \\
\hline $\begin{array}{l}\text { Analiza wielkości uzyskanych przychodów i poniesionych kosztów } \\
\text { wpływających bezpośrednio na kapitał własny }\end{array}$ & 2,50 \\
\hline Ustalenie bieżącej wartości posiadanych udziałów & 2,29 \\
\hline Budowa strategii rozwoju przez zarząd spółki dominującej & 1,47 \\
\hline
\end{tabular}

Źródło: opracowanie autorki na podstawie wyników badań opinii pracowników księgowości

Najczęściej wskazywany przez respondentów jest obszar dotyczący wpływu wyniku finansowego na wartość kapitałów własnych. Jednak za najważniejszy należy uznać obszar dotyczący możliwości wykorzystania informacji służącej określeniu bieżącej wartości firmy. Wyznacznikiem tego obszaru była najwyższa średnia ważona, która wynosi 3,86. Pozostałe obszary, w których równie ważnych informacji dostarcza zestawienie zmian w skonsolidowanym kapitale własnym, to:

- analiza dynamiki zmian aktywów netto,

- analiza sytuacji majątkowej i zdolności kredytowej,

- wpływ wyniku finansowego na wartość kapitałów własnych,

- aktualizacja wyceny składników majątkowych. 
Wymienione wyżej obszary w sposób pośredni dostarczają użytkownikom informacji o zmianach $\mathrm{w}$ aktywach netto, a przede wszystkim zaspokajają potrzeby informacyjne niezbędne do analizy wstępnej dla:

- akcjonariuszy, których interesuje wartość osiagniętego zysku, opłacalność zaangażowanego kapitału i wysokość dywidend,

- wierzycieli zainteresowanych oceną płynności finansowej przedsiębiorstwa i jego wypłacalnością,

- banków koncentrujących swoją uwagę przede wszystkim na udzielaniu kredytów.

Wskazane przez respondentów obszary stanowią cenne źródło informacji o ewolucji prawa własności, sygnalizując jednocześnie o preferencjach inwestycyjnych właścicieli jednostki gospodarczej.

Zdaniem biegłych rewidentów, za najważniejszy należy uznać obszar dotyczący możliwości wykorzystania informacji do określenia bieżącej wartości firmy (tab. 5). Jego wyznacznikiem była najwyższa średnia ważona $(4,03)$. Wykorzystanie informacji w zakresie określenia wpływu wyniku finansowego na wartość kapitałów własnych stanowi drugi obszar, w którym najczęściej wykorzystuje się dane zawarte w zestawieniu.

Kolejne obszary wskazane przez biegłych rewidentów to:

- wpływ wyniku finansowego na wartość kapitałów własnych,

- analiza wielkości uzyskanych przychodów i poniesionych kosztów wpływających bezpośrednio na wysokość kapitału własnego,

- ustalenie bieżącej wartości posiadanych akcji/udziałów,

- polityka wypłaty dywidendy i jej wpływ na wartość firmy.

Tab. 5. Najważniejsze obszary wykorzystania informacji zawartych w zestawieniu zmian w skonsolidowanym kapitale własnym w opinii biegłych rewidentów

\begin{tabular}{|l|c|}
\hline \multicolumn{1}{|c|}{ Treść } & Średnia ważona \\
\hline Określenie bieżącej wartości firmy & 4,03 \\
\hline Wpływ wyniku finansowego na wartość kapitałów własnych & 3,59 \\
\hline $\begin{array}{l}\text { Analiza wielkości uzyskanych przychodów i poniesionych } \\
\text { kosztów wpływających bezpośrednio na kapitał własny }\end{array}$ & 3,50 \\
\hline Ustalenie bieżącej wartości posiadanych akcji/udziałów & 3,29 \\
\hline Polityka wypłaty dywidend i jej wpływ na wartość firmy & 3,09 \\
\hline Analiza dynamika zmian aktywów netto & 2,86 \\
\hline Analiza sytuacji majątkowej i zdolności kredytowej & 2,81, \\
\hline Aktualizacja wyceny składników majątkowych & 2,57 \\
\hline Budowa strategii rozwoju przez zarząd spółki dominującej & 2,16 \\
\hline Podjęcie decyzji strategicznych przez potencjalnych inwestorów & 2,09 \\
\hline
\end{tabular}

Źródło: opracowanie autorki na podstawie wyników badań opinii biegłych rewidentów

Aby wskazać obszary, w których wykorzystywane są informacje zawarte w zestawieniu zmian w skonsolidowanym kapitale własnym, należy dokonać podziału ze względu na grupę badanych (tab. 6). 
Tab. 6. Najważniejsze obszary wykorzystania informacji zawartych w zestawieniu zmian w skonsolidowanym kapitale własnym w opinii pracowników służb finansowo-księgowych i biegłych rewidentów

\begin{tabular}{|l|l|}
\hline \multicolumn{2}{|c|}{ Najważniejsze obszary w ocenie } \\
\hline \multicolumn{1}{|c|}{ pracowników służb finansowo-księgowych } & \multicolumn{1}{c|}{ biegłych rewidentów } \\
\hline Określenie bieżącej wartości firmy & Określenie bieżącej wartości firmy \\
\hline Analiza dynamiki zmian aktywów netto & $\begin{array}{l}\text { Wpływ wyniku finansowego na wartość } \\
\text { kapitałów własnych }\end{array}$ \\
\hline Analiza sytuacji majątkowej i zdolności kredytowej & $\begin{array}{l}\text { Analiza wielkości uzyskanych przychodów } \\
\text { i poniesionych kosztów wpływających } \\
\text { bezpośrednio na kapitał własny }\end{array}$ \\
\hline
\end{tabular}

Źródło: opracowanie autorki na podstawie wyników badań opinii pracowników księgowości i biegłych rewidentów

Wskazane przez respondentów obszary pozwalają na ocenę zmian zachodzących w stanie majątkowym jednostki, przede wszystkim tej części majątku, która bezterminowo pozostaje do dyspozycji jednostki i stanowi jej własność. Na szczególną uwagę zasługuje uznanie przez respondentów określenia bieżącej wartości firmy za najważniejszy obszar wykorzystywania informacji o zmianach zachodzących w skonsolidowanym kapitale. Oznacza to, że podejmowanie decyzji inwestycyjnych oraz opracowywanie strategii działania jest tym łatwiejsze, im dokładniej znana jest bieżąca wartość majątku.

Jednostka dominująca posiada udziały w poszczególnych podmiotach wchodzących w skład grupy kapitałowej i chociaż na co dzień bezpośrednio nimi nie dysponuje, to jednak wpływa na politykę jednostek zależnych, współzależnych i stowarzyszonych. Dlatego do prawidłowej oceny sytuacji finansowej-zdaniem użytkowników - bardziej przydatne są szczegółowe informacje dotyczące zestawienia zmian w kapitałach własnych jednostki dominującej niż zestawienia zmian w jednostek podległych.

\section{Podsumowanie}

Informacje zawarte w zestawieniu zmian w skonsolidowanym kapitale własnym ułatwiają podejmowanie decyzji, a szczegółowa analiza tytułów zmian pozwala na określenie zyskowności kapitału i określenie bieżącej wartości akcji/udziału. Chociaż użytkownicy zestawienia dostrzegają korzyści wynikające z jego analizy, to jednak występujące różnego typu bariery nie pozwalają w pełni wykorzystywać informacji o skonsolidowanym kapitale. Krótki okres jego sporządzania nie pozwala użytkownikom na uzyskanie wystarczającej i ugruntowanej wiedzy.

Można przyjąć, że zestawienie zmian w skonsolidowanym kapitale własnym dostarcza szerokiej grupie użytkowników różnorodnych informacji, które bezpośrednio lub pośrednio wpływają na decyzje podejmowane przez adresatów sprawozdań. Wprowadzenie do rachunkowości zestawienia zmian w kapitałach własnych jest wynikiem globalizacji gospodarki i harmonizacji rachunkowości na skalę międzynarodowa. Zestawienie to dostarcza nowych informacji, a zarazem stanowi rozszerzenie danych zawartych w bilansie i rachunku zysków i strat. Jednak nie dla wszystkich użytkowników wewnętrznych i zewnętrznych, ma ono taką samą wartość użytkową, wykorzystywaną na jednakowym poziomie. Uzyskane z badań informacje mogą stanowić pewne wskazówki odnośnie do wykorzystania zestawienia zmian w skonsolidowanym kapitale własnym przez wybrane grupy użytkowników.

Na podstawie przedstawionych analiz przypadków grup kapitałowych: Apator S.A., Elektrociepłownia Toruń S.A. i Przedsiębiorstwo Handlowe Koekstra B.V. można wyciągnąć wniosek, 
że informacje zawarte w zestawieniach zmian w skonsolidowanych kapitałach własnych są przydatne przede wszystkim inwestorom, którzy śledzą zmiany w kapitałach, gdyż na ich podstawie właściciele mogą określić, jaka część majątku przypada na jedną akcję. Ponadto informacje dotyczące zmian w kapitale zapasowym pozwalają na określenie wielkości zatrzymanego zysku. Niestety, inwestorzy mają tu utrudnione zadanie, ponieważ w zestawieniu nie znajdą informacji o liczbie wyemitowanych akcji i o ich wartości nominalnej. Uzupełnienie zestawienia zmian w skonsolidowanym kapitale własnym o te informacje ułatwiłoby w znacznej mierze analizę zyskowności zainwestowanego kapitału i ograniczyło czas poświęcony na poszukiwanie tych informacji.

Zestawienie zmian w skonsolidowanym kapitale własnym stanowi jedynie uzupełnienie i poszerzenie informacji zawartych w bilansie i informacji dodatkowej, dlatego dla wielu użytkowników zarówno wewnętrznych, jak i zewnętrznych jest to nie w pełni wykorzystane źródło informacji.

\section{Statements of Changes in a Consolidated Ownership Capital}

Aim of the work is to present methods of developing and titles to implement changes in the ownership capitals for various legal entities. It covers the contents and the form of presentation of the statement of changes in consolidated ownership capital (with regard to domestic and foreign legal regulations). The work emphasize informational value of the statement for groups of users (internal and external) as well as its usability. Specific rules concerning a development of the financial statements and methods of their consolidation are presented. The work focuses on functions and relations in financial groups. 


\title{
Przedsiębiorczość
}

\author{
w edukacji
}




\section{Mariola Tracz}

Zakład Dydaktyki Geografii

\section{Tomasz Rachwal}

Zakład Przedsiębiorczości i Gospodarki Przestrzennej

Instytut Geografii

Akademia Pedagogiczna w Krakowie

\section{Przedmiot podstawy przedsiębiorczości - założenia realizacji a przygotowanie nauczycieli}

Wprowadzony od 2002 r. do wszystkich typów szkół ponadgimnazjalnych nowy przedmiot - podstawy przedsiębiorczości, zgodnie z założeniami ma na celu nie tylko wyposażenie uczniów w wiedzę z zakresu funkcjonowania gospodarki rynkowej w warunkach nasilających się procesów globalizacji i integracji europejskiej, ale także ma służyć rozwijaniu umiejętności, które będą niezbędne uczniom w dorosłym, aktywnym życiu zawodowym. Zgodnie z zapisem podstawy programowej oraz w nawiązaniu do wypowiedzi wielu uczestników ogólnopolskich konferencji z przedsiębiorczości, podczas realizacji tego przedmiotu powinny być kształtowane u uczniów m.in. postawy aktywności, otwartości, kreatywności i podejmowania rozważnego ryzyka w realizowaniu własnej kariery zawodowej przy uwzględnieniu wartości etycznych (Zioło, Rachwał 2005, 2006). Postawy te składają się na szeroko rozumianą postawę przedsiębiorczości (Gabała 2005, Rachwał 2004a, 2005, 2006, Strumska-Cylwik 2005).

Wprowadzenie edukacji w zakresie przedsiębiorczości do systemu szkolnego opierało się na kilku podstawowych założeniach, z których tylko niektóre znalazły wyraz w odpowiednich aktach prawnych i zostały przynajmniej częściowo zrealizowane. Większość z nich miała charakter postulatywny i nie została wdrożona, chociaż zwracało na nią uwagę wielu autorów (Górz, Rachwał 2006, Juchnowicz 2006, Osuch, Osuch 2005, Tracz 2005, 2006). Często te niezrealizowane założenia należy uznać w świetle dyskusji z praktykami życia szkolnego, a więc metodykami i nauczycielami, za fundamentalne i wręcz niezbędne do prawidłowego przebiegu edukacji w zakresie przedsiębiorczości.

Oto najważniejsze założenia edukacji w zakresie przedsiębiorczości, zrealizowane i niezrealizowane:

1. Edukacja w zakresie przedsiębiorczości ma się odbywać w gimnazjum (moduł,,wychowanie do aktywnego udziału w życiu gospodarczym" - 1 godz. w cyklu kształcenia) i wszystkich typach szkół ponadgimnazjalnych (przedmiot podstawy przedsiębiorczości - 2 godz.). Niestety, to podstawowe założenie nie jest w pełni realizowane, gdyż w gimnazjum moduł „wychowanie do aktywnego udziału w życiu gospodarczym" nie jest osobnym przedmiotem, lecz stanowi część przedmiotu wiedza o społeczeństwie. Konsekwencją jest to, że prowadzą go często nauczyciele niezbyt dobrze przygotowani (nie ukończyli studiów podyplomowych z przedsiębiorczości), którzy często marginalizują treści tego modułu, wypełniając go treściami związanymi z wiedzą obywatelską. Ponadto w zasadniczych szkołach zawodowych ten 
przedmiot jest realizowany tylko w wymiarze 1 godz. w cyklu kształcenia. Analiza obowiązującej podstawy programowej i nowego - przedstawionego przez MEN - jej projektu wskazuje, że podstawa programowa dla zasadniczej szkoły zawodowej jest nieco okrojoną wersją podstawy programowej dla szkół maturalnych. Nasuwa się więc pytanie, czy w przypadku przedmiotu podstawy przedsiębiorczości nie należałoby zrezygnować z tego podziału i stworzyć jednej podstawy programowej dla szkół ponadgimnazjalnych, przeznaczając na jego realizację co najmniej 2 godz. w cyklu kształcenia we wszystkich typach szkół. Jest to tym bardziej istotne, że ten przedmiot ma przygotowywać uczniów do życia we współczesnym świecie, stąd niecelowe wydaje się założenie, że uczniowie szkół zawodowych powinni być wyposażeni w tę umiejętność w mniejszym stopniu. Wręcz przeciwnie, ze względu na to, że wielu absolwentów szkół zawodowych (w przeciwieństwie do absolwentów szkół kończących się matura) bezpośrednio po ukończeniu szkoły rozpoczyna życie zawodowe (szuka zatrudnienia bądź zakłada własną firmę), w przypadku szkół zawodowych powinno się dążyć do rozszerzania zakresu treści programowych i przeznaczenia na nauczanie tego przedmiotu większej liczby godzin. Na marginesie należy zaznaczyć, że nietrafna jest decyzja autorów III wersji projektu podstawy programowej o włączeniu w zasadniczej szkole zawodowej treści z zakresu przedsiębiorczości w ramy przedmiotu wiedza o społeczeństwie. Będzie to prowadzić do ich całkowitej marginalizacji (tak, jak to ma miejsce w gimnazjum), szczególnie jeśli w wyniku takich zmian przedmiot będzie w całości realizowany przez nauczyciela WOS, który nie odbył studiów podyplomowych w zakresie nauczania przedsiębiorczości ani żadnych innych studiów o profilu ekonomicznym (Górz, Rachwał 2006).

2. Wprowadzenie nowych treści wymaga więc stworzenia odpowiedniej podstawy programowej. Obecnie obowiązująca podstawa jest daleka od doskonałości i nie odpowiada współczesnym wyzwaniom edukacyjnym. Nowa propozycja, mimo że jest krokiem milowym naprzód, wymaga szerokiej dyskusji w gronie specjalistów i dopracowania. Za zupełnie niezrozumiałe należy uznać próby likwidacji tego przedmiotu bądź ograniczenia treści kształcenia z zakresu przedsiębiorczości. Należy pamiętać, że przedsiębiorczość jest jednym z kluczowych przedmiotów w europejskim wymiarze nauczania i należy do podstawowych umiejętności w strategii edukacyjnej UE (Tracz 2006). Jak słusznie zauważa wielu autorów, w fazie informacyjnej rozwoju cywilizacyjnego o konkurencyjności człowieka i - w konsekwencji - całej gospodarki w największym stopniu będą decydować zasoby kapitału ludzkiego. Są one czynnikiem, bez którego nie jest możliwe osiąnnięcie trwałego i wysokiego tempa rozwoju społeczno-gospodarczego (Borowiec 2003, Janc 2003, Kołodziejski 1998). Kluczowe jest więc ukształtowanie w procesie edukacyjnym konkurencyjnego człowieka, cechującego się postawą przedsiębiorczą. Jak zauważa Z. Zioło (2005a), tylko konkurencyjny człowiek jest w stanie wyprodukować i zaoferować konkurencyjny produkt. Edukacja w zakresie przedsiębiorczości powinna zatem zostać rozszerzona na niższe szczeble edukacji. Wydaje się bowiem, że ukształtowanie postawy przedsiębiorczości i konkurencyjnego we współczesnym świecie człowieka jest możliwe tylko dzięki realizacji celów z zakresu kształtowania postaw przedsiębiorczych na wszystkich szczeblach edukacji i na różnych przedmiotach, a nie tylko na nowo wprowadzonym w szkołach ponadgimnazjalnych przedmiocie podstawy przedsiębiorczości. Konieczne jest więc dostrzeżenie przez wychowawców i nauczycieli innych przedmiotów - począwszy od nauczycieli kształcenia zintegrowanego w szkole podstawowej - roli, jaką mają do spełnienia w kształtowaniu postaw przedsiębiorczych uczniów (Rachwał 2006).

3. Edukacja w zakresie przedsiębiorczości nie jest możliwa bez wykształcenia kompetentnych nauczycieli tego przedmiotu. Poza sporadycznymi pilotażowymi cyklami bezpłatnych studiów podyplomowych, finansowanymi przez MEN, kształcenie w tym zakresie zrzucono na 
barki nauczycieli, tworząc w dodatku bariery biurokratyczne dla nauczycieli przedmiotów ekonomicznych, od których zaczęto wymagać ukończenia studiów z przedsiębiorczości. Jednocześnie zaniedbano całkowicie problem nauczycieli w szkołach gimnazjalnych, zakładając, że nauczyciel WOS sam dokształci się w zakresie nowego modułu. Często to dokształcanie nie było realizowane, gdyż nie wymagano od nauczycieli formalnego ukończenia studiów podyplomowych. Skutkiem zaniechania działań przygotowujących kadry nauczycielskie do realizacji nowych zadań jest stosunkowo słabe przygotowanie merytoryczne nauczycieli, o czym świadczą (omówione niżej) wyniki badań prowadzonych wśród nauczycieli. Ponadto należy podkreślić, że zgodnie ze strategią lizbońską nauczanie tego przedmiotu to zadanie nie tylko dla nauczyciela przedsiębiorczości, ale także dla całej społeczności szkolnej. W Polsce ta idea praktycznie nie jest realizowana, oprócz szkół, w których pracują wyjątkowo przedsiębiorczy i wyjątkowo społecznie nastawieni nauczyciele, gotowi bez dodatkowego wynagrodzenia organizować specjalne zajęcia pozalekcyjne i konkursy przedsiębiorczości czy przygotowywać uczniów do olimpiad.

4. Do edukacji w zakresie przedsiębiorczości potrzebne są specjalne warunki organizacyjne, m.in. dostęp do pracowni komputerowych i mobilnych zestawów multimedialnych (który bardzo często jest ograniczony tylko do nauczycieli technologii informacyjnej), organizacja specjalnych pracowni symulacyjnych (istnieją w nielicznych szkołach, bo brak środków na ich organizację), podział klasy na małe grupy wynikający ze specyfiki przedmiotu, na którym wyposaża się ucznia przede wszystkim w umiejętności, co wymaga pracy w grupach liczących 8-12 osób, konieczność organizacji częstych ćwiczeń terenowych, zajęć pozalekcyjnych itp. (bariery organizacyjne i finansowe).

5. Pozostaje nierozstrzygnięta sprawa matury z podstaw przedsiębiorczości. Należy zauważyć, że jej wprowadzenie jest opóźniane ze względu na liczne kontrowersje natury merytorycznej i trudności organizacyjne, do których przeciwnicy wprowadzenie matury $z$ tego przedmiotu zaliczają (Rachwał 2006):

- sprzeczność z istotą przedsiębiorczości;

- trudności w określaniu kryteriów sprawdzania umiejętności;

- konieczność ograniczenia liczby przedmiotów na maturze (według koncepcji zakładającej, że na maturze powinno się sprawdzać wiedzę i umiejętności tylko z przedmiotów o charakterze ogólnokształcącym);

- nieporównywalność zakresu wymagań z innymi przedmiotami;

- zmniejszenie atrakcyjności przedmiotu w oczach uczniów;

- zmniejszenie zaangażowania uczniów na lekcjach ze względu na konieczność realizowania przez nauczycieli materiału ,pod kątem” matury;

- mniejsza swoboda nauczycieli w doborze treści kształcenia;

- niebezpieczeństwo odejścia od kształcenia umiejętności na rzecz wyposażania uczniów w wiedzę o charakterze ekonomicznym i tym samym przekształcenie przedmiotu w ,podstawy ekonomii";

- konieczność przeczekania ,chaosu organizacyjnego” związanego z przeprowadzaniem ,nowej matury";

- brak odpowiedniej liczby dobrze przygotowanych nauczycieli przedsiębiorczości (szczególnie w zakresie przygotowania uczniów do matury na poziomie rozszerzonym);

Należy jednak przytoczyć istotne argumenty zwolenników jej wprowadzenia (por. Bartoń 2005):

- poszerzenie katalogu przedmiotów maturalnych do wyboru dla uczniów;

- możliwość uzyskania na świadectwie dojrzałości oceny z przedmiotu o charakterze ekonomicznym; 
- możliwość oceny kandydatów dla uczelni ekonomicznych;

- wyeliminowanie dodatkowego egzaminu wstępnego z podstaw przedsiębiorczości w uczelniach ekonomicznych;

- standaryzowanie wymagań;

- większy prestiż przedmiotu w strukturze nauczania szkoły;

- większe zaangażowanie uczniów na lekcjach (ze względu na świadomość, że przedmiot jest objęty sprawdzianem zewnętrznym);

- większa szansa na zwiększenie liczby godzin w cyklu kształcenia, szczególnie w obliczu zbyt małej liczby godzin (1-2 w cyklu kształcenia) na realizację treści wynikających z rozbudowanej podstawy programowej tego przedmiotu;

- zwiększenie roli edukacji o charakterze ekonomicznym w oczach społeczeństwa;

- popularyzacja postaw przedsiębiorczych w społeczeństwie.

Należy się więc zgodzić ze stanowiskiem M. Bartonia (2005) że - podążając za doświadczeniami innych krajów, w tym krajów europejskich - przedmiot podstawy przedsiębiorczości powinien zostać uznany za przedmiot maturalny, szczególnie wobec tego, że w założeniach nowej matury uczniowie mogą zdawać takie przedmioty, jak historia muzyki czy filozofia (od 2008 r.).

Funkcjonowanie nowego przedmiotu staje się okazją do refleksji nad jego wdrożeniem w systemie kształcenia i nad kompetencjami nauczycieli. Podjęto w tym celu badania diagnostyczne, mające na celu zebranie i analizę danych o realizacji założeń reformy oświaty w odniesieniu do podstaw przedsiębiorczości. Celem badań było:

- ustalenie poziomu kwalifikacji merytorycznych i dydaktycznych nauczycieli uczących podstaw przedsiębiorczości,

- poznanie opinii nauczyciela przedsiębiorczości o formach kształcenia,

- poznanie opinii nauczycieli o wprowadzeniu podstaw przedsiębiorczości do szkół ponadgimnazjalnych.

Badaniami ankietowymi objęto 215 nauczycieli podstaw przedsiębiorczości z ośmiu województw: lubelskiego, łódzkiego, małopolskiego, podkarpackiego, podlaskiego, śląskiego, wielkopolskiego i zachodniopomorskiego. Ankieta zawierała 20 pytań, w tym 15 zamkniętych i 5 otwartych. Badania przeprowadzono wśród nauczycieli wszystkich typów szkół ponadgimnazjalnych (tab. 1). Najliczniejszą grupę badanych stanowili nauczyciele liceów ogólnokształcących - 61 osób, czyli 28,4\%, oraz zespołu szkół: ponadgimnazjalnych (liceum profilowane, technikum, zasadnicza szkoła zawodowa) - 36 osób, czyli 16,7\%, i ogólnokształcących (liceum ogólnokształcące, liceum profilowane, technikum) - 31 osób, czyli 14,5\%.

Dane wskazują, że 46,5\% badanych nauczycieli prowadzi zajęcia z podstaw przedsiębiorczości w dwóch lub trzech szkołach. Wynika to m.in. z liczby godzin przeznaczonych na nauczanie tego przedmiotu oraz liczby klas w danym typie szkoły. W realizacji procesu dydaktycznego nie jest to korzystna sytuacja, szczególnie wtedy, kiedy szkoły są od siebie znacznie oddalone. Dojazdy powodują stratę czasu, który nauczyciele mogliby przeznaczyć na lepsze przygotowanie się do lekcji. Poza tym taka sytuacja sprawia, że nauczyciele w mniejszym stopniu identyfikują się z jedna, konkretną szkołą i tym samym rzadziej podejmują dodatkowe działania na jej rzecz.

Zawód nauczyciela wymaga odpowiednich kwalifikacji - gruntownego przygotowania merytorycznego i dydaktycznego oraz odpowiednich cech osobowych. Jak do nauczania podstaw przedsiębiorczości przygotowany jest nauczyciel? Wyniki badań wskazują, że nauczyciele podstaw przedsiębiorczości w $82,4 \%$ ukończyli magisterskie studia wyższe w trybie stacjonarnym (dzienne), tylko 2 osoby, czyli niecały 1\% badanych legitymuje się ukończeniem tylko studiów licencjackich I stopnia (tab. 2). 
Tab. 1. Nauczyciele uczący podstaw przedsiębiorczości według województw i typu szkoły

\begin{tabular}{|c|c|c|c|c|c|c|c|c|c|c|c|}
\hline Wyszczególnienie & LO & $\mathbf{L P}$ & $\mathbf{T}$ & ZSZ & $\begin{array}{c}\text { LO, } \\
\text { LP }\end{array}$ & $\begin{array}{l}\text { LO, } \\
\text { LP, T }\end{array}$ & $\begin{array}{c}\text { LP, T, } \\
\text { ZSZ }\end{array}$ & $\begin{array}{c}\text { T, } \\
\text { ZSZ }\end{array}$ & $\begin{array}{c}\text { Szko- } \\
\text { ty } \\
\text { po- } \\
\text { lice- } \\
\text { alne }\end{array}$ & $\begin{array}{l}\text { Ra- } \\
\text { zem }\end{array}$ & $\begin{array}{c}\text { Udzial } \\
\text { woj. w } \\
\text { liczbie } \\
\text { ogółem } \\
(w \%)\end{array}$ \\
\hline Lubelskie & 9 & 1 & 4 & 1 & 3 & 7 & 4 & 0 & 1 & 30 & 14,0 \\
\hline Łódzkie & 11 & 1 & 4 & 0 & 5 & 1 & 9 & 3 & 2 & 36 & 16,7 \\
\hline Małopolskie & 10 & 1 & 6 & 1 & 2 & 10 & 5 & 2 & 3 & 40 & 18,6 \\
\hline Podlaskie & 8 & 2 & 2 & 0 & 3 & 2 & 4 & 0 & 0 & 21 & 9,8 \\
\hline Podkarpackie & 3 & 4 & 6 & 0 & 1 & 3 & 4 & 1 & 0 & 22 & 10,2 \\
\hline Śląskie & 9 & 0 & 2 & 0 & 0 & 2 & 3 & 7 & 3 & 26 & 12,1 \\
\hline Wielkopolskie & 6 & 2 & 2 & 1 & 3 & 3 & 3 & 1 & 1 & 22 & 10,2 \\
\hline Zachodniopomorskie & 5 & 0 & 2 & 2 & 2 & 3 & 4 & 0 & 0 & 18 & 8,4 \\
\hline Razem & 61 & 11 & 28 & 5 & 19 & 31 & 36 & 14 & 10 & 215 & 100,0 \\
\hline $\begin{array}{l}\text { Udział typu szkoły } \\
\text { w liczbie ogółem } \\
(\text { w \%) }\end{array}$ & 28,4 & 5,1 & 13,0 & 2,3 & 8,8 & 14,4 & 16,7 & 6,5 & 4,7 & 100,0 & $\mathbf{x}$ \\
\hline
\end{tabular}

Źródło: opracowanie autorów na podstawie ankiet

Wyjaśnienie skrótów: LO - liceum ogólnokształcące, LP - liceum profilowane, T - technikum, ZSZ - zasadnicza szkoła zawodowa

Tab. 2. Kwalifikacje zawodowe nauczycieli podstaw przedsiębiorczości

\begin{tabular}{|l|c|c|c|c|}
\hline Wyszczególnienie & $\begin{array}{c}\text { Studia } \\
\text { magisterskie } \\
\text { dzienne }\end{array}$ & $\begin{array}{c}\text { Studia } \\
\text { magisterskie } \\
\text { zaoczne }\end{array}$ & $\begin{array}{c}\text { Studia } \\
\text { licencjackie }\end{array}$ & $\begin{array}{c}\text { Studia } \\
\text { podyplomowe } \\
\text { z podstaw } \\
\text { przedsiębiorczości }\end{array}$ \\
\hline Lubelskie & 22 & 8 & 0 & 14 \\
\hline Łódzkie & 31 & 5 & 0 & 16 \\
\hline Małopolskie & 34 & 6 & 0 & 16 \\
\hline Podlaskie & 19 & 2 & 0 & 14 \\
\hline Podkarpackie & 20 & 2 & 1 & 13 \\
\hline Śląskie & 24 & 2 & 0 & 11 \\
\hline Wielkopolskie & 14 & 7 & 0 & $\mathbf{1 0 3}$ \\
\hline $\begin{array}{l}\text { Zachodniopomorskie } \\
\text { Razem }\end{array}$ & $\mathbf{1 7 8}$ & $\mathbf{3 6}$ & $\mathbf{2}$ & $\mathbf{4 7 , 9}$ \\
\hline $\begin{array}{l}\text { Udział nauczycieli } \\
\text { kończących dany typ } \\
\text { studiów w ogólnej } \\
\text { liczbie badanych } \\
\text { (w \%) }\end{array}$ & $\mathbf{8 2 , 8}$ & $\mathbf{1 6 , 7}$ & $\mathbf{0 , 9}$ & \\
\hline
\end{tabular}

Źródło: opracowanie autorów na podstawie ankiet 
Większość badanych ukończyła studia ekonomiczne - 90 osób (41,5\%). Są oni absolwentami kierunków ekonomicznych akademii ekonomicznych, uniwersytetów i akademii rolniczych. Następną grupę stanowią absolwenci kierunków nieekonomicznych: matematyki, fizyki, informatyki - 18 osób (8,3\%), geografii - 15 osób (6,9\%), historii - 6 osób $(2,7 \%)$, pedagogiki - 5 (2,3\%) i innych - 81 osób (38,3\%). Najwięcej nauczycieli podstaw przedsiębiorczości po studiach ekonomicznych uczy w województwach: małopolskim (15 osób), podkarpackim (13 osób), lubelskim (10 osób) i wielkopolskim (10 osób). Jest to m.in. skutek funkcjonowania w tych województwach silnych ośrodków akademickich, zwłaszcza akademii ekonomicznych.

W ramach doskonalenia zawodowego 103 nauczycieli spośród badanych (47,9\%) ukończyło studia podyplomowe z podstaw przedsiębiorczości. Absolwentami studiów podyplomowych są głównie osoby, które nie ukończyły studiów ekonomicznych. Dane wskazują, że znaczna część nauczycieli uczących podstaw przedsiębiorczości nie podjęła doskonalenia zawodowego związanego z nauczaniem nowego przedmiotu. Studia ekonomiczne na wyższych uczelniach na ogół dobrze przygotowują z wybranych specjalności ekonomicznych, jednak treści kształcenia zawarte $\mathrm{w}$ podstawie programowej i programach nauczania podstaw przedsiębiorczości nie są prostym przełożeniem treści ekonomicznych do szkoły. Wiedza zawarta w podstawie programowej ma charakter zintegrowany i obejmuje zagadnienia z zakresu funkcjonowania gospodarki i rynku pracy, instytucji oraz komunikacji interpersonalnej jako całości (Tracz 2005, Rachwał 2004b).

Podstawowe znaczenie dla aktualizacji wiedzy nauczyciela ma zatem samokształcenie. Powinno ono się odbywać m.in. dzięki dostępowi do książek, czasopism, konferencji i seminariów, audycji telewizyjnych, internetu. Wydaje się potrzebą chwili powołanie do życia czasopisma dla nauczycieli podstaw przedsiębiorczości, które popularyzowałoby osiaggnięcia naukowe z zakresu objętego podstawą programową oraz nowatorskie, warte upowszechnienia rozwiązania metodyczne dotyczące programu nauczania, podręczników szkolnych, metod kształcenia i środków dydaktycznych. Częściowo tę lukę wypełniają seminaria metodyczne organizowane przez wydawnictwa oraz różnego typu fundacje i stowarzyszenia (np. Fundację „Edukacja dla Społeczeństwa"). Znaczącą rolę do odegrania mają Stowarzyszenie Nauczycieli Przedsiębiorczości oraz kluby, takie jak IMPULS stworzony przez Narodowy Bank Polski.

W jakim kierunku powinno zatem zmierzać przygotowanie nauczyciela do nauczania tego przedmiotu? Ankietowani nauczyciele wskazali kilka rozwiązań. Niemal 50\% badanych uważa, że nauczyciel podstaw przedsiębiorczości powinien ukończyć studia magisterskie dwuprzedmiotowe $(33,9 \%)$ lub magisterskie jednolite z podstaw przedsiębiorczości $(14,8 \%)$. Jedna czwarta badanych jest zdania, że przygotowanie powinno się odbywać poprzez doskonalenie, czyli studia podyplomowe z podstaw przedsiębiorczości (tab. 3).

Nauczyciele nie są zwolennikami studiów I stopnia (licencjackich) z podstaw przedsiębiorczości. Wydaje się być dobrym rozwiązaniem, z punktu widzenia realizacji założeń reformy oświaty, powołanie na niektórych kierunkach specjalności ,przedsiębiorczość” w uniwersytetach i akademiach pedagogicznych, co gwarantowałoby przygotowanie do zawodu nauczyciela w pełnym zakresie. Jest to ważne, bo przepisy nie pozwalają na uruchomienie samodzielnego kierunku studiów „przedsiębiorczość”, nie ma go bowiem w obowiązującym wykazie ministerialnym kierunków kształcenia. Na studiach wyższych możliwe jest więc tylko uruchamianie przedsiębiorczości jako specjalizacji. Taka specjalizacja jest realizowana m.in. na kierunku „geografia” w Akademii Pedagogicznej w Krakowie (Zioło 2005b). Wydaje się więc celowe umożliwienie uruchomienia studiów na kierunku ,przedsiębiorczość”.

Istotne jest pytanie o motywy wyboru tego przedmiotu przez nauczycieli. Wśród czynników, które decydowały o tym najczęściej, wymieniano kwalifikacje, głównie ukończone studia ekonomiczne (34,9\% badanych), a następnie uzupełnianie godzin brakujących do wypełnienia etatu, 
Tab. 3. Formy przygotowania nauczyciela podstaw przedsiębiorczości w opinii badanych

\begin{tabular}{|l|c|c|c|c|c|c|c|}
\hline & $\begin{array}{c}\text { Studia } \\
\text { magis- } \\
\text { terskie } \\
\text { z 2 przed- } \\
\text { miotów }\end{array}$ & $\begin{array}{c}\text { Studia } \\
\text { magis- } \\
\text { terskie } \\
\text { z podstaw } \\
\text { przedsié- } \\
\text { biorczości }\end{array}$ & $\begin{array}{c}\text { Studia } \\
\text { licen- } \\
\text { cjackie } \\
\text { z 2 przed- } \\
\text { miotów }\end{array}$ & $\begin{array}{c}\text { Studia } \\
\text { licen- } \\
\text { cjackie } \\
\text { z podstaw } \\
\text { przedsié- } \\
\text { biorczości }\end{array}$ & $\begin{array}{c}\text { Studia } \\
\text { pody plo- } \\
\text { mowe } \\
\text { z podstaw } \\
\text { przedsię- } \\
\text { biorczości }\end{array}$ & $\begin{array}{c}\text { Studia } \\
\text { ekono- } \\
\text { miczne }\end{array}$ & $\begin{array}{c}\text { Brak } \\
\text { zdania }\end{array}$ \\
\hline Lubelskie & 10 & 2 & 0 & 0 & 11 & 2 & 4 \\
\hline Lódzkie & 12 & 2 & 0 & 2 & 9 & 6 & 5 \\
\hline Małopolskie & 16 & 8 & 0 & 2 & 9 & 4 & 2 \\
\hline Podlaskie & 6 & 6 & 0 & 0 & 11 & 1 & 0 \\
\hline Podkarpackie & 9 & 3 & 2 & 0 & 4 & 1 & 3 \\
\hline Śląskie & 7 & 5 & 3 & 3 & 4 & 1 & 4 \\
\hline Wielkopolskie & 8 & 2 & 2 & 1 & 5 & 1 & 0 \\
\hline $\begin{array}{l}\text { Zachodnio- } \\
\text { pomorskie }\end{array}$ & $\mathbf{7 3}$ & $\mathbf{2 9}$ & $\mathbf{7}$ & $\mathbf{9}$ & $\mathbf{6 0}$ & $\mathbf{1 8}$ & $\mathbf{1 9}$ \\
\hline Razem & $\mathbf{3 4 , 0}$ & $\mathbf{1 3 , 5}$ & $\mathbf{3 , 3}$ & $\mathbf{4 , 2}$ & $\mathbf{2 7 , 9}$ & $\mathbf{8 , 4}$ & $\mathbf{8 , 8}$ \\
\hline $\begin{array}{l}\text { Udział nauczycieli } \\
\text { wyrażających daną } \\
\text { opinię w ogólnej } \\
\text { liczbie badanych } \\
\text { (w \%) }\end{array}$ & & & & & & & \\
\hline
\end{tabular}

Źródło: opracowanie autorów na podstawie ankiet

wynikające z wprowadzonej reformy systemu edukacji, która zmniejszyła ogólną liczbę godzin do przepracowania dla nauczycieli w szkole (26,5\%). Tylko 19,5\% nauczycieli wskazało własne zainteresowania, a 19,2\% nie udzieliło odpowiedzi (tab. 4).

Tab. 4. Czynniki wpływające na podjęcie nauczania podstaw przedsiębiorczości

\begin{tabular}{|l|c|c|c|c|}
\hline Wyszczególnienie & Zainteresowanie & $\begin{array}{c}\text { Wykształcenie } \\
\text { ekonomiczne }\end{array}$ & $\begin{array}{c}\text { Uzupełnienie } \\
\text { etatu }\end{array}$ & Brak odpowiedzi \\
\hline Lubelskie & 5 & 12 & 8 & 14 \\
\hline Łódzkie & 7 & 15 & 8 & 16 \\
\hline Małopolskie & 5 & 16 & 8 & 16 \\
\hline Podlaskie & 4 & 9 & 7 & 14 \\
\hline Podkarpackie & 4 & 3 & 3 & 9 \\
\hline Śląskie & 8 & 6 & 10 & 13 \\
\hline Wielkopolskie & 5 & 10 & 5 & 10 \\
\hline $\begin{array}{l}\text { Zachodniopomorskie } \\
\text { Razem }\end{array}$ & 4 & 4 & $\mathbf{5 7}$ & $\mathbf{1 9 , 1}$ \\
\hline $\begin{array}{l}\text { Udział nauczycieli } \\
\text { wyrażających daną } \\
\text { opinię w ogólnej } \\
\text { liczbie badanych } \\
\text { (w \%) }\end{array}$ & $\mathbf{4 2}$ & $\mathbf{7 5}$ & $\mathbf{2 6 , 5}$ & \\
\hline
\end{tabular}

Źródło: opracowanie autorów na podstawie ankiet 
Niski udział zainteresowania wśród powodów decyzji o podjęciu nauczania przedmiotu jest niekorzystny z punktu widzenia realizacji procesu dydaktycznego. Oznacza on pewną przypadkowość w podejmowaniu nauczania podstaw przedsiębiorczości, wynikającą z wykształcenia, chęci uzyskania dodatkowych godzin lub wewnętrznego przymusu spowodowanego sytuacją życiową. Może to ujemnie wpływać na jakość kształcenia.

Potwierdzeniem są wyniki analizy stażu pracy w zawodzie nauczyciela. W ankietowanej grupie blisko 30\% stanowili nauczyciele z ponaddwudziestoletnim stażem pracy. Drugą pod względem liczebności byli nauczyciele początkujący w zawodzie - 21,2\% (tab. 5). Najliczniejszą grupę nauczycieli podstaw przedsiębiorczości z najdłuższym stażem odnotowano w województwach małopolskim (20 osób) i łódzkim (15 osób). Największą grupę wśród badanych nauczycieli o najniższym stażu pracy odnotowano w województwach: podkarpackim (10 osób) i lubelskim (8 osób).

Tab. 5. Staż pracy nauczycieli podstaw przedsiębiorczości

\begin{tabular}{|l|c|c|c|c|c|}
\hline Wyszczególnienie & $\mathbf{0 - 5}$ lat & $\mathbf{6 - 1 0}$ lat & $\mathbf{1 1 - 1 5}$ lat & $\mathbf{1 6 - 2 0}$ lat & Powyżej 20 lat \\
\hline Lubelskie & 8 & 7 & 7 & 4 & 4 \\
\hline Łódzkie & 4 & 5 & 4 & 8 & 15 \\
\hline Małopolskie & 8 & 5 & 5 & 2 & 20 \\
\hline Podlaskie & 2 & 4 & 7 & 2 & 6 \\
\hline Podkarpackie & 10 & 7 & 1 & 2 & 2 \\
\hline Śląskie & 4 & 2 & 6 & 6 & 8 \\
\hline Wielkopolskie & 5 & 3 & 4 & 5 & 5 \\
\hline Zachodniopomorskie & 4 & 4 & 5 & 1 & 4 \\
\hline Razem & $\mathbf{4 5}$ & $\mathbf{3 7}$ & $\mathbf{3 9}$ & $\mathbf{3 0}$ & $\mathbf{6 4}$ \\
\hline $\begin{array}{l}\text { Udział nauczycieli } \\
\text { poszczególnych grup } \\
\text { wiekowych w ogólnej } \\
\text { liczbie badanych } \\
\text { (w \%) }\end{array}$ & $\mathbf{2 0 , 9}$ & $\mathbf{1 7 , 2}$ & $\mathbf{1 8 , 1}$ & $\mathbf{1 4 , 0}$ & $\mathbf{2 9 , 8}$ \\
\hline
\end{tabular}

Źródło: opracowanie autorów na podstawie ankiet

Od nauczyciela, który z konieczności prowadzi zajęcia, trudno oczekiwać motywowania uczniów i rozbudzania ich zainteresowania poznawanymi treściami. Wydaje się zatem konieczne podjęcie badań specyfiki zawodowej nauczyciela podstaw przedsiębiorczości i umiejętności, które powinien opanować w toku studiów.

Kolejnym badanym zagadnieniem była ocena wprowadzenia przedmiotu podstawy przedsiębiorczości do szkół ponadgimnazjalnych. Większość ankietowanych (89\%) uważa, że było ono słuszne, tylko $9,7 \%$ badanych nie miało zdania. Podobne opinie na tak postawione pytanie - w świetle wcześniejszych badań prowadzonych w krakowskich szkołach (Osuch, Osuch 2005) wyrazili badani uczniowie i rodzice. Za wprowadzeniem odrębnego przedmiotu podstawy przedsiębiorczości w gimnazjum było 60,0\% nauczycieli (130 osób), a 25,1\% (54 osoby) nie mało sprecyzowanego zdania. Przeciwko wprowadzeniu przedmiotu podstawy przedsiębiorczości w gimnazjum było 14,4 \% ankietowanych (tab. 6). Dane potwierdzają, że edukację w zakresie przedsiębiorczości należy rozszerzyć na niższe poziomy edukacji. Treści wzbudzające największe zainteresowanie wśród uczniów to w opinii nauczycieli: komunikacja interpersonalna, prawo pracy, rynek pracy, zarządzanie przedsiębiorstwem, przygotowanie biznesplanu i funkcjonowanie 
banków. Najwięcej trudności - zdaniem nauczycieli - uczniowie mają z funkcjonowaniem gospodarki rynkowej, wypełnianiem formularzy oraz podatkami i rachunkowością przedsiębiorstwa.

Tab. 6. Opinia nauczycieli o wprowadzeniu podstaw przedsiębiorczości do szkół

\begin{tabular}{|l|c|c|c|c|c|c|}
\hline \multirow{2}{*}{ Wyszczególnienie } & \multicolumn{2}{|c|}{ Tak } & \multicolumn{2}{c|}{ Nie } & \multicolumn{2}{c|}{ Nie mam zdania } \\
\cline { 2 - 7 } & ogółem & $\mathbf{\%}$ & ogółem & \% & ogółem & $\%$ \\
\hline $\begin{array}{l}\text { Czy wprowadzenie podstaw przedsiębior- } \\
\text { czości do szkoły było słuszne? }\end{array}$ & 193 & 89,0 & 1 & 0,3 & 21 & 9,7 \\
\hline $\begin{array}{l}\text { Czy w gimnazjum powinien być wprowadzo- } \\
\text { ny przedmiot podstawy przedsiębiorczości? }\end{array}$ & 130 & 60,0 & 31 & 14,4 & 54 & 25,1 \\
\hline $\begin{array}{l}\text { Czy podstawy przedsiębiorczości powinny } \\
\text { być do wyboru na maturze? }\end{array}$ & 133 & 62,0 & 30 & 14,0 & 52 & 24,0 \\
\hline
\end{tabular}

Źródło: opracowanie autorów na podstawie ankiet

O pozycji i randze przedmiotu szkolnego, oprócz kwalifikacji zawodowych nauczyciela, decyduje m.in. liczba godzin przeznaczonych na jego realizację oraz możliwość zdawania go na maturze. Większość badanych nauczycieli uważa, że liczba godzin przeznaczonych na nauczanie podstaw przedsiębiorczości w stosunku do założeń programowych jest za mała; możliwość realizowania treści przewidzianych programem nauczania dawałyby 3 lub 4 godziny tygodniowo. W opinii $62 \%$ ankietowanych, uczniowie powinni móc wybierać podstawy przedsiębiorczości na egzaminie maturalnym (tab. 6). Przeciwko umieszczeniu podstaw przedsiębiorczości na liście przedmiotów maturalnych było $14,0 \%$ badanych, a $24,0 \%$ nie miało sprecyzowanego zdania. Wprowadzeniem podstaw przedsiębiorczości do grupy przedmiotów do wyboru na egzaminie maturalnym najbardziej zainteresowani są nauczyciele liceów profilowanych i techników. Uważają oni, że zdawanie tego przedmiotu dałoby ich wychowankom szansę dostania się na studia ekonomiczne (gdyby oczywiście wynik maturalny z podstaw przedsiębiorczości stanowił kryterium kwalifikacyjne). Wynika to z faktu, że uczniowie liceów profilowanych i techników mogą przeznaczyć mniej czasu na przedmioty ogólne (np. matematykę) niż uczniowie liceów ogólnokształcących, co skutkuje nieco słabszymi wynikami na egzaminie maturalnym z przedmiotów, które są obecnie brane pod uwagę przez uczelnie ekonomiczne (w zależności od uczelni są to z reguły: matematyka, język obcy, historia, WOS bądź geografia). Wprowadzenie matury z podstaw przedsiębiorczości zwiększyłoby więc szanse uczniów tego typu szkół na zdanie matury oraz dostanie się na studia na podstawie wyniku egzaminu maturalnego z przedmiotu, którego zakres kształcenia jest zbliżony do kilku przedmiotów zawodowych realizowanych w technikach i liceach profilowanych.

Wyniki badań potwierdzają potrzebę przeprowadzenia dyskusji nad efektywnością realizacji założeń wprowadzenia podstaw przedsiębiorczości do szkół. Należy podjąć badania, których wyniki powinny dać podstawę do opracowania modelowej sylwetki nauczyciela podstaw przedsiębiorczości. Trzeba również opracować formy doskonalenia i samokształcenia nauczycieli tego przedmiotu odpowiadające wymogom stawianym współczesnej szkole, chociażby w formie e-learnigu. Bez rozpoczęcia takich działań na szeroką skalę trudno będzie mówić o świadomej i celowej edukacji młodzieży z podstaw przedsiębiorczości.

\section{Literatura}

1. Bartoń M., 2005, Przedsiębiorczość jako przedmiot matury 2008 [w:] Przedsiębiorczość a współczesne wyzwania cywilizacyjne, Z. Zioło, T. Rachwał (red.), seria: Przedsiębiorczość - Edukacja nr 1, 
Zakład Przedsiębiorczości i Gospodarki Przestrzennej IGAP w Krakowie, Wydawnictwo „MiWa”, Kraków

2. Borowiec M., 2003, Ksztaltowanie się krakowskiego ośrodka akademickiego w latach 1960-2001 [w:] Geograficzne aspekty globalizacji i integracji europejskiej, M. Śmigielska, J. Słodczyk (red.), Wydawnictwo PTG, Uniwersytet Opolski, Opole

3. Gabała J., 2005, Ksztaltowanie postaw przedsiębiorczych uczniów [w:] Przedsiębiorczość a wspótczesne wyzwania cywilizacyjne, Z Zioło, T. Rachwał (red.), seria: Przedsiębiorczość - Edukacja nr 1, Zakład Przedsiębiorczości i Gospodarki Przestrzennej IGAP w Krakowie, Wydawnictwo „MiWa”, Kraków

4. Górz B., Rachwał T., 2006, Uwagi do projektu zmiany podstawy programowej podstaw przedsiębiorczości [w:] Rola przedsiębiorczości w podnoszeniu konkurencyjności społeczeństwa i gospodarki, Z. Zioło, T. Rachwał (red.), seria: Przedsiębiorczość - Edukacja nr 2, Wydawnictwo Nowa Era, Zakład Przedsiębiorczości i Gospodarki Przestrzennej IGAP w Krakowie, Warszawa-Kraków

5. Janc K., 2003, Rola nauki i techniki we współczesnym świecie [w:] Geograficzne aspekty globalizacji i integracji europejskiej, M. Śmigielska, J. Słodczyk (red.), Wydawnictwo PTG, Uniwersytet Opolski, Opole

6. Juchnowicz M., 2006, Uwagi dotyczace realizacji przedmiotu podstawy przedsiębiorczości [w:] Rola przedsiębiorczości w podnoszeniu konkurencyjności społeczeństwa i gospodarki, Z. Zioło, T. Rachwał (red.), seria: Przedsiębiorczość - Edukacja nr 2, Wydawnictwo Nowa Era, Zakład Przedsiębiorczości i Gospodarki Przestrzennej IGAP w Krakowie, Warszawa-Kraków

7. Kołodziejski J., 1998, Strategiczna koncepcja przekształceń polskiej przestrzeni a wyzwania cywilizacyjne XXI w. [w:] Współczesne problemy rozwoju regionalnego, T. Marszał i M. Opałło (red.), Biuletyn KPZK PAN, Warszawa, z. 180

8. Makieła Z., 2004, Nowy przedmiot nauczania dla geografów - podstawy przedsiębiorczości [w:] Ksztatcenie $i$ doskonalenie nauczycieli geografii w Polsce $i$ w krajach Unii Europejskiej $w$ drodze do jednoczacej się Europy, Wydawnictwo Naukowe AP w Krakowie, Kraków

9. Osuch E., Osuch W., 2005, Przedmiot podstawy przedsiębiorczości w opinii uczniów i rodziców na przykładzie wybranych krakowskich szkót [w:] Przedsiębiorczość a wspótczesne wyzwania cywilizacyjne, Z. Zioło, T. Rachwał (red.), seria: Przedsiębiorczość - Edukacja nr 1, Zakład Przedsiębiorczości i Gospodarki Przestrzennej IGAP w Krakowie, Wydawnictwo „MiWa”, Kraków

10. Podstawa programowa kształcenia ogólnego (dla liceum ogólnoksztatcacego, liceum profilowanego i technikum), Rozporządzenie Ministra Edukacji Narodowej i Sportu z 26.02.2002 r., Warszawa

11. Przedsiębiorczość a współczesne wyzwania cywilizacyjne, Z. Zioło, T. Rachwał (red.), seria: Przedsiębiorczość - Edukacja nr 1, Zakład Przedsiębiorczości i Gospodarki Przestrzennej IG Akademii Pedagogicznej w Krakowie, Wydawnictwo „MiWa”, Kraków

12. Rachwał T., 2004a, Kształtowanie postaw przedsiębiorczych u uczniów - wyzwaniem dla nauczycieli geografii [w:] Kształcenie i doskonalenie nauczycieli geografii w Polsce i w krajach Unii Europejskiej $w$ drodze do jednoczqcej się Europy, Wydawnictwo Naukowe AP w Krakowie, Kraków

13. Rachwał T., 2004b, Cele i treści kształcenia przedsiębiorczości w szkołach ponadgimnazjalnych [w:] Przedsiębiorczość stymulatorem rozwoju gospodarczego, J. Brdulak, M. Kulikowski (red.), Instytut Wiedzy SGH, Warszawa

14. Rachwał T., 2005, Ksztaltowanie postaw uczniów na lekcjach podstaw przedsiębiorczości [w:] Przedsiębiorczość a współczesne wyzwania cywilizacyjne, Z. Zioło, T. Rachwał (red.), seria: Przedsiębiorczość - Edukacja nr 1, Zakład Przedsiębiorczości i Gospodarki Przestrzennej IG AP w Krakowie, Wydawnictwo „MiWa”, Kraków

15. Rachwał T., 2006, Ksztaltowanie postaw przedsiębiorczych w edukacji szkolnej [w:] Szkoła w nauce i praktyce edukacyjnej, t. II, B. Suchacka (red.), Oficyna Wydawnicza „Impuls”, AP w Krakowie, Kraków

16. Rola przedsiębiorczości w podnoszeniu konkurencyjności społeczeństwa i gospodarki, Z. Zioło, T. Rachwał (red.), seria: Przedsiębiorczość - Edukacja nr 2, Nowa Era i Zakład Przedsiębiorczości i Gospodarki Przestrzennej IG AP w Krakowie, Warszawa-Kraków

17. Strumska-Cylwik L., 2005, Rozważania nad zagadnieniem przedsiębiorczości w kontekście otwartości człowieka na świat [w:] Przedsiębiorczość a wspótczesne wyzwania cywilizacyjne, Z. Zioło, T. Rachwał (red.), seria: Przedsiębiorczość - Edukacja nr 1, Zakład Przedsiębiorczości i Gospodarki Przestrzennej IG AP w Krakowie, Wydawnictwo „MiWa”, Kraków 
18. Tracz M., 2005, O niektórych kryteriach doboru treści nauczania do podstawy programowej i programu nauczania podstaw przedsiębiorczości [w:] Przedsiębiorczość a współczesne wyzwania cywilizacyjne, Z. Zioło, T. Rachwał (red.), seria: Przedsiębiorczość - Edukacja nr 1, Zakład Przedsiębiorczości i Gospodarki Przestrzennej IG AP w Krakowie, Wydawnictwo „MiWa”, Kraków

19. Tracz M., 2006, Rola i znaczenie „podstaw przedsiębiorczości” w kształceniu ogólnym [w:] Rola przedsiębiorczości w podnoszeniu konkurencyjności społeczeństwa i gospodarki, Z. Zioło, T. Rachwał (red.), seria: Przedsiębiorczość - Edukacja nr 2, Nowa Era i Zakład Przedsiębiorczości i Gospodarki Przestrzennej IG AP w Krakowie, Warszawa-Kraków

20. Zioło Z., 2005a, Światowe uwarunkowania rozwoju przedsiębiorczości [w:] Przedsiębiorczość a wspótczesne wyzwania cywilizacyjne, Z. Zioło, T. Rachwał (red.), seria: Przedsiębiorczość - Edukacja nr 1, Zakład Przedsiębiorczości i Gospodarki Przestrzennej IG Akademii Pedagogicznej w Krakowie, Wydawnictwo „MiWa”, Kraków

21. Zioło Z., 2005b, Ksztatcenie nauczycieli do nauczania przedsiębiorczości na specjalności ,,geografia z przedsiębiorczościq i gospodarka przestrzennq" w Akademii Pedagogicznej w Krakowie [w:] Przedsiębiorczość a wspótczesne wyzwania cywilizacyjne, Z. Zioło, T. Rachwał (red.), seria: Przedsiębiorczość - Edukacja nr 1, Zakład Przedsiębiorczości i Gospodarki Przestrzennej IG AP w Krakowie, Wydawnictwo „MiWa”, Kraków

\section{Basis of Entrepreneurship Lessons - Assumption About Realization vs. Preparation of Teachers}

The implementation of an education about an entrepreneurship to Polish educational system was based on some fundamental assumptions, but only few of them were recognized in the legal acts and partly realized. More of them have a form of postulate and were not implemented; although many experts pointed at their significance. After discourse with practitioners from schools, i.e. methodologists and teachers, most of unrealized assumptions have to be considered as fundamental and essential to proper progress of the education about the entrepreneurship. In the first part of the article the most important conditions of effective education about the entrepreneurship - both realized and waiting for implementation - were presented. Great emphasis were putted on controversial problem of including this subject in Matura exam. The functioning of the new subject is a opportunity to reflect on its implementation to the educational system, and on a competency of teachers. Therefore in the second part of the paper, the study of results of the survey conducted among entrepreneurship teachers was presented. Survey aimed at:

- identify the level of essential and didactical competences among the entrepreneurship teachers.

- identify teacher's opinion on the forms of education

- identify teacher's opinion on the introducing the basis of entrepreneurship to secondary schools.

The results confirm the need of debate about the efficiency of the implementation the assumptions about the introducing the basis of entrepreneurship to schools. Research should be conducted on the model profile of the entrepreneurship teacher. Also new forms of education and self-education for the teachers are needed to meet requirements for modern school - for example e-learning. 


\author{
Wioletta Kilar \\ Zakład Przedsiębiorczości i Gospodarki Przestrzennej \\ Instytut Geografii \\ Akademia Pedagogiczna w Krakowie
}

\title{
Zagadnienia globalizacji i korporacji ponadnarodowych w edukacji przedsiębiorczości
}

Współczesnym tendencjom rozwoju społeczno-gospodarczego towarzyszy nasilający się proces koncentracji kapitału w coraz większych i sprawniej działających korporacjach ponadnarodowych (Zioło, Piróg 2002). Wpływają one w zasadniczy sposób na przebieg procesów globalizacji. „Motorem inicjującym te niezwykle złożone procesy jest nasilająca się konkurencja” (Zioło, Rachwał 2006, s. 5). W gospodarce rynkowej konkurencja dotyczy wszystkich jej elementów działających zarówno na rynku międzynarodowym, krajowym, regionalnym, jak i lokalnym. Wpływa ona na zmiany zachowań nie tylko przedsiębiorstw ponadnarodowych, ale również małych przedsiębiorstw na lokalnych rynkach oraz pojedynczych osób, w tym ucznia. Za Z. Zioło (2005, s. 15) należy przyjąć, ,iż tylko konkurencyjny człowiek jest w stanie wyprodukować i zaoferować konkurencyjny produkt, natomiast konkurencyjny człowiek kształtuje się w konkurencyjnym procesie edukacyjnym". Znaczenie korporacji ponadnarodowych w gospodarce globalnej jest coraz większe, gdyż „(...) poprzez różnorodne systemy sieciowych powiązań przestrzennoprodukcyjnych organizują światową przestrzeń gospodarczą" (Zioło 2006, s. 9). Należy zauważyć, że „nasilający się proces koncentracji kapitału, który uwidacznia się między innymi w kształtowaniu się coraz potężniejszych ponadnarodowych korporacji przemysłowych, finansowych, usługowych i innych, obejmuje swym zasięgiem coraz to rozleglejsze obszary oddziaływania i wpływa w głównym stopniu na globalizację gospodarki, a równocześnie na różnicowanie światowej przestrzeni gospodarczej, społecznej i kulturowej” (Kudełko, Zioło 2005, s. 337).

W nawiązaniu do przedstawionych założeń wydaje się, że problematyka globalizacji i korporacji ponadnarodowych powinna zająć znaczące miejsce na różnych etapach systemu edukacyjnego i znaleźć odzwierciedlenie w podręcznikach do nauczania podstaw przedsiębiorczości. Niniejsze rozważania zmierzają do określenia, w jaki sposób autorzy wybranych podręczników podstaw przedsiębiorczości dla liceum, liceum profilowanego i technikum podejmują tę tematykę.

W tym celu dokonano analizy 11 podręczników podstaw przedsiębiorczości dopuszczonych do użytku szkolnego przez Ministerstwo Edukacji Narodowej, a przeznaczonych do kształcenia ogólnego w liceach, liceach profilowanych i technikach ${ }^{1}$. Szczególną uwagę zwrócono na zagadnienia odnoszące się do: globalizacji, globalizacji gospodarki światowej, rynku globalnego, produktu globalnego, a także korporacji ponadnarodowych. Wielu autorów umieściło w podręcznikach powyższe pojęcia, zdając sobie sprawę z tego, że w globalizującym się świecie znaczenie korporacji ponadnarodowych w gospodarce światowej jest bardzo duże, a w następnym dziesięcioleciu, czyli w okresie, kiedy obecny licealista może stać się jedną z osób uczestniczących w działaniu korporacji ponadnarodowych, prawdopodobnie będzie jeszcze większe.

${ }^{1}$ Wykaz analizowanych podręczników zamieszczono na końcu pracy. 
Analizując zagadnienia globalizacji, poszczególni autorzy przedstawiają różne definicje tego pojęcia oraz cechy tego procesu. M. Pietraszewski (2002), zachęcając młodych ludzi do nauki i podnoszenia kwalifikacji, stara się im uświadomić, że w XXI w. procesy globalizacji i ujednolicania rynków pracy mogą spowodować, że jedynie osoby dobrze wykształcone będą w stanie obsługiwać coraz bardziej zautomatyzowane i skomplikowane maszyny i urządzenia. Pracownicy będą nie tyle pracować, co świadczyć usługi potrzebne gospodarce. Ponadto autor wskazuje czynniki, pod których wpływem proces globalizacji będzie się nadal kształtował. Są to: postęp naukowo-techniczny, międzynarodowa konkurencja i polityka ekonomiczna państw. Jak przyjmuje M. Pietraszewski (2002, s. 7 i 8), będą one wpływały i kształtowały także pokolenie wzrastające w dobie kolejnej fazy rewolucji naukowo-technicznej, czyli w rozpoczętym już XXI w. Autor definiuje pojęcie globalizacji jako „znaczące i złożone procesy, które zachodzą w skali ogólnoświatowej w różnych sferach: ekonomicznej, technicznej, socjologicznej i kulturowej”. Wyjaśnia, że podstawowymi cechami globalizacji w sferze ekonomicznej są:

- integrowanie w skali międzynarodowej działalności gospodarczej podmiotów na różnych poziomach: państwowym, rynkowym, dziedzin działalności oraz przedsiębiorstw powiązanych ze sobą handlowo, inwestycyjno-produkcyjnie i korporacyjnie;

- międzynarodowa współzależność między podmiotami gospodarki na różnych poziomach;

- związek z postępem naukowym, technicznym i organizacyjnym, powodujący unowocześnianie gospodarek państw ,poprzez rozwój gałęzi produkcji będących nośnikami postępu technicznego, zastosowanie nowoczesnych procesów produkcji w całej gospodarce, rozwój edukacji narodowej i wzrost liczby wysoko wykwalifikowanych pracowników";

- „skracanie czasu i przestrzeni”, które przejawia się m.in. możliwościami korzystania z oferty produktów i uczestnictwa wszystkich ludzi w wydarzeniach na całym świecie.

Podobna definicja globalizacji przyjmowana jest w podręczniku B. Stańdy i B. Wierzbowskiej (2002, s. 140), w którym procesom globalizacji poświęcono oddzielny rozdział. Autorki przyjmują następującą definicję globalizacji: „,...) bardzo szeroki i złożony proces, mający wpływ na wszystkie sfery naszego życia: ekonomiczna, społeczną, polityczną i kulturową w skali ogólnoświatowej”. Ponadto wymieniają, podobne jak M. Pietraszewski, czynniki, które w największym stopniu wpływają na proces globalizacji. Wskazują wśród krajów uczestniczących w globalizacji na grupę triady, która jest potęgą gospodarczą świata.

Na pojęcie globalizacji zwrócił także uwagę zespół autorski: W. J. Jakubowski, T. Maj, P. Załęski (2003, s. 225), którzy definiują pojęcie globalizacji jako proces ,integracji społecznej i gospodarczej świata", a także przedstawiają wiele przejawów globalizacji, w tym m.in. szybki wzrost wymiany handlowej, dzięki której następuje szybki dostęp do produktów zaawansowanej technologii. Z. Makieła i T. Rachwał (2005, s. 176 i 177) pojęcie globalizacji przedstawiaja jako proces „integracji społecznej i gospodarczej świata”. Wyjaśniają, że przejawami procesu globalizacji są m.in.: swobodny przepływ informacji, liberalizacja w handlu międzynarodowym, swobodny przepływ kapitału oraz swobodne przemieszczanie się osób.

Procesy globalizacji zostały omówione również przez M. Biernacką, J. Korbę i Z. Smutka (2006). Przyjęli oni, że globalizacja jest utożsamiana z działalnością międzynarodowych instytucji finansowych, a proces ten przyczynia się do szybszego rozwoju ekonomicznego wielu państw i warunków życia ich mieszkańców.

W podręczniku pod redakcją M. Belki (2005) przyjęto, że globalizacja jest związana z traktowaniem rynku światowego jak rynku działania przedsiębiorstwa, przez co następuje zanikanie granic państwowych w odniesieniu do przepływów produktów, usług, kapitałów, ludzi, informacji i idei. Autorzy tego podręcznika podkreślają że na globalizację składa się ,zbiór zjawisk, procesów 
i tendencji zachodzących obecnie w skali ogólnoświatowej w rozmaitych sferach: ekonomicznej, politycznej, prawnej, kulturowej, społecznej i technicznej”, lecz największy postęp tego procesu dokonał się w sferze ekonomicznej, przyczyniając się do tworzenia gospodarki globalnej (Belka 2005, s. 188). Ponadto wyróżniono wiele przejawów globalizacji, takich jak: technologia, gospodarka, polityka, kultura, środowisko naturalne, dlatego stanowi ona wielkie wyzwanie w dziedzinie konkurencji dla gospodarek i społeczeństw. W pozostałych podręcznikach przyjętych do analizy nie podjęto próby definiowania globalizacji.

W zróżnicowany sposób przedstawiane są również zagadnienia dotyczące globalizacji gospodarki światowej. M. Pietraszewski (2002) zwraca uwagą, że postęp globalizacji znacząco wpływa na gospodarki państw, które tworzą gospodarkę globalną. Wyjaśnia, że gospodarka światowa opiera się na możliwości swobodnego przepływu produktów oraz czynników produkcji pomiędzy wszystkimi państwami, a globalizacja działalności gospodarczej to nic innego, jak „,dokonujący się na świecie długofalowy proces łączenia coraz większej liczby gospodarek państwowych ponad granicami i rozszerzania wzajemnych powiązań w celu tworzenia ogólnoświatowego systemu ekonomicznego" (s. 8-10).

A. Mikinia i M. Sienna (2002, s. 65) w rozdziale dotyczącym wymiany międzynarodowej wyjaśniają pojęcie globalizacji gospodarki następująco: ,jest to proces powstawania i rozwoju rynków światowych oparty na swobodnym przepływie dóbr, usług, kapitału i pracy". Ponadto autorki przedstawiają główne czynniki, które wpływają na nasilanie się procesu globalizacji gospodarki. Przyjmują przy tym, że globalizacja jest zjawiskiem, którego nie da się uniknąć, procesem, którego nie da się zatrzymać, gdyż „wszyscy stajemy się częścią społeczeństwa globalnego" (s. 70). L. Piasecka (2002, s. 108) wyjaśnia, że ,globalizacja gospodarki oznacza tworzenie takiego systemu regulacji prawnych i administracyjnych, aby możliwy był swobodny przepływ dóbr, usług oraz kapitału i pracy bez względu na granice państw”.

Na pojęcie globalizacji gospodarki światowej zwrócił także uwagę zespół autorski: W. J. Jakubowski, T. Maj, P. Załęski (2003). Podając kilka wybranych przykładów, autorzy pokazują przejawy globalizacji gospodarki światowej w kraju i życiu codziennym ucznia. Przedstawiając omawianą definicję M. Biernacka, J. Korba i Z. Smutek (2006, s. 205) duże znaczenie przypisują wymianie gospodarczej, przyjmując, że: ,globalizacja gospodarki światowej polega na wzroście międzynarodowej wymiany gospodarczej i umiędzynarodowieniu produkcji, ale też prowadzi do wzrostu współzależności między państwami”. Na rolę globalizacji gospodarki światowej zwrócili także uwagę Z. Makieła i T. Rachwał (2005), wyjaśniając, że proces globalizacji gospodarki światowej jest częścią procesu globalizacji świata.

W dwóch kolejnych podręcznikach: autorstwa B. Stańdy i B. Wierzbowskiej (2002) oraz pod redakcją M. Belki (2005) nie zaprezentowano definicji globalizacji gospodarki światowej, lecz nawiązano do tego procesu w podrozdziałach dotyczących globalizacji.

W podręcznikach autorstwa B. Barańskiej., J. Gierczyckiej, D. Szostka (2002), S. Gregorczyka, M. Romanowskiej, A. Sopińskiej, P. Wachowiaka (2002) oraz M. Nasiłowskiego(2002) nie poruszono zagadnień związanych z globalizacją gospodarki światowej.

Kolejne pojęcie, które poddane zostało analizie, to rynek globalny. Jego definicja pojawia się u niewielu autorów.

B. Barańska, J. Gierczycka i D. Szostek (2002, s. 9) zwracają uwagę, że „musimy nauczyć się funkcjonować na rynku globalnym”. W klasyfikacjach rynku według różnych kryteriów zaznaczają istnienie rynku światowego, ,na którym transakcje zawierają przedstawiciele różnych krajów” (s. 65). Jak się wydaje, należałoby jednak wyraźnie zaznaczyć, że transakcje te zawierają przedstawiciele różnego typu korporacji ponadnarodowych i przedsiębiorstw krajowych, a rządy poszczególnych krajów stwarzająjedynie uwarunkowania regulujące rozwój firm i ich powiązań 
rynkowych. B. Stańda i B. Wierzbowska (2002), podobnie jak zespół autorski: B. Barańska, J. Gierczycka, D. Szostek (2002), w rozdziale dotyczącym klasyfikacji rynków ze względu na przestrzeń, wyróżniają jako jeden z jego typów rynek światowy, nie odnosząc się do procesów, które obecnie zachodzą w gospodarce światowej. W. J. Jakubowski, T. Maj, P. Załęski (2003), M. Nasiłowski (2002) oraz A. Mikinia i M. Sienna (2002), podobnie jak autorzy dwóch wcześniej analizowanych podręczników, pojęcie rynku globalnego zaznaczyli jedynie przy klasyfikacji rynku według terytorium (przestrzeni).

W podręczniku pod redakcją M. Belki (2005) autorzy uświadamiają uczniowi, że dziś dla wielu towarów i usług nie istnieje już pojęcie rynku lokalnego czy krajowego, konkurencja toczy się bowiem na rynku globalnym. Ponieważ podmioty gospodarcze funkcjonują nawet na odległych rynkach, produkty przez nie oferowane są dostępne powszechnie na świecie, czyli, jak wskazują autorzy, stają się produktami globalnymi. Potwierdza tę tezę L. Piasecka (2002, s. 109), zaznaczając, że „obecnie wolny przepływ informacji nie stanowi już żadnej bariery; można powiedzieć, że świat się skurczył, z zatem rozszerzyły się dla wielu firm perspektywy rozwoju”. W podręcznikach pozostałych zespołów autorskich, czyli S. Gregorczyka, M. Romanowskiej, A. Sopińskiej, P. Wachowiaka (2002), Z. Makieły i T. Rachwała (2005) oraz M. Biernackiej, J. Korby i Z. Smutka (2006) problematyka rynku globalnego nie została podjęta.

Funkcjonowanie gospodarki rynkowej i nasilające się procesy globalizacji powodują potrzebę zdefiniowania pojęcia ,produkt globalny”. Pojęcie produktu globalnego pojawiło się jedynie w dwóch podręcznikach; autorzy pozostałych je pominęli. L. Piasecka (2002), podobnie jak autorzy podręcznika pod redakcją M. Belki (2005), przedstawia przykłady produktów globalnych, takich jak coca-cola czy cheesburger firmy McDonald's, wyjaśniając, że te produkty dzięki globalizacji gospodarki światowej stały się dostępne na rynku globalnym. L. Piasecka (2002) stwierdza m.in., że działania korporacji ponadnarodowych zmierzają do tego, by ludzie na całym świecie używali tych samych lub podobnych produktów.

Problematyka korporacji ponadnarodowych jest podejmowana w większości analizowanych podręczników, najczęściej w połączeniu z procesami globalizacji gospodarki światowej. Najszerzej została omówiona przez M. Nasiłowskiego (2002, s. 32), który wyjaśnia, że korporacje to „wielkie spółki, zarządzane przez zespoły naukowców, inżynierów, organizatorów sprzedaży, reklamy i marketingu, pracowników, koordynatorów i dyrektorów różnych pionów, którzy tworzą technostrukturę korporacji, czyli mózg kierujący spółką, reprezentujący jej bieżące i długofalowe interesy". Autor twierdzi, że siła korporacji wyraża się tym, że wywierają one decydujący wpływ na cały system gospodarczy krajów, w których się znajdują, oraz określają rozmiary produkcji i wysokość cen, a także w dużym stopniu poprzez system reklamy, kształtują upodobania konsumentów. M. Nasiłowski szczegółowo analizuje proces powstawania i budowy korporacji, a także zagadnienie ich opodatkowania. Podkreśla, że korporacje transnarodowe są najpotężniejszymi przedsiębiorstwami we współczesnym świecie, dysponującymi ogromnym zasobem i bardzo mobilnym kapitałem. W analizowanym podręczniku wyjaśnienie pojęcia korporacji ponadnarodowej rozpoczyna osobny rozdział, dotyczący korporacji wielonarodowych. W rozdziale tym autor przybliża znaczenie korporacji transnarodowych $\mathrm{w}$ gospodarce świata, ich działanie na poszczególnych kontynentach oraz funkcjonowanie w gospodarce polskiej. Ponadto podkreśla, że „w epoce rosnącej globalizacji i łatwości przenoszenia kapitału z kraju do kraju korporacje ponadnarodowe nabierają coraz większego znaczenia" (s. 33).

W sposób zbliżony problematyka korporacji transnarodowych została podjęta w podręczniku autorstwa Z. Makieły i T. Rachwała (2005). Ten zespół autorski, jedyny spośród wszystkich zespołów autorskich analizowanych podręczników, dokonuje klasyfikacji korporacji w schemacie charakteryzującym związki spółek. Autorzy przyjmują że korporacje to „,wielkie organizacje 
ekonomiczne, często o zasięgu międzynarodowym” (s. 95). Ponadto, podobnie jak M. Nasiłowski, przyjmują, że ,stanowią one prawne połączenie wielu spółek, zarządzane są przez wybitnych fachowców wspomaganych przez zespoły naukowców, inżynierów organizatorów sprzedaży oraz, że często korporacje wywierają decydujący wpływ na gospodarkę krajów, a nawet politykę rządów" (s. 95). W końcowym rozdziale, dotyczącym procesów globalizacji, autorzy wskazują na wielkie korporacje transnarodowe jako na najważniejszych „sprawców” globalizacji, gdyż konkurują one skutecznie z państwami i największymi organizacjami międzynarodowymi, organizując gospodarkę światową. Dlatego należy stwarzać w państwach warunki zachęcające do inwestowania przez korporacje transnarodowe, ponieważ są one jednym z najpoważniejszych czynników przyspieszających rozwój gospodarczy krajów.

B. Stańda i B. Wierzbowska (2002) korporacje transnarodowe określają jako jeden z podmiotów uczestniczących w procesie globalizacji. Ponadto wyjaśniają, że działalność korporacji ponadnarodowych ,ppolega na rozszerzeniu i pogłębianiu działań przedsiębiorstw, zmierzających do wytwarzania i sprzedawania produktów oraz standardowych usług na skalę ogólnoświatową" (s. 142). Zespół autorski B. Barańska, J. Gierczycka i D. Szostek (2002, s. 128) zaznacza fakt istnienia korporacji w gospodarce międzynarodowej poprzez przyjęcie definicji korporacji („duża spółka akcyjna”) oraz stwierdzenie: ,jeżeli korporacja działa w kilku krajach, nazywa się ją wtedy korporacją międzynarodową". Charakteryzując gospodarkę rynkową autorzy podkreślają, że dominującą rolę korporacje ponadnarodowe pełnią w kapitalistycznej gospodarce rynkowej, realizowanej np. w Stanach Zjednoczonych.

M. Pietraszewski (2002) porusza problematykę korporacji transnarodowych, nawiązując do procesów globalizacji gospodarki. Autor zaznacza, że globalizacja przejawia się m.in. rozwojem międzynarodowych przedsiębiorstw i instytucji oraz prowadzi w konsekwencji do upowszechniania wspólnego modelu gospodarczego. W rozdziale „Gospodarowanie na rynku zintegrowanym" M. Pietraszewski (2002, s. 242) przypisuje korporacjom podstawowe znaczenie w wymianie międzynarodowej, która dokonuje się poprzez zakłady należące do korporacji i ich kooperantów w wielu państwach świata. Ogromne znaczenie korporacji w gospodarce światowej w ostatnich latach zauważają M. Biernacka, J. Korba i Z. Smutek (2006). Autorzy szacują, że liczba ponadnarodowych korporacji na świecie wynosi około 60 tys., z 500 tys. filii, a zatrudniają one ponad 6 mln pracowników. Podkreślają również fakt, że we współczesnej gospodarce rośnie ilość fuzji i megafuzji, czyli łączenia się największych korporacji oraz przejęć mniejszych korporacji przez większe, co stwarza poważne zagrożenie dla konkurencyjności gospodarki światowej. M. Biernacka, J. Korba i Z. Smutek podkreślają wzrost znaczenia korporacji w gospodarce światowej, przywołując to, że podczas corocznego Światowego Forum Gospodarczego spotykają się politycy reprezentujący gospodarki największych państw świata oraz szefowie największych korporacji ponadnarodowych, czyli osoby, które mają największy wpływ na kształtowanie się światowej gospodarki.

W. J. Jakubowski, T. Maj i P. Załęski (2003) w rozdziale dotyczącym gospodarki światowej podkreślają, że korporacje międzynarodowe, dysponujące tak dużym potencjałem ekonomicznym, są niezależne finansowo, technologicznie i organizacyjnie. Działając w wielu krajach, mogą prowadzić własną politykę gospodarczą. Korporacje ponadnarodowe, takie jak Mitsubishi czy Microsoft, skutecznie konkurują na świecie z oficjalnymi organizacjami i instytucjami, nawet takimi, jak Bank Światowy. Dlatego kraje, którym zależy na dynamicznym rozwoju gospodarczym, zabiegają o to, by korporacje inwestowały właśnie u nich. Ponadto autorzy dodają, że „najbardziej znaczącym przejawem globalizacji jest swobodny przepływ kapitału i inwestycji, co najbardziej jest widoczne w działalności ponadnarodowych korporacji gospodarczych" (s. 226). 
Zespół autorski: S. Gregorczyk, M. Romanowska, A. Sopińska, P. Wachowiak (2002) nie podejmuje zagadnień związanych z procesami globalizacji, natomiast problematykę korporacji ponadnarodowych porusza kilkakrotnie. Autorzy, przedstawiając formy organizacyjno-prawne przedsiębiorstw, zaznaczają, że korporacje ponadnarodowe nie mogą funkcjonować jako przedsiębiorstwa indywidualne czy spółki cywilne, lecz jako spółki kapitałowe. Ponadto, w rozdziale dotyczącym otoczenia ekonomicznego przedsiębiorstw zostają przedstawione motywy, jakimi kierują się przedsiębiorstwa ponadnarodowe w wyborze regionu do inwestycji. Wyróżniają dwie zasadnicze grupy motywów: ogólne i szczegółowe, które decydują o wyborze konkretnego państwa.

L. Piasecka (2002) nie wyjaśnia, co rozumie pod pojęciem korporacji ponadnarodowej. W modelu gospodarczym państw świata jako jeden z podstawowych jego elementów wyróżnia rozrost ponadnarodowych korporacji. Zagadnienie korporacji ponadnarodowych nie zostało poruszone w podręczniku pod redakcją M. Belki (2005), a w podręczniku autorstwa A. Mikinii i M. Siennej (2002) zostało jedynie zaznaczone, że rozwój korporacji ponadnarodowych jest jednym z czynników wpływających na globalizację gospodarki światowej.

W świetle przedstawionej analizy należy stwierdzić, że większość autorów podręczników podstaw przedsiębiorczości podejmuje problematykę globalizacji i korporacji ponadnarodowych. Zagadnienia dotyczące korporacji najczęściej powiązane są z tematyką globalizacji gospodarki światowej, co jest oczywiste, gdyż korporacje transnarodowe są głównymi „sprawcami” procesów globalizacji. Problematyka korporacji ponadnarodowych oraz procesy globalizacji gospodarki światowej są przedstawiane z różną szczegółowością w poszczególnych podręcznikach, a przez niektórych są traktowane marginesowo. Żaden z autorów nie wyjaśnia pojęcia produktu globalnego, co - jeśli pomija się również problematykę budowy korporacji ponadnarodowych utrudnia uczniowi zrozumienie mechanizmów występujących we współczesnej gospodarce krajowej i światowej. Analizowane zagadnienia najczęściej znajdują się w ostatnich rozdziałach podręczników, co uczeń może potraktować jako podsumowanie tego, czego nauczył się podczas lekcji podstaw przedsiębiorczości, a także wskazówkę, jakie procesy, obecnie i w najbliższej przyszłości, będą odgrywały istotną rolę w gospodarce światowej. Znajomość tych procesów stawia go w pozycji konkurencyjnej w stosunku do innych osób, które nie zdają sobie sprawy ze znaczenia globalizacji gospodarki światowej. Daje to możliwość podejmowania świadomych decyzji i odnalezienia się w rozwijającym się świecie.

W podstawie programowej podstaw przedsiębiorczości dla liceów, liceów profilowanych i techników brak jest zagadnień dotyczących funkcjonowania korporacji ponadnarodowych. Wydaje się, że ta tematyka powinna się znaleźć w podstawie programowej, ze względu na pierwszy punkt w celach edukacyjnych tego przedmiotu, czyli „Przygotowanie do aktywnego i świadomego uczestnictwa w życiu gospodarczym”, który dotychczas nie mógł być w pełni realizowany. Zatem generalnie wydaje się, że analizowana problematyka powinna być szerzej realizowana zarówno w treściach kształcenia w szkole ponadgimnazjalnej, jak i w podręcznikach podstaw przedsiębiorczości.

\section{Literatura}

1. Gierańczyk W., Stańczyk A., 2003, Korporacje międzynarodowe w przestrzeni globalnej [w:] Ksztattowanie się struktur przemysłowych, Z. Zioło, Z. Makieła (red.), Prace Komisji Geografii Przemysłu PTG, 5/2003, Warszawa-Kraków 
2. Kudełko J., Zioło Z., 2005, Przemiany potencjalu gospodarczego przestrzeni światowej w latach 1990-2003 [w:] Procesy i kierunki przemian w gospodarce, przestrzeni i spoleczeństwie - Ksiega Jubileuszowa dedykowana prof. dr hab. Z. Mikołajewiczowi w siedemdziesiata rocznice Urodzin, M. Bogucka, J. Słodczyk (red.), Uniwersytet Opolski, Opole

3. Podstawa programowa ksztatcenia ogólnego dla liceum ogólnokształcacego, liceum profilowanego i technikum [w:] Rozporzqdzenie Ministra Edukacji Narodowej i Sportu z dnia 26.02.2002 r. w sprawie podstawy programowej wychowania przedszkolnego oraz kształcenia ogólnego w poszczególnych typach szkót, Dz.U. Nr 51, poz. 458

4. Sala S., 2005, Rozwój korporacji transnarodowych w gospodarce światowej [w:] Przedsiębiorczość a wyzwania cywilizacyjne, Z. Zioło, T. Rachwał (red.), seria: Przedsiębiorczość - Edukacja nr 1, Zakład Przedsiębiorczości i Gospodarki Przestrzennej Instytutu Geografii Akademii Pedagogicznej Krakowie, Wydawnictwo „MiWa”, Kraków

5. Zioło Z. 2005, Światowe uwarunkowania rozwoju przedsiębiorczości [w:] Przedsiębiorczość a wyzwania cywilizacyjne, Z. Zioło, T. Rachwał (red.), seria: Przedsiębiorczość - Edukacja nr 1, Zakład Przedsiębiorczości i Gospodarki Przestrzennej Instytutu Geografii Akademii Pedagogicznej Krakowie, Wydawnictwo „MiWa”, Kraków

6. Zioło Z., 2006, Zróżnicowanie światowej przestrzeni przemysłowej w świetle koncentracji siedzib zarzqdów wiodacych korporacji [w:] Międzynarodowe uwarunkowania rozwoju przemystu, Z. Zioło, T. Rachwał (red.), Prace Komisji Geografii Przemysłu PTG nr 8, Warszawa-Kraków

7. Zioło Z., Piróg S., 2002, Lokalizacja zarzq̨ów i potencjat ekonomiczny wiodacych firm zachodnioeuropejskich [w:] Problemy transformacji struktur przemystowych, Z. Zioło (red), Prace Komisji Geografii Przemysłu PTG nr 4, Warszawa-Kraków-Rzeszów

8. Zioło Z., Rachwał T., 2006, Wprowadzenie [w:] Międzynarodowe uwarunkowania rozwoju przemysłu, Z. Zioło, T. Rachwał (red.), Prace Komisji Geografii Przemysłu PTG nr 8, Warszawa-Kraków

\section{Wykaz podręczników do przedmiotu podstawy przedsiębiorczości dla liceum ogólnokształcącego, liceum profilowanego i technikum, przyjętych do badań}

1. Barańska B., Gerczycka J., Szostek D., 2002, Przedsiębiorczość. Podręcznik dla liceów ogólnoksztatcacych, liceów profilowanych i techników, Videograf Edukacja, Chorzów

2. Belka M. (red.), 2005, Ekonomia stosowana. Podręcznik do podstaw przedsiębiorczości dla liceów ogólnokształcacych, liceów profilowanych i techników (wydanie II uaktualnione), Fundacja Młodzieżowej Przedsiębiorczości, Warszawa

3. Biernacka M., Korba J., Smutek Z., 2006, Podstawy przedsiębiorczości. Podręcznik dla liceum ogólnokształcacego, liceum profilowanego i technikum (wydanie II zmienione), Wydawnictwo Pedagogiczne Operon, Gdynia

4. Gregorczyk S., Romanowska M., Sopińska A., Wachowiak P., 2002, Przedsiębiorczość bez tajemnic. Podręcznik dla liceum ogólnokształcqcego, liceum profilowanego i technikum, WSiP, Warszawa

5. Jakubowski W. J., Maj T., Załęski P., 2003, Podstawy przedsiębiorczości. Podręcznik do liceów i techników, Oficyna Wydawnicza Krzysztof Pazdro, Warszawa

6. Makieła Z., Rachwał T., 2005, Podstawy przedsiębiorczości. Podręcznik dla liceum ogólnokształcacego, liceum profilowanego i technikum, wydanie czwarte, Nowa Era, Warszawa

7. Mikina A., Sienna M., 2002, Przedsiębiorczość - klucz do sukcesu. Podstawy przedsiębiorczości dla liceum ogólnokształcacego, liceum profilowanego i technikum, Wydawnictwo Rea, Warszawa

8. Nasiłowski M., 2002, Podstawy przedsiębiorczości. Podręcznik dla szkót ponadgimnazjalnych, Wydawnictwo Key Text, Warszawa

9. Piasecka L., 2002, Podstawy przedsiębiorczości 1. Podręcznik dla liceum ogólnoksztatcacego, liceum profilowanego i technikum, Wydawnictwa Edukacyjne Wiking, Wrocław

10. Pietraszewski M., 2002, Szansa dla przedsiębiorczych. Podręcznik podstaw przedsiębiorczości dla liceów i techników do aktywnego uczenia się, Oficyna Ekonomiczna Wydawnictwa eMPi² , Poznań

11. Stańda B., Wierzbowska B., 2002, Przedsiębiorczość (podręcznik dla szkót ponadgimnazjalnych), Wydawnictwo Szkolne PWN, Warszawa 


\section{Issues of Globalization and International Corporations in the Teaching Entrepreneurship}

The aim of the article is to define how the issue of entrepreneurship is tackled by authors of textbooks for high, vocational and technical schools.

According to presented study, it is possible to observe that the majority of authors of the textbooks on the basics of entrepreneurship raise the issues of globalization and international corporations. Usually the issue of corporations is related to the issue of globalization in the world's economy - with more or less details in different textbooks. The above mentioned issues can usually be found in the last chapters, which a student can treat as a guideline for what processes will take place in the world's economy in the future. The awareness of these processes is crucial to students' education and puts them in competitive position with relation to others who do not realize the full meaning of globalization in the world's economy. It also allows for making rational decisions and finding one's place in the developing world. 


\section{Edyta Osuch}

V Liceum Ogólnokształcące w Krakowie

Wiktor Osuch

Zakład Dydaktyki Geografii

Instytut Geografii

Akademia Pedagogiczna w Krakowie

\section{Wybrane projekty edukacyjne w aktywizacji uczniów na lekcjach podstaw przedsiębiorczości}

Jedną z ważniejszych form aktywizacji uczniów na lekcjach przedsiębiorczości jest praca nad tworzeniem projektów edukacyjnych. W czasach ogólnej dostępności komputerów i internetu jest wiele możliwości realizacji ciekawych przedsięwzięć edukacyjnych o tematyce ekonomicznej, bankowej, a także społecznej. Do realizacji tego typu projektów potrzebny jest najczęściej odpowiedni sprzęt komputerowy, internet oraz - oczywiście - chęci i zaangażowanie w tworzenie często dość pracochłonnych programów. Wiele instytucji naukowych i fundacji chętnie pomaga nauczycielom w zdobywaniu specjalistycznych materiałów. Niniejszy artykuł przedstawia kilka projektów edukacyjnych. Prezentuje także strony internetowe portali edukacyjnych, na których można znaleźć dobre i ciekawe materiały dydaktyczne.

Projekty, które można realizować na lekcjach z podstaw przedsiębiorczości, najczęściej są autorstwa:

- fundacji: Fundacji Młodzieżowej Przedsiębiorczości, Fundacji Bankowej im. Leopolda Kronenberga, Fundacji Centrum Edukacji Obywatelskiej, Fundacji Komandor, Fundacji PZU;

- banków: Narodowego Banku Polskiego (NBP portal), Citibanku Handlowego;

- gazet, m.in.: Gazety Wyborczej („Moje finanse - z klasy do kasy”);

- instytucji samorządowych, m.in.: Małopolskiego Instytutu Samorządu Terytorialnego (konkurs ,Junior Biznesu”);

- uczelni wyższych, m.in.: Akademii Ekonomicznej w Krakowie(Ogólnopolski Konkurs Menedżerski).

Narodowy Bank Polski, Fundacja Bankowa im. L. Kronenberga oraz Fundacja Młodzieżowej Przedsiębiorczości rozpoczęły w 2005 r. realizację ogólnopolskiego programu edukacji finansowej młodzieży „Moje finanse” (http://junior.org.pl). Jest on skierowany do uczniów szkół ponadgimnazjalnych, a jego celem jest pogłębienie wiedzy z zakresu finansów i bankowości oraz pokazanie możliwości praktycznego jej wykorzystania.

Sprawne poruszanie się w świecie gospodarki rynkowej wymaga znajomości zasad funkcjonowania sektora finansowego, szczególnie bankowego, sposobów planowania i inwestowania, a także umiejętności zarządzania finansami osobistymi. Z badań wynika, że uczniowie szkół ponadgimnazjalnych, wchodząc w dorosłe życie, mają zbyt małą wiedzę na ten temat i brak im umiejętności wykorzystania jej na użytek własny.

Program realizowany w trzech modułach w latach 2005-2007. Obejmuje następujące działy:

- „Polubić banki” - pieniądz, konto bankowe, lokaty, kredyty;

- „Moje inwestycje” - formy oszczędzania i inwestowania, rynek kapitałowy, akcje, obligacje;

- „Inwestycja w przyszłości” - system emerytalny, w tym fundusze emerytalne. 
Młodym ludziom, którzy po ukończeniu szkoły rozpoczną dorosłe życie, potrzebne są umiejętności zarządzania finansami osobistymi oraz lepsze rozumienie zasad rządzących ekonomią. Dlatego program ma ich nauczyć praktycznych umiejętności przydatnych w gospodarce rynkowej.

Program „Ekonomia w szkole”, którego współorganizatorami są Narodowy Bank Polski i Fundacja Młodzieżowej Przedsiębiorczości, jest skierowany do nauczycieli podstaw przedsiębiorczości. Celem programu jest pogłębienie wiedzy ekonomicznej nauczycieli oraz podniesienie efektywności przekazywania tej wiedzy na zajęciach z podstaw przedsiębiorczości.

Fundacja Młodzieżowej Przedsiębiorczości przygotowała również projekty dotyczące zarządzania firmą. ,Zarządzanie firmą” to program edukacyjny dla uczniów szkół ponadgimnazjalnych. Zajęcia opierają się na komputerowej symulacji procesów gospodarczych. W trakcie gry uczniowie przekonują się o przydatności, a wręcz konieczności posiadania wiedzy teoretycznej niezbędnej do podejmowania trafnych decyzji gospodarczych, prowadzących drużynę do zwycięstwa w symulowanej konkurencji.

„Dzień przedsiębiorczości” to program przeznaczony dla uczniów szkół ponadgimnazjalnych, organizowany za pośrednictwem Internetu. Sprzyja on podejmowaniu przez młodych ludzi trafnych decyzji w planowaniu dalszej drogi edukacyjnej i zawodowej. Uczniowie mają możliwość odbycia kilkugodzinnych praktyk w wybranym miejscu pracy, zweryfikowania swoich wyobrażeń o wymarzonym zawodzie, pozyskania informacji o wykształceniu, umiejętnościach i predyspozycjach niezbędnych do wykonywania danego zawodu.

Program „Być przedsiębiorczym” jest skierowany do uczniów szkół ponadgimnazjalnych. Wspiera działania nauczycieli, wychowawców, pedagogów i doradców zawodowych. Podkreśla rolę etycznego działania w kontaktach z innymi ludźmi i uczy odpowiedzialności za postępowanie własne i zespołu. Program „Być przedsiębiorczym” jest realizowany przez Fundację Młodzieżowej Przedsiębiorczości wspólnie z Fundacją PZU.

Fundacja Młodzieżowej Przedsiębiorczości wspólnie z Narodowym Bankiem Polskim przygotowała również program dla uczniów gimnazjum „Ekonomia na co dzień, czyli decyduj o sobie”. Jest to propozycja przygotowania uczniów do aktywnego wchodzenia w życie gospodarcze, decydowania o sobie, wytyczania własnej drogi rozwoju poprzez aktywne wzmacnianie swoich mocnych stron, zainteresowań, uzdolnień, a przez to dostosowania się do zmieniającej się struktury rynku pracy.

Nauczyciele mogą korzystać z wielu innych programów i projektów przygotowanych przez Fundację Młodzieżowej Przedsiębiorczości. Szczegółowe informacje znajdują się na stronie internetowej: http://junior.org.pl.

Na uwagę zasługują również projekty przygotowane przez Fundację Centrum Edukacji Obywatelskiej. W ramach programu „ZZ edukacją na ty” zostały przygotowane dwa projekty: „Zakładamy i prowadzimy firmę” i ,Z giełdą na ty”. Głównym celem projektu „Z giełdą na ty” jest przybliżenie, którymi rządzi się rynek kapitałowy. Poprzez stworzenie odpowiedniej platformy uczniowie gimnazjów i szkół średnich mają możliwość poznania mechanizmów działania giełdy. W trakcie gry inwestują środki pieniężne w papiery wartościowe, podejmują decyzje, których skutki nie zawsze można przewidzieć, ale przede wszystkim zdobywają wiedzę, która w przyszłości pozwoli im wejść na prawdziwą giełdę papierów wartościowych. Realizując drugi z projektów: „Zakładamy i prowadzimy firmę”, uczniowie moga przekonać się, na czym polega praca przedsiębiorcy oraz jak funkcjonuje mała firma. Dodatkowe informacje o tych programach można znaleźć na stronie: www.ceo.org.pl.

Na uwagę zasługuje Portal Edukacji Ekonomicznej Narodowego Banku Polskiego. Głównymi adresatami działań edukacyjnych NBP są ludzie młodzi - uczniowie szkół ponadpodstawowych oraz studenci, a także ci, którzy z racji wykonywanego zawodu sami przekazują wiedzę, m.in. nauczyciele. Przy realizacji projektów edukacyjnych NBP współpracuje z wieloma instytu- 
cjami i organizacjami. Celem Portalu (www.nbportal.pl) jest przekazywanie i pogłębianie wiedzy o ekonomii i gospodarce.

Na stronie internetowej NBP można znaleźć wiele ciekawych konkursów realizowanych metodą projektów. Jeden z nowszych to „Podstawowe pojęcia ekonomiczne”. W 2005 r. dużym zainteresowaniem wśród uczniów szkół ponadgimnazjalnych cieszył się konkurs na pracę: „Jakie są przyczyny bezrobocia i co może je skutecznie zmniejszyć?’”. Kolejny, nowy projekt NBP i Fundacji Młodzieżowej Przedsiębiorczości związany jest z uruchomieniem Klubu Przedsiębiorczych Nauczycieli IMPULS.

Należy zwrócić uwagę na stronę Fundacji Komandor: www.fundacja.komandor.pl. Można na niej znaleźć ciekawe projekty zajęć dotyczące: pieniądza w gospodarce rynkowej, instytucji finansowych (banków, wymiany handlowej przedsiębiorstw), sposobów inwestowania i innych, o tematyce realizowanej na lekcjach podstaw przedsiębiorczości.

Przykładem instytucji samorządowej aktywizującej młodzież jest Małopolski Instytut Samorządu Terytorialnego i Administracji (www.mistia.org.pl), który przeprowadził cztery edycje Konkursu „Junior Biznesu”. Celem konkursu była aktywna promocja przedsiębiorczości wśród uczniów szkół ponadgimnazjalnych województwa małopolskiego, a jego ideą - kreowanie aktywności oraz rozwijanie umiejętności poznawczych i organizacyjnych uczniów. Pracując w kilkuosobowych grupach, tworzyli oni biznesplan własnej działalności gospodarczej.

Ogólnopolski Konkurs Menedżerski realizowany metodą projektu przeprowadzany jest obecnie przez Akademię Ekonomiczną w Krakowie i dotyczy udziału w internetowej grze symulacyjnej TEES-6. Uczestnicy rozgrywki pełnią rolę menedżerów zarządzających przedsiębiorstwami przemysłowymi działającymi w warunkach silnej konkurencji - oligopolu bez jednostki dominującej (http://cee.ae.krakow.pl/konkurs/).

W niniejszym artykule przedstawiono tylko wybrane projekty edukacyjne, które można wykorzystać $\mathrm{w}$ nauczaniu podstaw przedsiębiorczości. Większość z nich jest dobrze znana nauczycielom i wykorzystywana jako alternatywny sposób aktywizacji młodzieży. Aby jednak nasi wychowankowie wykazywali zainteresowanie przedmiotem i tym, co się dzieje w otaczającym świecie, musimy im pomóc i zachęcić ich do aktywnej nauki, np. z wykorzystaniem projektów edukacyjnym.

\section{Selected Educational Projects on Students Activity on Basics of Entrepreneurship Lessons}

The article presents selected educational projects used by teachers on basics of entrepreneurship lessons. In the times of various multi-medial techniques, computerization and the Internet, using youth activating projects is necessary. The subject of basics of entrepreneurship gives large opportunities of realizations of this kind of undertakings. Nowadays there are many projects, for example created by Youth Foundation of Entrepreneurship, Foundation of The Centre of Civil Education or National Bank of Poland. The most known projects are: "Economics in School", "My Finances", "Firm Management", Day of Entrepreneurship and so on.

Teachers from secondary schools participate in workshops, gain suitable skills for implementing the youth activating projects.

This article describes briefly the projects mentioned above, encourage teachers to introducing them into their work. Moreover, the article contains Web site's addresses where you can find materials and information for teachers on these projects. 


\section{Malgorzata Kulikowska}

III Liceum Ogólnokształcące w Białymstoku

\section{Bożena Krasnodębska}

Centrum Kształcenia Ustawicznego w Białymstoku

\section{Techniki multimedialne w nauczaniu podstaw przedsiębiorczości}

Przełom XX i XXI w. to początek nowego okresu cywilizacyjnego, okresu społeczeństwa informacyjnego. Zmiany związane z rozwojem technologii informacyjnej i komunikacyjnej szybko nabierają charakteru cywilizacyjnego. Obserwujemy przejście od społeczeństwa postindustrialnego (przemysłowego) do globalnego społeczeństwa informacyjnego. Któż, jeśli nie nauczyciele „budujący społeczeństwo", ma zatem być przygotowany i przygotowywać młodego człowieka do korzystania z technologii informacyjno-komunikacyjnej i rozwiązań opartych na tej technologii.

Społeczeństwo oczekuje od szkoły dobrego przygotowania przyszłych pełnoprawnych obywateli również w zakresie wszechstronnego korzystania z technologii informacyjnej w życiu zawodowym i osobistym.

W czasach rozwoju techniki komputerowej bardzo ważne jest wykorzystanie nowoczesnej technologii w uczeniu się i nauczaniu. Nauczyciel sam powinien rozumieć wagę tego procesu, bowiem tylko pasjonat może przelać swoje zainteresowania na współpracującą z nim młodzież. Jakie zatem zalety ma komputerowe wspomaganie dydaktyki?

Do najistotniejszych należy zaliczyć:

- uatrakcyjnianie zajęć;

- pobudzanie uczniów do aktywnej pracy (wykorzystanie zafascynowania współczesnej młodzieży informatyka);

- zwiększanie zainteresowania uczniów przedmiotem, wzrost motywacji do nauki;

- zdobywanie doświadczenia poprzez udział w symulacyjnych grach dydaktycznych;

- wspomaganie procesu dydaktycznego poprzez przedstawianie trudnych procesów ekonomicznych w sposób przystępny i ciekawy.

Nauczyciele wykorzystują technologię informacyjno-komunikacyjną w nauczaniu głównie jako źródło informacji do samokształcenia: internet, portale edukacyjne, symulacyjne gry dydaktyczne (np. MESE - symulacje komputerowe procesów gospodarczych), i tworzą materiały dydaktyczne w postaci prezentacji multimedialnych, coraz częściej interaktywnych. Prezentacje multimedialne są niezwykle atrakcyjne zarówno z punktu widzenia nauczyciela, jak i ucznia. Przygotowanie ciekawej, przemyślanej merytorycznie, dobrej dydaktycznie prezentacji wymaga od nauczyciela ogromnego zaangażowania i dużego wkładu pracy, która w przyszłości przyniesie wymierne korzyści obu stronom. Praca na lekcji z prezentacją multimedialną pozwala uczniom na:

- lepsze przyswajanie wiedzy poprzez oddziaływanie na wiele zmysłów (po trzech dniach od momentu przekazania informacji zapamiętujemy $10 \%$ informacji odebranych przez słuch, $20 \%$ - przez wzrok, a 65\%, jeśli były równocześnie słyszane i widziane);

- samodzielną kontrolę stopnia opanowania wiadomości i umiejętności;

- zdobywanie potrzebnego doświadczenia poprzez symulację procesów gospodarczych (np. trening w zarządzaniu działalnością firmy na wirtualnym rynku). 


\section{Projekt edukacyjny „Mój uczeń - przedsiębiorca z klasą”}

Od października 2004 r. do stycznia 2005 r. w woj. podlaskim łomżyński Ośrodek Doskonalenia Nauczycieli realizował projekt edukacyjny pt. „Mój uczeń - przedsiębiorca z klasą”. Autorem projektu i kierownikiem przedsięwzięcia był mgr inż. Tadeusz Zaremba, konsultant ds. kształcenia zawodowego. Głównym celem przedsięwzięcia było promowanie aktywizujących metod nauczania podstaw przedsiębiorczości oraz opracowanie programów multimedialnych i komputerowych gier dydaktycznych. W szczególności projekt obejmował:

1. szkolenie dla nauczycieli podstaw przedsiębiorczości:

- motywujące funkcje pomiaru dydaktycznego w procesie kształtowania postaw przedsiębiorczości,

- projektowanie technik i narzędzi aktywizujących ucznia oraz mierzenie osiagnięć i zmian w postawach,

- przykłady wykorzystania programów multimedialnych oraz zasobów tematycznych internetu w procesie dydaktycznym przedmiotu podstawy przedsiębiorczości;

2. opracowanie przez uczestników scenariuszy zajęć, testów sprawdzających oraz programów multimedialnych i komputerowych gier dydaktycznych wspomagających kształtowanie postawy przedsiębiorczości u uczniów;

3. upowszechnienie efektów projektu w lokalnym środowisku oświatowym.

Powyższe przedsięwzięcie zaowocowało opracowaniem materiałów dydaktycznych w postaci:

- zestawu interaktywnych prezentacji multimedialnych przystosowanych do samodzielnego kontrolowania przez ucznia stopnia opanowania wiedzy i umiejętności,

- symulacyjnych gier dydaktycznych mających na celu kształtowanie postaw przedsiębiorczych oraz treningu w zarządzaniu działalnością firmy na rynku,

- scenariuszy zajęć edukacyjnych oraz testów sprawdzających, wydanych w postaci broszur informacyjnych.

Następnie efekty projektu zostały upowszechnione w lokalnym środowisku oświatowym, m.in. poprzez wydanie materiałów powarsztatowych (dzięki wsparciu finansowemu Narodowego Banku Polskiego) oraz przeprowadzenie lekcji opartych na powstałych materiałach dydaktycznych.

\section{Zajęcia multimedialne pt.: „Planuję kampanię promocyjną mojej firmy”}

W styczniu 2005 r. w Białymstoku w III Liceum Ogólnokształcącym im. K.K. Baczyńskiego oraz w Zespole Szkół Metalowo-Drzewnych im. gen. W. Andersa zostały przeprowadzone lekcje multimedialne z podstaw przedsiębiorczości pt.: „Planuję kampanię promocyjną mojej firmy” (scenariusz lekcji - zał. 1). Wykorzystano interaktywną prezentację dydaktyczną (utworzoną w ramach powyższego projektu) do opracowania planu promocji wirtualnej firmy Tra-Bic (przesyłki i zlecenia kurierskie).

Lekcje odbywały się w pracowni komputerowej, pod kierunkiem nauczycieli: mgr inż. Małgorzaty Kulikowskiej oraz mgr inż. Bożeny Krasnodębskiej. Uczniowie tworzyli plan promocji wirtualnej firmy, wykorzystując środki multimedialne. Celem zajęć było:

- poznanie roli marketingu w biznesie poprzez:

- wyjaśnienie pojęć: marketing, promocja i reklama,

- wskazanie różnicy pomiędzy promocją a reklamą,

- wskazanie celów promocji,

- poznanie mediów reklamy oraz etapów tworzenia planu marketingowego firmy; 
- kształtowanie umiejętności posługiwania się komputerem w wyszukiwaniu potrzebnych informacji oraz ich porządkowaniu i wykorzystywaniu do rozwiązywania problemów dotyczących :

- ustalenia grupy docelowej,

- doboru do wybranej grupy klientów odpowiedniej oferty usług firmy oraz formy reklamy,

- oszacowania kosztów reklamy przy założonym limicie finansowym,

- gospodarowania pieniędzmi,

- opracowania prostej reklamy firmy;

- kształtowanie umiejętności prezentowania wyników swojej pracy.

\section{PRZEWODNIK}

- Pojecie marketingu

- Cel marketingu

- Strategia marketingowa

- Marketing mix

- Dzialania marketingowe

- Promocja a reklama

- Funkcje reklamy

- Tworzenie reklamy

- Model AIDA
- Media reklamowe

- Reklama telewizyjna

- Reklama radiowa

- Reklama prasowa

- Ulotka reklamowa

- Program marketingowy

- Planowanie dzialalności gospodarczej

- Slownik

- Literatura

\section{MARKETING}

to sposób myślenia przedsiębiorców ukierunkowany na potencjalnych klientów.

Dzialania marketingowe zmierzają do:

- dostosowana wytwarzanych przez firmę produktów do potrzeb klientów,

- wplywania na zmiany tych potrzeb pod kątem strategii rozwoju firmy (kreowanie potrzeb).
Marketing pozwala firmie dzialać

w sposób racjonalny, nie w „,ciemno”. Racjonalność ta dotyczy:

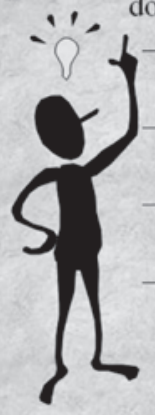

jyboru produktu, na który jest zapotrzebowanie, ustalenie progu oplacalności (rentowności),

- przekazanie informacji o produkcie,

- wyboru odpowiedniego czasu i miejsca sprzedaży. 


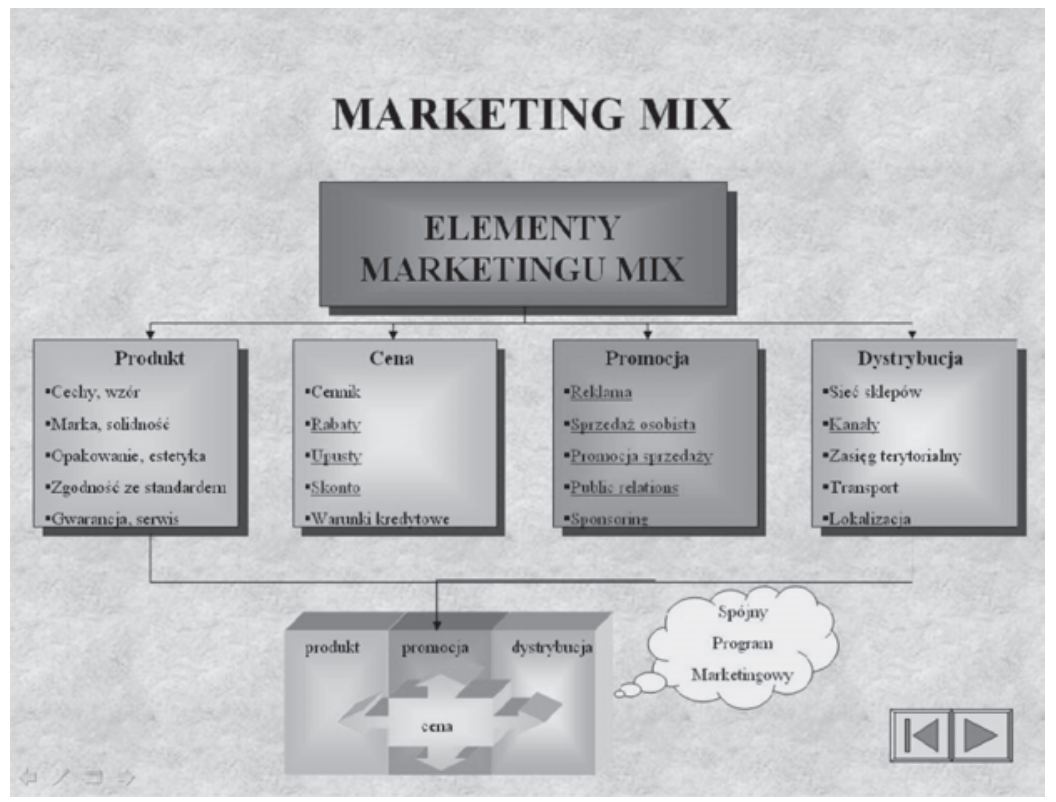

Zajęcia edukacyjne rozpoczęły się od przedstawienia przez nauczyciela pojęć związanych z marketingiem firmy, z wykorzystaniem prezentacji multimedialnej i przykładowych materiałów promocyjnych. Prezentujemy slajdy z prezentacji wprowadzającej „Marketing”.

W kolejnej części lekcji uczniowie tworzyli plan promocji firmy z wykorzystaniem interaktywnej prezentacji dydaktycznej „Planuję kampanię ...” (przykładowe slajdy poniżej). Pracowali samodzielnie, posługując się wskazówkami zawartymi w karcie pracy (zał. 2).

Uczniowie pracowali z prezentacją pełniącą funkcję doradcy i przewodnika po sekretach reklamy; podejmowali decyzje planistyczne kampanii promocyjnej, zaznaczając je w programie komputerowym.

Planuję kampanię promocyjną mojej firmy

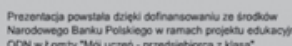

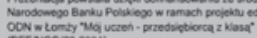
(PEENCORz:2004)

\section{Etap pierwszy: \\ Ustalamy cele promocji.}

poinformowanie klientów o istnieniu Twojej firmy i jej ofercie

zachęcenie klientów do skorzystania z konkretnych usług

zbudowanie dobrego wizerunku firmy

zdobycie nowych odbiorców (poszerzenie rynku) 

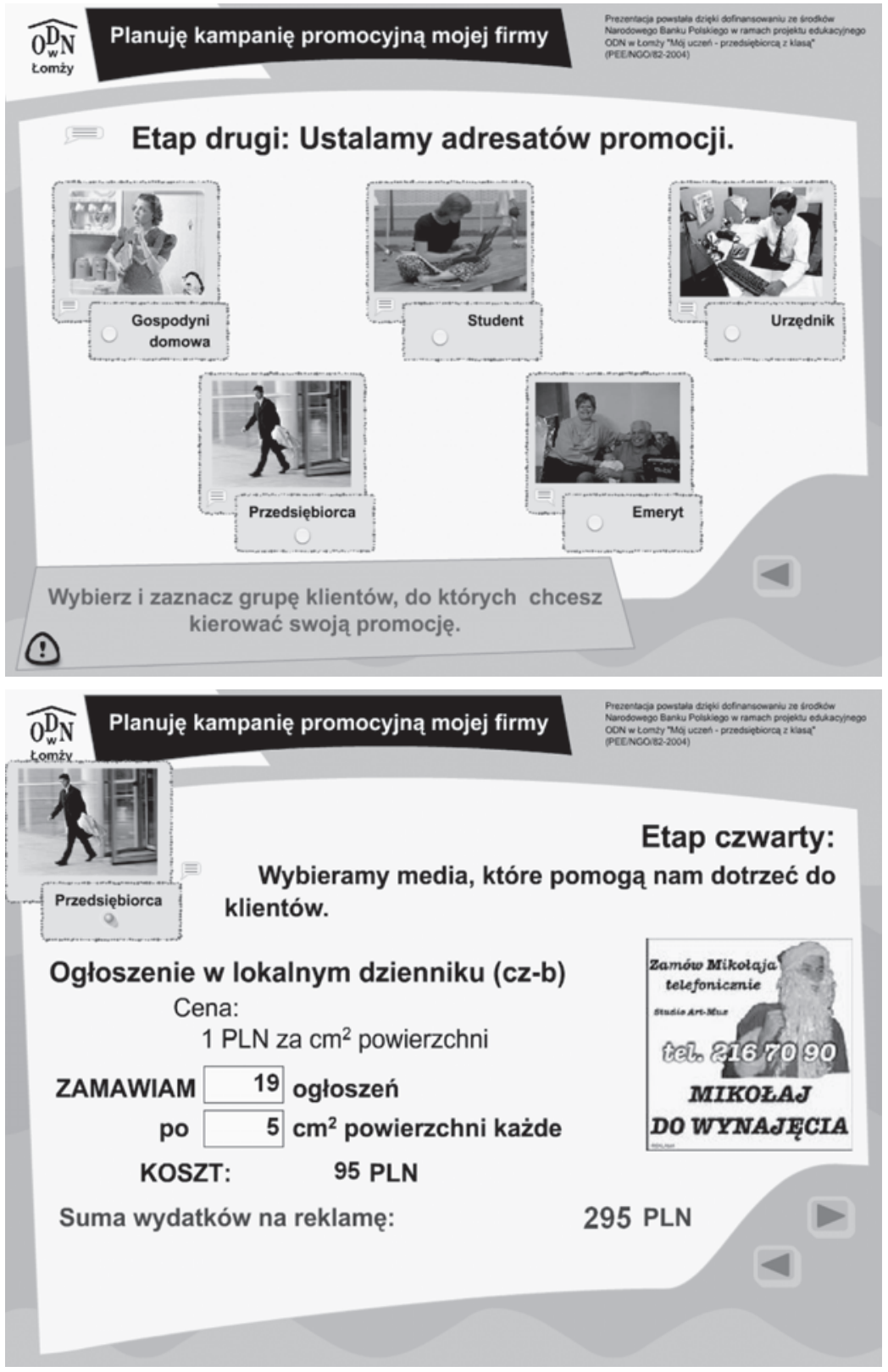

Kolejne zadanie polegało na zaprojektowaniu przez zespoły uczniów prostej reklamy, sloganu, ogłoszenia oraz logo firmy. Wybrani uczniowie prezentowali wyniki pracy na forum klasy.

Uczniom spodobała się nowa forma zajęć, pracowali z dużym zaangażowaniem; w efekcie powstały ciekawe projekty reklam.

\section{Podsumowanie}

Powszechne stosowanie technik multimedialnych w nauczaniu podstaw przedsiębiorczości i nie tylko jest wyzwaniem stawianym współczesnemu nauczycielowi. Nauczyciel w dzisiejszych 
czasach jest zobligowany do rozwijania swoich umiejętności w zakresie wykorzystania i stosowania technologii ICT. Odpowiedzialność za budowanie społeczeństwa informacyjnego spada w głównej mierze na osoby odpowiedzialne za kształtowanie postaw młodych ludzi. Wspomaganie procesu dydaktycznego prezentacją multimedialną wzbogaca proces nauczania i przynosi odbiorcy wymierne korzyści, a realizatorowi zajęć - ogromną satysfakcję.

Materiały dydaktyczne (w tym prezentacje multimedialne) wykorzystane podczas zajęć edukacyjnych można znaleźć na stronie internetowej www.ckubialystok.pl.

\section{Zalącznik 1}

\section{Plan metodyczny}

Przedmiot: podstawy przedsiębiorczości

Program nauczania: DKOS-4015-177/2

Podręcznik: Ekonomia stosowana

Nauczyciele: mgr inż. Małgorzata Kulikowska, mgr inż. Bożena Krasnodębska

Klasa: druga

Temat: Planuję kampanię promocyjną mojej firmy

Czas zajęć: 90 min

\section{Cele ogólne:}

- zrozumienie roli marketingu w biznesie,

- kształtowanie umiejętności poszukiwania, porządkowania i wykorzystywania informacji do rozwiązywania problemów.

\section{Cele szczegółowe - po zakończeniu lekcji uczeń:}

- wyjaśnia znaczenie pojęć: marketing, promocja, reklama,

- wskazuje różnicę między promocją a reklamą,

- wskazuje cele promocji,

- wymienia media reklamowe,

- wymienia etapy tworzenia prostego planu marketingowego firmy,

- ustala grupę docelową (klienci firmy),

- dobiera do wybranej grupy klientów odpowiednią ofertę usług firmy oraz media reklamowe,

- szacuje koszty reklamy przy założonym limicie finansowym,

- gospodaruje pieniędzmi,

- opracowuje prostą reklamę firmy,

- prezentuje wyniki swojej pracy.

Metody pracy: aktywizująca z wykorzystaniem komputera (praca z interaktywną prezentacją komputerowa), ćwiczenia: analiza tekstu, rozwiązywanie problemów, projektowanie prostej kampanii promocyjnej firmy, pogadanka z elementami prezentacji

Środki dydaktyczne: pracownia komputerowa z 15 stanowiskami komputerowymi, wprowadzająca prezentacja multimedialna „Marketing”, przykładowe materiały promocyjne (ulotki, ogłoszenia, etykiety), interaktywna prezentacja komputerowa „Planuję kampanię promocyjną mojej firmy", karta pracy ucznia 


\section{Przebieg lekcji:}

\begin{tabular}{|c|c|c|c|}
\hline $\begin{array}{l}\text { Częśść } \\
\text { lekcji }\end{array}$ & Czynności nauczyciela & Czynności uczniów & $\begin{array}{c}\text { Czas } \\
\text { (w min) }\end{array}$ \\
\hline Wstępna & $\begin{array}{l}\text { - Czynności organizacyjne: sprawdze- } \\
\text { nie obecności, przydzielenie uczniom } \\
\text { stanowisk komputerowych. } \\
\text { - Podaje temat lekcji, określa cele i je } \\
\text { uzasadnia. }\end{array}$ & $\begin{array}{l}\text { - Wskazują nieobecnych. } \\
\text { - Zajmują miejsca pracy. } \\
\text { - Dzielą się na dwuosobowe zespo- } \\
\text { ły zadaniowe. } \\
\text { - Zapisują temat lekcji. }\end{array}$ & 5 \\
\hline Główna & $\begin{array}{l}\text { - Wprowadza w zagadnienia lekcji } \\
\text { poprzez krótkie omówienie pojęć } \\
\text { związanych z marketingiem firmy; } \\
\text { zwraca uwagę na cele działań mar- } \\
\text { ketingowych i różnicę między pro- } \\
\text { mocją a reklamą. Ilustruje wypo- } \\
\text { wiedź prezentacją multimedialną } \\
\text { „Marketing” i przykładowymi } \\
\text { materiałami promocyjnymi. } \\
\text { - Rozdaje uczniom karty pracyi zwięź- } \\
\text { le omawia zamieszczone w nich } \\
\text { zadania. Wyjaśnia, w jaki sposób } \\
\text { korzystać z interaktywnej prezen- } \\
\text { tacji multimedialnej „Planuję kam- } \\
\text { panię promocyjną mojej firmy”. } \\
\text { - Obserwuje pracę uczniów, w razie } \\
\text { potrzeby udziela wyjaśnień. } \\
\text { - Prosi uczniów o zaprezentowanie } \\
\text { efektów pracy. }\end{array}$ & $\begin{array}{l}\text { - Słuchają objaśnień, oglądają prezen- } \\
\text { tację i materiały reklamowe. } \\
\text { - Zapoznają się z treścią ćwiczeń za- } \\
\text { mieszczonych w karcie pracy; po- } \\
\text { znają podstawy nawigacji w pre- } \\
\text { zentacji komputerowej. } \\
\text { - Poznają etapy tworzenia prostego } \\
\text { planu marketingowego firmy; pra- } \\
\text { cują z interaktywną prezentacją } \\
\text { multimedialná: } \\
\text { - wybór celów promocji (prezen- } \\
\text { tacja - krok I), } \\
\text { - ustalenie adresata promocji (pre- } \\
\text { zentacja - krok II), } \\
\text { - dobranie do wybranej grupy } \\
\text { klientów odpowiedniej oferty } \\
\text { usług (prezentacja - krok III), } \\
\text { - wybór mediów reklamy i osza- } \\
\text { cowanie jej kosztów (prezenta- } \\
\text { cja - krok IV). } \\
\text { - Pracując z prezentacja, wykonują } \\
\text { zadania z karty pracy. Odpowia- } \\
\text { dają na pytania pomocnicze. } \\
\text { Opracowują prostą reklamę firmy, } \\
\text { korzystając z informacji dotyczą- } \\
\text { cych tworzenia reklamy w prezen- } \\
\text { tacji „Marketing”. W wypadku trud- } \\
\text { ności proszą nauczyciela o pomoc. } \\
\text { Wybrani uczniowie prezentują } \\
\text { treść ulotki lub ogłoszenia, slogan } \\
\text { reklamowy oraz szkic logo firmy. }\end{array}$ & 75 \\
\hline Końcowa & $\begin{array}{l}\text { - Podsumowuje treści lekcji, zadając } \\
\text { pytania: Jak rozumiesz słowo mar- } \\
\text { keting? Jaka jest różnica między } \\
\text { promocją a reklamą? Jakie są cele } \\
\text { promocji? Jakie znasz media rekla- } \\
\text { my? Wymień i opisz etapy tworze- } \\
\text { nia planu marketingowego firmy. }\end{array}$ & $\begin{array}{l}\text { - Odpowiadają na pytania, korzy- } \\
\text { stając z interaktywnej prezentacji } \\
\text { komputerowej „Planuję kampanię } \\
\text { promocyjną mojej firmy” i prezen- } \\
\text { tacji multimedialnej „Marketing”. }\end{array}$ & 10 \\
\hline
\end{tabular}




\section{Załącznik 2}

\section{Karta pracy dwuosobowej grupy uczniów}

Autorzy opracowania:

Wykonaj następujące polecenia:

- Korzystając z interaktywnej prezentacji komputerowej „Planuję kampanię promocyjną mojej firmy”, opracuj plan promocji firmy Tra-Bic (przesyłki i zlecenia kurierskie), który polega na: wyborze celów promocji (prezentacja - krok I), ustaleniu adresata promocji (prezentacja - krok II), dobraniu do wybranej grupy klientów odpowiedniej oferty usług (prezentacja-krok III), wyborze mediów reklamy i oszacowanie jej kosztów (prezentacja-krok IV).

- Dobierając do wybranej grupy klientów odpowiednie media reklamy, zapoznaj się z ich wadami i zaletami opisanymi w prezentacji multimedialnej „Marketing”. Pamiętaj, że dopiero rozpoczynasz działalność i na reklamę możesz przeznaczyć tylko 500 zł.

- Przy opracowaniu planu promocyjnego firmy zastanów się nad następującymi pytaniami: Co zamierzasz osiagnać w wyniku promocji? Co wiesz o potencjalnym kliencie, jego potrzebach i zwyczajach, mentalności, zainteresowaniach itp.? Czym zachęcisz klienta do skorzystania z oferty twojej firmy? Przez jakie media dotrzesz do wybranych klientów, aby zainteresować ich usługami swojej firmy? Ile to będzie kosztowało? Czy zaplanowana kampania promocyjna będzie skuteczna? Jak ocenić jej efektywność?

- Po wykonaniu poszczególnych kroków prezentacji ułóż treść ulotki lub ogłoszenia i slogan reklamowy oraz zaprojektuj logo firmy.

\section{Treść ulotki lub ogłoszenia}

Slogan reklamowy

Projekt logo firmy (szkic)

\section{Literatura}

1. Bednarek J., 2000, Multimedia w działalności szkoleniowo-wychowawczej, Komandor, Warszawa

2. Krzyżewska J., 2000, Aktywizujace metody i techniki w edukacji, część II, Zakład Wydawniczy Letter Quality, Suwałki

3. Strykowski W., 1984, Audiowizualne materiaty dydaktyczne. Podstawy ksztatcenia multimedialnego, PWN, Warszawa 


\section{Multimedia Technologies in Teaching Basis of Entrepreneurship}

The subject presented during the conference is 'The Multimedia Techniques in the Teaching Basis of Entrepreneurship'. The topic was presented with a case study of multimedia classes titled 'I Plan Promotional Campaign of My Business', carried within the educational project 'My Student, a Businessman With Rank'.

The aim of the summary was to present activating methods of teaching with the use of Information Technology on Base of Enterprise classes. Practical use of multimedia programs and of Internet thematic sites, gives young people a chance to gain the ability to use a computer for searching necessary information. Furthermore it gives an opportunity to search, order and take advantage of information to solve a problem.

The paper is an example of good practice in teaching and it confirms thesis, that it is possible to teach and to learn with enjoyment. 


\section{Mirosław Soczówka}

Instytut Geografii

Akademia Pedagogiczna w Krakowie

\section{Wykorzystanie technologii informacyjnej w nauczaniu-uczeniu się podstaw przedsiębiorczości}

Od czasu wprowadzenia komputerów do szkół w Polsce w połowie lat 80. XX w., urządzenia te i ich oprogramowanie stały się jednymi ze środków dydaktycznych stosowanych m.in. w nauczaniu - uczeniu się podstaw przedsiębiorczości. Postęp techniczny zaowocował jednak nowymi środkami dydaktycznymi ${ }^{1}$, w tym niemieszczącymi się w dotychczasowych klasyfikacjach stworzonych na potrzeby takich dyscyplin naukowych, jak dydaktyka geografii (np. Piskorz 1997). Od 1998 r. realizowane są programy modernizacyjne obejmujące kolejno każdą gminę, szkołę podstawowa, gimnazjum i liceum (szkoły ponadgimnazjalne). Były one finansowane przez Ministerstwo Edukacji Narodowej (dawniej kolejno: MENiS, MEiN), a od czasu wejścia Polski do UE są w trzech czwartych współfinansowane przez Europejski Fundusz Społeczny. W wyniku realizacji wspomnianych programów publiczne szkoły ponadgimnazjalne zostały wyposażone w pracownie komputerowe z dostępem do internetu (złożone z 15 komputerów dla uczniów), komputery w bibliotekach (po 4 sztuki) tworzące internetowe centra edukacji multimedialnej, wybrane programy komputerowe, a obecnie są wyposażane m.in. w komputery przenośne i projektory multimedialne, czyli tzw. mobilne zestawy multimedialne ${ }^{2}$. Znaczącą aktywność w zakresie tworzenia środków dydaktycznych z zakresu technologii informacyjnej (TI) przejawiają komercyjne wydawnictwa edukacyjne.

\section{Komputerowe programy edukacyjne i ich obudowa internetowa}

Część wydawnictw edukacyjnych, wykorzystując wyposażenie szkół w środki dydaktyczne z zakresu technologii informacyjnej, próbuje, za pomocą komputerowych programów edukacyjnych na płytach CD-ROM dołączanych do podręczników lub z nimi powiązanych, przyciagnąć większą liczbę klientów i zwiększyć efekty procesu nauczania - uczenia się podstaw przedsiębiorczości. W 2002 r. ukazał się program „Kariera”, dołączony do podręcznika „Przedsiębiorczość bez tajemnic” wydanego przez WSiP (Gregorczyk, Romanowska, Sopińska, Wachowiak 2002). Składa się on z kilku modułów. W module „Curriculum vitae” zamieszczono zasady pisania życiorysów, interaktywne ćwiczenie w ich tworzeniu oraz 5 przykładowych życiorysów do wydrukowania. W dziale „List motywacyjny” znajdują się rady, jak pisać listy motywacyjne, oraz 5 przykładowych listów do wydrukowania. W module „Rozmowa rekrutacyjna” przedstawiono rady, jak przygotować się do rozmowy rekrutacyjnej i jak się podczas niej zachowywać oraz interaktywną rozmowę z przyszłym pracodawcą. W dziale „Testy” znajdują się informacje o testach

${ }^{1}$ Środki dydaktyczne zalecane do użytku szkolnego przez Ministerstwo Edukacji Narodowej w zakresie przedmiotów ogólnokształcacych, MEN, Warszawa, http://www.srodki-dydaktyczne.men.gov.pl/, 18.11.2006 r. ${ }^{2}$ Pracownie komputerowe dla szkót. Projekt na lata 2004-2006, MEN, Warszawa, http://www.men.gov.pl/ edu_infor/projekty_efs/pracownie.php, 18.11.2006 r. 
psychometrycznych, którym może zostać poddany kandydat do pracy, dotyczące ich rady oraz przykładowy interaktywny test psychometryczny. W module „Rób karierę!” użytkownik ma możliwość przejść procedurę rekrutacyjną (CV, rozmowa rekrutacyjna, test psychometryczny) do 4 wybranych zawodów. Program zawiera również demonstracyjną wersję obudowy internetowej podręcznika z przykładowymi modułami przeznaczonymi dla ucznia i nauczyciela, dostępną także w aktualnej, pełnej wersji na stronach serwisu internetowego WSiPnet (www.wsipnet.pl). W podręczniku umieszczono ikony odsyłające do obudowy internetowej. W obudowie internetowej, w części dla uczniów, każdy temat lekcji zawiera: informacje tekstowe ilustrowane interaktywnymi animacjami lub ćwiczeniami, ćwiczenia i zadania, a na zakończenie działu test interaktywny oraz odnośniki do wybranych stron internetowych. W części dla nauczyciela każdy temat lekcji zawiera: informacje tekstowe z celami kształcenia i zalecaną literatura; odnośniki do wybranych stron internetowych oraz materiały dodatkowe w postaci projektów ćwiczeń dodatkowych, możliwych do pobrania projektów testów w formatach pdf i doc; a także foliogramy w formacie pdf. W obudowie część odnośników do stron internetowych jest już nieaktualna.

Mankamentem programu dla użytkowników nowoczesnych monitorów jest stała rozdzielczość 800 x 600 pikseli, z którą on pracuje. Program „Kariera” dołączany jest również do wydanego przez WSiP podręcznika do podstaw przedsiębiorczości dla zasadniczej szkoły zawodowej.

W 2002 r. ukazał się również program „Szansa dla interaktywnych”, dołączony do podręcznika „Szansa dla przedsiębiorczych” wydanego przez Wydawnictwo eMPi (Pietraszewski 2002). Dzięki wykonaniu interfejsu programu w języku HTML, automatycznie dostosowuje się on do aktualnej rozdzielczości ekranu. Treści merytoryczne tworzące program „Szansa dla interaktywnych” są pogrupowane według rozdziałów w podręczniku. Oprócz zagadnień merytorycznych w postaci tekstów, rycin, interakcji i filmów dydaktycznych, w każdym dziale zamieszczono serię rysunków satyrycznych „Na wesoło o ...” oraz krótkie interaktywne testy z zadaniami wyboru wielokrotnego. Zawartość programu uzupełniają: wykaz kilkuset przydatnych adresów internetowych, „Kalkulator przedsiębiorczego” i „Słowniczek przedsiębiorczego” zawierający ponad 600 haseł oraz grę ekonomiczną pt. „Szansa na zysk”. W serwisie internetowym wydawnictwa dostępne są aktualizacje danych statystycznych do podręcznika „Szansa dla przedsiębiorczych” oraz aktualizacja 2 tabel do zeszytu ćwiczeń „Szansa dla aktywnych”. Mogą one być drukowane z poziomu strony internetowej. Część danych i adresów internetowych zamieszczonych w programie jest już zdezaktualizowana, ale jest możliwość ściągnięcia i zainstalowania pliku z aktualizacją treści podręcznika i płyty CD-ROM, która funkcjonuje jako osobny program. Wydawnictwo eMPi ${ }^{2}$ oferuje również podręcznik pt. „Elementarz życia gospodarczego” (Pietraszewski 2001) wraz z płytą CD-ROM pt. „Dociekliwy na rynku” do modułu „Wychowanie do aktywnego udziału w życiu gospodarczym” w przedmiocie wiedza o społeczeństwie w gimnazjum. Ze względu na czas powstania programu, w serwisie internetowym firmy jest dostępna jego aktualizacja. Oprócz nieaktualności danych wynikającej z czasu powstania programów Wydawnictwa eMPi ${ }^{2}$, wadą części ich stron jest to, że wymagają przewijania zawartości ekranu w pionie. Wyniki badań pokazują, że około połowy użytkowników komputerów czyni to rzadko lub nie czyni wcale, tym samym część zawartości programów jest dla nich niedostępna.

W 2005 r. Fundacja Młodzieżowej Przedsiębiorczości wydała uaktualnioną wersję podręcznika podstaw przedsiębiorczości pt. „Ekonomia stosowana”, wzbogaconą o płytę CD-ROM (Belka 2005). Pod tym samym tytułem po raz pierwszy wydano również zeszyt ćwiczeń wraz z płytą CD-ROM (Neneman 2005). W obu programach zawartość jest uporządkowana w modułach odpowiadających rozdziałom w podręczniku i zeszycie ćwiczeń. W każdym module jest kilka części. Program dołączony do podręcznika zawiera treści merytoryczne w postaci tekstów, interaktywnych rycin, wykładów multimedialnych, filmów, interaktywnych ćwiczeń itp. Do programu 
dołączono dwa osobne moduły zatytułowane „Słownik” i „Być przedsiębiorczym”. Ten ostatni moduł poświęcony jest rozwijaniu wiedzy i umiejętności z zakresu szeroko rozumianej komunikacji interpersonalnej. Na płycie CD-ROM dołączonej do zeszytu ćwiczeń zamieszczono wiele interaktywnych ćwiczeń z zadaniami: wyboru wielokrotnego, typu prawda-fałsz, na przeciaganie itp. Pracując z programem, uczeń nie ma możliwości udzielenia błędnej odpowiedzi, gdyż takie nie są akceptowane. Ćwiczenia w poszczególnych rozdziałach często kończą się krzyżówką związaną tematycznie z rozdziałem. Do programu ćwiczeniowego dołączono osobny moduł - słownik.

W czwartym wydaniu podręcznika podstaw przedsiębiorczości Wydawnictwa Nowa Era (Makieła, Rachwał 2005) zamieszczono płytę CD-ROM przygotowaną wspólnie z Wydawnictwem Young Digital Poland (Śrutowska 2006). Wydawnictwo Young Digital Poland ma kilkuletnie doświadczenie w konstruowaniu podręczników multimedialnych, m.in. z serii EduROM i EduLAN (Soczówka 2002). Program ma jasne tło, zastosowano w nim ciepłe barwy, funkcjonalne rozwiązania zapewniające przemieszczanie się między stronami, ułatwiające prezentację treści oraz interakcję z użytkownikiem. Na przykład: rozbudowane animacje mogą być odtwarzane w całości, zatrzymane w trakcie odtwarzania w dowolnym momencie lub odtworzone w części w postaci stanowiącej pewną całość wartą powtórzenia lub szczegółowego omówienia. Program składa się z 7 modułów odpowiadających rozdziałom w podręczniku. Przeciętny moduł składa się z kilkunastu stron (a te często dodatkowo z 2 lub 3 podstron), z których początkowe zawierają głównie treści merytoryczne. Mają one postać krótkich tekstów, rycin, wykresów, filmów, animacji, symulacji, wykładów multimedialnych itp. Ostatnie strony to ćwiczenia: wiele interaktywnych zadań wyboru wielokrotnego i zadań typu prawda-fałsz, których rozwiązywanie polega na zaznaczaniu, przeciąganiu lub łączeniu ze sobą różnych elementów. Uzupełnieniem omówionych modułów jest moduł „Druki urzędowe”. Zamieszczone z nim druki użytkownik może wypełniać. Program zawiera również moduły dodatkowe, ułatwiające korzystanie z niego: „Słowniczek” i „Szukaj” (umożliwiający wybór poszukiwanych treści z alfabetycznej listy). Inny sposób wyszukiwania polega na wpisaniu kodu z podręcznika na stronie startowej programu, w specjalnym polu edycyjnym, a następnie naciśnięciu klawisza ,enter”. Pojawia się wówczas strona tytułowa danej lekcji oraz kilka stron z treściami merytorycznymi i ćwiczeniami. Warto podkreślić, że autorzy omawianego programu również w innych publikacjach pakietu edukacyjnego często zalecają wykorzystywanie technologii informacyjnej w nauczaniu - uczeniu się podstaw przedsiębiorczości. W poradniku metodycznym (Makieła, Rachwał 2005) wskazują programy komputerowe, które mogą być wykorzystywane na lekcjach podstaw przedsiębiorczości, i zamieszczają katalog stron www przydatnych na tego typu zajęciach. W scenariuszach kilkunastu zajęć edukacyjnych (Bachta 2003) wskazują możliwości wykorzystania komputera i internetu, m.in. serwisu wydawnictwa Nowa Era, w którym są dostępne pliki zawierające aktualne wersje ważnych aktów prawnych.

Od jesieni 2005 r. nauczycielom podstaw przedsiębiorczości udostępniono nowy rodzaj komputerowych programów edukacyjnych, powiązanych z podręcznikami, lecz sprzedawanych jako odrębny produkt. Są to plansze interaktywne (Gregorczyk, Majewski 2005) przygotowane przez WSiP, które są rozszerzoną elektroniczną wersją publikacji „Przedsiębiorczość bez tajemnic. Zestaw foliogramów dla nauczycieli szkół ponadgimnazjalnych”. Program zawiera 54 plansze obejmujące treści z następujących grup tematów: psychologiczne i socjologiczne uwarunkowania przedsiębiorczości (6 plansz), makrouwarunkowania przedsiębiorczości (11 plansz), przedsiębiorczość w sferze życia zawodowego (17 plansz), przedsiębiorczość w rodzinie (12 plansz), zachowania przedsiębiorcze na rzecz środowiska lokalnego (6 plansz), pracownik w przedsiębiorstwie (2 plansze). Różnią się one od tradycyjnych foliogramów obecnością elementów multimedialnych i interakcyjnych. Stanowią je uruchamiane przez użytkownika krótkie komentarze 
dźwiękowe, interaktywne opisy tekstowe prawie wszystkich rycin i schematów, które można włączyć i wyłączyć jednym kliknięciem myszy. Ostatnia ze wskazanych funkcji umożliwia projektowanie i prowadzenie lekcji z programem w sposób zmierzający do odkrycia wyłączonego elementu, jego związków z innymi elementami schematu itp. Jest bardzo przydatna do kontroli wiedzy uczniów. Aby wybrać jedną z plansz, można skorzystać z 4 sposobów ich sortowania. Program umożliwia również sprawdzenie wiedzy uczniów w inny sposób, dzięki osobnemu modułowi testowemu, w którym zebrano po dwa pytania testowe wielokrotnego wyboru dotyczące każdej planszy. Użytkownik może określić zakres tematyki objętej testem, a po jego wykonaniu przejrzeć wyniki z automatycznie wygenerowanym wskazaniem poprawnych odpowiedzi, a nawet wydrukować oceniony test. Wady tego programu to długi, trwający około 40 sekund czas uruchamiania, niemożność sortowania plansz według działów w podręczniku, a także często zbyt mała liczba plansz przydatnych na pojedynczej lekcji.

Do prowadzenia lekcji z omawianym programem w pracowni przedmiotowej można wykorzystać dostępne w coraz większej liczbie szkół tzw. mobilne zestawy multimedialne. Inne rozwiązanie to lekcja w szkolnej pracowni komputerowej. Ta druga możliwość jest dostępna dzięki dostosowaniu programu do pracy w lokalnej sieci komputerowej i udzieleniu przez wydawnictwo licencji dla 10 stanowisk. Niestety, liczba udzielonych licencji nie została dostosowana do przeciętnej liczby komputerów w pracowniach informatycznych w szkołach ponadgimnazjalnych (co najmniej 15 sztuk). Najpóźniej po dwutygodniowym okresie testowania program należy zarejestrować za pośrednictwem internetu, aby móc z niego korzystać.

\section{Programy o charakterze ogólnym oraz pliki tworzone przez nauczycieli i uczniów}

Niektóre programy komputerowe nie zawierają co prawda treści z zakresu podstaw przedsiębiorczości, ale mogą być przydatne w ich pozyskiwaniu, archiwizowaniu i prezentacji. Brak łączy internetowych w większości pracowni przedmiotowych, ich ograniczona przepustowość w części tych pracowni, okresowe znikanie niektórych serwisów, np. na czas konserwacji serwera, oraz zmiany zawartości tych serwisów powodują że nauczyciel może być zainteresowany ich archiwizowaniem. Zdaniem autora niniejszego artykułu najlepszym programem do tego celu jest HTTrack Website Copier 3.40-2 (www.httrack.com). Istotną zaletą części programów komputerowych jest możliwość integracji przez nie różnych treści. Jednym z nich jest program StarTree Studio v. 3.0 firmy Inxight Software (http://pedagogika.net), który umożliwia tworzenie swoistych interaktywnych map myśli, złożonych z elementów, które za pomocą wpisanych w nie ścieżek dostępu pozwalają szybko uruchomić dowolne pliki znajdujące się na twardym dysku komputera, w stacjach roboczych lub w internecie. Taka konstrukcja programu, w powiązaniu z mobilnym zestawem multimedialnym, umożliwia nauczycielowi dostosowanie treści wykorzystywanych na lekcji do poziomu klasy i przebiegu lekcji, która nie zawsze jest zgodna z pierwotnym planem.

W nauczaniu - uczeniu się podstaw przedsiębiorczości, zwłaszcza z użyciem mobilnego zestawu multimedialnego, mogą być stosowane programy typu Office, np. pakiety biurowe Microsoft Office bądź bezpłatny OpenOffice 2.0, zawierające m.in. programy do edycji tekstów, arkusze kalkulacyjne oraz programy do tworzenia i wyświetlania prezentacji multimedialnych. Umiejętność tworzenia różnorodnych tekstów jest dziś niezbędna niemal w każdej pracy, a wykorzystanie arkuszy kalkulacyjnych znacznie ułatwia obróbkę danych liczbowych, w tym finansowych. Za stosowaniem prezentacji multimedialnych przygotowanych samodzielnie przez nauczyciela przemawia niewielka liczba gotowych do użycia w szkole materiałów w postaci elektronicznej, zawierających treści z zakresu podstaw przedsiębiorczości, np. informacji społeczno-gospodarczych, zwłaszcza dotyczących regionu, w którym znajduje się szkoła (Soczówka, Uliszak 2004). Przeciw wykonywaniu przez uczniów lub nauczycieli i stosowaniu prezentacji multimedialnych 
na lekcjach przemawia głównie ich pracochłonność oraz możliwość powstawania i upowszechniania błędów merytorycznych bądź metodycznych, np. w ułożeniu treści. Prezentacje multimedialne i witryny internetowe stwarzająjednak szansę na aktywizację przynajmniej części uczniów wokół tworzenia i udostępniania innym osobom efektów projektów edukacyjnych oraz na związaną z ich tworzeniem korelację międzyprzedmiotową realizowaną przez nauczycieli podstaw przedsiębiorczości i informatyki, wzorowanej na podobnej aktywności nauczycieli geografii oraz technologii informacyjnej (Rokicki, Kopaczyński 2004). Uczniowie mogą wówczas rozwijać umiejętności wyszukiwania, segregowania, oceniania informacji oraz pracy w grupach, w zbyt małym stopniu rozwijane na tradycyjnych lekcjach podstaw przedsiębiorczości.

Dość liczna grupa programów komputerowych ułatwia tworzenie „map” myśli w postaci graficznej. Aby znaleźć o nich informacje i odpowiednie pliki instalacyjne (najczęściej w wersji trial - działające bezpłatnie przez 3-4 tygodnie) wystarczy w dowolnej przeglądarce internetowej wpisać hasło „Mind Mapping”. Niektóre z takich programów, np. FreeMind 0.80, są bezpłatne. Dzięki takim programom można urozmaicić wykorzystywanie wskazanej metody kształcenia.

Osobną grupę, słabo dotychczas reprezentowaną w szkołach ze względu na wysokie ceny zestawów, są programy do obsługi tablic interaktywnych. Przykładem jest program StarBoard Software 6.2 (2005), opracowany przez firmę Hitachi dla tablicy interaktywnej StarBoard F-75. W Polsce są one dystrybuowane przez WSiP. Tablica interaktywna i jej oprogramowanie nie zawierajążadnych treści z podstaw przedsiębiorczości, umożliwiająjedynie, za pomocą komputera i projektora multimedialnego, prezentację zawartości innych programów, filmów i źródeł internetowych. Pozwalają ponadto na ich uzupełnianie o notatki użytkowników, archiwizowanie i drukowanie. Tablice interaktywne mogą być wykorzystywane jako mobilne lub stacjonarne; drugie rozwiązanie jest znacznie mniej skomplikowane ze względu na łatwiejszą obsługę.

\section{Internet w nauczaniu - uczeniu się podstaw przedsiębiorczości}

Oprócz korzystania z opisanych wyżej obudów internetowych podręczników i dołączanych do nich płyt CD-ROM do podstaw przedsiębiorczości, można sięgnąć do internetu. Znajduje się w nim wiele serwisów zawierających wartościowe informacje. W nauczaniu - uczeniu się podstaw przedsiębiorczości często wykorzystuje się dane statystyczne. W przypadku aktualizacji i rozszerzania danych dotyczących Polski warto korzystać z serwisu GUS (www.stat.gov.pl). Oprócz różnorodnych danych ogólnokrajowych zawiera on dużo danych dotyczących regionów. Są to przede wszystkim dane Banku Danych Regionalnych. Tego typu informacje są zbyt rzadko wykorzystywane na lekcjach podstaw przedsiębiorczości. Należy jednak pamiętać, że ludność Polski jest mało mobilna przestrzennie, a miejsce urodzenia ucznia jest często miejscem jego przyszłej działalności zawodowej. Dlatego dokładna charakterystyka tego regionu, zwłaszcza w zakresie szybko zmieniających się danych społeczno-gospodarczych, jest możliwa (Soczówka, Uliszak 2004), a będzie bardzo użyteczna. Godnym polecenia serwisem edukacyjnym jest Portal Edukacji Ekonomicznej NBPortal.pl, działający od 2003 r. Jest on dostępny w internecie lub w postaci 5 archiwów off-line na płytach CD-ROM. Te ostatnie powstawały od $2003 \mathrm{r}$., a obecnie 2 ostatnie (płyta 4 - Edycja MONETA, płyta 5 - Edycja BANKNOT) są dostępne dla wszystkich chętnych darmo w centrali i oddziałach terenowych NBP. Portal jest podzielony na kilka działów, w trzech zakładkach. W zakładce $N a$ poczq̨tek są dostępne m.in. działy Bloki tematyczne, Porady, Zbiory wiedzy; w zakładce Centrum wiedzy mieszczą się działy E-learning, Prezentacje, Gry i Rozrywka, a w zakładce Szkolny NBPortal.pl dostępne są m.in. działy Centrum nauczyciela i Centrum ucznia. Uzupełniają je narzędzia w postaci Stownika Ekonomicznego PWN, Wirtualnej Biblioteki i Kalkulatorów. Podstawową część portalu tworzy 7 e-lerningowych kursów multimedialnych, zatytułowanych: Ekonomia wokót nas, Euro coraz 
bliżej, Analiza finansowa firmy, Kredyty i Ty, Historia monetarna Polski, Bankowość oraz Grosz do grosza, czyli jak inwestować. W wersji on-line są one dostępne dla zarejestrowanych użytkowników w postaci ponad 200 godzin lekcji zawierających wykłady multimedialne, w których wykorzystywane są liczne animacje, ilustracje i krótkie filmy. Są one często przeplatane ćwiczeniami sprawdzającymi i utrwalającymi wiedzę.

W 2005 r. badano stan edukacji z zakresu podstaw przedsiębiorczości w wybranych szkołach oraz opinie nauczycieli tego przedmiotu, doradców metodycznych, dyrektorów szkół oraz uczniów (Szmulczyńska 2006). W wyniku porównania tych opinii z ofertą opisywanego portalu stwierdzono, że należy położyć większy nacisk na tematy dotyczące: poszukiwania pracy, planowania i podejmowania działalności gospodarczej, rynku pracy i bezrobocia. Można natomiast zredukować treści poświęcone na mało popularne wśród uczniów zagadnienia: etykę w biznesie, rolę banków w gospodarce i planowanie budżetu gospodarstwa domowego.

\section{Podsumowanie}

Ze względu na duże obciążenie szkolnych pracowni internetowych w szkołach ponadgimnazjalnych, najlepsze warunki do nauczania podstaw przedsiębiorczości z wykorzystaniem technologii informacyjnych istnieją w szkołach dysponujących kilkoma pracowniami, z których jedna może być używana głównie do nauczania przedmiotów innych niż informatyka (Uczkiewicz 2005). Istniejąjuż projekty i przykłady realizowanych w takiej pracowni lekcji (Kulikowska 2005). Jeżeli ten warunek nie jest spełniony, a szkoła ma jeden (lub więcej) z coraz powszechniej dostępnych mobilnych zestawów multimedialnych, to najlepszym miejscem do realizacji omawianego sposobu nauczania jest pracownia przedmiotowa. Aby się do tego nadawała, powinna mieć dobre zaciemnienie, miejsce na zamontowanie ekranu lub ekran zamontowany na stałe oraz doprowadzenie łącza internetowego. Niezbędne są również wartościowe programy. Przegląd komputerowych programów edukacyjnych dołączanych do podręczników postaw przedsiębiorczości lub z nimi związanych prowadzi do wniosku, że programy powstałe później są lepsze pod względem merytorycznym. Zastosowane w nich rozwiązania interfejsu oraz sposoby przedstawiania treści są bardziej przyjazne, dzięki interaktywności zwiększają zaangażowanie użytkownika w obsługę programu (aktywizacja) i ułatwiają poznanie oraz omówienie rozbudowanych filmów i animacji.

W celu poprawy efektów nauczania - uczenia się podstaw przedsiębiorczości z wykorzystaniem mobilnego zestawu multimedialnego, należy spełnić kilka warunków. Przy projektowaniu komputerowych programów edukacyjnych należy pamiętać o ograniczonej do 4-6 liczby stron z treściami merytorycznymi, które można, odpowiednio obudowane metodycznie, wykorzystać w ciagu jednej lekcji. Programy te należy projektować wraz podręcznikami, zeszytami ćwiczeń i ich obudową dydaktyczna, tak aby były wzajemnie w jak największym stopniu powiązane i skorelowane treściowo. Programy edukacyjne powinny móc pracować w 2 trybach lub być tworzone w postaci odrębnych wersji dla uczniów i nauczycieli. W tych ostatnich należy zamieszczać nieco mniej treści merytorycznych, ułożonych w sposób ułatwiający ich wykorzystanie na lekcji. W komputerowych programach edukacyjnych należy stosować bardziej kontrastowe barwy, by zwiększyć czytelność. Ponieważ korzystanie z treści z zakresu podstaw przedsiębiorczości w postaci elektronicznej jest bardziej czasochłonne niż korzystanie z treści zaprezentowanych tradycyjnym drukiem, a bywa mniej czytelne dla odbiorców niż podręcznik, należy dążyć do zamieszczania $\mathrm{w}$ tych programach i plikach głównie treści w postaciach niedostępnych lub rzadkich w tradycyjnych środkach dydaktycznych, czyli różnego rodzaju elementów interaktywnych, animacji, symulacji, filmów itp., a nie w postaci ciągłego tekstu do czytania, gdyż funkcję tę lepiej spełnia tradycyjna książka. Pozostałe elementy powinny być zamieszczane rzadziej, ale prezentowane w postaci pełnoekranowej lub do niej zbliżonej. Ze względu na trudności 
praktyczne w wykorzystywaniu mobilnych zestawów multimedialnych (Soczówka 2006), warto je zastąpić przez rozwiązania stacjonarne. Powinny również nastąpić zmiany w zakresie realizowanych treści merytorycznych, np. polegające na wprowadzeniu zajęć z zakresu funkcjonowania e-biznesu (Uczkiewicz 2005), oraz w używanych metodach kształcenia, polegające m.in. na częstszym stosowaniu metod aktywizujących (np. metody projektów).

\section{Literatura}

1. Bachta A. i in., 2003, Podstawy przedsiębiorczości. Scenariusze zajęć edukacyjnych, Nowa Era, Warszawa

2. Belka M. (red.), 2005, Ekonomia stosowana. Podręcznik do podstaw przedsiębiorczości dla liceów ogólnoksztatcqcych, liceów profilowanych i techników, Fundacja Młodzieżowej Przedsiębiorczości, Warszawa

3. Gregorczyk S., Majewski B., 2005, Podstawy przedsiębiorczości. Plansze interaktywne dla nauczycieli szkót ponadgimnazjalnych, (program na płycie CD-ROM), WSiP, Warszawa

4. Gregorczyk S., Romanowska M., Sopińska M., Wachowiak P., 2002, Przedsiębiorczość bez tajemnic. Podręcznik do nauczania podstaw przedsiębiorczości dla liceum ogólnokształcqcego, liceum profilowanego i technikum. Kształcenie w zakresie podstawowym, WSiP, Warszawa

5. Kulikowska M., 2005, Możliwość wykorzystania komputera na zajęciach podstaw przedsiębiorczości na przykładzie lekcji nt. podatków pośrednich (scenariusz lekcji) [w:] seria: Przedsiębiorczość - Edukacja nr 1, Przedsiębiorczość a współczesne wyzwania cywilizacyjne, Z. Zioło, T. Rachwał (red.), Wyd. MiWa, Kraków

6. Makieła Z., Rachwał T., 2005, Podstawy przedsiębiorczości. Poradnik metodyczny. Liceum ogólnokształcace, liceum profilowane i technikum. Kształcenie ogólne w zakresie podstawowym, wyd. 3 , Nowa Era, Warszawa

7. Makieła Z., Rachwał T., 2005, Podstawy przedsiębiorczości. Podręcznik dla liceum ogólnokształcacego, liceum profilowanego i technikum, Nowa Era, Warszawa

8. Neneman J., 2005, Ekonomia stosowana. Zeszyt ucznia z ćwiczeniami i ptyta CD do podstaw przedsiębiorczości. Dla uczniów liceów ogólnokształcacych, liceów profilowanych i techników, Fundacja Młodzieżowej Przedsiębiorczości, Warszawa

9. Pietraszewski M., 2001, Elementarz życia gospodarczego, Wyd. eMPi², Poznań

10. Pietraszewski M., 2002, Szansa dla przedsiębiorczych. Podręcznik podstaw przedsiębiorczości dla liceów i techników, Wydawnictwo eMPi², Poznań

11. Rokicki R., Kopaczyński B., 2004, Atrakcyjność turystyczna powiatu wschowskiego. Metoda projektu edukacyjnego, „Geografia w Szkole”, r. 57, nr 1

12. Soczówka M., 2002, Polskie podręczniki multimedialne do nauczania-uczenia się geografii i przyrody [w:] Interdyscyplinarne nauczanie przedmiotów przyrodniczych, A. Kaszubski (red.), Pracownia Dydaktyki Chemii Instytutu Chemii UMK w Toruniu, Toruń

13. Soczówka M., 2006, Mobilny zestaw multimedialny w nauczaniu - uczeniu się geografii [w:] Komputer w edukacji. 16 Ogólnopolskie Sympozjum Naukowe, J. Morbitzer (red.), Wydawnictwo Naukowe AP w Krakowie, Kraków

14. Soczówka M., Uliszak R., 2004, Możliwości wykorzystania Internetu do nauczania-uczenia sięo regionie ucznia [w:] Polska dydaktyka geografii jako nauka i sztuka, Wydawnictwo Naukowe AP, Kraków

15. Szmulczyńska B., 2006, Zapotrzebowanie środowiska szkolnego w zakresie edukacji ekonomicznej a oferta edukacyjna Portalu Edukacji Ekonomicznej Narodowego Banku Polskiego - NBPortal.pl [w:] seria: Przedsiębiorczość - Edukacja nr 2, Rola przedsiębiorczości w podnoszeniu konkurencyjności społeczeństwa i gospodarki, Z. Zioło, T. Rachwał (red.), Nowa Era, ZPiGP IG AP, Kraków

16. Srutowska D., 2006, Wykorzystanie multimediów w nauczaniu przedsiębiorczości (na przykładzie multimedialnego CD-ROM-u Wydawnictwa Nowa Era pt. Podstawy przedsiębiorczości) [w:] seria: Przedsiębiorczość - Edukacja $n r$ 2, Rola przedsiębiorczości w podnoszeniu konkurencyjności społeczeństwa i gospodarki, Z. Zioło, T. Rachwał (red.), Nowa Era, ZPiGP IG AP, Kraków 
17. Uczkiewicz P., 2005, Technologia informacyjna a przedsiębiorczość w szkole ponadgimnazjalnej [w:] seria: Przedsiębiorczość - Edukacja nr 1, Przedsiębiorczość a wspótczesne wyzwania cywilizacyjne, Z. Zioło, T. Rachwał (red.), Wyd. MiWa, Kraków

18. Zarys dydaktyki geografii, 1997, S. Piskorz (red.), wyd. 2 zmienione, Wydawnictwo Naukowe PWN, Warszawa

\section{The Use the Information Technology for Teaching Basis of Entrepreneurships}

This paper presents results of review and didactical analysis of some multimedia discs published with handbooks for "Basis of Entrepreneurships" for high schools, their internet casing and chosen thematic internet services. On the base of his own research the author presents some changes needed to better use the information technology in schools especially for teaching and learning "Basis of Entrepreneurships". 
Jerzy Desperak

X Liceum Ogólnokształcące, Kraków

Aneta Depczyńska

Zespół Szkół Budowlanych nr 2, Kraków

X Liceum Ogólnokształcące, Kraków

\section{Przedsiębiorczy uczeń w UE - propozycje tematów lekcji}

Mimo że podstawy przedsiębiorczości to przedmiot stosunkowo „młody”, wymaga ciagłej aktualizacji i zmian w programie nauczania. Istotne zmiany powinny zostać zauważone i wprowadzone po 1.05.2004 r.; tak się jednak nie stało. Dlaczego?

Niniejszy artykuł to refleksja po lekcjach wypełnionych licznymi pytaniami uczniów:

- Czy powinniśmy poruszać zagadnienie podatków, nie omawiając kwestii tzw. podwójnego opodatkowania i sposobu rozliczania się w innych krajach UE?

- Dlaczego nie informuje się uczniów o sposobach poszukiwania pracy poza Polską?

- Gdybyśmy poruszali zagadnienia legalnej pracy w UE, czy dochodziłoby do sytuacji znanych z mediów - uwięzienia w obozach pracy i innych dramatów ludzi, którzy skorzystali z ,pomocy" nielegalnych biur pośrednictwa pracy?

- Czy nie należałoby pokazać uczniom, a pośrednio i ich rodzicom, jak sprawdzać legalność ogłoszeń biur pośrednictwa pracy?

- Czy obywatel UE nie powinien znać podstawowych zasad prawa pracy w innych krajach?

- W jaki sposób funkcjonuje system emerytalny w innych krajach UE?

- Co należy zrobić, aby móc leczyć się bezpłatnie poza Polską? Czy obowiązuje taki sam pakiet bezpłatnego leczenia?

- Po wejściu do UE przed uczniami polskich szkół otworzyła się perspektywa pozyskiwania stypendiów i nauki w innych krajach. Czy wiedza o tym jest w należyty sposób rozpowszechniona? Wydaje się, że nie dociera do każdego ucznia.

- Wielu uczniów marzy o pracy na własny rachunek. Czy uczeń kończący szkołę wie, w jaki sposób wykorzystać fundusze UE na rozwój działalności? Czy wie, gdzie szukać informacji?

Takich pytań usłyszeliśmy kilkadziesiąt. Aby udzielić na nie odpowiedzi, nierzadko musieliśmy szukać informacji w internecie, np. na stronach Ministerstwa Gospodarki i stronach UE. A przecież przedmiot podstawy przedsiębiorczości powstał po to, aby przygotować ucznia do startu w ,gospodarcze” dorosłe życie. Niestety, nikt z piszących program nauczania nie wziął pod uwagę zmian, jakie nastąpiły po wstąpieniu Polski do UE. Obecnie uczniowi nie wystarcza przygotowanie do życia w gospodarczym świecie Polski; wymagania znacznie się rozszerzyły, tak jak rozszerzyły się granice Unii Europejskiej.

Uważamy, że zamieszczone niżej tematy powinny zostać wprowadzone do programu podstaw przedsiębiorczości. Jest to jedynie mała cząstka tego, czego brak w programie nauczania podstaw przedsiębiorczości.

- System edukacyjny w Unii Europejskiej. Instrumenty polityki młodzieżowej i edukacyjnej

- Ochrona zdrowia w Unii Europejskiej na przykładzie dwóch wybranych krajów 
- Prawo pracy w krajach wspólnoty - podobieństwa i różnice

- System podatkowy UE

- Fundusze unijne jako szansa rozwoju przedsiębiorczości.

Trudno uniknąć pytania: „Ale kiedy to uda się zrealizować przy tak ograniczonej liczbie godzin?”. Niestety, i tu jest konieczna zmiana programowa. Nasza propozycja jest bardzo prosta: zamiast powtarzać zagadnienia poruszane na lekcjach geografii, wiedzy o społeczeństwie czy historii, można wprowadzić proponowane zmiany. Po dokładnym przeanalizowaniu podstawy programowej oraz własnych przemyśleń doszliśmy do następujących konkluzji:

- Treści dotyczące postaw przedsiębiorczości, mocnych i słabych stron własnej osobowości, samoakceptacji, asertywności, pracy zespołowej, podejmowania decyzji - często są powtarzane na lekcjach wychowawczych. To zagadnienie mogłoby więc być tylko zasygnalizowane w treściach nauczania podstaw przedsiębiorczości, a rozszerzane na lekcjach wychowawczych.

- Treści dotyczące majątku przedsiębiorstw, kosztów i przychodów oraz zasad rozliczeń finansowych przedsiębiorstw są dla uczniów dość trudne, a ich tradycyjny sposób prezentowania na lekcjach nie sprzyja z reguły pokazaniu w należyty sposób, jak wprowadzać to zagadnienie w życie. Uważamy zatem, że - w wyniku braku możliwości poświęcenia na tę problematykę większej liczby godzin, co umożliwiłoby praktyczne przygotowanie uczniów do prowadzenia rozliczeń finansowych przedsiębiorstwa - powinno ono zostać ograniczone do minimum jednej jednostki lekcyjnej.

- Zagadnienia współpracy gospodarczej Polski z zagranica, integracji z Unią Europejską, procesów globalizacji gospodarki i jego konsekwencji dla Polski realizuje się na geografii, wiedzy o społeczeństwie i historii. Na lekcjach podstaw przedsiębiorczości są powtarzane. Uważamy, że mogłyby one ustąpić miejsca proponowanym wyżej tematom.

Poniżej przykładowe scenariusze lekcji dwóch z proponowanych przez nas tematów.

\section{Temat: System edukacji w Unii Europejskiej. Instrumenty polityki młodzieżowej i edukacyjnej}

Czas zajęć: 90 min - 2 jednostki lekcyjne

\section{Cele operacyjne-uczeń:}

- analizuje systemy edukacji w wybranych krajach UE

- wyszukuje informacje o uznawalności świadectw i dyplomów w Unii Europejskiej

- wymienia instrumenty wspólnej polityki młodzieżowej i edukacyjnej w UE

- omawia podstawowe założenia programów: Młodzież, Socrates, Leonardo da Vinci

- wymienia komponenty programu Socrates

- wybiera temat i opracowuje projekt, który mógłby zostać zrealizowany w ramach programu Socrates lub EFS

Metody: pogadanka wstępna, burza mózgów, metoda projektów, portfolio

Formy pracy: praca w grupach

Środki dydaktyczne: tablica lub plakat do zapisywania, słowniki integracji UE, materiały o programach: Młodzież, Socrates i Leonardo da Vinci, a jeśli jest możliwe przeprowadzenie zajęć w pracowni komputerowej, to komputer $\mathrm{z}$ dostępem do internetu; w przeciwnym wypadku informacje przygotowane przez nauczyciela i zebrane przez uczniów 
Uwaga. Kilka tygodni wcześniej należy poprosić uczniów o zgromadzenie materiałów: wycinków z gazet, wydruków z internetu, własnych opracowań dotyczących systemu edukacji w poszczególnych krajach UE oraz działań w ramach programów: Młodzież, Socrates i Leonardo da Vinci; kraje można przydzielić pojedynczym osobom lub grupom, w zależności od liczebności klasy.

\section{Przebieg lekcji:}

1. Wprowadzenie - krótka pogadanka. Nauczyciel informuje o polityce edukacyjnej UE i związanej z nią polityce młodzieżowej.

2. Uczniowie prezentują zgromadzone materiały; wspólnie z nauczycielem omawiają kolejne zagadnienia.

3. Uczniowie czytają informacje zamieszczone na stronach www.buwiwm.edu.pl oraz www.eurodesk.pl.

4. Nauczyciel informuje uczniów o rozwiązaniu problemu wzajemnego uznawania dyplomów i kwalifikacji zawodowych w państwach członkowskich UE.

5. Uczniowie wyszukują na stronie internetowej lub w słownikach UE informacje o Europejskim Systemie Punktów Kredytowych.

6. Nauczyciel dzieli uczniów na 10 grup; zadaniem wszystkich jest wyszukanie na stronach internetowych oraz/lub w przygotowanych materiałach informacji o zakresie działania i przeznaczeniu programów:

- Grupa 1 - Program Młodzież

- Grupa 2 - Program Socrates-Comenius

- Grupa 3 - Program Socrates-Erasmus

- Grupa 4-Program Socrates-Grundtvig

- Grupa 5 - Program Socrates-Lingua

- Grupa 6-Program Socrates-Minerva

- Grupa 7 - Program Socrates-Arion

- Grupa 8-Program Socrates-Eurydice

- Grupa 9-Program Socrates-Naric

- Grupa 10 - Program Leonardo da Vinci

7. Uczniowie prezentują swoje opracowania.

8. Na zakończenie pierwszej lekcji nauczyciel prosi uczniów o wypisanie przykładowych problemów, jakie mogłoby być rozwiązane w ramach programu Sokrates.

9. Na drugiej lekcji nauczyciel prosi uczniów o podanie przykładowych tematów, jakie mogłyby być opracowane w ramach programu Socrates.

10. Uczniowie zapisują propozycje na tablicy; następnie wspólnie wybierają 5-6 najlepszych możliwych do realizacji w warunkach własnej szkoły.

11. Uczniowie dobierają się w grupy czteroosobowe i wybierają temat; wspólnie określają możliwości wprowadzenia go we własnej szkole; następnie opracowują w punktach plan działań szkoły.

12. Na 10 min przed końcem lekcji uczniowie prezentują opracowane plany.

13. Nauczyciel prosi, aby uczniowie przygotowali (w domu) projekt wybranego tematu i po określonym czasie (tydzień lub dwa) przedstawili go w formie pisemnej lub multimedialnej. Najlepszy projekt może zostać przedstawiony np. na forum szkoły lub na radzie pedagogicznej. 


\section{Temat: Ochrona Zdrowia w Unii Europejskiej (na przykładzie dwóch wybranych krajów)}

Czas zajęć: $45 \mathrm{~min}$

\section{Cele operacyjne-uczeń:}

- wyjaśnia, co należy zrobić, aby móc korzystać z opieki medycznej podczas pobytu w innym kraju UE

- opisuje system ubezpieczeniowy w wybranych krajach UE

- wyjaśnia, czym jest Europejska Karta Ubezpieczenia Zdrowotnego.

- samodzielnie uzyskuje informacje o ośrodkach opieki zdrowotnej w krajach UE

- gromadzi dokumenty niezbędne do uzyskania zwrotu kosztów za usługi medyczne poza krajem

- podaje alarmowy numer telefonu w UE

- wyjaśnia zasady wykupu lekarstw w innych krajach

Metody: elementy dyskusji, techniki multimedialne

Formy pracy: praca w grupach

Środki dydaktyczne: słowniki integracji UE, materiały dotyczące opieki medycznej w krajach UE dostępne na stronie NFZ

Uwaga. Na poprzedniej lekcji nauczyciel powinien poprosić uczniów, aby odwiedzili siedzibę NFZ i poprosili o broszury informujące o ubezpieczeniu poza Polską oraz formularze E104, E106, E109, E111, E112, E120, E121, E123, E126 - lub wydrukowali je ze strony http:/www.nfz.gov.pl/ue Jeżeli jest możliwość odbycia zajęć w sali komputerowej; informacje można odczytać na stronie http://www.nfz.gov.pl/ue.

\section{Przebieg lekcji:}

1. Wprowadzenie - pogadanka. Nauczyciel nawiązuje dyskusję o przygotowaniach do wyjazdu na wakacje w jednym z krajów UE. Pyta, co należy załatwić przed wyjazdem, aby w razie wypadku móc skorzystać z bezpłatnego leczenia.

2. Nauczyciel omawia (na przykładzie dwóch krajów: Włoch i Irlandii-zał. 1) zasady świadczeń zdrowotnych w UE.

3. Nauczyciel dzieli uczniów na 11 grup, każdej przydziela po jednym pytaniu (opisie sytuacji, jaka może się zdarzyć). Uczniowie wyszukują niezbędne informacje w przyniesionych materiałach lub na stronie internetowej NFZ.

- Grupa 1 - Wybieram się do Szwecji na 2 tygodnie. Kiedy i gdzie mogę się starać o Europejską Kartę Ubezpieczenia Zdrowotnego? Czy w związku z wejściem do UE nie muszę kupować dodatkowego ubezpieczenia?

- Grupa 2 - Czy będzie można wykupić lekarstwa za granicą? Wybieram się na 4 miesiące do Grecji. Lekarstwa szybko tracą ważność, lepiej zatem kupić je na miejscu. Czy będzie możliwa refundacja?

- Grupa 3 - Czemu służy Europejska Karta Ubezpieczenia Zdrowotnego? Przecież w razie wypadku i tak udzielą nam pomocy.

- Grupa 4 - Jestem studentką/studentem i wyjeżdżam w czerwcu na 7-miesięczną praktykę do Francji. Z jakich świadczeń będę mogła/mógł skorzystać? 
- Grupa 5 - Często podróżuję jako turysta. Czy przed każdym wyjazdem muszę się zgłaszać do NFZ po Europejską Kartę Ubezpieczenia Zdrowotnego? Czy nie można otrzymać zaświadczenia ważnego np. rok?

- Grupa 6 - Latem chcę wyjechać do pracy do Wielkiej Brytanii. Jaki druk powinien pobrać student, gdzie i zjakim wyprzedzeniem załatwić wszelkie formalności związane z wyjazdem? Na jaką opiekę może liczyć?

- Grupa 7 - Wyjeżdżam na czterodniową wycieczkę do Estonii. Czy muszę starać się o EKUZ? Na co można liczyć w razie np. złamania nogi?

- Grupa 8 - Wyjeżdżam do Lichtensteinu na dwutygodniowy urlop, cierpię na alergię. Czy będę ponosić opłaty za konieczne wizyty u placówkach zdrowotnych? Jeśli tak, to w jakiej wysokości?

- Grupa 9 - Wyjeżdżam z żoną i rodzicami na dwa lata do Hiszpanii. Czy moi rodzice będą płacić za leki? Są osobami wymagającymi częstego leczenia farmakologicznego.

- Grupa 10 - Podczas pobytu w Słowenii skorzystałam/skorzystałem z usług prywatnej placówki zdrowia. Mam faktury za usługi oraz za leki. Czy przysługuje mi się refundacja w Polsce?

- Grupa 11-Mieszkam 2 km od granicy polsko-słowackiej. Czy mogę podjąć leczenie stomatologiczne u dentysty na Słowacji? Jeżeli tak, to w jakim zakresie?

4. Przedstawiciele grup odpowiadają na pytania. Uczniowie mogą podawać przykłady sytuacji. w jakich znaleźli się sami lub ich bliscy.

5. Nauczyciel prosi uczniów o odszukanie w różnych źródłach informacji aktów prawnych regulujących prawo do ubezpieczenia w krajach UE.

\section{Załącznik 1}

Informacje o opiece zdrowotnej w innych krajach UE można uzyskać na stronie internetowej www.nfz.gov.pl/ue

\section{Irlandia}

- Jak uzyskać opiekę zdrowotną

Możesz korzystać ze świadczeń lekarzy, stomatologów i szpitali działających w ramach publicznej służby zdrowia (General Medical Services - GMS). Ich listę można uzyskać w miejscowej Radzie ds. Zdrowia (Health Board).

Przedstaw lekarzowi swoją Europejską Kartę Ubezpieczenia Zdrowotnego i zaznacz, że chcesz być leczony zgodnie z przepisami UE. Uwaga. Wielu specjalistów przyjmuje zarówno w ramach publicznej służby zdrowia, jak i prywatnie.

Leczenie szpitalne wymaga skierowania. W nagłych przypadkach można zgłaszać się bezpośrednio do szpitala. Należy zawiadomić administrację szpitala, że chce się być leczonym zgodnie z przepisami UE, i okazać Europejską Kartę Ubezpieczenia Zdrowotnego.

- Opłaty za świadczenia zdrowotne

Leczenie w państwowym oddziale szpitala publicznego jest bezpłatne, z wyjątkiem leczenia skutków wypadków drogowych, którego koszty pokrywa pacjent.

- Transport sanitarny

Nr telefonu pogotowia ratunkowego - 112 lub 999. Każda Rada ds. Zdrowia stosuje własne rozwiązania w zakresie przewozu pacjentów w nagłych przypadkach. W niektórych przypadkach trzeba ponieść opłatę. Koszty transportu powrotnego do Polski są pokrywane w całości przez pacjenta. 
- Recepty

Uprawniony do wystawiania recepty objętej refundacją jest lekarz, który podpisał umowę z publiczną służbą zdrowia.

- Leczenie prywatne

Osoba lecząca się na prywatnym oddziale szpitala publicznego, w placówce służby zdrowia działającej poza publiczną służbą zdrowia lub u lekarza, który nie podpisał umowy z GMS, będzie musiała pokryć koszty leczenia. Nie przysługuje jej zwrot tych wydatków.

- Dokumenty niezbędne do uzyskania zwrotu kosztów

Oryginały rachunków, dowodów zapłaty.

- Miejsce, gdzie w razie wątpliwości można uzyskać informacje

Rada ds. Zdrowia (Health Boards).

\section{Wlochy}

- Jak uzyskać opiekę zdrowotną

Możesz korzystać ze świadczeń placówek państwowej służby zdrowia (Servizio Sanitario Nazionale, S.S.N.). Listę tych placówek można uzyskać w lokalnym urzędzie ds. opieki zdrowotnej ASL (Azienda Sanitaria Locale). W niektórych miejscowościach znajdują się specjalne ośrodki zdrowia dla turystów (Servizio di guardia turistica, Servizio di guardia medica estiva). Przedstaw lekarzowi swoją Europejską Kartę Ubezpieczenia Zdrowotnego. Leczenie specjalistyczne i szpitalne wymaga skierowania, ale w nagłych przypadkach można udać się bezpośrednio do szpitala, okazując Europejską Kartę Ubezpieczenia Zdrowotnego.

- Opłaty za świadczenia zdrowotne

Obowiązują opłaty za wizytę u lekarza (do 36 euro za poradę lub badanie) i leczenie stomatologiczne. Leczenie szpitalne jest bezpłatne, chyba że pacjent wybierze salę o podwyższonym standardzie. Za niektóre leki na receptę trzeba zapłacić wyłącznie niewielką opłatę ryczałtową, a za pozostałe płaci się pełną lub częściową cenę (na pełną odpłatność wskazuje słowo ticket na rachunku). Zniżki lub całkowite zwolnienie z opłat przysługują m.in. niepełnosprawnym, dzieciom do lat 6 , niewidomym i głuchoniemym, przewlekle chorym, kobietom w ciąży.

- Transport sanitarny Nr telefonu pogotowia - 118. Transport powrotny do Polski jest całkowicie odpłatny.

- Recepty Uprawniony do wystawiania recepty objętej refundacjąjest lekarz praktykujący w państwowej służbie zdrowia. Jeśli zapłacisz pełną cenę leku, zachowaj metkę z opakowania.

- Dokumenty niezbędne do uzyskania zwrotu kosztów Oryginały rachunków, dowodów zapłaty i metki z ceną z opakowań lekarstw.

- Miejsce, gdzie w razie wątpliwości można uzyskać informacje Lokalne urzędy ds. opieki zdrowotnej - Azienda Sanitaria Locale (ASL).

Mamy nadzieję, że poruszony przez nas temat spotka się z oddźwiękiem ze strony nauczycieli. Nie jesteśmy zapewne jedynymi osobami zasypywanymi przez uczniów gradem pytań. Z powodu ograniczonej liczby godzin przeznaczonych na lekcje podstaw przedsiębiorczości, zaproponowane przez nas tematy można tymczasem realizować w czasie zajęć kół zainteresowań lub zajęć dodatkowych. Jesteśmy jednak przekonani, że potrzebna jest zmiana programowa tego przedmiotu, wynikającą z potrzeb i zainteresowań uczniów, którym przedmiot ma służyć. 


\section{Enterprising Student in EU - Proposed Topics for Lessons}

Although Basis of Entrepreneurship is quite young subject its teaching program requires never ending changes. After May 1st, 2004 the most important changes should have been brought in. But it has never happened. In this article we indicate issues resulted from many students' questions that authors of the article tried to handle. We have been looking for right answers on the Ministry of Economy www as well as on website of European Union. Do working students need the basis of entrepreneurship in adult life in postindustrial economy? So far people who were in charge of teaching program elaboration have never put attention on all changes that have happened after Poland acceded to UE. Today every student needs not only an economy education but something more. On the basis of students questions we elaborated few cases which should be the part of a basic of entrepreneurship subject. We propose few examples of lessons scripts that take into account all changes in the new teaching program. 


\section{Janina Rosiak}

Ośrodek Doskonalenia Nauczycieli

Zachodniopomorskie Centrum Edukacyjne w Szczecinie

Piotr Szczypa

Zakład Rachunkowości

Katedra Zarządzania Finansami

Uniwersytet Szczeciński

\section{Proekologiczna edukacja w ksztaltowaniu postaw przedsiębiorczych}

Aktywizacja gospodarki narodowej wymaga nieustannej edukacji młodych ludzi, kreowania ich postaw, stanowią oni bowiem podstawę rozwoju przyszłego biznesu. Edukacja w przedsiębiorczości powinna podlegać nieustannym zmianom, aby sprostać wszystkim wyzwaniom. Takim wyzwaniem są obecnie: przygotowanie uczniów/studentów do aktywnego życia w warunkach gospodarki rynkowej oraz udzielanie im pomocy w zakresie kształtowania mentalności, postaw i umiejętności przydatnych w ciaggle zmieniających się warunkach. Znajomość podstaw przedsiębiorczości oraz kreowanie przedsiębiorczej jednostki, a także społeczeństwa, w warunkach nasilającej się globalizacji jest niezbędne każdemu człowiekowi, który chce aktywnie włączyć się w światowe procesy rozwoju cywilizacyjnego.

Edukacja w zakresie kreowania postaw przedsiębiorczych to również kształtowanie świadomości zagrożeń, jakie niesie ze sobą dynamiczny rozwój gospodarczy kraju i świata. Uważa się, że jednymi z największych zagrożeń ograniczających możliwości rozwojowe są zagrożenia ekologiczne. Człowiek przedsiębiorczy to człowiek świadomy zagrożeń, wrażliwy na problemy ekologiczne, który widzi zbieżność między interesem ekonomicznym a nowoczesna, efektywną, oszczędną gospodarką uwzględniającą problemy szeroko rozumianej ochrony środowiska.

Świadomość ekologiczną należy rozumieć jako „świadomość zależności ludzi od pozostałej części przyrody i świadomość wpływu, jaki działalność człowieka wywiera na otaczające środowisko. Świadomość oznacza nie tylko odpowiedni poziom wiedzy, ale również takie jej racjonalne i emocjonalne przyswojenie, które powoduje podejmowanie określonych działań" [Kobyłko (red.) 2000]. W Polsce obserwuje się z roku na rok coraz wyższy stopień świadomości ekologicznej. Niestety, nie zawsze ta świadomość przekłada się na zachowania proekologiczne. Można to zmienić, stosując skuteczny system edukacji proekologicznej, nastawiony na kształtowanie postaw przedsiębiorczych w zakresie zachowań przyjaznych dla środowiska.

W praktyce można zaobserwować cztery stopnie świadomości ekologicznej i przyporządkować im odpowiednie typy konsumenta, których charakterystykę przedstawiono w tab. 1 .

Proces kształtowania postaw przedsiębiorczych powinien być tak ukierunkowany, aby sprzyjał podwyższaniu świadomości i działalności proekologicznej, szczególnie w grupach „,czarnych” i „szarych”, żeby stali się bardziej wrażliwi na potrzeby środowiska przyrodniczego. Dzięki temu będą oni przyjmowali postawy typowe dla grup ,szarozielonych” i ,zielonych”. Kształcenie świadomości ekologicznej wymaga edukacji w dziedzinie środowiska przyrodniczego, a także informacji na ten temat na wszystkich szczeblach i formach kształcenia. Edukację proekologiczną, jako ważny aspekt kształtowania postaw przedsiębiorczych, można rozpatrywać w szerszej bądź węższej perspektywie. 
Tab. 1. Podejście do problemów ochrony środowiska - poziomy świadomości ekologicznej

\begin{tabular}{|c|c|c|}
\hline $\begin{array}{c}\text { Poziom } \\
\text { świadomości } \\
\text { ekologicznej }\end{array}$ & $\begin{array}{c}\text { Typ } \\
\text { konsumenta }\end{array}$ & Charakterystyka (prezentowane poglądy) \\
\hline 1 & 2 & 3 \\
\hline Niski & $\begin{array}{l}\text { czarny } \\
\text { (podporząd- } \\
\text { kowany } \\
\text { „kultowi } \\
\text { materii”) }\end{array}$ & $\begin{array}{l}\text { - Człowiek, jako istota odrębna i nadrzędna wobec przyrody, ma pra- } \\
\text { wo jej używać, zużywać ją i dowolnie ją kształtować. } \\
\text { - Najważniejsze potrzeby, które muszą być zaspokojone w celu osią- } \\
\text { gnięcia ogólnego dobrobytu społecznego, to pokój, wzrost gospo- } \\
\text { darczy, bezpieczeństwo ekonomiczne, wysoki poziom konsumpcji. } \\
\text { - Zależność zdrowia od stanu środowiska przyrodniczego nie jest za- } \\
\text { leżnością istotną. } \\
\text { - Prowadzony tryb życia nie ma istotnego wpływu na zachorowal- } \\
\text { ność na choroby cywilizacyjne. } \\
\text { - Indywidualne działania jednostki nie wpływają na stan środowiska } \\
\text { przyrodniczego. Za jego degradację odpowiedzialne są przede } \\
\text { wszystkim zakłady przemysłowe. } \\
\text { - Nie ma takiej szkody wyrządzonej przyrodzie przez „technikę”, } \\
\text { której „technika” nie mogłaby naprawić. } \\
\text { - Istniejący system ochrony środowiska jest wystarczający. }\end{array}$ \\
\hline Przeciętny & $\begin{array}{l}\text { szary } \\
\text { (przeciętny } \\
\text { konsument) }\end{array}$ & $\begin{array}{l}\text { - Człowiek, jako istota najwyżej rozwinięta intelektualnie w świecie } \\
\text { przyrody, ma prawo dowolnie jej używać w celu zaspokojenia swo- } \\
\text { ich potrzeb. } \\
\text { - Najważniejsze potrzeby, które muszą być zaspokojone w celu osią- } \\
\text { gnięcia ogólnego dobrobytu społecznego, to pokój, wzrost gospo- } \\
\text { darczy, bezpieczeństwo ekonomiczne, wysoki poziom konsumpcji, } \\
\text { ochrona przed skażeniem promieniotwórczym i degradacją środowi- } \\
\text { ska na obszarach ekologicznego zagrożenia. } \\
\text { - Zależność zdrowia od stanu środowiska przyrodniczego ujawnia się } \\
\text { jedynie na terenach silnie zdegradowanych. } \\
\text { - Prowadzony tryb życia nieznacznie się przyczynia do zmniejszenia } \\
\text { zachorowalności na choroby cywilizacyjne. } \\
\text { - Indywidualne działania jednostki mają niewielki wpływ na stan śro- } \\
\text { dowiska przyrodniczego. Za jego degradację odpowiedzialne są przede } \\
\text { wszystkim zakłady przemysłowe. } \\
\text { - Większość szkód wyrządzonych przyrodzie przez ,technikę” } \\
\text { (oprócz skażenia promieniowaniem i klęsk ekologicznych) może } \\
\text { być przez „technikę” naprawiona. } \\
\text { - Istniejący system ochrony środowiska nie jest wystarczający. Do- } \\
\text { skonalenie go to zadanie administracji państwowej. }\end{array}$ \\
\hline Wysoki & \begin{tabular}{|l|} 
szarozielony \\
(chce być \\
postrzegany \\
jako zielony, \\
dba \\
o zdrowie)
\end{tabular} & $\begin{array}{l}\text { - Człowiek, jako część przyrody, zaspokaja w pierwszej kolejności } \\
\text { swoje potrzeby, pamiętając o potrzebach otoczenia. } \\
\text { - Najważniejsze potrzeby, które muszą być zaspokojone w celu osią- } \\
\text { gnięcia ogólnego dobrobytu społecznego, to zapewnienie rozwoju } \\
\text { zrównoważonego (rozwój zrównoważony ekologicznie, ekonomicz- } \\
\text { nie, politycznie i społecznie). } \\
\text { - Zależność zdrowia od stanu środowiska przyrodniczego jest duża. } \\
\text { - Prowadzony tryb życia jest skutecznym sposobem profilaktyki m.in. } \\
\text { chorób cywilizacyjnych. }\end{array}$ \\
\hline
\end{tabular}




\begin{tabular}{|c|c|c|}
\hline 1 & 2 & 3 \\
\hline & & $\begin{array}{l}\text { - Indywidualne działania jednostki mają bardzo duży wpływ na stan } \\
\text { środowiska przyrodniczego. Zanieczyszczenia komunalne i pokon- } \\
\text { sumpcyjne przyczyniają się do degradacji przyrody niemal w takim } \\
\text { samym stopniu, jak zakłady przemysłowe. } \\
\text { - Przyroda stanowi naturalną barierę dla rozwoju naukowo-technicz- } \\
\text { nego z powodu nieodnawialności zasobów. } \\
\text { - Istniejący system ochrony środowiska nie sprzyja prowadzeniu eko- } \\
\text { logicznego stylu życia. Doskonalenie go to zadanie administracji pań- } \\
\text { stwowej oraz instytucji i organizacji społecznych. }\end{array}$ \\
\hline $\begin{array}{l}\text { Bardzo } \\
\text { wysoki }\end{array}$ & $\begin{array}{l}\text { zielony } \\
\text { (chce } \\
\text { zmienić } \\
\text { i zmienia } \\
\text { swój styl } \\
\text { życia, aby } \\
\text { chronić } \\
\text { środowisko) }\end{array}$ & $\begin{array}{l}\text { - Człowiek, będąc integralną częścią przyrody, w równym stopniu } \\
\text { dba o zaspokojenie swoich potrzeb i potrzeb otoczenia. Jeśli to } \\
\text { konieczne, weryfikuje swoje potrzeby i eliminuje te, które naruszaja } \\
\text { równowagę ekologiczną. } \\
\text { - Najważniejsze potrzeby, które muszą być zaspokojone w celu osią- } \\
\text { gnięcia ogólnego dobrobytu społecznego, to zapewnienie rozwoju } \\
\text { zrównoważonego (rozwój zrównoważony ekologicznie, ekonomicz- } \\
\text { nie, politycznie i społecznie). } \\
\text { - Stan środowiska przyrodniczego jest jedną z determinant zdrowia } \\
\text { człowieka. } \\
\text { - Ekologiczny tryb życia jest dla zdrowia człowieka najlepszy. } \\
\text { - Indywidualne działania jednostki mają decydujący wpływ na stan } \\
\text { środowiska przyrodniczego. Gdyby każdy człowiek kierował się } \\
\text { przede wszystkim dobrem środowiska przyrodniczego (w tym rów- } \\
\text { nież człowieka), nie byłoby problemów ekologicznych. To pojedyn- } \\
\text { czy ludzie tworzą społeczeństwa, państwa i rządy, które tymi pań- } \\
\text { stwami rządzą, decydując także o ochronie środowiska. } \\
\text { - Rozwój naukowo-techniczny to jedna z głównych przyczyn degra- } \\
\text { dacji środowiska. Wdrażanie nowych technologii powinno być obję- } \\
\text { te ścisłą kontrolą pod względem oddziaływania na środowisko. Jeśli } \\
\text { człowiek jako gatunek przyrodniczy zagrozi przetrwaniu życia na } \\
\text { planecie, to przyroda obróci się przeciwko niemu. } \\
\text { - Istniejący system ochrony środowiska na ogół utrudnia prowadze- } \\
\text { nie ekologicznego stylu życia. System ochrony środowiska będzie } \\
\text { spełniał swoje zadania, jeżeli jednym z głównych celów każdego } \\
\text { podmiotu gospodarki będzie ochrona środowiska. }\end{array}$ \\
\hline
\end{tabular}

Źródło: opracowanie autorów na podstawie Proekologiczne zarządzanie przedsiębiorstwem, 2000, G. Kobyłko (red.), Wydawnictwo AE we Wrocławiu, Wrocław

W kształceniu postaw przedsiębiorczych ukierunkowanych na działalność proekologiczną biorą udział przede wszystkim [por. Kobyłko (red.) 2000]:

- szkoły - na każdym poziomie kształcenia, odpowiednio do możliwości uczniów, przekazywane są wyniki badań dotyczących zagrożeń środowiska przyrodniczego i możliwości jego ochrony; zmiany w szkolnictwie sprzyjają coraz skuteczniejszej edukacji proekologicznej;

- media lokalne i ogólnopolskie (prasa, radio, telewizja);

- przedsiębiorcy, ludzie biznesu (ich postawa, działania na rzecz ochrony środowiska mogą być wzorcem dla innych);

- Kościół katolicki - ma w Polsce wielką siłę oddziaływania na świadomość społeczeństwa; nauki Kościoła nie kłócą się z poszanowaniem środowiska przyrodniczego i działaniami proekologicznymi; 
- ruch konsumencki - dbałość o jakość produktów i o prawa konsumenta wiąże się bezpośrednio z problemami ekologii i ochrony środowiska.

Tab. 2. Perspektywy podejścia w zakresie edukacji proekologicznej

\begin{tabular}{|c|c|}
\hline Podejście szerokie & Podejście wąskie \\
\hline $\begin{array}{l}\text { Kształcenie rozumiane w szerokim kontekście } \\
\text { powinno uwrażliwiać człowieka na problemy } \\
\text { związane z ekologia, wspierać ogólną świadomość } \\
\text { konieczności ochrony środowiska oraz stwarzać } \\
\text { warunki poznawcze i emocjonalne w celu wy- } \\
\text { tworzenia w społeczeństwie i kulturze proekolo- } \\
\text { gicznych sposobów zachowania. }\end{array}$ & $\begin{array}{l}\text { W węższym znaczeniu kształcenie na rzecz śro- } \\
\text { dowiska zawiera zarówno szkolne i przedszkolne } \\
\text { wychowanie w dziedzinie ekologii, jak i włącze- } \\
\text { nie tematów związanych ze środowiskiem w za- } \\
\text { kres dalszego kształcenia na wszystkich szcze- } \\
\text { blach zawodowych. Podstawą takiego założenia } \\
\text { jest interpretacja rozdziału } 36 \text { Agendy } 21 \text { (wspie- } \\
\text { ranie edukacji szkolnej, świadomości publicznej } \\
\text { oraz podstawowego i uzupełniającego kształcenia } \\
\text { zawodowego), a także praca wiodącego w tej dzie- } \\
\text { dzinie UNESCO oraz CSD (Comission of Sus- } \\
\text { tainable Development - Komisja ds. Zrównowa- } \\
\text { żonego Rozwoju). }\end{array}$ \\
\hline
\end{tabular}

Źródło: opracowanie autorów na podstawie: Międzynarodowe zarządzanie środowiskiem, t. 1: Interdyscyplinarne założenia proekologicznego zarządzania przedsiębiorstwem, 2004, A. Kryński (red.), C.H. Beck, Warszawa

Sama wiedza o ochronie środowiska (poziom świadomości ekologicznej) nie wystarczy, aby podjąć działania proekologiczne ukierunkowane na przekształcenie przedsiębiorstwa w jednostkę przyjazną środowisku. Świadomość ekologiczna nabyta w trakcie edukacji proekologicznej powinna przekształcić się w postawy przedsiębiorcze uwzględniające konieczność podejmowania działań na rzecz ochrony środowiska. Istotne jest zatem, aby na każdym poziomie nauczania kształtować postawy przedsiębiorcze, a zarazem proekologiczne. Wysoki poziom świadomości ekologicznej daje możliwość podjęcia takich inicjatyw w przedsiębiorstwie, które dadzą wymierne korzyści ekonomiczne (ograniczenie kosztów) i przyczynią się do ochrony środowiska przyrodniczego. Poziom świadomości ekologicznej ma zatem wpływ na sposób zarządzania przedsiębiorstwem, na styl pracy pracowników; może się przekładać zarówno na wyniki finansowe przedsiębiorstwa, jak i na trudne do zmierzenia korzyści dla środowiska przyrodniczego.

Wcześniej czy później społeczeństwo musi realizować ideę rozwoju zrównoważonego (ekorozwoju), która uznaje nadrzędność wymogów ekologicznych poprzez oszczędną produkcję i konsumpcję. Idea ekorozwoju zakłada bowiem uwzględnianie konsekwencji obecnych działań w przyszłości, i preferowanie takich, które nie zagrażają potrzebom i zdrowiu przyszłych pokoleń.

\section{Literatura}

1. Kobyłko G. (red.), 2000, Proekologiczne zarzadzanie przedsiębiorstwem, Wydawnictwo AE we Wrocławiu, Wrocław

2. Kryński A. (red.), 2004, Międzynarodowe zarzadzanie środowiskiem, t. 1: Interdyscyplinarne założenia proekologicznego zarzadzania przedsiębiorstwem, C.H. Beck, Warszawa 


\section{Pro-ecological Education in Shaping Entrepreneurial Attitudes}

Activation of national economy needs constant education of young people and creating their attitudes, because they are the foundation for growth of future business. In the environment of escalating in globalization understanding of the basis of entrepreneurship and creating of entrepreneurial individuals, as well as society, is essential for every man who wants actively participate in the processes of development of world's civilization. The goal of this article is to point that the education in the area of creating entrepreneurial attitudes should include shaping awareness of the threats related to the dynamic economical growth in the country and all the world. Ecological dangers are considered to be the greatest threats to the chance to the development. So the entrepreneurial man is conscious of the threats, sensitive to ecological problems and sees relationships between economic matters and modern, efficient economy that takes into account wide range of problems of environment protection. 


\section{SPIS TREŚCI}

Wprowadzenie

Część I.

Przedsiębiorczość w aktywizacji gospodarczej układów regionalnych i lokalnych

Zbigniew Zioło, Rola przedsiębiorczości w aktywizacji gospodarczej-zarys modelu ........ 10

Zbigniew Makieła, Przedsiębiorczość w Polsce w układzie regionalnym .......................... 18

Krzysztof Wiedermann, Regionalne efekty mnożnikowe rozwoju

przemysłu motoryzacyjnego w aktywizacji gospodarczej województwa śląskiego .............. 24

Krzysztof Wach, Potencjał małych i średnich przedsiębiorstw regionu południowego ....... 35

Diana Dryglas, Krzysztof Wach, Klimat dla rozwoju przedsiębiorczości turystycznej

w Małopolsce w świetle badań empirycznych

Mirosław Wójtowicz, Rozwój przewozów pasażerskich w Międzynarodowym Porcie

Lotniczym im. Jana Pawła II w Krakowie na tle innych portów regionalnych w Polsce

Magdalena Kochmańska, Działalność gminy w zakresie rozwoju przedsiębiorczości lokalnej 61

Wojciech Jarczewski, Duch przedsiębiorczości w proinwestycyjnych działaniach władz

lokalnych

Sławomir Dorocki, Stacja Narciarska „Wierchomla” - lokalny ośrodek aktywizacji gospodarczej.

Katarzyna Dajczak, Anna Rychły-Lipińska, Programy rozwoju przedsiębiorczości miasta Koszalin

Janusz Ustupski, Przedsiębiorczość w otoczeniu Tarnowa

Janusz Machowski, Płocki Park Przemysłowo-Technologiczny - projekt pobudzenia przedsiębiorczości lokalnej

Beata Namyślak, Przestrzenne aspekty funkcjonowania zagranicznych podmiotów przemysłowych we Wrocławiu i w okolicach

\section{Część II.}

\section{Przedsiębiorczość w obszarach wiejskich}

Joanna Buks, Agnieszka Otłowska, Rozpowszechnienie nierolniczej działalności gospodarczej na obszarach wiejskich

Mariusz Chądrzyński, Główne bariery rozwoju i funkcjonowania małych i średnich przedsiębiorstw na obszarach wiejskich województwa łódzkiego .....

Renata Rettinger, Gospodarstwa farmerskie jako forma aktywizacji gospodarczej

obwodu lwowskiego. 


\section{Część III.}

\section{Kapital społeczny w przedsiębiorczości}

Monika Borowiec, Rola szkolnictwa wyższego w podnoszeniu jakości kapitału ludzkiego .... 142

Nadine Bednarz, Czy uczenie się przez całe życie jest postawą przedsiębiorczą ................. 151

Maciej Tokarski, Andrzej Tokarski, Funkcjonowanie Akademickiego Inkubatora

Przedsiębiorczości przy Wyższej Szkole Bankowej w Toruniu ....................................... 156

Krystian Sowislok, Zachowania młodzieży na współczesnym rynku pracy w Polsce ......... 162

Kazimierz Nowak, Start młodzieży na rynku pracy ................................................... 172

\section{Część IV.}

\section{Postawa przedsiębiorcza i wizerunek przedsiębiorcy}

Paweł Żukowski, Wizerunek osobowościowy współczesnego menedżera w przedsiębiorstwie 180

Paweł Czapliński, Prasowy wizerunek przedsiębiorców ................................................. 187

Krystian Sowislok, Współczesny przedsiębiorca ............................................................ 193

Tomasz Tadeusz Brzozowski, „Przedsiębiorczość” - pojęcie polisemiczne czy niewłaściwie rozumiane? Próba systematyzacji

Anita Paszko-Janowska, Osobowość, motywacja, przedsiębiorstwo rodzinne.

Wybrane aspekty przedsiębiorczości

\section{Część V.}

\section{Przedsiębiorczość w funkcjonowaniu przedsiębiorstw}

Paweł Żukowski, Model i symulacja dynamiki systemu zarządzania organizacją gospodarczą (ujęcie modelowe)

Krzysztof Rejman, Wpływ innowacyjności na efektywność współczesnych przedsiębiorstw

Jacek Strojny, Magdalena Berezowska, Przedsiębiorczość jako determinanta konkurencyjności organizacji zorientowanej projektowo

Wanda Klepacka, Ilona Pietucha, Ustawa o niektórych formach wspierania działalności innowacyjnej - narzędziem w aktywizacji gospodarczej

Agnieszka Pichur, Elektroniczne wspieranie przedsiębiorczości. Wyniki badań empirycznych

Katarzyna Świerczewska-Pietras, Przedsiębiorczość w sieci

Jerzy Janczewski, Uwarunkowania rozwoju przedsiębiorczości w małych warsztatach samochodowych

Zbigniew Ożdżyński, Przedsiębiorczość a bezpieczeństwo ruchu drogowego

Grażyna Voss, Zestawienie zmian w skonsolidowanym kapitale własnym 


\section{Część VI.}

\section{Przedsiębiorczość w edukacji}

Mariola Tracz, Tomasz Rachwał, Przedmiot podstawy przedsiębiorczości - założenia realizacji a przygotowanie nauczycieli

Wioletta Kilar, Zagadnienia globalizacji i korporacji ponadnarodowych w edukacji przedsiębiorczości

Edyta Osuch, Wiktor Osuch, Wybrane projekty edukacyjne w aktywizacji uczniów na lekcjach podstaw przedsiębiorczości

Małgorzata Kulikowska, Bożena Krasnodębska, Techniki multimedialne w nauczaniu podstaw przedsiębiorczości

Mirosław Soczówka, Wykorzystanie technologii informacyjnej w nauczaniu - uczeniu się podstaw przedsiębiorczości

Jerzy Desperak, Aneta Depczyńska, Przedsiębiorczy uczeń w UE

- propozycje tematów lekcji

Janina Rosiak, Piotr Szczypa, Proekologiczna edukacja w kształtowaniu postaw przedsiębiorczych 


\section{CONTENTS}

Introduction

\section{Part I.}

\section{Entrepreneurships in Activation of Regional and Local Economic Systems}

Zbigniew Zioło, Role of Entrepreneurships in an Activation of Economy

Zbigniew Makieła, Entrepreneurship in Poland in Regional Configuration

Krzysztof Wiedermann, Regional Factor Effects of the Growth in Auto Industry as the Economic Activators in Silesian Province

Krzysztof Wach, Potential of Small and Medium-sized Enterprises in Southern Poland

Diana Dryglas, Krzysztof Wach, Climate for Tourist Entrepreneurship in Małopolska on the Basis of Empirical Research

Mirosław Wójtowicz, Development of Passenger Transport at the John Paul II International Airport in Kraków in Comparison with Other Regional Airports in Poland ....

Magdalena Kochmańska, Work of Commune in the Sphere of Local Entrepreneurship

Development

Wojciech Jarczewski, The Spirit of Entrepreneurship in Pro-investment Activities of Municipalities

Sławomir Dorocki, Ski Station "Wierchomla" as a Local Center of Economic Activation ....

Katarzyna Dajczak, Anna Rychły-Lipińska, Programs of Development of Enterprise in Koszalin

Janusz Ustupski, Enterprise Development in the Area of Tarnow

Janusz Machowski, The Płock Industrial and Technological Park - Program

for Nascent Local Entrepreneurship

Beata Namyślak, Spatial Aspects of Running Foreign Industrial Manufactures

in Wrocław and Neighborhoods

\section{Part II.}

\section{Entrepreneurships in Rural Areas}

Joanna Buks, Agnieszka Otłowska, Development of Non-agricultural Economic

Activity in Rural Areas

Mariusz Chądrzyński, The Main Barriers for Development and Performance of Small and Medium-sized Enterprises (SMEs) in Rural Areas of Łódź Province 


\section{Part III.}

\section{Social Capital in Entrepreneurships}

Monika Borowiec, The Role of Educational System in Improving the Quality

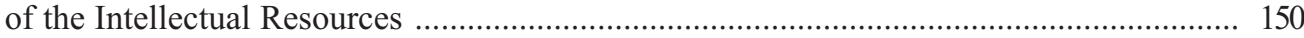

Nadine Bednarz, Is a Lifelong Learning an Entrepreneurial Attitude? .............................. 155

Maciej Tokarski, Andrzej Tokarski, An Operation of Academic Incubator of Enterprise Based on the Banking School in Toruń ........................................................................ 161

Krystian Sowislok, Youths' Behaviors on the Current Labour Market in Poland ................. 171

Kazimierz Nowak, Young People's Start on a Labour Market ........................................... 177

Part IV.

Entrepreneurial Attitude and Image of Entrepreneur

Paweł Żukowski, Profile of Modern Manager in a Company ............................................ 186

Paweł Czapliński, The Entrepreneur's Image in a Press ................................................... 192

Krystian Sowislok, An Entrepreneur for Modern Times ................................................. 195

Tomasz Tadeusz Brzozowski, Enterprise - Ambiguous or Misunderstood Concept?

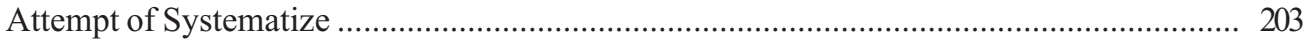

Anita Paszko-Janowska, Personality, Motivation and Family Business in Enterprise ........ 210

\section{Part V.}

Entrepreneurship in Company Operations

Paweł Żukowski, Model of Dynamic and Simulation of the Management System in Business Organization 219

Krzysztof Rejman, An Impact of an Entrepreneurship on a Performance of Modern Companies

Jacek Strojny, Magdalena Berezowska, Entrepreneurship as a Determinant

of Competitiveness for a Project-oriented Organization

Wanda Klepacka, Ilona Pietucha, Act of 29 July 2005 on Certain Forms of Support for Innovative Activities as a Tool for Economic Stimulation

Agnieszka Pichur, On-line Business Support - Research Analysis ................................ 248

Katarzyna Świerczewska-Pietras, Entrepreneurship on the Internet ............................... 259

Jerzy Janczewski, Conditions for Enterprise Development in Small Car Workshops ........... 269

Zbigniew Ożdżyński, Entrepreneurship and Traffic Safety ......................................... 277

Grażyna Voss, Statements of Changes in a Consolidated Ownership Capital ..................... 284

\section{Part VI.}

Entrepreneurship In the Education

Mariola Tracz, Tomasz Rachwał, Basis of Entrepreneurship Lessons - Assumption About

Realization vs. Preparation of Teachers 
Wioletta Kilar, Issues of Globalization and International Corporations in the Teaching Entrepreneurship

Edyta Osuch, Wiktor Osuch, Selected Educational Projects on Students Activity on Basics of Entrepreneurship Lessons

Małgorzata Kulikowska, Bożena Krasnodębska, Multimedia Technologies in Teaching Basis of Entrepreneurship .....

Mirosław Soczówka, The Use the Information Technology for Teaching Basis of Entrepreneurships

Jerzy Desperak, Aneta Depczyńska, Enterprising Student in EU - Proposed Topics for Lessons

Janina Rosiak, Piotr Szczypa, Pro-ecological Education in Shaping Entrepreneurial Attitudes 